


\section{UNIVERSIDADE DE SÃO PAULO \\ ESCOLA DE COMUNICAÇÃO E ARTES - ECA-USP DEPARTAMENTO DE MÚSICA}

MARIA CECÍLIA DE OLIVEIRA

\section{O DESPERTAR PARA UMA NOVA VOCALIDADE}

Tese apresentada ao Departamento de Música da Escola de Comunicação e Artes da Universidade de São Paulo, como cumprimento da exigência parcial para a obtenção do título de Doutora em Artes/Música - Processos de Criação Musical. Linha de pesquisa: Técnicas Composicionais e Questões interpretativas, sob orientação do Prof. Dr. Amilcar Zani Netto.

São Paulo

2013 


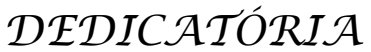

Dedico este trabalho

À minha linda e grande familia Servíha de Oliveira, em toda a sua integra: meus pais e meus nove irmãozinhos Arlindo de Oliveira Filho, Orlando Luiz de Oliveira, José Servilha de Oliveira, María Lídía de Oliveira, Eulálía Servílha de Olïveira, María Consolação de Olïveira, Ana Izabel de Oliveira, Sérgío Servilha de Oliveira e Lourival Servilha de oliveira

que me acolheram em um berço de extrema musicalidade, tornando nosso lar um verdadeiro ninho de amor e Graça. 


\section{Dedicação em especial e terno agradecimento}

(eterno)

\section{Ao meu papai}

Arlindo de Oliveira - de quem herdei a coragem, a garra para continuar mesmo nos momentos mais difíceis.

\section{À minha linda mãezinha}

Àquela a qual me ensinou os primeiros cânticos, minha primeira cantora e referência de excelêncía em afinação, bom gosto artístico

e musical, quem me ensinou "toda" decência e, principalmente a reconhecer e prestar atenção no Belo

María Servílha Morente de Oliveira - in memoriam

Aos meus irmãozinhos

Arlindo de Oliveira Fílho, Dídí - in memoriam

$\mathcal{A}$ aquele que deu o meu primeiro piano e proveu-me de confíança conscientizando-me da responsabilidade e importância do fruto do trabalho.

José Servilha de Oliveira, ou simplesmente, Zezinho - in memoriam $\mathcal{A}$ este grande artista e poeta anônimo José Servilha de Oliveira que em sua sábia simplicidade fez-me tão cedo buscar e entender que há poesia e beleza em tudo e que no devir da vida eu as reconhecería nos grandes nomes da literatura brasileira e universal e na arte da Música. Sob o olhar de um poeta em tudo pode haver poesia. 


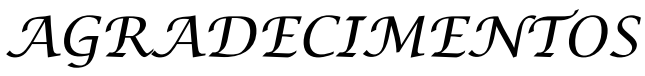

Amaury de Oliveira Pimenta

\author{
Cátía Suzano
}

Danieli Verônica Benedettí Longo

Giordana Mazzieri

Haydée Fígueirredo

Sérgío Servilha de Oliveirra Fîlho - meu doce afilhadinho

À Universidade de São Paulo e todo seu potencial humano

Coro de Repertórío da Fundação das Artes de São Caetano do Sul-todos integrantes e equipe

Aos meus queridos colegas, alunos, equipe técnica, equipe administrativa, enfím a todos os funcionários da Fundação das Artes de São Caetano do

Sul, em especial à Càssía Paula Bernardino e Daniel Volpín,

$\mathcal{A}$ todos os meus alunos e ex-alunos de todos os tempos de todas as instituições às quaís atuo ou atuei como docente (Pró-Música, Conservatórío Musical de São Caetano do Sul, Instituto Baccarelli, Fundação das Artes, Faculdade Paulista de Artes, UNICSUL, USP)

$\mathcal{A}$ todos os meus professores formais e os informais

AGRADECIMENTOS ESPECIAIS 
DEUS toda a honra e toda gloria

"... no príncípio era a Música

e a Música já era Deus..."

Cantares

Cantar Infinitivo do Verbo Divino

do Infinito Verbo musicar.

Agradecimento especial ao meu orientador Amilcar Zani Netto, este que além de cumprir com excelência o seu papel de orientador, trouxe à luz

uma comovente compreensão do que é saber ser paciente à vida e à

humanidade. Também por sua musicalidade e sabedoría.

Agradecimento especial ao meu irmão Sérgío Servilha de Oliveira Grilhante - que nas horas mais dificeis, incentivou-me como um guerreiro a continuar e propôs ideias brilhantes sobre física (timbre, formantes, teoría dos conjuntos...)

Aos muito queridos

Eduardo Albertino, Fernando Iazzetta, Flo Menezes, Heloisa Zani, Marcos

Branda Lacerda, Mônica Lucas, Rogério Costa, Sílvio Ferraz,

Mara Behlau - pessoa brilhante e verdadeira cientista da voz, com quem desde o inicio de meus estudos frequentei seus cursos, palestras que muito enriqueceram e trouxeram-me luz de intensa consciência vocal junto a minha professora Leilah Farah,

Márcía Guimarães - pela semente que cultivou em mim, incentivando-me a escrever um trabalho cientifico e dar continuidade e registrar minha

experiência e pesquisa,

María Lúcía Pascoal e Ronaldo Miranda - pelas ótímas sugestões colocadas com admirável humildade na banca de minha qualificação,

Martha Herr,

Rafael $\mathcal{N a s c i m e n t o ~ P a i ́ o l a , ~ m e u ~ a l u n o ~ c a n t o r ~ - ~ p e l a ~ c o m p e t e ̂ n c i a ~ e ~}$ dedicação na tradução dos textos em inglês.

Wanda Abrahão Thomas - minha querida madrinha

Fernando Carvalhaes - in memoriam

Homero de Magalhães - in memoriam

Leilah Farah - in memoriam

Ricardo Rizek - in memoriam 


\section{Índice de figuras}

Figura 1 - Harmonia - Exemplo 324

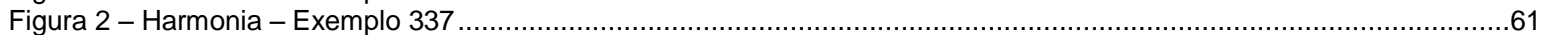

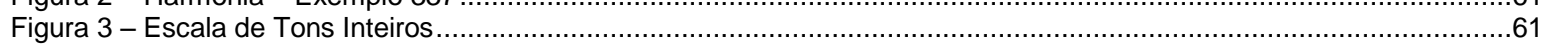

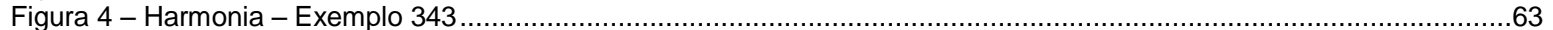

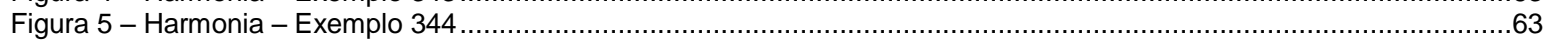

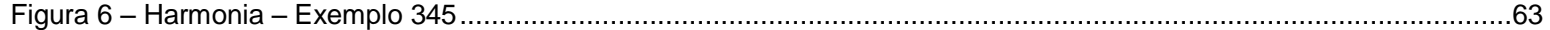

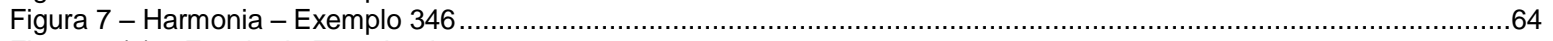

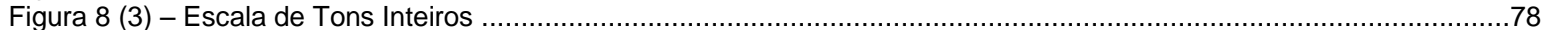

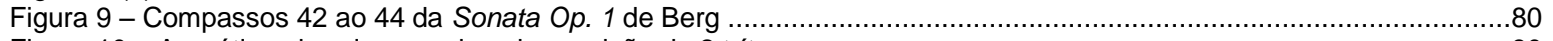

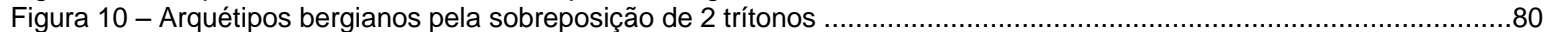

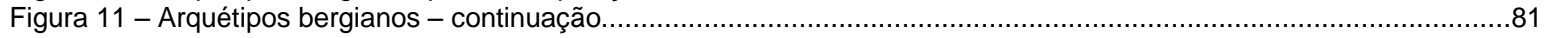

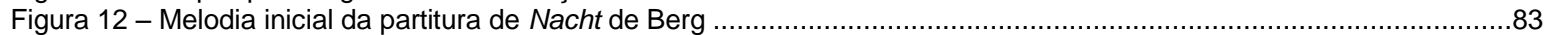

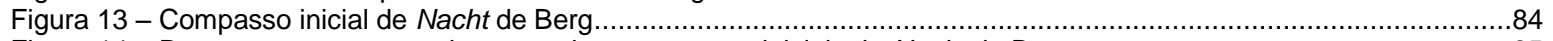

Figura 14 - Destaque para os acordes aum. dos compassos iniciais de Nacht de Berg ............................................85

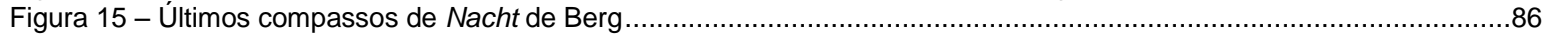

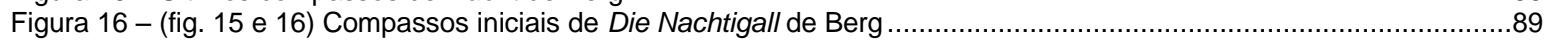

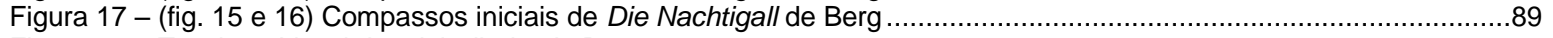

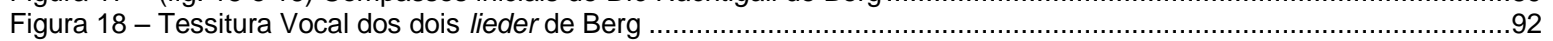

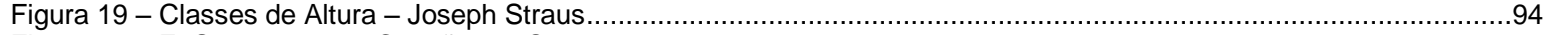

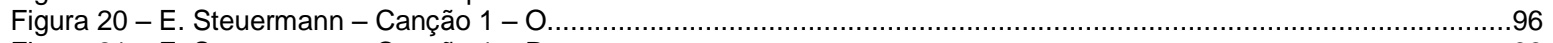

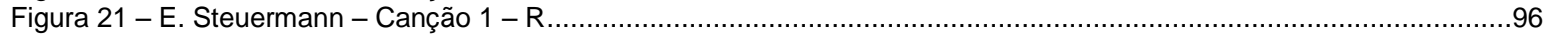

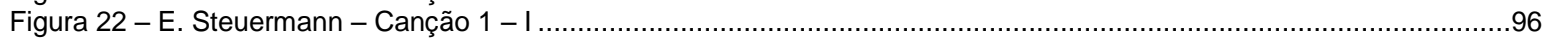

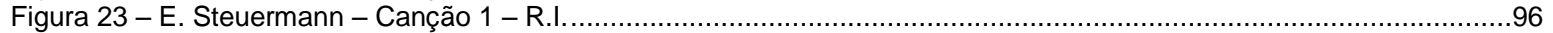

Figura 24 - (fig. 23 e 24) Início da partitura de Der Mensch, lied de Steuermann................................................................98

Figura 25 - (fig. 23 e 24) Início da partitura de Der Mensch, lied de Steuermann...........................................................99

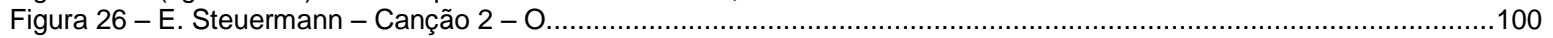

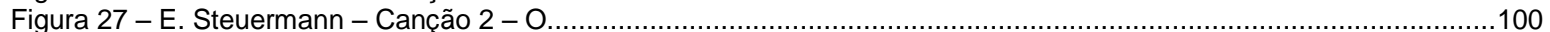

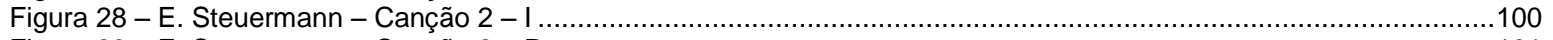

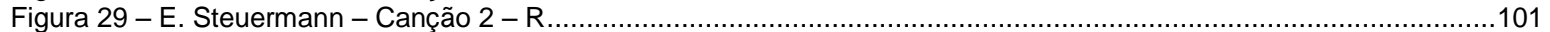

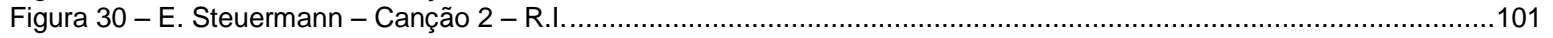

Figura 31 - Tessitura Vocal dos Drei Lieder de Steuermann............................................................................103

Figura 32 - S.O. apresentada no Movimento I da Cantata 2 de Webern ...................................................................112

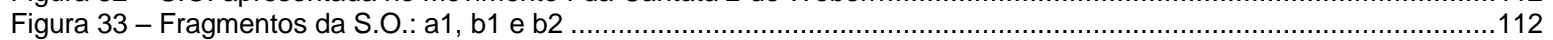

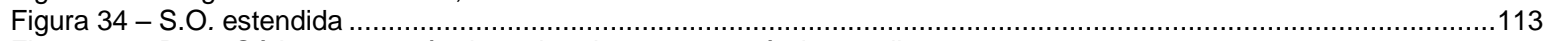

Figura 35 - Duas Séries em sequência projetadas por seu próprio espelhamento.............................................................113

Figura 36 - Acorde de base do Movimento I da Cantata 2 de Webern ....................................................................114

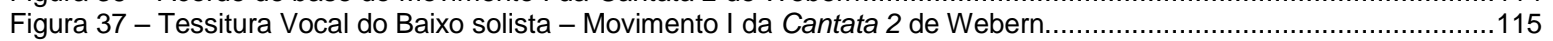

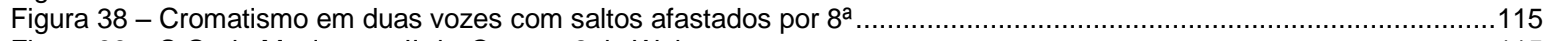

Figura 39 - S.O. do Movimento II da Cantata 2 de Webern ...................................................................................115

Figura 40 - S.O. do Movimento II da Cantata 2 de Webern, no âmbito de uma oitava ..................................................115

Figura 41 - R. do Movimento II da Cantata 2 de Webern .....................................................................................116

Figura 42 - R. do Movimento II da Cantata 2 de Webern, no âmbito de uma oitava ....................................................116

Figura 43 - S.O. do Movimento IV, que é o R.I. do Movimento III da Cantata 2 de Webern ..............................................118

Figura 44 - Transposições de S.O. do Movimento IV da Cantata 2 de Webern ............................................................118

Figura 45 - Tessitura do soprano solista no Recitativo do Movimento IV da Cantata 2 de Webern...................................119

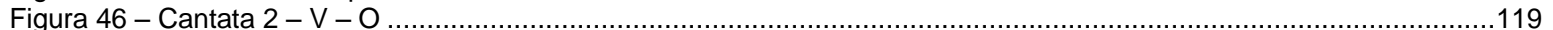

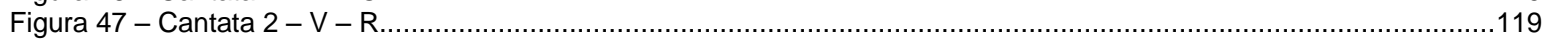

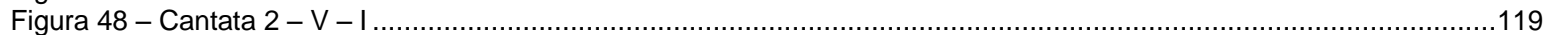

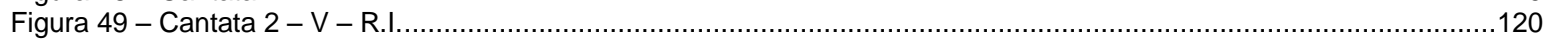

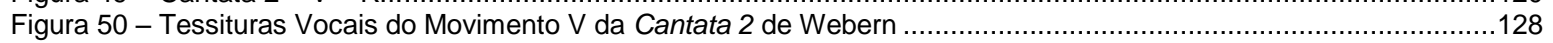

Figura 51 - Motivo a de Nacht - Pierrot Lunaire de Schoenberg ..........................................................................149

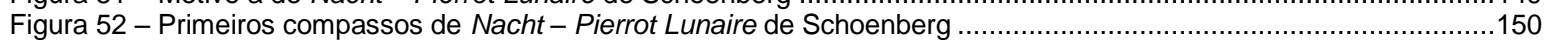

Figura 53 - Baixo ostinato de Nacht - Pierrot Lunaire de Schoenberg ..................................................................151

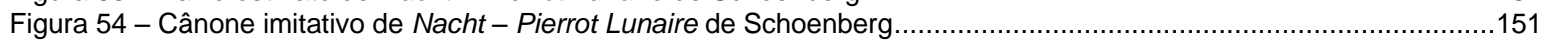

Figura 55 - O mesmo baixo com as classes de altura CA ….........................................................................152

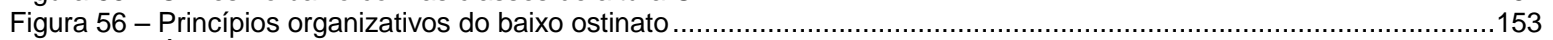

Figura 57 - Últimos compassos de Nacht - Pierrot Lunaire - Schoenberg .............................................................153

Figura 58 - Tessitura Vocal do(a) recitante - Nacht - Schoenberg..................................................................164

Figura 59 - Compassos 12 ao 19 do melodrama Nacht - Pierrot Lunaire - Schoenberg ...............................................165

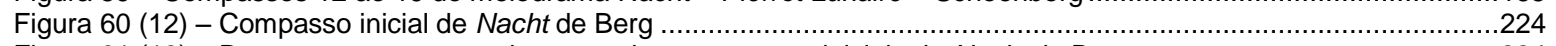

Figura 61 (13) - Destaque para os acordes aum. dos compassos iniciais de Nacht de Berg ......................................224

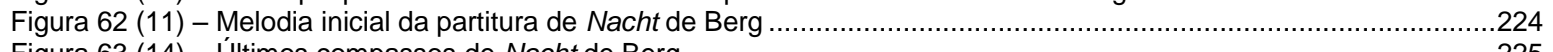

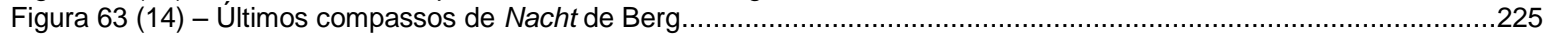




\section{Índice de tabelas}

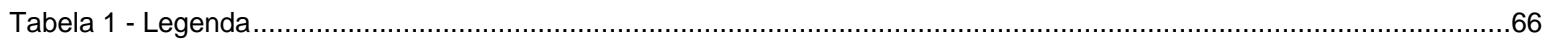

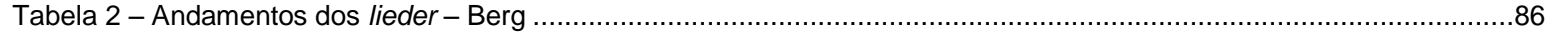

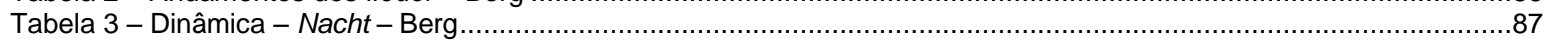

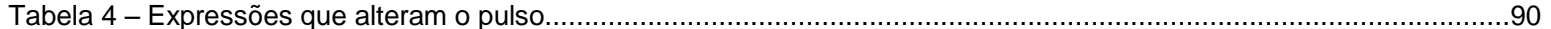

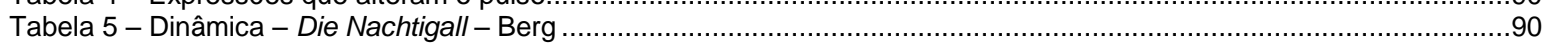

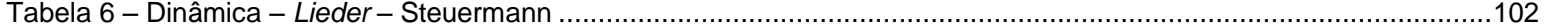

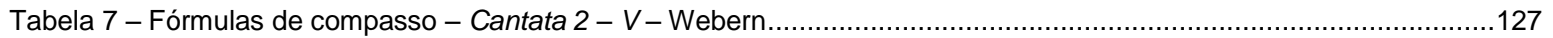

Tabela 8 - Expressões Germânicas - Nacht - Pierrot Lunaire - Schoenberg ...........................................................155

Tabela 9 - Dinâmica - Nacht - Pierrot Lunaire - Schoenberg …............................................................................156

Tabela 10 - J. Dunsby. Tabelab da p. 23 do livro Genesis by Schoenberg: Pierrot Lunaire. ..........................................159

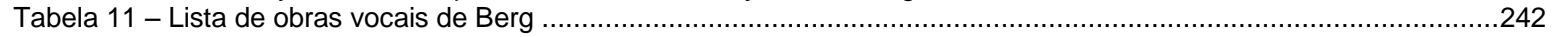

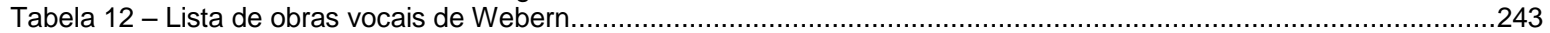

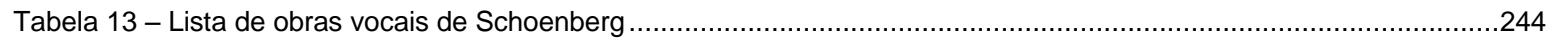




\section{SUMÁRIO}

\section{Parte I}

Introdução

1 Contexto histórico: O Panorama da Música Escrita na Europa Central na primeira metade do século $X X$

21

26

1.1 A Vigência da Prática Comum e sua Dissolução

29

33

35

37

40

43

1.3.1 O Atonalismo Livre e o Atonalismo Estruturado ou Organizado

1.4 Os processos de dissolução tonal na linha evolutiva de prospecção pela Segunda Escola de Viena e sua extensão em Steuermann

1.5 Os Desdobramentos do Dodecafonismo

\section{Parte II}

1 Análise Musical no século $X X$

57

2 Os Gêneros Vocais

2.1 O Lied

2.1.1. A Origem da Canção no Ocidente

2.1.2 O Lied Romântico

2.1.3 Nacht e Die Nachtigal - Alban Berg

2.1.4 Uma Canção dos Drei Lieder de Edward Steuermann

2.2 A Origem da Cantata

2.2.1 A Cantata na Alemanha

2.2.2 A Música Coral no Séc. XIX

2.2.3 A Cantata $N^{\circ} 2$ - op. 31 - Anton Webern

2.3 O Melodrama

2.3.1 A Passacaglia - Nacht - Arnold Schoenberg

2.3.2 Pierrot Lunaire - op. 21 - Arnold Schoenberg

2.3.3 A Gênese de Pierrot Lunaire

2.3.4 A Canção Discursiva

67

68

71

73

76

92

103

104

107

108

128

135

143

156

162

\section{Parte III}

$1 \quad$ A Complexidade das poéticas da Música \& Poesia 177

2 A Voz 191

2.1 O conceito separatista entre corpo e mente 194

2.2 A Musicalidade e o Corpo 203

2.3 Música e Voz 205

2.4 A Voz Cantada $\quad 212$

$3 \quad$ Uma Nova Vocalidade para a Música escrita no século XX 217

$4 \quad$ Questões Vocais e Interpretativas 223

5 Considerações finais - O Despertar para uma Nova Vocalidade 245

Referências Bibliográficas $\quad 253$

Anexo I (Traduções) 271

Anexo II (Partituras) 299 


\title{
O DESPERTAR PARA UMA NOVA VOCALIDADE
}

\author{
Resumo
}

Este trabalho tem por finalidade apontar determinados aspectos que nortearam algumas das principais especulações realizadas no campo da nova vocalidade na música escrita no despontar do século XX. A prática da voz inserida no mundo moderno se desenvolve com as bruscas mudanças que alteram os parâmetros da produção musical e da compreensão dos elementos de musicalidade que surgem nas primeiras décadas do século passado. Sucintamente, aborda o espectro de percepções estéticas e cognitivas que um ouvinte carrega em seu intelecto e o ambiente histórico de uma obra que são fundamentos para a contemplação, reflexão e que permitem entender a voz. Essa prática que se foi acrescendo paulatinamente de "novos" recursos tomados "emprestados" da prática da emissão vocal na fala e no canto cotidiano traz nova oralidade e vocalidade, fazendo surgir uma "nova" sonoridade que futuramente se intensificará em múltiplas tendências, principalmente a partir do final dos anos 50 e início dos 60 do século XX. O seu florescimento estende-se até os dias atuais teve como ponto de partida muitas das reflexões e pesquisas que a Segunda Escola de Viena trouxe para a música. Para embasar este estudo foi levantado um conjunto de obras vocais de Arnold Schoenberg, Anton Webern, Alban Berg e Edward Steuermann, que tem como ferramenta de análise a Teoria dos Conjuntos de Joseph Straus.

Palavras-chave: Segunda Escola de Viena, Sprechgesang, Sprechstimme, nova vocalidade, análise, voz, música do século XX, timbre, canção, melodrama, cantata, atonalismo. 


\title{
AWAKEN FOR A NEW VOCALITY
}

\begin{abstract}
This paper aims at pointing out specific aspects that guided some of the main theories made in the field of new vocality in writing music that happened in the beginning of the $20^{\text {th }}$ century. At that period the practice of speech inserted in the modern world was also developed by the sudden changes that altered the parameters of music production and the understanding of the elements of musicality. Shortly, this paper also discusses the spectrum of aesthetic and cognitive perceptions that a listener carries in his/her intellect and the historic setting which are grounds for contemplation and reflection for they allow the listener to understand the voice, and even extend the appreciation and understanding of the sound. Such practice gradually added to itself new features taken from vocal speech and everyday singing bringing new orality and voicing. This activity generated a "new" sound that would appear in multiple trends, mainly in the late 50 s and early 60 s of the $20^{\text {th }}$ century. It is there up to the present days and it had as a starting point reflections and researches that the Second Viennese School brought to the music.

To support this study a number of vocal works of Arnold Schoenberg, Anton Webern, Alban Berg and Edward Steuermann, were taken into consideration, which use Joseph Straus' Theory of Groups as tool for analysis.
\end{abstract}

Key Words: Second Viennese School, Sprechgesang, Sprechstimme, new voicing, voice, analyzing, twentieth century music, timbre, song, melodrama, cantata, atonalism. 


\section{Introdução}

$\mathrm{Na}$ transição do século XIX para o século XX, as linguagens artísticas ocidentais foram marcadas por profundas mudanças, as quais iniciaram um processo de questionamento das bases dessas linguagens.

Para a Música, as reflexões se voltaram para a tonalidade: pode haver música sem tonalidade? Ou a tonalidade é um requisito imprescindível para a criação musical?

O resultado dessas reflexões fez com que as bases do discurso musical fossem o foco do pensamento musical ocidental à procura de identificar seus materiais mais elementares e sua estrutura de organização.

Diversos compositores, como Franz Liszt, Arnold Schoenberg, Alban Berg, Anton Webern, Eduard Steuermann, Alexander Scriabin, Béla Bartók, Claude Debussy, Igor Stravinsky, Edgard Varèse, fizeram parte deste processo que marcou a História da Música e legaram um maior conhecimento sobre o discurso tonal e um vasto repertório de composições com experiências baseadas em novos modelos de construção pensadas para o discurso musical.

Também, surgem algumas das principais teorias contemporâneas relacionadas ao estudo da Harmonia, advindas de musicólogos como Hugo Riemann, Heinrich Schenker e Arnold Schoenberg, nesse período, e ainda ocorre a exploração dos limites mais remotos do discurso tonal.

Abre-se espaço para a exploração de outros padrões de organização discursiva e para a expansão dos conceitos musicais tradicionais. A tonalidade deixa de existir como elemento unificador em alguns novos modelos.

Em maior ou menor medida, as composições adquirem novas formas de organização temática, melódica, harmônica e formal, e algumas dessas são normalmente agrupadas dentro de certos estilos composicionais, algumas recebendo denominações como: Impressionismo, Expressionismo, Dodecafonismo, Neoclassicismo e Politonalismo. De modo que praticamente quase toda a produção musical de música escrita, após 1945 dialoga de 
alguma forma com as questões que foram levantadas a partir desse período. Serialismo, minimalismo, neo-romantismo, neo-modalismo, música espectral, música aleatória, pós-modernismo, nova complexidade, são herdeiros diretos de compositores da virada do século XIX para o século XX, devido a esse diálogo.

Este trabalho apresenta-se desmembrado em três partes (partes I, II e III).

A parte I - discursa sobre reflexões dos fatos históricos que ocorreram na música na transição do século XIX para o século XX.

A parte II - versa sobre os gêneros e análises do grupo de obras abordadas neste trabalho, são elas: dois dos sete lieder Nacht e Die Nachtigall do ciclo Sieben Frühe Lieder do compositor Alban Berg - Um dos Drei Lieder Der Mensch - de Eduard Steuermann - Nacht do melodrama Pierrot Lunaire de Arnold Schoenberg e os Movimentos I, IV e V da Cantata nํㅡ 2 de Anton Webern.

A parte III - consiste das reflexões de como o processo criativo de algumas propostas da Segunda Escola de Viena, alguns procedimentos técnicos de composição (vários) como Sprechgesang, Sprechstimme, Sprechmelodie, além da interválica como resultado da construção de materiais a partir da escala de tons inteiros e o acréscimo da utilização da nova ordenação da escala cromática instrumentalizaram o aspecto vocal na condução das vozes na textura contrapontística. 


\section{1 - Contexto histórico: O Panorama da Música Escrita na Europa Central na primeira metade do século $X X$.}

$O$ artista que tem coragem abandona-se completamente às suas inclinações. E somente quem se abandona às suas inclinações tem coragem, e somente quem tem coragem é artista.

Um artista, que tem uma boa ideia nova, não há de ser confundido com um incendiário ou bombardeador. Uma semelhança entre o aparecimento do novo campo espiritual e revoluções políticas consiste, no máximo, em que se sente ameaçado pelo novo. Contudo, as diferenças fundamentais são maiores: os resultados, as consequências espirituais de uma ideia, por serem de natureza espiritual, são duradouras; mas as consequências das revoluções, que se passam no campo material, são transitórias. E, sobretudo: nunca foi intenção e efeito da nova arte remover ou destruir completamente sua predecessora, a arte antiga. Ao contrário: ninguém ama mais profundamente, mais intimamente e mais respeitosamente seus predecessores do que o artista que traz o verdadeiramente novo, pois o respeito é aqui a consciência da profissão, e o amor, solidariedade. (...) O que de melhor se pode é comparar o aparecimento do novo com o florescer de uma árvore: é o devir natural da árvore da vida. Porém, se houvesse árvores que tivessem o interesse de impedir esse florecer, então bem se poderia denominar a isto "revolução". E os conservadores do inverno teriam o direito de lutar contra toda primavera, ainda quando a houvessem vivido cem vezes e pudessem constatar que ela havia chegado, finalmente, a ser também a sua primavera. Uma memória defeituosa e uma inteligência diminuta bastam a confudir devir com revolução, a acreditar que, quando o novo brota do que outrora foi novo, virá a destruição do antigo ${ }^{1}$

Quando em 1906, Gustav Mahler (1860-1911), ainda escrevia sua Oitava Sinfonia, muitos compositores como, por exemplo, Claude Debussy (18621918), Aleksander Scriabyn (1872-1915), já trabalhavam por novos caminhos, reagindo ao Romantismo tardio, que já era considerado um estilo excessivo e ultrapassado.

O lento, mas insistente, fluir cromático desintegrador da tonalidade, provocou a crise dos valores tonais no findar do século XIX. Faltava ainda acrescentar uma ação centralizadora e condensadora dos múltiplos esforços da desintegração tonal, assumida pouco mais tarde por Arnold Schoenberg.

\footnotetext{
${ }^{1}$ Schoenberg, Arnold. Harmonia. Tradução de Marden Maluf. São Paulo: Ed. UNESP, 1999.p.551.
} 
A ampliação da gama dos vários parâmetros dos aspectos musicais levou a música a um alto grau de expansividade; e no seu vasto repertório a obtenção da grandiosidade e por que não dizer, até a certa eloquência. $O$ Romantismo imprimiu à sonoridade musical certa densidade desde que Richard Wagner (1813-1883), havia utilizado livremente acordes dissonantes cromáticos, introduzindo notas estranhas à tonalidade para "colorir" suas harmonias. O uso corrente desses acordes seguidos de ousadas modulações repentinas, que em certos momentos causava instabilidade e a incerteza de um centro tonal, fez com que gradativamente, a tonalidade, o sistema tonal maior-menor, que perdurou por esses três últimos séculos se enfraquecesse. ${ }^{2}$

O cromatismo foi o elemento dinâmico e propulsor dos dois mais significativos acontecimentos musicais: a cristalização e posterior fragmentação do sitema tonal. A admissão de várias linhas, melódicas pela polifonia renascentista, que ampliava os estágios iniciais da tonalidade melódica medieval, conduziu ao uso de sensibilizações cromáticas (música ficta) em pontos cadenciais e, a partir da resolução destas sensibilizações, abriu caminho para a consolidação do sistema maior/menor de tonalidades. A "escolha" destes dois modos em especial deu-se em razão da posição privilegiada que os intervalos de semitons ocupavam na conformação interna destes modos (dado que até hoje é observado nos livros de teoria musical que retêm os termos sensível tonal e modal para indicar semitons das escalas diatônicas). Posteriormente, já em finais do século XIX, a inserção de cromatismos na harmonia de base diatônica da tonalidade harmônica viabilizou a criação de um estado de tonalidade expandida que desobrigava a permanência do discurso musical em regiões próximas da tonalidade de partida e gerava passagens com tonalidades suspensas e flutuantes. Todas as notas de uma escala diatônica já poderiam ser empregadas na constiutição de acordes, ideia que embasou o pandiatonicismo ${ }^{3}$

Na Europa Central, no final do século XIX, o compositor que houvesse decidido continuar a linha tradicionalista clássico-romântica, se depararia com a obstrução de vários caminhos, pois parecia que as vias haviam chegado ao extremo de sua trajetória. O entendimento do diatonismo, como sistema harmônico estrutural e unificador.

Constituía um fato patente pela dispersão ou hipertrofia de seus derradeiros recursos; a modulação ao infinito havia triunfado ao ponto de se converter quase na única função possível ou admitida da tonalidade, embora seja bem certo que apenas conseguido essa suprema escapatória, preparada por tão longo tempo, evaporou-se totalmente ${ }^{4}$

\footnotetext{
2 GRIFFITHS, Paul. A Música Moderna.

${ }^{3}$ CORRÊA, Antenor Ferreira. Estruturações Harmônicas Pós-Tonais.p. 168.

${ }^{4}$ PAZ, Juan Carlos. Introdução a Música de Nosso Tempo. p.108.
} 
Diante desse impasse se encontravam Arnold Schoenberg e seus contemporâneos.

A Segunda Escola de Viena é uma expressão que designa o grupo de compositores que trabalhou em Viena no início de século XX, em torno de Arnold Schoenberg (1874-1951), especialmente seus alunos e aqueles que adotaram a composição dodecafônica; e em particular é usada para se referir a três personalidades principais: Arnold Schoenberg, Anton Webern (1883-1945) e Alban Berg (1885-1935), que viam claramente a sua posição no tempo e espaço como uma situação histórica.

Para eles a História da Música era um vetor que indicava um sentido, uma direção inequívoca. Um movimento que eles deduziram e no qual se situaram e tomaram consciência de seu papel. Por consequência da emancipação das dissonâncias, e consumido por si mesmo, o sistema tonal sob ameaça de ser reduzido a uma ação redundante, teve que se transferir para novos princípios, e essa espécie de deslocamento que foi a linha mestra de raciocínio de dupla via, a da lógica e da intuição, seguiram Schoenberg e seus alunos, avançando até as consequências finais da tonalidade. ${ }^{5}$

A Atonalidade foi consequência lógica de uma tendência que já tinha sido iniciada no período romântico, visto que a tonalidade saturada se encontrava enfraquecida por demais para se opor ao processo de dissolução. A partir de então ao retirar toda a resistência daquilo que perdurou por alguns séculos, a sua tão arraigada concepção básica de concatenação entre os graus e de cadências estabelecidas na Música Tonal, precipitou sua dispersão definitiva e resultou no Serealismo Integral, base do relativismo musical.

A preocupação com a terminologia [pantonalidade] fica-nos evidente quando lemos a seguinte passagem: 'em geral não me falta coragem, mas se sou chamado a dar um nome a este estado de coisas, preferia me abster completamente; no meu 'Harmonielehre' insisti para que desitnãssemos por 'pantonal' o que hoje chamamos de atonal'. E, de fato, o termo pantonalidade parecia ter mais sentido a Schoenberg desde os tempos do Harmonielehre, onde se lê claramente que '...se se procura, pois, por nomes, poderia pensar-se em politonal ou pantonal. Mas de

\footnotetext{
${ }^{5}$ PAZ, Juan Carlos. Introdução a Música de Nosso Tempo. p.108.
} 
toda forma seria necessário primeiramente constatarmos se não se trata simplesmente de tonal de novo'. Visto que por politonalidade conota-se a sobreposição de tríades de tonalidades distintas (como muito comumente ouvimos na obra de Stravinsky), teríamos como termo ideal para o múltiplo discurso harmônico da primeira 'atonalidade' (que quase sempre evitou relações triádicas, mas nem por isso a presença de centros tonais diversos no desenvolvimento harmônico) o termo 'pantonalidade'.

$$
\text { (...) }
$$

As reservas quanto ao termo atonalidade, e a admissão de que um contexto atonal faz-se quase impossível, não foram restritas à Segunda Escola de Viena. Se formos à fonte considerada na época antagônica (mas que hoje deve ser vista criticamente como face diferente de uma mesma moeda), ou seja, se analisarmos a concepção harmônica presente na obra de Stravinsky, notamos de imediato uma proximidade entre ambas as escolas do pensamento composicional. Podemos ler a seguinte passagem na biografia de Stravinsky, feita por Romam Vlad:"É significativo que tanto Schoenberg quanto Stravinsky refutem o termo atonalidade, se por atonalidade pretendemos negar a existência de qualquer organização tonal"; (...) e cita as palavras do próprio Stravinsky (...) é....indispensável... reconhecer a exixtência determinada de dois polos de atração. A tonalidade diatônica é apenas um meio de orientar a música em direção a esses polos. A função da tonalidade é completamente subordinada à força de atração do polo da sonoridade. ${ }^{6}$

Neste trabalho optou-se pelo termo Atonalidade ${ }^{7}$, pois historicamente em 1934, Edgard Varèse, aborda o Atonalismo como uma corrente consolidada, reconhecendo a importante influência de Arnold Schoenberg, faz assumir a mesma postura da Segunda Escola de Viena, endossando que a Atonalidade é a própria tonalidade que se liberta da hierarquia das funções nos moldes tradicionais.

Schoenberg renovou criteriosamente tudo àquilo que se supusera quase que imutável, de maneira que, a partir dele tornou-se impossível estender ou adiar o rompimento definitivo com a tonalidade clássica e todo seu aparato formal, desenvolvimento temático, cadências e tudo que fora originado pela tonalidade. Já que os esforços e o processo de desintegração por superá-la, encontraram apenas resultados parciais ou redundantes, porém, muito contribuíram indiretamente com o estreitamento do círculo de possibilidades até chegar à solução que as circunstâncias impunham. ${ }^{8}$

\footnotetext{
${ }^{6}$ MENEZES, Florivaldo. Apoteose de Schoenberg. pp.61 e 62.

${ }^{7}$ Vide subcapítulo 1.3 Conceito de Atonalismo, deste trabalho.

${ }^{8}$ PAZ, Juan Carlos. Introdução a Música de Nosso Tempo. p.108.
} 
Tomando como base o relativismo musical, primeiramente, podem-se considerar as formulações harmônicas delegando autonomia total às doze notas de nossa escala temperada; e como consequência da outra a completa liberação da dissonância.

Em princípio, a ampliação do sentido cadencial, cumprida por Schoenberg nos Drei Klavierstücke, opus 11, em Das Buch der Hängenden Gärten, opus 15, os novos encadeamentos de acordes e 0 deslocamento ou a nova colocação de planos harmônicos superpostos nas Fünf Orchesterstücke, opus 16, ou no monodrama Erwartung - a evasão da melodia do processo simétrico cadencial a procura de uma livre articulação baseada em uma espécie de escala oral, originária do Oriente - no melodrama Pierrot Lunaire, no monodrama Erwartung e nos Vier Orchesterlieder, opus $22^{9}$

Começa então, uma profusão de idéias para Schoenberg e seus primeiros alunos, Anton Webern e Alban Berg. Caracterizam as obras desta etapa Atonal-Livre, que fora um estilo de composição atemático, a ampliação do sentido cadencial, novos encadeamentos de acordes e deslocamento, ou nova colocação e superposição de planos, evasão da melodia do processo simétrico-cadencial à procura de uma livre articulação baseada em uma espécie de "escala oral"10, ou seja, não a escala cantada, a "escala" da voz falada, originária do oriente, como no melodrama Pierrot Lunaire. Grandes saltos intervalares nas linhas melódicas, a saturação e a renovação máxima de elementos sonoros em função expressiva e escrita apropriada para a execução desta música, assim se deram os resultados de uma acurada pesquisa adquiridos para esta etapa inicial. Esses resultados propiciaram à música abertura para a aquisição e imposição de uma nova vocalidade ${ }^{11}$. "Vocalidade é a historicidade de uma voz: seu uso"

Nessa atmosfera onde paira um clima de desconcerto dos valores tradicionais e de esforços insuficientes para restaurá-los ou superá-los, emergiu a nova ordem criativa.

Dessa atitude cartesiana e experimental, levada a cabo por Schoenberg e os compositores provindos de sua escola, surge uma liquidação do "métier" tradicional e das antigas hierarquias teórico-estéticas da música.

É o ponto de partida de um "Novo estilo", entendido, não como simples

\footnotetext{
9 PAZ, Juan Carlos. Introdução a Música de Nosso Tempo. p.109.

${ }^{10}$ Obs: não que exista uma escala sistematizada para a fala, é uma suposição comentada por Juan Carlos Paz em seu livro Introdução a Música de Nosso Tempo.

${ }^{11}$ ZUMTHOR, Paul. A Letra e a Voz: A "literatura" medieval; tradução Amalio Pinheiro, Jerusa Pires Ferreira. São Paulo: Companhia das Letras, 1993.p.21.
} 
ampliação dos recursos no ofício do compositor - (...) mas, sim como verdadeira superação da crise de toda uma época musical, ao mesmo tempo que como foco gerador de novas forças encaminhadas a uma transmutação dos valores na música atual ${ }^{12}$

Schoenberg tinha a clara consciência de que, tão pouco trouxera substitutivos eficazes e que, o que ele próprio realizava como também o que outros tinham, por sua vez, realizado até então, não poderia renovar fundamentalmente as bases da concepção musical, o que considerava imprescindível para a prossecução de sua obra de compositor e de teórico.

Para ele era evidente que estivesse realmente concluída a função e a eficácia dos elementos consignados.

Dessa maneira, no despontar do século $X X$, assiste-se o término do antigo estilo. Sua base estava assentada no convencionalismo da escala diatônica, cujo princípio unificador, é a polarização da tônica, dominante e da subdominante.

\section{1- A Vigência da Prática Comum e sua Dissolução}

Para analisarmos a Altura como parâmetro essencial da música tonal, faz-se necessária a compreensão do que vem a ser o tonalismo através da perspectiva que trata do conceito de Prática Comum.

A Prática Comum ${ }^{13}$ é um conceito utilizado por Walter Piston para designar o conjunto de regras que prevalecia na música tonal. Como tem declarado no prefácio da edição italiana de seu livro intitulado Harmonia de 1989:

este conceito é usado em sentido mais amplo para indicar o conjunto da harmonia de Bach a Wagner, aceitando a hipótese de que as mudanças históricas e estilísticas ocorridas entre os dois extremos é mesmo de grande sintática gramatical da época da harmonia tonal ${ }^{14}$

Não se trata de igualar a música dos renomados compositores eruditos que abarcam esse longo momento que vai do século XVII ao final do século XIX.

\footnotetext{
12 PAZ, Juan Carlos. Op.Cit. p.103.

${ }^{13}$ PISTON Walter. Armonia. Torino. Ed. Torino, 1989.

${ }^{14}$ BOSCO, G. Gioanola, G., Vinay, G. "Prefazio" della ed. italiana de Armonia. Piston, Walter. Torino : Ed. Torino, 1989. p. XVI.
} 
Apesar de poderem ser observadas algumas tentativas de críticas ao sistema tonal, tomada por alguns compositores dessa mesma fase, através da reflexão, acima, de Walter Piston, o Tonalismo pode ser considerado um exercício comum, como um elemento unificador que nos permite abordar uma gama significativa de repertório que vai desde o legado de Johann Sebastian Bach (1685-1750) ao de Richard Wagner (1813-1883), por meio de uma mesma sintaxe, como sistema harmônico estrutural - o diatonismo.

A Prática Comum consolidou a existência de um sistema musical, que carrega coesão e força suficientes para suportar a grande diversidade de estilos e propostas oriundas em seu próprio interior, durante algumas centenas de anos, sem se extinguir, ou se desintegrar completamente.

Pode-se constatar que na música ocidental, o Tonalismo se tornou o grande referencial sistêmico utilizado até os dias de hoje.

Desde os princípios básicos desta teoria harmônica comum, condensados em O Tratado de Harmonia, de Jean-Phillip Rameau (1683-1764), livro, de 1722, que resume a prática que se tinha em torno das escalas, o seu campo harmônico e a hierarquia os acordes.

Com esse tratado de Rameau provou-se que com a importante inversabilidade dos acordes, se deu o nascimento da harmonia tonal moderna respaldada pela afirmação do temperamento.

A partir de profundos estudos matemáticos elaborados por teóricos do século $\mathrm{XVI}$, o temperamento por igual foi uma relativização da afinação dos instrumentos, proporcionando ao músico e aos ouvintes a possibilidade de se criar e compreender uma espécie de relação padronizada entre as alturas. ${ }^{15}$

O padrão de afinação passa pelo ajuste e compensação de intervalos de sons. A relação intervalar classificada conforme a distância entre dois ou mais sons que compõem uma frase musical, que estabelece tanto ao aspecto horizontal, ou melódico, quanto o aspecto vertical, ou harmônico, que também irá determinar o conceito de consonância ou dissonância advindo das leis de condução de vozes do contraponto, transferido para o aspecto harmônico.

\footnotetext{
${ }^{15}$ Lindley, M. "Temperaments" - in Sadie, Stanley. The New Grove Dictionnary of Music and Musicians, vol.18. London: Macmillan Publishers Limited, 1980, pp.660-674.
} 
Quando duas ou mais notas são sobrepostas ou reunidas, elas podem formar um acorde, que por sua vez, vem fundamentar uma configuração harmônica de um trecho musical.

No decorrer da História da Música, os estudos de muitos tratados e compêndios a respeito do tema apontam diretrizes e possibilidades para uma boa estruturação que viera garantir um resultado musical satisfatório para o tonalismo. $\mathrm{Na}$ literatura da Prática Comum, todo tipo de aconselhamento é proposto em prol da obtenção dos melhores efeitos da tonalidade.

Apesar de seu amplo significado, pode-se entender Harmonia, neste caso, como a prática musical que busca discorrer e organizar normas para compreensão e apreensão da utilização do Sistema Tonal.

Os acordes, os intervalos e todo o conjunto de alturas e seu discurso no tempo, o exercício de condução das alturas e as relações entre os acordes, de forma a manusear a combinação de sons e a resolução das dissonâncias, constituem o corpo teórico da Harmonia. Todos esses elementos e processos citados têm como base a altura do som.

$\mathrm{Na}$ prática tonal, a dissonância constitui capítulo importante, pois ela exige critérios diferenciados em sua preparação, suspensão e resolução. Em diversos períodos da Prática Comum, o tratamento da dissonância aponta caminhos e resoluções distintas.

Como vem elucidado por Marisa Ramires e Sérgio Figueiredo em seu livro de teoria da música:

Dentro do contexto da música tonal a consonância pode estar vinculada a impressões de establidade ou repouso, enquanto que a dissonância sugere instabilidade ou movimento. Pedagogicamente torna-se útil a adoção desta pespectiva, pois tais conceitos de consonância e dissonância podem ser aplicados a uma grande variedade de repertório de música tonal ${ }^{16}$

A classificação de sons dissonantes e consonantes é mutável ao longo da História e consequentemente, o tratamento da dissonância se alterou com esta variação proporcionando grandes transformações.

\footnotetext{
${ }^{16}$ LIMA, Marisa Ramires R. \& FIGUEIREDO, Sérgio Luiz F. de. Exercícios de Teoria Musical - Uma abordagem prática.São Paulo: Embraform, 2004.p.96.
} 
O conceito de definição de consonância e dissonância, até então, baseado na sensação em que o ouvido experimenta pode ser entendido como algo subjetivo, desde que admite os mais variados tipos de sons classificados como consonantes e dissonantes, eleitos, ou não, através da familiaridade que eles proporcionam a um número muito significativo de agrupamento de pessoas, de tempos em tempos, determinando um gosto transitório. Esta razão nos leva a refletir a cerca do contexto sócio cultural em que ocorre sua aceitação.

Trata-se de uma definição temporal que, de fato ocorreu na História da Música, afinal, sem esta mutabilidade a Música não haveria de se transformar.

\subsection{1 - A Dissolução da Prática Comum}

Ao longo da História, o tratamento das dissonâncias passou por muitas transformações, e de tanto que variou, conduziu o Tonalismo a uma expansão e fez com que a Prática Comum fosse descaracterizada.

No final do século XIX, a Prática Comum foi, definitivamente, se desintegrando a partir de Richard Wagner (1813-1883).

Embora, alguns estudos apontem como supostas críticas, endereçadas a esta prática em obras eventuais, como por exemplo, a Fantasia e Fuga Cromática, de Wolfgang Amadeus Mozart (1756-1791), que tem por base a escala cromática; e ainda, os últimos Quartetos de Cordas, de Ludwig Van Beethoven (1770-1827), que apresentam longos trechos com centro tonal instável, completamente indefinido com uso intenso do cromatismo; ao longo desses três séculos, em alguns compositores trata-se de ações isoladas que, mesmo assim, não foram suficientemente contundentes para formar um movimento eficaz de abandono à tonalidade. Eles próprios se voltavam novamente para a carga e os efeitos tentadores do desenvolvimento do tonalismo. ${ }^{17}$

Tem-se uma definição da estrutura cromática dominando a música, de fato mesmo, somente a partir da obra de Richard Wagner (1813-1883) através da melodia ininterrupta impulsionada pelo avançar cromático das harmonias.

\footnotetext{
${ }^{17}$ PISTON, Walter. Op.Cit.
} 
Assiste-se então, o abandono do sistema tonal, no findar do século XIX, de maneira mais ostensiva e sistemática nas composições de Franz Liszt (1811. 1886), Richard Wagner e Claude Debussy (1862-1918).

Em discurso, realizado em 1993, por ocasião de obtenção do prêmio Balzan, György Ligeti (1923-) registra importantes reflexões sobre o tratamento das dissonâncias, dominantes secundárias, modulações e o desmanche tonal, expondo resumidamente um Itinerário do Sistema Tonal, abarcando o século XII, percorrendo os séculos subsequentes, até chegar em sua própria maneira de compor. Ligeti, então narra que:

é com Chopin que o papel das dominantes secundárias se engendram de tal forma no seio do sistema de modulações que a coluna vertebral da tonalidade vacila. A primeira peça atonal da história da música poderia bem ser o final Prestíssimo da Sonata em si bemol menor de Chopin ${ }^{18}$

No ano de 1889, em comemoração ao centenário da Revolução Francesa, quando houve a Exposição Internacional de Paris, na cosmopolitana capital francesa, muitos artistas e compositores da Europa, ao visitarem esse evento, se depararam com uma enriquecedora mistura de expressões artísticas advindas do oriente próximo e do extremo oriente; ficaram então, fascinados ao constatar a beleza de outro universo sonoro não imbuído pelo sistema tonal, foi então que alguns deles passaram a experimentar e aplicar alguns procedimentos dessa "outra" música que, até então, era distante.

Com a incursão de escalas provenientes de outras culturas, além do cromatismo e alguns modelos particulares, alguns compositores dessa fase, tais como Claude Debussy, 1862-1918, Erik Satie, 1866-1925, Aleksander Scriabyn, 1872-1915, Paul Hindemith, 1895-1963, buscavam uma diferenciação na concepção sonora de suas obras.

Dentre outras questões, já citadas, também o acréscimo disto tudo fez com que a Prática Comum mais uma vez se enfraquecesse.

\footnotetext{
${ }^{18}$ LIGETI, Gyorgy. Sciences, Musique et Langues. (tradução do alemão por Lucie Kayas). In http:www.mactexier.ircam.fr/textes. Extraído do discurso para o prêmio Balzan. Editora original: Neue Zeitschrift für Musik, janeiro 1993.
} 
Passou-se a pensar para além da disposição dos graus da tonalidade, da hierarquia dos acordes, das tríades para constituir a forma, da estrutura e do próprio discurso musical.

O compositor e, também, regente francês Pierre Boulez (1925), considera que o Prélude à L'Après-Midi d'Un Faune, de Claude Debussy, obra de 1894, prefigura o início do Modernismo do século XX. ${ }^{19}$

Se a música moderna teve um ponto de partida preciso, podemos identificá-lo [na] melodia para flauta que abre o Prélude à L'Après-Midi d'Un Faune, de Claude Debussy ${ }^{20}$

\section{E acrescentando Roland de Candé:}

Debussy. Este escolheu o caminho mais "selvagem" de todos: o do prazer e da liberdade. Desde L'Après-Midi d'Un Faune (1894), ele progride fora dos caminhos conhecidos, lançando mão de tudo e deixando-se guiar por sua extraordinária sensibilidade auditiva, por sua intuição do inaudito. Ele inaugura uma nova maneira de perceber a música, de comover-se com ela, um tipo de comunicação musical audaciosamente independente das referências intelectuais ${ }^{21}$

Já não se poderiam enquadrar facilmente diversas obras de alguns compositores que viriam, por demasia, enriquecer o cenário musical nessa fase, e ainda que tomássemos algum manual de harmonia do século XIX e tentássemos analisar suas obras, seria, ainda assim, colocá-las em uma camisa de força.

É muito comum em algumas partituras figurar a armadura de clave dando referência a determinada tonalidade, como por exemplo, o mesmo prelúdio de Debussy, mencionado acima, apresenta a armadura de Mi Maior, e, no entanto, todo o discurso apresentado não corresponde mais a um centro tonal claro e bem definido. Isto vem demonstrar como que alguns compositores se ligavam ainda a uma tradição, ao mesmo tempo, que buscavam um caminho para se libertar da mesma.

Charles Rosen aponta o compositor russo Igor Stravinsky, também, como sendo um dos responsáveis pelo processo da dissolução da Prática

\footnotetext{
${ }^{19}$ BOULEZ, Pierre. A Música Hoje. São Paulo: Perspectiva Editora, 1995.

${ }^{20}$ GRIFFITHS, Paul. Op.Cit.p.7.

${ }^{21}$ CANDÉ, Roland de. História Universal da Música - Volume 2. Tradução: Eduardo Brandão. São Paulo: Martins Fonte, 2001.p.195.
} 
Comum $^{22}$ Pois, eis que até mesmo antes de sua última fase criativa, quando passa a adotar o Dodecafonismo, se pode observar o tratamento livre da tonalidade em muitas das obras de Stravinsky, como por exemplo, a melodia inicial da Sagração da Primavera, no registro agudo do fagote, o ballet Petrouschka, onde a sobreposição de tonalidades é utilizada, em O Pássaro de Fogo, a mistura de alguns trechos tonais com trechos modais.

A diferença entre a experiência de Arnold Schoenberg em relação a outros compositores contemporâneos seus que procuraram evitar a tonalidade, aplicando novos materiais composicionais, dissolvendo o fator tonal é, que por volta de 1921, este vienense elaborou um sistema específico, com elementos, relações e atributos determinados, propondo substitutivos que encaravam frontalmente a espinha dorsal do Tonalismo: uma reorganização das alturas sem sentido diatônico, que evitasse uma hierarquia à qual eram submetidas as alturas.

Com o desenvolvimento da era da eletricidade, os aparecimentos do rádio, do cinema, propiciaram um significativo e expressivo ambiente que deu terreno a acalorados movimentos que provocaram pontuais mudanças, a transição entre os séculos XIX e XX, trouxe experiências de renovação vivenciadas nas várias formas de arte.

Assim foi nas artes plásticas, na pintura que contavam com ícones como Wassily Kandinsky (1866-1944), Henri Matisse (1869-1954), Pablo Picasso (1881-1973), Marcel Duchamp (1887-1968), que tomados por essa efervescência, tinham como ponto de partida comum, dentre outros, o questionamento da validação de regras e conceitos no tocante à tradição.

$\mathrm{Na}$ diversidade da música contemporânea pode-se pensar que um dos pontos de partida foi estabelecido por Arnold Schoenberg, quando ele fundamentou a negação da Prática Comum. As várias faces de Schoenberg têm sido inspiração, através de algumas de suas idéias composicionais, de suas músicas, enfim, das referências musicais e filosóficas propostas por ele, não somente durante a sua existência, mas também à propagação e dimensão de sua acurada reflexão que, de maneira direta, com seus discípulos mais próximos,

\footnotetext{
${ }^{22}$ ROSEN, Charles. Schoenberg. Paris: Les Editions de Minuit, 1979. p.11.
} 
através de sua "escola", ou, de maneira indireta, com outros compositores de outras gerações que, viriam investigar tantas outras inquietações.

\section{2 - O Pensar da Segunda Escola de Viena}

Ao considerarmos a Primeira Escola de Viena como o grupo de alguns compositores do período Clássico, os quais escreveram significativamente na segunda metade do século XVIII, em Viena, e que sendo eles, Wolfgang Amadeus Mozart (1756-1791), Joseph Haydn (1732-1809), Ludwig Van Beethoven (17701827), e ainda, tomando como seus sucessores vienenses Franz Schubert (17971828), Anton Bruckner (1824-1896), Johannes Brahms (1833-1897) e Gustav Mahler (1860-1911); poder-se-ia pensar então que, posteriormente, um segundo grupo de compositores, que por sua vez, formado por Arnold Schoenberg (18741951), Anton Webern (1883-1945) e Alban Berg (1885-1935), viriam testemunhar juntos um conjunto de experiências e pesquisas composicionais, em um momento histórico muito particular, na capital austríaca. Partindo dessa premissa, então, poderíamos denominá-lo como a Segunda Escola de Viena.

Conforme Charles Rosen:

O mestre encontrou em seus discípulos um gênio igual ao seu e uma precocidade mais remarcável ainda (...) as pesquisas mais radicais foram engajadas por Schoenberg (...) mas a influência não tarda a ser ${ }_{23}$ recíproca, e Schoenberg deve muito ao estímulo vindo de seus discípulos

Para compreender a música no século $X X$, é necessário se aproximar Da reflexão proposta pela pesquisa da Segunda Escola de Viena. Pode-se dizer que Schoenberg condensou o pensamento musical de uma época, apresentando propostas desde a tradição até a vanguarda em um mesmo tempo, e que lançou bases para fundamentar uma música futura, criando um novo paradigma com células a partir de 3 ou 4 sons, e que estes estão presentes nos espelhamentos, como a inversão, retrógrado ou transposições. Os acordes surgem dessas células. As células são bases geradoras para todo o material composicional. No

\footnotetext{
${ }^{23}$ ROSEN, Charles. Op.Cit.p.15.
} 
decorrer da sua vivência Schoenberg vai experimentando esses princípios organizativos de séries que vão desde $2,3,4 \ldots$ sons, até chegar nos 12 sons, quando se estabeleceu a técnica dodecafônica. Nota-se nos procedimentos composicionais adotados por algumas gerações futuras de compositores, um traço semelhante: a ausência da Prática Comum, como ponto de partida, principalmente, após a Segunda Guerra Mundial. "Schoenberg tornou-se um clássico sem jamais receber do público uma acolhida unânime."24

Embora Arnold Schoenberg possa ser considerado um clássico, no sentido de ter se tornado uma referência histórica, um modelo, ou até mesmo, uma fonte de profusão de idéias, de onde se originaram muitas reflexões, deixou um rastro de libertação através da prospecção da técnica e do procedimento composicional. A técnica dodecafônica permite que cada compositor crie a ordenação dos sons conferindo-Ihe uma liberdade e autonomia mais expansiva.

Essa tendência libertadora dos compositores a partir dos anos 50 do século $X X$ remete-nos à transição ocorrida entre os séculos $X I X$ e $X X$, quando o tonalismo vigente é expandido, incorporando procedimentos e elementos que ainda não eram usuais no momento precedente. Na ânsia de estabelecer seu estilo próprio, a nova ordenação das alturas provoca em diversos níveis o desmanche do domínio tonal.

Desse momento, por diante, com a desconstrução do tonalismo e pouco mais tarde com a ascenção do Dodecafonismo, nota-se uma abertura de possibilidades na maneira de se compor. O Tonalismo e tudo que ele continha já não eram mais a única via de possibilidade para o labor composicional. As alturas se tornaram valores únicos, obtendo cada qual sua autonomia, sem haver a necessidade de uma pendência hierárquica para algum centro de gravidade.

O Dodecafonismo resultou de um longo caminho musical trilhado por Schoenberg que, até então, havia passado por muitas reflexões, experimentando inúmeras possibilidades, descartando e acrescentando materiais, advindos do próprio pensar tonal que ora descomposto servirá de base para o seu próprio desmontar.

\footnotetext{
${ }^{24}$ ROSEN, Charles. Schoenberg. Paris: Les Editions de Minuit, 1979. p 9.
} 


\subsection{1 - Sobre Webern}

Anton Webern, que viveu de 1883 a 1945, pode ser compreendido como o precursor do Serealismo Integral, movimento que mais tarde foi consolidado por Pierre Boulez (1925) e Karlheinz Stokchausen (1928-2003). Após o contato com a série dodecafônica, Webern incorporou-a de tal forma, que acabou criando maneiras de abordá-la dentro dos padrões de uma estrutura simétrica, dando sempre primazia à forma e, mesmo sendo habilmente comedido, efetivou uma linguagem por demais concentrada em suas obras.

Iniciou seus estudos com o Arnold Schoenberg em 1905. Durante esse período somente duas de suas composições aparecem com catalogação de opus: a Passacaglia e a peça para coro misto a 4 vozes, a capella, Entflieht auf liehten Kahnen, ambas compostas no ano de 1908.

É possível observar a frequência de harmonias inesperadas, em suas primeiras obras, um jeito, eventualmente, associado a Johannes Brahms. Nessas peças onde já se destaca claramente a preocupação com a estrutura e forma.

Logo, em suas primeiras composições apresenta a experiência com a atonalidade, escrevendo diversos lieder, quartetos de cordas, quintetos, temas e variações para piano e obras para orquestra.

O estilo de composição de Webern, conforme proposto pelo próprio compositor, em seu livro O Caminho para a Música Nova, ${ }^{25}$ pode ser dividido em três fases distintas: a primeira, a partir de 1908, que inclui do opus 3 até o opus 11 , quando experimenta abandonar a tonalidade e tem como resultado diversas peças curtas e pontilhísticas. ${ }^{26}$

A partir de 1914, o que se considera da segunda fase, nesse momento retoma a escrita para voz e inicia o trabalho de conexão entre as partes para constituir uma forma contínua e lograr unidade.

\footnotetext{
${ }^{25}$ WEBERN, Anton. O Caminho para a Música Nova. p.207.

${ }^{26}$ Pontilhismo: Técnica de composição que dá a impressão de a música consistir em sequencias de pontos de som, em vez de linhas melódicas fluentes. O Pontilhismo em música derivou da escola de pintura que teve no pintor francês Georges Seurat seu inventor e principal representante. Parte da música de Stockhausen e Webern é descrita como pontilhista. (Organizadores: Alan Isaacs e Elizabeth Marttin - tradução Álvaro Cabral) - Rio de Janeiro - Zahar Editores S.A. 1985.
} 
A última fase e terceira, de 1926 até sua morte, passa a compor para formas instrumentais maiores, sucessivamente, já plenamente confiante do uso da técnica dodecafônica. ${ }^{27}$

Inicialmente, Schoenberg introduz a técnica das doze notas a um grupo mais íntimo de discípulos e amigos no início de 1920; e é logo nesse ano que Webern já começa utilizá-la, mas só irá concretizar sua primeira obra totalmente dodecafônica o Trio para Cordas, opus 20, terminada em 1928.

Para apontar seu estilo aforístico, como revela o próprio título a Bagatellen opus 9, Drei Kleine Stucke, opus 11, para violoncelo e piano de 1914, onde a terceira de suas peças traz uma tênue e sutil gama de intensidade, construída inteiramente de ppp e pp; onde o violoncelo toca apenas oito notas e o piano três notas melódicas e mais três acordes. Este opus conta com 32 compassos, e representa o extremo da brevidade no estilo aforístico de Webern.

Na Sinfonia, opus 21, o gênio de Webern mantém sua intensa busca pela simetria, utilizando-se dos planos vertical e horizontal com espelhos e palíndromos por meio de cânones duplos.

Os principais elementos estilísticos inovadores na composição de Anton Webern estão intimamente ligados em grau de importância, compreendem o timbre, a intensidade e o silêncio. Utilizando o timbre como parâmetro, o compositor evolui por várias trilhas de desenvolvimento para o argumento musical, utilizando efeitos instrumentais como parte integrante da articulação musical. Com essa forma de trabalhar, Webern justapõe extremos de tessituras e contrastes tímbricos, registros e variedades constantes, propondo com essa experiência, verdadeira habilitação da gama de nuances, até aquele momento, inauditas.

Desde as primeiras peças, da juventude de Webern, pode-se notar o gosto pela simetria que Webern vai desenvolvê-lo ao extremo no Concerto de Camera, opus 24, construído a partir de um provérbio latino, podendo ser lido nas quatro direções.

\footnotetext{
${ }^{27}$ BAILEY, Kathryn. "Webern" In; The New Grove Dictionnary of Music and Musicians. London: Macmillan Publishers Limited, 1980, pp. 179-195.
} 
E ainda, as Variações - opus 27, de 1937, Quarteto de Cordas, opus 28,1936-1938; Cantata n.1 - opus 29,1938-1939; Variações para Orquestra opus $30 .^{28}$

\subsection{2 - Sobre Berg}

Alban Berg viveu de 1885 a 1935, optou por condensar e mesclar todas as experiências pensadas junto a seus pares, buscando associar o método dos doze sons sem, no entanto, abandonar por completo a tonalidade.

Herdou e absorveu completamente a cultura musical de sua origem vienense. Conforme relata Jameaux, Berg possuía um:

“modo vienense' de escrita instrumental (...) indo até o limite de suas possibilidades (...) também uma maneira vienense de escrever as frases com suas anacruses iniciais, o primeiro acento, o 'levare', o climax expressivo, a retomada, o acento final e desinência (...) Também uma maneira vienense de acompanhar uma frase de ligá-la à seguinte, uma maneira de juntar letras em palavras, palavras em frases, frases em parágrafos, parágrafos em discursos e de organizar tudo de maneira que tudo esteja lá, sem nada de supérfluo." ${ }^{29}$

Partindo do ambiente musical vienense pós-romântico, Berg também foi em direção ao Dodecafonismo, mas o faz inspirado no modelo vienense de escrita pontuado em toda a sua obra.

A cultura musical vienense, ao mesmo tempo, que aportara a criação, o culto à sinfonia, e também à ópera alemã, continha nomes de grande referência, foram eles, Robert Schumann, Richard Wagner, Johannes Brahms, Hugo Wolf, Richard Strauss, Gustav Mahler e agora Arnold Schoenberg.

Como em outros jovens compositores desse período, o inexorável hálito da modernidade batia-Ihe à porta. A expansão harmônica, as novas aquisições orquestrais, o teatro, a música, o drama musical, chegavam até Berg com Wagner e alguns antecessores através das reflexões junto a Schoenberg.

Berg iniciou seus estudos com Schoenberg, em 1904, que ao se lembrar de seu aluno jovem associa-o imediatamente ao movimento romântico da

\footnotetext{
${ }^{28}$ BAILEY, Kathryn. Op.Cit.

29 In: JAMEAUX, D. Berg. Paris, Ed.Seuil, 1980. p.9
} 
época. Schoenberg escreve "Eu examinei as composições que ele me apresentava, melodias num estilo que se situavam entre Hugo Wolf e Brahms, reconheci um verdadeiro talento."30

Dando continuidade à linha romântica, é possível elencar os traços comuns entre Robert Schumann e Alban Berg, esses podem ser notados em vários sentidos. Ambos possuíam apreço e dividiam seus gostos entre a poesia e a música desde a juventude, tanto que na produção musical de ambos se encontram grandes obras com referência e apoio no veículo verbal. Elementos musicais nas partituras de Alban Berg que passam pelas indicações expressivas de maneira minuciosa, a valorização e organização do silêncio, a acentuação, a construção fraseológica, o trabalho motívico, apontam um apreço ao Romantismo de Robert Schumann. Se melhor observado seu aspecto romântico, Berg é intenso na busca pela unidade no prolongamento de um discurso, onde faz predominar a tensão como a exemplo, em uma de suas primeiras obras, a Sonata para Piano, Opus 1, e também na última obra, inacabada por ele, o drama de Lulu. Jameaux afirma que em Berg ocorre "uma dramatização do discurso instrumental como paralelo complementar da sinfonização da ópera." ${ }^{31}$

Grande influência sobre a composição de Berg, também, foi a presença de Richard Strauss. O tratamento da voz e do texto poético nos Lieder, a Orquestração de Strauss, a exemplo de seus poemas sinfônicos, a importância dele na ocupação do espaço cênico teatral em sua época; são alguns traços indeléveis na obra de Alban Berg. Ainda que houvesse um ponto de encontro, no tocante aos elementos, ideias e estruturas musicais, a postura e ideais de Richard Strauss em relação ao passado, à cultura e à herança se opunham aos ideais de Berg. Como elucida Jameaux: "Strauss depois de 1910 acreditava no fazer o novo com o velho. (...) A atitude de Berg em relação à cultura é totalmente diferente e se faz sobre o modo da citação/ruptura."32

A citação/ruptura a que Jameaux se refere pode ser observada em Alban Berg, como uma das características essenciais que o acompanha e pontua

\footnotetext{
${ }^{30}$ BARILIER, Etienne. Alban Berg. Ed. L'Age d'Homme. Lausanne,1978.p.47.

${ }^{31}$ In: JAMEAUX, D. Berg. Paris, Ed.Seuil, 1980.p.11.

32 In: JAMEAUX, D. Berg. Paris, Ed.Seuil, 1980.p.13.
} 
sua obra durante a sua existência; especialmente como lida com cada uma das fórmulas instrumental ou vocal, como une de maneira enriquecedora essas transversais, habilitando-as a transitarem uma no terreno da outra. Como utiliza cada escolha, de forma a não repeti-la, em geral, propondo modificações, sutis ou por vezes mais contundentes, no decorrer da obra.

A figura de Gustav Mahler, também, exerceu grande poder de influência sobre aquela que se denomina A Segunda Escola de Viena. Dentre as várias razões, a figura conciliadora de Mahler que soube gerir tantos os aspectos de Johannes Brahms e Richard Wagner; utilizou o timbre como parâmetro estrutural e essencial em sua música; como sinfonista deu abertura a obras de seus contemporâneos, de outras vertentes; apesar de ser considerado um romântico tardio, em suas composições trabalhou com a instabilidade tonal; profissionalmente tomava claramente uma posição crítica ao stablishment vienense; e acima de tudo a dramaticidade expressiva.

Percebe-se, constantemente, a presença de Mahler em obras berguianas, seja nas reminiscências da valsa vienense como proposição de um universo amável, que pontua toda sua obra desde a Sonata opus 1 - 1907-1908, abrangendo o Concerto de Câmara - 1925, até a ópera Lulu, 1929-1935; o teor melancólico encontrado na Sonata, nos Lieder com texto de Peter Altenberg, opus 4 - 1912; no Interlúdio e vários trechos da ópera Wozzeck - 1917-1922, no último movimento da Suíte Lírica - 1925-1926; influências de canções de cunho popular, novamente nas óperas Wozzeck e Lulu - 1929-1935, no Concerto para Violino $1935 .{ }^{33}$

Mas, a figura carismática de Schoenberg, como professor e mentor, é que mais exercia um fascínio, não só pelas inquietações musicais e filosóficas, mas também pelo aspecto intelectual e pessoal. "Quatro de suas dezenas de obras da maturidade, ele dedicou a Schoenberg." 34

$\mathrm{Na}$ fase inicial de suas composições, Berg dedica-se, essencialmente, a canções para canto e piano, ou lieder; entre os anos de 1900 a 1908, quando a

\footnotetext{
${ }^{33}$ In: JAMEAUX, D. Op.Cit. p.14.

${ }^{34}$ GRIFFITHZ, Paul. Enciclopédia da Música do Século XX - 1995. Verbete: Berg, Alban - p.21.
} 
partir desse último ano, começa o estudo de composição com o mestre (Schoenberg), estendendo-o até 1911.

Uma admiração mútua pode ser notada entre ambos, visto que Schoenberg apreciando e reconhecendo o seu talento, ao examinar a situação precária das finanças de Berg; acolheu-o como aluno, ministrando-lhe curso de composição, gratuitamente. Segue um depoimento escrito por Arnold Schoenberg:

Desde as primeiras composições de Berg (...) pode-se assinalar duas coisas. Primeiro, que a música para ele é uma língua, e que ele se exprime verdadeiramente nesta língua; e segundo: um calor transbordante de sentimento ${ }^{35}$

Ao se afirmar que Anton Webern cuida criteriosamente da simetria, se aprofundando no Serialismo, pode-se então dizer que, Alban Berg sempre foi criterioso com a dramaticidade em todo o seu aporte musical, sem abandonar o tonalismo.

\section{3 - Conceito de Atonalismo}

O termo atonalismo foi utilizado, pela primeira vez, por críticos para argumentarem sobre Pierrot Lunaire ,1912, de Schoenberg. ${ }^{36}$

Arnold Schoenberg achava esse termo inadequado, deixando diversas declarações justificando que esta expressão não era apropriada para conceituar a música que acontecia naquele momento, e ainda menos definiria a música que ele fazia.

Em 1921, ao analisar uma configuração de acorde não convencional, Schoenberg prolonga-se em nota de rodapé, na terceira edição de seu livro intitulado Harmonia, explanando sobre a atonalidade:

A lista dos que hoje empregam tais procedimentos é muito grande. (...) A quantidade e qualidade dos companheiros de luta me dão uma grande satisfação. Para eles, naturalmente, existe uma nova "direção", e denominam-se atonais. Tenho que me distanciar deste termo, pois que eu sou músico e não tenho nada a ver com o atonal.

Atonal poderia simplesmente significar: algo que não tem nada a ver com a natureza do som. Já a expressão "tonal" se usa impropriamente se se entende em um sentido excludente e não includente. Só se deve

\footnotetext{
${ }^{35}$ In: JAMEAUX, D. Op.Cit. p.31

${ }^{36}$ BOUSSER, J-Y. Vocabulaire de la Musique Contemporaine. Paris: Ed. Minerve, 1992.
} 
entender de maneira includente: tudo o que procede de uma sucessão de sons, seja por relação direta com uma única fundamental, ou seja, mediante relações mais complexas, constitui a tonalidade. É evidente que se baseando nesta definição que é a única justa, não se pode estabelecer racionalmente uma oposição que corresponda a palavra "atonalidade. ${ }^{37}$

Ele chega a sugerir o termo "pantonal" e adverte sobre a questão da necessidade de refletir a respeito dessa música ser ou não ser tonal. Ainda que não houvesse um centro tonal claramente definido, mesmo neste caso, para Schoenberg a tonalidade continuava a existir.

Em Teoria e Composição artigo, da edição francesa de Estilo e Idéia, discorre o assunto:

composição através de doze sons que não tem outro parentesco que aquele de cada som com cada outro. Quanto à questão, não devemos nem podemos escrever tonalmente, não devemos nem podemos escrever atonalmente. Escrever ou não escrever, mas em todo caso não faça perguntas, faça o que você é capaz. Se você tem em si do que escrever uma bela obra, escreva, tonal ou atonal ${ }^{38}$

Ao analisar sua própria obra o Segundo Quarteto para Cordas opus 10, aponta-o como a transição para o segundo período criativo dizendo:

\begin{abstract}
Nessa época, eu renunciava construir minha música em torno de um centro tonal, inovação que chamaram incorretamente de "atonalidade". No primeiro e segundo movimentos desse quarteto, existem numerosas passagens onde as partes independentes se movem sem a preocupação de saber se a sobreposição produzirá ou não harmonias de escola. Entretanto aqui, como no terceiro e quarto movimentos, distingue-se claramente a tonalidade em todos os lugares essenciais de articulação da estrutura formal. ${ }^{39}$
\end{abstract}

Para a Segunda Escola de Viena, a atonalidade não implicaria em excluir a tonalidade, mas que essa primeira é um alargamento estendido da própria tonalidade, agora impregnada de recursos e vantagens concedidas que até àquele momento, ainda estava submetida aos princípios de subordinação normatizados pelo conceito de tratamento da dissonância. Idéia esta que foi bem

${ }^{37}$ SCHOENBERG, Arnold. Armonia. Trad. Ramon Barce. Madrid: Ed. Real Madrid, 1974. pp. 484-5.

${ }^{38}$ SCHOENBERG, $A$. Stile e Idea. Milano: Rusconi e Paolazzi Ed., 1960.

${ }^{39}$ SCHOENBERG, A. Stile e Idea. Milano: Rusconi e Paolazzi Ed., 1960. 
sintetizada por Arnold Schoenberg, em seu livro Harmonia, em 1911, quando afirmara que projetava um processo de "democratização da harmonia".

Anton Webern e Alban Berg compartilhavam da mesma opinião, viam a expressão atonalidade como um termo degenerativo, como um entendimento da negação da música, e que esse termo poderia ter sido aplicado pelos adversários da música nova, e que além de recusá-la, criticavam-na, à medida que percebiam que ela tomava vulto. Webern concluiu "A tonalidade foi, até nossos dias, um dos meios mais importantes para criar uma coerência. Ela é a única aquisição da música do passado que desapareceu, todo o resto existe ainda." ${ }^{40}$

Em 1934, Edgard Varèse, aborda o atonalismo como uma corrente consolidada, reconhecendo a importante influência de Schoenberg, assume a mesma postura da Segunda Escola de Viena, endossando que a atonalidade é a própria tonalidade que se liberta da hierarquia das funções nos moldes tradicionais:

Acredito (...) que Schoenberg tem muito mais importância. Sua influência será grande, mas seu "sistema" provavelmente, contestado: ele é para música o que o cubismo é para a pintura. 0 "sistema" atonal não existe verdadeiramente; é uma concepção falsa, pois sentimos uma tonalidade, que recusamos sua presença ou não. Não é necessário ter uma tônica com sua terça ou quinta para estabelecer uma tonalidade; de fato, o que é o acorde senão uma fundamental com seus segundos e terceiros harmônicos? Que se designe como atonal ou não, Schoenberg é um romântico para a concepção e um impressionista para execução ${ }^{41}$

E ainda Bela Bártòk, discorre no mesmo sentido:

A música de nossos dias tende resolutamente ao atonal. Entretanto, não parece exato de conceber o princípio tonal como o contrário do princípio atonal. Este último é bem mais a consequência de uma evolução que se deu pouco a pouco a partir do tonal, que progride gradualmente e que não mostrou nenhuma quebra nem salto violento ${ }^{42}$

Entretanto, é com a composição de Bela Bártòk que a expressão atonalismo vai se consolidar como vocabulário na história da música moderna, logrando uma conotação não pejorativa, mas adquirindo um conceituado respeito.

\footnotetext{
${ }^{40}$ BOUSSER, J-Y. Vocabulaire de la Musique Contemporaine. Paris: Ed. Minerve, 1992. pp.21 a 23.

${ }^{41}$ BOUSSER, J-Y. Vocabulaire de la Musique Contemporaine. Paris: Ed. Minerve, 1992. pp.21 a 23.

42 BOUSSER, J-Y. Vocabulaire de la Musique Contemporaine. Paris: Ed. Minerve, 1992. pp.21 a 23.
} 
Outros termos difundidos na bibliografia podem dar referência a essa concepção histórica, tais como: pós-tonalismo, pantonal, atonal livre, tonal livre, transtonal. Ainda nos dias de hoje, existe uma tentativa de denominar ou mesmo classificar mais corretamente essa prática musical que extraída do sistema tonal não é tonal.

\subsection{1 - O Atonalismo Livre e o Atonalismo Estruturado ou Organizado}

Adentrando-se na fase atonal da Segunda Escola de Viena, percebe-se

uma subdivisão bem clara, em duas etapas. A primeira etapa é a liberdade dentro do atonalismo, interpretada por muitos como a fase atonal livre; e, a segunda etapa, é a fase do atonalismo estruturado ou organizado que pode ser entendido sobre essas perspectivas.

Sobre um texto datado em 24.11.1931, Das Werk Arnold Schoenberg, de Rufer e citado por Leibowitz:

De Bach: 1. O pensamento contrapontístico; quer dizer a arte de inventar figuras sonoras capazes de se acompanhar a si mesmas. 2 A arte de derivar o todo de uma só unidade e a maneira de encadearas figuras entre elas. 3.A emancipação de tempos do compasso. De Mozart: 1. A desigualdade do tamanho das frases. 2. O agrupamento de caracteres heterogêneos em uma só entidade temática. 3.0 desvio em relação ao número pares de compassos do tema e de seus compostos. 4. A arte da formação de ideias secundárias. 5. A arte de introduzir e de 'transitar'. De Beethoven: 1. A arte de desenvolvimento de temas e de movimentos. 2. A arte da variação e da diferenciação. 3. A diversidade na construção de movimentos de longa expiração. 4. A arte de alongar sem hesitação, mas também de reduzir brutalmente segundo as 'necessidades da causa'. 5. Ritmicamente: o deslocamento das figuras sobre outros tempos do compasso. De Wagner: 1. O uso que se pode fazer dos temas segundo suas expressões assim que suas concepções corretas em vista deste uso. 2. A familiaridade entre os sons e as cores. 3. A possibilidade de manter os temas e os motivos como entidades autônomas, o que permite suas superposições dissonantes à certas harmonias. De Brahms: 1. Muito do que tinha procurado inconscientemente em Mozart, sobretudo a irregularidade do número de compassos, extensão e condensação das frases. 2. A plasticidade das

formações: (...) não economizar quando a claridade exige mais espaço : levar cada figura às suas últimas consequências. 3. A concepção sistemática do aspecto global de um movimento. 4. Economia e, entretanto, riqueza. Também aprendi muito de Schubert e também Mahler, Strauss e Max Reger. Eu não me subtraí a ninguém e eu posso por consequência, dizer de mim mesmo: minha originalidade vem de todo 
o "bem" que nunca percebi e imitei ${ }^{43}$

O longo caminho que Schoenberg experienciou, de utilização e expansão da Tonalidade pode ser encontrado em uma peça, considerada de extrema significância intitulada Verklärte $\mathrm{Nacht}^{44}$, opus 4, do ano de 1899. Esta peça prefigura o processo de libertação criativa de material e procedimentos no tocante dos limites entre a tonalidade e a atonalidade e seu uso livre.

Schoenberg alargou a tonalidade e chegando ao Dodecafonismo, em 1921, onde procurou fundamentar suas escolhas musicais e assim justificá-las teoricamente.

A partir de Schoenberg, o tonalismo se encerra como domínio de sistema único. Para reiterar a citação de Carl Dahlhaus:

A tonalidade harmônica que dominou a cena por três séculos tem seu fim por volta de 1910. Foi um sistema universal de referência. Em contraste, nenhum sistema projetado no século $X X$, com exceção a técnica de 12 notas, apresentou específica validade para o trabalho dos compositores, a não ser em sua individualidade ${ }^{45}$

Em uma emissão da Rádio Frankfurt ao analisar seus Lieder, opus 22, para voz e orquestra, ele afirma:

Por volta de 1908, eu havia dado os primeiros passos (...) no domínio da composição chamada, injustamente de, atonal, e o traço característico é o abandono de um centro tonal e dos métodos de tratamento da dissonância em vigor até esta época ${ }^{46}$

Dentro ainda da fase atonal, em meio a tantas proposições e pesquisa, Arnold Schoenberg, "intui" de maneira metódica, uma idéia organizativa, para sustentar uma teoria e dar base ao que chamaria de método de composição dos doze sons.

O tratamento livre para com a Tonalidade manuseado por Schoenberg culminou em uma técnica denominada Dodecafonismo.

Inserido na fase Atonal Estruturada, ou Organizada surge, então, como fruto do próprio tonalismo, o Dodecafonismo que pode ser entendido como uma

\footnotetext{
${ }^{43}$ LEIBOWITZ, René. Schoenberg. Colection Solfèges n³0. Paris : Editions du Seuil, 1969. p.21.

${ }^{4}$ Noite Transfigurada

${ }^{45}$ DAHLHAUS, Carl. "Harmony" In; The New Grove Dictionnary of Music and Musicians. London: Macmillan Publishers Limited, 1980, p.183.

${ }^{46}$ SCHOENBERG, Arnold. Armonia. Tradução: Ramon Barce. Madrid: Ed. Real Madrid, 1974. p.43.
} 
concepção onde as mesmas alturas regulamentadas pelo sistema tonal, perderam a sua disposição diatônica em escala, tomando os doze sons da escala cromática, dispostos em uma sequência determinada pelo compositor, denominada série, tendo em vista a dispersão dos pólos atrativos do sistema tonal.

A série servirá como base estrutural para o material composicional. A partir da elaboração de uma série pode-se fazer criar uma composição musical. Em princípio a série deve ser elaborada em uma sequência onde não haja possibilidade de uma estrutura tonal se alojar.

Em uma conferência realizada na Universidade da California - Los Angeles em 1939, intitulada A Composição de Doze Sons, Schoenberg descreve de forma aprofundada.

Dessa conferência resultou a publicação de uma transcrição feita pela primeira vez em 1948, que foi revisada por René Leibowitz. Nela Schoenberg comenta: "A composição com doze sons não tem outro objetivo que a compreensibilidade"

Acerca de suas reflexões, referindo-se aos problemas da aceitação que suas músicas sofriam:

"As obras compostas no estilo não conseguiram se fazer compreender e isso malgrado a seus novos meios de organização."47

Apoiado na idéia da emancipação da dissonância faz uma breve incursão sobre Richard Wagner e Claude Debussy, e prossegue:

eu entendo que a compreensibilidade da dissonância é equivalente à compreensibilidade da consonância. (...) tratando a dissonância como consonância é a maneira de renunciar à supremacia do centro tonal. Evitando o estabelecimento de uma tonalidade, ultrapassamos a noção da modulação ${ }^{48}$

O Dodecafonismo, um método pensado para libertar e enriquecer o trabalho de composição do sistema tonal, emerge como "uma harmonia nova, rica em cores, ${ }^{\prime 49}$ compara o mestre vienense.

\footnotetext{
${ }^{47}$ LEIBOWTZ, René. Schoenberg. São Paulo: Perspectiva Editora, 1989.

48 LEIBOWTZ, René. Schoenberg. São Paulo: Perspectiva Editora, 1989.p.86.

${ }^{49}$ LEIBOWTZ, René. Schoenberg. Colection Solfèges n³0. Paris : Editions du Seuil, 1969.p.86
} 
Arnold Schoenberg aponta o Dodecafonismo como um sistema, que baseado na formação de uma ordem particular das doze notas da escala cromática de temperamento por igual, traz o substitutivo de algumas tendências unificadoras e formativas do centro tonal.

O pensar de Schoenberg em relação à autonomia do som, como que se cada freqüência de som, ou altura, trouxesse em seu interior um valor intrínseco, independente da relação com o outro, mas, que seu relacionamento abordasse uma série de significados. Este pensar veio endossar a autonomia que os compositores buscavam naquele momento, e ainda, influenciou por demasia não somente a música escrita, mas outras vertentes.

Respaldado por um momento histórico muito particular, a técnica Dodecafônica traz em seu seio as sementes de tantas moções que eclodiram com o movimento posterior. E por fim "o método dos doze sons" que passou a ser estudado historicamente pelas gerações vindouras, foi a força motriz para fomentar muitas transformações, trazendo em seu cerne a altura como núcleo gerador da existência primordial de outros parâmetros essenciais e simultâneos da vitalidade sonora.

Capítulo essencial para se entender a Música do século XX, o Dodecafonismo é entre tantas, uma das produções polêmicas da Segunda Escola de Viena, onde se elaborou uma reorganização das alturas que, por sua vez, gerou múltiplas possibilidades e experimentos no interior da criação e na forma de conceber a música, efetivando uma liberdade buscada por um grande número de compositores e apreciadores, alargando a percepção humana.

\section{4 - Os Processos de Dissolução Tonal na Linha de Prospecção por Schoenberg e sua extensão em Webern, Berg e Steuermann.}

O artista é um homem que em qualquer campo científico ou humanístico, percebe as implicações de suas ações e de novo conhecimento de seu tempo. Ele é o homem da consciência integral ${ }^{50}$

Pode-se entender que a música do século $X X$ é uma mistura complexa de diferentes tendências que constitui longa história de tentativas e experiências,

\footnotetext{
${ }^{50}$ MaCHULAN, Marshall. Os Meios de Comunicação e Extensões do Homem.
} 
as quais levaram a uma série de novas e fascinantes tendências, técnicas e, em certos casos, à criação de nova sonoridade, com base na síntese dos sons. Surgiram então correntes como: o Impressionismo, Expressionismo, Atonalismo, Serialismo, Microtonalismo, Música Concreta, dentre outras. ${ }^{51}$

\section{Conforme Juan Carlos Paz:}

Este movimento renovador, literário, teatral, pictórico e musical que foi o Expressionismo, irrompe pouco antes do começo do século [XX] e decorre de um princípio metafísico: a irrealidade entendida como única realidade possível, e cuja cristalização no plano estético deve ser obtida na expressão pressuposta como valor primordial, sacrificando-lhe tudo quanto não corresponda estritamente a essa finalidade. Nem seria necessário dizer que ao afirmar tais princípios, o Expressionismo revela uma evidente filiação oitocentista. O manifesto de Gauguin, Van Gogh, Sérusier, etc., fixa seu início em $1890^{52}$

\section{$(\ldots)$}

O Expressionismo pretende, em última instância, expressar a verdade subjetiva dos sentimentos, fazendo caso omisso dos antigos ideais estéticos. Seu ponto de partida é o realismo transfigurado pela visão interior, tende ao monodrama e dá origem à lírica pura. Supõe a atitude do homem só no mundo: observador, juiz, e intérprete sensorial e mental do universo. É o plano de Nolde, Munch, Kokoschka, Wrubel, Kandinsky, Modigliani, Chagall, Klimt, Rouault, na pintura; Wedekind, Frank Döblin, Toller, Kafka, Werfel, Kayser, na literatura e no teatro; Pabst, Dreyer, Wienne, Lang, no cinema; Schoenberg, Anton Webern, Alban Berg, Carl Ruggles, Hans Eric Apostel, Bem Weber, Nikolai Obujov, em música ${ }^{53}$

\section{$(\ldots)$}

O Expressionismo sonoro, que é de origem literária, psicológica e introspectiva, foi o processo que chegou ao ponto extremo e mais agudo do enfoque romântico-realista; trouxe consigo uma estimativa diversa dos fenômenos musicais e de sua aplicação ao terreno prático; mergulhou no plano introspectivo, chegando a densidades dramático-musicais até então não registradas e que procedem de uma interpretação obscura, misteriosa e incontrolada, produto direto da subconsciência ${ }^{54}$

$$
(\ldots)
$$

"É inegável que no Expressionismo é patente certa categoria de niilismo estético, de relatividade artística - na qual se poderia demonstrar tudo ou nada - de atração de princípios opostos, de inconformismo manifesto, de negação do conceito estabelecido de beleza, substituídos pelas

\footnotetext{
${ }^{51}$ PAZ, Juan Carlos. Introdução a Música do Nosso Tempo.

52 PAZ, Juan Carlos. Op.Cit. p.127.

${ }^{5}$ PAZ, Juan Carlos. Op.Cit. p.129.

${ }^{54}$ PAZ, Juan Carlos. Op.Cit. p.132
} 
sensações multiformes, pelo projetar-se em direção ao ainda não instituído ${ }^{55}$

Os integrantes da Segunda Escola de Viena, Arnold Schoenberg, Anton Webern e Alban Berg, viam a si mesmos, e sua própria música, como historicamente inevitáveis. Sentindo-se então, responsáveis pela reputação histórica obtida através das obras de grandes mestres da Música do passado como, Joseph Haydn (1732-1809), W. Amadeus Mozart (1756-1791), Ludwig Van Beethoven (1770-1827), Johannes Brahms (1833-1897), dentre outros, e que esta deveria continuar garantida. A questão era a seguinte, como legitimar sua arte e proceder a escrever a história? "Nos dias de hoje, onde a música atual é a música histórica (quer queiramos ou não)."56

No Modernismo Musical, Arnold Schoenberg foi o expoente da atonalidade. Ainda que vários outros compositores experimentassem abandonar 0 arraigado esquema da tonalidade, fosse pela bitonalidade ou pela politonalidade, jamais o fizeram por completo. Schoenberg logo considerou a falta de estruturação composicional sobre um eixo harmônico central, ou seja, que a linguagem atonal ainda se encontrava demasiadamente sem regras. Partindo, então, da escala cromática de doze sons, propôs um método para organizá-la de maneira que cada um de seus sons obtivesse igual valor, e que não seria repetido um som enquanto toda a série das doze notas não fosse apresentada, método esse que se tornou conhecido como o Dodecafonismo.

A utilização dos procedimentos composicionais elaborados por Schoenberg se estendeu, não só à sua primeira geração de alunos, mas a outras tantas, que indiretamente ou diretamente estudaram com ele.

Edward Steuermann (1892-1964), compositor com notável catálogo de obras, que de maneira direta se tornou seu aluno de composição, em 1912. Além de seu gosto e entusiasmo em relação à "Música Moderna," também trazia suas habilidades como pianista ora executando, ora escrevendo arranjos para obras de

\footnotetext{
${ }^{55}$ PAZ, Juan Carlos. Op.Cit. p.133

${ }^{56}$ HARNNONCOURT, Nikolaus. O Discurso do Som.
} 
alguns compositores modernos, desempenhando importante papel para soluções técnicas de execução da música que renascia nesse período. ${ }^{57}$

Pode-se dizer que a partir da primeira apresentação mundial de Pierrot Lunaire, em 1912, ele foi o pianista oficial da Segunda Escola de Viena, ${ }^{58}$ obtendo estreito laço com o mestre e seus alunos, em um rico e produtivo convívio na Sociedade de Concertos Particulares. ${ }^{59}$

\begin{abstract}
As origens compósitas do expressionismo - literárias, pictóricas, teatrais fatalmente deveriam impulsionar em direção à representação concreta; daí a importância e a categoria que o drama musical ou simplesmente o melodrama e até o lied - música de comentário ou música aplicada, em todos os casos - alcançou graças àquelas, sem esquecer, é claro, a cantata e o poema sinfônico. Naturalmente não é o da música de programa o único aspecto musical que se chegou a cultivar, confesso ou não; (...) mas frente a essa produção que corresponde ao critério de música absoluta, cabe considerar uma quantidade apreciável de música de comentário ou de música aplicada a uma ação literária ou teatral: por exemplo, os três ensaios cênicos referidos, o melodrama Pierrot Lunaire, o poema sinfônico Verklärte Nacht, os Gurrelieder, o oratório Die Jakobsleites, a Ode to Napoleon Buonaparte, The Survivor from Warsaw, - Kol Nidre, a ópera inacabada Moses und Aaron, quatro extensas obras corais - os oppi $13,27,28$ e 35 - e dez séries de lieder ${ }^{60}$
\end{abstract}

A Segunda Escola de Viena, na fase que precedeu o atonalismo organizado, ou Dodecafonismo Serial, a qual é denominada, atonal-livre, em contrapartida às miniaturas (ou, a brevidade das obras), a fim de recuperar o discurso musical, efetivou diversas incursões por outra via extra-musical, apoiando-se no discurso verbal que, de certo modo, conseguiu lograr tempo para a elaboração e sistematização da técnica serial que daria suporte e maior fôlego às obras para a música instrumental.

A utilização do texto como referência para um discurso musical em tais obras contribuiu também, para a evolução de outro importante aspecto musical, a musicalidade da fala. Como por exemplo, a utilização do Sprechgesang ${ }^{61}$,

${ }^{57}$ ZANI, Amílcar. Edward Steuermann: Um Esboço de Figura, 1991, Tese de Livre Docência. ECA-USP.

58 ZANI, Amílcar. In; Maria L.Sekeff \& Edson Zampronha (org). Arte e Cultura IV - Estudos Interdisplinares, pp. 51 a 57.

59 GRIFFITZ, Paul. Enciclopédia da Música do Século XX, p.211, verbete sobre Sociedade para Apresentações Musicais Privadas: Organização criada em Viena por Schoenberg para apresentar concertos ensaiados de novas obras a platéias que as ouviam pelo puro desejo de ampliar sua experiência.(...) O repertório incluía obras de Schoenberg, Berg, Webern, Mahler, Reger, Ravel, Stravinsky, Bártòk, etc.

60 PAZ, Juan Carlos. Introdução à Música de Nosso Tempo, p.139.

${ }^{61}$ Termo de expressão vocal designado para a partitura de Pierrot Lunaire, para o canto-falado. 
Sprechstimme, Sprechmelodie ${ }^{62}$, dentre outros, que por sua vez, fizeram suas incursões pela música escrita.

Aquilo que na voz-falada (Sprechstimme) for apresentado como melodia através das notas (salvo alguma exceção especialmente assinalada) não se destina a ser cantado. O executante deve levar em conta a altura do som indicada para transformá-la em uma melodia-falada (Sprechmelodie)

Os compositores da Segunda Escola de Viena recorreram ao apoio dos textos literários e do discurso verbal para retomar a discursividade na música. Consequentemente, estes compositores que ao se utilizarem do veículo verbal como suporte ou essência do desenvolvimento musical, fizeram com que as formas e gêneros historicamente interligados com o texto e seu significado emergissem em meio à produção atonal. Enfim, o florescimento das formas ou gêneros conectados com o desenvolvimento semântico como o lied, a ópera, o melodrama, o monodrama, a cantata, dentre outros, estabeleceu considerável profusão de idéias e propostas deste grupo de compositores.

Tal recurso que, por um lado, veio dar respaldo à solução do problema da expansão da escrita atonal na música instrumental ou música pura, adiando o confronto direto da consciência musical pelos recursos próprios; por outro lado, obteve a inevitável reformulação da composição vocal, re-significou o canto, e buscou musicalizar a linguagem falada.

Um profundo questionamento ao nível harmônico trouxe em si mesmo um potencial de reflexão com relação aos aspectos sonoros, dentre eles a musicalidade da fala, que nesse momento histórico se encontrava apta a auxiliar a produção atonal na busca pela recuperação do ato discursivo na música. ${ }^{64}$

O argumento dramático, até então coadjuvante do discurso musical, protagoniza, celebremente, uma significativa transcendência, uma verdadeira transformação, de suas formas, tal como eram tradicionalmente concebidas.

\footnotetext{
62 CAMPOS, Augusto de. Música de Invenção, p.47. Prefácio de Schoenberg ao Pierrot Lunaire.

${ }^{63}$ CAMPOS, Augusto de. Música de Invenção, p.47. Prefácio de Schoenberg ao Pierrot Lunaire.

${ }^{64}$ MENEZES, Florivaldo. Apoteose de Schoenberg.
} 


\section{5 - Os Desdobramentos do Dodecafonismo}

A revolução que foi instaurada pela Segunda Escola de Viena, passa por várias contribuições que ocorreram para a propagação do Dodecafonismo. Além da publicação de dois livros determinantes em Paris, entre 1947 e 1949: Schoenberg et Son École e Introduction à la Musique des Douze Sons, ambos de René Leibowitz; também na Alemanha, no Internationales Musikinstitut Darmstadt $^{65}$, essas duas ações fizeram com que as idéias da Segunda Escola de Viena viessem a se propagar em maior proporção.

A contribuição de Olivier Messiaen, 1908-1992, que então era professor do Conservatório Nacional Superior de Paris revela-se determinante para toda uma geração de músicos. Entre tantos, estavam: Pierre Boulez, 1925, Jean Barraqué, 1928-1973, Karlheinz Stockhausen, 1928-2003; são eles os principais disseminadores e que também darão continuidade aos germens ideológicos propostos pela Segunda Escola de Viena. Com base na divulgação das ideias adotam o método de composição dodecafônico, e, a partir desse, entre 1949-50, Olivier Messiaen compõe Quatre Études de Rythme ${ }^{66}$ para piano, o segundo dos quais se intitula Modes de Valeurs et d'Intensités. ${ }^{67}$ Utilizou nesta peça, pela primeira vez, a técnica serial, não somente aplicada às alturas, mas, também às durações, aos ataques e às intensidades, pode ser considerada como uma primeira etapa em direção à obra serial integral. ${ }^{68}$

Pierre Boulez apresenta a obra Livre pour Quatuor, em 1951, e propondo um tratamento serial sucessivo de todos os parâmetros, mas, no entanto, somente em obras posteriores concretizará sua idéia de serialização total e simultânea: como em Polyphonie X, 1951, para 18 instrumentos solistas, e no primeiro livro de Structures. ${ }^{69}$

Também em 1951, Karlheinz Stockhausen compõe Kreuzpiel e Kontra Punkte, em 1952, as duas para conjunto instrumental em estímulo à proposta de

\footnotetext{
${ }^{65}$ Cursos Internacionais de Música de Darmstadt.

${ }^{66}$ Quatro Estudos do Ritmo

${ }^{67}$ Modos de Valores e de Intensidade.

${ }^{68}$ BOUSSER, D. et BOUSSER, J-Y. Revoluções Musicais. Lisboa : Ed. Caminho, 1990. pp.16 e 17.

${ }^{69}$ VIGNAL, Marc. (dir) Dictionnaire de la Musique. Paris : Larousse, 1994. p.86.
} 
Messiaen. Quando Stockhausen passa a trabalhar com a música eletrônica, continua adotando o serialismo. Como nas peças Gesang der Junglinge, 1956, para sons vocais e sintetizados, Zeitmasse, 1956, para quinteto de sopros e Gruppen, 1957, para três orquestras. Ao contrário do pontilhismo da herança de Webern e Messiaen trabalha com grandes grupos de notas. ${ }^{70}$

A partir de suas experiências, Boulez e Stockhausen perceberam possibilidades de uma nova concepção musical, onde as enfraquecidas leis do sistema tonal poderiam ser substituídas por novos conjuntos de regras, baseada em estruturas.

Já não havia necessidade de um apoio textual para dar suporte a uma obra, bastava uma idéia organizada em série estruturada e respaldada por séries. Séries essas que utilizavam todos os parâmetros do som, as alturas, agora incluindo as figuras de valores, dos ritmos, intensidades e timbres, que definidos em séries bem delineadas, viriam lograr unidade e coesão à música.

Em Revoluções Musicais, ${ }^{71}$ os primeiros compositores a adotarem ao serialismo integral foram Luigi Nono (1924-1990), Bruno Maderna (1920-1973) e Franco Donatoni (1927-), com um interesse de considerar a técnica serial como ponto de partida, não para trabalhar a obra musical através de um processo mnemônico, repetível para salvaguardar a sua absorção através do tempo, mas especificamente trabalharam com a concepção temporal, colocando em questionamento os princípios fundamentais da composição musical.

Embora muitos compositores viessem aderir com certa rapidez ao serialismo, é muito importante salientar que cada compositor absorvia o serialismo de uma maneira muito particular, como pode ser observado no texto acima, a maneira individualizante de compor, proporcionada a partir do gérmen da reorganização das alturas, onde em princípio lograriam autonomia a essas na proposta iniciada por Schoenberg.

\footnotetext{
${ }^{70}$ SADIE, Stanley. The New Grove Dictionnary of Music and Musicians (20 vol) London: Macmillan Publishers Limited, 1980. p.905.

${ }^{71}$ BOUSSER, D. et Bosseur, J-Y. Revoluções Musicais. Lisboa : Ed. Caminho, 1990. p.23.
} 


\section{Parte II}




\section{Parte II}

$1 \quad$ Análise Musical no século XX $\quad 57$

2 Os Gêneros Vocais $\quad 67$

$\begin{array}{lll}2.1 & \text { O Lied } & 68\end{array}$

2.1.1. A Origem da Canção no Ocidente $\quad 71$

2.1.2 O Lied Romântico $\quad 73$

2.1.3 Nacht e Die Nachtigal - Alban Berg 76

2.1.4 Uma Canção dos Drei Lieder de Edward Steuermann 92

2.2 A Origem da Cantata 103

2.2.1 A Cantata na Alemanha 104

2.2.2 A Música Coral no Séc. XIX 107

2.2.3 A Cantata № 2 - op. 31 - Anton Webern 108

2.3 O Melodrama $\quad 128$

2.3.1 A Passacaglia - Nacht - Arnold Schoenberg 135

2.3.2 Pierrot Lunaire - op. 21 - Arnold Schoenberg 143

2.3.3 A Gênese de Pierrot Lunaire 156

2.3.4 A Canção Discursiva 162 


\section{Análise Musical no Século XX}

Ian Bent, em seu artigo, inicialmente define a análise musical como a segmentação da estrutura musical em elementos mais simples, e a investigação das funções desses elementos dentro dessa estrutura em como eles operam. ${ }^{72}$

A análise como uma ferramenta de estudo musical pode ser traçada a partir de cerca de 1750, porém somente no final do século XIX se estabeleceu como uma atividade assumida em si mesma.

Em decorrência das profundas mudanças que aconteceram no pensamento musical durante esse período, visto que é na transição para o século $X X$ que ocorre a fragmentação do discurso tonal, cujo modelo hegemônico na história da Música Ocidental perdurou cerca de 250 anos, essa fragmentação cria um momento histórico de grande instabilidade na Música, que pode ser observado nas diversas correntes das estéticas composicionais surgidas ao longo do século $X X$.

Em princípio, a análise musical tradicional consistia na identificação da forma em uma peça tendo como base a comparação com os protótipos formais encontrados em manuais e livros teóricos sobre este conteúdo.

$\mathrm{Na}$ tentativa de "responder diretamente à questão 'Como isto funciona?", palavras de lan Bent, ${ }^{73}$ essa busca voltava-se especialmente para um repertório clássico-romântico considerado fundamentalmente sistemático para o pensamento tonal encontrado nas obras Haydn, Mozart e Beethoven, e que se diferenciava de maneira considerável das composições do findar do século XIX.

Nesse processo que adentrou o século $X X$, a análise musical era tratada como uma ferramenta capaz de entender a construção como um conjunto de notas, de acordes que podia ser transformada em uma obra musical, e ainda desvendar o receituário dos mestres do passado entendendo as relações entre as partes da peça, o seu sentido ou significado.

Relacionadas à análise musical surgem, nesse período, algumas das

72 BENT, Ian. Analysis: "Analysis". In: SADIE, Stanley (ed.). The New Grove Dictionary of Music and Musicians. London: Mac Millan, 1980, v. 1, p. 340-388.

${ }_{73}$ BENT, Ian. Analysis: "Analysis". In: SADIE, Stanley (ed.). The New Grove Dictionary of Music and Musicians. London: Mac Millan, 1980, v. 1, p. 340-388. 
principais propostas teóricas que atualmente constituem as bases para a análise do repertório tonal, como por exemplo, o caráter funcional da harmonia proposta pelo musicólogo Hugo Riemann; ou o conceito de estrutura profunda presente no método analítico desenvolvido pelo musicólogo Heinrich Schenker.

Mesmo que através dos diferentes procedimentos, os métodos desenvolvidos para a análise do repertório tonal buscavam a compreensão dos pilares de sustentação desse discurso, e como entender quais as características das relações estabelecidas entre elementos mínimos que the serviam de unidades básicas e suas conexões. Procuravam extrair modelos que esclarecessem 0 funcionamento de um determinado conjunto de obras e encontrar meios que tornassem possível a criação de novas obras com discursos similares aos das obras de referência.

Diante de tantas variáveis presentes nos processos de composição, tais modelos não atendem a todas as possibilidades de interpretação e audição musical. Mesmo obras do repertório tonal já não se enquadram facilmente nesses modelos formais, e o que dizer das obras que lidam com as fronteiras do discurso tonal, como por exemplo, parte significativa da produção musical da transição do século XIX para o século XX?

O processo de análise, então, passa por uma profunda reflexão no devir do século XX, qual sua relevância, sua determinação, quais métodos proporcionariam precisão e ao mesmo tempo imparcialidade na concepção de uma interpretação acurada; "o analista está preocupado com a natureza da obra musical com o que ela é, ou personifica, ou significa; de como ela se tornou o que é; com seus efeitos ou implicações; com sua relevância para, ou valor para, seus receptores." 74

Notam-se, nessa definição de análise, alguns pontos importantes e que alargam o processo analítico para fora da partitura. A interação e os aspectos como o contexto histórico entre obra e seu receptor passam a ser considerada parte do conjunto de questões que um analista deve investigar ao se deparar com

74 BENT, Ian. Analysis: "Analysis". In: SADIE, Stanley (ed.). The New Grove Dictionary of Music and Musicians. London: Mac Millan, 1980, v. 1, p. 340-388. 
um trabalho deste sobre uma obra.

A análise como processo neutro e objetivo, o que nos leva a observar que a questão de como isto funciona, (?) aponta que pode-se encontrar diferentes caminhos e respostas, de acordo com a responsabilidade de quem analisa a peça e que o analista da atualidade está propenso a uma abertura maior de interpretação e que também dá espaço para muitas releituras, desde que embasadas.

Segundo Nicholas Cook, o processo de classificação é a base indispensável da análise musical; e o ato de classificar algo pressupõe: ${ }^{75}$

1) a tipologia - conjunto de possíveis classificações nas quais esse algo possa ser enquadrado,

2) a possibilidade de identificação de certas características naquilo que se projeta classificar. A identificação dessas características é possível através da série de questões que o analista realiza em relação ao objeto analisado.

Para uma visão sobre diferentes métodos de análise verifica-se em Nicholas $\mathrm{Cook}^{76}$, dois pontos de vista: o primeiro conduz a uma análise psicológica; e conforme o método de Rudolph Reti; o segundo conduz a uma análise schenkeriana.

A teoria pós-tonal dos grupos, também denominada como teoria dos conjuntos, baseada nos grupos matemáticos tem suas raízes nos trabalhos de Milton Babbitt, Allen Forte, David Lewin, Robert Morris, George Perle e Joseph Straus.

Em seu livro intitulado Harmonia, é curioso que Schoenberg utiliza-se de certos conceitos da pedagogia tonal para explicar algumas passagens atonais. ${ }^{77}$

Ele trata essas passagens, tal como os exemplos tonais, como sucessões homofônicas de acordes, e identifica seus principais meios de continuidade para condução das vozes:

\footnotetext{
${ }^{75}$ COOK, Nicholas. A Guilde to Musical Analysis. London: J. M. Dent and Sons, 1987.p.7.

${ }^{76}$ COOK, Nicholas. Op.Cit.

77 ROEDER, John. Harmonic Implications of Schoenberg's Observations of Atonal Voice Leading. Journal of Music Teory. Vol.33, nº1, 1989. pp.27-62.
} 
1 - os intervalos melódicos conectando membros notadamente correspondentes em ordem. Ele ainda observa interessantes características intervalares entre esses acordes e suas conexões de condução.

2 - sucessões de acordes aparentemente sem alturas e conteúdo intervalar correlatos e os liga, não por suas relações harmônico-funcionais ou similaridade intervalar, mas pela propriedade de suas conexões melódicas.

Apesar de as derivações entre acordes provirem da natureza dos acordes por si próprios, em detrimento do ritmo, a melodia, etc., ele geralmente concebe os acordes como produto do soar simultâneo de vozes, tanto que proíbe cruzamentos.

Observe o interessante exemplo 324, Harmonia, Schoenberg, p.541, sobre progressão de tríades aumentadas em movimento contrário por semitons, tanto nas extremidades das vozes do baixo e soprano quanto nas vozes internas.

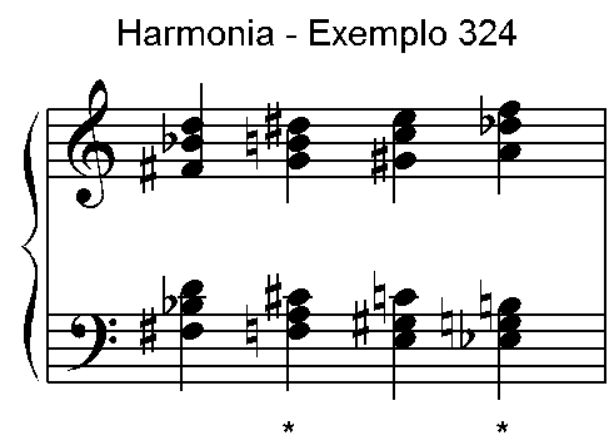

Figura 1 - Harmonia - Exemplo 324

Apontando que as tríades são resultados alternados entre uma tríade aumentada e um acorde da escala hexatônica.

Verifique o exemplo 337b, p. 557 do livro Harmonia, sobre acordes de quartas.

O exemplo 337b mostra de que forma, através da descida de três sons (de si para sib, de lá para láb, e de sol para fa\#), surge o acorde de tons inteiros a seis vozes (um tipo de encadeamento que também se apresenta em minha Sinfonia de Câmara), e como este se transforma 
novamente em um acorde por quartas a seis vozes através da descida dos três sons restantes (de dó para si, de ré para do\#, de mi para mib) ${ }^{78}$

\section{Harmonia - Exemplo 337}

a)

b)

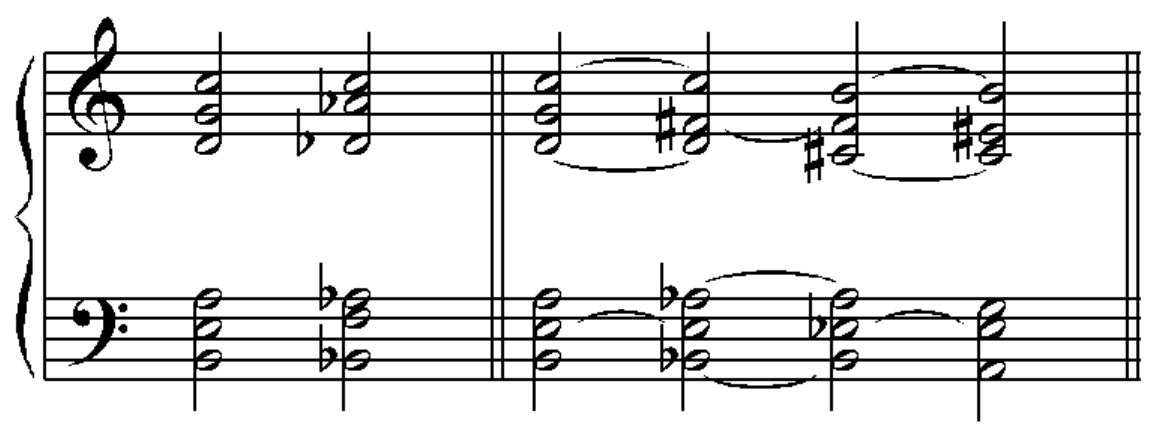

Figura 2 - Harmonia - Exemplo 337

No último capítulo de Harmonia "valorização estética dos complexos sonoros de seis e mais sons" a escala hexafônica, segundo a tradução de Marden Maluf, Schoenberg discorre:

Há aproximadamente dez anos ocorre, cada vez mais frequente, em obras de compositores modernos, uma escala constituída por seis sons que têm igual distância entre si: a escala de tons inteiros [Ganztonskala].

\section{ESCALA DE TONS INTEIROS}

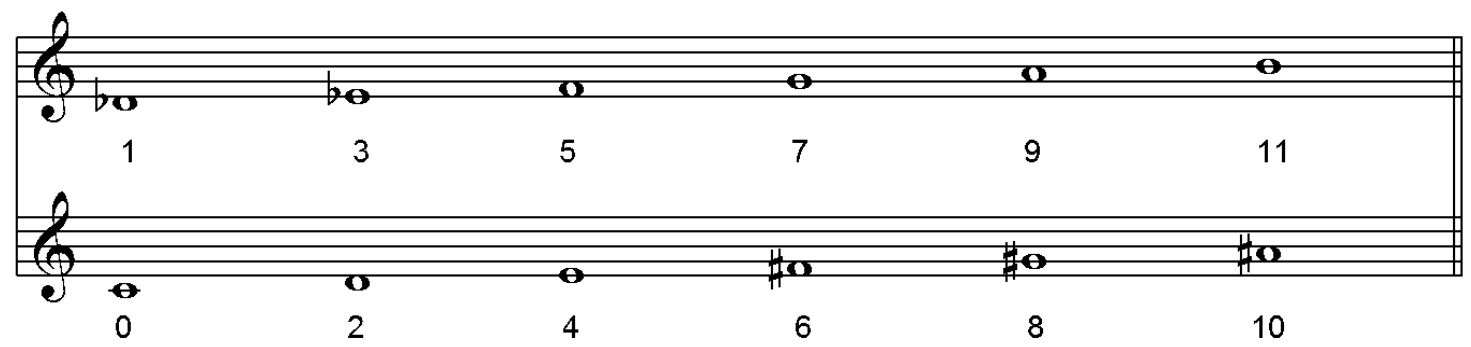

Figura 3 - Escala de Tons Inteiros

Classe de Alturas das escalas de tons inteiros $=\mathrm{CA}(0,2,4,6,8,10-$ pares $1,3,5,7,9,11$ ímpares)

\footnotetext{
${ }^{78}$ SCHOENBERG, Arnold. Harmonia. Tradução de Marden Maluf. São Paulo: Ed. UNESP, 1999.pp.557.
} 
Diz-se que os modernos russos ou os franceses (Debussy e outros) a empregara pela primeira vez. Não sei exatamente, mas parece que foi o Liszt o primeiro. Escutei, este ano (1910), a Don Juan-Phantasie, a qual me era até então desconhecida; ali ouvi, para minha grande surpresa, a escala de inteiros. Todavia, de uma coisa estou certo: eu não conhecia nem os russos, nem Debussy e nem essa composição de Liszt quando a escrevi pela primeira vez; e já muito antes a minha música demosntrava aqueles elementos iniciais que, necessariamente, deviam conduzir a esta dita escala. Alguns pensam que a escala de tons inteiros origina-se sob a influência do exótico. Dizem que tal é a música de povos exóticos, nos quais se encontra esta e também outras escalas semelhantes. No que diz respeito a mim, nunca tive conhecimento dessa música exótica. Minha ligação com esses povos poderia ter sido, se muito, telepática, pois não fiz uso algum de outras possibilidades de comunicação com outras culturas. E também não creio que os russos ou franceses tenham-se aproveitado de sua relação com os japoneses, talvez mais próxima pela via marítima, para importar, com isenção alfandegária, este produto em bruto. Ao contrário, acredito que a escala de tons inteiros originou-se completamente por si mesma nas cabeças de todos os músicos de nosso tempo, como natural consequência dos últimos acontecimentos com a música.

(...) A nova música alemã gostava realmente de utilizar a tríade aumentada, e de maneira abundante. $E$ isto havia ocorrido do seguinte modo: o motivo das Valquírias e algumas outras viragens em Wagner eram o ponto de partida, ajudado a seguir por alguns acordes alterados de sétima e de nona; e assim pode-se, eu acho, mostrar onde a escala de tons inteiros tem a sua origem ${ }^{79}$

Schoenberg refere-se a acordes e vozes por três observações:

1 - a progressão de acordes parece ser regulada de forma a incluir no segundo sons que não havia no primeiro, geralmente por "meio passo" ascendente ou descendente (progressão cromática - primeira classe intervalar).

2 - notas dobradas e intervalos de oitavas raramente aparecem.

3 - há uma aversão quase instintiva de se utilizar, mesmo que remotamente, os acordes tradicionais.

Veja os exemplos 343 ao 346, página 575, do livro Harmonia, de Schoenberg: 80

${ }^{79}$ SCHOENBERG, Arnold. Harmonia. Tradução de Marden Maluf. S.Paulo: Ed. UNESP, 1999.pp.537 e 538.

${ }^{80}$ SCHOENBERG, Arnold. Harmonia. Tradução de Marden Maluf. S.Paulo: Ed. UNESP, 1999.pp.575 e 576. 
Harmonia - Exemplo 343

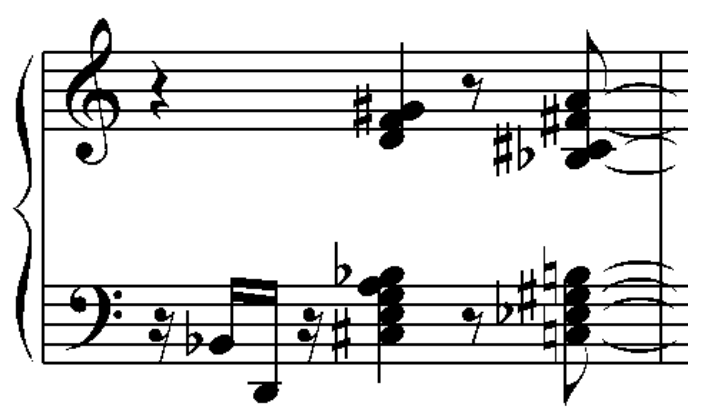

Figura 4 - Harmonia - Exemplo 343

Harmonia - Exemplo 344

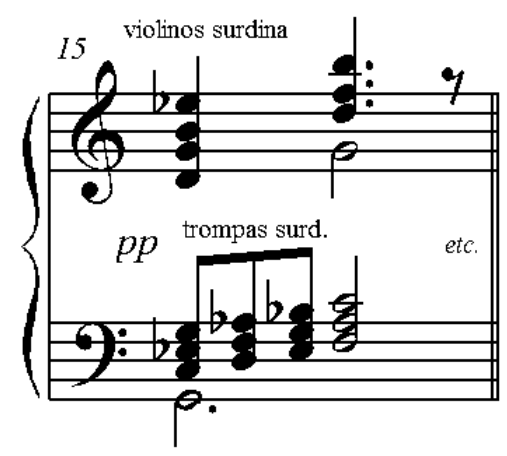

Figura 5 - Harmonia - Exemplo 344

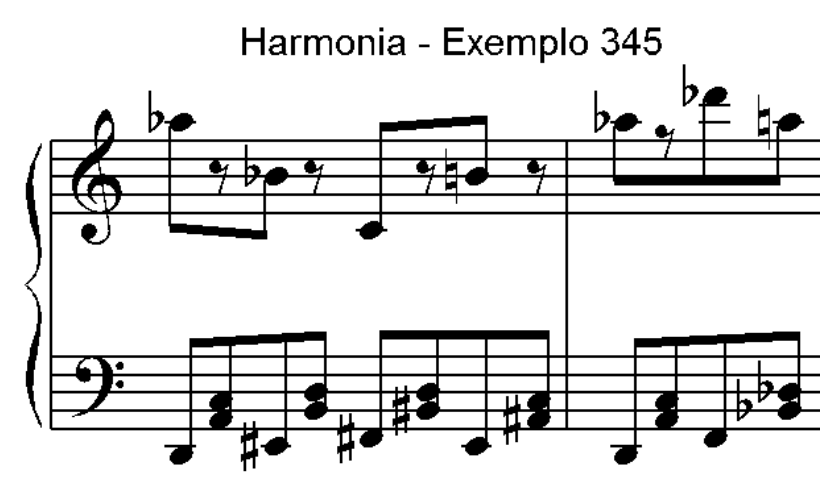

Figura 6 - Harmonia - Exemplo 345 
Harmonia - Exemplo 346

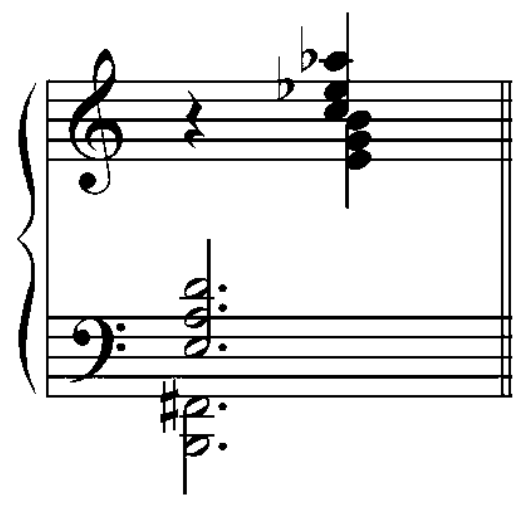

Figura 7 - Harmonia - Exemplo 346

É praticamente impossível evitar sons comuns, principalmente ao se conduzir acordes de seis ou sete sons, embora essa tendência possa ser observada em Anton Webern e Alban Berg.

Entre as edições de Harmonia de 1911 e 1922, nota-se uma diferença crucial em determinada passagem:

Em 1911 - o segundo acorde deve conter a maior quantidade de sons possível a possuir relação cromática com os membros do acorde anterior, embora não afirme categoricamente que todos os membros entre os acordes devam ser diferentes.

Em 1922 - Implicita que os acordes não tenham sons comuns, implicando, portanto, em um processo de preenchimento cromático, não sugerido em 1922, mas percebido à luz do desenvolvimento composicional de Schoenberg no período entre as duas edições.

Em $1984^{81}$ percebe-se uma reafirmação dos três ideais acima, excluindo-se dobramento de sons, acordes consoantes tradicionais, resolver acordes complexos um intervalo acima e evitar sons comuns e relações harmônicas tradicionais.

${ }^{81}$ SCHOENBERG. A. Style and Idea. Edited by Leo Stein. Translation by Leo Black. Revised Paperback Edition. Berkeley and Los Angeles: University of California Press, 1984. 
Homofonia e polifonia são apenas duas formas diferentes da mesma coisa, dois princípios de estilo em um mesmo fundamento; portanto, as composições envolvem escritas de partes que se somam a um todo politonal. ${ }^{82}$

Em 1938, Schoenberg, na ocasião, refere-se a Berg por motivo das novas formas de acordes que surgem da escala cromática resultando de uma polifonia coletiva que "não é acidental, mas conscientemente construída e ouvida." ${ }^{83}$

O compositor, hesitante em assumir o papel de teórico em Harmonia, não discutiu como as conduções de voz se relacionam às classes de altura e classes intervalares desordenadas.

O modelo homofônico atonal parece essencialmente contrapontístico, tratando sonoridades verticais estritamente como resultado de movimento dos sons. Entretanto, uma análise mais aprofundada de sua condução de vozes revela não apenas que sonoridades ordenadas específicas melhor se aplicam a esses princípios, mas, também, quais propriedades harmônicas essas sonoridades tem em comum.

Homofonia atonal - sucessão de verticalidades, por conseguinte, verticalidade de acorde - série de classes de alturas em que as alturas são ordenadas verticalmente. ${ }^{84}$

Em decorrência da aplicação dos processos de dissolução tonal e as várias mudanças, uma nova vocalidade vai surgindo e se impondo no despertar do século XX. Para melhor elucidar o acréscimo desses recursos, este trabalho tem por objeto de estudo as seguintes obras vocais: Nacht e Die Nachtigall que são dois lieder do ciclo Sieben Frühe Lieder, de 1905-1907, de Alban Berg; Melodrama n.8 do Pierrot Lunaire, opus 21, de 1912, de Arnold Schoenberg; as partes I, IV, e $V$ da Cantata n.2, opus 31, de 1941-1943, de Anton Webern; os Drei Lieder, de 1931, de Edward Steuermann. A escolha das peças considera o trabalho vocal individual, solístico, ou em grupo, coro.

\footnotetext{
82 STEFAN, Rudolf. 'Schoenberg's Entwurf über' Das komponieren mit selbständingen Stimmen. Archiv für Musikwiessenschaft, 29/4:239-256. Ano de 1972.

${ }^{83}$ STEFAN, Rudolf. 'Schoenberg's Entwurf über' Das komponieren mit selbständingen Stimmen. Archiv für Musikwiessenschaft, 29/4:239-256. Ano de 1972.

${ }^{84}$ STEFAN, Rudolf. Op.Cit.
} 


\begin{tabular}{|l|l|}
\hline \multicolumn{2}{|c|}{ LEGENDA } \\
\hline AUM & aumentado \\
\hline C.A. & Classes de Alturas \\
\hline CR. & Cromatismo \\
\hline dim & diminuto \\
\hline G.C. & grau conjunto \\
\hline I & inversão (inversão da série) \\
\hline J & Justo \\
\hline $\mathbf{M}$ & maior \\
\hline $\mathbf{m}$ & menor \\
\hline m.d. & mão direita \\
\hline m.e. & mão esquerda \\
\hline $\mathbf{O}$ & original (série original) \\
\hline $\mathbf{R}$ & retrógrado (série) \\
\hline R.I. & retrógrado da inversão (série) \\
\hline S & semitom \\
\hline T & tom \\
\hline T.S. & tom e meio \\
\hline
\end{tabular}

Tabela 1 - Legenda 


\section{Os Gêneros Vocais e o Conjunto de Obras de Alban Berg, Edward Steuermann, Anton Webern e Arnold Schoenberg}

A música é uma linguagem. E, como todas demais, é uma linguagem organizada. A "gramática" musical, da mesma forma que a das línguas faladas, evoluiu muito desde os primeiros balbucios do homem préhistórico. Mas, é preciso lembrar sempre que o código sempre sucedeu a experiência; tal como no domínio da ciência, também aqui só se estabele a lei depois de observado o fenômeno. Na música, a intuição dos compositores e suas descobertas sempre precederam a codificação da linguagem. Esta é razão porque a "gramática" está continuamente mudando ${ }^{85}$

A música é considerada uma linguagem cujos elementos constitutivos são apresentados organizadamente. Desses elementos, a linguagem musical como as demais linguagens - retira as formas que lhe são próprias. E as formas de qualquer linguagem organizam-se em vários e diferentes níveis, como:

1 - quanto à morfologia, que abrange a forma gramatical. As palavras têm forma, há maneiras de serem flexionadas, assumem diferentes formas quanto ao gênero e número, (plural e singular). Há concordância entre sua disposição e colocação na frase, ou oração, seguindo uma escala de valores de acordo com regras gramaticais. Assim também acontece com a construção do encadeamento de acordes a qual obedece a hierarquia dentro do diatonismo, seja pela homofonia, polifonia, cânones imitativos, ou outra forma elementar da gramática musical.

2 - quanto à organização das estruturas elementares da linguagem onde se estabelece conexões e relações lógicas entre as orações para expressar causa, consequência, comparações às quais as frases estão subordinadas ou coordenadas umas às outras. É a dinâmica da linguagem. Desta maneira também se procede a forma de empregar (ou organizar) as complexas estruturas para efetuar uma composição musical, valendo-se da forma lied, rondó, sonata, a estas chamamos formas musicais propriamente dita.

3 - quanto à concepção da obra como mensageira da ideia principal na escolha de um determinado gênero correspondente ao seu estado de espírito e sensibilidade.

\footnotetext{
${ }^{85}$ BEAUSSANT, Philippe, com colaboração de Marc VIGNAL, in Brigitte \& Jean MASSIN. Op.Cit.p.63.
} 
No conjunto de obras selecionadas para este trabalho, há que perceber quanto o gênero e a forma, intrinsecamente ligados à composição, contribuem para reforçar a dramaticidade inerente às ideias musicais.

Cada gênero possui suas próprias leis, que não são necessariamente arbitrárias, mas destinadas a lhe reforçar os efeitos. E assim também procede ao músico quando decide escrever um concerto - cujas leis são diferentes das que regem uma sinfonia - ou resolve compor uma sonata, que obedece outras leis que não são as da suíte, e assim por diante. A isto chamamos gêneros musicais. A partir do Romantismo até nossos dias, a literatura e a música, numa evolução análoga, foram cada vez mais se mostrando tendentes a afastar-se das leis estritas dos gêneros, que os doutos tantas vezes buscam conservar rígidos (...). A que gênero, por exemplo, poderia pertencer o "poema em prosa" de Baudelaire Une Mort Héroique que diríamos quase um conto? E o Ulysses, de Joyce, que se apresenta como uma nova Odisséia, é um romance ou uma epopeia? O mesmo aconteceu com a música ${ }^{86}$

No período romântico foram escritos determinados tipos de obras musicais que não se podiam definir ou encaixar em gêneros estritamente estruturados. Surgiram então o poema sinfônico, noturno, estudo, rapisódia, etc... Ao findar do século XIX e posteriormente também, houve uma tendência de inúmeras composições com formas mais abertas e de maior singularidade. No entanto alguns gêneros, como por exemplo, o lied, o melodrama, a cantata continuam despertando o interesse de vários compositores até os dias de hoje.

\section{1-O Lied Breve histórico do lied}

O termo lied é de origem germânica que traduzido para o português, significa canção, e é geralmente utilizado para a canção de câmara romântica. Segundo Sadie Stanley ${ }^{87}$, tem como seus principais representantes os compositores dos períodos de Franz Schubert, 1797-1828, a Hugo Wolf, 18601903, e Richard Strauss, 1864-1949.

\footnotetext{
${ }^{86}$ MASSIN, Jean \& Brigitte. História da Música Ocidental. RJ: Ed. Nova Fronteira,1997.p.64.

${ }^{87}$ STANLEY Sadie, Op.Cit.p. 536 e 537
} 
Ao remontarmos à evolução histórica do lied, poderíamos retornar até mesmo ao século $\mathrm{XV}$, incluindo as primeiras formas dos trinta e seis lieder de Oswald Von Wolkenstein, 1377-1445, todas elas para duas ou três vozes.

O Tenorlied é um tipo especificamente alemão, baseado em uma linha vocal preexistente, determinada como cantus firmus (ou tenor), que surge primeiramente no Lochamer Liebderbuch (c.1460).

Já no primeiro quarto do século XVI, nas canções de Heinrich Isaac, 1450-1517, e outros compositores, a escrita corrente é para quatro vozes, sendo o tenor a voz mais aguda. Diversas possibilidades estilísticas, incluindo a imitação, sendo o cantus firmus geralmente no soprano, já são características utilizadas nas duzentas e sessenta canções de Ludwig Senfl, suíço que viveu c. 1486-1542.

Pode-se considerar que a idade de ouro do tenorlied encerra-se por volta de 1550. No entanto, mais adiante, essa forma recebeu impulso decisivo com Orlando di Lassus, 1530-1594, atingindo seu apogeu com os lieder (plural de lied) Hans Leo Hassler, 1564-1612, cuja síntese entre o estilo italiano com o lirismo alemão exerceu grande influência sobre o lied. ${ }^{88}$

A presença do lied polifônico, figura discretamente nas composições de Johann Hermann Schein, 1586-1630, mas depois disso não se estabelece como forma. No século XVII, surge uma nova forma de lied, usada pela classe mais culta e por literatos, denominada Generalbass (baixo contínuo), em geral pouco menos elaborada do que as canções solo cortesãs de outros países.

Um grande compositor do "lied contínuo" foi Adam Krieger, 1634-1667, com os Arien, 1667, a maioria dos solos com contínuo; e ritornellos instrumentais, que vão desde canções pastorais às canções de brinde lascivas. Este tipo de lied caiu em desuso a partir de 1670, ressurgindo em meados do século XVIII, com George Phillipp Telemann, 1681-1767, e Johann Valetin Gõrner, 1702-1762.

O lied recebeu uma nova estética após 1750 , ingressando para uma nova fase: os lieder estróficos, que são melodias simples, de caráter folclórico harmonizado, sem complicações e acompanhamento independente. Um dos principais centros do lied é a cidade alemã de Berlim, e seu grande colaborador foi

${ }^{88}$ Ibidem.p.536 
Carl Philipp Emanuel Bach, 1714-1788. Para a evolução do lied, podemos também destacar a contribuição significativa do vienense Wolfgang Amadeus Mozart, 1756-1791.

Da Segunda Escola Berlinense ${ }^{89}$, podemos citar Joahnn Friedrich Reichardt, 1752-1814, e Carl Friedrich Zelter, 1758-1832, os quais buscaram um estilo mais complexo e uma poesia de melhor qualidade, como, por exemplo, a de Goethe e Schiller.

O lied romântico tem como criador Ludwig van Beethoven, 1770-1827, mas foi Franz Schubert, 1797-1828, que, durante seu curto tempo de vida, legounos mais de seiscentos lieder, como Gretchen Am Spinnrade ou Erlkõnig, com poema de Goethe, concretizando assim uma estreita identificação entre poeta, personagem e cantor (intérprete), em uma concentração de ideias líricas, dramáticas e pictóricas, abordando inúmeras das possíveis emoções e estados da alma.

Franz Schubert, 1797-1828, utilizou, em vários de seus lieder, recursos onomatopaicos, imagens literário-musicais fundindo-as e combinando-as entre si. Essa perfeita junção obtida por Schubert serviu de inspiração para muitos outros compositores, sendo este o motivo pelo qual o compositor sempre se destacou.

Carl Loewe, que viveu de 1796 a 1869, também foi mais reconhecido por suas canções narrativas, embora a música de seus trezentos e setenta e cinco lieder esteja mais subordinada ao texto. Em algumas de suas melhores partituras estão suas primeiras obras vocais solo, como também Erlkõnig, de Goethe, 1818, e Das Hebren Melodies, de Byron.

Algumas canções estróficas com um último verso ou coda variados adquiriram a perfeição formal por Felix Mendelssohn, 1809-1847.

Considerado como o verdadeiro herdeiro de Schubert, Robert Schumann, 1810-1856, em seus duzentos e sessenta lieder, recombina elementos básicos de equivalência verbal e independência musical, porém, a grande contribuição de Schumann para o lied é a significativa ampliação do papel do piano.

\footnotetext{
${ }^{89}$ Década de 1770.
} 
Esse prolífero desenvolvimento do lied, a partir de então, passa a contar com outros grandes contribuidores como: Richard Wagner, 1813-1883, Franz Liszt, 1811-1886, Peter Cornélius, 1824-1874, entre outros. Essa fase se prolongou até o final do século XIX, destacando principalmente dois grandes compositores, que se contrapõem em extremos opostos no âmbito da composição do lied: Johannes Brahms e Hugo Wolf. Johannes Brahms, 1833-1897, considerado como tradicionalista supremo, em seus duzentos lieder destaca-se pelos acompanhamentos pianísticos geralmente complexos e raramente independentes, apresentando estruturas estróficas ou ternárias, constituindo uma unidade muito bem aplicada.

Contrastando com Brahms, tem-se Hugo Wolf, 1860-1903. Seus procedimentos eram orientados pela poesia, tendo publicado livro de canções dedicado a determinados poetas, como: Mòrike, Goethe e Eichendorff. Na totalidade de seus trezentos lieder, estilisticamente emprega a harmonia expandida, enriquecida pelo contraponto vocal e instrumental, abrangendo uma gama emocional muito ampla.

A partir de 1900, o lied passa a ser pensado com destaque também junto à orquestra e não somente com o piano. Nesse sentido, destacam-se outros compositores, como Richard Strauss, 1864-1949, - As Quatro Últimas Canções; Gustav Mahler, 1860-1911, que foi seguido por Arnold Schoenberg, 1874-1951, Anton Webern, 1883-1945, e Alban Berg, 1885-1935.

\subsection{1 - Origem da Canção no Ocidente}

A canção pode ser classificada como sacra ou secular. Modernamente, o termo pode ter ainda o significado de música secular para vozes. Primeiramente, trata-se de canções sacras por possuírem relatos mais antigos. Conta-se que, na Grécia e na Roma antigas, existia um grande repertório de canções, mas como eram transmitidas oralmente, poucas chegaram até nós; a maioria dessas canções é grega e provavelmente do período helenístico. 
Nas canções sacras temos, como exemplos mais remotos, as judaicas, das quais se aproximam as cristãs, que, na realidade, são antigas canções baseadas em salmos; por isso denominadas salmódicas.

Os cânticos medievais, por sua vez, foram influenciados pelas canções populares. As primeiras melodias de canções da Antiguidade de que se tem conhecimento e que obtiveram notação musical são datadas do século IX. Há ainda alguns relatos sobre canções latinas não-litúrgicas, dos séculos $\mathrm{X}$ e $\mathrm{XI}$, que chegaram até os dias atuais através de manuscritos; e um repertório maior está associado aos goliardos ${ }^{90}$ do século XII. Desse mesmo período tem-se, ainda, o conductus, que consiste em canções estróficas, em geral com texto em latim.

Sobraram poucas canções seculares em vernáculo, datadas anteriormente a 1100. Dos séculos seguintes permaneceram inúmeros exemplares, com o florescimento da canção monofônica entre os Trovadores, na França, e do Minnesang (que posteriormente se tornou Meistergesang) no repertório alemão.

Os compositores franceses, após 1300, começam a musicar formas como a Ballade, o Rondeau e o Virelai, que se tornaram, na sua maioria, canções polifônicas.

$\mathrm{Na}$ Itália, no século XIV, existiu uma forma de canção polifônica semelhante à francesa, que se denominava Ballata, a Caccia e o Madrigal.

Após 1450 , a canção monofônica foi perdendo a sua importância na música erudita, mas as formas antigas permanecem populares nas canções polifônicas de compositores franceses e neerlandeses até o século $\mathrm{XVI}$, quando cedem espaço ao surgimento da Chanson ou Mélodie (na França), da Frottola (na Itália), do Lied (na Alemanha). Contemporaneamente, o tipo de canção que se identifica, na Inglaterra, é denominado Carol, de caráter estrófico, que permaneceu popular até o século XVI.

A Monodia italiana nasce, posteriormente, do desejo de alguns compositores de madrigais do século $\mathrm{XVI}$, de imitar o texto, ilustrando as palavras isoladamente. Esse fato deu-se no início do período Barroco, onde as linhas

\footnotetext{
${ }^{90}$ Estudantes e clérigos itinerantes.
} 
vocais expressivas são apoiadas por baixos geralmente estáticos e acordes simples, com alaúde ou algum outro instrumento.

Esse estilo muito influenciou o lied com contínuo alemão, tal como o cultivado por Heinrich Albert, 1604-1651, Adam Krieger, 1634-1666, Philipp Heinrich Erlebach, 1657-1714, e ainda o Air inglês para alaúde, de John Dowland, 1564-1626, e as canções declamatórias de Henry Lawes,1596-1662, e Henry Purcell, 1659-1695. Porém, influenciou muito pouco as formas francesas, o Air de Cour e os tipos posteriores de air, mas reafirmou-se na Cantata francesa da virada do século. Em contrapartida, dentro da própria Itália, a canção desvia-se para a Ária, que tinha lugar dentro das formas mais extensas, como na Cantata, na Serenata e na música teatral e de igreja.

A Romanza (romance), que já significava canção do tipo balada na Itália e na Espanha, surge na França, como um novo gênero de canção, no século XVIII.

\subsection{2 - O Lied romântico}

Historicamente o lied romântico começa com o compositor austríaco Franz Schubert, mas já na alta Idade Média, se fazia o uso corrente do daz Liet que era um poema curto, lírico e estrófico que tanto poderia servir ao reportório religioso como ao profano. Ambos careciam de um cuidado especial na relação de música e poesia (recorde-se a ênfase dada a este pormenor criativo em Die Meistersinger von Nürnberg de Richard Wagner) ${ }^{91}$

Inicialmente durante o Renascimento, o lied adota um estilo mais polifónico, e um pouco mais tarde, torna-se simples monodia, seguido pelo acompanhamento do baixo contínuo que posteriormente é substituído pelo piano, no período clássico.

Como grande admirador de Johann Abraham Peter Schulz, 1714-1800, Joseph Haydn, 1732-1809, compõe os seus Lieder im Volkston,1782, como ideal de época para serem cantados da maneira mais simples e natural possível.

\footnotetext{
${ }^{91}$ CARDOSO, José Maria Pedrosa. Goethe e o Romantismo musical: uma abordagem pedagógica - artigo Faculdade de Letras da Universidade de Coimbra.
} 
Wolfgang Amadeus Mozart, 1756-1791 também compôs Das Veilchen, 1785, sobre poema de Goethe, e outros lieder que fazem lembrar Schubert, como Das Lied der Trennung e Abendempfindung.

Mozart só compôs sobre Goethe, Das Veilchen (1785), mas compôs Lieder que já fazem lembrar Schubert, como Das Lied der Trennung e Abendempfindung. Haydn também só fez um Lied sobre poema de Goethe, por influência aliás de Mozart: Heiss mich nicht reden, de W. Meister, é uma obra magistral. Dele é, obviamente Gott erhalte den Keiser (1797), feito hino austríaco até 1918 e, com outro texto, hino alemão até hoje ${ }^{92}$

Apresentando grande interesse pela poesia, Ludwig van Beethoven compôs 93 melodias, tendo grande respeito pela declamação, em um estilo que de certo modo é considerado precursor de Hugo Wolf com grande variedade formal. Com Wolf afirma-se a predileção por ciclos,

(depois de Christoph Willibald Gluck e do seu mestre C. G. Neefe): Sechs Gediechte von Gellert (1803) e An die ferne Geliebte (1816) sobre poemas de Alaoys Geittels. Sabe-se que Beethoven preferia Goethe, de quem pôs em música, por exemplo, quatro versões de Nur wer die Sehnsucht kennt, de W. Meister. É também na tendência para a composição de Lieder que o autor da IX Sinfonia, se pode considerar um compositor romântico ${ }^{93}$

A partir do século XIX, passa a haver uma cisão entre a canção denominada popular e a outra mais elaborada, obtida como séria, com maior erudição. Seu precursor foi Franz Schubert que influenciou outros compositores dentro e fora da Alemanha os quais contribuíram imensamente para essa rico desenvolvimento.

A partir de Schubert o lied sai do âmbito doméstico e converte-se em acontecimento programado para as salas de concertos. Sobretudo, com ele, o lied é um canto solístico com acompanhamento ao piano que estreita laços de íntima relação entre poesia e música, melodia e acompanhamento, entre gênero e forma. A forma originalmente alemã, influencia formas semelhantes de compositores estrangeiros, que adotarão o seu nome. O lied romântico é, definitivamente, uma obra musical não muito extensa em que palavra e a música convergem para uma realidade poética diferente e única. Revestido com uma escrita pianística mais

\footnotetext{
92 CARDOSO, José Maria Pedrosa. Op.Cit.

${ }^{93}$ CARDOSO, José Maria Pedrosa. Op.Cit.
} 
elaborada ainda pelos gênios românticos como Robert Schumann e Johannes Brahms.

Em Schubert, nas suas primeiras composições do gênero, o Lied é ainda clássico, mais na linha das baladas do tipo de J. R. Zumsteeg (17601802). O Lied é romântico quando poesia romântica (de um Schlegel, Novalis, Müller, Heine, etc) desperta a emoção do compositor e quando este compositor (em Schubert depois das canções de Wilhelm Meister e dos poemas de W. Müller que deram origem ao ciclo Die schöne Müllerin, 1823) começa a repartir a sua atenção para uma melodia condicionada pelo seu sentimento mas também pelo espírito da canção e por um acompanhamento tendencialmente autônomo como que sublinhando quase sinfonicamente, e até prolongando, o próprio texto. Chega-se assim ao conceito pleno de Lied romântico: o texto é pre-texto para a música, é utilizado, quase determinado pelo poder descritivo da Música ${ }^{94}$

Paralelamente à Alemanha, a canção, no decorrer dos tempos, tem sido um gênero de destaque em vários países do ocidente, como, por exemplo, o Brasil, a França, a Espanha, a Itália, a Inglaterra, a Finlândia, a Noruega, etc. Na França, o termo utilizado para canção é chanson ou mélodie. ${ }^{95}$ Canção também pode ser definida como uma peça musical, composta habitualmente de uma peça curta e independente, para ser cantada por uma ou mais vozes com ou sem acompanhamento.

Foi levada à perfeição por Henry Duparc,1848-1933, Gabriel Faure,1845-1924; Ernest Chausson,1855-1899; Claude Debussy,1862-1918, na França; por Václav Jan Tomásek, 1774-1850; Bedrich Smetana,1824-1884; Antonin Dvorak, 1841-1904, na Boêmia; Edward Grieg,1843-1907, na Noruega; na Rússia, Modest Mussorgsky,1839-1881, Piotr Tchaikovsky, 1840-1893; Sergei Rachmaninov, 1873-1943; e Igor Stravinsky,1882-1971, além do Grupo dos Cinco. ${ }^{96}$

A canção erudita do século $X X$ foi inegavelmente influenciada pelas canções alemãs e francesas do século XIX. É só observarmos as canções de Alban Berg, 1885-1935, Arnold Schoenberg,1874-1951 e Erik Satie,1866-1925.

\footnotetext{
${ }^{94}$ CARDOSO, José Maria Pedrosa. Op.Cit.

95 STANLEY Sadie. Op.Cit.

${ }^{96}$ Compositores russos do século XIX (Balakirev, Borodin, Cui, Mussorgsky e Rimsky-Korsakov) unidos pelo objetivo comum de criar uma escola nacionalista característica para música russa.
} 
O tradicionalismo viu-se integrado por experimentos de alcance mais amplo, como, por exemplo, o uso do Sprechgesang e Sprechtsimme para voz e conjunto de câmara para acompanhamento, em Pierrot Lunaire, 1912, de Arnold Schoenberg.

Isso também é claramente observado nos repertórios de canções em língua inglesa, representado na Inglaterra por Vaughan Williams,1872-1958, Gerald Finzi, 1901-1956, Benjamin Britten, 1913-1976 e outros; e nos Estados Unidos, nas obras de Charles Ives, 1874-1954, Virgil Thompson, 1896-1989, George Gershwin, 1898-1937 e Aaran Copland,1900-1991.

Simultaneamente, em vários países surge novo repertório de canções de linhagem mais tradicionalista, também por redescobertas da música folclórica locais, ou ainda por notáveis compositores de música vocal. No caso do Brasil: Alberto Nepomuceno, 1864-1920, Carlos Gomes, 1836-1896, Henrique Oswald,1852-1931, Glauco Velazquez, 1884-1914, Villa-Lobos, 1887-1959, Luciano Gallet, 1893-1931, Lorenzo Fernandez, 1897-1948, Francisco Mignone,1897-1986, Heckel Tavares, 1896-1969, Waldemar Henrique, 19052002), Camargo Guarnieri, 1907-1993, Cláudio Santoro, 1919-1989, Gilberto Mendes, 1922, Osvaldo Lacerda, 1927-2011, Villani Cortes, 1930, Marlos Nobre, 1939, Almeida Prado, 1943-2009, Ronaldo Miranda, 1948 e tantos outros.

\subsection{3 -Nacht e Die Nachtigall - (dois lieder do ciclo Sieben Frühe Lieder de Alban Berg)}

Embora, Alban Berg não tenha deixado grande quantidade de obras,

mas a qualidade de suas composições tem extraordinária importância como conteúdo e realização técnica.

O nome Berg, imediatamente nos remete às obras como: as óperas Wozzeck, 1917-1925, Lulu, 1929-1935, Suíte Lírica para quarteto de cordas 19251926, dentre outras. Para representar a etapa inicial que já carrega em si a solidez dos procedimentos de técnica de composição exemplares, o ciclo Sieben Frühe Lieder, ou As Sete Primeiras Canções, de 1905-1907, o qual dois dos lieder Nacht e Die Nachtigall são objetos de estudo deste trabalho, traz as seguintes canções: 
$1^{\text {a }}$ Nacht - texto de Carl Hauptmann

$2^{\mathrm{a}}$ Schieflied - texto de Nikolaus Lenau

$3^{\text {a }}$ Die Nachtigall - texto de Theodor Storm

$4^{\text {a }}$ Traumgekrönt - texto de Rainer Maria Rilke

$5^{\text {a }}$ Im Zimmer - texto de Johannes Schlaf

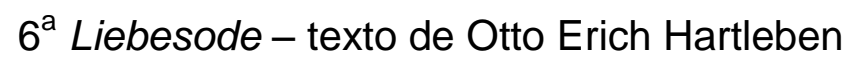

$7^{\mathrm{a}}$ Sommertage - texto de Paul Hohenberg

Quando Berg inicia sua trajetória como compositor, o faz impulsionado por elementos complexos, procedentes tanto do impressionismo francês quanto do cromatismo wagneriano, como o demosntra sua "Sonata", opus 1 e algumas séries de lieder"97

"Pelo fato de se ter composto cadências cada vez mais ricas, substituído progressivamente os acordes de subdominante, dominante e tônica por outros, e depois alterando ainda estes últimos, a tonalidade acabou sendo levada à explosão. Os acrodes substitutos tornaram-se cada vez mais autônomos. Foi possível atingir, aqui e ali, uma outra toanlidade. Os acordes substitutos tornaram-se tão predominantes que não houve mais necessidade de retornar à tonalidade principal. É a esse estágio da tonalidade que pertencem todas as obras que Schoenberg, Berg e eu mesmo escrevemos antes de $1908^{98}$

A característica predominante do Expressionismo Musical, ${ }^{99}$ quanto à integração de elementos em uma unidade organizada, encontra-se no comentário lírico-dramático, e Berg é nesse sentido, a personalidade que se destaca no grupo de expressionistas austríacos em torno de Schoenberg.

Da segunda escola vienense, Berg é o que mais responde aos imperativos da tradição, que estabelece o elo ou transição entre aquela e as decisivas contribuições do atonalismo e dodecafonismo.

\footnotetext{
${ }_{97}^{9}$ PAZ, Juan Carlos. Introdução à Música de Nosso Tempo, p.141.

${ }^{98}$ WEBERN, Anton. O Caminho para Música Nova, p.110.

99 Paul GRIFFTHS. Enciclopédia da Música do Século XX, p.74.Qualidade da arte que manifesta emoção extrema, intensa e imediata. O termo foi aplicado pela primeira vez às pinturas de Kandinsky, Nolde e outros, em 1910-1, depois estendeu-se rapidamente à discussão da música de Schoenberg e seus discípulos, como talvez fosse inevitável, já que Schoenberg era muito ligado a Kandinsky e a outros pintores do "Blauer Reiter". A suposição é de que o expressionismo resulta do impulso de dar voz a certa realidade mais íntima.
} 
Estes lieder muitas vezes são mencionados como trabalhos elementares e essencialmente românticos, devido à etapa schoenberguiana de construções temáticas e acórdicas, à base de intervalos de quarta advindos da utilização da escala de tons inteiros.

ESCALA DE TONS INTEIROS

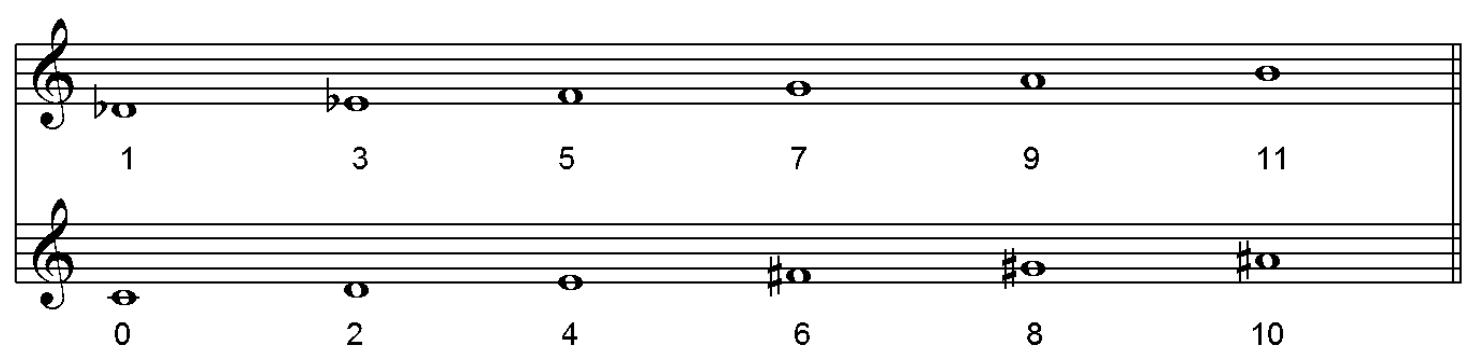

Figura 8 (3) - Escala de Tons Inteiros

Partindo da gama cromática dos doze sons, pode-se obter duas possibilidades resultantes em dois agrupamentos de seis tons inteiros [Ganztonskala]. Observe que os dois grupos com as classes de altura CA, o grupo ímpar e o grupo par se complementam.

Com a aplicação recorrente de acordes construídos por quartas ou harmonia quartal, mesclada a tríades e acordes também construídos por terças, alguns resultaram no que denominou de arquetípicos berguianos.

\begin{abstract}
A presença de fortes gestos tonais, mais ainda, de trechos tonais com nítida textura harmônica tonal, incomodaria inevitavelmente a postura de rompimento com a mesma. Mas o que se torna essencialmente importante, em Berg, é a pluralidade arquetípica na qual se apoia a construção de sua harmonia, bem como a coragem de, em meio à sublevação atonal (da qual fez indubitavelmente parte como um dos principais polos de vanguarda), subordinar o universo tonal ao contexto atonal, conferindo ao primeiro um sentido nitidamente metalinguístico ${ }^{100}$
\end{abstract}

As primeiras canções, obras de menor fôlego, datam de 1907 quando Alban Berg tinha apenas vinte e dois anos. Mais tarde, em 1928, este ciclo foi revisto e também orquestrado pelo próprio autor e dedicados à sua companheira e

\footnotetext{
${ }^{100}$ MENEZES, Flo. Apoteose de Schoenberg. p.124.
} 
esposa Helene. Estas canções já retratam a síntese de algumas de suas características que irão permanecer por toda a sua produção. A exploração de diversos recursos obtidos pela expansão de elementos técnicos musicais para encontrar uma sonoridade que pudesse atingir a máxima expressividade, movida por uma dramaticidade interna de cunho psíquico. Berg, às vezes demonstra essa inquietação tanto na construção da trama das vozes internas, quanto à transparência das extremidades, como por exemplo: cromatismo ascendente em uma voz, enquanto a outra descende, tons inteiros em movimentos contrários, oblíquos, trançados entre si, proporções de medidas sonoras, rítmicas, melódicas, etc.

Utiliza-se da fragmentação desses diversos elementos, sobrepondo acordes, ora inteiros, ora recortados, construídos de tríades tradicionais, tríades aumentadas, porém, às vezes recortadas e somadas a acordes de quartas sobrepostas, recombinando-os à sua maneira. Berg constrói um verdadeiro mosaico harmônico-melódico, desmembrando as escalas de tons inteiros, cromática, diatônica, como material básico e temático, com sobreposição de quartas, para adquirir acordes que trouxessem a desambientação e instabilidade tonais, de modo a enriquecer o colorido harmônico. Esses recursos aumentaram consideravelmente as amplitudes vertical e horizontal, com os quais Alban Berg trabalha em vários planos a partitura, utilizando permutações, às vezes, fazendo colagens desse rico material, recortando-o e recompondo-o de inúmeras maneiras, ainda mantendo os moldes tradicionais, pois, este compositor não provocou uma ruptura definitiva com a maneira antiga de compor, mas traçou um verdadeiro e significativo elo entre o estilo do passado e o moderno.

A seguir um trecho do compasso 42 ao 44 , da Sonata para piano opus 1 de Alban Berg, obra composta mesma década que suas primeiras canções. Exemplos de harmonia quartal, a construção de acordes por intervalos de quarta, material que a Segunda Escola de Viena passa a utilizar em seu repertório, mesclados aos acordes de tríades aumentadas, ou acordes construídos por terças como ditava a tradição.

ALBAN BERG - SONATA PARA PIANO OPUS 1 (1907-1908) 


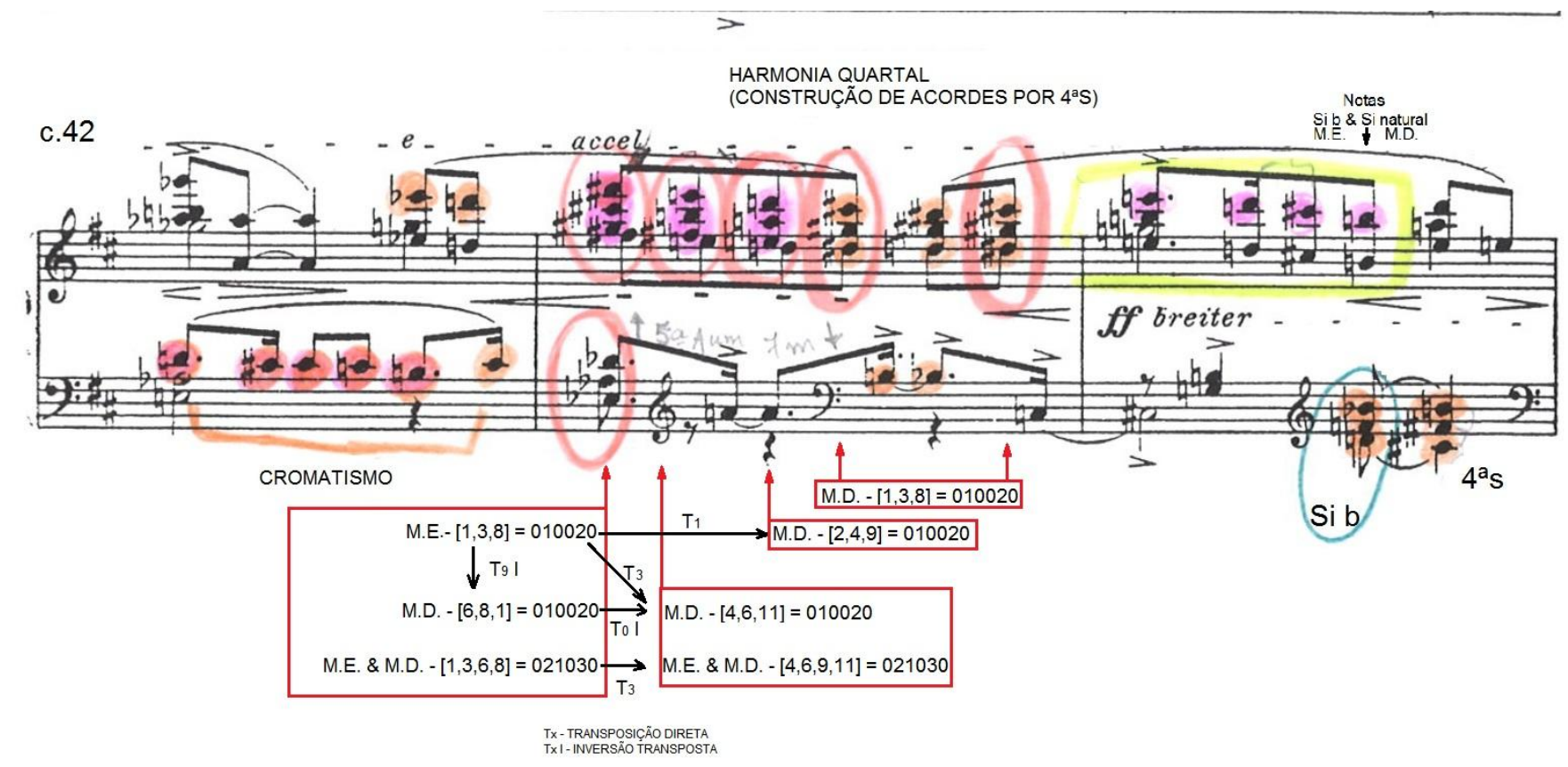

Figura 9 - Compassos 42 ao 44 da Sonata Op. 1 de Berg

A seguir os protótipos da construção de acordes, denominados arquétipos ${ }^{101}$ bergianos, nos demonstram como que Berg os manipulava:

Arquétipos bergianos pela sobreposição de 2 trítonos

a)

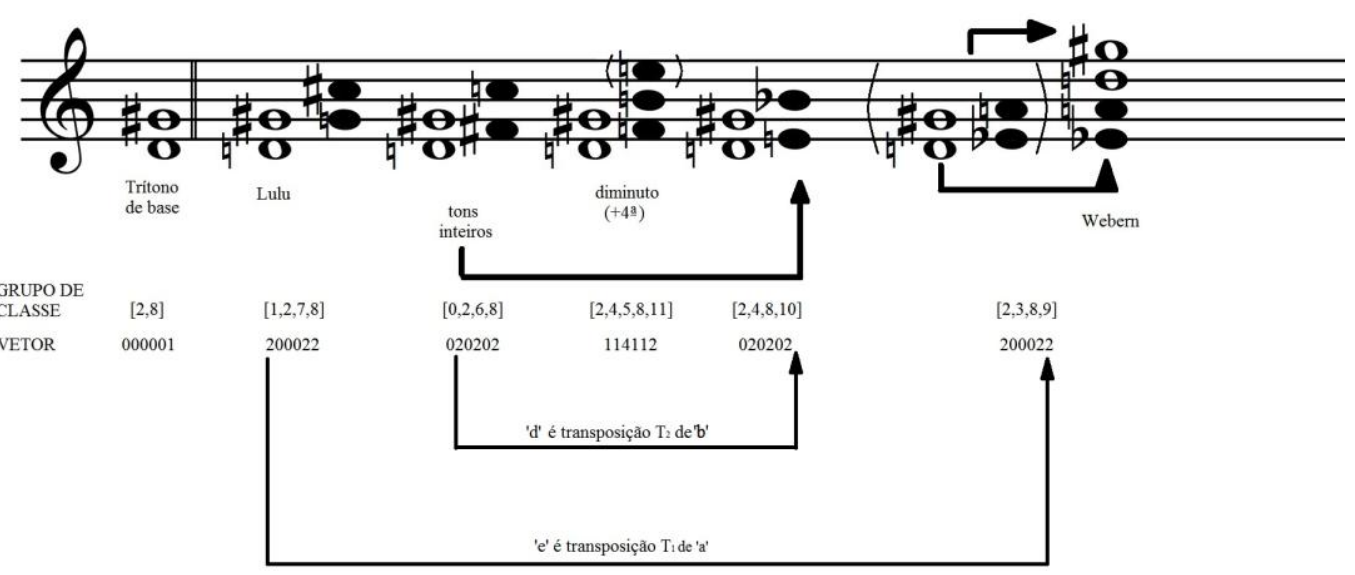

Figura 10 - Arquétipos bergianos pela sobreposição de 2 trítonos

A música de Berg está infiltrada por uma grande quantidade de arquétipos harmônicos, muitos dos quais contribuem eficazmente para o

${ }^{101}$ MENEZES, Flo. Apoteose de Schoenberg. pp.125 e 126. 
aumento do repertório harmônico arquetípico. (...) Muitas harmonias edificaram-se na sua música enquanto entidades específicas, transmitindo-nos sempre a escuta harmônica essencialmente heterogênea, pluralista. Para entendermos tal mundo é preciso, antes de mais nada, observarmos que é justamente o intervalo mais apolar - ou seja, o trítono -, mais antitonal, que serve a Berg tipos preferidos. É através da sobreposição de um trítono determinado com algum dos 5 trítonos restantes possíveis do temperamento que Berg constrói tais acordes, como se pode notar exemplo anterior. Dos 5 arquétipos possíveis, é exatamente o central [(letra c)] que tem sua conotação histórica mais definida, pois nada mais é que o Acorde-diminuto, uma das forças harmônicas que mais destabilizaram o sistema tonal tradicional. Embora com grande potencial pantonal, é possível que exatamente por sua forte conotação histórica e seu abundante uso na época tonal, tal acorde tenha sido via de regra alterado, por Berg, tendo tido sua aparição frequentemente acrescentada de uma $4^{\text {a }}$ superior (Suite Lírica, Lulu). Os arquétipos b e d são o mesmo: tons-inteiros. Seu uso era pouco comum, tendo sido difundido principalmente pela música de Debussy. O e é nada mais nada menos que, se o espacializarmos, o que convencionamos denominar de arquétipo-Webern. E o primeiro (a) é a grande contribuição do próprio Berg enquanto a esta específica fusão de trítonos: é a harmonia-chave de Lulu, e que por tal razão chamaremos de arquétipoLulu. (Podendo-se ouvir tal acorde como sobreposição de dois trítonos em distância de intervalo polar e apolar tendo, contudo, forte predominância polar pelos intervalos de meio-tom decorrentes desta sobreposição: e que nada mais é que uma versão específica do arquétipo-Webern) ${ }^{102}$

GRUPOS DE CLASSES

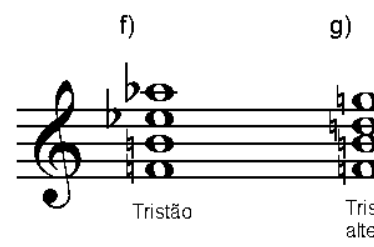

h)

i)

j)

k)

l)

m)

VETORES

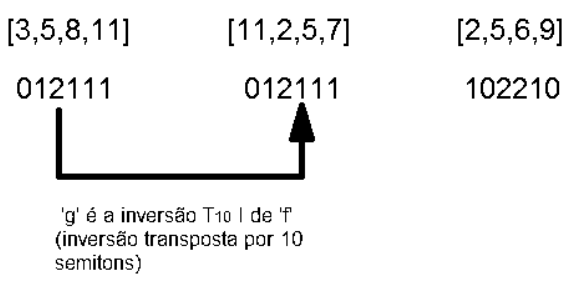

$\begin{array}{cclc}{[3,4,7,10,0]} & {[10,0,3,5]} & {[1,5,9]} & {[9,0,2,5]} \\ 113221 & 021030 & 000300 & 012120 \\ & & \\ & \begin{array}{l}\text { Vetor próprio das } \\ \text { tríades } \\ \text { aumentadas, por } \\ \text { conterem 4 } \\ \text { intervalos de } 4 \\ \text { semitons } \\ \text { (3as Maiores) }\end{array}\end{array}$

Figura 11 - Arquétipos bergianos - continuação

Também o arquétipo-Maior-menor é utilizado por Berg, sem acréscimo da $7^{\mathrm{a}}$ (ex:h). Destacam-se, enfim, dois arquétipos ainda em meio à harmonia em Berg: 0 arquétipo-de- $4^{\mathrm{a}} \mathrm{s}$, anteriormente utilizado como destaque por Schoenberg e ainda antes por Skriabin, mas que foi já em 1907, na

\footnotetext{
${ }^{102}$ MENEZES, Flo. Apoteose de Schoenberg. pp.125.
} 
Sonata, op.01, utilizado por Berg (sua última obra tonal); e o que mais tarde se denominou cluster, presente profeticamente em Lulu, antecipando o que seria mais tarde a utilização frequente de complexos sonoros ou ruídos na música contemporânea (agrupamentos, estes, que Pierre Schaeffer, pai da música concreta, denominará de sons nodais em seu Traité dês Objets Musicaux. A presença de tais arquétipos é audivelmete clara no decorrer de sua obra, a qual inclui, neste processo, outros arquétipos (...) A começar das 7 frühe Lieder (1901), que contém passagens baseadas ora em tons-inteiros; ora nos mesmos tons-inteiros funcionalizados em D7/5 - (...). ${ }^{103}$

\section{Quanto à forma e estrutura das canções}

1 - Nacht - para canto e piano é o primeiro lied do ciclo.

No aspecto formal este lied apresenta-se como forma ternária, contém 38 compassos e pode ser seccionado da seguinte maneira:

\section{A B A'}

Parte A - do compasso 1 ao 15

Parte $B$ - do compasso 15 ao 25

Parte $A^{\prime}$ - anacruse do compasso 25 ao 38

Morfologicamente, a divisão das partes, não ocorre de maneira simétrica, e Berg não repete literalmente as partes, mas utiliza elementos da parte $A$, na parte $A^{\prime}$ de maneira não convencional, como se ele recortasse partes do acompanhamento do piano, e sobrepusesse nesses fragmentos de frases, elementos composicionais utilizados na canção, e que são apresentados logo nos primeiros compassos. Alban Berg alterna acordes construídos a partir da escala de tons inteiros, acordes híbridos de tríades maiores, menores, aumentadas, justaposição de quartas, corta-os, recorta-os, fazendo verdadeira colagem sonora.

A partitura inicia com um compasso de introdução com o piano, com orientação do andamento Sehr langsam (muito lento), e logo a seguir o canto é introduzido a partir do segundo compasso, apresentando-se como uma melodia descendente que traz em si intervalos de $4^{a}$ diminuta descendente e $3^{\mathrm{a}}$ diminuta ascendente.

\footnotetext{
${ }^{103}$ MENEZES, Flo. Apoteose de Schoenberg. p.126.
} 


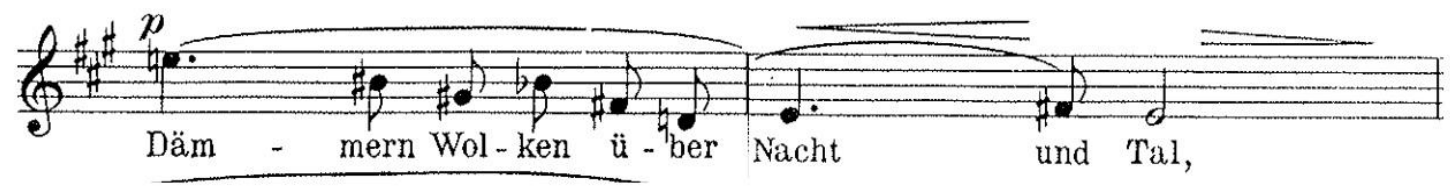

A melodia dos compassos 2 e 3 é composta pelo grupo de classes de altura $[0,2,4,6,8,10]$, ou seja, a escala de tons inteiros. Observe os intervalos de $3^{a}$ e $4^{a}$ diminutas, que até então não eram muito utilizados.

Figura 12 - Melodia inicial da partitura de Nacht de Berg

Nesta canção do ciclo que ainda é considerado dentro da fase tonal da Segunda Escola de Viena. Pode-se observar que o iniciar da peça com a mão esquerda do piano, as notas mi, fa\#, (melodicamente) e sol\# e si\# sobrepostos (harmonicamente), e logo a seguir no 1.2 (segundo tempo do $1^{\circ}$ compasso) atinge uma tríade aumentada de Sib, repetindo-a na mão direita estas mesmas classes de altura, porém no registro mais agudo do piano. E, logo na segunda colcheia do primeiro tempo no segundo compasso a superposição de duas tríades aumentadas (Mi aum. com Ré aum. - sendo que Ré aumentada e Si bemol aum. são enarmônicos), percebe-se logo neste início aquilo que viria germinar como princípio dos vários procedimentos técnicos na construção de estruturas para diversas possibilidades de material composicional.

Vejamos também que a escolha das duas tríades supracitadas, ou seja, as notas, fá\#, lá\#, mi, sol\#, si\# - [6, 10, 4, 6, 0] mão esquerda do piano, na clave de sol, primeira colcheia e segunda colcheia mi,sol\#,si\#,fa\#,lá\#,ré [4, 8, 0, 6, 10, 2]; é a resultante dos seis sons pares da escala de tons inteiros que na ordem das classes de altura $[0,2,4,6,8,10]$ pode ser observada nas figuras a seguir. Ora! Utilizando-se das tríades aumentadas, Alban Berg cria uma atmosfera de instabilidade, no que diz respeito à tonalidade sugerida pela armadura de fá\#menor.

Essa atmosfera de instabilidade tonal, mais a utilização de intervalos melódicos, baseados nas tríades aumentadas [Mi aum, Re aum e Sib aum descendentes melodicamente - sendo ainda que a nota sib pode ser o sib fundamental do acorde de sib, como pode ser enarmônica de lá\#, ou seja, a quinta aum. de ReM)]. Este é um dos aspectos que vão alterar a curva melódica do lied, o que lhe conferirá certa estranheza, já que as conduções melódicas advindas das 
normas do contraponto prescreviam que se evitassem tais dissonâncias. Para um cantor é muito mais orgânico, exercitar vocalizes com uma tríade perfeita maior do que com uma tríade aumentada.

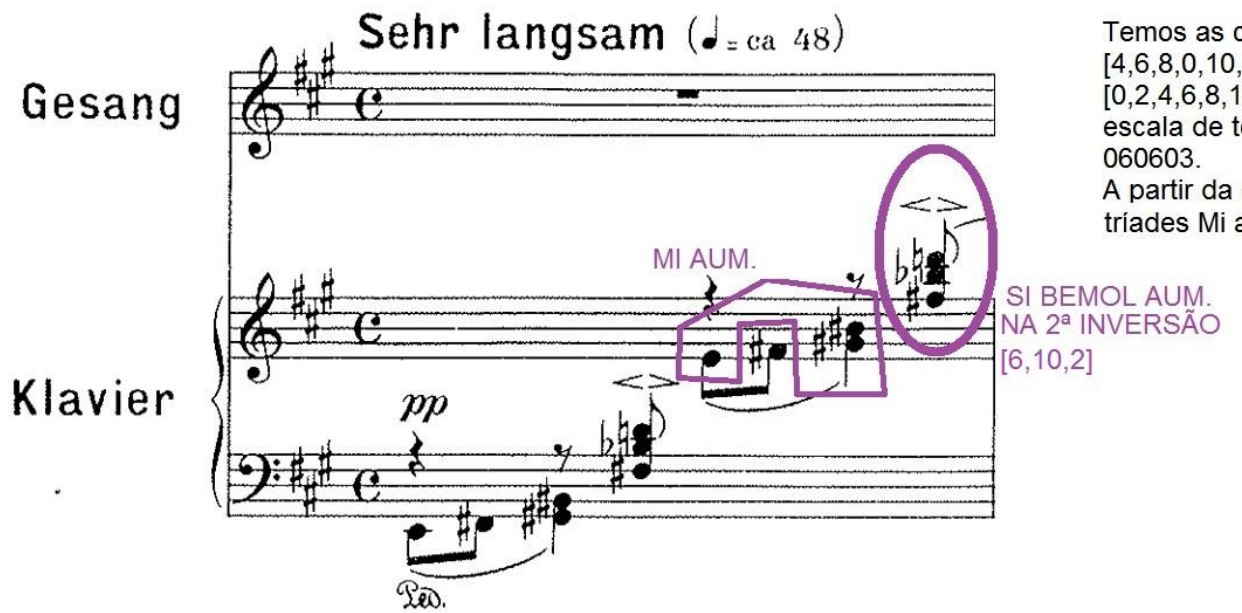

Temos as classes de alturas, em ordem,

[4,6,8,0,10,2], sendo sua forma normal ,10]. Berg utiliza-se, portanto, da de tons inteiros, cujo vetor próprio é A partir da escala hexatônica, Berg constroi as triades Mi aum. e Si bemol aum.

Figura 13 - Compasso inicial de Nacht de Berg 


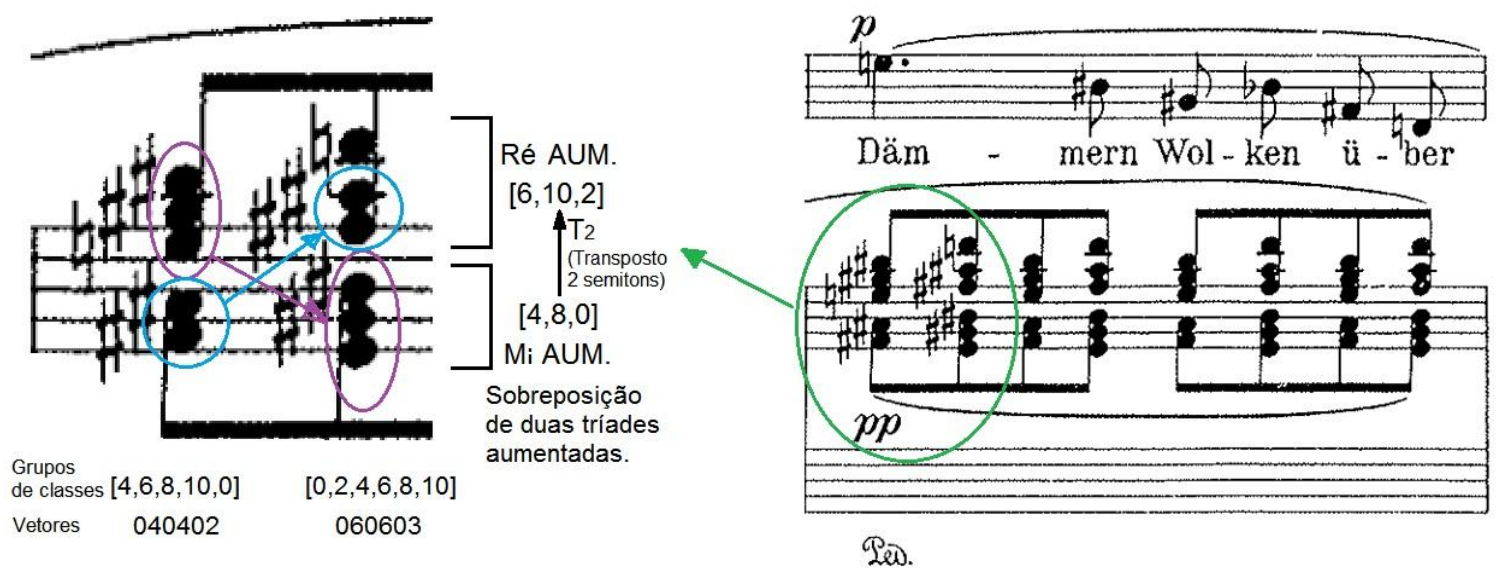

Figura 14 - Destaque para os acordes aum. dos compassos iniciais de Nacht de Berg

A seguir, podem-se observar os três últimos compassos da partitura de Nacht, onde Berg alarga o primeiro motivo (circulado em azul), apresentado pelo piano logo no início da peça, agora no procedimento técnico de aumentação nas três últimas mínimas da mão esquerda com dobramento de oitava abaixo. 


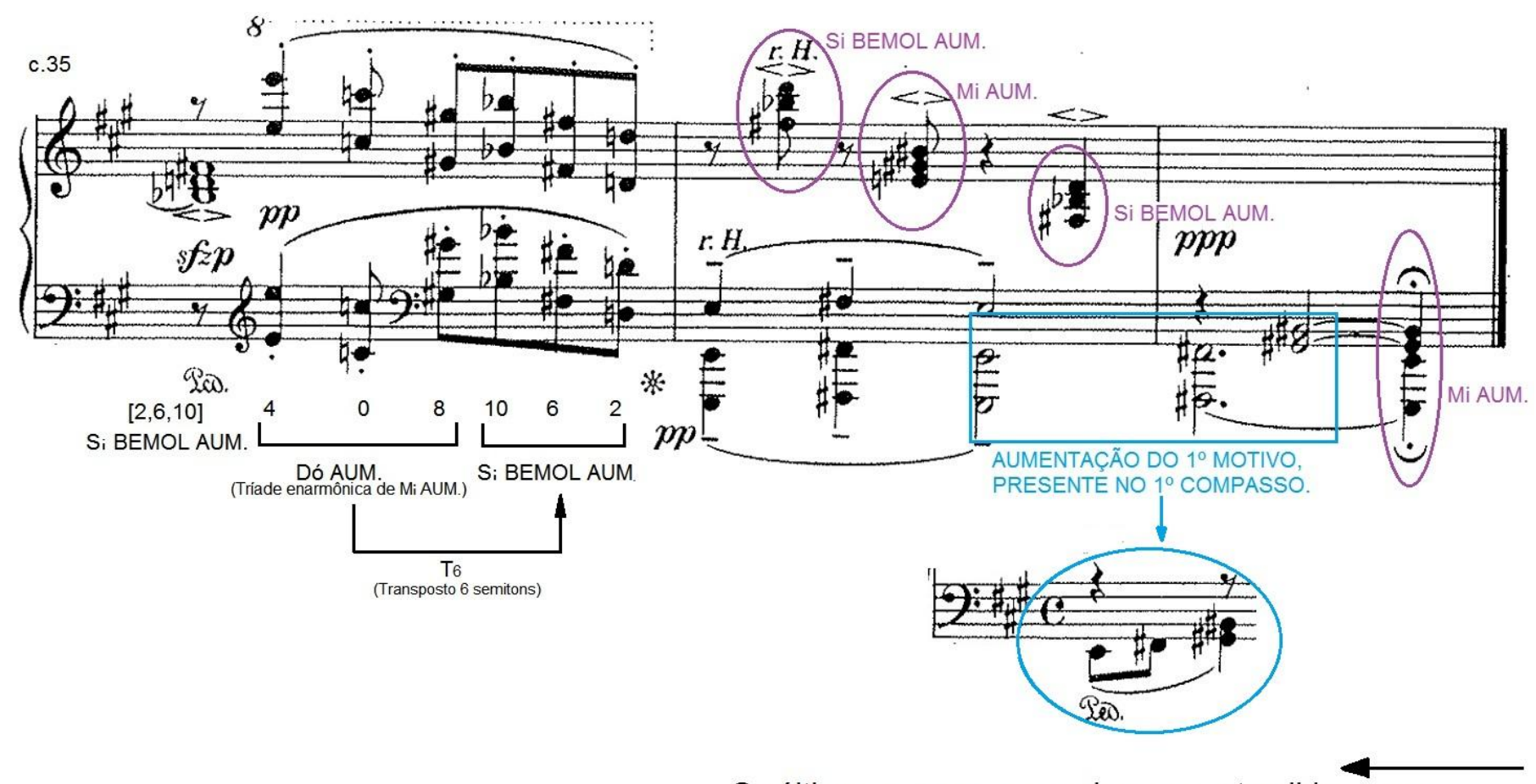

Os últimos compassos podem ser entendidos como espécie de retrógrado do primeiro compasso. Como acima o motivo (célula geradora), são as quatro notas que dão início ao Lied logo no $1^{\circ}$ compasso.

Figura 15 - Últimos compassos de Nacht de Berg

\section{Quanto aos andamentos}

Segue o quadro com os seguintes andamentos:

\begin{tabular}{|c|c|}
\hline \multicolumn{2}{|c|}{ ALBAN BERG } \\
NACHT \\
\hline TERMO NO ORIGINAL & TRADUÇÕES DO ALEMÃO \\
\hline Sehr Langsam & Muito Lento \\
\hline Etwas Langsamer & Um pouco mais lento \\
\hline Ganz Breit & bem largo \\
\hline Wie Zu Anfang & Como no Começo \\
\hline Etwas Zunehmend & Um pouco crescendo \\
\hline Zeit Lassen & Sem pressa \\
\hline Wieder abnehmend & Novamente desapegado \\
\hline
\end{tabular}

Tabela 2 - Andamentos dos lieder - Berg 


\section{Quanto ao plano da dinâmica}

Berg, mesmo em uma canção não muito extensa, pode-se perceber a utilização de uma gama que vai de 3 pês (ppp) - ou seja volume abaixo do pianíssimo (pp) até $1 f$ (forte) para o instrumento piano e, desde um $1 p$ (piano) até $f$ (forte) para a voz. Observe quadro a seguir:

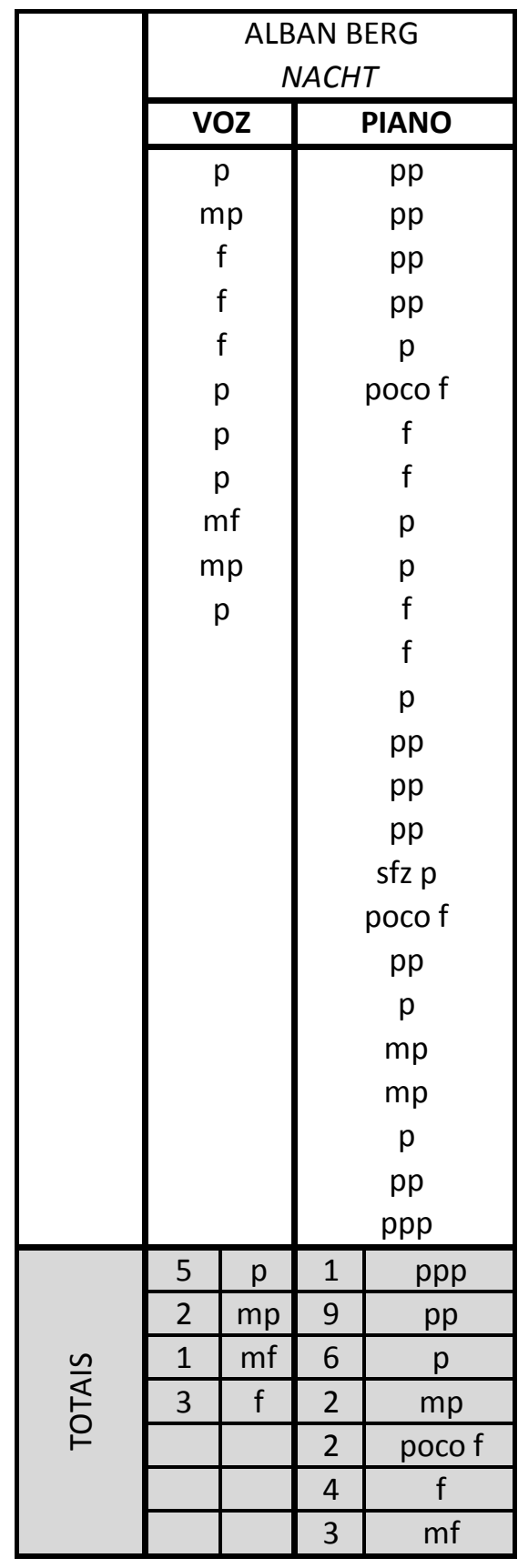

Tabela 3 - Dinâmica - Nacht - Berg 


\section{2 - Die Nachtigall - Alban Berg}

A partitura de Die Nachtigall contém o total de 44 compassos, e pode ser seccionada na seguinte forma ternária:
A B A'
Parte A - compassos 01 ao 15
Parte B - compassos 16 ao 26
Parte A' - compassos 27 com anacruse (c.26.3) ao c. 40
Codetta - compassos 40 (c.40.2) ao c.44

Este lied apresenta-se com um caráter tonal muito mais evidente do que os outros lieder deste ciclo. O piano introduz um acorde arpejado em Ré Maior com sétima, I (primeiro grau) da tonalidade concordando com a armadura de clave (fá\# e dó\#), muito embora os baixos com fá\# e si (na distância de uma décima) que acontecem logo no segundo compasso podem causar a sensação da tônica relativa menor que é Si menor, ou seja, o VI (sexto grau) de RéM.

Dentre os sete lieder do ciclo Sieben Frühe Lieder, podemos considerar Die Nachtigall como a canção que melhor representa a tradição, pois é a peça que consiste em si o centro tonal mais claro, cuja tonalidade é de Ré Maior. Também o seccionamento das partes, $\mathrm{ABA}^{\prime}$ que é bastante evidente apresenta certo equilíbrio na proporção e divisão dos compassos em relação aos demais lieder,

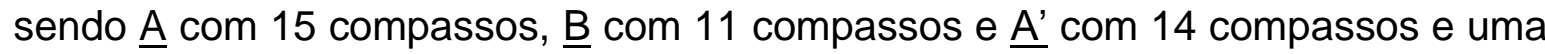
pequena coda com 5 compassos, construção que está estruturada nos moldes clássico-romântico, porém com a harmonia mais expandida. 


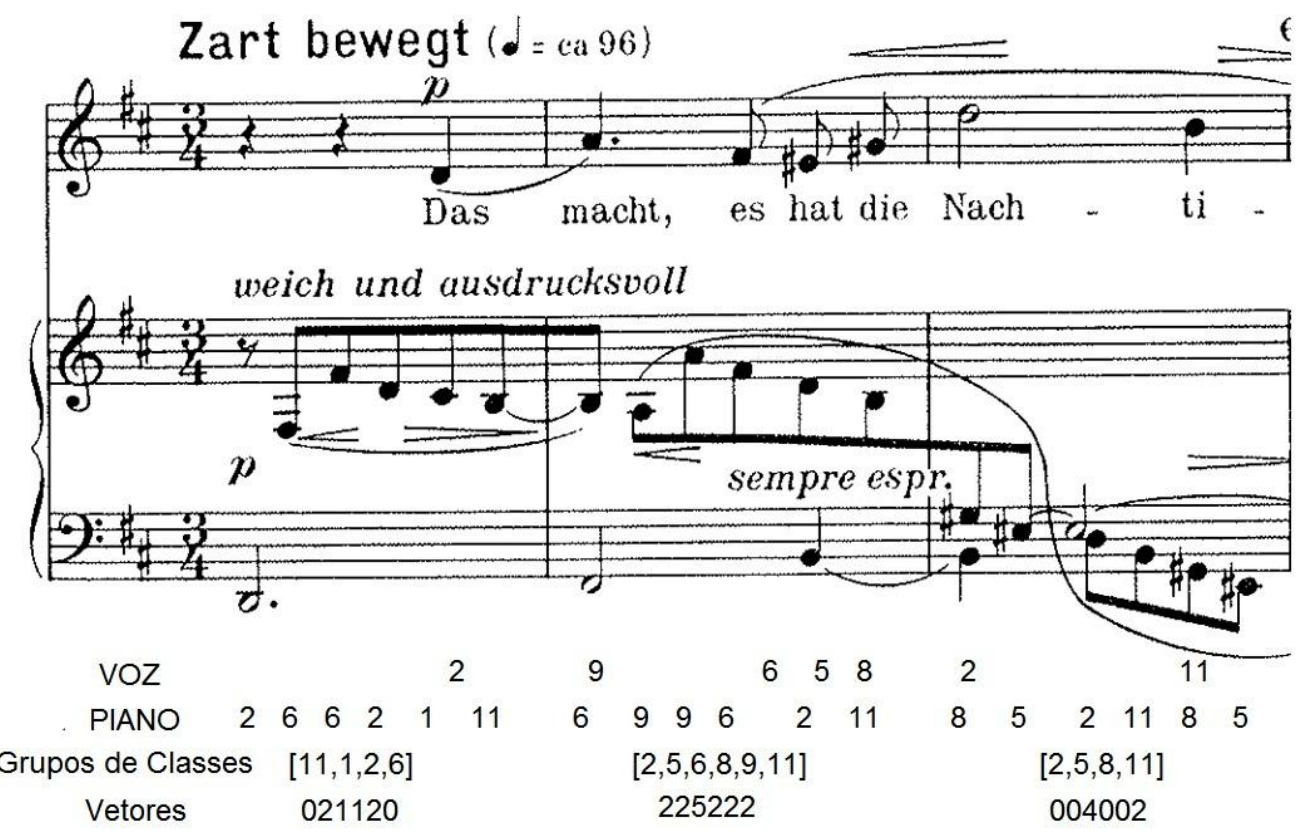

Figura 16 - (fig. 15 e 16) Compassos iniciais de Die Nachtigall de Berg

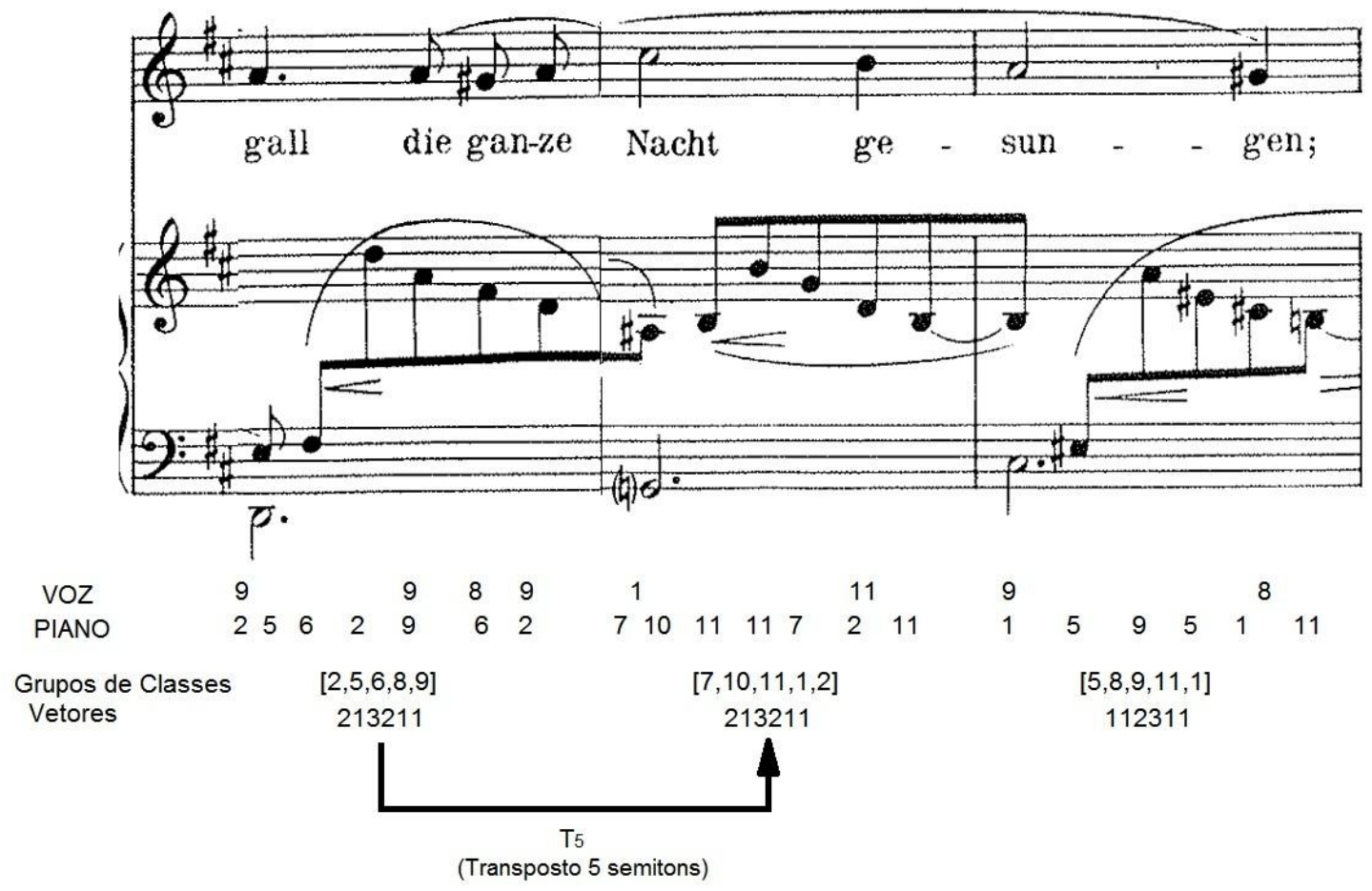

Figura 17 - (fig. 15 e 16) Compassos iniciais de Die Nachtigall de Berg 


\section{Quanto ao pulso}

A seguir vide tabela com expressões que caracterizam a temporalidade do lied Die Nachtigall:

\begin{tabular}{|l|c|}
\hline \multicolumn{2}{|c|}{ ALBAN BERG } \\
NACHTIGALL \\
\hline \multicolumn{2}{|c|}{ TERMO NO ORIGINAL } \\
\hline Zart bewegt & TRADUÇÕES DO ALEMÃO \\
\hline Etwas langsamer & um pouco mais lento \\
\hline etwas zögernd & um pouco hesitante \\
\hline Schwungvoll den Gesang fortsetzend & prosseguir cantando com ênfase \\
\hline \hline
\end{tabular}

Tabela 4 - Expressões que alteram o pulso

\section{Quanto ao plano da dinâmica}

Berg utiliza, mesmo em uma canção não muito extensa, uma gama que vai de 2 pês (pp) - ou seja o volume de pianíssimo (pp) até mf (meio forte) para o instrumento piano e, desde um 2 pês (pp) até f (forte) para a voz. Observe quadro a seguir:

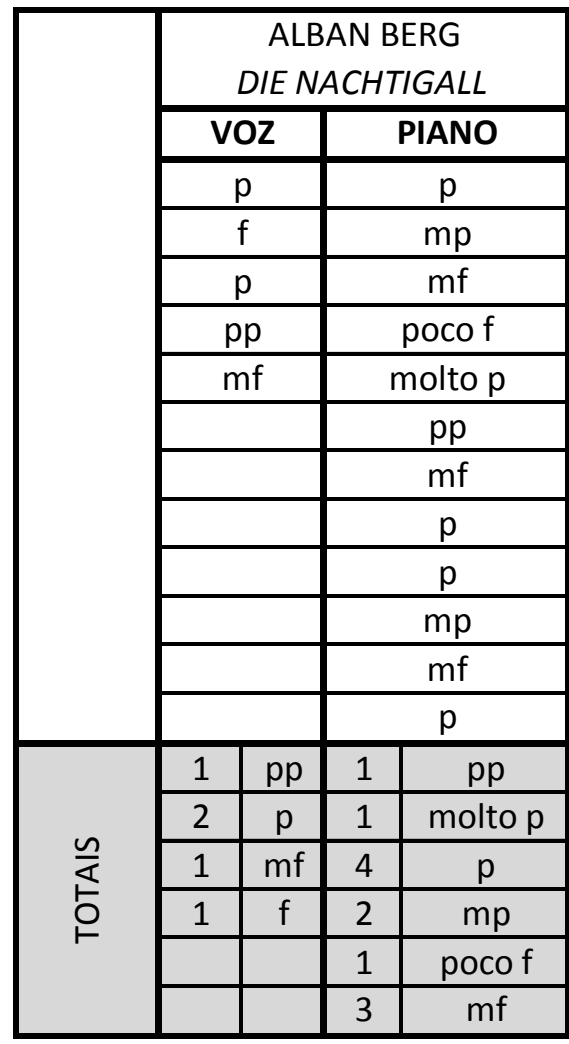

Tabela 5 - Dinâmica - Die Nachtigall - Berg 


\section{Quanto aos andamentos e dinâmica dos dois lieder Nachte Die Nachtigall}

Quanto ao pulso, Berg utiliza nas partituras de Nacht e Die Nachtigall, variações quanto à pulsação, propondo mudanças de andamento ou expressões que alteram o caráter temporal em trechos muito curtos, ou em alguns um pouco mais prolongados. Se pensarmos que, em geral, canções são peças de curto fôlego comparadas a uma ópera ou com o oratório na íntegra, este aspecto do caráter temporal confere às canções um ganho de elasticidade em pequenas seções, tanto para o pulso quanto para as alterações da gama de dinâmica, ganho este o qual faz parte de toda expansão, ou seja, um alargamento de amplitude nos diversos parâmetros do som contribuindo maior riqueza ao gênero canção.

\section{Quanto à textura das duas canções de Berg}

Como pode ser observado nesses vários trechos ilustrados, Berg utiliza os vários planos da partitura, explorando todos os aspectos ampliados, dos parâmetros do som, utilizando recorte de frases, combinação diversa de acordes, obtendo camadas finas desses planos que se interceptam entre si, proporcionando amplitudes mais profundas, como uma malha trançada em uma rede de inúmeras possibilidades. Isto é alcançado com maior profundidade em obras mais extensas e na sua maturidade, mas já em obras de sua primeira fase, percebe-se já a habilidade com que trabalha essa pluralidade, na maneira de discursar e concatenar os diversos elementos musicais e de como é hábil no aspecto contrapontístico mesclado e inserido ao plano harmônico. 


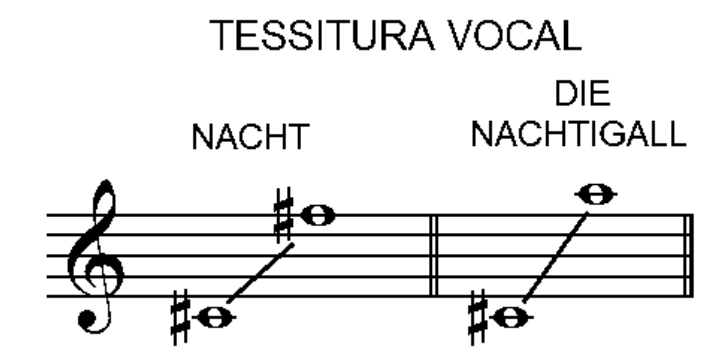

Figura 18 - Tessitura Vocal dos dois lieder de Berg

\subsection{4 - Uma canção dos Drei Lieder de Edward Steuermann}

Edward Steuermann começou a compor, logo na infância, aos oito anos de idade. Desenvolveu-se rapidamente na arte da música, devido à atividade musical intensa em seu ambiente familiar, mostrando grande e notável predisposição para o piano. Sua mãe foi quem o iniciou ao piano e também na formação musical, esta tinha um gosto especial pelo lied, pois, por algum tempo sonhara em ser cantora lírica, fato que se acredita ter influenciado diretamente Steuermann a compor canções. ${ }^{104}$

Os Drei Lieder Für eine Tiefe Männerstimme, de 1931 são:

I - Der Mensch (texto de Claudius)

II - Wandrers Nachtlied (texto de Goethe)

III - Gesang der Geist über den Wassen (texto de Goethe)

Dedicados a seu amigo e compositor, Alban Berg, que morreria pouco mais tarde, em 1935. Estes três lieder são um conjunto de obras essencialmente dodecafônico, escritos em um período bastante fértil para Steuermann, inspirariam composições que escreveria mais tarde: as Sete Valsas para Quarteto de Cordas, 1946; o Trio para Violino, Violoncelo e Piano, 1954; a Suíte para Piano, 1952; a Improvisação e Allegro para Violino e Piano, 1955. Em 1952, Steuermann recebeu a Medalha Schoenberg, a maior honraria concedida pela Sociedade Internacional

${ }^{104}$ ZANI, Amílcar. Edward Steuermann: Um Esboço de Figura. Tese de Livre Docência. ECA-USP, 1991. 
de Música Contemporânea, em Salzburgo, Áustria, por sua intensa atividade em promover e aprofundar a compreensão das obras musicais contemporâneas. ${ }^{105}$

Podem-se apontar as obras de Edward Steuermann, como espécie de prolongamento daquilo que foi síntese do material composicional utilizado pela Segunda Escola de Viena; pois além de ter sido aluno direto de Arnold Schoenberg, com seu trabalho na Sociedade de Concertos Particulares, obteve estreito laço com os componentes desta escola.

a principal característica da música E. Steuermann, (...) a originalidade. (...) não (...) que esta música não tenha traços em comum com outras expressões de nosso tempo. Nenhum artista verdadeiro poderia ou deveria se abstrair das influências mais férteis do período em que vive; pelo contrário, ai é que reside sua grandeza, a maneira pela qual o artista absorve e é precisamente neste processo de absorção e transformação que a originalidade de Steuermann se revela em sua totalidade. Sabe-se que [ele] deve muito de seus conceitos musicais a seu professor A. Schoenberg e não seria difícil reconhecer a influência schoenbergiana em suas obras. (...) [a originalidade de Steuermann] não consiste numa busca consciente de materiais jamais escutados, as tão chamadas "sonoridades" raras de combinações incomuns dos instrumentos, pelo contrário, isto se manifesta através de um discurso composicional dos mais extraordinários, complexos em sua textura e em sua total liberdade ${ }^{106}$

\section{* Lied no1 dos Drei Lieder ${ }^{107}$ - Edward Steurmann}

1 - Der Mensch - Claudius

2 - Wandrers Nachtlied - Goethe

3 - Gesang der Geister über den Water - Goethe

Inseridos na técnica dodecafônica estão estes lieder para barítono ou baixo e o instrumento piano, de Steuermann, o ciclo foi composto no ano de 1931.

\footnotetext{
105 ZANI, Amílcar. Op.Cit.

106 LEIBOWITZ, René. (“Nachruf' o Necrológio de Steuermann escrito por Leibowitz). In; Heloisa Zani. Correspondência - Clara e Edward Steuermann \& René Leibowitz. Tese de Doutorado. ECA-USP, 2002, p.166.

107 Tradução Anexo I (final - após a bibliografia)
} 


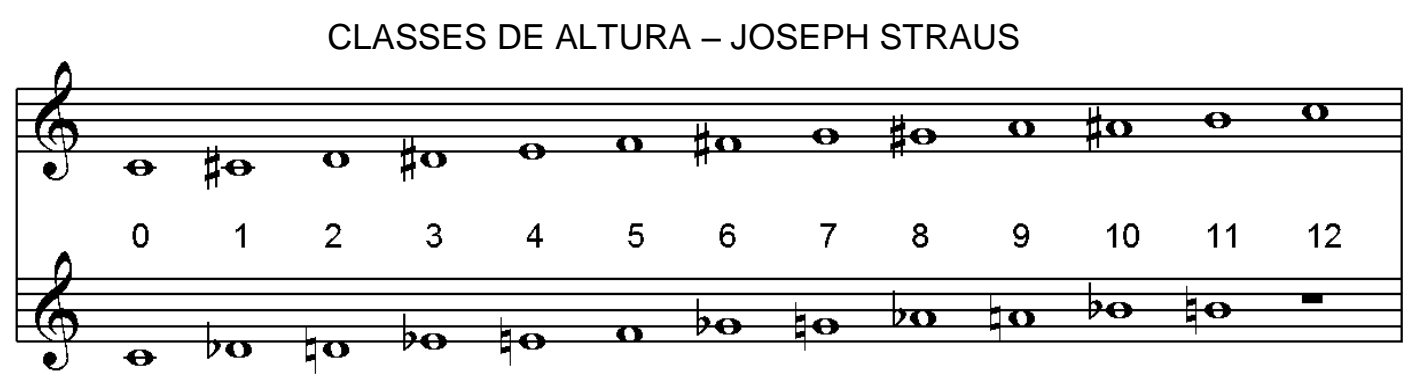

Figura 19 - Classes de Altura - Joseph Straus

1- Der Mensch-Claudius

Este lied contém 56 compassos regulares com a fórmula de compasso de 2/2 (dois por dois), desde o c. 1 ao c.56.

Introdução - c.1 e c.2

Seção 1 - c.3 ao c.11 - sendo que do c.3 ao c.7 - apresentação da série

Ponte - elemento de ligação - c.12 com anacruse

Seção 2 - c.13 ao c.35 - sendo que há duas subseções

Subseção 2.1 - c.13 ao c.23

Ponte - c.24 com anacruse e c.25

Subseção $2.2-$ c.26 ao c.34

Ponte - c.35

Seção 3 - c.36 ao c.47 - reminiscência da seção 1

Subseção $3.1-$ c.36 ao c. 41

Subseção $3.2-c .42$ ao c.46

Coda - c.48 ao c.56 - onde volta ao tema da seção 1 de forma alargada com o procedimento de aumentação.

Andamento - Moderato

A introdução de apenas dois compassos inicia com um lá bemol oitavado, na mão esquerda do piano, no registro mais grave do piano, mão direita mi, lá natural, dó natural, o baixo sobe oitavado em graus conjuntos adentrando o segundo compasso. 
Seção 1 - c.3 ao c.11 - sendo que do c.3 ao c.7 - apresentação da série pela voz de barítono.

Pode-se observar na Seção 1 - c.3 ao c.11 - sendo que do c.3 ao c.7, Steuermann faz apresentação da série.

A série é a ideia musical da qual se constrói o plano horizontal e o plano vertical para os acordes. Muito embora Steuermann trabalhe com maior ênfase no plano horizontal e linear nesta canção.

A série pode ser apresentada na forma original que é a sequência, ou a ordem em que os sons acontecem consecutivamente passando então a ser a ideia básica ou primária. A partir da série original $\underline{\mathrm{O}}$ ou $\underline{\text { S.O }}$ podem surgir as possibilidades das formas por espelhamento que são: I - Inversão, $\underline{\mathrm{R}}$ Retrógrado ${ }^{108}, \underline{\text { R.I }}$ - Retrógrado da Inversão, a saber:

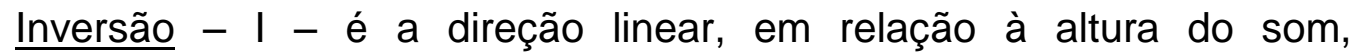
ascendente ou descendente dos intervalos melódicos de uma série, ou agrupamento de notas, um tema ou melodia. Inverte-se a direção do intervalo, entoa o que era ascendente torna-se descendente e vice-versa. Exemplo: La, do, mi (ascendente) - La, fa\#, ré (descendente).

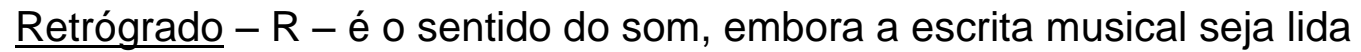
sempre da esquerda para a direita, se o agrupamento for pensado ou lido da direita para a esquerda, obtém-se então, o retrógrado; aproveitando o exemplo original acima La, do, mi (ascendente) resultaria em mi, do La (descendente).

Retrógrado da inversão, ou inversão do retrógrado, ou inversão retrogradada - R.I - é a mistura dos dois recursos de inversão e retrogradação.

Estes procedimentos transformam-se em novos recursos utilizados gerando ainda mais elementos na construção das várias seções deste lied e no repertório da Segunda Escola de Viena.

\footnotetext{
108 SADIE, Stanley. Retrógrado:(em relação á Série original) seqüência de notas tocadas de trás para frente.(...) é importante no sistema de composição dodecafônico de Schoenberg, em que séries de 12 notas podem ser usadas em retrógado e em inversão retrógada. [Enquanto que] *Série: [é] Uma sucessão organizada de parâmetros a serem usados como material básico numa composição. A palavra é usada para descrever uma organização dos 12 graus de altura [onde as 12 notas de nossa escala temperada aparece em uma ordem criada pelo próprio compositor, de acordo com os procedimentos do Dodecafonismo, nenhum desses sons se repetirá enquanto toda a Série não for apresentada por completo].
} 
E. STEUERMANN - Canção 1 - O

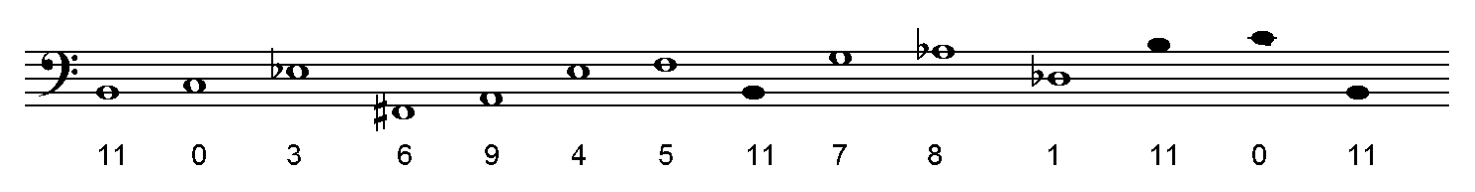

Figura 20 - E. Steuermann - Canção 1 - O

Este primeiro lied é trabalhado de forma linear, logo na anacruse do terceiro compasso, Edward Steuermann apresenta a série que é a célula geradora deste lied.

E. STEUERMANN - Canção 1 - R

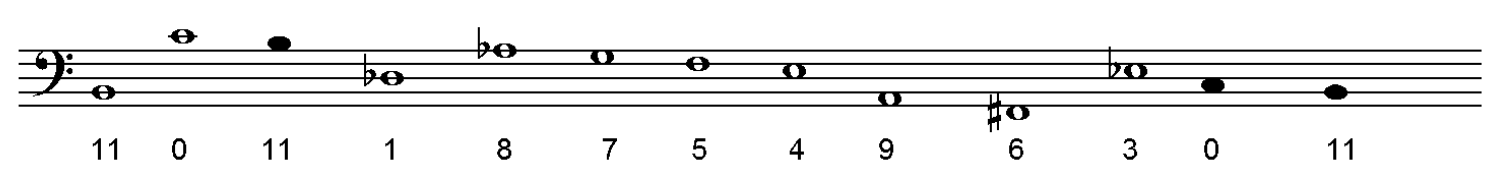

Figura 21 - E. Steuermann - Canção 1 - R

E. STEUERMANN - Canção 1 - I

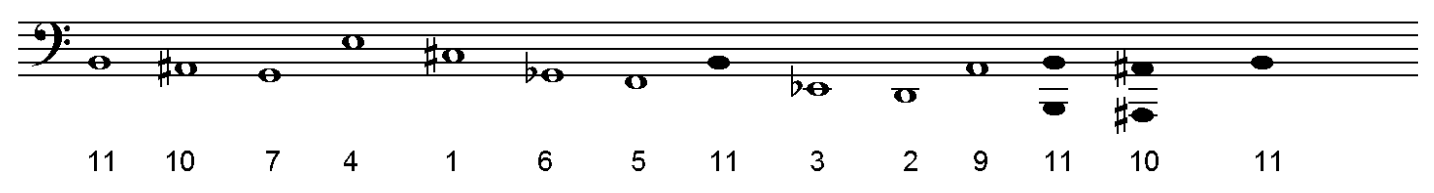

Figura 22 - E. Steuermann - Canção 1 - I

E. STEUERMANN - Canção 1 - R.I.

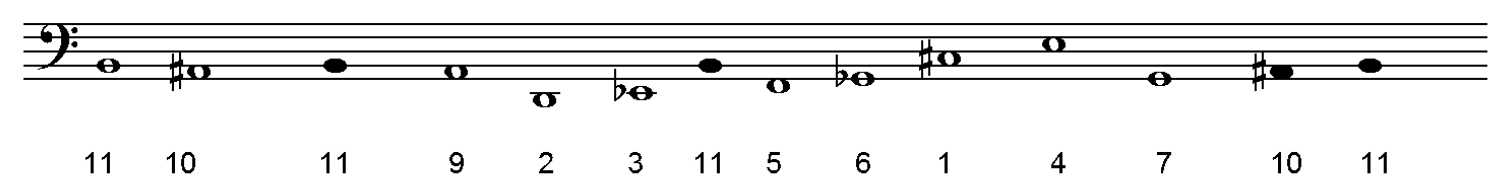

Figura 23 - E. Steuermann - Canção 1 - R.I. 
Os graus conjuntos escalares tornam-se fragmentos extraídos da série como, por exemplo, as notas si-do, na partitura de Edward Steuermann. 
Classes de Alturas

Classes Intervalares

Cromatismo

Graus Conjuntos

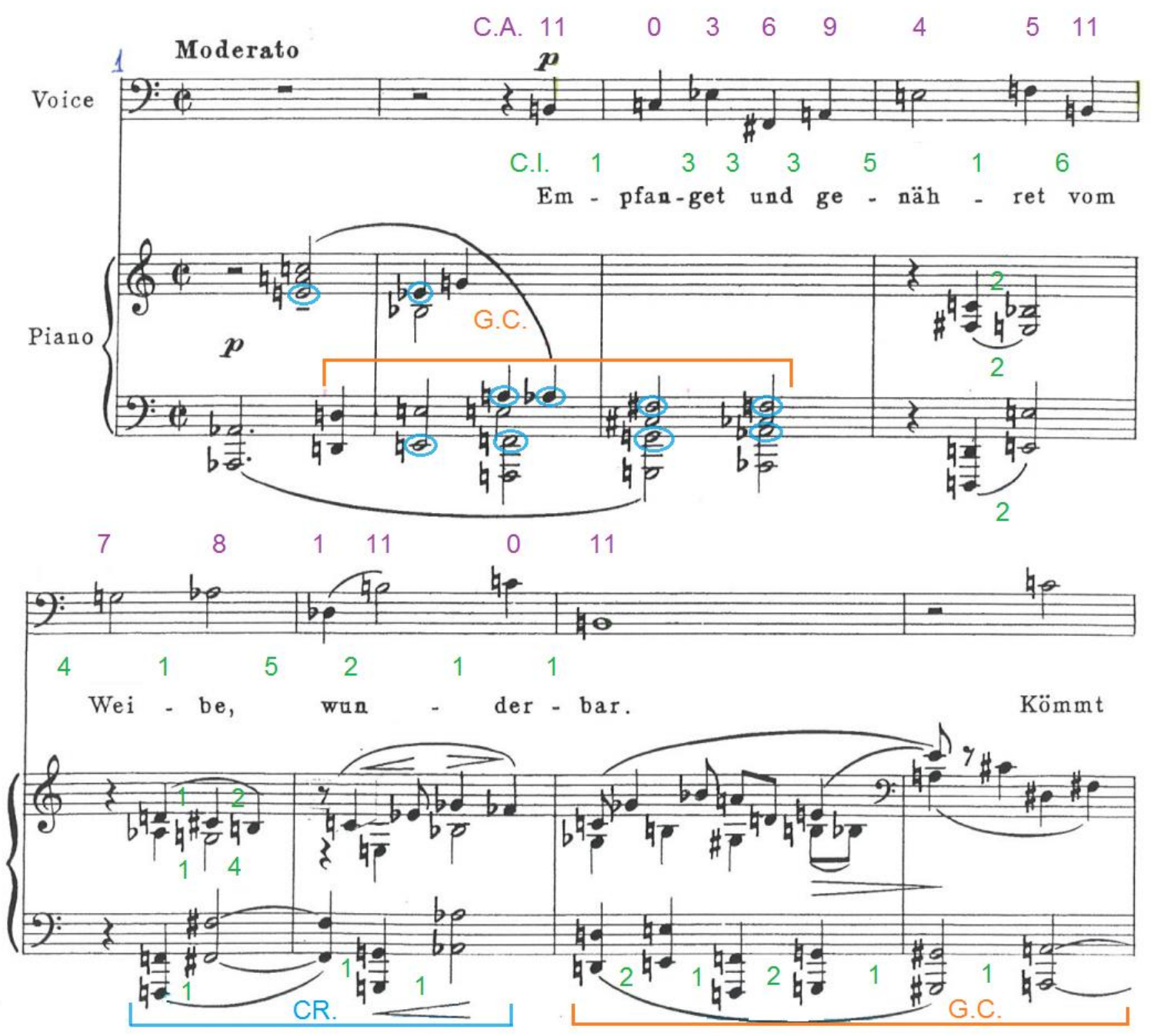

Figura 24 - (fig. 23 e 24) Início da partitura de Der Mensch, lied de Steuermann 

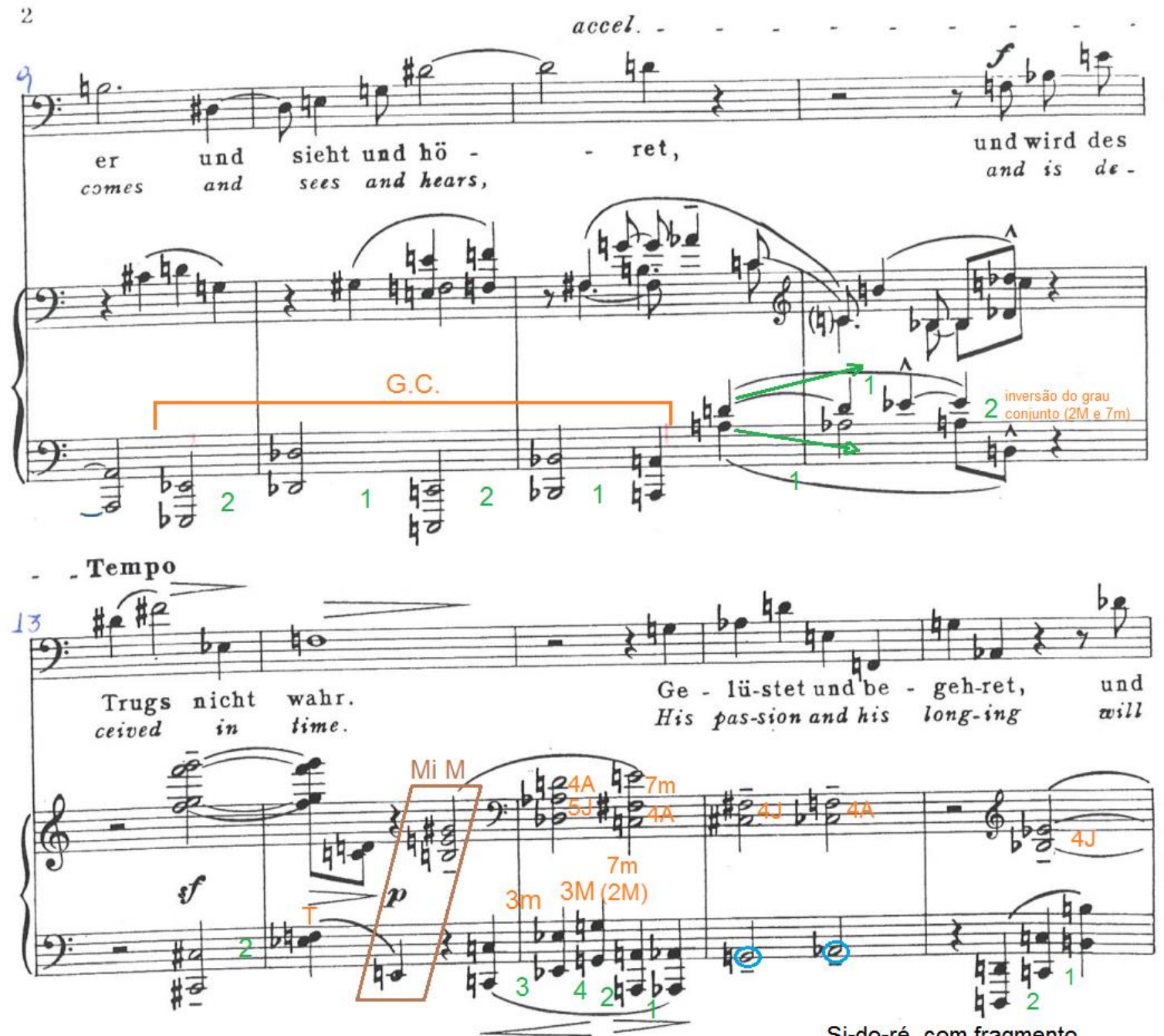

Si-do-ré, com fragmento dessas notas, graus conjuntos em permutação intervalar:

ré-do $7 \mathrm{~m}(2 \mathrm{M})-1^{\circ}$ intervalo do baixo extraído do fragmento si-do-ré do-si $7 \mathrm{M}(2 \mathrm{~m})$

ré-si $13 \mathrm{M}(3 \mathrm{~m})$

Figura 25 - (fig. 23 e 24) Início da partitura de Der Mensch, lied de Steuermann 


\section{Wandrers Nachtlied - Goethe}

Este contém 28 compassos com mudanças de fórmulas, são elas $4 / 4$ (quatro por quatro), 3/4 (três por quatro), 2/4 (dois por quatro), 3/2 (três por dois), $5 / 4$ (cinco por quatro).

Introdução - c.1 - cromatismo, porém com salto de $7^{\mathrm{a}} \mathrm{M}$ descendente, que seria dó natural e ré bemol (descendente) e ascendente (inversão interválica).

Seção 1 - c.2 ao c.12 - no canto

Ponte - c.12 ao c.14 - onde há um deslocamento com as fórmulas de compasso (sendo na voz 3/4 - c.12 e c.13; no piano 4/4 - c.11 ao c.13)

Seção 2 - c.14, ou c.13 [piano e voz respectivamente] ao c.19

Ponte - elemento de ligação de um compasso - c.20

Seção 3 - c.21 ao c.26 - reapresentação da série original

Coda - c.26 ao c.28

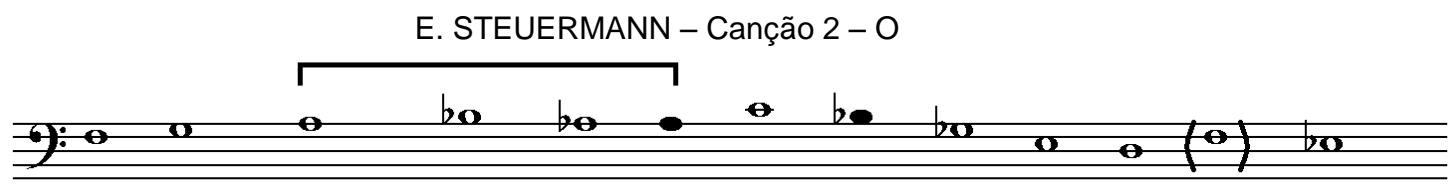

$\begin{array}{lllllllllllll}5 & 7 & 9 & 10 & 8 & 9 & 0 & 10 & 6 & 4 & 2 & 5 & 3\end{array}$

Figura 26 - E. Steuermann - Canção 2 - O

E. STEUERMANN - Canção 2 - O

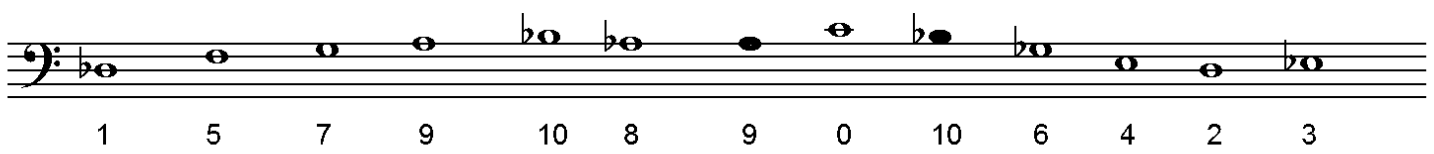

Figura 27 - E. Steuermann - Canção 2 - O

E. STEUERMANN - Canção 2 - I

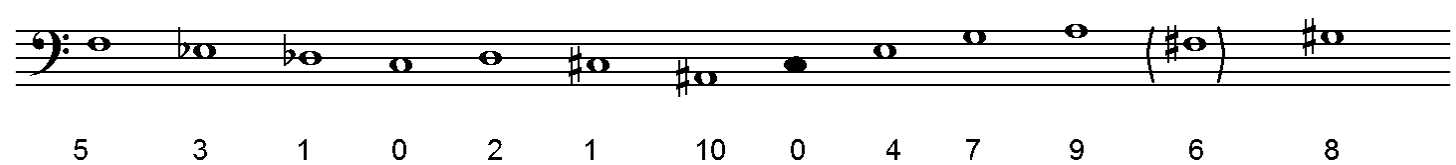

Figura 28 - E. Steuermann - Canção 2 - I 


\section{E. STEUERMANN - Canção $2-R$}

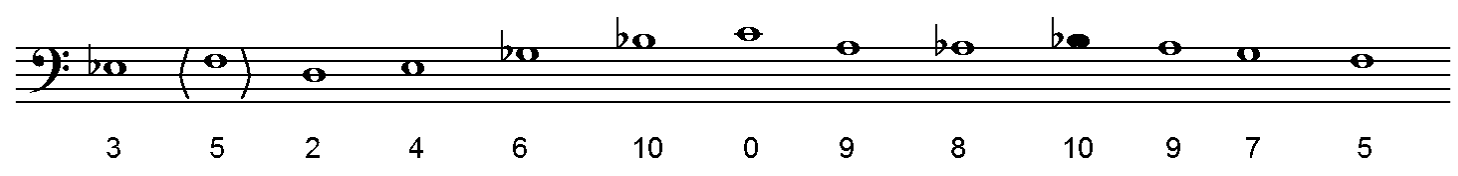

Figura 29 - E. Steuermann - Canção 2 - R

E. STEUERMANN - Canção 2 - R.I.

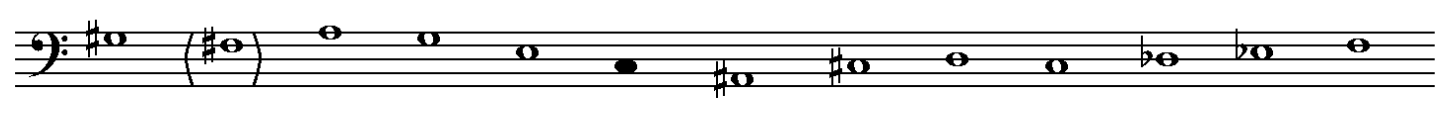

$\begin{array}{lllllllllllll}8 & 6 & 9 & 7 & 4 & 0 & 10 & 1 & 2 & 0 & 1 & 3 & 5\end{array}$

Figura 30 - E. Steuermann - Canção 2 - R.I.

Segue tabela com dinâmica, mais uma indicação do minucioso detalhamento de Edward Steuermann: 


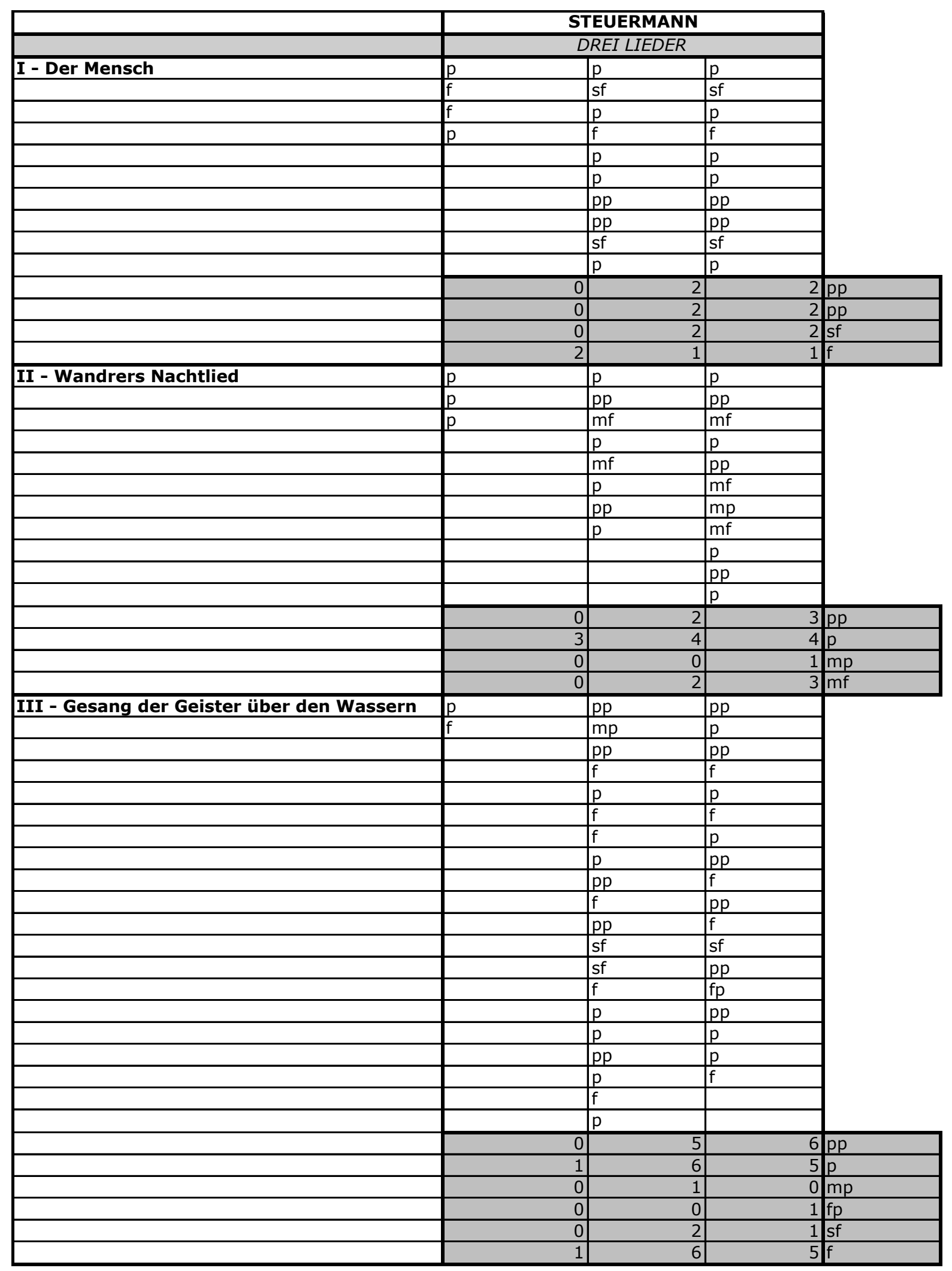

Tabela 6 - Dinâmica - Lieder - Steuermann 
Quanto à tessitura vocal dos Drei Lieder:

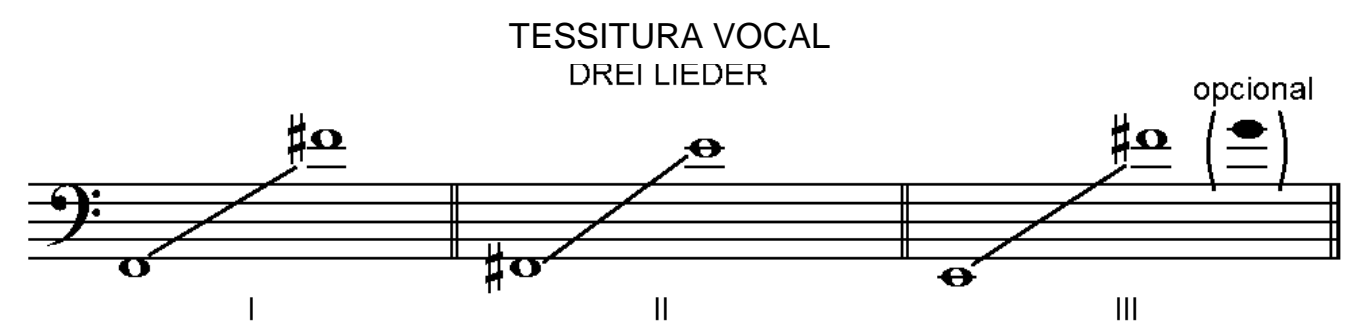

Figura 31 - Tessitura Vocal dos Drei Lieder de Steuermann

\section{2 - A Origem da Cantata}

O termo cantata surge pela primeira vez, em 1620 na Itália, como uma monodia com variação estrófica que se desenvolve em uma forma musical composta por seções contrastantes, quando alguns notáveis compositores venezianos, como Alessandro Grandi, (?)1575-1630 e Giovanni Berti (?), publicaram um livro de canções seculares intitulado Cantate et Aria. O termo foi adotado por Grandi para definir três peças as quais se pensou inadequado utilizar o termo aria. Essas eram essencialmente peças com variações estróficas, mas que se diferenciavam no uso do baixo que se movia regularmente em semínimas e a linha vocal variava em cada estrofe, se assemelhando a um madrigal. ${ }^{109}$

A partir da segunda metade do século XVII, a cantata assume uma forma mais definida com recitativos e árias alternando-se entre si com algum solista somado ao acompanhamento de contínuo sobre um texto lírico ou por vezes semidramático, sob a forma de uma narração ou monólogo.

Em princípio a cantata se assemelhava bastante a uma cena lírica extraída da ópera, porém era concebida para uma sala pequena (camara) para um público mais restrito e seleto, sem o aparato cênico como figurino e cenários

109 SADIE, Stanley. The New Grove Dictionnary of Music and Musicians (5 vol). London: Macmillan Publishers Limited, 1980. 
pensados para um teatro.

Com um caráter mais elevado, proporcionava aos compositores oportunidades maiores de elaboração e efeitos musicais. O importante compositor de ópera da escola romana o italiano Luigi Rossi, 1597-1653, foi talvez, o primeiro a ganhar destaque nesse novo gênero musical.

\subsection{1 - A Cantata na Alemanha}

Na Alemanha, a cantata obteve um desenvolvimento diferenciado das cantatas dos demais países europeus, por encontrar em sua origem e em seu desenvolvimento muitas diferenças em relação ao modelo italiano e, sobretudo por ter sido cultivada para ser um gênero mais essencialmente sacro. Além das estruturas musicais germânicas, a maneira de combinar as texturas e a natureza heterogênea dos textos, em muito contrastam com a maioria dos elementos italianos e sua forma de conceber música. ${ }^{110}$

Assim como os oratórios têm vital importância na composição de Friedrich Georg Haendel, 1685-1759. A cantata da chiesa (para ser cantada em igreja), um produto típico do período Barroco desempenhou papel substancial na vida composicional de Johann Sebastian Bach, 1685-1750.

As cantatas sacras formam a maior parte da produção musical de Bach. Ele compôs cantatas durante grande parte de sua vida, porém foi nos seus últimos anos, período em que se encontrava em Leipzig, que houve sua maior produção e onde há a maior documentação. De acordo com o seu obituário, escrito por seu filho Carl Philipp Emanuel e por seu aluno Johann Friedrich Agricola, Bach compôs "cinco ciclos anuais (Jahrgänge) completos de peças de igreja para todos os domingos e festas" (DAVID; MENDEL, 1988, p. 304). Dos cinco ciclos anuais, os três primeiros estão completos e os dois últimos fragmentados. Um ciclo anual completo era composto de aproximadamente 65 cantatas, levando a uma soma total de 300 cantatas, das quais cerca de 200 foram preservadas. As "peças de igreja" referidas no obituário de Bach foram muito raramente chamadas de cantatas por ele próprio. Ele algumas vezes usou termos como: "Ode"; "Diálogo"; "Moteto" ou "Concerto" (STAPERT, 2000, p. 20). $\mathrm{Na}$ maioria das obras ele não usou nenhum termo para designá-las,

110 SADIE, Stanley. The New Grove Dictionnary of Music and Musicians (5 vol). London: Macmillan Publishers Limited, 1980. 
sendo simplesmente identificadas pelo dia do ano litúrgico para a qual foram compostas. Todavia, o termo cantata, que mais tarde veio a ser usado em seu sentido genérico para designar composições sacras para voz(es) e instrumentos, tornou-se a designação geral para as suas peças de igreja. O modelo de texto do poeta-teólogo Erdmann Neumeister foi o usado para os textos das cantatas sacras de Bach de Leipzig, que se baseava de maneira severa na dupla função de pregação da homilia luterana: explicatio e aplicatio, a exegese bíblica e a instrução teológica, e seguiam uma direção de aproveitamento prático e moral. O libreto normalmente era iniciado com o dictum bíblico, usualmente uma passagem prescrita pela lição do Evangelho, que servia de ponto de partida (Eröffnungschor - coro de abertura). Depois seguia-se a explanação escritural, doutrinal e contextual da lição ( $1{ }^{\circ}$. par de recitativoária), que faziam as considerações das conseqüências e das advertências tiradas da lição, e que conduziriam o fiel a uma verdadeira vida Cristã (2‥ par de recitativo-ária). O texto se concluiria com a oração congregacional em forma de hino (Chora) (WOLFF, 2000a, p. 278) ${ }^{111}$

A cantata foi resultado do concerto sacro com texto em alemão, um gênero seiscentista em que o fascínio da época pela utilização de grupos de sons rivais encontrou plena expressão em oposição ao do concerto grosso, porém seguindo esquema semelhante. Na prática era como se os solistas competissem entre si e com o coro, e os instrumentistas por sua vez, com os cantores em uma trama elaborada para dar notabilidade a várias ideias musicais.

Frequentemente brilhante o tratamento vocal propiciava a exposição de habilidades técnicas ancoradas por uma interpretação do texto altamente expressiva. Importantes tarefas também eram confiadas aos instrumentos, aos quais eram delegadas longas introduções com partes puramente instrumental que podem ser localizadas em partituras de Samuel Scheidt, 1587-1654, Franz Tunder, 1614-1617 e Johann Pachebell, 1653-1706, que fundamentaram seus concertos em canções de igreja, bem como os compositores Heinrich Schütz, 1585- 1672 e Dietrich Buxtehude, 1637-1707, optaram musicar textos bíblicos com determinada liberdade.

No mundo moderno, Kantate é o termo germânico que se refere tanto à forma secular barroca quanto à forma protestante da música de igreja, tendo seu ápice de desenvolvimento e materialização com as cantatas de Johann Sebastian Bach, 1685-1750. A palavra Kantate foi utilizada primeiramente no século XIX

111 JUSTI, Katia Regina Kato. O Oboé e a Representação da Confiança nas Árias das Cantatas Sacras de J.S.Bach. São Paulo: Dissertação de Mestrado - UNICAMP, 2007.p.27. 
pelos editores da Bach-Gesellschaft ${ }^{12}$ para designar de forma mais abrangente as obras de Bach deste gênero.

Spitta foi o responsável por estender esta denominação para as demais obras análogas no gênero dos outros compositores alemães desde Schütz. ${ }^{113}$

No ano de 1700 Erdmann Neumeister, 1671-1756, de Hamburgo, um teólogo ortodoxo e também poeta com inclinações pietistas, criou um novo tipo de poesia sacra designada para ser musicada que determinou o termo cantata. ${ }^{114}$

Com o intuito de que a poesia musicada levasse o fiel a uma reflexão individual e devota do texto, Neumeister acrescentou a este repertório estrofes de poesia, versos madrigalescos que comentavam um dado do texto das Sagradas Escrituras e explicavam o seu sentido de fidelidade a Deus; pois até o final do século XVII os textos das composições luteranas consistiam-se principalmente de passagens bíblicas ou da liturgia da Igreja, juntamente com versos extraídos de corais.

Os textos poéticos acrescidos eram concebidos para serem musicados com a introdução de um recitativo mais os ariosos ou arias. Foram incorporadas mais duas novas formas inspiradas na cantata secular e na ópera: o recitativo seco e a aria da capo. Tornam-se regra os contrastes separados claramente pelos movimentos musicais. A partir de então, Erdmann Neumeister deu início ao desenvolvimento desse tipo de texto que resultou como sermão musical à função da cantata.

\footnotetext{
112 SADIE, Stanley. Op.Cit.p.364. Geselschaftlied - (Al.“canção de sociedade”) Canção polifônica alemã, cultivada entre as classes médias nos séculos XV-XVII (em contraste com Hoflied, canção da corte, e Volkslied, canção popular). A palavra ampliou-se na Alemanha para abranger canções de caráter predominantemente popular que refletem os interesses e gostos de grupos sociais claramente definidos. Também aplicou-se a canções corais dos séculos XVIII-XX, e às vezes serve como sinônimo de "Geselliges Lied" (canção de camaradagem).

${ }^{113}$ SPITTA, P. Johann Sebastian Bach, Vol II. Dover Publication, New York, 1952.

114 GROUT, J. \& PALISCA, Op.Cit. 2005. p.386.
} 


\subsection{2 - A Música Coral do Século XIX}

As mais importantes realizações dos compositores românticos no campo da música coral estão na forma do Oratório e o Requiem (missa fúnebre). Dentre os mais belos oratórios, compostos com inspiração aos de George Haendel, incluem-se o Elias, de Felix Mendelsohn, 1809-1847; A Infância de Cristo $^{115}$, de Hector Berlioz, 1803-1869; O Sonho de Gerôncio ${ }^{116}$, de Edward Elgar, 1857-1934, que, em vez de se basear em algum texto bíblico, constitui uma adaptação de um poema de cunho religioso.

Importantes missas de requiem adquirem maior extensão e densidade mais apropriadas para serem realizadas em uma casa de concertos do que propriamente em uma igreja. O Requiem, de Hector Berlioz, 1803-1869, por exemplo, exige uma imensa orquestra com oito pares de tímpanos e quatro grupos extras de metais, posicionados nos quatro cantos do coro e da orquestra. Tanto o Requiem, de Giuseppi Verdi, 1813-1901, quanto o Requiem, de Berlioz apresentam um caráter e estilo mais dramático sobrepujando a condição da impotência humana no que diz respeito a sua finitude. Em nítido contraste com essas duas obras está o calmo e sereno Requiem, de Gabriel Fauré, 1845-1924. Outra importante obra coral do século XIX é o Requiem, de Brahms, composto em 1868. Para essa obra, ao invés de musicar o texto de missa religiosa com o idioma latino, Brahms utiliza passagens bíblicas significativas selecionadas por ele próprio com o texto no idioma germânico, Ein Deutsches Requiem - opus 45. "A maior obra vocal de Brahms, e crucial em sua carreira, é o Requiem alemão, combinando coro misto, vozes solistas e orquestra completa, em uma declaração de fé extremamente sincera, mas não sectária."117

No findar do século XIX, e na primeira metade do século XX, o grupo de compositores da Segunda Escola de Viena utilizou-se bastante dos gêneros que empregam o veículo verbal, assim como lied, a cantata, o melodrama. Anton Webern, por exemplo, compôs duas cantatas. A primeira, opus 29 Cantata ํㅜ 1 ,

\footnotetext{
${ }^{115}$ L'Enfance du Christ.

${ }^{116}$ The Dream of Gerontius.

117 SADIE, Stanley. Op.Cit.p.130.
} 
de 1939, e a opus 31, a Cantata ํo2, de 1943.

\subsection{3 - Cantata no 2, opus 31 - 1943 - Anton Webern}

Importante salientar que muito embora seja uma obra para duas vozes solistas, baixo e soprano, coro misto a quatro vozes e orquestra, neste trabalho não será abordada a questão instrumental das peças, mas, somente o ponto de vista vocal.

Obra dodecafônica, para vozes solistas, soprano e baixo, coro misto a quatro vozes (SATB) e orquestra:

Parte I e II - Solo de Baixo

Parte III - Coro Feminino a três vozes e Soprano Solo

Parte IV - Soprano Solo

Parte V - Soprano Solo e Coro Misto a quatro vozes

Parte $\mathrm{VI}$ - Coro Misto a quatro vozes.

Conforme cartas endereçadas a Willi Reich, Anton Webern, inicialmente, denominou esta cantata de oratório e mais tarde rebatizou-a de Cantata. ${ }^{118}$

A primeira peça ou o Movimento I da Cantata no 2 é uma ária para baixo solista, onde Webern trabalha com base em um duplo cânone perpétuo por inversão e compõe com plena liberdade, por meio de variação, aumentação, diminuição, etc.

Formalmente a ária tem três partes, com um tema de trinta e dois compassos construídos periodicamente.

Quanto ao caráter, esta ária se apresenta como espécie de hino: Dir Stille um den Bienenkorb in der Heimat. ${ }^{119}$

Do ponto de vista formal, na parte IV, trata-se de um recitativo que deve ser cantado por um soprano solista, o qual expõe uma melodia, que aqui neste caso, também é a própria Série utilizada como fundamento, ou nomos como Webern gostava de denominá-la, é uma espécie de fio condutor utilizado por toda

\footnotetext{
${ }^{118}$ WEBERN, Anton. O Caminho para a Música Nova.

${ }^{119}$ A calma em torno da colméia, no país natal. (tradução nossa)
} 
a obra. Importante observar que esta parte foi a primeira das peças a ser escrita para o opus 31 .

A quinta parte é estruturada a partir de um cânone a quatro vozes, carrega em si enorme complexidade ressaltando ainda mais o gênio de Webern.

A sexta e última parte da Cantata $n^{\circ} 2$, é para coro e orquestra, que traz em suas relações internas: a segunda voz, que é o contralto, para cantar o retrógrado da primeira voz, que é o soprano; tenor, a terceira voz, realiza a inversão da segunda voz. A quarta voz, que é o baixo, realiza a inversão da primeira, que por sua vez, é o retrógrado da terceira. Pode-se dizer que existe aí, uma dupla relação interna: a primeira e quarta vozes ( $1^{\underline{a}}$ e $\left.4^{\underline{a}}\right)$ estão na mesma relação que a segunda e a terceira ( $2^{\underline{a}}$ e $\left.3^{\underline{a}}\right)$, em inversão; a primeira e a segunda ( $1^{\underline{a}}$ e $\left.2^{\underline{a}}\right)$ estão na mesma relação que a terceira e a quarta ( $3^{\underline{a}}$ e $\left.4^{\underline{a}}\right)$, em retrogradação. Os valores de notas geralmente são longos, mas o andamento é bastante fluente. ${ }^{120}$

O compositor é minucioso na descrição rítmica e na questão dos andamentos. Em sua última etapa criadora, Webern retomou suas preferências pelas sonoridades compactas e sutilmente contrastadas. Compôs duas cantatas, opus 29 e opus 31, para coro e conjunto instrumental, com texto de Hildegard Jone, estas revelam essas características gerais unidas a diversas disposições formais simétricas.

As partes I, IV e V da Cantata $n^{\circ} 2$, opus 31, também são objetos de nosso estudo, são de proporções maiores do que a Cantata $n^{\circ}$ 1, opus 29; na número dois Webern investe recursos renovados para desenvolver sua dialética, pois está bastante adaptada ao texto.

Analisando o conjunto das peças propostas neste trabalho, nota-se o procedimento adotado pelos compositores da Segunda Escola de Viena, que são as formas de variar motivo, tema, série, acordes, grupo de acordes, enfim todas as células de sons, ou fragmentos que são ideias geradoras de construção composicional. As formas usuais de variação que podem modificar uma ideia musical, entre outras, seriam: transposição, mudança de registro, articulação,

\footnotetext{
${ }^{120}$ WEBERN, Anton. O Caminho para a Música Nova.p.168.
} 
aumentação (ampliação), diminuição (redução), espelhamento (inversão, retrógrado e retrógrado da inversão).

E é através desses procedimentos, principalmente, que esses compositores adquirem com esmero, a simetria das formas restrita ou alargada, tanto pelo aspecto da altura, nos planos vertical e horizontal, como na plasticidade desses elementos musicais, que resultariam nos fragmentos de tempo que são nada mais que os tamanhos de frase, tema, motivo, célula, período, seção, parte, enfim a forma. A terceira dimensão seria a dinâmica do som, as nuances de timbre, o colorido e a densidade. Todos esses parâmetros constituem o relevo entre o plano mais profundo até o plano mais superficial. Essa plasticidade seria encontrada desde a fragmentação das pequenas ideias no espaço interno da peça, até a obra como um todo dentro desse processo criativo. $\mathrm{Na}$ arte de exercitar desde as formas mais pequeninas, estariam os palíndromos, os quais muitos deles são encontrados nas diversas camadas de superposição dos planos da partitura, ora melodicamente, ora harmonicamente.

\section{Movimentos I - IV- V - Cantata no2 - opus 31 de Anton Webern ${ }^{121}$}

Movimento I - pode ser seccionado em três partes, seção1, 2 e 3.

Seção 1 - introdução - c.1 ao c.07

Seção 2 - c.08 com anacruse ao c.21

Sendo que as duas seções unidas indicam a Exposição do material temático.

Ponte - do c.22 - elemento de ligação

Seção 3 - c.23 ao c.38 - Desenvolvimento

Sendo que do c.23 ao c.25 - material harmônico, construído através da série somente a parte orquestral. Os c.26 ao c.29 - material melódico, a voz solista permanece sem acompanhamento - de fato é um solo, no sentido de a voz estar sozinha mesmo. Ou ainda, do c.23 ao c.38 - diluição da série em retrógrado.

\footnotetext{
${ }^{121}$ As traduções dessas peças encontram-se no final deste trabalho, no Anexo I, após a bibliografia.
} 
Seção 2' - c.39 - c. 45 - Reexposição do material temático, sem repeti-lo literalmente, reexpõe o material temático de forma bastante condensada. Codetta - c.46 com anacruse ao c.48.

A seção 1 - contém 07 compassos, onde Webern expõe o material básico o qual ele trabalhará durante o todo o Movimento I, que por sua vez, foi construido a partir do Movimento IV, ou seja, o recitativo do soprano que foi a primeira parte da cantata concebida por Webern, para a qual deixou um relato comentado em cartas endereçadas a Willi Reich, editadas em seu livro O Caminho para a Música Nova. Posteriormente, Webern reagrupa as partes enumerando-as da forma a qual a conhecemos hoje.

A Seção 2 - contém 14 compassos do c.23 ao c.36, sendo que c.37 e c.38 - [fórmula de compasso 1/2] - pode-se pensar que estes dois compassos teriam o papel tanto de codetta da seção 3 , como ponte para a volta da seção 2 , modificada e bastante condensada.

A plasticidade do material composicional, com que curiosamente trabalha as obras a Segunda Escola de Viena é por demais interessantes a maneira artesanal que utiliza os procedimentos técnicos com espelhamento que podem gerar vários palíndromos encontrados em todo tipo de arte que lida com proporções de simetria, desde a antiguidade.

O espelhamento pode ser obtido através da Inversão de algum agrupamento de notas, plasticamente tanto nos planos horizontal e vertical da partitura, ou seja, pela harmonia, ou seja, pela melodia. Essa forma de trabalhar o material ou a ideia musical é encontrada em todas as fases da Segunda Escola de Viena. 
A Série apresentada no Movimento I - que é a ideia geradora de toda a obra - nomos

A. WEBERN - Cantata $2-I-O$

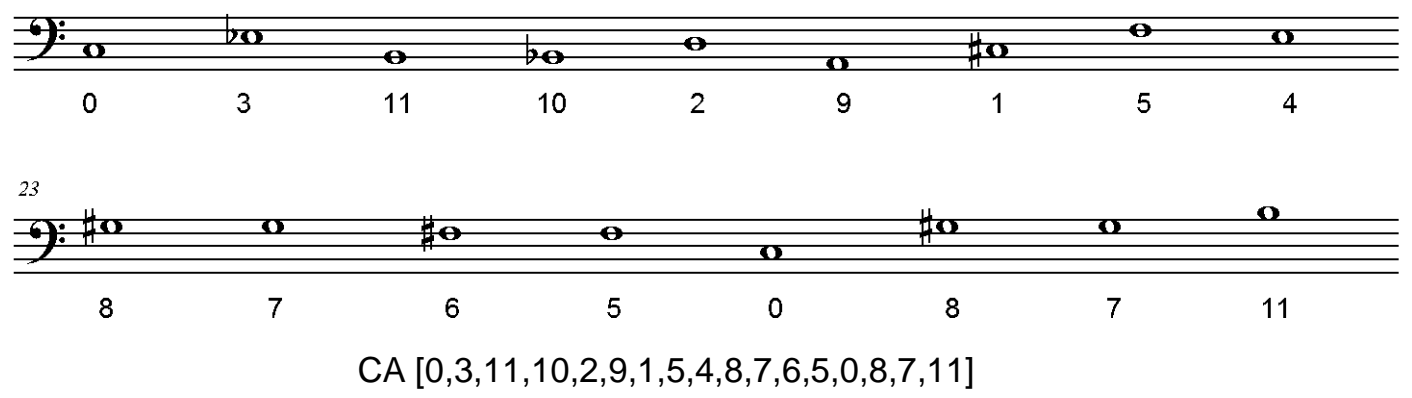

Figura 32 - S.O. apresentada no Movimento I da Cantata 2 de Webern

Há muitas maneiras de se analisar uma obra tão rica quanto as partes da Cantata oㅜ de Webern. Tais movimentos trazem em si uma riqueza de poéticas tão profundas que cada parte, cada seção é em si uma singularidade única, através dos mesmos princípos de espelhamento.

Em princípio Webern expõe a série de 12 notas, que imediatamente é estendida, para 17 sons, projetada em si própria através de espelhamentos.

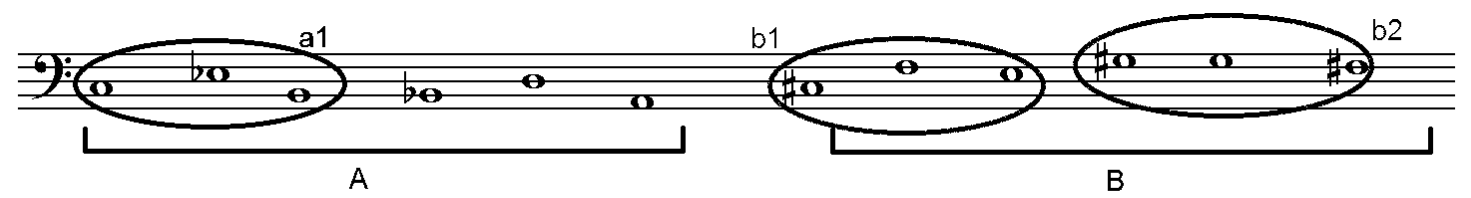

Figura 33 - Fragmentos da S.O.: a1, b1 e b2

Repare os grupos de classes de alturas separados por chaves, A e B, esses dois grupos melódicos contém as 12 notas da série: $[0,3,11,10,2,9,1,5,4,8,7,6]$ Circulados estão a1, b1 e b2 que por sua vez estão contidos e A e B.

$\mathrm{Na}$ figura a seguir, pode-se perceber que na série expandida de 17 sons que Webern criou, representada agora com três grupos de seis sons, A, B e $C$, sendo que a nota fá\# é o ponto de intersecção dos grupos $B$ e $C$, e que ainda apresenta semelhanças grifadas com chaves acima do pentagrama em dois semigrupos denominados $x$ e x com fá\# (grifado) que é o ponto de intersecção, é $X=$ 
[fá,mi,sol\#,sol natural] 4 notas contidas nos agrupamentos de B e C; sendo C, o RI (retrógrado da inversão) de B.

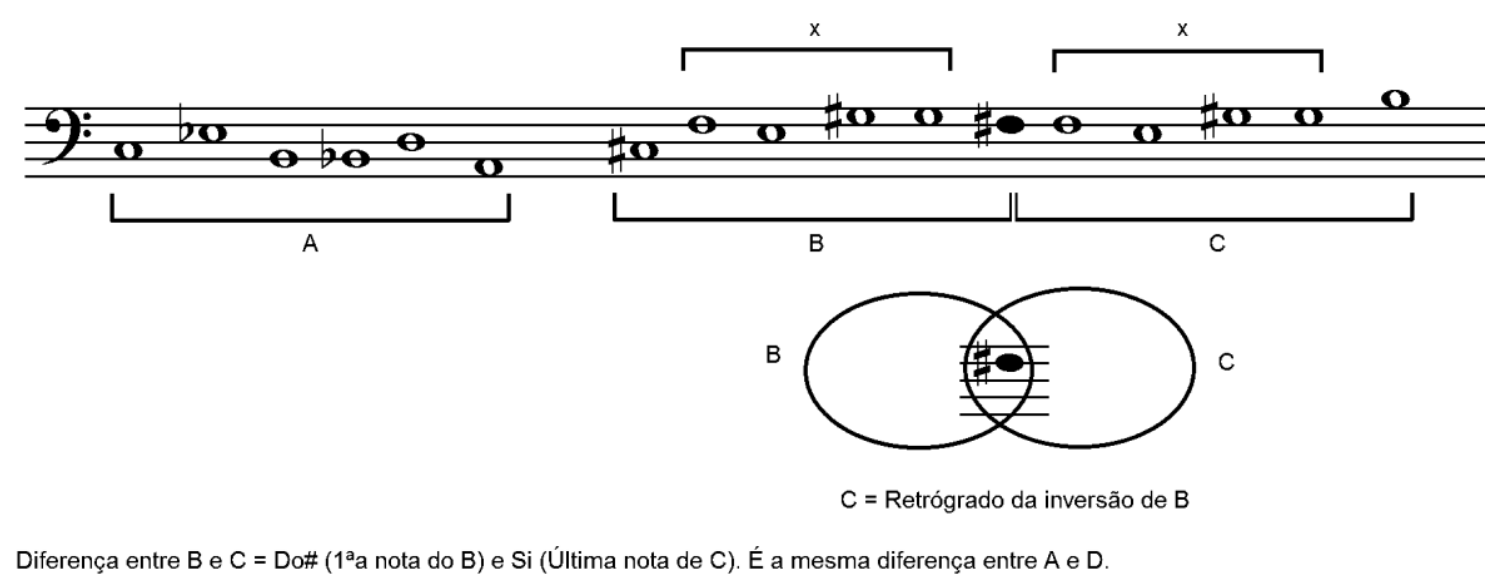

Figura 34 - S.O. estendida

Mais abaixo, a diferença entre $\mathrm{B}$ e $\mathrm{C}=$ do\# (primeira nota de $\mathrm{B}$ ) e si natural (última nota de $\mathrm{C}$ ). É a mesma diferença entre $\mathrm{A}$ e D. Resultam em duas séries em sequência, tendo o fá\# como pivô central e participante das duas.

Classes de alturas $C A$

A $[0,3,11,10,2,9] ;$ B $[1,5,4,8,7,6] ;$

$\underline{\mathrm{C}}[6,5,4,8,7,11] ; \underline{\mathrm{D}}[, 9,2,10,1,3,0]$

$\underline{D}$ é projeção, foi escolhida esta ordem por espelhamento com $A$, trocando dó\# e si natural.

Desta forma obtêm-se duas séries em sequência unidas pela nota fá\#.

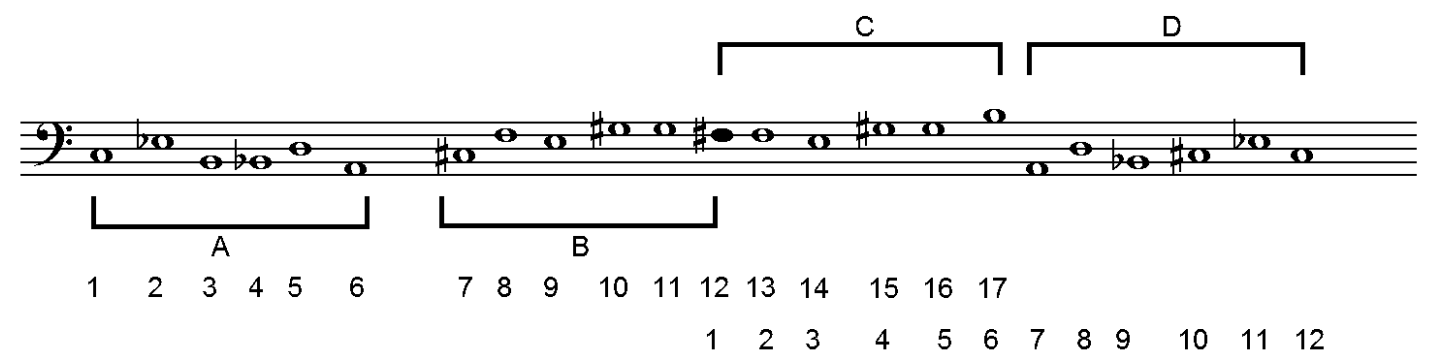

Figura 35 - Duas Séries em sequência projetadas por seu próprio espelhamento

(Obs.: neste exemplo acima, os números aqui estão representando a colocação dos sons dentro das séries e não as classes de altura CA) 
Olhando para a série exposta horizontalmente, nota-se a simetria na construção melódica desta mesma:

$D$ é retrógado de $A$, sendo $C$ a inversão do retrógrado de $B$.

E a partir dessas células melódicas, Webern constrói o plano vertical da partitura com os mesmos princípios de espelhamento.

Classe de altura ordenada do acorde base $=C[9,0,2,10,1,3]$ seria 0 espelhamento não literal do agrupamento de $\underline{A}$ para a utilização vertical das mesmas, gerando o acorde base.

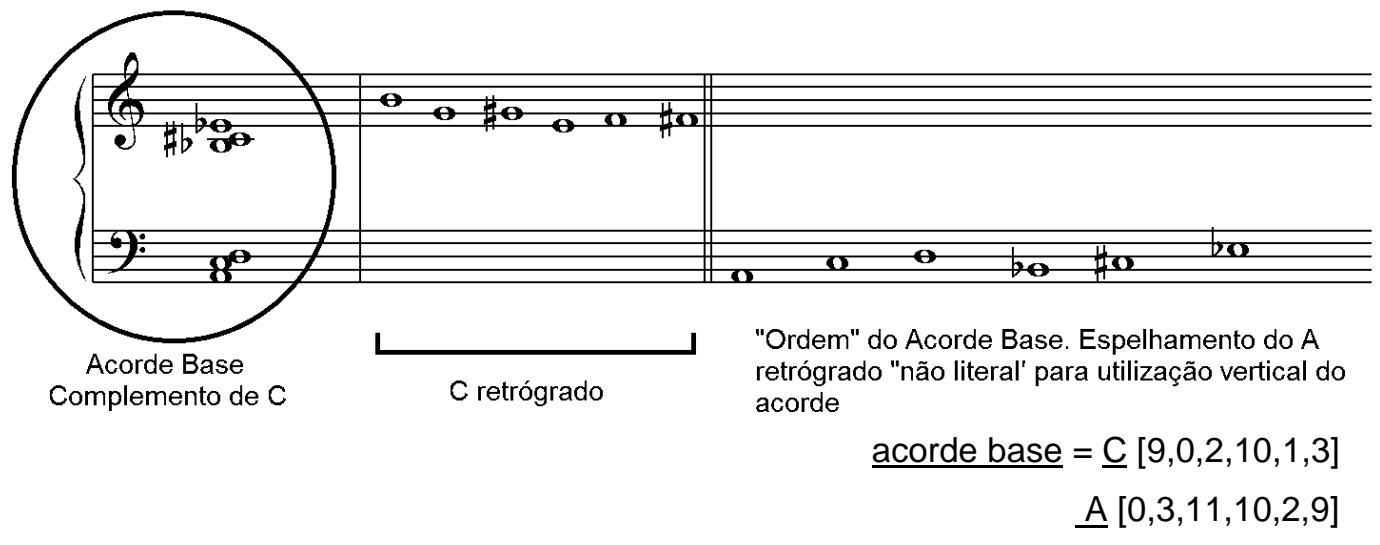

Figura 36 - Acorde de base do Movimento I da Cantata 2 de Webern

Outro fator importante é como Webern se utiliza das pausas, as pausas são verdadeiras expressões sonoras, ainda que venham ser a ausência do som. Compassos inteiros demarcados com a precisão da pausa escrita para o grande agrupamento, pausa geral, mesmo, que carrega em si a pura expressão do silêncio. 


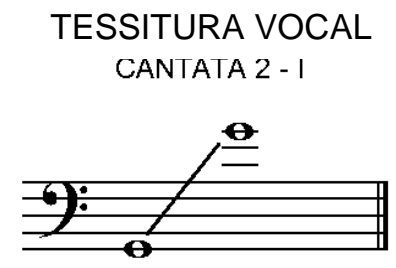

Figura 37 - Tessitura Vocal do Baixo solista - Movimento I da Cantata 2 de Webern

\section{Movimentos II e III}

Estes movimentos não serão abordados neste trabalho, mas segue material básico utilizado por Webern:

\section{Movimento II}

Cromatismo em 2 vozes com saltos afastados por $8^{a}$

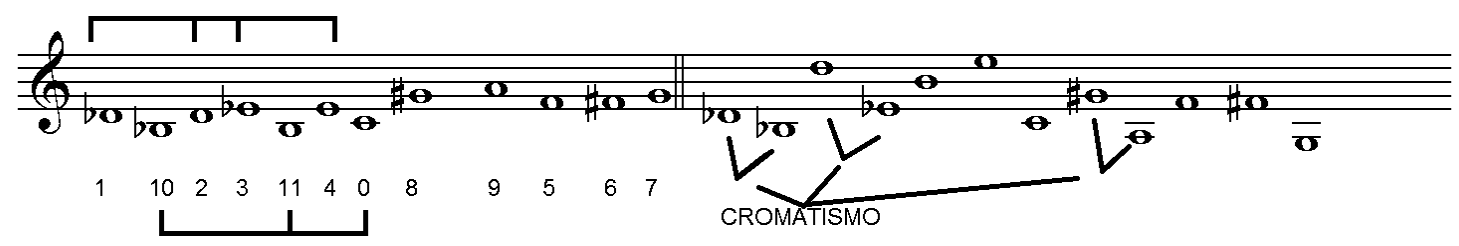

Figura 38 - Cromatismo em duas vozes com saltos afastados por $8^{a}$

A série como ela se apresenta no Movimento II no registro original.

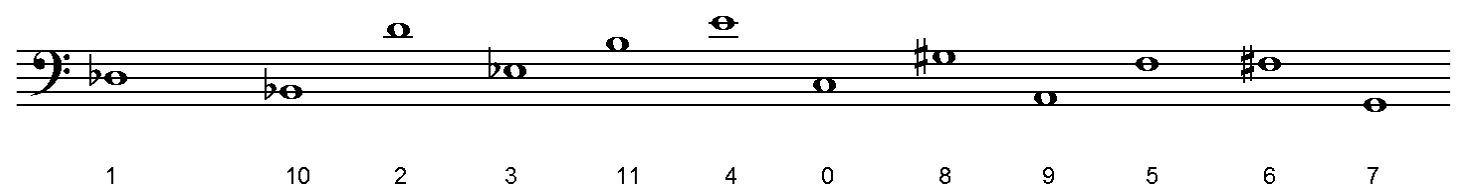

Figura 39 - S.O. do Movimento II da Cantata 2 de Webern

A série como ela se apresenta no Movimento II, no âmbito de uma oitava.

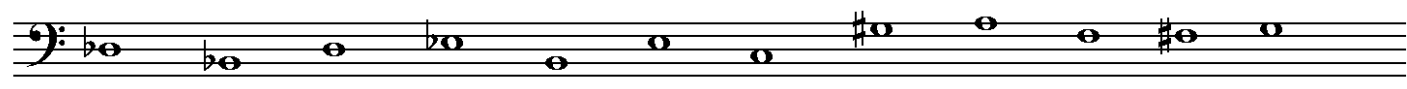

$\begin{array}{lllllllllllll}1 & 10 & 2 & 3 & 11 & 4 & 0 & 8 & 9 & 5 & 6 & 7\end{array}$

Figura 40 - S.O. do Movimento II da Cantata 2 de Webern, no âmbito de uma oitava 


\section{Movimento III}

Material composicional para compreensão da ideia que esta irá fornecer para o Movimento IV, pois a série do Movimento IV é o R.I. da série a seguir.

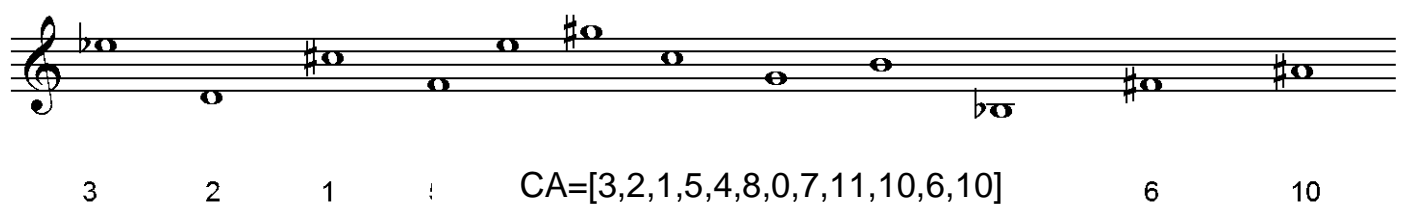

Figura 41 - R. do Movimento II da Cantata 2 de Webern

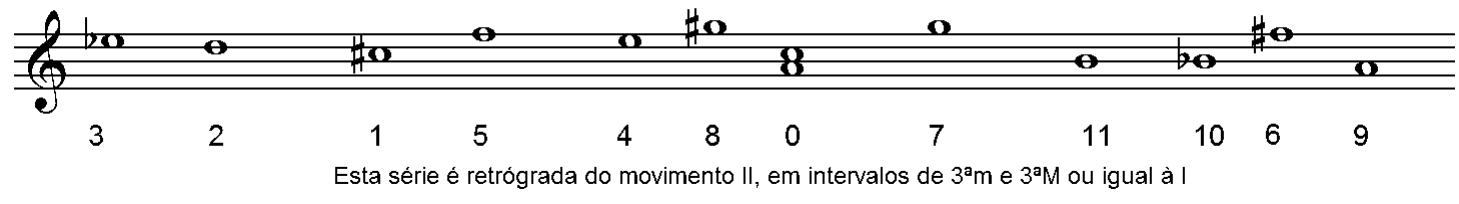

Figura 42 - R. do Movimento II da Cantata 2 de Webern, no âmbito de uma oitava

\section{Movimento IV e V}

Dentre as partes que podem caracterizar a cantata como gênero tem-se o recitativo, ária ou arioso, as partes dos coros com textura mais polifônica ou forma coral de textura mais homofônica.

No oratório nos moldes do período barroco, a presença do narrador ou o personagem que faz o comentário, ou observações com caráter de sermão, como portador da mensagem, ou ainda aquele que concebe a mensagem do texto como uma verdade e a coloca seja para o indivíduo (o solista), ou seja, para o coletivo (o coro), fazendo observações que do ponto de vista humano mais terreno poderia ser pouco observado, daí então, a necessidade emergir essa entidade profética capaz de fazer-se notar com a percepção objetiva atenta para a justiça dos fatos. Esses elementos são encontrados nas Paixões de Johann Sebastian Bach, nos oratórios de George Haendel e em outros autores desse e de outros 
períodos. Dessa perspectiva pode-se pensar então que a diferença entre aquele que prega o sermão, ou a reflexão dos fatos, dentro da cantata seria o próprio herói, um mito, ou um personagem carnal que busca a reflexão através da condição humana reconhecendo suas fraquezas e vicissitudes diante da grandeza de um ser, no caso da música sacra Deus, ou um messias, mas sempre alguém de valores éticos com virtudes destacáveis como a humildade, bondade, caridade e com amor ao próximo. Na Cantata ํㅡ, Anton Webern leva essa reflexão para todos os personagens, seja o personagem masculino solista, o baixo, seja 0 personagem solista feminino, o soprano, e ainda nas partes do coro, o coletivo, como que atribuindo essa responsabilidade de reflexão para todos, ou seja, a humanidade aqui representada de forma simbólica; ou seja, cada ser humano deve refletir buscando exercitar as virtudes e a qualidade de caráter em relação ao próximo, seja individualmente, ou, seja no coletivo, junto à comunidade.

O Movimento IV é um recitativo com solo de soprano, traz a marcação de pulso, semínima ca= 168 , mais uma vez, a busca pela precisão ritmica de Webern.

Contém 23 compassos no total.

Do ponto de vista morfológico lembra uma forma binária e pode ser seccionada da seguinte maneira:

Introdução: c.1 e c.2 - já de imediato indica a nota fá\# da série que será exposta a partir do compasso $03 \mathrm{com}$ anacruse.

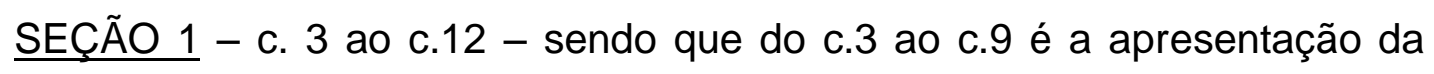
série, que pode ser subdividida:

Subseção 1.1 - c.3 ao c.6 - série na forma original - O

Subseção 1.2 - c.7 ao c.9 - série na inversão - I

Subseção 1.3 - Ponte - c.10 ao c.12

SEĈ̃O 2 - c.13 ao c.18

Subseção 2.1 - Coda - c. 19 ao c.23

No compasso c.2, e no último compasso c.23, a sobreposição de duas "sétimas" no baixo ré/dó (sétima menor) e na clave de sol si natural e si bemol, 
(oitava diminuta), logo após vem a nota ré\# na introdução c.2, e na anacruse do compasso 03 o soprano solista ataca com a série.

No quarto movimento, Webern mantém o mesmo princípio técnico de trabalhar a série de modo que a sua sequência básica é a seguinte:

Série original do Movimento IV, que é o R.I. do Movimento III

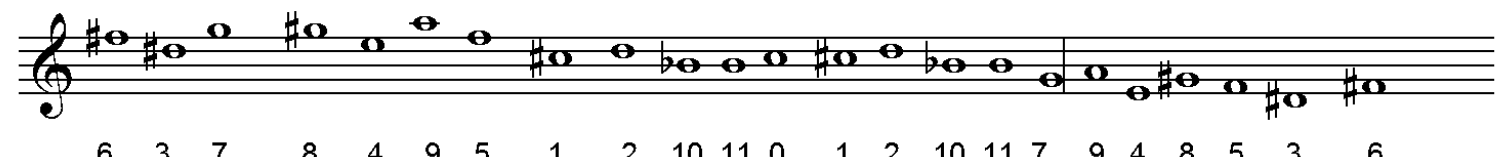

Figura 43 - S.O. do Movimento IV, que é o R.I. do Movimento III da Cantata 2 de Webern

A série é apresentada na parte orquestral e na melodia do soprano.

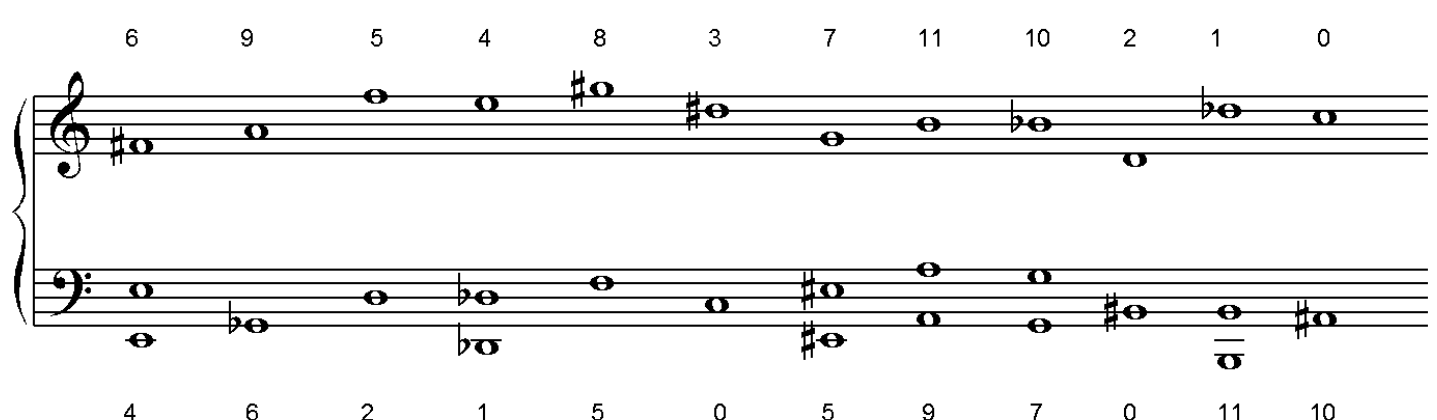

Figura 44 - Transposições de S.O. do Movimento IV da Cantata 2 de Webern 
Quanto a tessitura dos Movimentos IV - da Cantata ํㅡ 2 - Webern

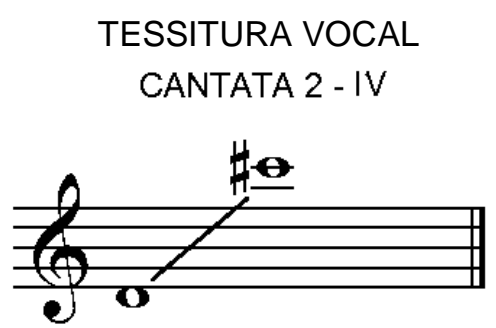

Figura 45 - Tessitura do soprano solista no Recitativo do Movimento IV da Cantata 2 de Webern

\section{Movimento V}

\section{Cantata no 2 - opus 31 - Anton Webern}

Cantata $2-\mathrm{V}-\mathrm{O}$

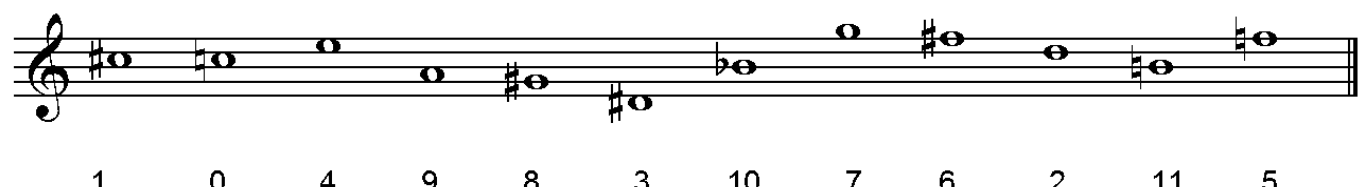

Figura 46 - Cantata $2-\mathrm{V}-\mathrm{O}$

Cantata $2-\mathrm{V}-\mathrm{R}$

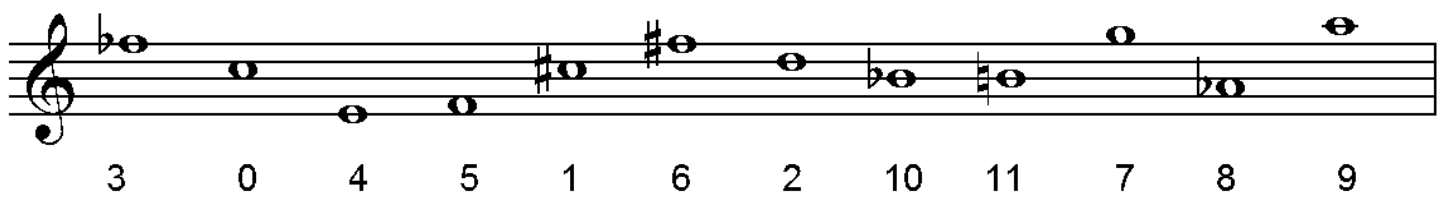

Figura 47 - Cantata $2-\mathrm{V}-\mathrm{R}$

Cantata $2-\mathrm{V}-\mathrm{I}$

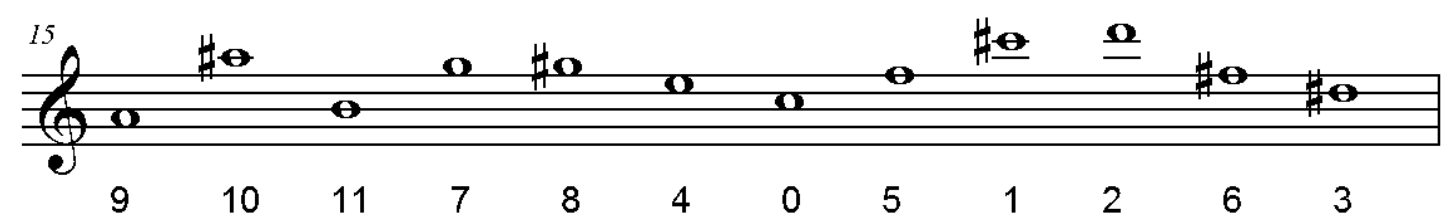

Figura 48 - Cantata $2-\mathrm{V}-\mathrm{I}$ 
Cantata $2-$ V - R.I.

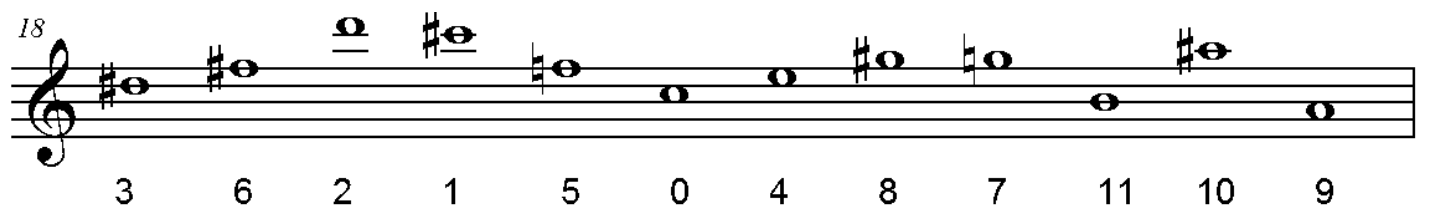

Figura 49 - Cantata $2-$ V - R.I.

Este movimento será um exemplar para descrever acima de tudo sobre a questão morfológica. $\mathrm{O}$ avanço que isto trouxe para a História da Música, a amplitude da forma, ainda que com um gênero tão tradicional que é a cantata, sendo uma das últimas das obras que Webern compôs, em um momento de plena maturidade e aproveitamento de tudo o que fora refletido e filosofado junto aos seus pares da Segunda Escola de Viena. Uma verdadeira síntese deste conjunto de experiências, intersectada por vários planos de procedimentos. Desde o processo da dissolução tonal até o Serialismo estruturado e a prospecção que tornou viável o enriquecimento sonoro a partir de então.

O Movimento $\mathrm{V}$ remete-nos à ideia de um responsório.

Responsório: Uma categoria de cântico ocidental que serve como poslúdio musical à leitura de lições. Grandes responsórios ocupam posição de destaque nas matinas e nas vésperas monásticas. A fonte mais antiga remonta ao século XI. Envolvem o canto de um salmo alternadamente entre um solista, que canta um versículo, e um coro, que canta o refrão, ou responso. As seções solistas são musicadas polifonicamente no repertório de Notre Dame; no século XVI os textos eram geralmente musicados na forma de motetos elaborados. Grupos de responsórios continuaram a ser compostos durante o século XVIII. Responsórios curtos são cantados após breves leituras das horas menores e de completas, no ofício secular, e nas laudes e vésperas do ofício monástico ${ }^{122}$

O responsório ocupava status nas leituras litúrgicas das missas, ou de algumas formas monásticas dentro do repertório de música sacra, tais como as matinas, vesperae, ou motetos. Ele traz em si a ideia de pergunta e resposta, através de uma reflexão dada pelo texto, ou mesmo uma confirmação em

122 SADIE, Stanley. Op.Cit.p.778. 
concordância com o texto anteriormente exposto. Webern reforça essa ideia com o soprano solista e a resposta do coro, o responso que dividem a responsabilidade, em alternância, de refletir as palavras proferidas pela solista. Embora o texto não seja um texto propriamente litúrgico, carrega em si um caráter humanista bastante enfático. A ideia de construir esta obra nos moldes da antiga cantata, e o antigo responsório, Webern constrói um entrelaçamento do texto com a ideia musical, com tanta força que um se torna essência para o outro. Aqui Webern trata a fonética como se fosse uma espécie de "quinta" propriedade do som, de tão íntima que surge essa amálgama de ordens inseparáveis nesta sua música, considerando os fonemas como unidades básicas do som emitidas pela voz. Eis que para o instrumento voz, o som surge através de um fonema qualquer, como parte inerente deste instrumento, som este que possui a altura, frequência, duração, intensidade, timbre ${ }^{123}$ que concomitantemente produzidos torna 0 fonema como parte intrínseca da vocalidade, e que é através deste que se faz acontecer o som da voz. Webern propõe isto de forma bastante consciente, em cada som, seja o que deverá ser produzido pelos cantores solistas, seja o que deverá ser produzido em conjunto, pelo coro, seja pelos solistas.

o timbre não constitui um parâmetro do som, mas consiste antes na resultante dos demais atributos sonoros (a altura, a intensidade e a duração) inter-relacionados entre si. Aquilo que designamos por timbre de um som traduz-se, na verdade, como a micro-organização interna de um determinado espectro sonoro, 0 qual, em sua estruturação microscópica, resulta da inter-relação entre as alturas, as amplitudes, as durações e os comportamentos dinâmicos (evolução das amplitudes no tempo) de seus parciais constituintes.

Helmholtz definiu o timbre como sendo aquela propriedade que permite a distinção de um som e de outro contendo a mesma altura e intensidade. Ou seja, aquilo que diferenciava o som de um instrumento emitindo a mesma nota com a mesma intensidade era definido como o timbre desse instrumento.

A escolha do grupo, que é o coletivo representado pelo coro, e o soprano solista, o indivíduo, contribui na aplicação para dar forma às seções e às subseções neste movimento. Aqui neste caso, a voz do soprano é a portadora da

\footnotetext{
${ }^{123}$ MENEZES, Flo. A Acústica Musical em Palavras e Sons. Cotia, São Paulo: Ateliê Editorial, 2003.pp.199 e 200.
} 
essência da mensagem, aquela que compreende a Palavra ou o Verbo ${ }^{124} \mathrm{e}$ propõe vivê-la(o) e materializá-la(o).

Neste caso essa identidade com o responsório é a maneira que Webern, inteligentemente, encontrou uma solução para a aplicação da forma que pode ser seccionada em às seções e, ainda no seu interior, às subseções.

SEĈ̃̃ 1

Introdução c. 1 ao c.16

Subseção 1 - c.1ao c.6 - o coro inicia com o texto e soprano solista

SEĈ̣̃O 2

Ária para soprano solista c. 17 ao c. 40

Ponte - c. 42 ao c. 45

SEĈ̃O 3

c. 46 ao c. 60

A seguir, maior detalhamento do que propõe Webern dentro dessas grandes seções, desmembrando-as em outras subseções:

SEÇÃO 1

Introdução c. 1 ao c.16

Subseção 1 - c.1ao c.6 - o coro inicia com o texto e soprano solista (de três em três compassos)

Coro: Freundselig (caridade) - pausa de colcheia

Ist das Wort (é das palavras [do Verbo])

e o soprano solista complementa

Solo soprano: das uns um unsre Liebe zu sich fragt (que nos atrai para si clamando por nosso amor)

\section{Subseção 1.1}

Ponte - c.7 - pausa escrita em compasso 2/8 para todo o agrupamento, coro, solista e orquestra.

\section{Subseção 1.2}

Do c.8 ao c. 16 - coro e soprano solista alternam suas frases de dois em dois compassos.

\footnotetext{
124 "e o Verbo se fez carne" - versículo das Sagradas Escrituras.
} 
Coro: "fürchte dich nicht," (não temas,)

Soprano solo: "ich bin es" (sou eu)

Coro: tröstet durch die Dunkelheit (vem uma voz nos consolar)

Soprano solo: Was kann denn andres mitten unter uns sein, (Que outro poder poderia haver entre nós)

Soprano solo: das mitten unter uns ist (através da escuridão)

Subseção 1.3

c.14, com fórmula de $3 / 8$

Sendo que no c.14, com fórmula de $3 / 8$, as vozes se calam, porém a orquestra continua tocando com uma dinâmica entre $p$ e pp.

Mais uma vez, a presença do silêncio, a pausa como reflexão.

\section{SEĈ̃̃ 2}

Ária para soprano solista c. 17 ao c.40

Soprano solo: das mitten unter uns ist (através da escuridão)

Coro: Wenn wir friedlich sind (quando nos amansamos)

als das Wort? (senão a palavra [o Verbo]?)

Weil es am Kreuz verstummte (Por ter morrido na cruz, continuaremos;)

Müssen wir ihm nach,

in allen Ernst der bitternis ihm folget - unser Hauch* (em toda a angústia das lágrimas a si seguem nosso suspiro)

Doch wenn es wieder aufklingt in der Morgen frühe, (Apesar disso, quando novamente soou ao amanhecer,)

dann wenden wir uns alle selig als Gerufne um. (nós todos a si nos voltamos alegremente, e sabemos que fomos chamados.)

Sendo:

Subseção 2.1 - c.17 ao c.24

Subseção 2.2

Ponte - c.25 ao c.27 - (seher getragen)

Subseção 2.3

c.28 ao c.31 - ápice da seção 2 - soprano solo pp, na palavra Hauch

Subseção 2.4 
Ponte - pausa não, porém no compasso integral, 3/4 (de um tempo de semínima) - wider ruhig

Subseção 2.5

c.33 ao c.36 - a voz do soprano ataca um si natural com dinâmica $f$ - do $f$ diminui para p no c. 34 - c.35 poco forte - orquestra (do\#, do natural - $8^{\text {a }}$ diminuta ascendente).

Subseção 2.6

c.37 ao c.41 - c.37 (3/4) - c.38 (3/2) - ritenutto - dinâmica mp ao pp ápice da parte do soprano solista - selig

Subseção 2.7

Ponte - c.42 ao c. 45

SEĈ̃O 3

Coro retoma no c.46 ao c.51 - o responsório de dois em dois compassos alternam soprano solo e coro

Coro: Freundselig (caridade) - pausa de colcheia -

Ist das Wort (é das palavras [do Verbo])

Solo soprano: Und wenn Du weisst, dass es um alles Deine Weiss (e quando perceberes que sabe de ti todas as coisas,)

Coro: Dann kennst Du es: (então saberás:)

Solo soprano: dann tut's dir weher als der Tod (te ferirá mais profundamente que a morte,)

Subseção 3.1

c.52 ao c.57- comentário do coro alternando de um em um compasso com o soprano solista

Coro: Wenn eine Wolke (quando uma nuvem negra se aproxima,)

Solo soprano: Feindseligkeit: (cólera amarga,)

Coro: der Tränen Mutter (a mãe de todas as lamúrias,)

Soprano solo: sich zwischen dir - und ihm erweitert (assim te ensombrando)

Subseção 3.2

c. 58 - pausa para as vozes, porém orquestra continua soando $3 / 8$

Subseção 3.3 
Coda final - c.59 e c.60 - coda final feita pelo conjunto das vozes - orquestra tem pausa.

Coro: und die Kälte schafft. (e fazendo de ti frio como a morte.)

\section{Texto}

Observando-se pelo texto:

Coro: Freundselig (caridade) - pausa de colcheia

Ist das Wort (é das palavras [do Verbo])

Solo soprano: das uns um unsre Liebe zu sich fragt (que nos atrai para si clamando por nosso amor)

Coro: "fürchte dich nicht," (não temas,)

Soprano solo: "ich bin es" (sou eu)

Coro: tröstet durch die Dunkelheit (vem uma voz nos consolar)

Soprano solo: Was kann denn andres mitten unter uns sein, (Que outro poder poderia haver entre nós,)

Soprano solo: das mitten unter uns ist (através da escuridão)

Coro: Wenn wir friedlich sind (quando nos amansamos)

als das Wort? (senão a palavra [o Verbo]?)

Weil es am Kreuz verstummte (Por ter morrido na cruz, continuaremos;)

Müssen wir ihm nach,

in allen Ernst der bitternis ihm folget - unser Hauch* (em toda a angústia das

lágrimas a si seguem nosso suspiro)

Doch wenn es wieder aufklingt in der Morgen frühe, (Apesar disso, quando novamente soou ao amanhecer,)

dann wenden wir uns alle selig als Gerufne um. (nós todos a si nos voltamos alegremente, e sabemos que fomos chamados.)

Coro: Freundselig (caridade) - pausa de colcheia -

Ist das Wort (é das palavras [do Verbo])

Solo soprano: Und wenn Du weisst, dass es um alles Deine Weiss (e quando perceberes que sabe de ti todas as coisas,)

Coro: Dann kennst Du es: (então saberás:) 
Solo soprano: dann tut's dir weher als der Tod (te ferirá mais profundamente que a morte,)

Coro: Wenn eine Wolke (quando uma nuvem negra se aproxima,)

Solo soprano: Feindseligkeit: (cólera amarga,)

Coro: der Tränen Mutter (a mãe de todas as lamúrias,)

Soprano solo: sich zwischen dir - und ihm erweitert (assim te ensombrando)

Coro: und die Kälte schafft. (e fazendo de ti frio como a morte.)

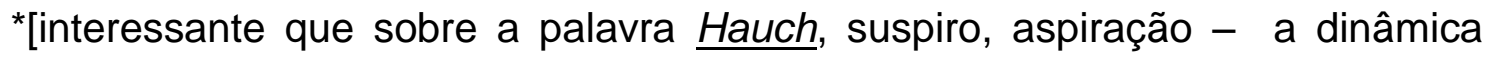
pedida ao soprano solista por Webern, é pp - pianíssimo]

Este pianíssimo traz em si uma luminosidade tão incrível que pode nos lembrar da última palavra proferida pela personagem protagonista Isolda: "Lust" (desejo) na ópera Tristão e Isolda de Richard Wagner, na ária de sua própria morte, o Liebestod.

\section{Quanto à precisão na métrica}

As fórmulas de compasso:

do $\underline{\text { c. } 1 \text { ao } \text { c. } 5}$ - 3/8, 2/8, 3/8, 2/8, alternadas entre si de um em um compasso; do c. 6 ao c.16 - 4/8, 2/8, 4/8, 3/8,(2), 2/8, (3), 3/8,2/8, 3/8 - até então a colcheia é unidade de tempo dos compassos.

Mudança de caráter

C.17 ao c.44 - 3/4, (3), 2/2 (3), 3/4(2), 3/2(4), 2/2(1),3/2(1), 4/2(1), 3/4(1), 2/2(1), 3/4(2), 2/2(1), 3/4(1), 3/2(2), 3/4(5) e mais um compasso de 3/4 que é uma ponte com fermata.

c. 46 ao c. 60

3/8(1), 4/8(1), 3/8(1), 4/8(1), 3/8(7),4/8(1), 3/8(1),2/8(1),3/8(1).

Fórmulas de compasso 


\begin{tabular}{|c|c|}
\hline & ANTON WEBERN, op. 31 \\
\hline & KANTATE $2-V$ \\
\hline c.1 ao c.5 & $3 / 8,2 / 8,3 / 8,2 / 8$, alternadas entre si de um em um compasso \\
\hline c.6 ao c.16 & $\begin{array}{r}4 / 8,2 / 8,4 / 8,3 / 8,(2), 2 / 8,(3), 3 / 8,2 / 8,3 / 8-\text { até então a } \\
\text { colcheia é unidade de tempo dos compassos. }\end{array}$ \\
\hline \multicolumn{2}{|c|}{ Ária do Soprano - Mudança de caráter } \\
\hline c.17 ao c.44 & $\begin{array}{c}3 / 4,(3), 2 / 2(3), 3 / 4(2), 3 / 2(4), 2 / 2(1), 3 / 2(1), 4 / 2(1), 3 / 4(1), \\
2 / 2(1), 3 / 4(2), 2 / 2(1), 3 / 4(1), 3 / 2(2), 3 / 4(5) \text { e mais um } \\
\text { compasso de } 3 / 4 \text { que é uma ponte com fermata. }\end{array}$ \\
\hline c.46 ao c.60 & $\begin{array}{c}3 / 8(1), 4 / 8(1), 3 / 8(1), 4 / 8(1), 3 / 8(7), 4 / 8(1), \\
3 / 8(1), 2 / 8(1), 3 / 8(1) .\end{array}$ \\
\hline
\end{tabular}

Tabela 7 - Fórmulas de compasso - Cantata $2-V$ - Webern

Tessitura do soprano solista e partes do Coro no Movimento V:

TESSITURAS VOCAIS 


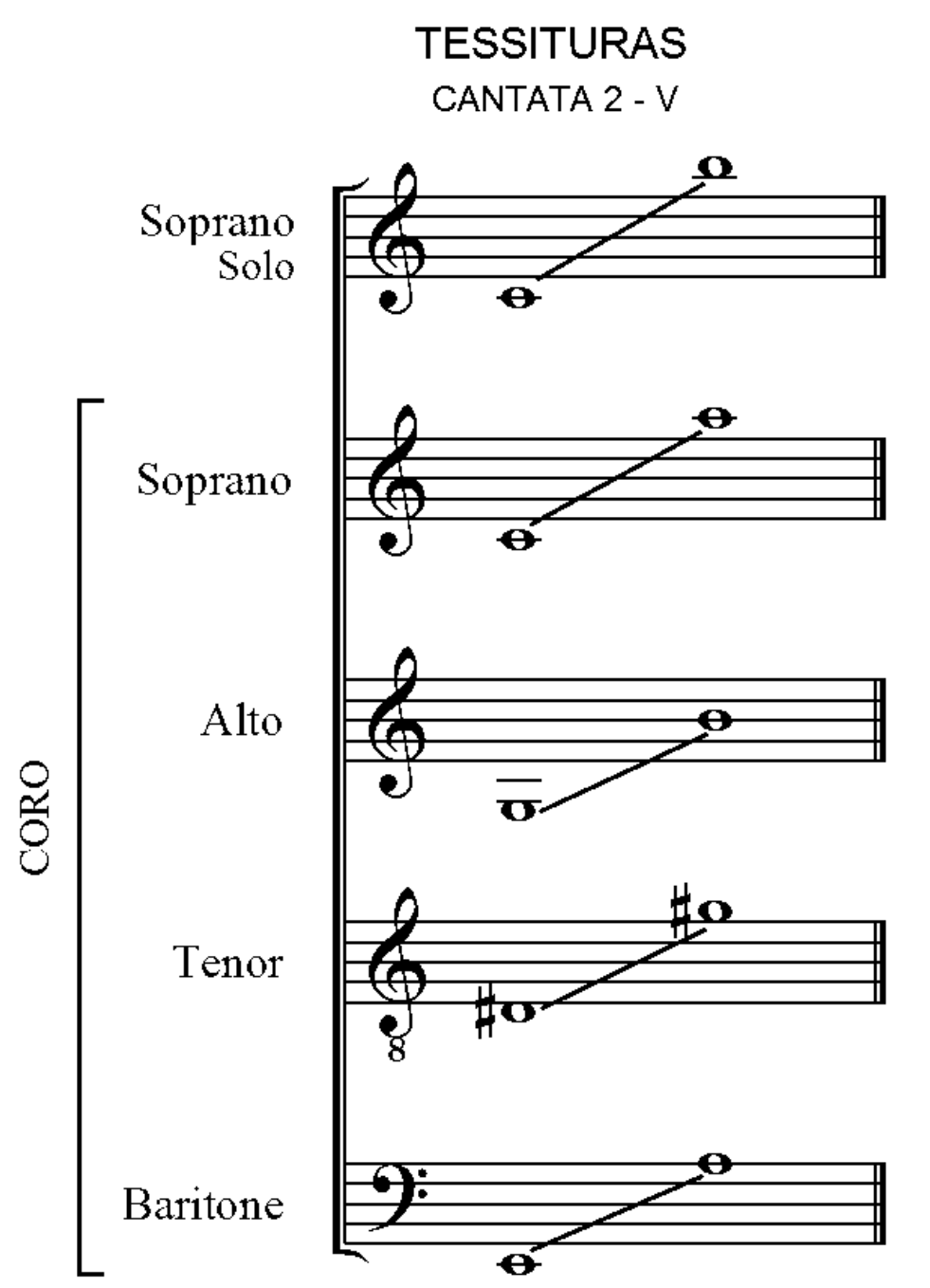

Figura 50 - Tessituras Vocais do Movimento V da Cantata 2 de Webern

\section{3 - O Melodrama}

Este termo pode ser encontrado similarmente nos idiomas grego, francês, alemão e italiano. Do grego Melos vem a ser, drama - que é um tipo de drama, ou enredo que por sua vez é parte de um drama literário, que conjuntamente com a ação central é conduzida pelo protagonista falando nas pausas de um acompanhamento musical, e mais tarde, comumente, durante um acompanhamento musical. Distinto do italiano, melodramma, que significa simplesmente drama musical, ou ópera. As breves passagens orquestrais que 
separam os diálogos são claramente relacionadas a, e presumivelmente em algum sentido derivadas de, aquelas de um recitativo operístico acompanhado.

O termo melodrama também pode ser aplicado a um tipo de peça, em um sentido menos especificamente musical. Particularmente popular no século XIX, mais comum encontrá-lo sem acompanhamento musical, no qual a trama dos acontecimentos mais românticos e sensacionais que seguem certas convenções morais e maniqueístas conduzidas para que pelo menos ao final da história o bem triunfe e o mal seja frustrado. ${ }^{125}$

Embora haja uma boa razão para datar a invenção do melodrama a Jean Jacques Rousseau, 1712-1778, em sua obra Pygmalion, provavelmente escrita em 1762. Muito embora, J.E. Eber já tivesse utilizado a voz falada em contraposição com um acompanhamento musical em seu drama latino Sigismund, em Salzburgo, na Áustria, em 1753; e, de fato a utilização da música como veículo adjunto à ação dramática é provavelmente quase tão antiga quanto o drama em si. $^{126}$

Pode-se considerar o melodrama como uma técnica que busca um tipo particular de equilíbrio entre palavras e música, do que concebê-lo como um gênero dramático independente, uma vez que os mais conhecidos exemplos - a cena do labirinto, na masmorra, em Fidélio, ${ }^{127}$ bem como o papel do mordomo na versão revisada em 1916 da ópera Ariadne auf Naxos, ${ }^{128}$ de Richard Strauss, 1864-1941, são efetivos por conta do contraste que provém com relação ao restante da peça.

A problemática de nomenclatura vem ocorrendo, desde o início, quando Jean Jacques Rousseau prescrevera o subtítulo de Pygmalion, como uma scène

\footnotetext{
125 BRANSCOMBE, Peter. GROVE - Verbete sobre Melodrama - In: SADIE, Stanley. The New Grove Dictionnary of Music and Musicians (20 vol). London: Macmillan Publishers Limited, 1980.

126 BRANSCOMBE, Peter. GROVE - Verbete sobre Melodrama - In: SADIE, Stanley. The New Grove Dictionnary of Music and Musicians (20 vol). London: Macmillan Publishers Limited, 1980.

${ }^{127}$ Do compositor Ludwig van Beethoven (1770-1827), ópera do ano de 1805.

128 Do compositor Richard Strauss (1864-1949), ópera do ano de 1916.
} 
lyrique $^{129}$; frequentemente usava-se o termo mélodrame, mas sempre como sinônimo para ópera, como na expressão italiana.

Embora o texto de Rousseau, provavelmente date de 1762, foi depois da páscoa de 1770, em Lyons, na França, que ele pediu a Horace Coignet, 17351821, para musicá-lo. O texto estreou em Paris, em março de 1772 e frequentemente interpretado pelos comédiens français, entre 30 de outubro de 1775 e o começo do século XIX. Grimm escreveu Correspondences Littéraires sobre o Ėffet Supremant, que o trabalho causou, e Rousseau que se recusou a reconhecer a peça na produção de 1775 , resumiu sua conquista quando escreveu Fragments d'observations sur l' Alceste italien de M. Le Chevalier Gluck, ${ }^{130}$ que em sua concepção, "La phrase parlée est de quelque sort annoncée et préparée par La phrase musicale."131 Esta cláusula, em verdade, pode ser tomada como indicativo da principal diferença entre os melodramas francês e alemão. O primeiro é dividido em partes musicais curtas e independentes, denominadas número. ${ }^{132}$

A despeito da popularidade da montagem de Coignet-Rousseau na França, a influência de Pygmalion deve ser vista como largamente teórica e textual. Franz Asplmayr, 1728-1786, arranjou música para o texto de Rousseau em 1772; o letreiro da página-título do libretto deixa claro que o trabalho foi idealizado para ser apresentado na ópera da corte de Viena - Pygmalion de J.J. Rousseau, scène lyrique exécutée sur le Théâtre Imperial de Vienna avec la musique du Sieur Aspelmayer; a obra foi executada no local em Janeiro de 1772. O libretto contém as durações dos números musicais, assim como as direções pantomímicas, indicando que a obra obtivesse a duração de cerca de nove ou dez minutos, aproximadamente. Ao que se sabe, a partitura não sobreviveu. Outra montagem do texto de Rousseau, por Anton Schweitzer, 1735-1787, foi apresentada em Weimar em 1772; Johann Wolfgang Von Goethe,1749-1832, escreveu admirado sobre essa em Dichtung und Wahrheit. O texto de Rousseau ficou conhecido na Itália em 1771; ele aproveitou um sucesso considerável por lá

\footnotetext{
129 Cena lírica.

${ }^{130}$ Christoph Willibald Gluck - compositor boêmio-germano, considerado o reformista da ópera. (nasceu em Erasbach, 1714 e morreu em Viena em 1787).

${ }^{131}$ BRANSCOMBE, Peter. Op.Cit.

132 Ou seja, o mèlodrame é subdividido em partes que são enumeradas.
} 
e também, a partir de 1788. O famoso Pygmalion, montagem de Georg Benda em Gotha, Alemanha, 20 de setembro de 1779, utilizou-se de uma tradução quase literal do francês original, com apenas um corte considerável, e algumas pequenas alterações desentendidas.

Apesar da prioridade das montagens de Pygmalion por Asplmayr e Schweitzer, o aperfeiçoador do melodrama na Alemanha foi do compositor boêmio Georg Benda,1722-1795. Se o acaso ditou que ele deveria montar a versão de J. C. Brandes para Ariadne auf Naxos de Gerstenberg ao invés de Schweitzer que abandonou o trabalho para dedicar-se ao libreto da ópera Alceste, de Christoph Martin Wieland, 1733-1813, ele obteve brilhantemente o sucesso nessa tarefa. Suas partituras para o melodrama mostram uma memorável flexibilidade e sustentam inventividade musical. Ariadne foi primeiro apresentado em Gotha, para onde a companhia Seyler havia se mudado após o incêndio que consumiu um teatro de Weimar em maio de 1774, e, em janeiro de 1775, dois meses após a mesma companhia ter apresentado Pygmalion de Schweitzer. Ariadne de Georg Benda obteve sucesso imediato entre o público e músicos profissionais e chegou a Paris em 1781, com tradução por Dubois e subintitulada mélodrame. Foi seguida por Medea, texto por Gotter em $1^{\circ}$ de maio do mesmo ano, e seu Pygmalion quatro anos mais tarde. Theone também data de 1779 , foi mais tarde revisado como Almansor und Nadine; nele, Benda utilizou a voz cantada (voz solista e coral) bem como a voz falada.

Embora nunca tenha atingido novamente a maestria ou o sucesso de Ariadne, pois de fato ele escreveu mais óperas e Singspiel ${ }^{133}$ do que melodramas, o gênero que ele aperfeiçoou foi avidamente continuado por uma leva de compositores contemporâneos e tardios, incluindo Neefe, Reichardt, Zumsteeg, e muitos dos músicos de Mannheim. Proserpina de Goethe, 1775, em montagem por Seckendorff e mais tarde, 1814 por Eberwein, é um conhecido exemplo literário. Alguns desses trabalhos foram chamados 'monodramas' porque tinham

\footnotetext{
${ }^{133}$ SADIE, Stanley - Peça com música, da Alemanha .O termo já estava em uso no séc. XVI, mas atualmente aplica-se em geral a óperas ligeiras ou cômicas, com diálogos declamados do século XVIII e início do século XIX, e das quais o Rapto do Serralho, de Mozart, é um exemplo de primeira classe. Em Fidélio, Beethoven fez com que o gênero servisse a um tema mais dramático. Nos anos 1870 o Singspiel já havia se difundido com a opereta. (verbete do Grove p. 875).
} 
somente uma parte falada, ou 'duoadramas' porque continham duas partes faladas.

O primeiro grande compositor a adotar o melodrama foi Wolfgang Amadeus Mozart, 1756-1791, de quem os comentários entusiásticos sobre os 'duodramas' Ariadne e Medea de Georg Benda que ele ouvira, podem ser encontrados mencionados nas cartas ao seu pai, Leopold Mozart, 1719-1787, endereçadas de Mannheim em 12 e 24 de novembro, e em 03 de dezembro de 1778, e de Kaisheim em 18 de dezembro. ${ }^{134}$ Nada restou do melodrama integral Semiramis que Mozart escreveu em colaboração com Gemmingen, a repetida inclusão da obra no Theater-Kalender em Gotha, entre os anos de 1779 e 1780 como uma obra em progresso, em 1781 e 1782 como uma obra completa - é quase certamente apenas um dentre os muitos erros contidos naquela publicação. Apesar de seu comentário em 03 de dezembro de 1778 que ele estava trabalhando nisso, ele pode não ter tido um progresso muito avançådo, uma vez que a chance de uma apresentação específica houvesse passado. Mozart, entretanto, escreveu dois exemplos refinados e expressivos de melodrama no Singspiel incompleto Zaide de 1779-80, e incluiu um na música contemporânea para Thamos, König in Ägypten, № 04. Os dois exemplos de Zaide estão entre os números mais impactantes e extensos da partitura; o segundo conduz a uma ária.

A maioria dos melodramas do século XVIII era rigorosa em tom e clássicos no assunto; por volta do século XIX o alcance em matéria do assunto estava se expandindo para incluir textos bíblicos ou temas dramáticos mais comuns, e melodramas cômicos começaram a se popularizar. Em Viena, Kotzebue parodiou Ariadne de Georg Benda, e Wenzel Müller incluiu melodramas cômicos, bem como exemplos mais sérios e tradicionais, em algumas de suas partituras para serem encenadas. Wether de Pugnani, 1790, predominantemente uma série de monólogos para o herói epônimo, é um exemplo interessante provindo da Itália.

O interesse de Beethoven pelo melodrama se estendeu para além do exemplo familiar da cena da masmorra em Fidelio. Há melodramas na música

\footnotetext{
${ }^{134}$ BRANSCOMBE, Peter. Op.Cit.
} 
incidental de Die Ruinen von Athen e König Stephan, e essa é a forma que ele escolheu para a despedida de Egmont $^{135}$ à vida, o último número da música incidental Egmont, que também inclui passagens pantomímicas. Carl Maria Von Weber,1786-1826, utilizou o melodrama em Der Erste Ton, de 1808, em Preciosa e, também, em Der Freischütz, e Die Zauberharfe - D644, iniciada em 1820, é uma interessante aposta em larga escala, que incluem meia dúzia de cenas melodramáticas, sete coros e um romance que existe em versões para dois tenores e um somente para a orquestra. Franz Schubert,1797-1828, também utilizou o melodrama em Des Teufels Lustchloss, e em uma sequência de três números próximo ao encerramento do Ato II de Fierrabras; e também escreveu um melodrama à maneira de lied para piano e voz falada, Abschied von der Erde D829, 1826.

O Gênero foi de fato particularmente popular em Viena, onde exemplos das obras de Starzer, Paradis, Eberl e Winter podem ser citados em adição àquelas já mencionadas.

Mais generalizadamente, Lélio, de Hector Berlioz' 1803-1869, é um ambicioso, embora difuso, exemplo; Marschner incluiu um exemplo particularmente impactante no Ato II de Hans Heiling, 1833, na spinning-song de Gertrude, que progride de melodrama, por meio de um humming (não falado), à canção propriamente, Des Nachts wohl auf der Heide, № 12. Felix Mendelssohn, 1809-1847; Robert Schumann, 1810-1856; Franz Liszt, 1811-1886; Richard Wagner, 1813-1883, e Engelbert Humperdinck' 1854-1921, todos tentaram à sua maneira. De fato, dificilmente há um compositor de óperas do século XIX que não tenha tentado. Foi uma característica da opera comique francesas durante 0 período da Revolução, utilizada em obras de Etiénne-Nicolas Méhul, 1763-1817, Nicolas Isouard, 1773-1818, François Boieldieu, 1775-1834, e outros, e notavelmente Luigi Cherubini, 1760-1842. Les deux journées, 1800. Giochino Rossini, 1792-1868, apresentou uma passagem impressionante de melodrama em La Gazza Ladra, e houve outros instantes em La Muette de Portici de Auber, Manon e Werther de Jules Massenet, 1842-1912, assim como na Cavalleria

\footnotetext{
${ }^{135}$ Egmont - Abertura e música incidental, op.84, de Beethoven (1810), para peça de Goethe.
} 
Rusticana, I Pagliacci, de Rugiero Leoncavallo, 1857-1919, e La Bohème de Giacomo Puccini, 1858-1924. Giuseppe Verdi, 1813-1901, considerou conveniente utilizar para as cenas da carta no Ato I de Macbeth e Ato II de La Traviata, e Bedrich Smetana, 1824-1884, fez algo similar no Ato II de The Two Widows.

O gênero desenvolveu-se bem no século XIX, onde hoje é a República Tcheca. Zdeneck Fibich, tcheco que viveu de 1850-1900, foi, talvez, o mais importante e ambicioso dentre todos os compositores de melodrama, sua Hippodamia, de 1889-91, sendo uma trilogia de trabalhos integrais. Ele havia escrito anteriormente exemplos menores para voz e orquestra ou piano. Utilizouse do leitmotiv ${ }^{136}$ como uma ferramenta à coesão dramática e estilística inspirado na obra de Richard Wagner, embora seja interessante ressaltar que o primeiro compositor importante de melodramas, Georg Benda, o compatriota de Fibich, havia usado uma forma elementar de leitmotiv em seus trabalhos. Čelansky, mais lembrado como o fundador do P.O. tcheco, também, escreveu vários melodramas.

Tem havido um aumento do uso do melodrama no século XX. Arnold Schoenberg,1874-1951, utilizou o melodrama em uma vasta gama de estilos e peças: Gurrelieder, 1910-11, emprega o discurso com notação. Pierrot Lunaire, 1912, é estritamente notado, um discurso com altura definida embora não se deva propriamente cantá-lo; Die Jakobsleiter tem um recitativo coral em Sprechgesang; Die Glückliche Hand, 1910-13, emprega alturas relativas e ritmos precisos; Moses und Aron,1930-32, tem coros parcialmente falados e o Sprechstimme de Moisés é notado. Há outras formas em Kol Nidre, 1938, Ode to Napoleon, 1942, A Survivor from Warsay, 1947, e Modern Psalm, 1950. William Walton, 1902-1983, renomadamente arranjou 'Façade',1922, de Edith Sitwell para voz (em discurso) e conjunto de câmara; Ferrucio Busoni,1866-1924, utilizou discurso rítmico de altura não definida em Arlecchino; Alban Berg, 1885-1935, fez diversos usos de

\footnotetext{
${ }^{136}$ Motivo condutor - tema ou ideia musical claramente definido, representando ou simbolizando uma pessoa, objeto, ideia, etc. que retorna na forma original, ou em forma alterada, nos momentos adequados numa obra dramática (principalmente operística). O termo foi cunhado por F.W.Jähns em 1871, mas esse recurso tem longa linhagem. Sua influência na ópera romântica foi reconhecida pela primeira vez por Weber, e Wagner elevouo a uma posição de importância capital, tanto como meio de desenvolvimento sinfônico quanto a alusão dramática. O leitmotiv foi adotado pelos discípulos de Wagner, incluindo Cornelius e Humperdinck, e por outros compositores. A utilização feita por Strauss deriva tanto de Wagner quanto da técnica de metamorfose temática, de Liszt.
} 
melodrama em Wozzeck, 1925, e cobriu toda a gama de gêneros de interpretação vocal em Lulu,1935 -1979. ${ }^{137}$

Richard Strauss,1864-1949, utilizou passagens melodramáticas em várias óperas e em Enoch Arden, 1897. Compositores do período entre guerras que exploraram o melodrama incluem Kurt Weill, 1900-1950, em Happy End, 1929; Igor Stravinsky, 1882-1971, em Perséphone; Darius Milhaud, 1892-1974, em Le Livre de Cristophe Colomb e Oréstia (Claudel) e Arthur Honegger,18921955, em Jeanne d'Arc au Bûcher, oratório cênico de 1938.

Exemplos mais recentes podem ser encontrados nos trabalhos de Benjamin Britten, 1913-1976, e Hans Werner Henze, 1926, entre outros. Uma larga seleção de melodramas foi prontamente disponível, publicada para execução doméstica com acompanhamento de piano, e alguns volumes também com orquestra ou grupo de câmara.

O desejo de experimentar está produzindo constantemente novos meios, ou à volta aos meios antigos de combinação de voz falada com música, na música escrita.

\subsection{1 - A Passacaglia}

Do italiano passacaglia, passacaglio, passagallo, passacaglia, passacaglie; do francês passacaille; do alemão passacalia e do espanhol pasacalle ou passacalle.

Na música dos séculos XIX e XX, uma sequência (set), de baixo contínuo (ground) ou variações em ostinato, geralmente de caráter sério e sombrio; nas fontes mais antigas, um curto ritornello improvisado entre as estrofes de uma canção.

\footnotetext{
${ }^{137}$ SADIE, Stanley - A criação de Lulu foi interrompida duas vezes por obras de encomenda - ária Der Wein, sobre poemas de Baudelaire (1929), e o Concerto para Violino (1935) - e permaneceu inacabada quando da morte de Berg: sua viúva embargou o terceiro ato incompleto, que até 1979 não pode ser publicado nem apresentado. Tal como aconteceu com Wozzeck, ele fez seu próprio libreto a partir de material cênico, desta vez escolhendo duas peças de Wedekind, a qume há muito admirava por seu tratamento da sexualidade. Dramática e musicalmente a ópera é um palíndromo, mostrando a ascensão de Lulu na sociedade através de seus sucessivos relacionamnetos, depois sua queda na prostituição e finalmente sua morte nas mão de Jack, o Estripador. Mais uma vez a partitura é repleta de esquemas formais elaborados, em torno de um lirismo descontraído pela compreensão individual de Berg do serialismo dodecafônico. Algo de sua sensualidade de trenodia tem prosseguimento no Concerto para violino, concebido em memória da filha adolescente da viúva de Mahler. (verbete do Grove p.97)
} 
O termo algumas vezes é usado alternadamente com chaconne (as formas chaconne e passacaglia são mencionadas no decorrer deste texto).

\section{O princípio nos países Espanha e Itália}

A passacaglia parece ter-se originado no começo do século XVII, na Espanha, como a 'passacalle', uma breve improvisação, geralmente nada mais que uns poucos acordes cadenciais ritmicamente rasgueados, ou palhetados que os violonistas tocavam entre as estrofes de uma canção, de certa forma uma introdução ou improvisação.

O termo vem de pasar - caminhar e calle - rua, possivelmente derivado das apresentações ao ar livre ou do hábito de alguns músicos populares andarem entre esses interlúdios. As primeiras referências a passacalles aparecem na literatura espanhola por volta de 1605; em alguns contextos o termo parece ter sido usado com o mesmo sentido de paseo, ou ainda, o percurso descendente de um basso ostinato caminante, com o acompanhamento pesante que lembra un corteo - um cortejo.

O termo foi logo exportado para a França e Itália, em princípio, novamente, para aludir aos ritornellos - reprise - improvisados entre as estrofes. Assim como a chaconne, os exemplos escritos mais antigos foram encontrados na Itália em tablaturas de alfabeto para violão, e tem a forma de breves progressões harmônicas rítmicas delineando uma fórmula cadencial, geralmente I-IV-V-I ou uma elaboração desta.

As progressões normalmente aparecem em um número determinado de tonalidades, ritmos e padrões de palhetada, tanto em compasso binário quanto ternário; seu propósito parece ser primariamente pedagógico. $\mathrm{Na}$ Itália passacaglio foi mais frequentemente usado para se referir a uma única ocorrência de um determinado esquema de acorde, e o plural passacagli para uma sucessão ou coleção de mais de uma ocorrência; mas ambos os termos, assim como para o feminino passacaglia e seu plural passacaglie, e as variantes como passagallo, 
passagalli, passachaglie e numerosas outras variações, foram usados com uma distinção mínima pelos séculos.

\section{Na Itália a partir de 1627}

Nenhum exemplo de composições notadas intituladas passacagli (ou qualquer de suas variantes) a não ser as fórmulas de palhetada de violão pode ser datado como antes de 1627, quando Girolamo Frescobaldi, 1583-1643, publicou uma 'Partite sopra passacagli', junto com uma 'Partite sopra la ciaccona'. Não se está claro se ele deveria ser creditado quanto à criação da passacaglia como um gênero musical independente, em oposição ao ritornello improvisado para outra composição, mas esse esquema de 1627 contem muitas das características das numerosas passacaglias para todos os tipos de combinações vocais e instrumentais que apareceram nos anos subsequentes. As passacaglie mais recentes estão tipicamente na forma de variações contínuas sobre um baixo que pode ser também sujeito a uma variação considerável. A velha fórmula I - IV- V - I

é expandida para uma quantidade inumerável de variantes, frequentemente na forma de elaborações de um baixo descendente de tetracorde, como por exemplo, $\mathrm{i}$ - $\mathrm{v}_{6}$ - iv6 - V geralmente com a frase métrica permanecendo como quatro grupos de três pulsos. Intervalos cromáticos intermediários são frequentes, assim como outras digressões, também como versões ascendentes, como por exemplo: i - VII6 $-\mathrm{i} 6-\mathrm{iv} \mathrm{c}-\mathrm{V}$.

As notações mais antigas da passacaglia como um ritornello improvisado, algumas vezes sobre um baixo específico, sobreviveram por algum tempo, como pode ser encontrado, por exemplo, em L'incoronazione di Poppea,1642 de Claudio Monteverdi,1567-1643. Sem dúvida, relacionado a essa prática está uma contínua tradição de conjuntos de passacaglie para violão em uma vasta gama de modos, tonalidades, tanto maiores quanto menores, provendo, desta forma, ao instrumentista, modelos e exercícios para prelúdios improvisatórios e interlúdios de duração arbitrária. Um propósito similar tem sido 
intentado para uma coleção de 44 variações anônimas ${ }^{138}$ não intituladas para teclado sobre padrões de baixos descendentes. As peças estão ordenadas por tonalidade, ascendentemente a partir de Dó, e incluem grupos em compasso binário e ternário; aqueles em ternário se assemelham muito às passacaglie de Girolamo Frescobaldi. Interlúdios improvisados de violão continuaram a ser chamados de passagalli na música folclórica de algumas áreas da Itália pelo século XIX. A essa nova guisa como uma corrente variante independente, a passacaglia dividiu várias características com a chaconne, incluindo as ligações entre as variações, articulação cadencial e o uso de métrica ternária. Ainda as passacaglie de Frecobaldi mostram algumas distinções, não necessariamente em toda instância, tais como caráter mais retraído, menos exuberante, andamento mais vagaroso, maior uso de tonalidades menores, maior suavidade, movimentação melódica e dissonâncias mais frequentes em suspensões que ocorrem em tempos fortes. As similaridades, diferenças e ambiguidades entre a passacaglia e chaconne são exploradas ao máximo na extraordinária Cento partite sopra passacaglie do compositor italiano Girolamo Frescobaldi, com suas seções alternadamente marcadas 'passacaglie' e 'ciaccona', e por vezes há uma gradual, subta metamorfose de uma a outra.

Algumas dessas distinções entre os dois gêneros continuaram presentes nas obras dos compositores vindouros na Itália e onde quer que fosse, particularmente quando uma chaconne e uma passacaglia aparecem lado a lado ou na mesma coleção; entretanto, quando uma ou outra aparecem por si só, as características que as diferenciam podem ser menos evidentes ou totalmente ausentes. Compositores como o italiano do século XVII, Bernardo Storace, também seguiram os passos de Frescobaldi, alterando a tonalidade, modo e métrica em algumas de suas passacaglie.

Nos arranjos vocais, as passacaglie italianas eram algumas vezes interrompidas por recitativos, como por exemplo, Cosi mi Disprezzate, 1630. Seções que se assemelham a uma passacaglia sem serem propriamente identificadas como tal são encontradas em óperas, cantatas e peças sacras.

${ }^{138}$ Em I-Rvat Chigi Q IV 27, um manuscrito provavelmente associado a Frescobaldi e seus pupilos. 
Entretanto, a tendência de tratar qualquer lamento durante esse período com um baixo descendente entre tetracordes como passacaglia não parece ter precedência histórica, a menos que a peça também mostre outras marcações de gênero. No começo do século XVIII a passacaglia rapidamente perdeu terreno na Itália, mas continuou a florescer na França, Alemanha e em todo lugar por algum tempo.

\section{Mais tarde na Espanha}

$\mathrm{Na}$ Espanha uma tradição de passacaglia ativa e artisticamente significante sobreviveu independentemente à chaconne; permaneceu enraizada na velha prática do ritornello e praticamente não foi afetada pelos desenvolvimentos da passacaglia na Itália e França. Como os exercícios de palhetada antigos, as passacaglie tardias continuaram a ser apresentadas em um grupo de peças abrangendo as tonalidades mais utilizadas, em modos maiores e menores e em compassos binários e ternários. As passacaglie de Francisco Guerau, 1694, Antonio de Santa Cruz, 1700 e Santiago de Murcia, 1732 não eram simples fórmulas de acordes, entretanto, mas continham um conjunto de variações que se aproveitavam totalmente das possibilidades técnicas e de expressividade ao violão. Passacaglie muito similares podem ser encontradas no repertório contemporâneo para teclado, incluindo alguns maravilhosos exemplos por Juan Cabanilles,1644-1712.

Depois de Passacalles y Obras, 1732, de Santiago de Murcia, a passacaglia desapareceu da tradição escrita na Espanha. O termo 'passacalle' continuou a ser usado na prática popular, entretanto, para se referir a prelúdios instrumentais e interlúdios durante a dança, por exemplos as seguidillas em La Mancha, assim como para a música de acompanhamento para as danças em si. Em algumas áreas da América Latina os ritornellos de violão para danças populares ainda são chamadas 'passacalles'. 


\section{França}

Na França, a passacaglia hispânico-italiana, assim como a chaconne, foi transformada durante os meados do século XVII num gênero nativo distinto, embora antes que o gênero já tivesse algum impacto como uma importação exótica da Espanha. Uma 'passacalle', no sentido antigo ritornello, ocorre em uma aria de um texto espanhol por De Bailly,1614, e em 1626 o expatriado espanhol Luis de Briçeño publicou em Paris um método de violão que incluía em tablaturas de acordes breves chaconnes e passacaglias similares aos exemplos italianos mais antigos. Durante os anos 1640 a promoção de música e músicos Italianos pelo Cardeal Mazarin trouxe uma familiaridade mais ampla entre os dois gêneros em suas novas formas. Uma passacaglia para cravo de Luigi Rossi, 1597-1653, que visitou Paris em 1646 onde um ano mais tarde Orfeo de sua autoria seria apresentado, obteve grande circulação. Francesco Corbetta, 1615-1681, que se mudou para Paris por volta de 1648 e tornou-se professor de violão de Louis XIV, foi talvez o maior virtuoso ao violão na Itália em seu tempo, e compositor de inúmeras chaconnes e passacaglie.

Ao final dos anos 1650, a tradição da passacaglia francesa estava consolidada, já mostrando muitas das características que marcariam o gênero durante o final do século XVII e século XVIII. Assim como a chaconne, a passacaglia foi cultivada tanto em música de câmara, especialmente por violonistas, alaudistas e tecladistas, quanto nos palcos. Dentre os exemplos sobreviventes estão duas passacailles para cravo por Louis Couperin, 1626-1661, que são baseadas em ostinatos que delineiam tetracordes descendentes. Compositores franceses geralmente dão preferência à chaconne ao invés da passacaglia. Entretanto, a longa e impressionante passacaille da ópera Armide, 1686, de Jean-Batistte Lully,1632-1687, tornou-se um modelo muito admirado do gênero, imitado por muitos, incluindo Johann Sebastian Bach,1685-1750, e o

famoso Lamento de Dido, da ópera Dido e Eneas do compositor inglês Henry Purcell,1659-1695. 
De acordo com teóricos como Brossard, 1703, e Rousseau, 1767, a passacaglia era normalmente em tonalidade menor e a chaconne em tonalidade maior 'regras' frequentemente violadas, e as passacaglie eram executadas em andamentos mais deliberados do que as chaconnes, relatos do século XVIII indicam c. 100 b.p.m., comparado a c.120 -160 para chaconne.

Uma peça favorita entre as passacaglie francesas é a altamente cromática Passacaille em Si menor de François Couperin, 1668-1733, de sua obra Ordre no 8 para cravo, 1717, uma estrutura de rondeau estendido. Após 1740 diminuiu o número de passacaglia para música instrumental e de câmara, desvantagem numérica com relação à chaconne.

\section{Inglaterra}

Peças denominadas 'passacaglia' ou 'passacaille' são raramente encontradas nas fontes inglesas; composições que deveriam ter tido tais títulos no continente [europeu] são geralmente designadas 'chaconne' ou 'ground'.

Uma exceção notável é a passacaille 'How happy the Lover' em King Arthur, 1691, do mesmo compositor do Lamento de Dido,1689, Henry Purcell. Com suas seções alternadas de instrumental, solo e voz, a peça parece ser modelada na passacaglia de Lully em Armide (à qual há também uma referência textual).

\section{Alemanha}

As formas de passacaglia distintamente alemãs desenvolveram-se apenas nos últimos anos do século XVII, principalmente na música para órgão solista. Os organistas alemães, galgados nas tradições da improvisação do cantus-firmus e divisões de baixo contínuo, o 'ground', criaram uma série de majestosas composições com ostinatos, formados por figurações cada vez mais brilhantes. Uma passacaglia anterior a 1675 por Johann Kaspar Kerll, 1627-1693, que foi para Roma estudar com Giacomo Carissimi, 1605-1674, ainda usava a 
fórmula tradicional de tetracorde descendente; entretanto, compositores que 0 sucederam, tal como Dietrich Buxtehude,1637-1707 e Johann Pachelbel, 16531706, intruduziram fórmulas de baixo de concepção própria, que eram tratadas durante pelo menos a primeira metade da composição como rigorosos ostinatos. Essas progressões no baixo assumem uma significância temática não presente nas fórmulas tradicionais, ao passo que várias técnicas emprestadas da improvisação vocal foram trazidas para sustentar-se nelas. O intrincado conteúdo técnico e densamente contrapontístico ofuscou amplamente qualquer sensação relacionada à dança, e as relações com as origens do gênero tornaram-se cada vez mais tênues. Esse é o caso da passacaglia mais famosa dessa tradição, a Passacaglia em Dó menor de Johann Sebastain Bach,1685-1750, BWV 582, que é concluída com uma longa fuga sobre o ostinato do sujeito, possivelmente derivado de uma curta passacaglia proveniente de uma missa para órgão de 1687, por André Raison, c.1650-1719.

Passacaglie escritas durante o mesmo período para formações instrumentais seguiram mais de perto os modelos franceses ou combinaram as maneiras francesas e alemãs, conforme foram concebidas primariamente para cravo. Bach também fez uso do gênero em algumas obras vocais, embora não indicado como tal, BWV12, mais tarde retrabalhado no 'Crucifixus' da Missa em Si menor, BWV78. Alguns podem discordar dizendo que o coro de abertura do BWV12 (assim como o 'Lamento der Freunde' no Capriccio para teclado BWV992) deva ser classificado como um lamento 'lament' ao invés de passacaglia, mas não deve haver dúvidas quanto à magnífica abertura do BWV78, que tem todas as marcas registradas de um número operístico de chaconne/passacaglia francês; de fato, a passacaglia de Armide de Lully deve ter sido sua fonte direta de inspiração. 


\section{Depois de 1800}

Quando os compositores dos séculos XIX e XX voltaram a escrever passacaglie, encontraram modelos em um vasto número de peças 'redescobertas' dos mestres germânicos, especialmente a Passacaglia de Bach para órgão e, também, talvez a Passacaglia da Suite no 7 em Sol menor de Friedriech Georg Haendel, 1685-1759, obras merecedoras de seu status canônico, mas atípicas com relação às formas anteriores mais comuns na tradição do gênero, a passacaglia em Haendel era, na verdade, em compasso binário. Da passacaglia de Bach, foi extraida o que agora virou uma característica marcante: o baixo ostinato. A ideia de tema e variação, frequentemente incidental às passacaglie mais antigas tornou-se central aos gêneros quando revividos. Assim como Bach, o tema ostinato é geralmente apresentado logo no começo em forma menos desenvolvida e em registro grave. A associação de passacaglia com Bach e o órgão também contribuiu para uma atmosfera de gravidade; a maioria dos exemplos dos séculos XIX e XX preza por um andamento cadenciado. Alguns escritores tentaram definir a distinção entre passacaglia e chaconne baseados primariamente nos exemplos de Bach, mas não chegaram a nenhum consenso e para a grande maioria das peças os termos continuaram a ser usados indistintamente.

\subsection{2 - Pierrot Lunaire, ${ }^{139}$ opus 21 - Arnold Schoenberg}

Parte I: 1 - Mondestrunken, 2 - Colombine, 3-Der Dandy, 4 - Eine Blasse Wäscherin, 5-Valse de Chopin, 6-Madonna, 7-Der Kranke Mond

Parte II: 8 - Nacht, 9 - Gebet an Pierrot, 10 - Raub, 11 - Rote Messe, 12 Galgenlied, 13 - Enthauptung, 14 - Die Kreuze

Parte III: 15 - Heimweh, 16 - Gemeinheit, 17-Parodie, 18-Der Mondfleck, 19 - Serenade, 20 - Heimfahrt, 21 - O Alter Duft

\footnotetext{
${ }^{139}$ As traduções do texto para o português de Augusto de Campos encontram-se no Anexo I desta tese.
} 
De todas as obras de Schoenberg, Pierrot Lunaire op.21 é a que se tornou mais célebre. Naturalmente, a originalidade de sua concepção contribuiu muito para o seu grande sucesso. Trata-se de 21 melodramas (...) Apesar do estilo aforístico já estar ultrapassado aqui, podemos dizer que a concepção da obra praticamente não teria sido possível sem as experiências composicionais adquiridas por meio dele. ${ }^{140}$

Ciclo de vinte e um poemas de Albert Giraud em versão alemã de Otto Erich Hartleben, esses melodramas são para recitante, flauta, que alterna com flautim, clarineta que alterna com clarinete baixo, violino, que alterna com viola, violoncelo e piano. Apresenta três partes que se agrupam de sete em sete melodramas cada uma.

Schoenberg resgata por meio desse estilo, novas aquisições para o melodrama. Aqui o compositor consegue criar uma diversidade de timbre tão acentuada, com um pequeno agrupamento de instrumentos.

À medida que cada peça é instrumentada de maneira diferente, percebe-se um colorido sonoro, ou seja, uma cor apropriada a cada uma delas, através de procedimentos instrumentais habilmente utilizados muitas vezes de forma inusitada.

Acrescentando-se a isto, a voz do recitante e toda a gama de variação da fala misturada ao canto, o que contribui essencialmente para a originalidade da obra, que vem definir os princípios deste novo meio de expressão vocal, o Sprechgesang. ${ }^{141}$

A realização puramente sonora deve ser ainda mais uma vez posta em relevo, e é espantoso ver até que ponto a imaginação de Schoenberg consegue criar uma diversidade de timbre tão acentuada, com um número tão reduzido de insturmentos. Os procedimentos instrumentais utilizados são de louca habilidade, e podemos dizer, sem exagero, que cada peça possui sua cor própria, na medida em que cada uma é instrumentada de maneira diferente. A isto acrescente-se a voz do recitante, que contribui essencialmente para a originalidade da obra. Definamos os princípios deste novo meio de expressão vocal que é o Sprechgesang

Resumidamente, o que o próprio Schoenberg comenta no seu prefácio da partitura temos:

\footnotetext{
140 LEIBOWITZ, René. Schoenberg.p.91.

${ }^{141}$ GRIFFTHS, Paul. Op.Cit. p.213. Tipo de emissão vocal entre a fala e o canto, exigido pela primeira vez por Humperdinck em sua ópera Die Königskinder (1897), embora substituida pelo canto normal na edição de 1910. Foi inteiramente explorada por Schoenberg em Gurrelieder, Die Glückliche Hand, Pierrot Lunaire, etc.

142 LEIBOWITZ, René. Op.Cit.p.91.
} 
A questão rítmica deve ser observada estritamente, como se tratasse de um cantar, mas, enquanto a melodia cantada mantém a altura do som, a melodia falada não faz senão indicá-la, abandonando-a imediatamente de maneira ascendente ou descendente ${ }^{143}$

A partir de um ensaio encomendado pelo próprio Schoenberg ao seu discípulo Erwin Stein, conclui-se que nenhuma altura determinada de som deve ser produzida. Os intervalos escritos, somente sugerem modulações decorrentes das inflexões baseadas nas variações da fala. ${ }^{144}$

Com estes recursos vocais, mais os glissandi sobre intervalos mais curtos, Schoenberg atinge uma sonoridade especialmente rica, um efeito novo para a linha melódica em relação à entonação da música do repertório tradicional, pois, sendo a voz um instrumento visceral que não sofreu o ajuste do temperamento por igual, ou seja, pode-se emitir através dela, frequências ou alturas de intervalos sonoros menores do que o espaço de som entre os semitons de nossa escala temperada.

Porém, a tentativa de adaptar e inserir essa nova melodia para o interior da música escrita, ou seja, a tentativa de grafar essa vocalidade tão rica causava certas dúvidas na execução dessa música. Também, o tradicional sistema de grafia, haveria de passar por certos acréscimos e transformações. Isto fez com que Schoenberg sempre se voltasse a numerosas alusões para essa obra. Eis um extrato de carta, endereçada ao primeiro secretário de uma sociedade de concertos holandesa que programara uma execução de Pierrot Lunaire:

Quero somente insistir sobre o fato de que nenhum dos poemas é destinado a ser cantado, mas devem ser falados sem alturas de sons fixos. (23 de julho de 1949) ${ }^{145}$

Segundo René Leibowitz,

Pierrot Lunaire foi escrito muito rapidamente. Schoenberg, que já há alguns anos tinha retornado a Berlim, era o titular de uma cadeira de composição no conservatório Stern de Berlim. Escreveu a maior parte das peças durante as poucas horas de descanso que the sobravam de seu tempo bastante apertado (parece mesmo que trabalhava

\footnotetext{
143 LEIBOWITZ, René. Schoenberg.

${ }^{144}$ LEIBOWITZ, René. Op.Cit.

145 LEIBOWITZ, René. Schoenberg. p.91.
} 
frequentemente entre uma aula e outra). A maior parte das quatorze peças foi escrita em uma só semana, duas foram compostas no mesmo dia, e a maior parte da obra foi realizada entre 12 de março e 30 de maio de 1912 (duas peças somente foram terminadas mais tarde, a 06 de julho e 09 de julho respectivamente). ${ }^{146}$

Pertencente à fase atonal-livre de Schoenberg, onde prevalecem os valores contrapontísticos sobre a harmonia expressiva.

Mais tarde, Schoenberg efetiva a notação do Sprechstimme sobre uma única linha do pentagrama, a fim de fazer uma notação mais precisa e mais adequada, para que também se evitasse a tentação de cantá-la.

Os primeiros indícios de mudança de orientação do atonalismo-livre aparecem no $n^{\circ}$ 8, de Pierrot Lunaire, ou seja, a Passacaglia, que é um dos melodramas, onde podemos considerar a primeira expressão do atonalismo organizado, ${ }^{147}$ no qual Arnold Schoenberg emprega diversos fatores de unificação, como a autonomia de planos harmônicos superpostos, harmonias geradoras, escrita polifônica com diversas espécies de cânone, sequências ou referências concretas a núcleos determinados.

Ao ultrapassar os limites da tonalidade, Schoenberg sentiu-se obcecado pela busca de obtenção de novos recursos de unidade e forma. Este problema que foi o fio condutor de toda sua produção, completa seus enunciados com o acréscimo que a diversidade supõe, ou seja, a não repetição.

Dessa maneira, assistimos ações simultâneas de desintegração dos valores tradicionais e a firme imposição daqueles que são o produto de novos enunciados de harmonia, contraponto, estrutura e sonoridade; que ainda não tinham a base imutável conferida pela tonalidade e pelas forças que nela se alicerçam, deviam continuamente deslocar-se à procura de diferentes respostas exigidas pelo constante problema da unidade e da formulação apriorística de harmonias determinadas.

Este deslocamento, essa busca incessante do elemento unificador em asas da infinita diversidade, cumpria-se em diversas hierarquias sonoras, até em último limite ou esgotamento; surge então um período construtivo,

\footnotetext{
${ }^{146}$ LEIBOWITZ, René. Schoenberg. pp.91 e 92.

147 LEIBOWITZ, René. Schoenberg. pp.91 e 92.
} 
em que o material extratonal é canalizado dentro das novas aquisições formais. É o período atonal-organizado, cujo espírito vivifica as antigas fórmulas mecânicas do contraponto, das formas fugadas, do cânone e da polimelodia $^{148}$

\section{A Passacaglia de Pierrot Lunaire - opus 21 - de Arnold Schoenberg}

\section{Melodrama no 8 - Nacht}

\section{NACHT}

Finstre, schwarze Riesenfalter

Töteten der Sonne Glanz.

Ein geschlossnes Zauber buch

Ruht der Horizont - verschwiegen.

Aus dem Qualm verlorner Tiefen

Steigt ein Duft, Erinnrung mordend!

Finstre, schwarze Riesenfalter

Töteten der Sonne Glanz.

Und von Himmel erdenwärts

Senken sich mit schweren Schwingen

Unsichtbar die Ungetüme

Auf die Menschenherzen nieder...

Finistre, schwarze Riesenfalter.
NOITE

Cinzas, negras borboletas

Matam o rubor do sol.

Como um livro de magia

O horizonte jaz - soturno.

Um perfume de incensório

Sobe de secretas urnas.

Cinzas, negras borboletas

Matam o rubor do sol.

E do céu a revoar

Revolvendo as asas lentas,

Vêm, morcegos da memória, Invisíveis visitantes...

Cinzas, negras borboletas.

A Passacaglia de Pierrot Lunaire - opus 21, composta no ano de 1912, para baixo clarinete em Si bemol, violoncelo, piano e voz (recitante). É o primeiro melodrama da segunda parte dos 3 grupos de sete em sete, dos 21 melodramas.

Pode-se observar no texto de Otto Erich Hartleben, e traduzido para o português pelo poeta brasileiro Augusto de Campos, que a noite (Nacht) que é o título, já por si própria figura algo sombrio, obscuro. Neste poema as palavras iniciais:

"Cinzas, matam o rubor do sol, (...) o horizonte jaz - soturno" - e ainda a passacaglia que ao mesmo tempo pode figurar em concordância com um lamento, enquanto gênero e forma, que carrega em si o baixo ostinato

\footnotetext{
${ }^{148}$ PAZ, Juan Carlos. Introdução à Música de Nosso Tempo. p.115.
} 
descendente, pesante, seria o momento em que Pierrot identifica-se com a morte, ou sua própria decadência. Representado aqui como o ocaso, a luz do dia que se esvai, e em seguida as forças telúricas da noite sobrepõem a escuridão.

"Um perfume de incensório - Sobe de secretas urnas." - revolvem as asas lentas - "Vêm, morcegos da memória, Invisíveis visitantes...", seja este o desejo de transfigurar as "Cinzas, negras borboletas” em nova luz, que novamente é mais um nascer do sol, o astro obstinado que pode ser representado pelo motivo a do baixo ostinato.

Se ainda, fôssemos analisar essa peça identificando figuras de retórica correntemente, utilizadas no período Barroco, tomadas da Teoria dos Afetos, ${ }^{149}$ teríamos a própria passacaglia (o lamento), o baixo ostinato (cromático e descendente), a obstinação descendente - semelhante ao caráter de cortejo, atribuição dada à passacaglia na Espanha, no século XVII - elementos que justificam a atmosfera sombria de Nacht e ao mesmo tempo são alegorias construídas pela interpretação da metáfora. ${ }^{150}$

\section{Este movimento contém 26 compassos.}

\footnotetext{
${ }^{149}$ A Teoria dos Afetos desenvolvida por Werkmeister em sua obra "Harmonologia Musica", de 1702, tornouse objeto de estudo de muitos músicos e pensadores como: J.D.Heinichen (1711), Mattheson (1739), J.J.Quantz (1752), F.W. Malpurg (1763) e outros escritores do séc. XVIII. Em 1739, Mattheson chega a descrever a teoria com ampla gama de riqueza de afectus, contando com mais de 20 feições e pelo modo que cada uma delas deveria ser expressa na música. Embora tenha florescido no período Barroco, a Teoria dos Afetos foi inspirada na doutrina do Ethos, da Grécia antiga, com Platão e Aristóteles, e que continuou a florescer durante a Idade Média, a Renascença e o início do Barroco, com Isidoro de Sevilha, Glareano, Ramos de Pareja, Claudio Monteverdi e Renée Descartes, dentre outros. No entanto, os escritores e compositores do Barroco alemão estavam bem familiarizados com essa doutrina estética e, com freqüência utilizavam essas manifestações em suas composições. Normalmente era se aceito que uma obra ou um movimento de uma obra mais extensa, como por exemplo, a ópera podia expressar uma emoção e sua gama de nuances.A Doutrina das Figuras que se reabilita nesse mesmo período concebe a música de maneira análoga à retórica, ou seja, a arte do bem falar, como era conhecida desde a época latina. Ligados à oratória os preceitos da retórica eram empregados também na composição musical. Surgida no último período, Barroco, a Teoria dos Afetos tenta explicar a relação dos eventos musicais com os sentimentos.(OLIVEIRA, Maria Cecília - Análise do Ponto de Vista Retórico de Didos's Lament de Henry Purcell - monografia).p.3.

${ }^{150}$ HANSEN, João Adolfo. Alegoria: construção e interpretação da metáfora. p.3.
} 
Nacht - Pierrot Lunaire (Passacaglia) - Schoenberg

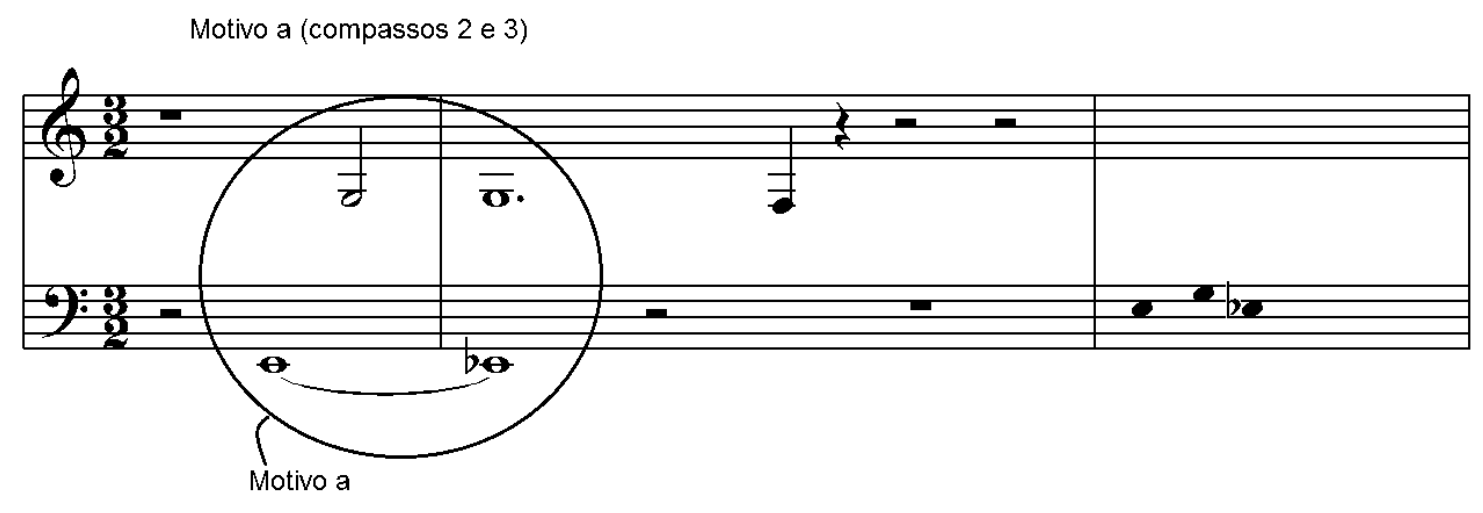

Figura 51 - Motivo a de Nacht - Pierrot Lunaire de Schoenberg

Logo no compasso inicial, Schoenberg introduz o motivo a gerador, no registro bem grave do teclado, com as notas mi, sol, mi bemol (um do piano), que pode ser conferido no trecho da partitura acima e ainda, a seguir. 


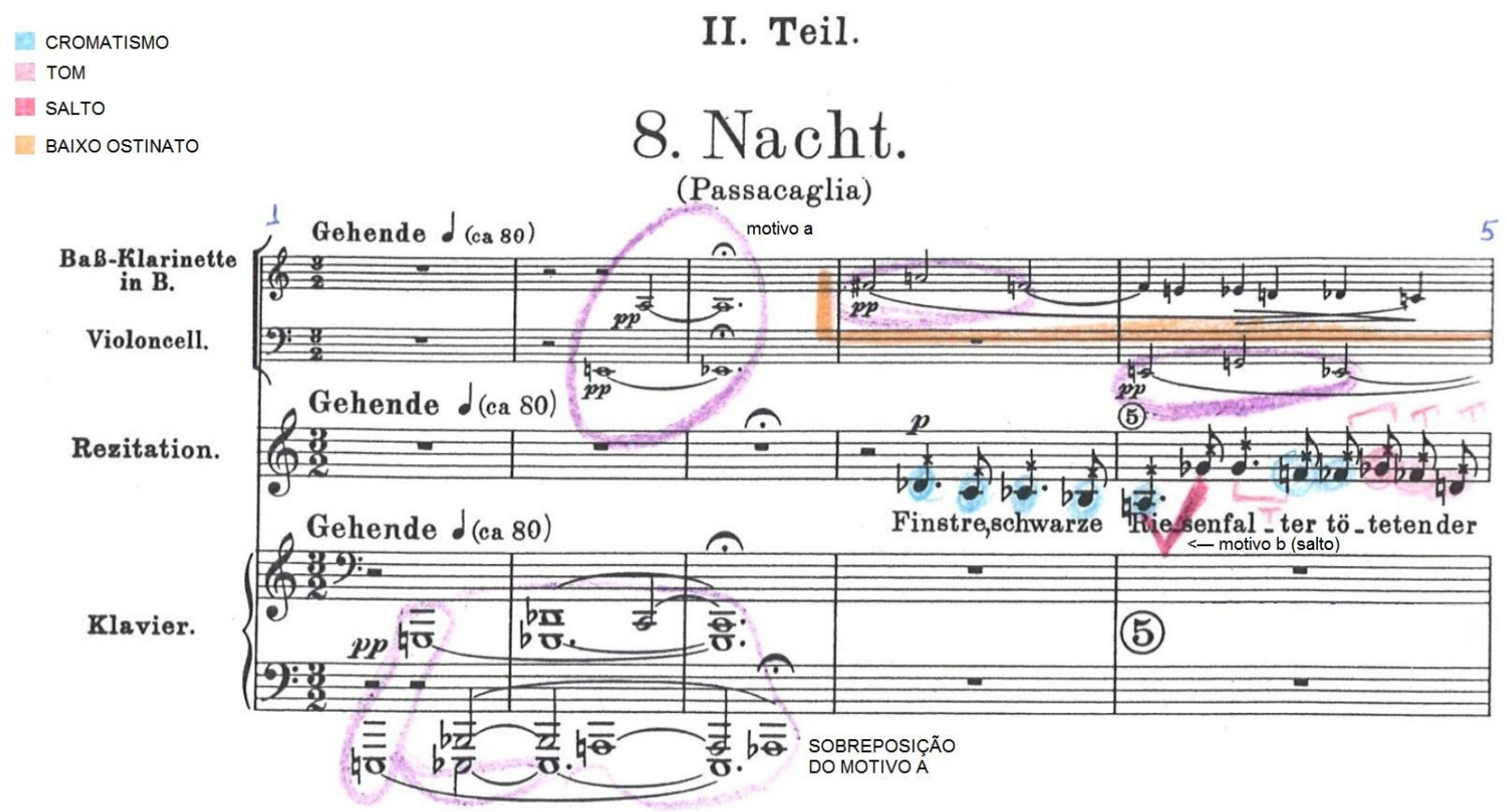

Figura 52 - Primeiros compassos de Nacht - Pierrot Lunaire de Schoenberg

- O que está circulado na cor violeta é o motivo $\underline{\mathbf{a}}$ - mi,sol,mib, com os instrumentos piano, já no início da cabeça do compasso, m.e e md. no piano, baixo-clarinete e violoncelo - sobreposição do motivo $\underline{\text { a. }}$

- A cor azul indica cromatismo

- Rosa-vinho indica salto

- A cor laranja indica parte do baixo ostinato 
BAIXO OSTINATO (c.5 ao c.7)

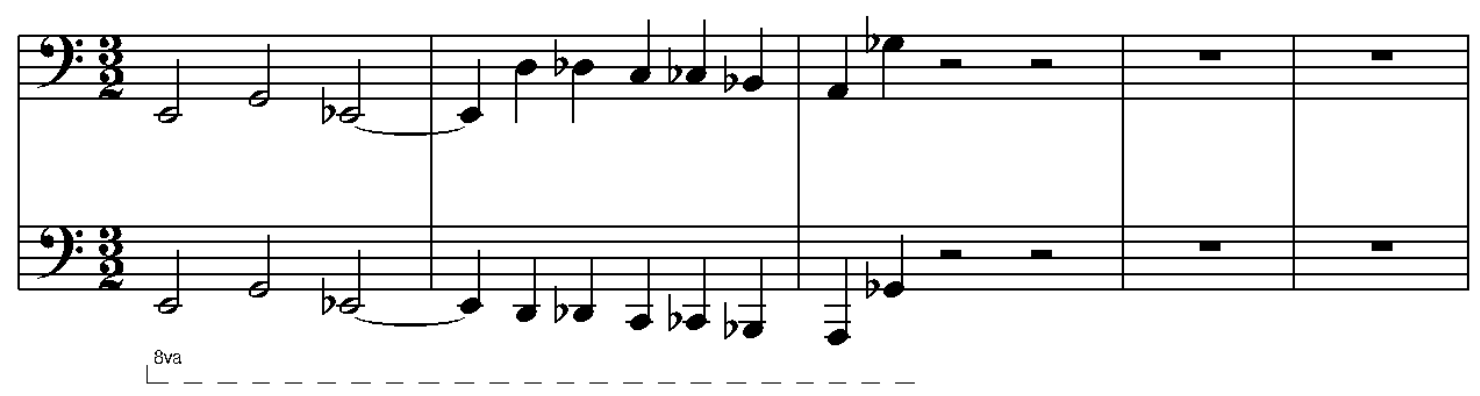

Figura 53 - Baixo ostinato de Nacht - Pierrot Lunaire de Schoenberg

Com este motivo o qual chamaremos de $\underline{\mathbf{a}}$, que entre os compassos 01 ao 03 Schoenberg faz uma verdadeira sobreposição dessa célula embrionária para construir o baixo ostinato que se inicia no compasso 04 e vai até o c. 07 , com o baixo clarinete e a partir do compasso 05 até o c. 07 também, e entre os compassos 06 e 08 pela mão esquerda do piano, e ainda, entre os compassos 07 e 09, todas essas entradas em cânone imitativo, porém com o baixo "ostinato" variado. À medida, em que os instrumentos entram, após a apresentação do baixo ostinato que esses fazem, os instrumentos vão delineando o motivo a modificado de várias maneiras, ora reduzido, fragmentado, transposto, invertido (ascendente/descendente).

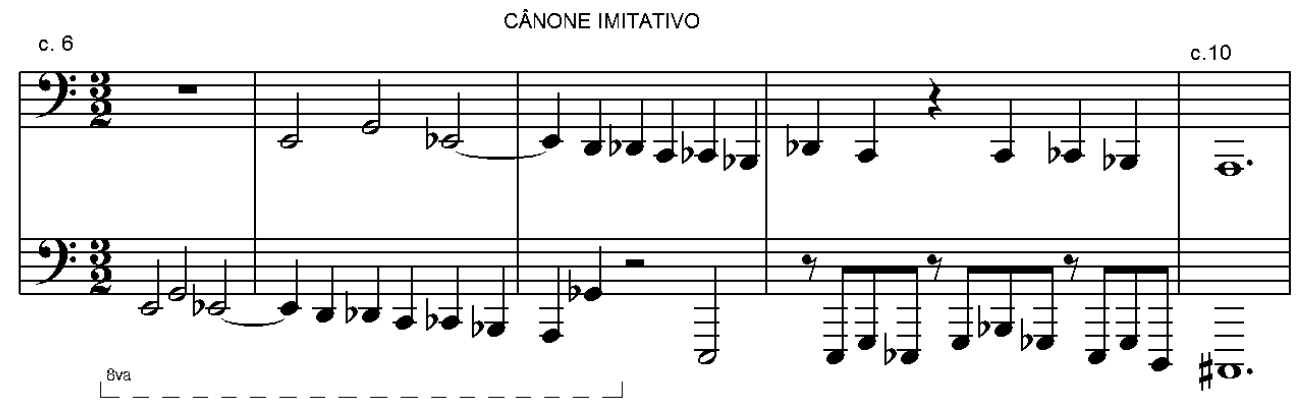

Figura 54 - Cânone imitativo de Nacht - Pierrot Lunaire de Schoenberg 
O mesmo baixo com as classes de altura CA.

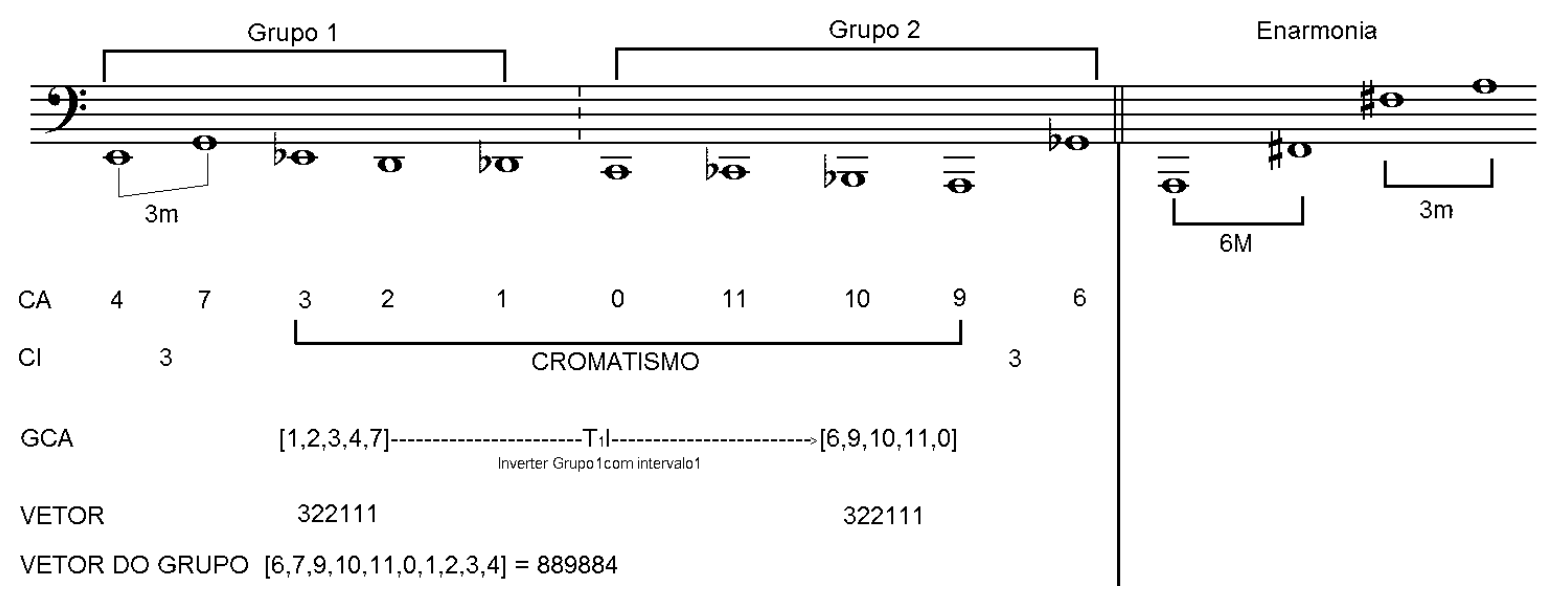

Figura 55 - O mesmo baixo com as classes de altura CA

Em contraste com este motivo a, entra a voz do recitante no compasso 04, em figuras reduzidas mescladas com notas pontuadas às notas mais prolongadas, em um cromatismo que é a sequência do baixo ostinato e um salto, mas na cabeça do 5o compasso a voz do recitante apresenta um salto de $7^{\text {a }}$ diminuta ascendente também em "contraste" com os graus conjuntos, neste caso qualquer intervalo a partir de $4^{a}$, os quais chamarão de motivo b (salto). Este salto de $7^{\text {a }}$ diminuta é repetido pelo violoncelo no $7^{\circ}$ compasso. Embora, haja recomendações de Arnold Schoenberg no prefácio de Pierrot Lunaire para que o executante não cáia em tentação de cantar as notas, utilizando as hastes cruzadas $(x)$ no corpo das figuras ritmicas, o que indicará o meio termo entre a fala e o canto, o Sprechgesang ou Sprechstimme. Sendo Schoenberg considerado o primeiro compositor a utilizar a figura rítmica com hastes cruzadas por um (x).

Ainda que muito já tenha sido dito, sobre esta preciosa obra, toda vez que observamos a sua partitura, encontramos algo para relacionar e refletir. Ela é um belo exemplo de amálgama timbrística à qual Schoenberg fez com tanto capricho. A peculiaridade da mistura dos harmônicos entre as frequências de altura determinadas em contraste com a voz recitante, a própria métrica, as indicações minuciosas de dinâmica, a interválica no plano melódico e harmônico é uma das aquisições históricas que vem de acréscimo para a nova sonoridade. Através de Pierrot Lunaire, Arnold Schoenberg abre portas para uma nova música de fato. Tanto timbricamente, quanto nos planos harmônico-melódico. Embora 
Schoenberg chegue a estruturar o atonalismo, mais tarde, em 1921. Nacht, composta em 1912, já apresenta indícios que indicariam os princípios da técnica dodecafônica. Pode-se pensar que um dos princípios organizativos é, por exemplo, a apresentação dos dez sons apresentados no baixo ostinato, e o motivo a como célula geradora do material para este melodrama. Se tomarmos o motivo $\underline{\mathrm{a}_{1}}$ as notas $\mathrm{mi}, \mathrm{sol}, \mathrm{mi}$ bemol até o décimo som do baixo ostinato, temos um salto de terça menor ascendente (mi-sol) e as demais notas são cromatismo até as notas lá-sol bemol (sétima diminuta, enarmonia da $6^{a} \mathrm{M}$, inversão da $3^{\mathrm{a}} \mathrm{m}$ ). Mesmo as notas lá-sol bemol em salto ascendente, não deixa de ser grau conjunto com mudança de direção.

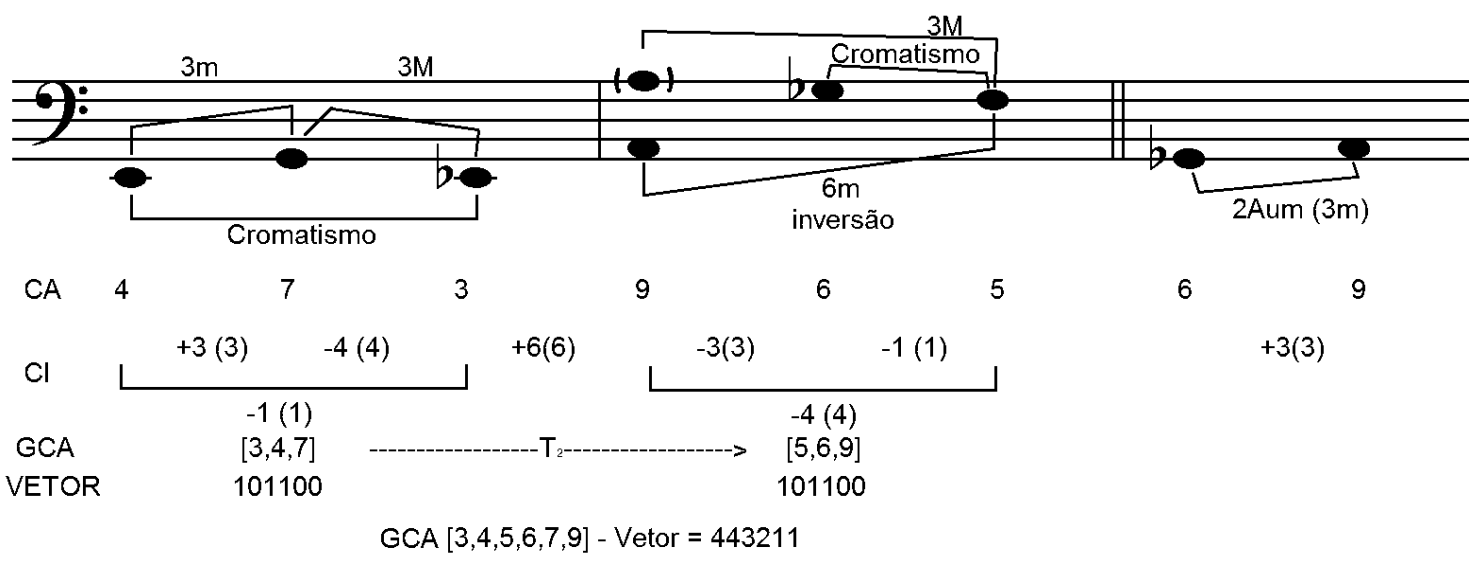

$\mathrm{CA}=$ Classes de Altura

$\mathrm{Cl}=$ Classes Intervalares - +/- intervalos ordenados (intervalos desordenados)

GCA = Grupos de Classes de Altura

Figura 56 - Princípios organizativos do baixo ostinato

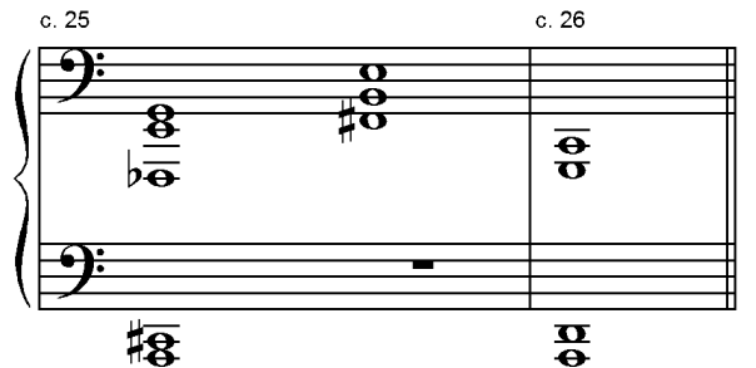

Figura 57 - Últimos compassos de Nacht - Pierrot Lunaire - Schoenberg 
Movimento n־8 - Nacht - a Passacaglia de Pierrot Lunaire - opus 21, de 1912. Morfologicamente Nacht pode ser dividida em seções e subseções:

Contém 26 compassos no total, com fórmula apresentada regularmente em compasso de $3 / 2$ (três por dois).

Introdução - c.1 ao c.3 - apresentação do motivo a e a construção do baixo ostinato.

SEÇÃO 1 - c.4 ao c. 10

Inserção da voz recitante e utilização do cromatismo - o pulso semínima ca = 80 , é mantido desde a introdução, e torna-se um pouco mais tranquilo com figuras que prolongam o som, em relação à seção 2.

SEC̣ÃO 2 - c. 11 ao c. 16

A variação cromática dentro de cada compasso, o tipo de figuração (fusa) no baixo clarinete e violoncelo, a utilização do motivo a na mão esquerda do piano em contraste com a construção vertical dos acordes na mão direita, mais a mudança de andamento para Etwas rascher (um pouco mais depressa) conferem a esta seção um caráter de maior mobilidade e inquietação em relação à seção 1.

Subseção 2.1

Ponte - c.16 - dinâmica ff e fff para o piano (mão esquerda) no registro bastante grave adicionando o uso do pedal harmônico, isto garante a produção de harmônicos perdurando com bastante sonoridade (volume), provocada tanto pela dinâmica quanto pelas alturas do som. Aqui é o ápice de Nacht, com a mescla dos harmônicos ocorridos do registro grave do piano o violoncelo e o baixo clarinete em cromatismo, e a voz recitante, bem na cabeça do compasso os termos, Sonne Glanz = rubor do sol [Töteten der Sonne Glanz - Matam o rubor do sol], na nota si natural no grave (Glanz), com o instrumento piano no grave ressoando pode simbolizar o sepultamento da luz do sol. 


\section{SEÇÃO 3}

c.17 ao c.22 - I tempo - retoma o pulso, oitavas diminutas recheadas com o motivo a , e já no compasso 18 a sequência do motivo a intercalada por cromatismo (vide figura 59 - trecho da partitura de Nacht).

\section{Subseção 3.1}

Coda - c.23 ao c.26 - novamente o motivo a transposto (material variado da introdução).

Pausa longa, mas, praticamente a tempo, para atacar o próximo movimento Gebet Pierrot.

\begin{tabular}{|l|l|}
\hline \multicolumn{2}{|c|}{$\begin{array}{c}\text { ARNOLD SCHOENBERG } \\
\text { PIERROT LUNAIRE - 08 - NACHT }\end{array}$} \\
\hline \multicolumn{1}{|c|}{ EXPRESSÃO EM ALEMÃo } & \multicolumn{1}{c|}{ TRADUÇÃO PARA O PORTUGUÊS } \\
\hline Gehende (q c. 80) & Andamento (q c. 80) \\
\hline Am steg & na teia \\
\hline Etwas rascher & um pouco mais depressa \\
\hline Gesungen (wömoglich die tieferen noten) & cantado (talvez as notas mais profundas) \\
\hline Gesprochen & falado \\
\hline Flatterzunge & vibrar a língua \\
\hline Am Griffbrett & no braço (do instrumento) \\
\hline Nimmt Klarinette in A & conduz clarinete em A \\
\hline Sehr grosse Pause, aber quase im Takt, dann folgt & grande pausa (cadência), porém não muito prolongada, então segue \\
\hline pp aber deutlich hörbar & pp, mas claramente audivel \\
\hline
\end{tabular}

Tabela 8 - Expressões Germânicas - Nacht - Pierrot Lunaire - Schoenberg

Como pode ser percebido, através das duas tabelas, às quais se referem às expressões de caráter, andamento e dinâmica desta obra de Schoenberg, revela um nível muito profundo de detalhamento naquilo que a grafia permitia registrar. Sinais que buscam garantir a expressividade em toda sua consistência; esta qualidade é comum e pode ser estendida aos demais compositores escolhidos para o trabalho deste texto: Anton Webern, Alban Berg e Edward Steuermann. 


\begin{tabular}{|c|c|c|c|c|}
\hline \multicolumn{5}{|c|}{$\begin{array}{c}\text { ARNOLD SCHOENBERG } \\
\text { PIERROT LUNAIRE - } 08 \text { - NACHT }\end{array}$} \\
\hline Baixo-Clarinete & Violoncelo & Recitante & Piano & \\
\hline $\mathrm{pp}$ & $\mathrm{pp}$ & $p$ & $\mathrm{pp}$ & \\
\hline$p$ & $\mathrm{pp}$ & ppp & $\mathrm{pp}$ & \\
\hline $\mathrm{pp}$ & $\mathrm{pp}$ & $\mathrm{pp}$ & $\mathrm{pp}$ & \\
\hline$f$ & $p$ & ppp & $\mathrm{ff}$ & \\
\hline $\mathrm{ff}$ & $\mathrm{ff}$ & $f$ & $\mathrm{fff}$ & \\
\hline $\mathrm{pp}$ & $\mathrm{pp}$ & $p$ & $\mathrm{pp}$ & \\
\hline$p$ & $\mathrm{f}$ & $p$ & $\mathrm{pp}$ & \\
\hline $\mathrm{p}$ & $p$ & $\mathrm{mf}$ & $p$ & \\
\hline $\mathrm{pp}$ & $\mathrm{mf}$ & & $\mathrm{pp}$ & \\
\hline sf & $\mathrm{pp}$ & & $\mathrm{pp}$ & \\
\hline & sf & & & \\
\hline 0 & 0 & 2 & 0 & ppp \\
\hline 4 & 5 & 1 & 7 & $\mathrm{pp}$ \\
\hline 3 & 2 & 3 & 1 & $p$ \\
\hline 0 & 1 & 1 & 0 & $\mathrm{mf}$ \\
\hline 1 & 1 & 1 & & $f$ \\
\hline 1 & 1 & 0 & 1 & $\mathrm{ff}$ \\
\hline 0 & 0 & 0 & 1 & $\mathrm{fff}$ \\
\hline 1 & 1 & 0 & 0 & sf \\
\hline
\end{tabular}

Tabela 9 - Dinâmica - Nacht - Pierrot Lunaire - Schoenberg

\subsection{3 - A Gênese de Pierrot Lunaire}

Em um respeitável artigo intitulado Schoenberg: Pierrot Lunaire. Cambridge: University Press, 1992, Jonathan Dunsby argumenta que a obra Pierrot Lunaire, composição de Arnold Schoenberg tem sido, praticamente, toda documentada ao longo de sua existência histórica. A primeira compilação do conhecido acervo de Schoenberg foi efetivada em The Works of Arnold Schoenberg de 1962, publicado originalmente na Alemanha em 1959.

Pode-se considerar o manuscrito de Josef Rufer com referência ao Pierrot Lunaire na Biblioteca do Congresso, por vários outros itens que apontam fatos a respeito da composição da obra, que posteriormente foi suplantado pelos 
estudos de Jan Maegaard ${ }^{151}$ em uma obra acadêmica detalhada baseada no exame de todos os materiais que seriam armazenados a partir de 1976, no Arquivo do Instituto Arnold Schoenberg, em Los Angeles, a cidade para onde Schoenberg se mudou em 1934. Mais recentemente, o editor de Pierrot Lunaire para a Collected Edition da música de Schoenberg, Reinhold Brinkmann publicou, 'What the sources tell us: a chapter of Pierrot philology ${ }^{152}$ um confiável artigo sobre a gênese da obra. Uma pesquisa musicológica detalhada pode, por vezes, mudar opiniões, e com Schoenberg não é diferente: por exemplo, alguns dos primeiros relatos, nos anos 1930, de sua técnica dodecafônica estavam bastante duvidosos. Entretanto, o que os livros amplamente consultados dizem sobre a gênese e estrutura de Pierrot Lunaire é em grande parte bastante respeitável - 0 leitor pode muito bem encontrar, por exemplo, um artigo consistente de William Austin, ${ }^{153}$ um dos poucos estudos de história geral da música desse período a discutir Pierrot Lunaire com um relativo detalhamento. ${ }^{154}$

O ciclo de cinquenta poemas de Albert Giraud de 1884, intitulado Pierrot Lunaire, foi traduzido para o alemão, e consideravelmente adaptado, por Otto Erich Hartleben ${ }^{155}$ da edição em 1911. Desse trabalho, Arnold Schoenberg estudou e selecionou vinte e um poemas, tendo sido contratado por Albertine Zehme para compor um ciclo de melodramas. A Sra. Zehme que era ex-atriz, havia por algum tempo estudado e mergulhado no personagem Pierrot da commedia dell'arte. Havendo descoberto o ciclo de poemas de Giraud, Pierrot Lunaire, traduzido por Otto Erich Hartleben e composto como melodrama por Otto Vrieslander que na verdade o fez simplesmente em forma de canções. Não satisfeita a Sra. Zehme excursionou pela Alemanha declamando esses textos interessantes e, considerados, de certa forma, 'bizarros'. Mas obviamente a música não era forte o suficiente, e foi orientada a procurar por Schoenberg, que também era considerado 'bizarro'.

\footnotetext{
${ }^{151}$ MAEGAARD, Jan. Studies in the Development of Dodecaphonic Composition in Arnold Schoenberg, 1972

${ }^{152}$ O que nos dizem as fontes: um capítulo da filologia de Pierrot?

${ }_{153}^{153}$ Music in the Twentieth Century, 1966.

154 DUNSBY, Jonathan. Genesis by Schoenberg: Pierrot Lunaire. Cambridge: University Press, 1992. pp.2127.

${ }^{155}$ A tradução para o português dos 21 melodramas feita por Augusto de Campos pode ser encontrada no Anexo I - desta tese.
} 
Arnold Schoenberg ouviu suas instruções pela primeira vez em 25 de janeiro de 1912, assinou o contrato para uma composição que inicialmente seria para voz e piano em 9 de março e começou a escrever a peça em 12 de março, e essencialmente finalizou Pierrot Lunaire em meados de julho, e não em setembro, como costumava-se pensar. ${ }^{156} \mathrm{O}$ compositor esteve em Berlim desde o outono de 1911, lecionando estética e composição no Stern Conservatory, e se encontrava em um período tanto quanto deprimido e infértil. Até chegou a escrever em nota em 12 de março: "eu já havia pensado na possibilidade de que eu nunca mais iria compor." 157

Os materiais sobreviventes mostram que Schoenberg estava certo sobre vinte dos vinte e um poemas. O $\mathrm{n}^{\circ} 21$, O Alter Duft, o último melodrama a ser iniciado, em 30 de maio, pode ter sido uma decisão tardia, e planejou um ciclo em metades aproximadamente iguais. A decisão de propor 'três vezes sete poemas', números de significância mística, formou um ciclo de vinte e um, que é o mesmo número de opus de Pierrot Lunaire, como ele sabia que seria. Ele iniciou pelo que definitivamente é hoje o o 9, Gebet an Pierrot, solicitando que Zehme o deixasse usar uma clarineta, e por um período de aproximadamente quatro semanas já havia determinado os instrumentos e a formação.

Segue tabela ${ }^{158}$ de instrumentação:

\footnotetext{
${ }_{157}^{156}$ DUNSBY, Jonathan. Genesis by Schoenberg: Pierrot Lunaire. Cambridge: University Press, 1992. pp.21-27. ${ }^{157}$ DUNSBY, Jonathan. Idem.

${ }^{158}$ DUNSBY, Jonathan. Genesis by Schoenberg: Pierrot Lunaire. Cambridge: University Press, 1992. Tabela copiada da página 23 deste livro.
} 
GENESIS (Capítulo)

Página 23 - Tabela 1

\begin{tabular}{|c|c|c|c|c|c|c|c|c|c|}
\hline \multicolumn{2}{|c|}{ Título Abreviado } & \multicolumn{8}{|c|}{ Instrumentos } \\
\hline & & Pf. & Fl. & Pic. & $\mathrm{Cl}^{*}{ }^{*}$ & $\mathrm{BCl}$. & $V n$. & Va. & Vc. \\
\hline 1 & Mondestrunken & $x$ & $x$ & & & & $x$ & & $x$ \\
\hline 2 & Colombine & $x$ & $x$ & & $x$ & & $x$ & & \\
\hline 3 & Dandy & $x$ & & $x$ & $x$ & & & & \\
\hline 4 & Wäscherin & & $x$ & & $x$ & & $x$ & & \\
\hline 5 & Valse & $x$ & $x$ & & $x$ & $x$ & & & \\
\hline 6 & Madonna & $\dagger$ & $\dagger$ & & & $\dagger$ & $\dagger$ & & $\dagger$ \\
\hline 7 & Mond & & $x$ & & & & & & \\
\hline 8 & Nacht & $x$ & & & & $x$ & & & $x$ \\
\hline 9 & Gebet & $x$ & & & $x$ & & & & \\
\hline \multirow[t]{2}{*}{10} & Raub & & $x$ & & $x$ & & $x$ & & $x$ \\
\hline & [Transição] & $x$ & & & & & & & \\
\hline 11 & Messe & $\dagger$ & & $\dagger$ & & $\dagger$ & & $\dagger$ & $\dagger$ \\
\hline 12 & Galgenlied & & & $x$ & & & & $x$ & $x$ \\
\hline \multirow[t]{2}{*}{13} & Enthauptung & $x$ & & & & $x$ & & $x$ & $x$ \\
\hline & [Transição] & & $x$ & & & $x$ & & $x$ & $x$ \\
\hline 14 & Kreuze & $\dagger$ & + & & $\dagger$ & & $\dagger$ & & $\dagger$ \\
\hline \multirow[t]{2}{*}{15} & Heimweh & $x$ & & & $x$ & & $x$ & & \\
\hline & [Transição] & $\dagger$ & & $\dagger$ & $\dagger$ & & $\dagger$ & & $\dagger$ \\
\hline 16 & Gemeinheit & $\dagger$ & & $\dagger$ & $\dagger$ & & $\dagger$ & & $\dagger$ \\
\hline \multirow[t]{2}{*}{17} & Parodie & $x$ & & $x$ & $x$ & & & $x$ & \\
\hline & [Transição] & $x$ & & & & & & & \\
\hline 18 & Mondfleck & $\dagger$ & & $\dagger$ & $\dagger$ & & $\dagger$ & & $\dagger$ \\
\hline \multirow[t]{2}{*}{19} & Serenade & $x$ & & & & & & & $\dagger$ \\
\hline & [Transição] & $\dagger$ & $\dagger$ & & $\dagger$ & & $\dagger$ & & $\dagger$ \\
\hline 20 & Heimfahrt & $\dagger$ & $\dagger$ & & $\dagger$ & & $\dagger$ & & $\dagger$ \\
\hline 21 & Duft & + & $\dagger$ & $\dagger$ & + & $\dagger$ & $\dagger$ & $\dagger$ & + \\
\hline
\end{tabular}

$\mathrm{x}=$ instrumento é utilizado

$\dagger=$ instrumento é utilizado e todos os cinco instrumentistas estão tocando

* = clarineta é em A exceto em 'Der Mondfleck', que requer clarineta em Bb

Tabela 10 - J. Dunsby. Tabelab da p. 23 do livro Genesis by Schoenberg: Pierrot Lunaire.

Houve algumas informações equivocadas, frequentemente retomadas pela imprensa musical popular por décadas, sobre a disposição precisa de forças instrumentais em Pierrot Lunaire. Até mesmo Egon Wellesz, um associado próximo de Schoenberg que escreveu o primeiro livro sobre sua música, evoca desaprovação ao escrever que "cada poema está orquestrado de uma maneira", e 
algumas vezes o comentário apresenta alguns equívocos, por exemplo, "cada peça está escrita para voz e dois ou três instrumentos." ${ }^{159}$

Certamente, a mesma combinação não é utilizada duas vezes da mesma forma. A maneira como Arnold Schoenberg lista os instrumentos na partitura da Universal Edition deixa isso claro: o n 14, por exemplo, é listado para 'piano e depois flauta, clarineta em Lá, violino, violoncelo', mas o ํㅜ 15 é para 'clarineta em Lá, violino, piano e depois flauta e violoncelo', como em um dos livros de história da música do século XX, mais recentemente publicado, 'cada uma das vinte e uma peças do ciclo apresenta uma combinação diferente'.

Mesmo uma contagem mais crua do número de canções em que cada instrumento é utilizado confunde-se nos números 05 e 21 com seus vários dobramentos, e uma melhor contagem deve ser por instrumentista (pianista 17 de 21, flautista 16 , clarinetista 19 , violinista 15 , violoncelista 13$).{ }^{160}$ E mesmo essa estatística pouco interessante para 0 violoncelista, que aparece menos frequentemente e tem de esperar pelo tempo mais longo a indicação em Serenade, memoravelmente perto do fim da peça. Não há dúvidas que o compositor considerou essas questões cuidadosamente. O jornalista Dika Newlin registra que, para uma lição de composição de 1940, Schoenberg "nomeou todas as possíveis combinações de instrumentos, e pediu-me para listá-los e contálos." ${ }^{161}$ Ele considerava uma boa ideia listar as combinações dessa maneira e assim ter uma melhor concepção de sua variedade de recursos. Foi isso que ele fez para a instrumentação de Pierrot Lunaire.

Relativamente pouca informação sobre os eventos precedentes à estreia está disponível. Sabe-se que Arnold Schoenberg passou a limpo cada item como se houvesse finalizado para o pianista Edward Steuermann utilizar ao ensaiar Albertine Zehme. Em 02 de outubro de 1912, Schoenberg escreveu a Zemlinsky que ele havia reservado vinte e cinco ensaios gerais, e que a estreia em 16 de outubro seria muito boa, como realmente foi. ${ }^{162}$ Três apresentações

\footnotetext{
${ }^{159}$ ABRAHAM, Gerald. A Hundred Years Of Music.London: Duckworth, 1974. In DUNSBY, Jonathan. Op.Cit. 160 DUNSBY, Jonathan. Op.Cit.

161 NEWLIN, Dika. Schoenberg Remembered: Diaries and Dodecaphony, trans. R.Mann. London, Calder, 1977.

${ }^{162}$ DUNSBY, Jonathan. Op.Cit.
} 
públicas foram feitas no pequeno Choralion Hall, em casas cheias consistindo principalmente de músicos profissionais e críticos:

Telas pretas estavam sobre o palco, e entre elas Albertine Zehme na fantasia de Colombina. Nos bastidores, um punhado de músicos conduzidos por Schoenberg tocaram... na apresentação - para o espanto dos críticos - resultou em uma ovação a Schoenberg. A maior parte da audiência permaneceu na sala após a conclusão e forçaram uma repetição ${ }^{163}$

Schoenberg foi lendário durante sua vida por sua velocidade de composição estonteante, e ele repetidamente encorajou tal reputação:

Eu compus três quartos do segundo e quarto movimentos de meu Segundo Quarteto de Cordas em um dia e meio cada. Eu completei a meia hora de música de minha ópera Erwartung em catorze dias. Por várias vezes eu escrevi duas ou três peças de Pierrot Lunaire e o ciclo de canções Hängende Gärten [sic] em um dia. Eu poderia mencionar muitos outros exemplos como esses ${ }^{164}$

Embora haja sinceridade em seu depoimento, isso corrobora claramente com a campanha de Arnold Schoenberg para contrapor a lendária imagem do cerebralismo de seu trabalho, que foi frequentemente usado e comentado com duras críticas que ele teve de enfrentar durante sua vida. Sempre, em suas aulas, artigos e escritos mais formais, que ele podia com integridade usar a palavra inspiração, ele assim o fazia.

Não se deve permitir que isso amenize a imagem clara de árduo trabalho e pensamento relativamente prolixo, embora isso emirja da evidência sobrevivente - mesmo que se, Schoenberg fosse em um senso geral moldado e preparado para essa tarefa.

O № 9, o primeiro melodrama a ser iniciado, foi também finalizado ao mesmo dia. $O$ no 3 veio em seguida, iniciado em $1^{\circ}$ de abril, finalizado no dia seguinte. Houve então uma pausa, e no nำ, iniciado em 17 de abril, não estaria completo até 29 de abril, período durante o qual foram iniciados mais seis melodramas, dos quais quatro foram completados.

Die Kreuze - o $n^{0}$ 14, um dos melodramas chave em muitos aspectos, mas mínimo comparado a um dos itens citados por Arnold Schoenberg acima -

\footnotetext{
${ }_{164}^{163}$ STUCKENSCHMIDT, H. Arnold Schoenberg. London: Calder 1959. pp.60-1.

164 SCHOENBERG, Arnold. Style and Idea: Selected Writings of Arnold Scheonberg. Ed.L.Stein, trans. L. Black. London: Faber, 1975. p.55.
} 
tomaram bastante tempo, de 27 de abril até 9 de julho. Há também evidência de trabalhos detalhados abandonados. Um rascunho mostra a tentativa de combinar doze fragmentos. Nele permaneceu, de fato, uma grande quantidade de negócios inacabados no arquivo composicional de Schoenberg, das menores ideias aos mais amplos projetos, inclusive Moses und Aron, que foi trabalhado durante suas duas décadas, do qual o Ato III estava apenas iniciado quando ele morreu em 1951.

Ao invés de concentrarmo-nos na velocidade com que Schoenberg trabalhou na gênese de Pierrot Lunaire, é melhor que percebamos a confiança renovada e a determinação que o conduziu pela primavera e verão férteis de 1912. O que impressiona é a certeza com a qual possibilidades tornaram-se certas. O historiador, seguindo os passos de Arnold Schoenberg, pode tentar imaginar, munido com o conhecimento das conquistas anteriores do compositor, como ele chegara a esse ou aquele material potencial; mas sua habilidade de desenhar a linha, de decidir 'isto está finalizado', está além de uma explicação plausível. Os registros históricos da gênese de Pierrot Lunaire, por conta da aparente experimentação composicional, e seu potencial para catástrofe criativa, são exemplares do que ele chamava 'visão'. Uma vez que temos a partitura de Pierrot Lunaire, pode-se verificar que isso não poderia ter sido de outra forma. Arnold Schoenberg vislumbrou o trabalho magicamente. ${ }^{165}$

\subsection{4 - A Canção Discursiva de Schoenberg}

Se Pierrot Lunaire nunca obteve o sucesso que um trabalho de genialidade como este merece, sobretudo, a razão tem sido a confusão que resultou da mistura vocal conhecida como a canção discursiva. ${ }^{166}$ Não é como, certa vez, Erwin Stein afirmou uma invenção de Arnold Schoenberg - Rudolph Stephan lembrou-nos que as notas faladas com durações e alturas determinadas foram anteriormente utilizadas no melodrama de Engelbert Humperdinck,1854-

\footnotetext{
165 DUNSBY, Jonathan. Op.Cit.

166 STADLEN, Peter. Schoenberg's Speech-Song - Music \& Letters, Vol. 62, No. 1 pp. 1-11 Oxford University Press, 1981. URL: http://www.jstor.org/stable/734794.
} 
1921, Die Königskinder,1897. Sua crença que Arnold Schoenberg é propenso a ter comparecido a uma das apresentações em Viena em 1897, é endossada pelo fato de que a canção composta em 1899 recebe uma orientação na partitura marcada "menos cantada do que declamada, a ser executada de maneira descritiva". Isso não tem como objetivo, em contrapartida em traçar o uso de canção discursiva por Schoenberg e suas conexões com Überbrettl de Wolzogen. Esse cabaret de Berlim não apresenta o gênero de discurso, e Schoenberg não começou seu engajamento lá antes de dezembro de 1901, isso deve ter sito depois de ele ter composto seu Brettl Lieder: Eles não devem ser cantados, e ele recebeu os textos por volta do Natal de 1900. Ainda naquela época, ele já havia concebido a essência do melodrama em Gurrelieder.

A melodia de Pierrot Lunaire, Schoenberg diz em seu prefácio, não foi idealizada para ser cantada, mas deve ser transformada, "com o devido respeito às alturas indicadas", em uma melodia-discurso. ${ }^{167}$

O artista deve estar a par da diferença entre sons cantados e falados: 0 som cantado mantém uma altura constante; o som falado começa de ${ }_{168}$ uma dada altura, mas instantaneamente a deixa por ascensão ou queda

"Aquilo que na voz-falada Sprechstimme for apresentado como melodia através das notas (salvo alguma exceção especialmente assinalada) não se destina a ser cantado. O executante deve levar em conta a altura do $\underset{169}{\text { som indicada para transformá-la em uma melodia-falada (Sprechmelodie) }}$

A esta formulação de um indubitável fato fonético é que se deve a causa de gerações de recitantes falharem em realizar uma amálgama de impressões de discurso versus altura determinada - precisamente porque elas tentaram seguir as instruções de Arnold Schoenberg. Em verdade, as alturas nunca permanecem estacionárias no decorrer do discurso, cada sílaba deve começar com uma frequência definida; mas é inadequado concluir disso que a

\footnotetext{
${ }^{167}$ Speech-melody - Sprechmelodie

${ }^{168}$ LEIBOWTZ, René. Schoenberg. Prefácio de Pierrot Lunaire - Arnold Schoenberg -São Paulo: Perspectiva Editora, 1989.

${ }^{169}$ CAMPOS, Augusto de. Música de Invenção. Prefácio de Schoenberg ao Pierrot Lunaire. p.47
} 
frequência inicial de uma sílaba ocupe uma posição privilegiada. Nem no começo de uma sílaba nem em qualquer outro momento de sua duração a altura pode ser percebida tão inequívocamente quanto no caso da nota cantada. O ouvido deve se contentar em estabelecer uma espécie de 'altura média', e terá mais sucesso nisso com notas curtas, staccato, por exemplo. Uma inspeção mais detalhada pode revelar que isso compreende um décimo - inesperadamente, porque um intervalo produzido dessa maneira tende a ser velado pela produção musicalmente não demonstrativa da fala.

Em Pierrot Lunaire as recitantes sempre acharam mais fáceis reproduzir as alturas sem cantá-las, em se tratando de notas curtas e longos saltos, como por exemplo, 'Erinn'rung mordend!' em 'Nacht', precisamente porque em tais casos não há tempo para as mudanças bruscas que Schoenberg, em suas instruções, demanda para cada nota.

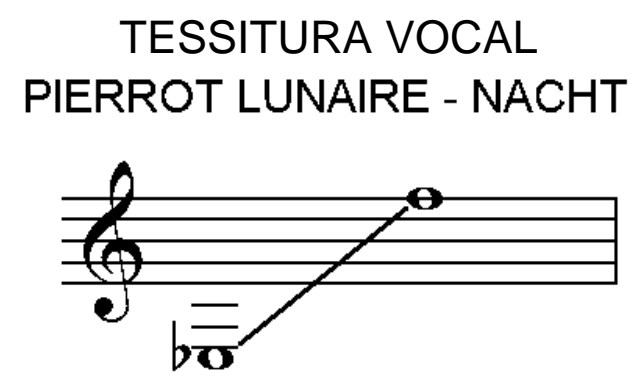

Figura 58 - Tessitura Vocal do(a) recitante - Nacht - Schoenberg.

A seguir uma célebre página do melodrama VIII, Nacht, de Pierrot Lunaire, ilustrando o último parágrafo acima, compasso 13. 


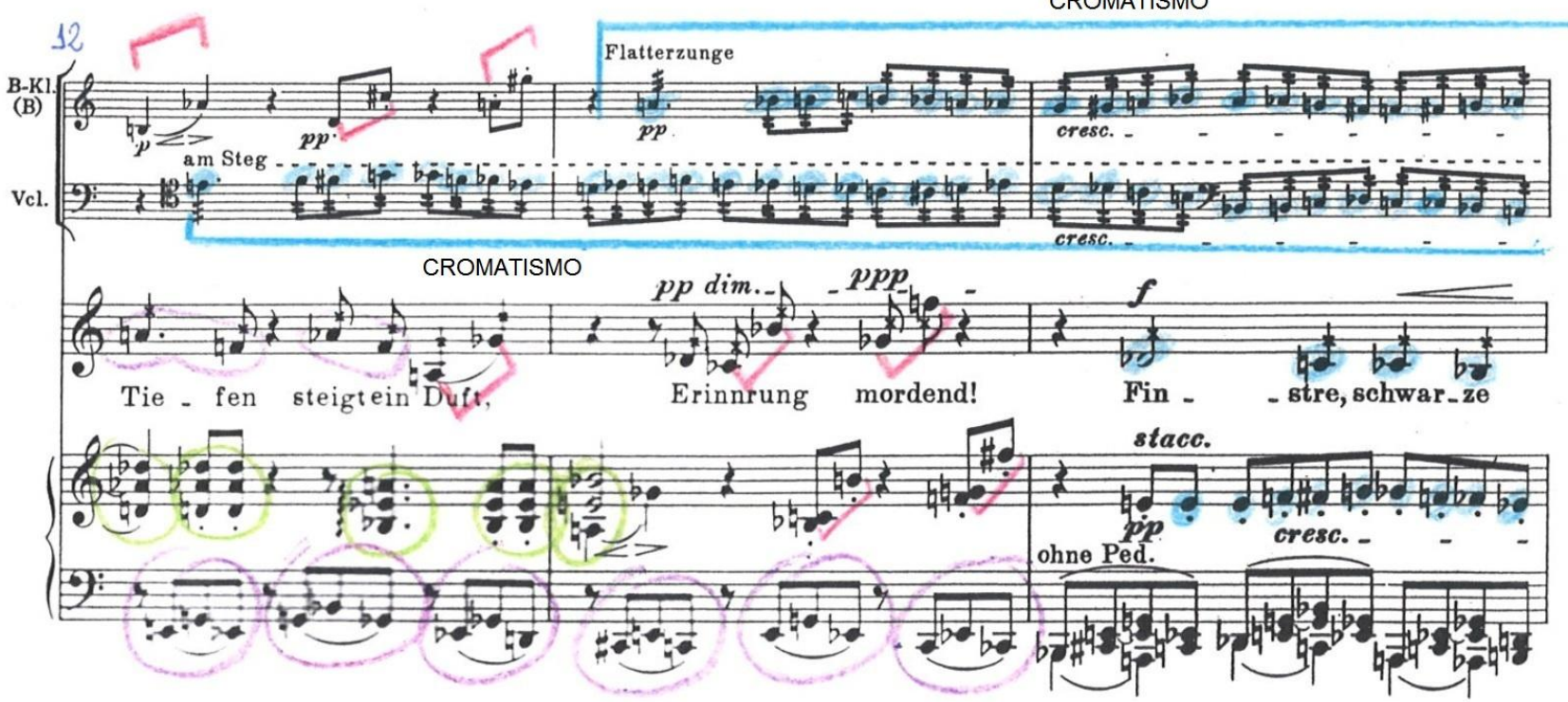

15

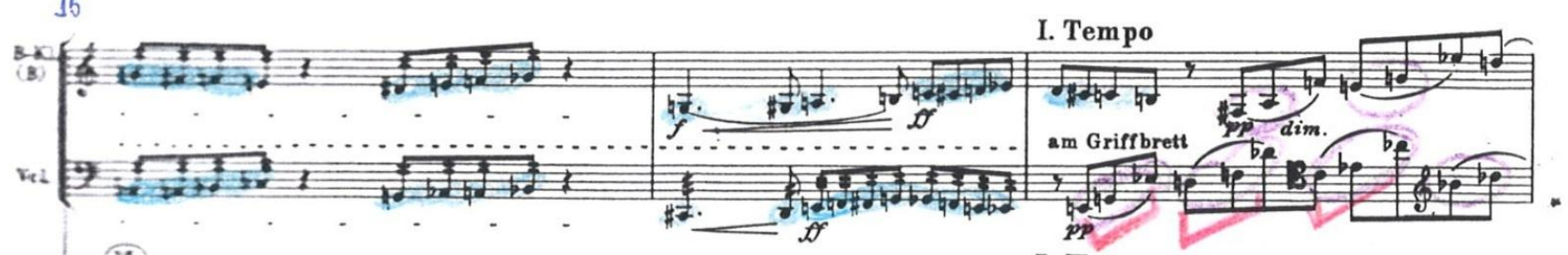

Sit I. Tempo Rie - senfal_ter tö - - te_tender Sonne Glanz.

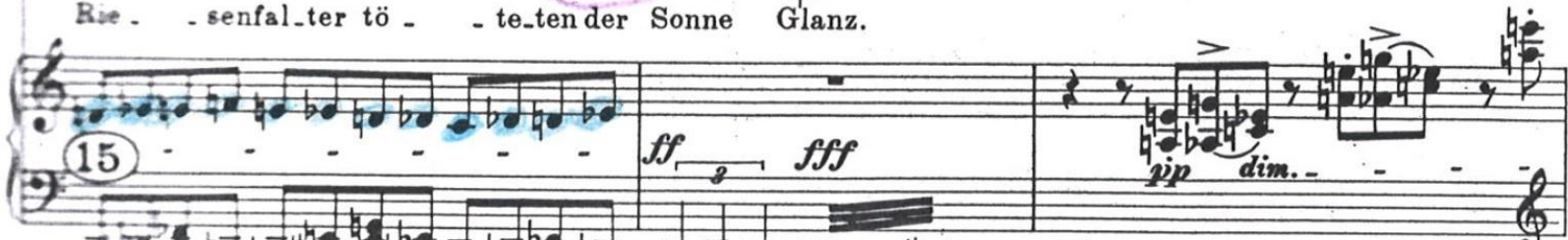

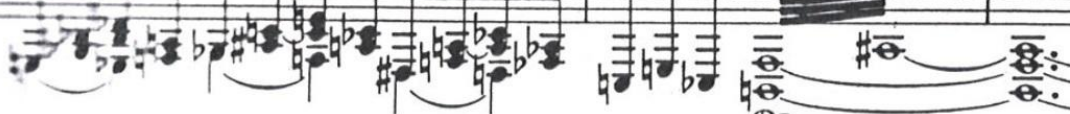

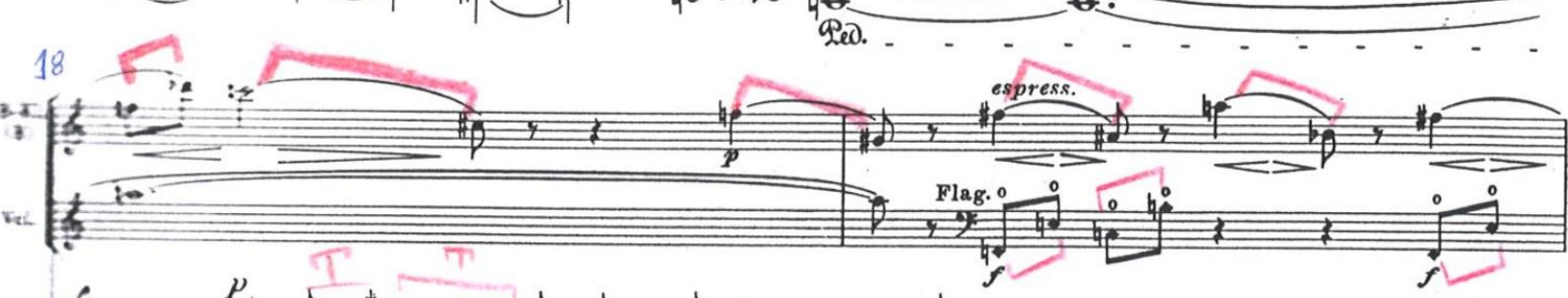

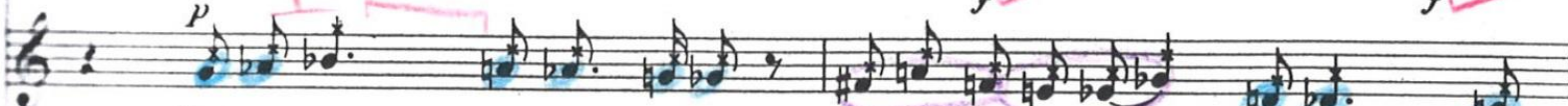
5 Und vom Him _ _ mel er - denwärts sen_ken sichmit schwe - renSchwin - gen

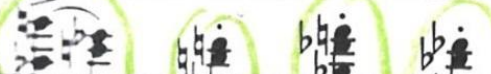

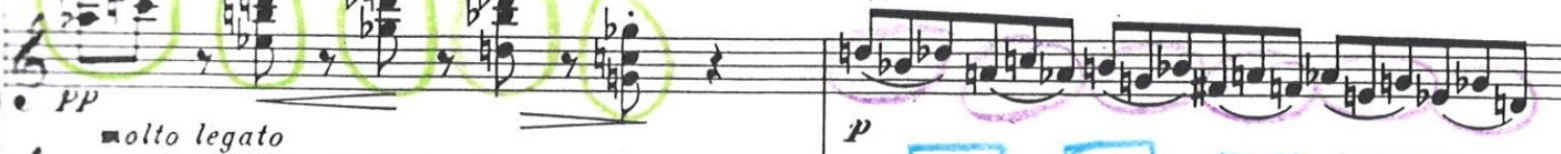

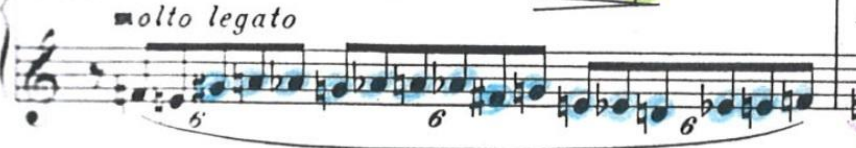

*

CROMATISMO
SEQUÊNCIA DO MOTIVO A INTERSECCIONADO POR SUA INVERSÃO REPARE QUE DO GRUPO DE SEXTINAS, AS COLCHEIAS Nacht $\quad 85$
IMPARES DESCEM CROMATICAMENTE, ASSIM COMOAS N PARES, POREM A PARTIR DE ALTURAS DIFERENTES.

AS DISTÂNCIAS ENTRE M.E. \& M.D. SE ALTERNAM ENTRE $7^{\mathrm{a}} \mathrm{s} \mathrm{m}$

e $3^{\mathrm{a}} \mathrm{s} \mathrm{m}\left(2^{\mathrm{a}} \mathrm{s}\right.$ aum. $)$ 
Há grupos étnicos nos quais os sons-de-discurso são algumas vezes mais longos que em muitas das notas cantadas, mas nas linguagens europeias 0 contrário é claramente verdade. Em Pierrot Lunaire é acima de tudo as notas mais longas que causam as dificuldades. Não apenas a anotação imprecisa de Schoenberg tende a fazer com que as recitantes executem as notas inequivocamente por simplesmente caírem em tentação de cantá-las, correta ou incorretamente; a fim de minimizar essa impressão inicial e restaurar o caráter da fala, há o glissando.

Arnold Schoenberg não escreveu um relato detalhado que trouxesse clareza na execução da peça. Quando se há tantas nuances entre os sons da fala e do canto, inevitavelmente, incorre-se a equívocos. As curvas 'melódicas' do discurso natural não podem ser desaceleradas sem que se chegue a um tipo de uivo que é díspare ao discurso e frequentemente adicionará uma nuance desentendida e mal conduzida à poética da obra. Esses glissandi não autênticos, sobretudo, em distinção dos poucos expressamente notados na partitura, tem uma tendência de pousar logo abaixo da próxima nota, uma falha que conduz ainda para outra, igualmente condenável, é o glissando na direção oposta. Mais estranho, entretanto, é a alteração das impressões de afinação como resultado dessas subidas e descidas - sempre providas, é claro, pela ideia de que as alturas notadas tenham realmente sido intencionadas.

Tais dúvidas parecem absurdas, dado o papel altamente significante que é designado ao declamar em Pierrot Lunaire e aos coros cantados em Die Glückliche Hand. Em Pierrot Lunaire a voz falada assume tarefas temáticas vitais, por exemplo, em Parodie, onde forma cânones em uníssono ou em oitava com vários instrumentos, ou, novamente, em Oh Alter Duft, onde dobra uma linha instrumental, como já havia ocorrido em Gurrelieder.

Há, mais adiante, casos de frases contidas em si mesmas quando algumas notas são cantadas e outras faladas: em Pierrot, compasso 10 de Mondestrunken, compasso 35 de Colombine, compassos 16-18 de Dandy, compasso 13 de Gebet an Pierrot; em Die glückliche Hand compasso 8 na parte do primeiro tenor. Finalmente, o começo da seção polifônica mais adiante consiste em cantar, falar sonoramente e sussurrar. Pode-se bem imaginar como Schoenberg idealizou a 
realização das notas nos trechos sussurrados; mas o que ele intentava para essas pode, também, ser deduzido do fato que uma das passagens sussurradas, compasso 30 de Dandy, está notada sem altura definida. Instruções verbais quanto à altura ocorrem em ambos trabalhos, entretanto. Em Pierrot pode-se encontrar no compasso 10 de Madonna a instrução 'muito agudo', nas vozes masculinas de Die glückliche Hand no compasso 09, este sussurrado com alguma afinação, no agudo e 0 compasso 216 , falado, 'mais agudo que as vozes femininas ${ }^{170}$

Schoenberg, talvez, não se preocupou em dar uma precisão nessas indicações por não ter feito alguma espécie de bula. Isso levanta a questão se essas indicações foram feitas durante a composição ou em estágio mais avançado. O 'muito agudo' em Madonna, melodrama $n^{\circ}$ 6, é encontrado em ambos os manuscritos de Pierrot Lunaire, mas isso não prova que as datas das anotações sejam do tempo em que a peça foi escrita, em 09 de maio de 1912. Pois embora o manuscrito que eventualmente serviu como matriz de impressão pareça ter sido aquele usado largamente durante a composição, as páginas de Madona pertencem àqueles que Rufer declarou não terem estado nas mãos de Schoenberg. Observando o carimbo de Berlim-Zehlendorf de Schoenberg ao fim da peça, conclui-se que ela pode ter sido escrita em qualquer período anterior ao fim de maio de 1913. O outro manuscrito certamente data de um período após a finalização da obra, uma vez que as peças estão escritas em dois grupos de onze e dez respectivamente, cada grupo em papel pautado do mesmo tamanho, mas não na sequência em que foram compostos. ${ }^{171}$ Segundo Peter Stadlen, admitidamente, a sequência aqui também não é a sequência final, o que parece implicar que o manuscrito foi escrito pouco antes das primeiras apresentações, no outono de 1912 - a menos, para que se tenha certeza, que a sequência nessas ocasiões não fosse a definitiva.

As instruções verbais em Die Glückliche Hand são encontradas não apenas na cópia final, finalizada em 20 de novembro de 1913, mas também em um rascunho manuscrito. Embora essa partitura não estivesse completa até 18 de novembro daquele ano, sua primeira página (que contém o compasso 09) traz a nota: 'iniciado em sexta-feira, 9 de setembro de 1910'. Na margem, Arnold

\footnotetext{
${ }^{170}$ STADLEN, Peter. Schoenberg's Speech-Song-Music \& Letters, Vol. 62, No. 1 pp. 1-11 Oxford University Press, 1981. URL: http://www.jstor.org/stable/734794 . (tradução nossa).

${ }^{171}$ STADLEN, Peter.Op.Cit.
} 
Schoenberg escreveu, claramente ao mesmo tempo em que (quase) tudo na página: "as notas com hastes cruzadas" devem ser faladas exatamente aos momentos prescritos e sustentadas conforme indicado; a afinação deve ser realizada aproximadamente através da fala'. Apesar do aspecto rascunhado dessas anotações, outras indicações sugerem que essa página do manuscrito interrompida, como se sabe, por um longo período - pode ter sido escrita substancialmente antes da cópia definitiva, talvez realmente em 1910. Todos os instrumentos estão escritos na altura exata, enquanto a cópia definitiva e a partitura publicada empregam a escrita das transposições convencionais, ${ }^{172} \mathrm{e}$ pode-se encontrar aqui o método, mais tarde abandonado, de distinguir passagens cantadas de faladas, não apenas cruzando-se as hastes, mas também - como é especialmente indicado em uma nota de margem - por sublinhados de diferentes espessuras.

Pode-se descartar a possibilidade que tão cedo quanto a época de concepção de Pierrot Lunaire, ou mesmo talvez de Die Glückliche Hand, Arnold Schoenberg fosse capaz de não ser fiel em matéria das afinações de canção discursiva. Tal suposição é corroborada mais adiante pela indicação encontrada como uma nota de rodapé de Gebet an Pierrot, a primeira peça a ser composta em 12 de março de 1912, e originalmente intentada para abrir o ciclo: "A recitação deve apenas sugerir a afinação". O contraste gritante entre essa atitude indiferente quanto à realização das alturas e, em contrapartida, suas, minuciosamente, diferenciadas elaboração e integração na composição sugerem um conflito, desde o princípio, na mente de Schoenberg entre um desejo pelo caráter do discurso e outro, aparentemente incompatível desejo por uma execução exata das notas. Não é de se espantar se a confusão causada por tal conflito continua a fazer-se sentir constantemente.

A recitante não deve apenas transpor a parte dela a despeito do acompanhamento, apenas para se encaixar ao registro de sua voz; ela deve também reduzir os intervalos individualmente de acordo com a maneira de sua voz; o que importa são meramente as proporções da linha melódica, por assim

\footnotetext{
172 a cerca da escrita dos instrumentos transpositores encontrada em duas versões,sendo inicialmente com a altura exata, e uma outra posteriori como a escrita adotada para insrumentos transpositores.
} 
dizer, contanto que uma quinta represente um salto mais longo que uma quarta, e assim por diante.

\title{
Sprechgesang, Sprechstimme, Sprechmelodie
}

\author{
Sprechgesang, Sprechstimme, segundo Stanley Sadie, é a expressão \\ germânica para o canto falado ou declamado:
}

\begin{abstract}
Termos para um tipo de enunciação vocal entre o canto e fala. Foram usados pela primeira vez por Humperdinck, 1897, porém explorados particularmente por Schoenberg, o qual escreveu (prefácio a Pierrot Lunaire) que a voz devia "dar a altura com precisão, mas imediatamente depois deixá-la descer ou subir; o intérprete deve fazer de tal forma que o Spresch-gesang não pareça nem com a fala natural nem com o canto autêntico". A notação pode ser feita de várias maneiras, sendo a mais frequente uma cruz atravessando a haste da nota ou formando seu corpo - ou, como no caso do "Spreschgesang - semicantado", das óperas de Berg, com um traço cruzando a haste da nota ${ }^{173}$
\end{abstract}

\section{Um estudo mais aprofundado certamente apontará o quanto estes}

procedimentos enriqueceram e trouxeram mudanças para a música escrita, experiências que intentaram compositor e intérpretes a encontrar uma medida mais exata na intermediação das duas formas de expressão canto e fala.

E aqui tocamos no ponto nevrálgico do Pierrot. O Sprechgesang ou canto-falado. Muito se tem discutido sobre os exatos contornos dessa modalidade de expressão vocal, que fica numa zona intermediária entre o canto e fala. $\mathrm{Na}$ introdução que escreveu para a partitura, Schoenberg frisa que a melodia correspondente à voz não deve ser cantada. A intérprete deve manter estritamente o ritmo, como se cantasse, mas não deve evocar uma canção ${ }^{174}$

(...) Em nenhum momento o compositor parece ter correlacionado o seu Sprechgesang - inovador, nos quadros da música ocidental - com práticas orientais semelhantes, como as que ocorrem, por exemplo, nas peças Nô japonesas, onde, no dizer de Pound, as palavras do texto são faladas ou semicantadas ou entoadas, com um acompanhamento adequado e tradicional de movimento e cor, parecendo, elas próprias, apenas meias-sombras. A ligação não escapou a André Schaeffner, que escreveu: Quanto à Sprechmelodie, seu princípio se encontra já na declamação cantada do teatro do Extremo Oriente ${ }^{175}$

(...) Para Pierre Boulez (Note sur Le Sprechgesang), os textos de Schoenberg sobre o assunto não são muito claros. Entre outras

173 SADIE, Stanley.Op.cit.p.895.

${ }_{174}$ CAMPOS, Augusto de. Música de Invenção, p.41.

${ }^{175}$ CAMPOS, Augusto de. Música de Invenção.p.41. 
observações, Boulez assinala que "a voz puramente falada é uma espécie de percussão de ressonância muito curta: daí a impossibilidade total do som falado propriamente dito sobre uma obra duração longa". Relembra o compositor francês que Schoenberg não admitia que a obra fosse cantada ("Pierrot não é para ser cantada! [...] A obra seria completamente destruída se fosse cantada e todos teriam razão de dizer: não é assim que se escreve para canto!" - carta a Jemnitz). Acentuando que a obra foi dedicada não a uma cantora, mas a uma declamadora, Albertine Zehme, e que a intérprete de que Schoenberg mais gostava parece ter sido Erika Wagner-Stiedry (que gravoua obra nos EUA, sobregência do compositor em 1941) ${ }^{176}$

Em seu livro Música de Invenção, onde pode ser encontrada a tradução dos 21 melodramas de Pierrot Lunaire, Augusto de Campos conta as razões que o levaram a empreender a versão para a língua portuguesa. Dentre elas a de ofertar maior desenvoltura a uma intérprete brasileira e liberá-la, para uma maior familiaridade com as palavras. ${ }^{177}$ Também a convicção de que o entendimento imediato e particularizado do que se ouve é imprescindível para que a obra se comunique.

Há uma permanente tensão entre o texto e a música, um relacionamento isomórfico, isto é, uma procura de identificação entre ambos, que foge à percepção quando se desconhecem os valores semânticos e as suas ressonâncias motivacionais na materialidade do texto. A palavra Mond (lua), por exemplo, é elaborada de diversas formas, e cercada de recursos icônicos que vão até a fisiognomia imitativa, como na linha $D u$ nächtig todeskranker Mond (literalmente, "Tu, lua noturna, enferma de morte"), do poema $n^{\circ}$ 9, Der Kranke Mond (A Lua Doente), na qual as duas últimas palavras devem ser cantofaladas com "tremolo", '178

\section{George Perle em comentário sobre Pierrot Lunaire, discorre sobre a iconicidade musical, como os cânones no poema no 17, Parodie, a que corresponde aos arremedos da lua, no texto; ou a passagem da descrição da}

\footnotetext{
${ }_{177}^{176}$ CAMPOS, Augusto de. Música de Invenção.p.41.

177 Poucas terão sido as apresentações do Pierrot Lunaire em nosso meio. Segundo me informou o crítico J.J.de Moraes, houve uma, integral, em São Paulo, em 12 de agosto de 1966, sob o patrocínio do Instituto Goethe, tendo como recitante Anneliese Kupper. Em julho de 1976, assisti a uma execução ao vivo de Pierrot, no MASP, pelo conjunto alemão Das Neue Werk. Nesse mesmo ano, a peça veio a ser interpretada em Belo Horizonte e em São Paulo, pela primeira vez por um conjunto local, sob regência de Ronaldo Bologna, tendo Edmar Ferreti como solista vocal e, como instrumenttistas, Amilcar Zanni Netto (pianista), Jean Noel Saghaard (flauta e flautim), Leonardo Righi (clarineta), Nicola Gregório (clarinete baixo), Maria Vischnia (violino), Perez Dwoewcki (viola) e Zygmunt Kubala (violoncelo). O espetáculo foi reprisado no Teatro Municipal [São Paulo], em 29 de março de 1977. (CAMPOS, Augusto de. Música de Invenção, p.39.).

${ }_{178}$ CAMPOS, Augusto de. Música de Invenção. p.42.
} 
performance de Pierrot e sua viola, acompanhada pelo violoncelo, no o 19 , Serenade. ${ }^{179}$

São vários os problemas da tradução. A própria qualidade do texto utilizado por Schoenberg da versão alemã é uma adaptação livre de Otto Erich Hartleben, da série de poemas do belga Albert Giraud, em forma de rondó, de treze versos, com repetição do primeiro no $7^{\circ}$ e no $13^{\circ}$. O texto alemão já não é rimado como o francês, o ritmo octossilábico no original, passa a ser mais variado, estreitando-se a quatro sílabas no poema ํo 12 .

Em 1884, foi publicado o ciclo de poemas de Giraud, alguns anos depois da popularização de Fêtes Galant, de Paul Verlaine, 1869, o tema de Pierrot e outras personagens da Commedia dell'Arte, à esfumaçada luz da lua simbolista.

De certa forma, em sua versão, Hartleben além de amenizar o tom irônico do texto em francês, traz uma riqueza poética inferior, segundo Augusto de Campos. No entanto, do ponto vista da prosódia soe com maior fluência e eficácia. É isto que se deve ter como ponto de partida, para realizar a música de Schoenberg que se modela e modula através de suas matrizes fônicas e ritmicas. ${ }^{180}$

\footnotetext{
${ }^{179}$ CAMPOS, Augusto de. Música de Invenção.p.41.

180 CAMPOS, Augusto de. Música de Invenção.p.43.
} 


\section{Parte III}


Parte III

$1 \quad$ A Complexidade das poéticas da Música \& Poesia 177

2 A Voz 191

2.1 O conceito separatista entre corpo e mente 194

2.2 A Musicalidade e o Corpo 203

2.3 Música e Voz 205

2.4 A Voz Cantada $\quad 212$

$3 \quad$ Uma Nova Vocalidade para a Música escrita no século XX 217

$4 \quad$ Questões Vocais e Interpretativas 223

5 Considerações finais - O Despertar para uma Nova Vocalidade 245 


\title{
1. Complexidade das poéticas da Música \& Poesia
}

\begin{abstract}
É quase um lugar-comum dizer que a Literatura é um vetor fundamental para a definição do Romantismo musical. A verdade é que a relação entre poesia e música é um fato quase natural documentado pelo menos desde a Grécia dos aedos até à poética contemporânea. No entanto, se os cantos chãos da Igreja antiga não se explicam mais do que por uma dependência fiel entre som e palavra, se o madrigal ultrapassa de longe a sua época histórica na intencionalidade da própria definição, fornecendo o conceito de madrigalismo a uma produção quase infinita da música ocidental, se o conúbio poesia-música é a essência de um género musical tão importante como a ópera, também é certo que o pendor e a afirmação do conceito romântico circunscrito a uma época da arte ocidental levou à renovação de uma aliança poético-musical, com consequências muito sérias para o futuro imediato da música no século XIX. É o que se depreende naturalmente da importância adquirida nesta época por géneros tão significativos como o Lied, o poema sinfónico e uma nova música dramática. São estes géneros, aliás, paradigmas da verdadeira música romântica, inseridos que são em alguma das antinomias que a definem: pequena peça instrumental (Charakterstück) e música monumental (grandes orquestras e grandes coros), o salão (intimismo) e o grande espaço (música espetacular para grandes igrejas ou praça pública), o amadorismo burguês e o virtuosismo interpretativo, a música de programa e a música absoluta, a originalidade e a tradição.Por volta de 1800 , a relação poesia-música converte-se em verdadeiro tema quente ${ }^{181}$
\end{abstract}

Dentro da concepção de estética do bel canto faz-se necessária a prática de exercitar o canto em vários idiomas, posto que na intenção de obter uma maior maleabilidade e uma ação mais ágil e coesa no trato vocal, por meio da experimentação de múltiplos fonemas combinados com uma infinidade de frequências e esquemas rítmicos os quais, consequentemente, o farão adquirirem emissão e articulação mais perfeitas dos vocábulos inseridos na música.

A relação texto/música tem sido um fascínio para o homem desde os primórdios.

Muitos gêneros musicais desenvolveram-se através do veículo verbal, tais como o lied, a canção, a cantata, o oratório, o melodrama, dentre outros que, se encontram tão intimamente ligados e quase que notadamente inseparáveis.

Para além, coloca-se a questão de se perceber qual a mensagem literária e musical estabelecidas por seus autores (poeta e compositor), para que a

\footnotetext{
${ }^{181}$ CARDOSO, José Maria Pedrosa. Goethe e o Romantismo musical: uma bordagem pedagógica - artigo Faculdade de Letras da Universidade de Coimbra.
} 
partir de então se opte por uma linha mestra de interpretação.

Uma vez que, o texto literário já foi escolhido pelo compositor, o seu sentido, então deverá ser decodificado pelo intérprete e, em condições ideais, também pelo ouvinte. Estes criteriosos entendimento e esclarecimento ideais que hão de se refazer por meio da performance no momento de cada execução e de cada intérprete.

A questão é a seguinte: o que será mais relevante, o texto ou a música?

Ao considerar-se a narração cuidada sobre a via crucis de Jesus Cristo nas Paixões de Johann Sebastian Bach, nota-se que os recitativos dão destaque aos textos sagrados do Novo Testamento. As árias e os ariosos, por muitas vezes, incidem apenas em um pequeno refrão do texto ou tema que é repetido. Ricos em melismas, que, em determinados pontos, remetem mais para o sentido musical do que propriamente para o significado das palavras utilizadas. O sentido musical vem reforçar e enriquecer as ideias literárias, de acordo com a alta percepção do compositor.

O quase diário de Goethe, Wilhelm Meisters Lehrjahre, aflora constantemente a música como ambiente vital, inserindo mesmo alguns poemas que deviam ser cantados. Depois de um pronunciamento artístico do romântico por parte de um Ludwig Tieck, Wackenroder e de um F. Schlegel, Novalis manifesta o maior entusiasmo pela expressão musical. Segundo ele a Música ocupa o nível superior no mundo das artes: nela o inefável tem expressão, sente-se: ela completa o sentido das palavras e da visão quando estas atingem os seus limites. Desenvolve-se toda uma devoção à música por parte dos escritores e poetas. É certo que esta entrega à Música, na maioria dos casos, é essencialmente diletante. Todavia, este pensamento impõe-se em profundidade na pessoa de um E.T.A. Hoffmann: ele é jurista, desenhador, poeta, compositor e mestre de capela. Em muitas das suas obras, desde Ritter Gluck (1809) até Nachträglichen Bemerkungen über Spontinis Oper "Olympia" (1821), ele introduz na Alemanha o conceito musical de romântico. É ele quem afirma, juntamente com Tieck, que Mozart foi o romântico por excelência. De fato, Christian Schubart, no seu livro póstumo Ideen zu einer Ästhetik der Tonkunst (1806), prova já que o Romantismo musical retrocede às últimas décadas de Setecentos, dando exemplos como as sonatas para piano de Johann Schobert (c. 1760) e as Sonaten und freie Phantasien (1783-87) de C. Ph. E. Bach. Pode-se afirmar que alguns dos poetas e escritores oitocentistas não se podem compreender sem uma confessada cumplicidade com a música: é o caso de Novalis, Tieck, Hoffmann e Goethe. Da mesma forma, não é possível conhecer a personalidade de alguns dos maiores compositores românticos sem reconhecer nos mesmos uma dependência quase 
congénita da Literatura: caso de um Berlioz, Schumann, Liszt e Wagner ${ }^{182}$

Como tudo que se move em constante evolução, assim também é a música que, apesar disto, persiste com esta antiga e complexa relação entre texto e música, entre palavra e melodia, entre o som da palavra e os sons musicais escolhidos para estas.

O que terá levado o sentido da audição a cair em tentação, a ponto de desvirtuar o conteúdo da palavra? Por que a submissão ao efeito sonoro?

Em que se modifica a percepção humana quando se ouve uma interpretação do Adagio $^{183}$ de Samuel Barber, 1910-1981, para cordas e o que se ouve posteriormente na versão escrita para coro, intitulada Agnus Dei, onde o texto haveria de condicionar a maneira singular de fruição da música, e a melodia, por sua vez, não haveria de enriquecer o conteúdo da mensagem literária?

Tendo em conta a versão original, para cordas e a versão posterior, para cordas e vozes, chega-se a várias versões de interpretação do Adagio de Samuel Barber, pois considerando que o aspecto melódico, em si, quer nas cordas quer na versão vocal, resulta manifestamente diferente, em termos de fluição fraseológica, não se podendo comparar a respiração das cordas, que tem uma articulação puramente instrumental com a respiração de um coro, a qual confere à linha melódica a sua própria articulação, podendo vir a desencadear um momento de rara beleza e expressividade. Ambas as versões têm seu valor intrínseco da beleza e riqueza inerentes às peculiaridades do instrumento voz e das cordas.

As vogais representam o som contínuo e as consoantes o ruído, as consoantes são oclusões dos órgãos do aparato vocal, que interceptam a continuidade da sonoridade que vai sendo alternada com o fluir dos sons vocálicos que são os sons mantidos pelos matizes de vogais e ruídos (sons consonantais).

O ruído não deve ser ignorado, pois é uma parte muito importante da linguagem e também para a sonoridade da música. A riqueza tímbrica se dá pela

\footnotetext{
182 CARDOSO, José Maria Pedrosa. Op.cit.

183 SADIE, Stanley. Op.cit. Adagio - originalmente o II Movimento do Quarteto de Cordas, 1936, sendo que o Adagio lírico elegíaco, tornou-se um clássico popular.p.73.
} 
alternância de vogais e consoantes, posto que o ruído intrínseco provocado pelo som consonantal não pode ser imitado por qualquer outro instrumento acústico, tamanha a sua peculiaridade.

A música e a linguagem coexistem unidas por grandes laços de afinidade entre si ao longo da história do homem. Esta forma de expressão diferencia-se dos sons e dos ruídos produzidos pelos animais no modo de comunicar. A partir do instante que o homem, desde o seu nascimento, coloca em funcionamento o mecanismo de seu aparelho fono-respiratório, surge daí uma ação sistêmica que vai tornando-o capaz de gerir e gerar inúmeras possibilidades de sons como consequência da utilização desse sistema. Uma vastidão de sequências sonoras pode resultar como frases ou melodias distintas, que desmonstram ser espontâneas no decorrer da infância de um ser que desde o primeiro momento utiliza o aparelho fonador como um verdadeiro laboratório onde experimenta vários sons. Ao serem expressos alguns sons vão se organizando como verdadeiras canções, muitos desses sons podem ser registrados tanto oralmente quanto por escrito, mediante sinais previamente convencionados permitindo que o desenvolvimento da manipulação desses venha potencializar a maturação que reflete na maneira de falar ou de cantar, em conformidade com a recepção das influências do meio envolvente em consonância com as culturas às quais estão inseridos. Esta dinâmica dos laços das formas de linguagem oral e de música vocal pode ser dividida em três componentes: fonologia, sintaxe e semântica.

Em investigações relativas à estrutura da música e da linguagem, feitas pelo musicólogo e teórico austríaco e Heinrich Schenker:

A teoria de Schenker para a música tonal pode ser descrita em termos de Urlinie (linha melódica fundamental), Ursatz (composição fundamental) e - o conceito mais genérico - Schichten (camadas estruturais: plano de fundo, plano médio e primeiro plano). A Urlinie abrange efetivamente, a voz superior de uma composição inteira, e coordena-se com o Bassbrechung (baixo arpejado) estrutural em ampla escala, subindo da tônica à dominante e retornando à tônica; a estrutura contrapontística resultante é o Ursatz. Assim a harmonia e contraponto se combinam ao nível estrutural mais profundo, onde o Ursatz representa o auskompornierung (processo de desenvolvimento compositivo) em grande escala da harmonia fundamental, a tríade tônica. O conceito de níveis estruturais proporciona uma diferenciação hierárquica dos componentes musicais, 
que estabelece uma base para a descrição e interpretação das relações entre os elementos de qualquer composição. Segundo o ponto de vista de Schenker, a obra total em todos os níveis, não apenas no nível plano de fundo, é objeto de estudo e da sensibilidade estética ${ }^{184}$

\section{E pelo linguista Noam Chomsky (1928)}

Chomsky teoriza que todas as línguas humanas atuais têm alguma coisa em comum, fundamentalmente idêntica que representa uma estrutura profunda, impressa no patrimônio hereditário do homem. Por esta teoria, a linguagem seria uma propriedade biológica do espírito humano, como se a capacidade de expressar ideais coletivos estivesse vinculada às atividades grupais ancestrais, como caçar, acampar e migrar ${ }^{185}$

Estudos recentes dividem em três categorias formais os estreitos laços de afinidade de música e linguagem:

Fonologia - que tem implicação na maneira que a infinidade de sons pode ser organizada e reduzida a categorias basilares de sons que fundamentam a comunicação;

Sintaxe - que diz respeito ao entendimento da construção fraseológica e se essa possibilidade está inserida ou não na linguagem de referência;

Semântica - permite a compreensão do significado da frase, e se essa possui sentido e que sentido é este;

Ao ouvir-se uma frase tomada como incompreensível, a razão disto pode ser porque essa frase ouvida não contenha um significado explícito que evidencie o seu sentido; contudo esta mesma frase poderá ter sido construída corretamente do ponto de vista sintático.

A escuta está condicionada a um cabedal de regras de construção gramatical.

Talvez se possa dizer que há também uma gramática musical, a qual poderá ser requisitada para fundamentar, pelo menos, o senso básico do que funciona em maior ou menor grau dentro da aceitação da prática comum que dá suporte à ideia de que a música é uma arte regrada, cujo significado é trabalhado ao longo da sua estrutura.

De maneira geral, o compositor planeja a sua criação musical com base

\footnotetext{
${ }^{184}$ SADIE, Stanley. Op.cit. p.831.

${ }^{185}$ COSTA, O. H. \& SILVA, M. A Voz Cantada. 1998.
} 
em determinadas regras pré-estabelecidas, que conferem à sua obra maior garantia de aceitação pelo público, em geral, apoiados em determinados conceitos e noções sobre o que soa bem ou não.

Acerca da natureza da sintaxe musical, torna-se, então, necessária uma reflexão da gramática em música. Considerando que a música é uma linguagem assimilada, em alguns casos, deve-se notar que uma peça musical pode ser construída corretamente do ponto de vista sintático, porém não fazer sentido ao senso da prática comum. E no que diz respeito as nossas intuições o que soa bem ou não, pode-se atribuir a três partes: sintaxe, semântica e estilo. ${ }^{186}$

A diferença da linguagem verbal em relação à musical é que nesta última não há advérbios ou adjetivos. Pode, até, ser que em determinados trechos, o discurso musical venha insinuar uma reticência ou até mesmo uma conclusão. Com esta arte temporal as frases podem ocorrer a qualquer momento, sem estarem confinadas ou submissas à localização textual; ou seja, o elemento melódico vai se impondo em decorrência de sua própria clareza e construção, sem mesmo esperar pelas palavras.

Pensemos em uma melodia de sintaxe simples, apoiada numa escala maior, sem acidentes, entre os limites da tônica e da dominante, usando apenas a harmonia I-V-I. Uma nota errada, fora da harmonia, remeternos-á para o campo do significado (da semântica); parecer-nos-á estranha e sem aparente razão de ser, tal como um tempo verbal errado ou um substantivo colocado no lugar do advérbio. Não há equivalente musical para o discurso verbal. Não há advérbios ou adjetivos. A linguagem é diferente e se é certo que, em determinadas partes, a melodia pode, por exemplo, evocar uma conclusão ou uma paragem, certo é também que estas frases ocorrem em qualquer momento, sem se confinarem à localização textual; isto é, a melodia vai acontecendo sem esperar pelo momento do texto em que poderia contribuir para a sua clarificação. Os compositores podem escrever com a mesma sintaxe mas com estilo diferente. A sintaxe tem regras, o estilo não. Com a sua abordagem única e particular, é próprio do compositor que se identifica pela audição da sua obra. É o caso de Haendel e Bach, cuja música, dotada de uma sintaxe perfeita e que coincide a um nível temporal, se distingue relativamente ao estilo. Apesar destas diferenças entre música e linguagem, a busca de uma sintaxe musical permanece válida, uma vez que as regras da gramática musical deverão ter o mesmo caráter generativo das regras da sintaxe linguística ${ }^{187}$

Ouvir e compreender música são um processo cognitivo, em que todos os dados se relacionam com a estrutura em si.

\footnotetext{
${ }_{186}^{180 M B O}$, Fátima. Traços de Música. Aveiro: Universidade de Aveiro, 2001.

187 POMBO, Fátima. Traços de Música. Aveiro: Universidade de Aveiro, 2001.
} 
Retemos em nossa memória alguns trechos musicais, ou mesmo peças inteiras, de acordo com sua extensão, que quando ouvidas no seu todo somos capazes de decodificar as partes e a sua estrutura através do armazenamento de informações capturadas pela nossa percepção e intuição. Ato fundamental que nos faz apreciar a perfeição de obras dos grandes compositores de maneira geral.

A essência deste fenômeno ao perceber a música remete-nos a uma comparação com a linguagem em busca de um discurso coerente que é o agrupamento das palavras em uma ou mais frases.

A afinidade entre os sons é que dá suporte ao nosso sentido de sintaxe musical. As nossas atividades cognitivas fazem com que agrupemos os sons, os tempos fortes e a harmonia, accentus e accenti, e que os ouvimos como um todo na coexistência desses elementos.

Não existe na música um objeto de arte tão palpável como nas outras artes. A essência da abstração musical necessitará que a sua apreciação realizarse-á seguindo outros parâmetros em uma rede de conexões.

A liberdade de fruição encontrada em todas as outras artes que se detém perante os efeitos dos elementos artísticos não é tão explícita na música. Inúmeras pessoas não conseguem captar o que se expressa através da música, em relação a aquilo que se pode considerar puramente essência musical.

Por vezes, são mais compreendidas músicas que se encontram ligadas ao texto, ou à palavra, sendo então o auxílio do veículo verbal, o que torna a sua percepção mais acessível. Acima de tudo a música de uma canção é uma composição que não abandona a sua riqueza ou peculiaridade enquanto música em si mesma e possui uma poética que lhe é própria, mesmo sem palavras. A exemplo da obra para piano solo de Felix Mendelssohn, Canções sem Palavras, ${ }^{188}$ que revela um encanto poético para este tipo de composição. No entanto, o texto contido em uma canção conduz, de fato, a uma responsabilização no sentido de aproximar a expressividade musical à afetividade e dramaticidade patentes em um poema.

\footnotetext{
188 Lieder ohne Worte - oito livros de peças para piano, (1829-1845); caracterizam-se por uma melodia cantante na mão direita. Também escreveu uma Canção sem palavra op.109 para violoncelo e piano (c.1845). SADIE, Stanley. Op.Cit. p.162.
} 
No caso da canção - o lied, o melodrama, a cantata, o oratório ou da música programática.

Hofmannsthal e Strauss não necessitam de promover grandes justificações sobre o que é uma obra de arte musical ou de como se conjugam a palavra e a música, porque cada obra que criam em conjunto é a circunstância específica dessas discussões. E em cada obra nova que o tema da ligação da palavra com o som é abordado, como se se tratasse da primeira vez. Ambos desejam que cada obra seja conseguida e, com esse objetivo, conseguem conciliar a presença da arte em que são mestres com a presença forte da alteridade. Unia-os, contudo, um mesmo universo estético, de que não precisam de falar, porque se thes tornou natural a partir de Der Rosenkavalier ${ }^{189}$

Quanto maior clareza obtiver uma narração, quanto mais se valer a obra da semelhança e repetição de determinados fragmentos musicais, quanto mais os acontecimentos estiverem baseados em seu próprio significado, tanto maior será a chance do ouvinte se familiarizar com os elementos determinantes para se aperceber da estratégia contextual. Por exemplo, quando o tema musical principal aparece revestido e transformado de muitas maneiras, o receptor notará contido nele uma estratégia relativamente indentificável como uma técnica da narração com cariz dramático, não somente por uma questão de variação de caráter.

Após memorizar e identificar a estrutura de uma melodia ou canção, o ouvinte está apto a realizar o estudo do enunciado musical.

Em sua definição tradicional, canção é a arte que reune música e poesia, entoação e discurso como meios de expressão e que se reveste de um inefável caráter de criação. É uma forma condensada dos recursos musicais e literários de expressão.

Buscando utilizar-se de onomatopeias de ruídos, de modo geral, os poetas futuristas ${ }^{190}$ se libertaram revelando a grande importância deste elemento para a linguagem que esteve quase sempre submetido ao valor das vogais. Com a inserção dos ruídos através da utilização das consoantes pelos poetas futuristas em suas free words, resgata-se uma gama enorme de elementos emotivos e

\footnotetext{
189 POMBO, Fátima. Traços de Música. Aveiro: Universidade de Aveiro, 2001.p. 44.

190 Vladimir Maiakovski (poeta e dramaturgo russo), Filippo T.Marinetti (escritor, editor e poeta italiano), Émile Verhaeren (poeta belga), Fernando Pessoa (poeta e escritor português), Joan Salvat-Papasseit (poeta espanhol).
} 
expressivos extraídos da riqueza subjacente a esta fonte de expressão patente em nossa linguagem, que até então havia sido evitada pelas correntes literárias anteriores durante séculos. "A zona limítrofe de poesia e música pode ser vista onde a leitura de um poema lírico está a ponto de transformar-se em canção."191

Quando um veículo verbal, no caso um poema, parece ser inseparável da música, como se um fosse cara-metade para o outro, é importante sempre lembrar que tanto o poema quanto a música são duas artes autônomas e singulares que quando bem aproveitadas, o seu todo resulta em uma interessante união.

Um poema é a arte literária que porta em si mesmo uma musicalidade própria constituída em sua estruturação.

Como toda obra de arte, o poema tem unidade, fruto de características que lhe são próprias. Ao analisar um poema, é possível isolar alguns de seus aspectos, num procedimento didático, artificial e provisório. Nunca se pode perder de vista a unidade do texto a ser recuperada no momento da interpretação, quando o poema terá sua unidade orgânica restabelecida. Nos textos comuns, não literários, o autor seleciona e combina as palavras geralmente pela sua significação. Na elaboração do texto literário, ocorre uma outra operação, tão importante quanto a primeira: a seleção e a combinação de palavras se fazem muitas vezes por parentesco sonoro. Por isso se diz que o discurso literário é um discurso específico, em que a seleção e a combinação das palavras se fazem não apenas pela significação, mas também por outros critérios, um dos quais, o sonoro. Como resultado, o texto literário adquire certo grau de tensão ou ambiguidade, produzindo mais um sentido. Daí a plurissignificação do texto literário ${ }^{192}$

A interpretação dificilmente será a palavra final se for feita por uma só pessoa. $O$ texto literário talvez seja aquele que mais se aproxima do sentido etimológico da palavra "texto": entrelaçamento, tecido. Como "tecido de palavras", o poema pode sugerir múltiplos sentidos, dependendo de como se perceba o entrelaçamento dos fios que 0 organizam. Ou seja: geralmente, ele permite mais de uma interpretação. Dada a plurissignificação inerente ao poema, a soma das várias interpretações seria o ideal ${ }^{193}$

Tomando o texto acima, substituindo o que se refere à palavra, e aplicarmos à música, podemos lembrar que a construção desta e suas estruturas resultam naquilo que chamamos de textura, seja através da polifonia, homofonia

\footnotetext{
191 PIVA, Luiz. Literatura e Música. p.29.

192 GOLDSTEIN, Norma. Versos, Sons, Ritmos. São Paulo: Editora Ática, 1990. p.5

193 GOLDSTEIN, Norma. Op.Cit. p.6.
} 
e/ou a mistura dessas.

A poesia tem um caráter de oralidade muito importante: ela é feita para ser falada, recitada. Mesmo que estejamos lendo um poema silenciosamente, perceberemos seu lado musical, sonoro, pois nossa audição capta a articulação (modo de pronunciar) das palavras do texto $^{194}$

O compositor serve-se da interpretação que concebe do poema para transformá-lo em música. A música como portadora infinita de expressividade apropria-se do poema com toda a sua carga de atributos fonéticos, dramático, sintático e semântico que lhe é inerente.

Uma canção tem alguns direitos, tais quais os de outros cidadãos comuns. Se ela quiser andar pelo lado esquerdo da rua, passar à porta da fisiologia ou sentar-se no meio-fio, por que não deixá-la? Se ela tiver vontade de chutar uma lixeira, o castelo de um poeta, ou a lei da prosódia, você a deterá? Será que ela deve ser sempre uma tríade comportada, um "breve gladium," um laço para combinar com a voz? ${ }^{195}$ (Charles Ives, Essays Before a Sonata, The Majority, and Other Writings, in Kramer).

Para Arnold Schoenberg a obra de arte torna-se tão autêntica e plena de unidade que não se pode dissociar-se em fragmentos. O ouvinte quando faz a sua apreciação não deve desconectá-la, reduzindo-a apenas em uma das suas partes sem apreciar o todo.

Para um cantor e intérprete conhecer o texto em sua íntegra é um ponto de honra, pois o significado das palavras mais o entendimento musical são imprescindíveis para valorizar sua expressividade e consciência artística.

Como compositor e poeta, Friedrich Nietzsche, 1844-1900, argumenta de modo radical ao se referir da disjunção existente entre ambos os elementos, o que de certa forma ele reduz o valor da palavra:

Quando um compositor escreve para um poema lírico... ele, enquanto músico, não está interessado nem nas imagens nem nos sentimentos que o texto possa evocar. Uma relação necessária entre poema e música

\footnotetext{
${ }^{194}$ GOLDSTEIN, Norma. Op.Cit. p.7.

195 KRAMER, Lawrence. Music and Poetry. The Nineteenth Century and After. London: University of California Press, Ltd, 1984. p. 128. (A) song has a few rights, the same as other ordinary citizens. If it feels like walking along the left-hand side of the street, passing the door of the physiology or sitting on the curb, why not let it? If it feels like kicking over an ash can, a poet's castle, or the prosodic law, will you stop it? Must it always be a polite triad, a "breve gaudium," a ribbon to match the voice? Charles Ives, Essays Before a Sonata, The Majority, and Other Writings has a few rights, the same as other ordinary citizens. If it feels like walking along the left-hand side of the street, passing the door of the physiology or sitting on the curb, why not let it?

If it feels like kicking over an ash can, a poet's castle, or the prosodic law, will you stop it? Must it always be a polite triad, a "breve gaudium," a ribbon to match the voice?
} 
não faz sentido; apenas se consegue uma relação externa. Relacionado com a música o poema é apenas um símbolo, tal como um hieroglifo de coragem o é para um corajoso soldado. ${ }^{196}$ (Friedrich Nietzsche: On Music and Words)

Pode-se dizer então que a canção, ao contrário do que se pensa não é um meio de promoção para a palavra? Ou uma forma muito particular de colocá-la em um plano secundário?

Robert Schumann corrobora com as mesmas ideias, colocando a desimportância do poema quando submetido à música na canção. Alguns de seus comentários indicam que considera os lieder como uma forma de peças líricas para piano, que dobra quase sempre a voz do cantor, com efeito de uma canção sem palavras, mas que contém palavras. Não é o poema que tem importância, mas sim a voz que deve funcionar como instrumento. Pierre Boulez, compositor da vanguarda, segue esta linha, manifestando-se em um comentário a respeito do seu Ciclo Pli selon pli, quase com um certo prazer pela abolição da palavra ${ }^{197}$

Em contrapartida a esta perspectiva surge o nome de Sir Michael Tippett que expressou o seu desagrado no que diz respeito aos "estragos" que a música provoca na poesia.

Importante, sim, é construir mais do que destruir, será de bem salvaguardar e preservar o poema. A essa atitude positiva de Sir Michael Tippett, 1905-1989, acrescentou um comentário relativamente à sua obra Words for Music Perhaps, onde apresenta uma série de interlúdios que promove a recitação dos poemas, garantindo assim qualquer tipo de adulteração, buscando proteger o valor inerente que a arte da poesia porta em si própria. Hoje em dia não estou interessado em destruir mas em construir, eu próprio, um cenário de palavras. ${ }^{198}$

A mensagem musical, enquanto experiência estética é algo que deve ser sugerida pelo compositor e fielmente transmitida pelo intérprete e absorvida pelo ouvinte, podendo ser apreendida como uma nova vivência ou como uma interpretação. Somente assim o receptor estará perante um autêntico universo de

\footnotetext{
196 KRAMER, Lawrence.Op.Cit.p.128. When the composer writes music for a lyrical poem... he, as a musician, is not excited either by the images or by the feelings speaking through this text... A necessary relation between poem and music... makes no sense, for the two worlds of tone and image are too remote from each other to enter more than an external relationship. The poem is only a symbol and related to the music like the Egyptian hieroglyph of courage to a courageous soldier.

197 POMBO, Fátima. Traços de Música. Aveiro: Universidade de Aveiro, 2001.p. 45.

198 KRAMER, Lawrence. Music and Poetry. The Nineteenth Century and After.p.132. (tradução nossa): Nowadays, I am disinclined to "destroy" the verbal music of any real poetry by instrumental or vocal music and prefer to "manufacture" a scenario of words myself).
} 
rendição às suas memórias e à imaginação construtiva, quando se render a uma experiência estética que está condicionada quer seja ao esquema do compositor, quer seja ao esquema do ouvinte, intermediado pelo papel do intérprete.

A utilização de outros recursos emprestados das outras formas de arte fez com que aumentasse o interesse pela música programática, como a sinfonia descritiva, o poema sinfônico e o drama musical, o que provocou uma reflexão sobre a natureza da mensagem musical, bem como a maneira de sua transmissão. A questão que delimita estas duas vertentes depreende-se no caráter da mensagem musical concebido na mente do compositor, assim como na subordinação inerente à forma de como este é transmitido. Isto tem causado acaloradas discussões e críticas que fizeram emergir, neste panorama, divergências entre os que se aliam à música pura com os que defendem a música programática.

O som e sua organização são matérias, existem e compõem a natureza como os outros elementos, como por exemplo, uma árvore que pode até nos trazer lembranças, sentimentos, mas ela não é o sentimento, ou seja, ela pode despertar emoções, mas não existe por causa dessas, nem se constitui delas.

Emanuel Geibel criou dois dísticos para exprimir essa relação entre música e o extramusical:

Por que nunca tens êxito em descrever a música com palavras? Porque ela, elemento puro, rejeita imagem e ideias. Mesmo o sentimento é apenas uma superfície translúcida de um rio, sobre o qual se agita a corrente caudalosa e sonora ${ }^{199}$

Hegel demonstrou como a análise das "sensações" (segundo nossa terminologia, dos sentimentos) provocadas por uma arte permanece totalmente indefinida e não leva em consideração o próprio conteúdo concreto. "O que se sente" - diz ele - "fica envolvido na forma da subjetividade singular mais abstrata, e por isso também as diferenças do sentimento são de todo abstratas, não diferenças da coisa mesma. (Estética I.p.42) ${ }^{200}$

O impulso a um conhecimento do objetivo possível das coisas, que em nossa época agita todos os campos do saber, deve necessariamente também, passar pela investigação do belo. Esta só poderá chegar a ele se romper com um método que parte do sentimento subjetivo para mais uma vez retornar, depois de um poético passeio por toda a periferia do objeto, ao sentimento. A investigação do belo, se não quiser tornar-se

\footnotetext{
${ }^{199}$ GEIBEL, Emanuel. Neue Gedichte - in Eduard Hanslick. Do Belo Musical. p.10

${ }^{200}$ HANSLICK, Eduard. Do Belo Musical.p. 168.
} 
totalmente ilusória, precisará aproximar-se do método das ciências naturais o suficiente para, no mínimo, tentar tocar o cerne das coisas e examinar o que há de duradouro e objetivo nelas, prescindindo das milhares de impressões variáveis. A poesia e as artes plásticas estão muito mais à frente da música em sua investigação e fundamentação estética. Seus estudiosos, em sua maior parte, abandonaram a ilusão de que a estética de uma determinada arte possa ser obtida por um simples ajuste do conceito geral metafísico do belo (que admite, em toda arte, uma série de novas diferenciações). A dependência servil das estéticas particulares em relação ao supremo princípio metafísico de uma estética geral abranda cada vez mais a convicção de que toda arte espera ser conhecida em suas próprias características técnicas e compreendida em si mesma. O sistema dá lugar, aos poucos, à investigação, e esta se atém ao postulado de que, em qualquer arte, as leis do belo são inseparáveis das propriedades do seu material, de sua técnica (...) A partir de agora devemos acrescentar o conteúdo positivo, respondendo à questão de que natureza é o belo da música. É um belo especificamente musical. Com isto, entendemos um belo que, sem depender e sem necessitar de um conteúdo exterior, consiste unicamente nos sons e em sua ligação artística. As engenhosas combinações de sons encantadores, seu concordar e opor-se, seu afastar-se e reunir-se, seu elevar e morrer - isto é que, em formas livres, se apresenta à contemplação de nosso espírito e que dá prazer enquanto belo ${ }^{201}$

\title{
O importante é a forma com que se concebe a beleza e o sentimento intrínsecos ao próprio som. Em contraposição, na música descritiva o compositor serve-se dos vários recursos que the permitam esclarecer as ideias e os
} sentimentos.

\begin{abstract}
Descrever esse belo independente da música, esse elemento especificamente musical é extraordinariamente difícil. Como a música não possui um modelo na natureza e não exprime um conteúdo conceitual, só se pode falar dela com áridos termos técnicos ou com imagens poéticas. Seu reino, na verdade, "não é o deste mundo". Todas as fantásticas representações, caracterizações, descrições de uma peça musical são alegóricas ou errôneas. O que para qualquer outra arte não passa de descrição, para a música já é metáfora. A música quer, de uma vez por todas, ser percebida como música, e só pode ser compreendida e apreciada por si mesma ${ }^{202}$
\end{abstract}

Ouvir e compreender a música são de fato algo bastante pessoal e subjetivo, cujo resultado está condicionado por alguns fatores, tais como aptidão e conhecimento musical, intelecto e temperamento.

Schopenhauer, o filósofo do 'ideal romântico' da música, defende que o mundo da música é o mundo dos sentimentos, porque representa o que é mais íntimo, mais indizível, mais misterioso da vontade. O compositor revela a essência íntima do mundo numa linguagem que a sua razão não

\footnotetext{
201 HANSLICK, Eduard. Do Belo Musical.p.14.

202 HANSLICK, Eduard. Op.Cit.p.65.
} 
saberia apreender. A música opõe-se aos conceitos, por excesso ${ }^{203}$

O compositor ao idealizar uma obra, no ato da criação, pode procurar evocar este ou aquele cenário ou, algo que até venha provocar no ouvinte um determinado caráter emotivo, como por exemplo, o bucólico ou o eufórico, ou ainda outros.

No entanto, tomando consciência do trabalho de execução, o intérprete, que em geral, não tem contato pessoal com o compositor, deve tentar desvendar o processo criativo sempre com muito critério, pois de certa maneira, a interpretação condiciona a percepção do ouvinte que se tem em relação a uma peça musical.

A análise de uma performance só pode ocorrer se prevalece-se a proposta sugerida pelo compositor, não esquecendo que, quer seja a obra musical em si mesma, quer seja a interpretação que se faz dela, ambas são criadas para obter determinados significados musicais.

Música e poesia são duas artes da comunicação que compartilham os mesmos atributos do som, como a articulação, a entonação, enfim, quando executadas se expressam em uma decorrência temporal. Ambas autônomas e com valores em si próprios não necessitam uma da outra para subsistir, muito embora, historicamente seus caminhos cruzam-se no fascinante universo da canção.

O texto, outrora declamado, passa a coexistir com os sons definidos musicalmente recebendo uma nova roupagem. A música, por sua vez, recebe mais um componente, cuja articulação através da fonação passa a contribuir para o enriquecimento do resultado final.

Mas como é que duas artes se encontram para a realização de uma obra mais perfeita? Há um equilíbrio natural entre essas duas artes ou esse equilíbrio nunca chega verdadeiramente a conseguir-se? (Hugo von Hoffmannsthal) ${ }^{204}$

\footnotetext{
${ }^{203}$ POMBO, Fátima. Traços de Música. Aveiro: Universidade de Aveiro, 2001.p.128.

${ }^{204}$ POMBO, Fátima. Traços de Música. Aveiro: Universidade de Aveiro, 2001.p. 40
} 


\section{A Voz}

Este capítulo visa apresentar conceitos que permitam uma compreensão do que é a voz.

Segundo o Collins English Dictionary - Complete and Unabridged (c) Harper Collins Publishers 2003, voz é o som feito pela vibração das cordas vocais modificado pela ressonância do trato vocal.

Portanto a voz está intimamente ligada ao corpo humano e suas estruturas. A voz é produzida por uma interação entre o corpo e a audição.

A integração entre corpo e ambiente é intermediada por uma escuta. Esta estrutura de existência pode produzir uma música, e esta, por sua vez, uma voz.

A existência material do corpo mais o aparato que permite a escuta produzem um som. $\mathrm{O}$ som alimentado por outra escuta transmite vibrações ao corpo e produz outro som.

O processo de geração de som é interativo, isto é, há uma retroalimentação de som, escuta, corpo e novamente som. Este processo interativo ocorrendo em uma sucessão temporal resulta em uma produção musical específica.

Estes elementos da produção musical - som, escuta e corpo - não são neutros ou puros. Eles são dependentes dos ambientes onde se materializam.

Qualquer produção musical específica implica nos conceitos de beleza e sensibilidade oportuna, conforme Carl Dalhaus:

A imersão numa obra de arte, por esquecida que seja de si, raramente é
um estado místico em sentido definido, uma rigidez insensível e extática.
Mas é uma oscilação entre contemplação e reflexão, de modo que o
estágio por ela alcançado depende das experiências estéticas e
intelectuais que um ouvinte traz consigo e em cujo contexto insere a
obra, que justamente contempla. Os momentos intelectuais não são
ingredientes supérfluos, mas encontram-se sempre já contidos na
percepção estética e, claro está, de forma rudimentar ou desenvolvida ${ }^{205}$

A conceituação de beleza e sensibilidade em música é complexa e não determinística, depende da percepção intelectiva, da sensibilidade e interação com os contextos social, histórico, cultural e psicológico em análise. A valoração

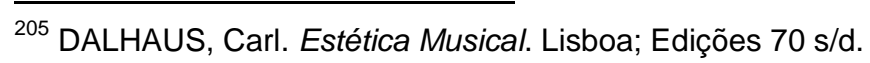


do produto artístico não é livre, é dependente do contexto.

Novamente fecha-se um elo. O contexto tem influência da cultura, da ideologia, do estado psicológico das pessoas que ao seu turno dependem do contexto histórico.

A voz como fonte de energia sonora deve repercutir sobre a sensibilidade e os nervos do espectador através de qualidades e vibrações de sons não habituais. Não há a intenção de suprimir o texto ou a fala no teatro, mas libertá-lo da tutela de ambos, utilizando a palavra num sentido concreto e especial, exprimindo o que de hábito ela não exprime. A palavra deverá ser manipulada "como um objeto sólido, um objeto que derruba e perturba as coisas." É vital reuni-la de novo aos movimentos físicos que a suscitam, tomando-a em sua sonoridade, e não exclusivamente no seu significado gramatical; apreendê-la enquanto movimento que é, retornando desse modo às origens ativas, plásticas e respiratórias da linguagem. As palavras deverão ser interpretadas não só no sentido lógico, mas também no seu sentido de sortilégio, o que dará maior amplitude à voz, tirando partido das vibrações, das modulações e evoluções de toda espécie ${ }^{206}$

Este trabalho não tem o intuito de aprofundar este ciclo interativo, mas ponderá-lo como influência que mesmo não sendo a maior, influi no processo de compreensão para uma nova vocalidade e o formato que esta vem assumindo.

Vocalidade é a historicidade de uma voz: seu uso. (...) Hipótese do autor: o conjunto dos textos legados a nós pelos séculos X, XI, XII e, numa medida talvez menor, XIII e XIV passou pela voz não de modo aleatório, mas em virtude de uma situação histórica que fazia desse trânsito vocal o único modo possível de realização (de socialização) desses textos. Essa hipótese abrange as canções, narrativas e declamações de todo tipo e crônicas ${ }^{207}$

Desse modo, discute-se a forma estética da voz na atualidade que difere muito da estética anterior. Esta última foi traçada pela prática vocal que dominou e perdurou desde o período gregoriano até o século XIX.

A prática da voz inserida no mundo moderno, também se desenvolve com as bruscas mudanças que alteram os parâmetros da produção musical e da compreensão dos elementos de musicalidade que surgem desde os primórdios do século XX.

Nessa prática que se foi acrescendo paulatinamente com os "novos" recursos, tomados emprestados da prática da emissão vocal na fala e no canto

${ }^{206}$ JANUZELLI, Antônio. A Aprendizagem do Ator. São Paulo: Editora Ática, 2003. p.22.

207 ZUMTHOR, Paul. A Letra e a Voz: A “Literatura” Medieval; tradução: Amalio Pinheiro, Jerusa Pires Ferreira. São Paulo: Companhia das Letras, 1993.p.21. 
cotidiano, nota-se o surgimento de uma nova oralidade e vocalidade, despertando uma para uma nova sonoridade que futuramente, se intensificará, principalmente, a partir do final dos anos 50 e início dos 60 do século passado. Seu florescimento se estende até os dias atuais, teve como ponto de partida muitas das reflexões e pesquisa que a Segunda Escola de Viena trouxe para a música escrita, e como consequência do serialismo integral.

Muito embora os padrões do bel canto ainda estejam muito arraigados no que se conhece por música erudita, portanto o emprego dessa nova vocalidade ainda é muito limitado e pouco difundido.

É neste contexto que a música erudita está inserida.

À medida que uma nova vocalidade vai se impondo no cantar do mundo contemporâneo pode-se dizer que é uma contraposição ao padrão estético do bel canto, ou mesmo a sua contestação. A evolução da voz lírica esbarrou nas limitações do sistema tonal, ela tornou-se pós-tonal, atonal, serial, eletro-acústica.

A voz contemporânea nega toda a estética do bel canto, contrapõe-se a ela, sendo a própria transformação a que chegou a voz lírica em seu devir histórico, como o esgotamento do sistema tonal que se transformou em pós-tonal, atonal, serial, eletro-acústico. Mas claro, para entendê-la e ouvir sua beleza, contemplar e refletir depende das experiências estéticas e intelectuais que um ouvinte traz consigo e em cujo contexto insere a obra, que justamente contempla. O que escutamos e apreciamos é filtrado por nossas experiências estéticas e intelectuais e em cujo contexto inserimos a obra. Portanto, se uma determinada obra não se encaixa em nossas experiências, dificilmente iremos atingir um estágio de fruição. A escuta banal recusa uma voz que se remete a um corpo livre, um corpo que não tem medo de sua humanidade. Precisamos então começar por libertar a própria escuta e a concepção que temos do corpo, para podermos entender e fruir a voz-música contemporânea. A concepção que temos do corpo é algo muito complexo e definido por uma rede de condicionamentos mentais, psicológicos, sociais, culturais, filosóficos, que, praticamente, se não impedem, dificultam muito a possibilidade de termos uma outra concepção do corpo. Muito desse limite se deve à herança do pensamento ocidental que se desenvolveu a partir de uma concepção dualista entre mente e corpo ${ }^{208}$

O espectro de percepções estéticas e cognitivas a que um ouvinte carrega em seu intelecto e o ambiente histórico de uma obra são fundamentos para a contemplação, reflexão e permitem entender a voz, e ainda a apreciação de sua sonoridade.

${ }^{208}$ BECKER, Susie - A Voz Contemporânea - Dissertação de Mestrado - ECA-USP, 2008. 
O ser humano possui um filtro em cuja base estão experiências estéticas e intelectivas. Esse filtro atua na percepção daquilo que se escuta e se aprecia em uma obra.

Disso se depreende que se uma voz não se enquadra no cabedal de experimentos históricos de um indivíduo, este certamente não faz uma oportuna apreciação da obra.

A escuta eventual de uma voz, sem estar inserida no contexto da experiência humana e sua dimensão histórica, não permite a devida fruição dessa arte.

São necessárias, para a devida apreciação, a libertação da escuta e a internalização conceitual sobre o corpo para a compreensão e fruição da vocalidade na música contemporânea.

Uma rede de conceitos pré-estabelecidos por experiências cognitivas, sociais, culturais, religiosas e filosóficas impedem o indivíduo de compreender os complexos mecanismos e os diversos conceitos a respeito do corpo. O ser humano, neste contexto, praticamente não consegue posicionar-se como observador externo e objetivo.

Pode-se atribuir tais limitações à bagagem filosófica do pensamento ocidental que foi desenvolvido do pressuposto dualista entre mente e corpo.

A seguir faz-se uma pequena análise para melhor compreensão desse conceito.

\section{1 - O conceito separatista entre corpo e mente.}

Alguns conceitos clássicos da Grécia dos séculos V e IV a.C. são fundamentos do pensamento no Ocidente. O pensar de Sócrates, Platão e Aristóteles formam a base filosófica ocidental.

Sócrates implementou método e racionalismo que influenciaram decisivamente toda a produção filosófica que se seguiu.

Uma abordagem racional já havia surgido no período pré-socrático, como tentativa de explicar o mundo real, sem amparar-se em mitologia ou 
conceitos religiosos. $^{209}$

Houve, então, uma alteração nos paradigmas da compreensão do homem sobre a vida. Passou-se de uma visão mística e poética, para um entendimento racional e cognitivo.

No período pós-socrático a razão é alçada com padrão de superiodade intelectual e desvaloriza-se o corpo e as emoções. Há uma visão dialética entre corpo e mente.

Tal dualismo, oriundo de Sócrates e Platão, foi propagado por Plotino. Este, utilizando uma abordagem do cristianismo, influenciou os pensadores dos períodos posteriores.

O lluminismo é o marco da vitória do racionalismo. Ele é o produto, o pensamento filosófico e científico, que partiu da abordagem dualista da Era Cristã e Medieval.

Para uma melhor compreensão sobre mente e corpo, e sobre a voz que é produzida nesse corpo convém entender bem que os conceitos a respeito de música sempre estiveram influenciados pela concepção filosófica geral do momento histórico.

Naturalmente as ideias sobre música estavam subordinadas a uma concepção filosófica genérica sobre os fatos e as coisas, como tudo, aliás, e é essa visão geral que temos que entender um pouco mais para podermos pensar sobre o tema mente e corpo, e a voz que é produzida por esse corpo.

A ideia de que a nobreza da música é fundamentada em base intelectiva, espiritual, acima dos impulsos corporais e emocionais prevaleceu nos escritos de Platão ${ }^{210}$, Aristóteles ${ }^{211}$, Santo Agostinho ${ }^{212}$ e Boécio ${ }^{213}$ sobre música. $\mathrm{Na}$ concepção de Platão sobre justiça individual, o indivíduo justo eleva sua racionalidade, apoiado na vontade e com controle sobre seus desejos. Sua teoria ética fundamenta-se na hipótese de que a virtude é conhecimento e que este pode ser adquirido.

\footnotetext{
${ }^{209}$ SEVERINO, Antônio Joaquim. Filosofia. São Paulo: Cortez Editora, 1992.

${ }^{210}$ PLATÃO - A República, livro III, 380 a.C.

211 ARISTÓTELES - Política, livro VIII, cap 3, 330 a.C.

212 SANTO AGOSTINHO - Confissões, livro X, 400 d.C.

${ }^{213}$ BOÉCIO - De Institutione Musica, livro I , 510 d.C.
} 
$\mathrm{Na}$ concepção de Platão, a música deve ser aprendida e devem-se eliminar as formas de lamentação, ou os instrumentos que emitem vários sons tais como harpas, trígonos e aulo. Sobrevivem para o mundo rural a sirinx e para a urbe a lira e a cítara, sendo o modo dórico, o único verdadeiramente digno.

Platão adverte que a música exerce função importante na educação e no Estado, buscando a manutenção dos ideais cívicos.

O Estado predisposto a ser pró-ativo, de comportamento expansionista, valoriza a produção de marchas para exaltação dos atos heroicos. Já uma sociedade em decadência cultiva cantos lamuriosos que amplificam sua impavidez.

As concepções de Aristóteles são semelhantes ao seu predecessor, afirma:

\begin{abstract}
Voltando ao modo dórico, todos estão de acordo que ele seja o modo mais sério e o que melhor manifesta um caráter varonil. Ademais, posto que nossa aprovação se dirige ao que ocupa um lugar intermediário entre extremos, e o modo dórico se acha nessa situação, é evidente que as melodias dóricas se acomodam melhor à educação dos jovens dos bons costumes do povo ${ }^{214}$
\end{abstract}

Para Aristóteles havia nobreza em fundamentar a música pelo racional, uma vez que isso leva à Virtude e ao Bem. Assim, se dava a educação. A instrução musical era muito eficiente e poderosa, ao introduzir a alma do neófito à graça, ao amor, à beleza e à virtude. E este processo poderia ser desenvolvido desde a mais precoce puberdade.

Um indivíduo educado por instrução musical alcançaria mais diretamente os ideais de beleza e a harmonia e também renegaria o feio e o mal, evitando fortemente o desvio da harmonia, lutando contra as deformidades.

Em relação a Platão, a visão de Aristóteles é mais flexível, pois mesmo compreendendo a importância do modo dórico e da música para a educação, tal como Platão, entende que a música pode desempenhar diversos papéis.

Admitimos, pois, a classificação das melodias, proposta por alguns entendidos em filosofia, em "melodias morais","melodias ativas" e "melodias que induzem ao entusiasmo".

Tanto para Platão, como Aristóteles, a natureza dos modos musicais se

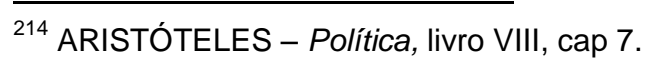


adapta às melodias, havendo correlação entre seus tipos.

A concepção do século IV a.C entende que as vantagens que justificam a práxis musical não são únicas como no ideal aristotélico, no entanto são várias e tem como finalidade a educação; a katarsis; o ócio digno e o relaxamento após grande esforço.

Nesse ambiente evidencia-se a necessidade do uso de modos musicais variados, de empregos multiformes. Então, utiliza-se para a educação os modos morais, e para a audição de música executada por outros, aceitam-se os modos ativos e entusiásticos. ${ }^{215}$ Sua obra influenciou o grande doutor da igreja, Santo Agostinho. Esse religioso compreendeu a influência da música sobre o corpo compreendendo o prazer que ela proporciona. Em suas Confissões, Santo Agostinho adverte sobre o perigo. ${ }^{216}$

Sinto que todos os afetos da minha alma se encontram, na voz e no
canto, segundo a diversidade de cada um, as suas próprias modulações,
vibrando em razão de um parentesco oculto, para mim desconhecido,
que entre eles existe. Mas o deleite da minha carne, de enervar a alma,
engana-me muitas vezes. Os sentidos, não querendo colocar-se
humildemente atrás da razão, negam-se a acompanhá-la. Só porque,
graças à razão, merecem ser admitidos, já se esforçam por precedê-la e
arrastá-la! Deste modo peco sem consentimento, mas advirto depois ${ }^{217}$

Já Boécio, autor da baixa Idade Média, aponta: "A música nos é relacionada pela natureza, e pode enobrecer ou corromper o caráter." Este autor, de forma similar aos predecessores, procurou orientar a música para o correto e o racional. Ele, ao compreender o poder que a música exerce sobre o corpo, aponta para o dever da mente sobrepujá-la.

Fundamentado em Platão, ele apresenta o persistente interrelacionamento entre música e alma. Na concepção da Idade Média, havia a música humana e a música exterior que se interagiam.

Boécio afirmava ser trivial que o estado de espírito de uma pessoa estivesse diretamente relacionado com o tipo de música que a aprazia. Por exemplo, uma pessoa alegre compõe cânticos aprazíveis e se deleita ao ouvir canções alegres. Em contrapartida, uma alma impura, se rejubila com melodias

\footnotetext{
${ }^{215}$ ARISTÓTELES - Política, livro VIII, cap 7.

216 SANTO AGOSTINHO - Confissões, livro X, 400 d.C.

217 SANTO AGOSTINHO - Confissões, livro X, 400 d.C..
} 
lascivas, as quais reforçam sua lascívia.

Estes princípios Boécio e Platão estenderam dos indivíduos aos povos.

Foi por isso que Platão escreveu que os meninos não deveriam ser treinados nesses modos, mas somente naqueles fortes e simples. E devemos, acima de tudo, ter em mente que se em tal assunto uma série de pequenas mudanças forem feitas, não ocorrerá uma mudança com frescor, e isso posteriormente criará uma grande diferença e passará através do sentido de audição à mente. Por essa razão Platão considerou esta música, da mais alta qualidade moral e puramente composta, sendo modesta e simples e masculina, e não efeminada ou selvagem, ou mal construída, uma grande guardiã da comunidade.

Muito mais admirável então é a ciência da música, por apreender pela razão e não pela realização através do trabalho e ação performática! $\mathrm{E}$ mais além, ou seja, como o corpo é suplantado pela mente, porque a pessoa destituída de razão viverá em servidão ${ }^{218}$

Expoente e precursor do Neoplatonismo o filósofo romano Plotino, 205270 d.C, difundiu na Era Cristã,100-450 d.C, a noção de que o homem pertence a dois mundos: o dos sentidos e o da inteligência pura.

Uma vez que a matéria é a causa de todo o mal, o neoplatonista propõe que o objetivo da vida deveria ser escapar do mundo material dos sentidos, portanto, os indivíduos deveriam trocar todos os interesses mundanos pela meditação intelectual.

As escolas filosóficas e o método científico que surgiram depois partiram dessa concepção dualista e chegaram à vitória da razão com o Iluminismo.

Compreende-se que a estrutura do pensamento filosófico e científico ocidental é baseada em uma concepção dualista entre razão e emoção, intelecto e sentimento, mente e corpo. Estes são fenômenos separados e até antagônicos.

Com Renée Descartes,1596-1650, no seu Discurso do Método,1637, atinge-se o apogeu dessa concepção dualista. Descartes definiu o racionalismo situando-se fora do espectro religioso que orientou o pensamento ocidental no período medieval.

A Razão como verdade primeira e última, foi de extrema importância para o desenvolvimento científico que se sucedeu. Livre dos impedimentos da religião, a visão dualista predominou de forma ainda mais intensa.

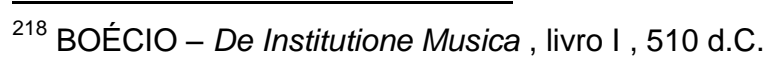


Descartes apresentou o princípio da irredutibilidade entre matéria e espírito dividindo-os matéria (res extensa) e espírito (res cogitans). Estabelecendo assim, duas categorias, algo ou é material ou é espiritual. ${ }^{219}$ Desse pressuposto vem a ideia que corpo e mente são separados entre si.

O filósofo alemão Friedrich W. Nietzsche, 1844-1900, foi marcante no seu questionamento a esse dualismo pré-estabelecido na cultura do Ocidente. Em A Origem da Tragédia, 1871, ele evoca Sócrates como responsável por separar Eros e Logos.

O Apolíneo e Dionisíaco são dois princípios fundamentais que Nietzsche identifica na cultura Grega e que é base para a análise da cultura ocidental.

O princípio associado às figuras de Sócrates e Platão é o princípio Apolíneo. Referente ao deus Apolo ele fundamenta-se na racionalidade e dele advém a serenidade, a claridade, a medida, racionalidade. Ele tipifica bem a imagem tradicional da Grécia clássica.

Já o princípio Dionisíaco está associado às forças impulsivas, ao excesso, ao erotismo, à orgia, à afirmação da vida e dos seus impulsos (força, vontade - o mundo sensório), refere-se ao deus Dionísio.

Antes de Sócrates, estes dois princípios já estavam presentes na cultura grega, ou seja, na tragédia. O sucesso alcançado pela filosofia de Sócrates restringiu os impulsos vitais e a sua energia excessiva às limitações da razão. No período pós-platônico, na filosofia europeia predominou a repressão aos instintos vitais e a negação do prazer.

Nietzsche propõe que a arte é a resultante de um conflito dos princípios apolíneos e dionisíacos na sua obra $A$ Origem da Tragédia. Apolo individualiza e dá forma à energia vital e Dionísio a emana.

No apogeu da cultura clássica estava a tragédia antiga anterior a Eurípides. Nela havia dissenções entre as forças apolíneas e as dionisíacas. Tipicamente a poesia era de Apolo - racional e estética - e a música de Dionísio irracional, irreverente, sensual. Eram artes complementares.

${ }^{219}$ LOBO, HADDOCK. A Filosofia e sua Evolução: Pequena História do Pensamento Humano. São Paulo: Ed. Populares, 1979. 
Para o filósofo niilista, a percepção pós-socrática de tranquilidade no Olimpo é exclusivamente apolínea, sendo uma afronta e negação às forças dionisíacas que foram excluídas. A arte reduziu-se à individualização, ao racionalismo, à moral. A música foi submetida a esse ideal clássico de retidão, formas platônicas e perdeu seu elemento de irreverência, de irracional, de força vital.

Nietzsche rompeu com o império da racionalidade e propugnou o reino da força vital e instintiva, resgatando o que fora excluído do dualismo, basicamente o princípio dionisíaco.

O século XIX apresentou a influência de outro grande pensador para reposicionar o homem no universo entre o racional e o irracional: Sigmund Freud, 1856-1939.

Esse médico austríaco foi contundente em dizer que o homem não é estritamente racional, mas é tutoriado por poderosíssimas forças interiores que interagem com o consciente em suas decisões. São impulsos instintivos que prevalecem na maior parte da mente e das ações humanas.

A dialética que contrapõe o racional e o irracional, corpo e mente fundamentada por pensadores como Nietzsche e Freud, vem sendo superada desde o início do século passado.

A segunda metade do século XX apresenta pesquisas interdisciplinares e específicas que fazem face ao dilema.

Platão exaltou a mente à nobreza comparando o corpo, os afetos e sua força vital a barreiras do conhecimento. Isto ainda reflete que em nome da consciência, do conhecimento e da razão, que haja então a supressão do erotismo na ação humana. A confrontação entre Eros, as forças sensuais, e a cognição ocorre porque o irracional é uma ameaça por seu caráter de incontrolabilidade.

O que fica latente na filosofia desde o período pós-socrático até os primórdios do século passado, é que a razão que adquiriu suma importância é superior às emoções e aos sentimentos do corpo.

Com a metafísica, René Descartes evidenciou a dicotomia corpo/mente. Isto impactou o pensamento do Ocidente, pois a partir dele a 
separatividade do ser humano em corpo físico e subjetividade ficaram enunciadas, e o físico submeteu-se à razão.

Para Descartes, a relevância da razão tornou-se tão grande e superior que passou a ser um princípio pré-estabelecido e inquestionável. Francisco Fontanella ${ }^{220}$ observa que:

o 'eu', - o sujeito - se separou e se tornou todo-poderoso em relação ao mundo. E o corpo, conjunto biológico, material, mundano, cheio de humores e excreções ficou relegado, mais ainda que o mundo.

No mundo ocidental, este princípio subjetivo foi estendido a outras dualidades: espírito/matéria; masculino/feminino; branco/preto; dominante/dominado; civilizado/primitivo; culto/inculto; letrado/analfabeto; desenvolvido/subdesenvolvido. Esta dialética manteve-se inatingível até o século passado, pois:

o movimento dessas dicotomias ganhou força em diferentes áreas e culminou numa discussão quase inconciliável entre os sistemas teóricos empiristas e inatistas, que dominaram o cenário dos debates sobre conhecimento, pensamento, comportamento e sentimentos humanos. Os empiristas 'cuidaram' da razão e os inatistas da emoção. Posteriormente, com a consolidação de grandes teorias psicológicas como a gestalt, a psicanálise, o behaviorismo, a epistemologia genética, a psicologia cultural e a psicologia sócio-histórica, o problema passa a ser debatido de modo mais aprofundado por cada modelo e começaram a aparecer estudos sobre as relações entre cognição e afetividade ${ }^{221}$

A obra O erro de Descartes, 1996, de Damásio, propõe que há um grande vínculo entre razão e emoção. E Valéria Amorim Arantes fundamentada no neurologista Damásio, argumenta que sentimentos e emoções são percepção direta do estado corporal do indivíduo e são uma ligação fundamental entre o corpo e a consciência. Ele ainda faz um convite à observação da essência do erro de Descartes, segundo Damásio:

a separação abissal entre o corpo e a mente, entre a substância corporal, infinitamente divisível, com volume, com dimensões e com um funcionamento mecânico, de um lado, e a substância mental, indivisível, sem volume, sem dimensões e intangível, de outro; a sugestão de que o raciocínio, o juízo moral e o sofrimento adveniente da dor física ou agitação emocional poderiam existir independentemente do corpo.

220 FONTANELLA, FRANCISCO. O Corpo no Limiar da Subjetividade. Piracicaba: Unimep, 1995. Apud in Rosário, Nísia Martins do. Mundo Contemporâneo: Corpo em Metamorfose. Artigo disponível no site www.comunica.unisinos.br/semiotica/nisia semiotica/conteudos/corpo.

${ }^{221}$ VASCONCELOS, Mário Sérgio. Afetividade na Escola: Alternativas Teóricas e Práticas. Educ. Soc, Campinas, vol. 25, n 87, maio/ago 2004. Disponível em www.cedes.unicamp.br. 
Especificamente: a separação das operações mais refinadas da mente, para um lado, e da estrutura ou funcionamento do organismo biológico para o outro ${ }^{222}$

Uma ruptura com a ideia cartesiana da mente separada do corpo é a conclusão de Arantes sobre Damásio. Ele propõe que a famosa sentença "Penso, logo existo" - devesse ser substituída pela anticartesiana - "Existo e sinto, logo penso."

Conclui-se que o dualismo arraigado à consciência do pensamento do Ocidente no período pós-socrático, estendeu-se a concepções religiosas cristãs e tornou-se base do pensamento científico contemporâneo, com a dialética cognição/emoção, corpo/mente, razão/sentimento, com a consequente superioridade da mente/razão/cognição.

Tal conceituação tem sido crescentemente contrastada e refutada por descobertas da física, biologia, neurociência e ciências cognitivas. Esta nova concepção permite novo entendimento sobre o corpo, a escuta, e consequentemente a voz, especialmente na produção musical e artística.

Iniciada a segunda metade do século XX, várias pesquisas argumentam contra o dualismo e sobre a superioridade da razão sobre o corpo vivo que minimiza o papel do corpo como um objeto a serviço da razão da civilização.

Surgem novos questionamentos e contraposições: corpo-natural/corpocultural; corpo humano/corpo animal; corpo universal/corpo singular. Evidencia-se a ideia do corpo como viabilização da existência.

O corpo, assim como aprende a camuflar muito do que é registrado durante sua vivência, também é capaz de questionar as separações e fixações impostas pela ciência clássica, é simultaneamente imperfeito e maravilhoso.223 Não há no corpo reações determinísticas como em uma máquina. Para o ser vivo, um hábito verdadeiro é adquirido pela incorporação de um modo capaz de transformação.

Por outro viés, uma máquina executa uma montagem prevista para um

\footnotetext{
222 ARANTES, Valéria Amorim. Afetividade e Cognição: Rompendo a dicotomia na Educação. Publicado originalmente em Oliveira, M. K.; Trento, D ; Rego, T( org ). Psicologia, Educação e as Temáticas da vida contemporânea. São Paulo: Moderna, 2002.

${ }_{223}$ MENDES, Maria Isabel Brandão de Souza. Corpo, Natureza e Cultura: Contribuição para a Educação. Disponível no site www.anped.org.br/rbe27/anped-n27-art08.pdf.
} 
número finito de casos. Há uma pequena margem de imprevisto, de risco. A máquina funciona, o animal vive, pois seu corpo se reestrutura no mundo..$^{224}$

A intuição, a selvageria, o improviso, o imprevisto e inúmeras transformações marcam o corpo. Um ser é submetido a constante modificação.

A lógica dinâmica de um corpo, que é marcado por infinitas transformações, pode ser entendida pela capacidade de auto-organização e pela união de domínios até então distintos tais como humanidade e animalidade; natureza e cultura; corpo e mente; razão e emoção.

Há muitas dimensões a se considerar no corpo; pois eis que ele é técnico e racional, mítico, festivo, dançante, capaz de manifestar nuances de sentimentos e afetividade que vão do amor à agressividade.

Tudo que é humano possui ligação com a vida. ${ }^{225}$ Considera-se o ser humano como um ente bio-cultural: totalmente biológico e totalmente cultural. Pode-se concluir que a rejeição ao ruído na musicalidade ocidental, superada posteriormente por atração é reflexo da mudança de perspectiva da dicotomia corpo e mente. Nesse contexto pode-se compreender que o evitar ao ruído está intimamente ligado ao recalque do corpo.

Portanto, a revolução que grassou na poesia no sentido de resgate da voz e do corpo, no teatro buscando suas profundezas e manifestações no corpo, acenava com o forte desejo de superar essa dicotomia entre mente e corpo.

\section{2 - A Musicalidade e o Corpo}

A análise sobre o corpo e sua separação da mente, no subcapítulo anterior permite a compreensão, de forma mais clara, dos variados modos que 0 canto vem assumindo, com constante mutação, ainda que por mais estática que pareça, essa transformação é consequência intimamente ligada à vida da humanidade. Inicia-se então uma reflexão sobre a estética da voz cantada.

$O$ estudo que pesquisa as melhores formas assumidas pela voz tendo

\footnotetext{
${ }^{224}$ MERLEAU-PONTY, M. A Natureza: Notas: Cursos no Collège de France. Martins Fonte, 2000 - in Apud Mendes.

${ }^{225}$ MORIN, Edgard. O Paradigma Perdido: A Natureza Humana. 5a edição. Tradução de Hermano Neves. Lisboa: Publicações Europa-América, 1973. Apud Mendes, Maria Isabel Brandão de Souza, op. cit.
} 
por base o corpo é fundamentado no intenso inter-relacionamento entre voz e corpo.

A escuta, não é neutra. Isto possibilita definir a compreensão de como se produz a voz. Tanto quanto é necessário educar o olhar para a percepção de formas ocultas por ideologia e massificação, deve-se almejar ver além do óbvio aparente da realidade, também se faz necessário educar a audição para que se possa escutar o amplo espectro de formas sonoras, incluindo as formas escondidas pela inculturação.

Sempre houve uma ligação intrínseca entre música e corpo. José Miguel Wisnik em seu livro O Som e o Sentido mostra que isto é perceptível nas dicotomias: pulso musical e pulso sanguíneo, frase musical e respiração, as categorias de andamento Largo, Andante, Allegro, Vivace e as disposições físicas e psicológicas. Ele lembra:

Podemos usar uma metáfora corporal: a onda sonora obedece a um pulso, ela segue o princípio da pulsação. Bem a propósito, é fundamental pensar aqui nessa espécie de correspondência entre as escalas sonoras $\mathrm{e}$ as escalas corporais com as quais medimos o tempo. Porque 0 complexo é um medidor freqüencial de freqüências. Toda a nossa relação com os universos sonoros e a música passa por certos padrões de pulsação somáticos e psíquicos, com os quais jogamos ao ler o tempo e o som. (...) Mas é preciso dizer como se apresenta o pulso na música. Assim como o corpo admite ritmos somáticos (a exemplo do sanguíneo) e ritmos psíquicos (como as ondas cerebrais), que operam em diferentes faixas de onda, as freqüências sonoras se apresentam basicamente em duas grandes dimensões: as durações e as alturas (durações rítmicas e alturas melódico - harmônicas (...) É impossível a um som se apresentar sem durar, minimamente que seja, assim como é impossível que uma duração sonora se apresente concretamente sem se encontrar numa faixa qualquer de altura, por mais indefinida e próxima do ruído que essa altura possa ser ${ }^{226}$

Dessa forma, é intrínseco da sonoridade que haja a existência de ruído.

Ao fazer música, as culturas trabalharão nessa faixa em que som e ruído se opõem e se misturam (...) Nos rituais que constituem as práticas da música modal invoca-se o universo para que seja cosmos e não caos. Mas, de todo modo, os sons afinados pela cultura, que fazem a música, estarão sempre dialogando com o ruído, a instabilidade, a dissonância. (...) Som e ruído não se opõem absolutamente na natureza: trata-se de um continuum, uma passagem gradativa que as culturas irão administrar, definindo no interior de cada uma qual a margem de separação entre as duas categorias (a música contemporânea é talvez aquela em que se tornou mais frágil e indecidível o limiar dessa distinção)

O jogo entre o som e ruído constitui a música. O som do mundo é ruído,

${ }^{226}$ WISNIK, José Miguel. O Som e o Sentido. São Paulo: Companhia das Letras, 1989. pp.19,20,21. 
o mundo se apresenta para nós a todo o momento através de freqüências irregulares e caóticas com as quais a música trabalha para extrair-lhes uma ordenação (ordenação que contém também margens de instabilidade, com certos padrões sonoros interferindo sobre os outros ${ }^{227}$

José Wisnik, observando a história da música no Ocidente, propõe que depois do canto gregoriano a música se deslocou para o plano das alturas e houve uma rejeição ao ruído. Esta rejeição só foi resgatada no século passado.

A música que evita o pulso e o colorido dos timbres é uma música que evita o ruído, que quer filtrar todo o ruído, como se fosse possível projetar uma ordem sonora completamente livre da ameaça da violência mortífera que está na origem do som (...) Recalcar os demônios da música equivale de certa forma, no plano sonoro, a cobrir (ou rasurar) o sexo das estátuas (...) A partir do século XX opera-se uma grande reviravolta nesse campo sonoro filtrado de ruídos, porque barulhos de todo tipo passam a ser concebidos como integrantes efetivos da linguagem musical. A primeira coisa a dizer sobre isso é que os ruídos detonam uma liberação generalizada de materiais sonoros. Dá-se uma explosão de ruídos na música de Stravinsky, Schoenberg, Satíe, Varèse (para citar alguns nomes decisivos. (...) O canto gregoriano, que inaugura uma tradição que conhecemos bem, aquela que vai dar na música barroca e clássico romântica dos séculos XVII, XVIII, e XIX é uma música que primou por evitar sistematicamente os instrumentos acompanhantes, não só os percussivos, como também o colorido vocal dos múltiplos timbres ${ }^{228}$

\section{3 - Música e Voz}

A abordagem histórica da separação entre o corpo e a voz cantada, permite a compreensão de que a não aceitação ao ruído induziu, na sequência, a rejeição do corpo e a voz em sua plenitude.

Houve exclusão da participação feminina inicialmente nos cantos das igrejas e depois no teatro. Desde sua introdução no século $X V$ até sua decadência no século XVIII, houve profusão do emprego dos castrati ${ }^{229}$ que em geral suas vozes eram ou soprano ou contralto, porém sua função ultrapassava a função feminina, pois suas vozes eram encaradas como um misto de voz masculina, feminina e infantil. Eram figuras angelicais que foram supervalorizadas em sua época.

\footnotetext{
${ }^{227}$ WISNIK, José Miguel. Idem. pp.27,30,33.

${ }^{228}$ WISNIK, José Miguel. Idem. pp.42,43,44.

${ }^{229}$ Castrati- plural de castrato, que eram indivíduos masculinos castrados na adolescência para manterem na vida adulta vozes agudas.
} 
Incorporavam à sua história a verdadeira tragédia: sua mutilação podia levá-los ao ápice, ao êxtase com a experiência do canto dos anjos. Era a expressão máxima da contradição clássica: assexuados e de canto angelical. Ao mesmo tempo em que prefiguravam a separação mente-corpo ao despertarem desejos sexuais em mulheres e homens, traziam à tona o elemento dionisíaco esquecido e apartado daquela época.

O lluminismo ao defender com veemência a razão impulsionou o desaparecimento dos castrati. Paulatinamente os compositores eliminam o papel de sopranistas. Por exemplo, Cristoph Willibald Gluck,1714-1787 e Wolfgang Amadeus Mozart,1756-1791, reservaram um grande número de papéis protagonistas em suas óperas e missas em dedicação às mulheres.

O dualismo cartesiano faz ressurgir o contraste da coexistência de vozes femininas e masculinas, porém, como clamam em Janete el Haouli,1993, estas tornam-se reféns da moral burguesa vitoriana.

O corpo humano e a voz renascerão para uma nova incursão repressora de conteúdo essencialmente moral pelos sábios e filósofos do século XIX. (...) No mesmo século surge a moral vitoriana e a sexualidade camuflada da burguesia, há o advento do casal legítimo e procriador, que trancafia o erotismo no quarto, recobre o discurso com o decoro e oculta ou exclui os mais simples atos de desejo, como nos diz M. Foucault ${ }^{230}$

A voz também teve seu processo de libertação no século anterior e paulatinamente apresenta o resgate do ruído que vai se reintegrando à nova visão do corpo, tentando se desvencilhar da repressão, da dualidade ou artificialidade.

Aspecto interdisciplinar de seus trabalhos sobre voz. (...) Introdução à poesia oral significou o primeiro resultado, situa-se de fato num cruzamento interdisciplinar. (...) É fato que a voz é hoje objeto de estudo para numerosas ciências, ainda dispersas: a medicina (pensemos nos trabalhos de Dr. Tomatis), a psicanálise (já há extensa bibliografia sobre o tema, a mitologia comparada (de maneira muito parcial), a fonética (um belo livro de Fonagy surgiu há alguns anos) e, indiretamente, mas com grande pertinência, a linguística, em muitos de seus desenvolvimentos pós-estruturalistas, a pragmática, a análise do discurso, a teoria da enunciação. (...) alías, pela linguística que comecei minha pesquisa. Acrescente-se,quanto ao semiológico, tudo que concerne às formas de comunicção interpessoal; enfim, a sociologia das culturas populares (em autores como Ginzburg ou Burke) bem como a história da tradições orais $^{231}$

\footnotetext{
${ }^{230}$ HAOULI, Janete el. Demétrio Stratos: A escuta da voz - música. Dissertação de mestrado - ECA - USP, 1993. p.55.

${ }^{231}$ ZUMTHOR, Paul. Performance, Recepção, Leitura. Tradução: Jerusa Pires Ferreira e Suely Fenerich.
} 
Esta nova versão da interpretação da simbiose entre voz e corpo iniciou-se na música escrita do século XX com a interação dos músicos, poetas e teatrólogos.

A revolução industrial e o intenso barulho por ela gerado inserem na vida cotidiana o ruído-barulho. Este será fundamento do Futurismo e das artes de vanguarda da primeira metade do século passado,

\begin{abstract}
o ruído ganha status de elemento estrutural na composição. (...) A música do século $\mathrm{XX}$, pelo que mostram as mais diversas obras conhecidas, necessitam do virtuosismo técnico; em alguns aspectos, até mais que em épocas anteriores. A diferença reside no fato de que os referenciais estéticos não são mais os mesmos. A voz do século XX rompeu com 0 legato, o som redondo, valores inalienáveis do bel canto. Em contrapartida, incorporou sons vocálicos outrora banidos do universo da arte (soluço, sussurro, tosse, etc.); ou, dito de outro modo, agregou o ruído ${ }^{232}$
\end{abstract}

Alguns exemplos da introdução do ruído podem ser citados como a incorporação de sirenes, máquina de escrever, garrafafone, como instrumentação, como por exemplo: Parade, em 1916 de Eric Satie, Edgard Varèse, em 1931, Ionisation 10, composta para 37 instrumentos de percussão de altura indeterminada. Esta última experimentação estabeleceu que o parâmetro da altura (frequência) não seria mais imprescindível para a criação musical. ${ }^{233}$

Os recursos Sprechgesang, Sprechstimme e Sprechmelodie - situados nas mediações do canto falado - foram adotados por Arnold Schoenberg, como por exemplo, em Pierrot Lunaire de 1912. Neles a voz emite uma espécie de canto-falado que não se apoia em alturas fixas como as notas musicais, ou melhor, atinge a frequência exata do som, abandonando-a depois.

No despontar do século XX, uma nova vocalidade vai tomando impulso, em decorrência das várias contribuições afloradas a partir de uma acurada pesquisa realizada pelos compositores da Segunda Escola de Viena, que vai desde os primeiros experimentos, já na etapa inicial, até o emprego da técnica

Cosacnaify - São Paulo, 2010. pp.9 e 10.

${ }^{232}$ VALENTE, Heloísa de Araújo Duarte. Os Cantos da Voz - entre o ruído e o silêncio. São Paulo: Annablume, 1999. p.132.

${ }^{233}$ VALENTE, Heloísa. Op.cit. 
dodecafônica e seus desdobramentos.

A voz vai absorvendo o ruído para a música escrita com o canto sussurrado, sussurrado bem sonoramente, sussurrado sem sonoridade, falado sonoramente, e ainda, a declamação rítmica sugerida por Alban Berg na ópera Wozzek,1925.

Esse despertar para uma nova vocalidade proporcionou inúmeras experimentações que também contribuíram para o agregamento das múltiplas possibilidades de sons emitidos pelo aparelho fonador viessem a ser incorporados à música no século $\mathrm{XX}$.

As obras de Luciano Berio contrapõem-se deliberadamente à tradição da corrente surgida na Itália: o bel canto. ${ }^{234}$ "Expressão geralmente usada para se referir ao elegante estilo vocal italiano dos séculos XVII ao XIX, caracterizado pela beleza de timbre, emissão floreada, fraseado bem feito e técnica "fácil" e fluente." ${ }^{235}$

Muito embora este estilo tenha surgido na Itália, vários compositores de outros países se orientaram com o estilo de cantar italiano na edificação de suas óperas, como os alemães Georg Friedrich Haendel, Wolfgang Amadeus Mozart, Carl Maria Von Werber, dentre outros.

As obras de Luciano Berio,1925-2003, são um novo marco na pesquisa do canto. Em Sequenza III, 1966, temos o riso em suas diversas manifestações. O riso é absorvido em suas várias nuances, desde o sorriso, gargalhada, o riso nervoso, forte, fraco orientado por expressões vocais como: langoroso, terno, tenso, sonhador e não mais por sinais musicais meio-forte, forte, piano. ${ }^{236}$

Luciano Bério - conviveu com uma das maiores cantoras do século XX, Cathy Berberian que viveu de 1925 a 1983 - esta união muito propiciou outras novas experiências com a utilização das sonoridades emitidas para enriquecer a música no século XX.

Cantora norte-americana. Sua grande agilidade vocal e presença cênica marcante (estudou mímica e dança) chamaram a atenção de compositores de vanguarda; em 1958, apresentou obras de Cage em Roma e, em sua estreia norte-americana (1960, Tanglewood) fez Circles,

\footnotetext{
234 Belo cantar

235 SADIE,Stanley - verbete sobre o bel canto, p.90.

${ }^{236}$ VALENTE, Heloisa. Op Cit.
} 
de Berio. De 1950 a 1966 foi casada com Berio, que escreveu para ela Sequenza III, Visage e Recital I 237

A pesquisa sobre poesia no período aponta para a poesia fonética, o letrismo e a poesia sonora. A poesia fonética surge com os poetas futuristas e dadaístas. Ela visa obter uma linguagem fonética destituída de carga semântica.

A subversão da linguagem à ironia e ao humor baseados em uma linguagem pré-verbal, é o mote do dadaísmo. O próprio nome, Dada vem do balbuciar infantil. $\mathrm{O}$ aparelho fonador passa a ser uma espécie de laboratório, assim como na fase da primeira infância.

O Futurismo trabalha a língua dos loucos e dos folclores dialetais e cria uma linguagem transmental. Ele é contemporâneo ao dadaísmo, e, como tal, tem uma proposta de linguagem sem sentido, de palavras destituídas de significado. Porém o Dadaísmo apoia-se na linguagem infantil de comunicação pré-gramatical.

Futurismo: Movimento iniciado pelo escritor F.T. Marinetti (1876-1942) em 1909 , basicamente nas artes visuais, dedicado a criar uma arte apropriada para uma sociedade industrial. Foi adaptado à música pelo compositor F.B. Pratella (1880-1955) e por Luigi Russolo (1885-1947), pintor que se tornou músico em 1913 e criou obras feitas de ruídos de "intonarumori" ("entonadores de ruídos"). Uns poucos outros compositores adotaram por breves períodos os ideais futuristas, mas o interesse logo declinou; o movimento, no entanto, pode ter tido alguma influência sobre Varèse e possivelmente sobre Mosolov ( $A$ fundição, 1928). Alguns aspectos do futurismo musical anteciparam os métodos da musique concrète e eletrônica. ${ }^{238}$

Já, com o uso de onomatopeias, apresentando nova sonoridade da vida moderna, o futurismo italiano visa colocar as parole in libertà. Sucedeu-se o letrismo alguns anos depois, 1947, "radical como o dadá na experimentação acústica com sons não verbais produzidos pelo aparelho fonador humano (arroto, tosse, espirro, suspiro, etc.) é o último movimento de vanguarda anterior ao aparecimento da aparelhagem eletromagnética." 239

Surge então a poesia sonora:

Com o surgimento dos estúdios eletroacústicos nos anos 50 , a poesia oral das vanguardas dá lugar às potencialidades de modificação do som vocal, com efeitos de repetição, alongamento, contração, sobreposição

\footnotetext{
237 SADIE,Stanley. Op.Cit. p. 96.

238 SADIE,Stanley - verbete sobre Futurismo, p.350.

${ }^{239}$ MENEZES, Philadelpho. Poesia Sonora: Poéticas Experimentais da Voz no Século XX. 1992.
} 
de fonemas nunca antes ouvidos. Os poetas, denominados então sonoros, associam-se aos músicos concretos e eletroacústicos ${ }^{240}$

Tomando a voz em sua materialidade pura, explorada no seu aspecto sonoro, por intermédio da manipulação dos recursos da eletroacústica, a poesia sonora conseguiu reunir um conjunto de obras que poderiam ser encaradas como obras musicais ${ }^{241}$

Se as vanguardas históricas haviam mantido uma marca nítida da poética em seus experimentos fonéticos, ainda que em ruptura com os cânones clássicos, e uma distinção mais ou menos clara entre poesia e canto, a poesia sonora e as músicas concreta e eletrônica pareciam buscar, ao contrário, o definitivo cancelamento de suas diferenças ${ }^{242}$

Os caminhos apontados na pesquisa desenvolvida por Antonin Artaud foram decisivos para o teatro. O Teatro Alquímico, 1932, e principalmente $O$ Teatro e seu Duplo, 1938, são baluartes para os estudos sobre a voz e corpo. Eles seriam pesquisados mais intensamente nos anos 60 , pelos estudos vocais de Jerzy Grotowski. Deve-se citar também Roy Hart e o seu Roy Hart Theatre, cujo trabalho remete a Alfred Wolfsohn.

Wolfsonh tornou-se professor de canto após ter escapado para Londres depois de intensas experiências como soldado na primeira grande guerra. A partir de uma perspectiva holística, ele desenvolveu um método em que os cantores, chegavam a um alcance vocal de seis oitavas. Dizia: "A voz é o músculo da alma."

Seu aluno na década de 50, Roy Hart, difundiu suas pesquisas na década de 60 através do Roy Hart Theatre. Noah Pikes, do qual é integrante e cofundador, propaga essas ideias através da publicação, em 1999, do livro chamado "Dark Voices - the Genesis of Roy Hart Theatre".

Jean-Jacques Roubine diz:

as vozes, os ruídos e a música no teatro de Artaud têm o objetivo de atingir fisicamente o espectador no mais profundo do seu ser, onde a voz é arrancada das profundezas do corpo humano, onde as palavras devem ser utilizadas num sentido encantatório, em função de sua forma, de suas emanações sensíveis, e não mais do seu significado

Grotowski também buscou vozes não audíveis e, de acordo com Roubine:

\footnotetext{
${ }^{240}$ MENEZES, Philadelpho. Op.Cit.p.13.

241 VALENTE, Heloisa. Op.Cit.p. 155.

242 MENEZES, Philadelpho. Op.Cit.p.14.
} 
O corpo humano, segundo observação de Grotowski, só utiliza no cotidiano uma parte ínfima dos seus recursos vocais. Isso vale também para 0 ator ocidental, e até mesmo para o cantor. Um treinamento adequado capacitará o ator a fazer sair de dentro de si mesmo, e, portanto a explorar, vozes literalmente inauditas, que parecerão emanar de diferentes pontos de seu organismo: occipício, plexo solar, ventre etc.. São essas zonas que ele denomina caixas de ressonância. Desse modo, o ator grotowskiano disporá de uma paleta sonora inteiramente nova, e mil vezes mais rica do que a do intérprete convencional, que geralmente só domina a caixa de ressonância da laringe. No caso, a voz pode tornarse, à vontade, esse ruído ao mesmo tempo humano e desumano suscetível de transtornar o ouvinte, essa pura energia sonora, em busca da qual Artaud também se havia lançado. *Já Artaud havia lamentado que $o$ ator ocidental se tivesse tornado incapaz de emitir um verdadeiro grito... ${ }^{243}$

Luis Otávio C. G. de Souza, em seu trabalho também argumenta que:

É muito importante destacar o fato de que, na música da cena artaudiana, vamos encontrar nitidamente a manipulação de características do som, que eram, também, objeto de pesquisa nas tentativas revolucionárias dos músicos contemporâneos, como, por exemplo, Edgar Varèse. Pierre Boulez, um dos nomes mais expressivos no panorama da música atual, declarou: Pude encontrar em Artaud, as preocupações fundamentais da música atual; tê-lo visto e ouvido ler seus próprios textos, acompanhados de gritos, ruídos e ritmos, mostrou-nos como efetuar uma fusão do som e da palavra, como fazer explodir o fenômeno, quando a palavra nada mais consegue; em resumo, como organizar o delírio ${ }^{244}$

Artaud explorava os sons, os ruídos, os timbres e as pulsações da palavra, da música de instrumentos, da voz e do corpo do ator, buscando articular, essencialmente as vibrações e os ruídos em vez da melodia e do ritmo mensurado 245

Heloísa Valente ${ }^{246}$ discorre alguns pontos em seu livro de 1999, "Os Cantos da Voz - entre o ruído e o silêncio:"

a) A aquisição do ruído, representado por sons anteriormente banidos do universo da arte (arrotos, tosse, gritos, etc.) e pela voz "mal" colocada, isto é, sem a impostação tradicional do bel canto;

b) A utilização dos recursos da eletroacústica, que permite recompor o som vocal em seus harmônicos, reorganizá-los; submetê-los ainda à sobreposição, aceleração ou retardo, repetição, fragmentação, retrocesso

\footnotetext{
${ }^{243}$ ROUBINE, Jean-Jacques. A Linguagem da Encenação Teatral. 1998.p.164.

${ }^{244}$ SOUZA, Luis Otavio C. G. de. A Música e os Efeitos Sonoros na Cena Teatral: Reflexões sobre uma Estética.1999.p.42.

${ }^{245}$ SOUZA, Luis Otavio C. G. de. A Música e os Efeitos Sonoros na Cena Teatral: Reflexões sobre uma Estética.1999.p.42.

${ }^{246}$ VALENTE, Heloisa. Op Cit.p. 164.
} 
etc.; inclui-se nesse item a recuperação do ruído, banido do bel canto;

c) O rompimento da integridade do texto linguístico, muitas vezes fragmentado, com vistas a uma utilização meramente dos elementos fonéticos, sobretudo após a introdução do pontilhismo serial; o rompimento semântico coincidindo, muitas vezes, com uma escritura pontilhista da parte vocal, evitando o fraseado melódico tradicional;

d) A eliminação da fronteira entre som vocal e signo linguístico, portador de significação precisa, permitindo à música engendrar gestos (também vocais) como expressão de afetos, subjacentes à expressão verbal;

e) A voz extraída de seu uso cotidiano, banal, submetida a um tratamento musical bem mais complexo, exigindo virtuosidade por parte do executante, e por fim;

f) A incursão, na música, de expressões vocais não linguísticas (grito, sussurros, choro, riso, etc) despojadas de seus valores afetivos e encaradas como elementos expressivos de uma linguagem musical de horizontes mais amplos como, por exemplo, o riso em Sequenza III, de Berio, também o inverso: expressões emotivas transportadas diretamente para a linguagem musical (que podem ser ouvidas em Eight songs for a Mad King, de Peter Maxwell Davis, 1969).

Todos esses fatores vieram contribuir para um significativo enriquecimento de uma nova vocalidade fazendo com que o despertar já impulsionado a partir da prospecção da Segunda Escola de Viena viessem abrir novas possibilidades, na questão do som de frequências indeterminadas, nos planos horizontal e vertical da música.

\section{4 - A Voz Cantada}

Para a composição da voz humana, falada ou cantada, deve-se sempre considerar que o corpo é o aparato material que lhe dá apoio. É necessário que se trabalhe o corpo para a projeção e o desenvolvimento da voz para que ela alcance os espaços com brilho, aveludamento, potência, flexibilidade, velocidade, sustentação e força dramática e expressividade. 
O corpo necessita ser trabalhado de forma intensa e de ser exercitado profundamente para que se atinja a expressão máxima da materialização da voz. Este é o principal desafio do profissional do canto.

É certo que o profissional da voz cantada deve ter como requisitos desejáveis do aparelho fonador: a obtenção do tônus ideal, com vigor e relaxamento, perfeitamente sincronizados e o mecanismo fono-respiratório perfeitamente articulado.

É desejável que o corpo tenha a liberdade de expressar os estados emocionais através das inflexões vocais podendo abranger uma larga amplitude da gama de nuances dos parâmetros do som para que tornem este em uma unicidade expressiva.

A projeção da voz em um volume é viável devido a integração interativa da escuta, do corpo e do som. Então, é a audição da própria voz e outros sons que funciona como filtro de realimentação e avaliza as correções necessárias e indica um direcionamento seguro.

O canto é produzido em um corpo e está sujeito às emoções vivenciadas, repassando-as por meio de diversos sinais. Ele ocupa uma série temporal no espaço físico. A harmonização entre o som puro (música) e o verbo (palavra) é uma argumentação básica na arte do canto. Em relação a esta arte a discussão não se esgota, pois, a voz humana é o único instrumento que reúne no mesmo corpo, executante e meio de execução. ${ }^{247}$

Há diversos argumentos a considerar e Paul Zumthor defende:

O que quer que evoque, por meios lingüísticos, o texto dito ou cantado, a performance lhe impõe um referente global que é da ordem do corpo. É pelo corpo que nós somos tempo e lugar: a voz o proclama, emanação de nós ${ }^{248}$

Uma compreensão propiciada pela íntima organicidade de um conjunto de ações com voz-corpo-gesto-espaço forma um todo coeso, que permite compreender o domínio de uma ocasião onde o desempenho é fundamental.

\footnotetext{
${ }^{247}$ VALENTE, Heloisa. Op cit.

248 ZUMTHOR, Paul. A Letra e a Voz. 2001.
} 
Hesíodo, poeta grego expoente da era arcaica, viveu por volta de 800 a.C. na Beócia, região situada na região central da Grécia. Em "Teogonia, $A$ Origem dos Deuses, de Zeus e Memória geram as Musas", em sua poética Hesíodo propugna que as Musas são o Canto e o Canto é Presença.

Então, as palavras cantadas são forças divinas e só a força nomeadora da voz das Musas pode retirar os seres e fatos passados e futuros do reino noturno do esquecimento, isto é, da força de ocultação e torná-los presentes, mostrá-los à luz, em uma revelação.

Há uma unidade entre o canto e a dança, entre a voz e o gesto. As Musas, invisíveis são ocultas por muita névoa e manifestam-se exclusivamente com o canto e o som da dança dentro da noite. Uma procissão de cantorasdançarinas faz surgir, por suas vozes e gestos, os deuses. Segundo Jaa Torrano, no prefácio de Teogonia, 1992 - livro que traduziu:

\begin{abstract}
Em verdade, o mo(vi)mento do Cantar ( das Musas ) é analogicamente o mo(vi)mento mesmo do que o Cantar presentifica, já que o Cantar é Ser. As musas nascidas na Piéria não vêm à luz de um tempo preexistente a elas e indiferente à existência ou inexistência delas, pois não há, para Hesíodo e sua época, essa preexistência incondicional do tempo. Assim como cantar é a função pela qual as Musas se dão como Musas, já que musa é essa força divina que canta em cada cantar, - o tempo, em que as Musas nascem, nasce como a temporalidade própria das Musas e, além deste tempo qualificado e originado pelo nascimento - natureza das próprias Musas, não há para elas nenhum outro tempo a que a Presença absoluta dessas deusas possa ser referida. A presença luminosa, por excelência, só se refere a Si mesma, e, ao dar-Se como Presença o Deus, sua Presença impõe-Se e impõem, como única remissão e referência possível ante sua Presença, a remissão e referência a Si mesma $^{249}$
\end{abstract}

A partir desse relato de Hesiodo pode-se concluir que a força do canto é que se faz presente. O momento torna viável a existência de algo que advém do caos, do esquecimento, da ocultação e é revelado. O presente mesmo se autoimpõe tendo a si próprio como referência.

Originado do Caos, com criatividade assume uma forma no presente, de palavras cantadas, uma vez que a Musa é uma força divina que canta em cada cantar. Assim, canto e a dança, a voz e o gesto, são uma unidade e a presentificação dessa unidade.

${ }^{249}$ HESÍODO. Teogonia, A Origem dos Deuses. Estudo e Tradução de Jaa Torrano. 1992.p.84. 


\section{Paul Zumthor afirma que $O$ Canto é Presença.}

Um laço funcional liga de fato à voz ao gesto: como a voz, ele projeta o corpo no espaço da performance e visa conquistá-lo, saturá-lo de seu movimento. A palavra pronunciada não existe (como o faz a palavra escrita) num contexto puramente verbal: ela participa necessariamente de um processo mais amplo, operando sobre uma situação existencial que altera de algum modo e cuja totalidade engaja os corpos dos participantes. Marcel Jousse, ao cabo de vinte anos de pesquisas e de tentativas de descer às próprias raízes da espontaneidade expressiva, colocava como indissociáveis o gesto e a palavra, num dinamismo complexo que ele chamava de verbomotor. A partir de outras premissas, e na perspectiva da performance, Brecht criou para si a noção de gestus, envolvendo, com o jogo físico do ator, certa maneira de dizer o texto e uma atitude crítica do locutor quanto às frases que ele enuncia. $\mathrm{Na}$ fronteira entre os dois domínios semióticos, o gestus dá conta do fato de que uma atitude corporal encontra seu equivalente numa inflexão de voz, e vice-versa, continuamente ${ }^{250}$

Não se podem precisar os conceitos de corpo, voz e escuta quando se questiona sua essência. A intuição aponta sobre a consistência da íntima relação entre voz falada, voz cantada e corpo.

Essa discussão não é óbvia e é muito importante para a reflexão acerca das várias estéticas que são apresentadas como possibilidades e não como verdades únicas inquestionáveis, e para o entendimento da voz no mundo contemporâneo.

Dentro da História, o corpo e suas reflexões assumem significados díspares e que variam em culturas diferentes. Para sua compreensão e definição se fazem necessários conceitos de filosofia, de ciências cognitivas, biologia, antropologia, psicologia e do pensamento artístico sobre o corpo.

O corpo é um ente complexo. Para ele caminham e dele saem informações de um espectro diversificado. Não se restringe aos ambientes biológicos e psicológicos. Dessa base material da voz,

A diferença entre discutir "o corpo" ou "as suas corporeidades" permite o enuciado das hipóteses de pesquisa para "diferentes estados" de um corpo vivo, em ação no mundo ${ }^{251}$

O que interessa aqui é perceber que a imagem do corpo alimentou o esquema do corpo, para que pudesse ser organizado novamente ${ }^{252}$

(...)

\footnotetext{
250 ZUMTHOR, Paul. Poesia do Espaço. In Poesia Sonora: Poéticas Experimentais da Voz no Século XX. 1992.p.243.

${ }^{251}$ GREINER, Christine. O Corpo - Pistas para estudos indisciplinares. São Paulo: Anablume, 2005.p.22.

252 GREINER, Christine. O Corpo - Pistas para estudos indisciplinares. São Paulo: Anablume, 2005.p.102.
} 
Assim, lembrando o corpo - organismo, o corpo sem órgãos, o corpo como plataforma semântica e o corpo treinado, percebe-se que se a metáfora muda, muda o entendimento ontológico do corpo e sua possibilidade de experimentação ${ }^{253}$

A hipótese que a mudança sistemática da ideia sobre o corpo gera a alteração na compreensão ontológica do corpo e sua possibilidade de experimentação é desafiadora. Ela permite a reflexão sobre as diversas estéticas vocais situadas no espaço geográfico e do tempo histórico.

O entendimento da voz cantada no mundo contemporâneo em um corpo é desafiador e é organizado a partir de outra metáfora, que certamente, não é aquela vinculada ao século XIX.

$\mathrm{Na}$ percepção conceitual da voz, na atualidade, entende-se que ela prove de um corpo que se concebe com liberdade plena e admite suas imperfeições, contradições, ruídos, dimensão sensorial e até agressividade.

Outras formas possíveis de experimentação vocal só foram viabilizadas, devido ao novo posicionamento que vai ocorrendo ao longo do século XX.

Neste contexto, a voz artística parte do pressuposto sobre o corpo e sua relação com o mundo. Nesta abordagem permite-se uma compreensão da produção da estética delineada, e desperta a voz para uma nova vocalidade que é gerada a partir de um "novo" corpo, de um "novo" pensar, e "nova" escuta, agora enriquecida daquilo que fora evitado até então.

A escuta interage ativa e simultaneamente sobre a base corporal e um influi na produção vocal que age sobre o outro.

${ }^{253}$ GREINER, Christine. O Corpo - Pistas para estudos indisciplinares. São Paulo: Anablume, 2005.p.122. 


\section{Uma Nova Vocalidade para a Música escrita no século XX}

Mas é outra voz - outra escuta à qual nos convida nossa música mais recente - que se recusa a pensar o uno, que se recusa a reduzir o ato vocal ao produto de uma cadeia causal unívoca ${ }^{254}$

É inevitável todo ator passar pelo momento em que ele perde a voz várias vezes, mas se ele tem conjugado com isso, todo um trabalho científico e poético, ele novamente aprende a falar, a balbuciar de novo... Eu acho que a voz é uma coisa que cada peça inventa, cada peça talvez derrube as vozes que existem, construindo outras, sendo necessário aprender a falar tudo de novo ${ }^{255}$

A conclusão dos estudos sobre voz e corpo vão do erudito, ao popular e ao étnico. As múltiplas faces e cores da voz trazem e revelam outras técnicas, formas e sensibilidades artísticas possíveis.

Obtendo quase um caráter semelhante o de um ritual de iniciação, artistas tentam recuperar para a voz uma ampla dimensão performática e corporal. Por exemplo, em seu trabalho Demétrio Stratos: A Escuta da Voz-Música - a autora Janete El Haouli versa sobre Demétrio e Meredith Monk.

As intensivas experimentações que Demetrio Stratos, 1945-1979, desenvolveu em seu trabalho de cantor solista são encaradas como verdadeiros estudos sobre voz, e ainda, as pesquisas vocais especialmente embasadas por importantes fonoaudiólogos como novos parâmetros vocais, são decididamente um marco nesse percurso da voz na época atual.

Demétrio inaugura o tempo do fragmento ou o tempo do ruído como uma presentificação do instante onde ocorre uma interação de eventos sonoros ao acaso. Assim não se admite a voz como uma linearidade préconstituída simbolicamente por certas construções objetivadoras, como no canto lírico. A voz não se deixa amordaçar porque quer gemer de prazer. (...) A desmetaforização da voz ocorre no trabalho de Demetrio Stratos pela ruptura do tempo linear dessas convenções vocais. Cria tempo de ritual, tempo do que é simultâneo e não entendido como isolado e único. Limpa-se a voz de qualquer significado fixo e sujeito a uma interpretação "verdadeira", definitiva. O que a voz de Demétrio reclama é a improvisação, aquilo que no instante se apresenta como irrepetível e não passível de fixação monolítica. A indeterminação é desejada como sedução. Tempo de erotização, prelúdio ao ato sexual,

\footnotetext{
254 ZUMTHOR, Paul. Poesia do Espaço. In Poesia Sonora: Poéticas Experimentais da Voz no Século XX. 1992.p.21.

${ }^{255}$ GAYOTTO, Lúcia Helena. Voz - Partitura da Ação.p.22. (Este trecho faz parte da entrevista que me foi concedida pelo diretor teatral Zé Celso Martinez Correa da Companhia Teatßo Oficina Uzyna Uzona, em 1994 durante a temporada da peça "Ham-let", dirigida por ele).
} 
onde a voz é um aglomerado de sussurros, gemidos, sopros e gritos. Grito do recém-nascido, grito de guerra, grito do Xamã... a voz de Stratos não é "neutra." Ela é puro desejo de um corpo que se canta ${ }^{256}$

\section{O sistema de emissão vocálico do século $\mathrm{XX}$, especialmente a partir} dos anos 60 busca a sua materialidade nesse novo contexto. Inúmeras discussões filosóficas, psicológicas, antropológicas, biológicas, científicas que vão se cruzando e gerando outra sensibilidade artística que irá buscar expressar em um "outro" corpo que a partir de agora procura se aceitar por inteiro, imperfeitamente natural, para além de todas as convenções civilizatórias ao qual já fora submetido.

Murray Schafer, em seu livro O Ouvido Pensante, disse na década de 60 do século $X X$ :

O vocabulário básico da música se modificará. Falaremos talvez de "objetos sonoros", de "envelopes" e transientes de ataque em vez de "tríades", sforzando e appoggiatura. Sons isolados serão estudados mais atentamente, e se prestará atenção aos componentes de seus espectros harmônicos e às suas características de ataque e queda. O estudo será talvez dirigido à descrição da música em termos de frequências exatas ou faixas de frequência, em vez da limitada nomenclatura do sistema tonal. (...) A psicologia e a fisiologia da percepção de padrões auditivos suplantarão muitos estudos musicais passados, em que os sons musicais eram emudecidos por exercícios escritos, (Os livros tradicionais de teoria negam vida aos sons, considerando-os como cadáveres imóveis.) ${ }^{257}$

\section{Murray Schafer continua:}

Quanto mais a língua se torna civilizada, tanto menor a quantidade de exclamações e interjeições, menos os risos e inflexões que a voz adota. O lingüista Otto Jespensen conjeturou sobre as razões para isso: Agora, é uma consequência do avanço da civilização que a paixão seja moderada, e, desse modo, podemos concluir que a fala dos homens não civilizados e primitivos era mais apaixonadamente agitada que a nossa, mais parecida com o canto ${ }^{258}$

\section{(...)}

Não comecei com o canto tradicional. Pelo contrário, minha intenção foi trabalhar com o som vocal bruto, recomeçar tudo como os aborígines, que nem sabem a diferença entre fala e canto, significado e sonoridade. Gostaria de poder cantar esta parte, e entoa-la, sussurrá-la e gritá-la. Quero tirá-la de seu sarcófago impresso. Ela precisa ser tocada no instrumento humano 259

\section{$(\ldots)$}

\footnotetext{
${ }^{256}$ HAOULI, Janete el. Demétrio Stratos: A Escuta da Voz-Música.1993.p.37.

257 SCHAFER, Murray. O Ouvido Pensante. 1992. pp.122 e123.

258 SCHAFER, Murray. O Ouvido Pensante. 1992.p.208.

259 SCHAFER, Murray. O Ouvido Pensante. 1992.p.235.
} 
Como podemos liberar a linguagem de seu sarcófago impresso? Como podemos quebrar os ataúdes cinzentos de murmúrios e permitir que as palavras uivem da página, como que possuídas por espíritos? Os poetas tentaram. Primeiro, os dadaístas e futuristas, e agora os poetas concretistas de nosso tempo ${ }^{260}$

A abertura da escuta para outros sons que o corpo é capaz de produzir e disso fazer música ainda é algo incipiente no início do século XX. A voz no mundo contemporâneo projeta-se como fruto de uma nova compreensão sobre 0 corpo e sobre a escuta.

Com a nova apreciação sobre o corpo, a voz habita o corpo em sua íntegra e, portanto, incorpora todos os sons possíveis a serem produzidos por este corpo. Simultaneamente, são abertas possibilidades que permitem a escuta de outros sons antes banidos do universo da arte.

Também, a experiência e o legado de Antonin Artaud foram radicais e seminais, muito provavelmente por trabalhar com profundidade em termos da unidade entre corpo e voz. A existência da voz ocorre pela libertação do corpo em um processo encadeado a partir de várias frentes, onde, porém não foram únicos.

Houve também, grande influência da dança de Nijinsky, Mary Wigman ou Isadora Duncan sobre as questões corporais e o mental desde o início do século XX.

tanto na sua componente semântica e lógica quanto na sua componente sonora, uma força material, um verdadeiro ato põe em movimento, dirige, dá forma, pára. $\mathrm{Na}$ verdade, pode-se falar em ações sonoras que provocam uma reação imediata naquele que é atingido. Como uma mão invisível, a voz parte do nosso corpo e age, e todo o nosso corpo vive e participa desta ação. O corpo é a parte visível da voz (...) A voz é o corpo invisível que opera no espaço. Nâo existem dualidades, subdivisões: voz e corpo. Existem apenas ac̃ões e reações que envolvem o nosso organismo em sua totalidade ${ }^{2 \hat{b} 1}$

A apreciação de três influências decisivas: as pesquisas da poesia fonética e sonora, as pesquisas teatrais com corpo e voz e as pesquisas das músicas concreta, eletroacústica e indeterminada, permitem uma melhor compreensão do ambiente. Após décadas, até o final dos anos 50 , para que uma nova estética da voz principiasse a se configurar de fato.

\footnotetext{
${ }^{260}$ SCHAFER, Murray. O Ouvido Pensante. 1992.p.236.

${ }^{261}$ BARBA, E. Além das llhas Flutuantes. Trad. Luis Otávio Burnier. São Paulo - Campinas: Hucitec/Editora da UniCamp, 1991.p.56.
} 
Este trabalho não abordará o estudo aprofundado desse período mais recente, mas propõe-se a analisar apenas o seu despertar na delimitação do conjunto de obras, já citado como objeto de estudo, cujos exemplos abrangem desde a etapa inicial de composição até 0 dodecafonismo e seus desdobramentos.

O novo perfil da voz inicia-se no final dos anos 50 , desenvolve-se nos anos 60 e 70 do século XX e caminha até os nossos dias no século XXI, quando agora, aos poucos, vai sendo descoberta; seu despertar tem raízes a partir das intensas pesquisas sobre um substitutivo ao diatonismo na prospecção de Arnold Schoenberg. Esse despertar desde seu início também esteve afinado com pesquisas em voz na área de teatro. Eis que Pierrot Lunaire foi uma proposta de trabalho ao compositor Arnold Schoenberg, idealizada pela atriz Albertine Zehme.

Então veio Pierrot Lunaire com a Sra. Zehme. Duas ou três vezes por semana, com a primeira correspondência, eu recebia uma nova peça de Pierrot e ia ensaiar a Sra. Zehme em sua casa, Olivaerplatz, 40. Ela era uma atriz aposentada que ainda tinha ambições artísticas e algumas ideias estranhas, incluindo a identificação que ela tinha com 0 personagem Pierrot. Foi ideia dela de escrever a partir de um livro de poemas de Otto Erick Hartleben, que traduziu o texto de Albert Giraud da língua francesa. Primeiro ela pediu a um compositor chamado Friesländer escrever alguns acompanhamentos para piano, os quais ela usou ao recitar os poemas de Pierrot. Mas de algum jeito ela não estava satisfeita com essa música, e uma vez que alguém a disse que havia um compositor chamado Schoenberg que dizia-se ser um grande gênio, ela o pediu para escrever a música para os poemas de Pierrot, e ele aceitou fazê-lo. GS: Qual foi a reação dele ao texto? ES: Ele achou alguns trechos um pouco indecentes. Lembro de uma vez estar presente quando ele disse à Sra. Zehme, "Da schauen Sie, das ist doch nicht wirklich Ernst zu nehmen! Das machen wir doch nicht mit!", mas no final das contas, tais coisas pareciam de alguma forma inspirá-lo, e Pierrot é, é claro, a melhor prova disso. A princípio, Sra Zehme queria que Schoenberg usasse apenas um piano; seu contrato com ela também estipulava que haveria uma turnê em catorze ou quinze cidades, portanto o tamanho do conjunto era uma consideração muito importante. Mas como Schoenberg era Schoenberg, a primeira coisa que ele fez foi ligar para Sra Zehme e avisá-la que ele já havia escrito a primeira peça para piano e clarineta (essa era "Gebet na Pierrot"). Logo em seguida ele a telefonou noamente para perguntar se ele poderia também usar uma flauta. Então veio a terceira peça, que agora é a primeira - "Den Wein, den man mit Augen trinkt" - e muito em breve ele já tinha clarineta, flauta, violino e violoncelo. Então, já que ele queria mais variedade instrumental, teve a ideia de que cada peça deveria ter um conjunto de instrumentos diferentes, alternando flauta com Piccolo, clarineta com clarineta baixo, e violino com viola (que 
era na época muito incomum - nosso violinista Maliniak com certeza não estava acostumado a isso) ${ }^{262}$

A "nova" estética vocal inicialmente foi encarada como não música na ambiência da música erudita, tanto quanto boa parte da música contemporânea tem sido encarada. Entre os eruditos ainda é muito forte a estética do bel canto, do canto lírico. Embora o processo de incorporação desta nova vocalidade para a música escrita se apresente bastante moroso, fora do âmbito erudito há várias experimentações e até tradições que desde períodos muito anteriores empregaram o ruído em seu cantar. Por vezes, tornaram-se o estilo de cantar ou referencial de voz, próprios. Verifica-se bastante isto na música popular, na música popular experimental - que abrange procedimentos conhecidos como populares. Dentre os vários motivos de sua não aceitação, muito provavelmente, está o fato de que uma melhor precisão no registro dessas formas de expressão esbarra na limitação do sistema de grafia tradicional, o que impede que esta nova vocalidade venha a se disseminar com maior despojamento e rapidez.

O rock em todas as suas formas é um exemplo típico da introdução e já tradição do ruído. Houve uma explosão do emprego do corpo e da voz em larga escala. O grito primal, as risadas, os gemidos de dor e de prazer, urros e suspiros, som de cuspe, de vômito, palavras sem valor semântico, vozes utilizadas em seus registros limites, o som fry, o canto falado, etc, são constituintes da voz no estilo rock, em maior ou menor destaque, ou em algum nível de caráter experimental, mas que foram o seu principal diferenciador.

Por exemplo, o próprio pesquisador Demetrio Stratos, antes de realizar seu trabalho solo no âmbito da música contemporânea, cantava em um grupo italiano de rock progressivo Area.

Pode-se entender que três grandes vetores forjaram a estética da voz do século $X X{ }^{263}$

a) as transformações radicais da música no século $X X$, sobretudo com o

\footnotetext{
262 SCHULLER, Gunther \& STEUERMANN, Eduard - A Conversation with Steuermann - Perspectives of New Music, Vol. 3, No. 1 (Autumn - Winter, 1964), pp. 22-35. - URL: http://www.jstor.org/stable/832234.

${ }^{263}$ BECKER, Susie. A Voz Contemporânea. 2008.
} 
advento da música eletroacústica;

b) a poesia, com o surgimento da poesia fonética e posteriormente a poesia sonora; e

c) as pesquisas teatrais com a voz. 


\section{Questões Vocais e Interpretativas}

Para a abordagem das questões interpretativas, este conjunto de obras vocais pode ser dividido tanto pelos seus gêneros, como no capítulo 2 da parte II deste trabalho, ou ainda, pelos aspectos estilísticos nos quais estão historicamente inseridos, como aqui a seguir. Por isto pode-se notar que o lied de Edward Steuermann ora se encontra em um grupo separado pelo gênero, ora em outro grupo pelo estilo.

Para representar a fase do tonalismo expandido, dois lieder do compositor Alban Berg, Nacht e Die Nachtigall do ciclo Sieben Frühe Lieder, de 1905-08.

Para representar a fase do atonalismo-livre, do compositor Arnold Schoenberg, Nacht - o Melodrama №8 de Pierrot Lunaire, de 1912, e, para representar a fase do atonalismo estruturado ou organizado, do compositor Edward Steuermann, o lied no 1 - Der Mensch - dos Drei Lieder, de 1931, e ainda, de Anton Webern, os Movimentos I, IV e $V$ que podem representar o canto individual de voz masculina e feminina, o canto-solo e o canto coletivo na Cantata nำ, de 1943, peça para coro misto e vozes solistas.

\section{Os dois lieder do ciclo Sieben Frühe Lieder - 1905-1908 - Alban Berg para representar a fase da tonalidade expandida: a etapa inicial}

Historicamente os lieder de Alban Berg estão inseridos na etapa inicial de composição tonal, conforme George Perle:

Nessa ocasião, Berg estava quase no final de sua aprendizagem. As Sete Primeiras Canções (1905-1908), que ele revisou e publicou em 1928, são ainda na tradição do romântico lied germânico e mostram influências que vão desde Schumann até o Schoenberg inicial. A Sonata para Piano, opus 1 (1907-1908), em um movimento, recapitula em uma escala em miniatura os principais aspectos das obras tonais mais avançadas do mestre, de 1904-1908. A interação complexa e a transformação de poucas unidades motívicas geram tanto o material melódico quanto o acompanhamento dos componentes temáticos mais longos. As resoluções tonais claras em pontos estruturais salientes 
conferem um sentido à obra como um todo, apesar do alto grau de cromatismo e da ambiguidade tonal ${ }^{264}$

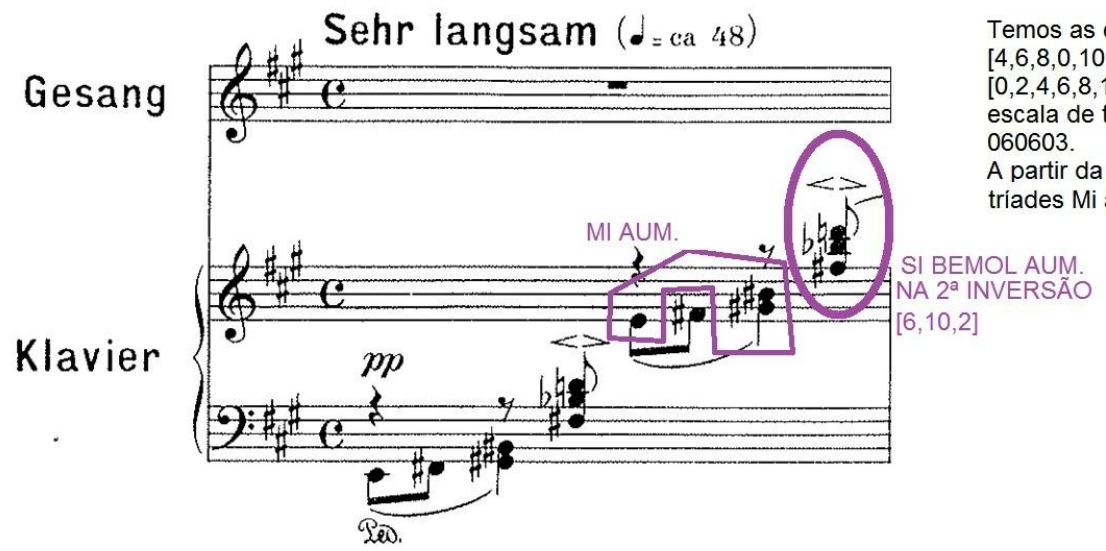

Temos as classes de alturas, em ordem,

[4, $6,8,0,10,2]$, sendo sua forma normal

$, 2,4,6,8,10]$. Berg utiliza-se, portanto, da 060603.

partir da escala hexatônica, Berg constroi as

triades Mi aum. e Si bemol aum.

Figura 60 (12) - Compasso inicial de Nacht de Berg
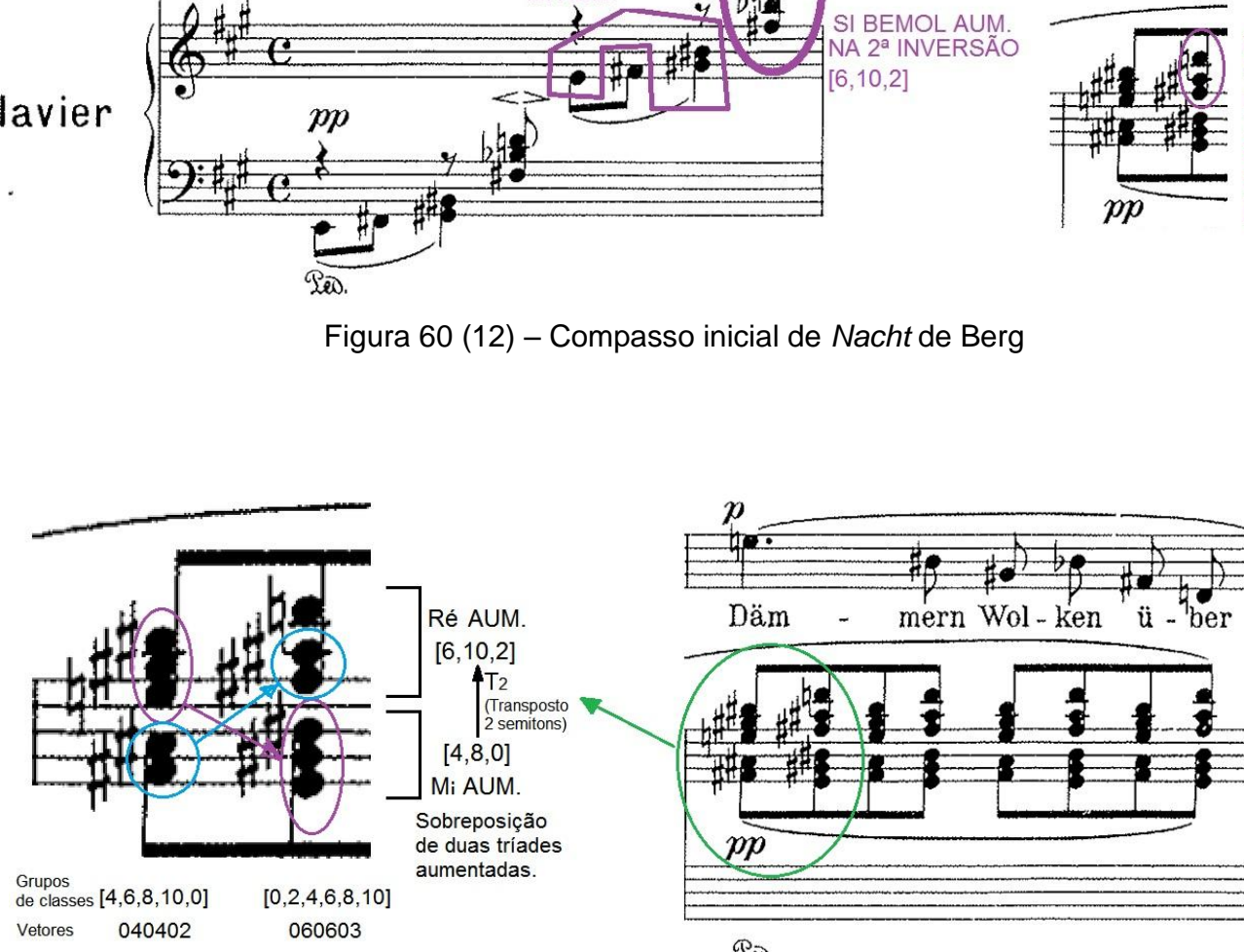

NO COMPASSO 2 É FORMADA A TRÍADE DE RÉ AUM. NA $1^{a}$ INVERSÃO ENARMÔNICA DE SI BEMOL AUM.

$[6,10,2]$
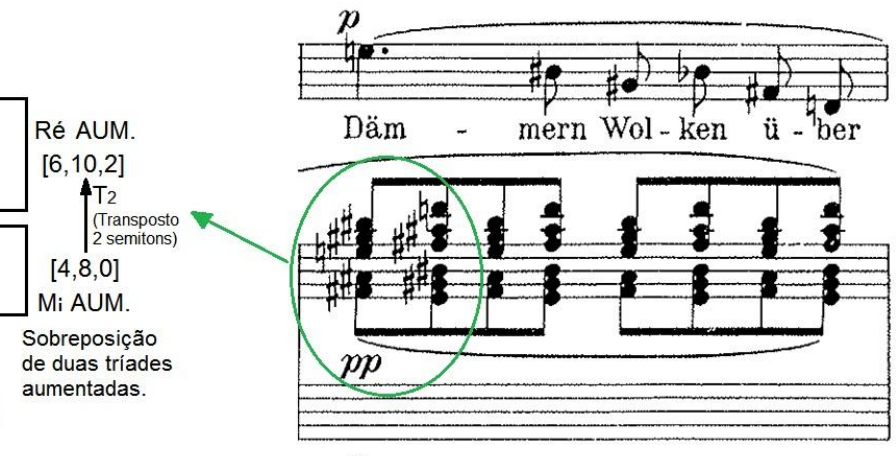

T20.

Figura 61 (13) - Destaque para os acordes aum. dos compassos iniciais de Nacht de Berg

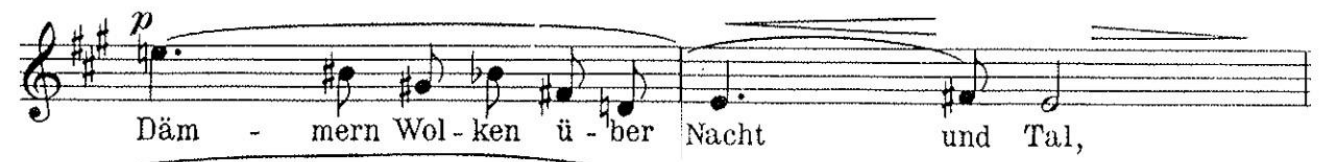

A melodia dos compassos 2 e 3 é composta pelo grupo de classes de altura $[0,2,4,6,8,10]$, ou seja, a escala de tons inteiros. Observe os intervalos de $3^{\mathrm{a}}$ e $4^{\mathrm{a}}$ diminutas, que até então não eram muito utilizados.

Figura 62 (11) - Melodia inicial da partitura de Nacht de Berg

${ }^{264}$ PERLE, George. Berg.p.158. 


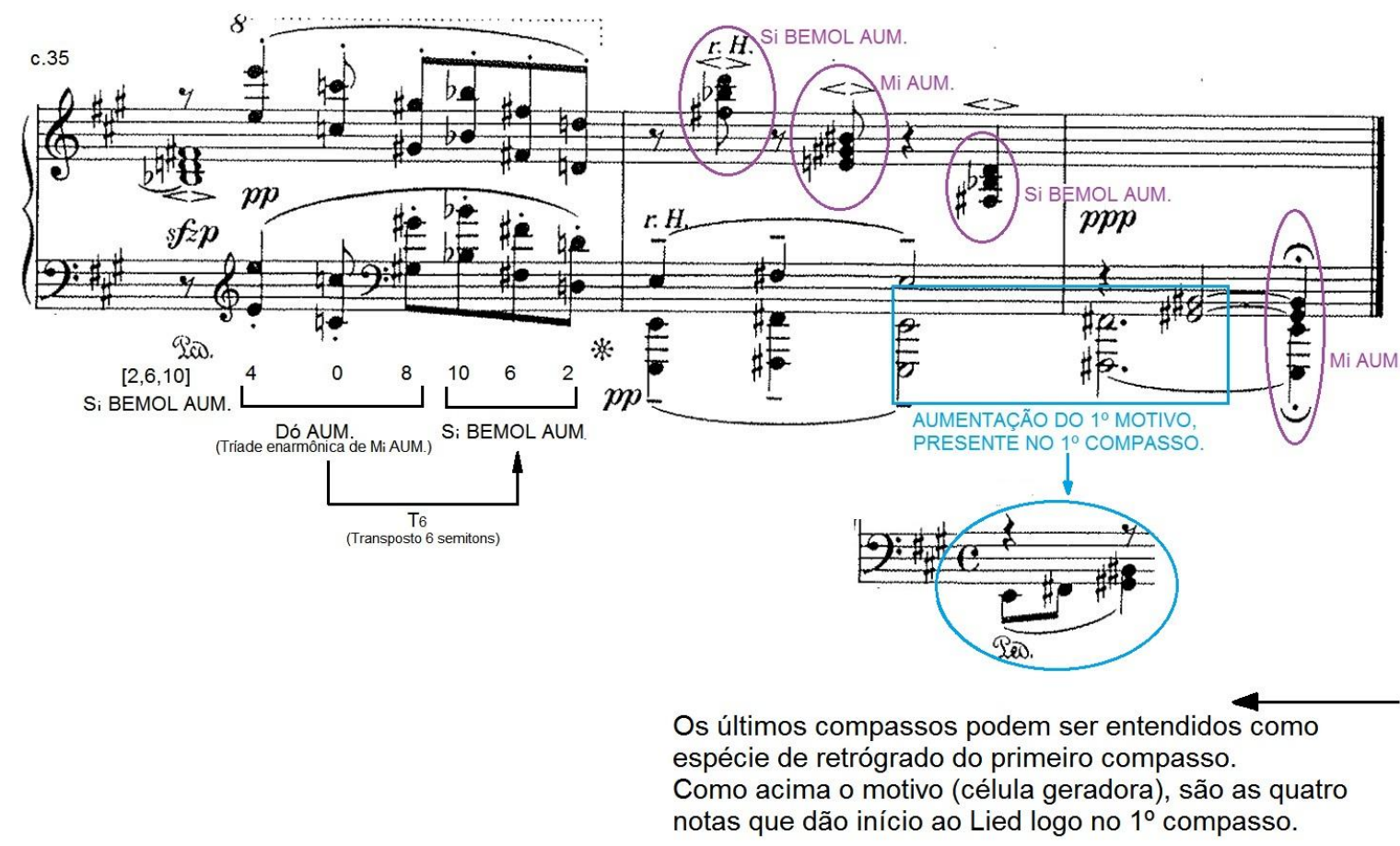

Figura 63 (14) - Últimos compassos de Nacht de Berg

Nessa fase inicial de suas composições, Berg dedica-se, essencialmente, a canções para canto e piano, ou lieder; entre os anos de 1900 a 1908. Herdou e absorveu completamente a cultura musical de sua origem, partindo do ambiente musical vienense pós-romântico, dando continuidade à linha romântica. É possível elencar os traços comuns aos de Robert Schumann, que podem ser notados em vários sentidos.

Ambos possuíam apreço e dividiam seus gostos entre a poesia e a música desde a juventude, tanto que na produção musical de ambos se encontram grandes obras com referência e apoio no veículo verbal.

Encontram-se elementos musicais nas partituras de Alban Berg que passam pelas indicações expressivas de maneira minuciosa, a valorização e organização do silêncio, a acentuação, a construção fraseológica, o trabalho motívico. Se melhor observado seu aspecto romântico, Berg é intenso na procura pela unidade e no prolongamento de um discurso e, assim como Robert Schumann, também buscava elementos musicais que pudessem traduzir o teor dramático absorvido pela percepção que traziam da vida e de humanidade desde 
a juventude. Berg faz predominar a tensão, como a exemplo, em suas primeiras obras, a Sonata para Piano, opus 1, o ciclo Sieben Frühe Lieder de 1905-08, e também em sua última obra, inacabada por ele, o drama de Lulu.

A figura de Gustav Mahler, também, exerceu grande poder de influência sobre aquela que se denomina a Segunda Escola de Viena, com criteriosa fidelidade estes compositores traçaram uma ponte entre a tradição e a modernidade preservando respeito e admiração pelos seus antecessores. Dentre as várias razões, a figura conciliadora de Mahler que soube gerir tantos os aspectos de Johannes Brahms, tais como a sutileza e clareza com que propõem a construção da malha texturial na maneira de trançar os planos harmônico e melódico, bem como a aquisição de densidade nos planos mais profundos da partitura em Richard Wagner. Gustav Mahler utilizou o timbre como parâmetro estrutural e essencial em sua música; como sinfonista deu abertura a obras de seus contemporâneos, de outras vertentes; apesar de ser considerado um romântico tardio, em suas composições trabalhou com a instabilidade tonal, e acima de tudo com a dramaticidade expressiva.

Jameaux afirma que em Berg ocorre "uma dramatização do discurso instrumental como paralelo complementar da sinfonização da ópera." 265

O tratamento da voz e do texto poético nos lieder, a orquestração de Richard Strauss, a exemplo de seus poemas sinfônicos, a importância que este ocupara no espaço cênico teatral em sua época, são alguns traços indeléveis que aportam na obra de Alban Berg.

A expansão harmônica, as novas aquisições orquestrais, o teatro, a música, o drama musical, chegavam até Berg com Richard Wagner e alguns antecessores através das reflexões junto a Schoenberg. Berg também foi em direção ao Dodecafonismo, mas o faz inspirado no modelo vienense de escrita pontuado em toda a sua obra. Optou por condensar e mesclar todas as experiências pensadas junto a seus pares, buscando associar o método dos doze sons sem, no entanto, abandonar por completo a tonalidade.

265 JAMEAUX, D. Berg. Paris, Ed.Seuil, 1980. p.11 
Uma das características essenciais que acompanha e pontua a obra de Alban Berg é especialmente como lida com cada uma das categorias instrumental ou vocal, como traça a união de maneira enriquecedora essas transversais, habilitando-as a transitarem uma no terreno da outra. Como lida com cada escolha, de forma a não repeti-la literalmente, em geral, propondo modificações sutis ou por vezes mais contundentes, no decorrer de uma obra.

Adentrando-se na fase atonal da Segunda Escola de Viena, percebe-se uma subdivisão bem clara, em duas etapas. A primeira etapa é a liberdade dentro do atonalismo, interpretada por muitos como a fase atonal livre; e, a segunda etapa, é a fase do atonalismo estruturado ou organizado.

O longo caminho que experienciou Schoenberg de utilização e expansão da tonalidade pode ser encontrado em uma peça considerada de extrema significância, intitulada Verklärte $\mathrm{Nach}^{266}$, opus 4, de 1899. Esta peça prefigura o processo de libertação criativa no tocante dos limites entre a tonalidade e o uso livre da atonalidade. Schoenberg alargou a tonalidade e chegando ao Dodecafonismo, em 1921, procurou fundamentar suas escolhas musicais e assim justificá-las teoricamente.

A partir de Schoenberg, o tonalismo se encerra como domínio de sistema único.

\section{Nacht - Melodrama nㅇ de Pierrot Lunaire - 1912, de Arnold Schoenberg - etapa atonal-livre}

Do ponto de vista da instrumentação, o espírito de distância, ou alienação, que contém Pierrot Lunaire é conduzido de maneira lógica. Arnold Schoenberg evita qualquer verdadeiro exoticismo instrumental - ou seja, ele diz evitar utilizar um harmonium, como em Herzgewäsche, ${ }^{267}$ um saxofone, ou a competição de instrumentos de percussão. O desafio era fazer novos sons com recursos tradicionais.

\footnotetext{
${ }^{266}$ Noite Transfigurada

${ }^{267}$ Canção com poema de Maeterlinck, op.20, para soprano, celesta, harpa, harmônio.
} 
Há grupos étnicos nos quais os sons-de-discurso são algumas vezes mais longos que em muitas das notas cantadas, mas nas linguagens europeias 0 contrário é claramente verdade. Em Pierrot Lunaire é acima de tudo as notas longas que causam as dificuldades. A imprecisão da anotação leva as recitantes a executarem notas inequivocamente por simplesmente cantá-las, correta ou incorretamente; em decorrência do estranhamento causado pela interválica, as intérpretes incorrem na tentação de glissar alguns sons. Isso as leva ao equívoco de execução das curvas 'melódicas' do discurso natural que não podem ser desaceleradas sem que se chegue a um tipo de uivo que é díspare com o discurso e frequentemente adicionará uma nuance desentendida e mal conduzida à poética da obra. Esses glissandi não autênticos, sobretudo, em distinção dos poucos expressamente notados na partitura, têm uma tendência de pousar logo abaixo da próxima nota, certamente falha que conduz para outra posteriormente, igualmente recusável, o glissando na direção oposta. Mais estranho, entretanto, é a alteração das impressões de afinação como resultado dessas subidas e descidas - sempre providas, é claro, pela ideia de que as alturas notadas tenham realmente sido intencionadas.

Em Pierrot Lunaire, a voz falada assume tarefas temáticas vitais, por exemplo, em Parodie, onde forma cânones em uníssono ou em oitava com vários instrumentos, ou, novamente, em Oh Alter Duft, onde dobra uma linha instrumental, como já havia ocorrido em Gurrelieder.

Schoenberg, não se ateve em dar uma precisão nessas indicações por meio de uma espécie de bula. Isso levanta a questão se essas indicações foram feitas durante a composição ou em estágio mais avançado. $\mathrm{O}$ 'muito agudo' em Madonna é encontrado em ambos os manuscritos de Pierrot Lunaire, mas isso não prova que as datas das anotações sejam do tempo em que o movimento foi escrito, em 09 de maio de 1912.

Erwin Stein levanta uma sugestão, em sua carta a Schoenberg ${ }^{268}$, em 13 de Janeiro de 1913, onde ele pergunta: "É suficiente se alcançar-se o mais

\footnotetext{
${ }^{268}$ STADLEN, Peter. Schoenberg's Speech-Song - Music \& Letters, Vol. 62, No. 1 pp. 1-11 Oxford University Press, 1981. URL: http://www.jstor.org/stable/734794.
} 
próximo possível a afinação indicada?" Não menos memorável é a resposta de Schoenberg:

Aqui na parte falada de Gurrelieder a notação de altura certamente não deve ser levada tão a sério quanto nos melodramas de Pierrot Lunaire. O resultado aqui não deve ser sob qualquer circunstância uma melodiadiscurso ${ }^{269}$ similar ao canto, como no final, as alturas devem ser meramente consideradas como diferenças de registro, o que quer dizer que a passagem em questão (!!! não a nota individual) deve ser falada mais aguda ou mais grave, respectivamente. Mas sem proporções intervalares!

Dessa forma Schoenberg, finalmente revela a Erwin Stein que alguns equívocos podem acontecer em decorrência do alcance da voz falada ser mais estreito que o da voz cantada, pois sons falados têm uma tolerância menor do que a dos sons cantados. Em comparação com um cantor, um recitante tem à sua disposição uma variedade de sons muito maior que podem ser entendidos à mesma afinação, precisamente porque, uma impressão de altura na voz falada resulta em uma vaga e dificilmente previsível tendência de uma curva de frequência. E, não apenas o recitante opera com um número maior de impressões de frequências à mesma altura que o cantor; a diferença entre uma nota e a próxima é menos distinta, pois não se tem registro escrito de escalas orais para cada idioma e com todas as nuances de inflexões em decorrência da alternância da carga afetiva transcorrida durante o seu expressar.

A diferença entre cantar e falar não é, de maneira alguma, restrita ao contraste entre alturas estáveis e 'deslizantes'. Isso também depende, e não menos importante, da produção do som, por exemplo, distribuição, densidade e intensidade das faixas do espectro de frequência que funcionam como formantes da voz.

No cantar, as vogais preservam seus timbres, enquanto no decorrer da fala há uma alternância contínua de vários ditongos e tritongos. Enquanto uma voz cantada dificilmente pode produzir as rápidas curvas de alturas de um discurso realístico, natural, é perfeitamente possível que a voz falada mantenha uma determinada altura por períodos consideravelmente mais longos do que os períodos mantidos no discurso cotidiano. Schoenberg, de fato, não desejava um

\footnotetext{
${ }^{269}$ song-like=speech-melody
} 
discurso realista para seu estilo melodramático, e repetidamente pediu um determinado tipo de declamação: Stein escreve sobre um "discurso elevado" e Schoenberg, no prefácio de Pierrot, de um "discurso que contribua de maneira musical." Mas, evidentemente, Schoenberg falhou em levar em consideração o fato de que o discurso elevado de leiloeiros, sacerdotes e artistas cênicos, para citar um grupo de profissionais que utilizam a fala, não só exageram os altos e baixos do discurso, como ocasionalmente prolongam uma determinada altura de maneira não natural. Se isso passa despercebido na maioria dos casos, é porque as notas dessa sequência apenas raramente pertencem à escala cromática.

Ainda há a questão de por que tais alturas determinadas artificialmente ainda não soam como se fossem cantadas. A resposta é que de certa forma, a impressão do cantar resulta das mínimas flutuações de altura que compreendem o vibrato, ou seja, o colorido tímbrico causado pela aquisição de harmônicos que completam a onda sonora de cada som emitido. Uma formação vocal que evitava vibrato permitiu que Marie-Thérèse Escribano, e até certo ponto Helga Pilaeczyk $^{270}$ anteriormente, executar nas apresentações de Pierrot as alturas prescritas sem violar o tabu ao cantar. Justamente, aí estão os problemas de alcance e de notas sustentadas por tempo demais. No fim das contas, estas devem ser encurtadas a menos que ocorram ao final em uma das "consoantes musicais" I, m, n, ou r, nas quais é possível manter alturas.

Entretanto, essa é a técnica que permite a realização do grandioso Pierrot de Schoenberg, que é também extremamente autêntico, não apenas musicalmente. Schoenberg, na verdade, anotou em seu diário na época da composição: 'Aqui o som adquire um imediatismo nada mais que animalesco ao representar emoções sensoriais e espirituais'. Parece que isso tinha mais relação com o estilo expressionista da música do que com a execução da canção discursiva.

Ao menos, pode-se abstrair isso da carta aos Stiedrys datada de agosto de 1940, onde ele escreve: “... dessa vez quero capturar perfeitamente aquele tom leve, irônico, satírico no qual a peça na verdade foi idealizada," Isso é confirmado

${ }^{270}$ STADLEN, Peter. Schoenberg's Speech-Song - Music \& Letters, Vol. 62, No. 1 pp. 1-11 Oxford University Press, 1981. URL: http://www.jstor.org/stable/734794. 
pelo relato da reação de Schoenberg contado por Edward Steuermann, quando a primeira recitante dentre todas mostrou uma tendência a interpretar uma heroína trágica e ficar extremamente chorosa em Der kranke Mond: "Não se desespere, Frau Zehme, afinal existe uma coisa chamada Seguro de Vida!"271

Embora haja recomendações de Arnold Schoenberg no prefácio de Pierrot Lunaire para que o executante não caia em tentação de cantar as notas, utiliza as hastes cruzadas $(x)$ no corpo das figuras ritmicas, o que indicará o meio termo entre a fala e o canto, o Sprechgesang ou Sprechstimme. A seguir uma citação do artigo da cantora Martha Herr:

Em 1912, Schoenberg nos apresenta com Pierrot Lunaire na qual utiliza o Sprechstimme, um estilo vocal usado por E. Humperdinck em sua ópera Königskinder em 1897. Porém Humperdinck substituiu o próprio "Sprechstimme" por canto tradicional na sua subsequente revisão de ópera. O próprio Schoenberg utilizou o Sprechstimme na sua composição Gurrelieder, orquestrada em 1910, mas é em Pierrot que encontramos pela primeira vez, uma peça inteira neste estilo vocal, cuja prática, até hoje, não está padronizada. Schoenberg usa uma notação de pauta comum, com uma indicação específica do ritmo e um " $x$ " na haste da nota para indicar a sua altura. Ele foi explícito no prefácio de Pierrot onde diz que a voz deve "dar o tom exato, mas depois deixá-lo imediatamente numa queda ou ascensão." Porém, na prática isso é extremamente difícil e existem muitas diferenças de opinião sobre sua produção. É fala entoada ou canto preguiçoso? Existem os termos Sprechgesang, Sprechstimme e Sprechmelodie. Schoenberg preferiu os últimos dois e isso nos dá uma ideia melhor das suas intenções: menos canto e mais fala entoada, reconhecendo que a fala tem sua própria melodia ${ }^{272}$

Se Schoenberg tivesse a clara ciência de um método efetivo para registrar com precisão as diversas nuances de sons idealizados por ele para que isto viesse garantir a realização dessa peculiar sonoridade em sua canção discursiva, certamente o teria feito. Para ele poderia ser bastante clara a diferença entre as ideias do Sprechgesang, Sprechstimme e Sprechmelodie, porém esses recursos que despertaram um caminho para a nova vocalidade inserida para dentro da música escrita esbarram na descrição gráfica da infinidade dos sons formantes, alturas indeterminadas, além de diversas inflexões vocais que não poderiam ser atendidas apenas com o convencional sistema de grafia musical.

\footnotetext{
${ }^{271}$ STADLEN, Peter. Schoenberg's Speech-Song - Music \& Letters, Vol. 62, No. 1 pp. 1-11 Oxford University Press, 1981. URL: http://www.jstor.org/stable/734794.

272 HERR, Martha. In: Arte e Cultura II - Estudos Interdisciplinares. Maria de Lourdes Sekeff e Edson Zampronha (organizadores). São Paulo: Annablume: FAPESP, 2002.p.16.
} 
A realização puramente sonora deve ser ainda mais uma vez posta em relevo, e é espantoso ver até que ponto a imaginação de Schoenberg consegue criar uma diversidade de timbre tão acentuada, com um número tão reduzido de instrumentos. Os procedimentos instrumentais utilizados são de louca habilidade, e podemos dizer, sem exagero, que cada peça possui sua cor própria, na medida em que cada uma é instrumentada de maneira diferente. A isto acrescente-se a voz do recitante, que contribui essencialmente para a originalidade da obra. Definamos os princípios deste novo meio de expressão vocal que é o Sprechgesang ${ }^{273}$

Resumidamente, o que o próprio Schoenberg comenta no seu prefácio da partitura temos:

A questão rítmica deve ser observada estritamente, como se tratasse de um cantar, mas, enquanto a melodia cantada mantém a altura do som, a melodia falada não faz senão indicá-la, abandonando-a imediatamente de maneira ascendente ou descendente ${ }^{274}$

A partir de um ensaio encomendado pelo próprio Schoenberg ao seu discípulo Erwin Stein, conclui-se que nenhuma altura determinada de som deve ser produzida. Os intervalos escritos, somente sugerem modulações decorrentes das inflexões baseadas nas variações da fala. ${ }^{275}$

Com estes recursos vocais, mais os glissandi sobre intervalos mais curtos, Schoenberg atinge uma sonoridade especialmente rica, um efeito novo para a linha melódica em relação à entonação no repertório tradicional da música escrita, pois, sendo a voz um instrumento visceral que não sofreu o ajuste do temperamento por igual, pode-se emitir através dela, freqüências ou alturas de intervalos sonoros menores do que o espaço de som entre os semitons de nossa escala temperada.

Ainda que muito se tenha dito sobre esta preciosa obra, toda vez que observamos a sua partitura, encontramos algo para relacionar e refletir. Ela é um belo exemplo de combinação timbrística, fruto da magistral criatividade de Schoenberg. A peculiaridade da mistura dos harmônicos entre as frequências de altura determinadas em contraste com a voz recitante, a própria métrica, as indicações minuciosas de dinâmica, a interválica, no plano melódico e harmônico

\footnotetext{
273 LEIBOWITZ, René. Schoenberg.p.91.

${ }^{274}$ LEIBOWITZ, René. Schoenberg.

275 LEIBOWITZ, René. Op.Cit.
} 
é uma das aquisições históricas que vem de acréscimo para a nova sonoridade. Através de Pierrot Lunaire, Arnold Schoenberg abre portas para uma nova música de fato. Embora Schoenberg chegue a estruturar o atonalismo, somente mais tarde, em 1921, Nacht, composta em 1912, já apresenta indícios que indicariam os princípios da técnica dodecafônica.

Ao ultrapassar os limites da tonalidade, Schoenberg sentiu-se obcecado pela busca de novos recursos para obtenção da unidade da forma. Este problema que foi o fio condutor de toda sua produção, completa seus enunciados com o acréscimo que a diversidade supõe, ou seja, a não repetição.

Dessa maneira, assistimos ações simultâneas de desintegração dos valores tradicionais e a firme imposição daqueles que são o produto de novos enunciados de harmonia, contraponto, estrutura e sonoridade, que ainda não tinham a base imutável conferida pela tonalidade e pelas forças que nela se alicerçam.

\section{Os Movimentos I, IV e V da Cantata no2, de 1943 de Anton Webern e Um lied - Der Mensch - dos Drei Lieder - 1931 - Edward Steuermann - etapa: atonalismo estruturado}

Capítulo essencial para se entender a Música do século $\mathrm{XX}$, o Dodecafonismo é, entre tantas, uma das produções polêmicas da Segunda Escola de Viena, onde se elaborou uma reorganização das alturas que, por sua vez, gerou múltiplas possibilidades e experimentos no interior da criação e na forma de conceber a música, efetivando uma liberdade buscada por um grande número de compositores e apreciadores, modificando e alargando a percepção humana.

A técnica dodecafônica que foi pensada para libertar o trabalho de composição do sistema tonal, emerge como "uma harmonia nova, rica em cores," ${ }^{276}$ como compara o mestre vienense.

Arnold Schoenberg aponta o Dodecafonismo como uma técnica, que baseada na formação de uma ordem particular das doze notas da escala

${ }^{276}$ LEIBOWTZ, René. Schoenberg. Colection Solfèges n`30. Paris : Editions du Seuil, 1969.p.86. 
cromática de temperamento por igual, traz o substitutivo de algumas tendências unificadoras e formativas do centro tonal e Webern aprofundou-se nesse método de composição.

Inicialmente, Schoenberg introduz a técnica das doze notas a um grupo mais íntimo de discípulos e amigos no início de 1920; e é logo nesse ano que Webern já começa por utilizá-la, mas só irá concretizar sua primeira obra totalmente dodecafônica, no Trio para Cordas - opus 20, terminada em 1928.

Os principais elementos estilísticos, inovadores na composição de Anton Webern, intimamente ligados em grau de importância, compreendem o timbre, a intensidade e o silêncio. Utilizando o timbre como parâmetro, 0 compositor evolui por várias trilhas de desenvolvimento para o argumento musical, utilizando efeitos instrumentais e vocais como parte integrante da articulação musical. Com essa forma de trabalhar, Webern justapõe extremos de tessituras e contrastes tímbricos, registros e variedades constantes, propondo com essa experiência verdadeira habilitação da gama de nuances, até aquele momento eram inauditas.

A Cantata №2 de Webern, também aponta para seu estilo aforístico, como revela o seccionamento das partes, que trazem em seu interior outras pequenas seções, que são brevidades construídas pelo princípio de espelhamento. Suas peças trazem uma tênue e sutil gama de intensidade, construída com detalhamento bastante preciso.

Podem-se apontar vários traços comuns entre Edward Steuermann e Anton Webern, a admiração profunda pelo mestre, o gosto pela técnica dodecafônica, o respeito em difundir as pesquisas elaboradas pela Segunda Escola de Viena, a fidelidade na construção através dos mesmos princípios, a não repetição literal, precisão métrica e a agógica. Memorável a maneira com que eles trabalham a acentuação do texto, a prosódia, o silêncio e as pausas. Webern dá um status à pausa tornando-a entidade atuante na expressividade.

Agógica: termo para um tipo de acentuação que se baseia antes na duração (certo repouso sobre a nota a fim de enfatizá-la) do que na intensidade; é importante na música para instrumentos como o cravo ou órgão nas quais a intensidade sonora não pode ser alterada imediatamente, sendo preciso encontrar outros meios de acentuação. $O$ 
termo "agógica" às vezes é usado para designar qualquer tipo de desvio em relação ao rigor rítmico ${ }^{277}$

\section{Características Comuns deste conjunto de obras}

Quanto às características, as peças pertencentes ao conjunto de obras em questão podem comungar por duas maneiras, quanto ao procedimento técnico na construção e utilização dos elementos composicionais:

a) tais como as formas e os gêneros antigos, como o lied, a cantata, o melodrama, formas antigas revestidas de nova roupagem;

b) os procedimentos da técnica por espelhamento.

Estas peças representam a evolução das formas e dos gêneros como 0 lied, o melodrama e a cantata. Ainda que este grupo de compositores viesse presenciar um momento histórico de mudanças e ruptura, não deixou de utilizar em suas composições as formas e gêneros antigos. Eles traçaram um elo entre o passado e o futuro e imprimiram uma aura de riqueza com os diversos recursos conquistados por meio de suas pesquisas.

Os compositores vienenses da segunda escola buscaram unidade e a permanência de estruturas formais que viessem garantir a organicidade da obra. Através do plano de construção das texturas harmônica e melódica, da instrumentação, dinâmica e a duração como pontos de articulação, percebe-se um planejamento na maneira de arquitetar o labor composicional. Para a Segunda Escola de Viena a forma é mais um status, um ponto de honra com o qual esses compositores procuraram garantir a primazia e o gosto por ela, considerando 0 quanto esta havia sido conquistada e consolidada ao longo dos séculos tão especialmente pelos mestres da música germânica.

Em todas as fases composicionais da Segunda Escola de Viena e sua extensão em Edward Steuermann, é muito comum notarmos a utilização de palíndromos através das ideias musicais apresentadas, por meio de

\footnotetext{
${ }^{277}$ SADIE, Stanley.Op.Cit.p.12.
} 
espelhamentos estes compositores trabalharam com técnicas canônicas com os quais propõem um máximo aproveitamento de materiais, desde células básicas, fragmentos, motivos, séries, acordes, tornando-as elementos composicionais que atuam diretamente com a plasticidade da obra, como um mosaico onde cada partícula é tratada como peça intrínseca do todo, deslocando-as, no tempo, para as diversas camadas e sobreposição dos planos da partitura.

A plasticidade do material composicional, com que curiosamente os compositores da Segunda Escola de Viena e extensão em Steuermann, trabalham suas obras é demasiadamente interessante, a maneira artesanal que utilizam os procedimentos técnicos com espelhamento geram vários palíndromos, como os encontrados em todo tipo de arte que lida com proporções de simetria, desde a Antiguidade. As seções invadem uma a parte da outra como formas contínuas, quase que inseparáveis não delimitadas por um corte rigoroso, e utilizam elementos antigos, como gênero, forma e procedimentos técnicos de construção de ideias, revestindo-os de uma nova roupagem.

\section{Quanto à prosódia musical}

Quanto à prosódia musical das obras com trechos "cantáveis" ou trechos "declamáveis", vale-se de maneira geral do apoio das sílabas tônicas, reforçada pelas questões das alturas melódicas unidas ao prolongamento dos valores da figuração rítmica. Os compositores deste conjunto de obras procuraram precisão na escrita para revelar o peso do veículo verbal contando com os pontos de articulação através da instrumentação, da agógica, da interválica, e tratam os fonemas com peculiar importância dando-Ihes status de parâmetro do som, assim como o timbre, a altura, a duração e a intensidade.

Elementos musicais na escrita das partituras destes compositores passam pelas indicações expressivas de maneira minuciosa, como a valorização e organização do silêncio, a acentuação, a construção fraseológica e o trabalho motívico. 


\section{Questões vocais}

A questão vocal tanto dos lieder, das partes solistas, ou em conjunto, como as partes do coro, destas obras em questão, apresenta traços comuns que devem ser submetidos a uma análise aprofundada para nortear uma boa interpretação, para assim garantir todas as propostas das poéticas, tanto literária, quanto musical em sua totalidade.

Estas obras por vezes enfantizam e reiteram musicalmente algumas passagens ou ilustrações propostas pelo texto criando uma ambientação sonora muito peculiar.

Lembrando que de tempos em tempos surge uma nova vocalidade. Esta nova vocalidade observada aqui neste trabalho começa o seu despertar na aurora do século $X X$, e também é consenquência dos desdobramentos de correntes que precederam aquele momento, ou pela afinidade, ou pela contraposição.

Importante ressaltar que uma das questões características do Expressionismo é a reflexão do homem contido no universo voltado para sua própria condição humana, na procura de como se libertar dos limites terrenos em busca de atingir algo maior em seu interior. Essa busca pode ser alcançada em pequenas doses através da contemplação e entendimento da poética integrada à natureza humana e o universo artístico. Os compositores da Segunda Escola de Viena e Steuermann concebiam a música como um dos meios que pode orientar essa caminhada. Poder-se-ia abordar diversos exemplos neste conjunto de obras, pois todos estes compositores aqui estudados fazem valorizar as várias virtudes como a generosidade, coragem ou altruísmo em seu discursar através da música. Tomando a Cantata n-2 de Webern, e seu estilo aforístico, podemos condensar o que há de mais singular em todo o percurso traçado pela Segunda Escola de Viena e considerar sua extensão em Edward Steuermann.

A escolha pela utilização do responsório no Movimento $V$ da Cantata n2 foi uma maneira de contemplação a essa forma antiga que se aplicava ao discurso, ocupando status nas leituras litúrgicas das missas, ou de algumas 
formas monásticas dentro do repertório de música sacra, tais como as matinas, vesperae, ou motetos. Este recurso traz em si a ideia de resposta e responsabilidade concedida através de uma reflexão dada pelo texto, ou mesmo uma confirmação em concordância com o texto anteriormente exposto. Webern reforça essa ideia com o soprano solista e a resposta do coro, o responso, que dividem a responsabilidade pela força da palavra exposta. Embora o texto não seja um texto propriamente litúrgico, carrega em si um caráter humanista bastante enfático. A ideia de Webern era estruturar esta obra nos moldes da antiga cantata, construindo um rico entrelaçamento do texto com a ideia musical, com tanta força que um se torna essência para o outro.

Aqui Webern trata a fonética como se fosse uma espécie de "quinta" propriedade do som, e de tão íntima que é, faz surgir entre música e texto uma amálgama de ordem inseparável nesta peça, considerando os fonemas como unidades básicas do som quando emitidos pela voz. Eis que para o instrumento voz o som surge através de um fonema qualquer, como parte inerente deste instrumento, som este que possui a altura, frequência, duração, intensidade, timbre que concomitantemente produzidos tornam o fonema como parte intrínseca da vocalidade, e que é através do som do fonema que se faz acontecer o som da voz. Webern propõe isto de forma bastante consciente, em cada som, seja o que deverá ser produzido pelos cantores agrupados em coro, seja o que deverá ser produzido pelos cantores solistas.

No oratório nos moldes do período barroco, há a presença do narrador ou o personagem que faz o comentário ou observações com caráter de sermão, como portador da mensagem, ou aquele que concebe a mensagem do texto como uma verdade e a coloca seja para o indivíduo (o solista), seja para o coletivo (o coro), fazendo observações que do ponto de vista humano e visionário poderiam ser pouco observadas pelo homem comum. Surge então a necessidade desta entidade profética capaz de se fazer notar com a percepção objetiva atenta para a justiça dos fatos. Esses elementos são encontrados nas Paixões de Johann Sebastian Bach, nos oratórios de George Haendel e em outros autores desse e de outros períodos. 
Dessa perspectiva pode-se pensar então sobre a diferença entre aquele que prega o sermão, ou a reflexão dos fatos, dentro da cantata - que seria o próprio herói, um mito, ou um personagem carnal que busca a reflexão através da condição humana reconhecendo suas fraquezas e vicissitudes diante da grandeza de um ser reconhecidamente maior (no caso da música sacra Deus, ou um messias, mas sempre é alguém de valores éticos com virtudes destacáveis como a humildade, bondade, caridade e com amor ao próximo) - e o homem comum. Webern leva essa reflexão para todos os personagens, seja o personagem masculino solista, o baixo, seja a personagem solista feminino, o soprano, e ainda nas partes do coro, o coletivo, como que distribuindo essa responsabilidade de reflexão para todos, seja a humanidade aqui representada pelo coro; ou cada ser humano, como indivíduo analítico que visa reconhecer as qualidades e virtudes de caráter em relação ao próximo, projetando-as para o coletivo junto à comunidade.

Tanto individualmente, quanto dentro de um agrupamento como, por exemplo, no coro, cada intérprete deve procurar explorar ao máximo as nuances de cores tímbricas de seu registro vocal, para encontrar efeitos mais profundos dos matizes entre o claro e o escuro do som. O intérprete deve-se questionar: como encontrar as medidas mais exatas de densidade, ou clareza, para a realização desta nova vocalidade? Como e quando utilizar os sons mais cristalinos, como por exemplo, na parte do soprano solista da Cantata no2 de Webern, ou em outras obras?

Um cantor deve-se exercitar continuamente, tomando como base a vocalidade de cada obra em si. Reforçaria aqui a questão para uma abordagem das análises dos planos horizontal e vertical (melodia e harmonia), estudo da fraseologia, morfologia, oriundos de um contexto histórico e tomar consciência de todo o aparato fisiológico para envolver-se com o cantar de cada peça. Criar propostas de exercícios vocálicos com base nos elementos estruturais do material composicional deste novo estilo, até que a linha de canto possa se tornar orgânica.

A construção harmônico- melódica sem a hierarquia da base diatônica é um dos aspectos que muito vai alterar a curva melódica do repertório deste novo 
estilo, o que the conferirá certa estranheza, já que as conduções melódicas advindas das normas do contraponto prescreviam que se evitassem tais dissonâncias; pois para um cantor é muito mais orgânico, exercitar vocalizes com uma tríade perfeita maior do que com uma tríade aumentada, ou ainda cantar arpejando um acorde construído por quartas.

Pode-se pensar então que para uma voz profissional que treina, durante um largo período, vocalizações com os graus conjuntos, tríades, ou acordes, construídos com base no sistema diatônico, passe, então, da mesma forma a adquirir organicidade, a exercitando também os acréscimos desenvolvidos pela expansividade do próprio sistema tonal, sem necessariamente excluir as estéticas anteriores. Consequentemente treinar vocalizando melodias construídas das escalas diatônicas, de tons inteiros, cromática, criar séries (experimentá-las com 4, 5, 6, até chegar aos doze sons da escala cromática como a proposta dodecafônica), construir melodicamente (pois serão cantados, posto que a voz seja um instrumento melódico) aquilo que poderia ser material harmônico abstraído da própria melodia, exercitar cantando acordes arpejados, construídos por quartas justas, aumentadas, combiná-los com toda sorte de intervalos simples (no âmbito da oitava) depois misturá-los aos compostos, acrescentar fragmentos cromáticos, tons inteiros, etc... A partir daí já se pode obter um bom preparo para compreender a interválica desta nova vocalidade; acrescente-se a isto a alternância de andamentos, sons mais prolongados, curtos, rápidos, muito velozes, experimentados com uma variedade de fonemas; articulação, legato, non legato, stacatto; timbricamente, exercitar sons que resultam mais metálicos, brilhantes, mais aveludados, pesados, mais leves ou cristalinos. Notam-se quantas possibilidades de nuances, quantos matizes que e ainda colocadas em prática com toda a dinâmica e as inflexões dos sons vocálicos, têm-se um verdadeiro leque com autêntico alargamento da amplitude dos parâmetros do som.

Conhecer historicamente a prática comum de todos os estilos com profundidade e exercitar seu cantar junto ao corpo de maneira integrada, experienciando de maneira consciente os acréscimos adquiridos através do 
desenvolvimento técnico-musical como um verdadeiro investigador. Observar com familiaridade todo recurso sonoro que vier a ser incorporado, procurando estar sempre aberto para uma nova escuta. Porque é através desta abertura que se prenuncia um próximo passo para conceber as diversas possibilidades sem estranhamento. Imagine-se tudo isto sendo praticado em conjunto, onde outras experiências vocais harmônicas podem ser propostas, como em um coro, por exemplo.

Um novo ganho nas amplitudes da maleabilidade vocal deve ser conquistado, afim de adquirir técnica suficiente para expressar as diversas nuanças situadas entre os extremos do som mais cristalino e o som mais denso, mais metálico e mais aveludado, mais ásperos e mais suaves, executando com todo o critério a gama da dinâmica, dos andamentos e de todos os parâmetros do som.

Nesse período, que abrange a transição entre os séculos XIX e XX, e as primeiras décadas do século $X X$, para uma execução mais satisfatória desse repertório, passa-se exigir do intérprete uma elasticidade muito maior que a dos estilos anteriores. O caráter aforístico no estilo das obras da Segunda Escola de Viena e sua extensão em Edward Steuermann condensa em um trecho musical muito curto tudo aquilo que uma obra mais extensa logra em uma apresentação de espaço/tempo muito maior. Miniaturas de formas, divididas em seções, podem imitar a construção de uma forma mais extensa, que necessitarão o mesmo rigor. 


\section{Os gêneros vocais como parte substancial no cojunto de obra da Segunda Escola de Viena}

Parte substancial do repertório da Segunda Escola de Viena é referente a algum gênero vocal.

Somando as obras levantadas por Paul Griffiths, ${ }^{278}$ então, Arnold Schoenberg escreveu em torno de 04 óperas, 06 conjuntos de obras coralorquestral, 09 conjuntos de obras corais, 14 ciclos de canções (mais de 50 canções), 02 melodramas. Anton Webern fez 05 obras corais, 12 ciclos de canções, em torno de 53. Alban Berg compôs obras orquestrais com voz, 05 ciclos e 01 ária Der Wein, 03 ciclos de lieder e 02 óperas; ou seja, parte substancial das obras dos vienenses da segunda escola utilizam gêneros vocais.

A seguir algumas tabelas demontrativas:

\begin{tabular}{|c|c|c|c|}
\hline \multicolumn{4}{|c|}{ Lista de Obras Vocais } \\
\hline \multicolumn{4}{|c|}{ Alban Berg } \\
\hline Óperas & Orquestrais com Voz & Canções com Piano & $\begin{array}{l}\text { Obras Para } \\
\text { Outras } \\
\text { Formações } \\
\end{array}$ \\
\hline Wozzeck, 1917-22 & $\begin{array}{c}\text { Canções de Altenberg, } \\
\text { op. } 4,1912\end{array}$ & $\begin{array}{l}7 \text { Primeiras Canções, } 1905-8 \text {, rev. } \\
1928\end{array}$ & Orquestrais: 4 \\
\hline \multirow[t]{4}{*}{ Lulu, 1929-35 } & $\begin{array}{l}3 \text { Fragmentos de } \\
\text { Wozzeck, } 1924\end{array}$ & $\begin{array}{l}4 \text { Canções, op. 2, (Hebbel, } \\
\text { Mombert), ?1909-10 }\end{array}$ & Câmara: 5 \\
\hline & $\begin{array}{c}7 \text { Primeiras Canções, } \\
1905-8 \text {, orquestra, } \\
1928\end{array}$ & $\begin{array}{c}\text { Schliesse mir die augen beide } \\
\text { (Storm), musicado duas vezes, em } \\
1907 \text { e } 1925\end{array}$ & \\
\hline & $\begin{array}{c}\text { Der Wein } \\
\text { (Baudelaire/George), } \\
1929\end{array}$ & & \\
\hline & $\begin{array}{c}5 \text { Peças Sinfônicas de } \\
\text { Lulu, } 1934 \\
\end{array}$ & & \\
\hline
\end{tabular}

Tabela 11 - Lista de obras vocais de Berg

${ }^{278}$ GRIFFITHS, Paul. Enciclopédia da Música do século XX.pp.21,22,198,199,238. 


\begin{tabular}{|c|c|c|}
\hline \multicolumn{3}{|c|}{ Lista de Obras Vocais } \\
\hline \multicolumn{3}{|c|}{ Anton Webern } \\
\hline Coral & Canções & $\begin{array}{c}\text { Obras Para Outras } \\
\text { Formações }\end{array}$ \\
\hline $\begin{array}{c}\text { Entflicht auf Leichten } \\
\text { Känen, op. 2, SATB, } 1908\end{array}$ & $\begin{array}{c}5 \text { Canções de Dehmel, voz, } \\
\text { pn, 1906-8 }\end{array}$ & Orquestral: 7 \\
\hline $\begin{array}{c}2 \text { Canções, op. } 19 \text {, SATB, } \\
5 \text { instrs, } 1926\end{array}$ & $\begin{array}{c}5 \text { Canções, op. 3, voz, pn, } \\
1908-9\end{array}$ & Câmara: 14 \\
\hline $\begin{array}{l}\text { Das Augen Licht, op. 26, } \\
\text { SATB, orq, } 1935\end{array}$ & $\begin{array}{c}5 \text { Canções, op. 4, voz, pn, } \\
1908-9\end{array}$ & Piano: 3 \\
\hline $\begin{array}{c}\text { Cantata } \mathrm{n}^{\circ} 1, \text { op. } 29, \mathrm{~S}, \\
\text { SATB, orq, } 1938-9\end{array}$ & $\begin{array}{c}2 \text { Canções (Rilke), op.8, } \\
\text { Mez, } 8 \text { instrs, } 1910\end{array}$ & Arranjos: 2 \\
\hline \multirow[t]{9}{*}{$\begin{array}{c}\text { Cantata } n^{\circ} 2, \text { op. } 31, \mathrm{~S}, \mathrm{~B}, \\
\text { SATB, orq, } 1941-3\end{array}$} & $\begin{array}{c}4 \text { Canções op. 12, voz, pn, } \\
1915-7\end{array}$ & \\
\hline & $\begin{array}{c}4 \text { Canções, op. 13, S, peq } \\
\text { orq, } 1914-8\end{array}$ & \\
\hline & $\begin{array}{c}6 \text { Canções (Trakl), op. 14, } \\
\text { S, } 4 \text { instrs, 1917-21 }\end{array}$ & \\
\hline & $\begin{array}{c}5 \text { Canções Sacras, op. 15, } \\
\text { S, } 5 \text { instrs, 1917-22 }\end{array}$ & \\
\hline & $\begin{array}{l}5 \text { Cânones sobre textos } \\
\text { em latim, op. } 16, \mathrm{~S}, \mathrm{cl}, \mathrm{cl}\end{array}$ & \\
\hline & $\begin{array}{c}3 \text { Rimas Tradicionais, op. } \\
17,5,3 \text { instrs, } 1924-5\end{array}$ & \\
\hline & $\begin{array}{c}3 \text { Canções, op. 18, S, cl mi } \\
\text { bemol, gui, } 1925\end{array}$ & \\
\hline & $\begin{array}{c}3 \text { Canções, op. 23, voz, } \\
\text { pn, 1933-4 }\end{array}$ & \\
\hline & $\begin{array}{c}3 \text { Canções, op. 25, voz, } \\
\text { pn, } 1934\end{array}$ & \\
\hline
\end{tabular}

Tabela 12 - Lista de obras vocais de Webern 


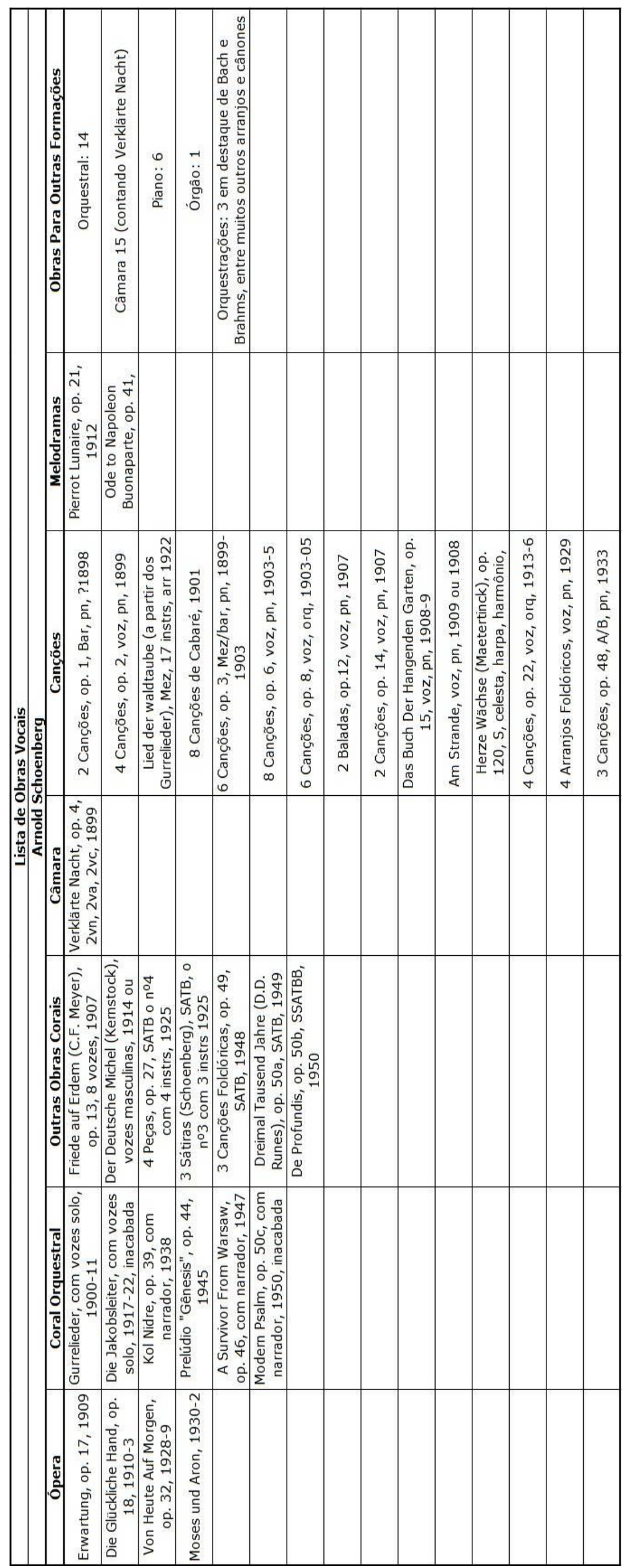

Tabela 13 - Lista de obras vocais de Schoenberg 


\section{Considerações finais O Despertar para uma Nova Vocalidade na Música Escrita}

Belavoz é a mais importante das musas, porque ela é que acompanha os reis venerandos. A voz é bela não porque seja agradável e requintada, não é bela por características que consideraríamos formais - mas por este poder, compartilhado por reis e poetas, de configurar e assegurar a ordem, por este poder de manutenção da vida e de custódia do ser. (...) Bela, pelo poder de influir decisivamente nas fontes do ser e da vida, pela sua pertinência às dimensões do mundo e ao sentido e totalidade da vida $^{279}$

Os compositores da Segunda Escola de Viena recorreram ao apoio dos textos literários e do discurso verbal para retomar a discursividade na música. Consequentemente, estes compositores, ao se utilizarem do veículo verbal como suporte ou essência do desenvolvimento musical, fizeram com que as formas e gêneros historicamente interligados com o texto e seu significado emergissem em meio à produção atonal. Enfim, o florescimento das formas ou gêneros conectados com o desenvolvimento semântico como o lied, a ópera, o melodrama, o monodrama, a cantata, dentre outros, estabeleceu considerável profusão de idéias e propostas deste grupo de compositores.

Tal recurso, por um lado, veio dar respaldo à solução do problema da expansão da escrita atonal na música instrumental ou música pura, adiando o confronto direto da consciência musical pelos recursos próprios; por outro lado, obteve a inevitável reformulação da composição vocal, re-significou o canto, e buscou musicalizar a linguagem falada.

Um profundo questionamento ao nível harmônico trouxe em si mesmo um potencial de reflexão com relação aos aspectos sonoros, dentre eles a musicalidade da fala, que nesse momento histórico se encontrava apta a auxiliar a produção atonal na busca pela recuperação do ato discursivo na música. ${ }^{280}$

O argumento dramático, até então coadjuvante do discurso musical, protagoniza, celebremente, uma significativa transcendência, uma verdadeira transformação, de suas formas, tal como eram tradicionalmente concebidas.

\footnotetext{
${ }^{279}$ HESÍODO. Teogonia, A Origem dos Deuses. Estudo e Tradução de Jaa Torrano. 1992.

${ }^{280}$ MENEZES, Florivaldo. Apoteose de Schoenberg.
} 
Deve-se entender que as inovações demonstradas nos exemplos do conjunto de obras em questão para este trabalho se orientam substancialmente pelas análises harmônica e morfológica. Por se tratarem de gêneros vocais apontam para inovações na vocalidade que emana através dos recursos adotados para o interior destas composições, ainda no despontar do século $\mathrm{XX}$, que por sua vez virão promover outros desdobramentos na música contemporânea.

Considera-se que o despontar de tais inovações não transformariam por completo nem a forma nem o gênero a um nível de se tornarem irreconhecíveis como tais, sendo assim, passariam a adquirir outro termo que não o tradicional.

A aplicação dos processos de dissolução tonal trouxe, através das pesquisas da Segunda Escola de Viena, o despertar para uma nova vocalidade que pouco a pouco vai se impondo na música escrita.

Analisando o conjunto das peças vocais: Nacht e Die Nachtigall que são dois lieder do ciclo Sieben Frühe Lieder, de 1905-1907, de Alban Berg; Melodrama no 8 do Pierrot Lunaire, opus 21, de 1912, de Arnold Schoenberg; as partes I, IV, e $V$ da Cantata n.2, opus 31, de 1941-1943, de Anton Webern; os Drei Lieder, de 1931, de Eduard Steuermann, nota-se que alguns procedimentos adotados por estes compositores provocam uma verdadeira transcedência formal ao contrapor simetria e assimetria nos espaço/tempo dessas partituras.

Ocorre uma compactação de ideias, tanto no plano horizontal como no plano vertical, que resultaria nos fragmentos de tempo que nada mais são do que os tamanhos de frase, tema, motivo, célula, período, seção, parte, enfim elementos que influem diretamente na forma. Elementos que compõem pequenas formas no interior das formas maiores, tornando esses gêneros enormemente elásticos. Contidos nas formas mais extensas estão fragmentos, que se podem considerar como micro-formas, espécie de "partículas", que em seu interior acabam por dar unidade ao todo, conferindo-Ihes grande riqueza na plasticidade.

Outra dimensão seria o plano da dinâmica do som, nuances de timbre, o colorido e a densidade, todos esses parâmetros constituem uma espécie de relevo, desde as nuances do plano de fundo até o plano mais superficial. Essa 
plasticidade seria encontrada desde a fragmentação das "pequenas" ideias no espaço interno da peça, até a obra como um todo dentro desse processo criativo. $\mathrm{Na}$ arte de exercitar desde as formas mais pequeninas, estariam os palíndromos, os quais muitos deles são encontrados nas diversas camadas de superposição dos vários planos da partitura, ora melodicamente, ora harmonicamente.

Os procedimentos técnicos principais podem ser, por exemplo, a maneira de variar motivo, tema, série, acordes, grupo de acordes, enfim todas as células de sons, ou fragmentos que são ideias geradoras para uma construção composicional, ou ainda, as formas usuais de variação que podem modificar uma ideia musical, entre outras, seriam: transposição, mudança de registro, instrumentação, articulação, aumentação (ampliação), diminuição (redução), espelhamento (inversão, retrógrado e retrógrado da inversão).

Pode-se perceber que em curto espaço temporal, estes compositores propõem grande elasticidade em uma gama de nuances imbuída na profundidade dos vários parâmetros do som.

$O$ período que abrange as criteriosas pesquisas realizadas pelos compositores da Segunda Escola de Viena e seus desdobramentos deixou marcas indeléveis nas diversas propostas de tudo aquilo que supuseram Schoenberg e seus discípulos. Muito embora tenham recorrido à utilização de formas e gêneros já tradicionalmente consagrados, como por exemplo, o lied, cantata e o melodrama, citados ao longo deste trabalho, as inovações apontadas aqui nesta pesquisa são relativas de como o acréscimo de novos recursos modificaram sensivelmente a sonorização na música, tanto instrumental quanto vocalmente, tornando possível a esses gêneros o despertar para uma nova vocalidade. Reiterando que não são inovações que transformaram por completo a forma ou os gêneros a um nível de não serem reconhecidos como tais, mas sim uma verdadeira transcendência da forma.

Inovações que se deram principalmente no plano da interválica, ou seja, uma nova curva melódica, advinda através da liberação das dissonâncias no contraponto, que são geridas, também, pela harmonia. A recorrência, tanto de saltos de intervalos de sons mais amplos $\left(7^{a}, 9^{a}, 11^{a} \ldots\right)$, quanto intervalos 
melodicamente dissonantes como $3^{\underline{a}}, 5^{\underline{a}}, 8^{\underline{a}} s$ diminutas; $2^{\underline{a}}, 4^{\underline{a}}, 5^{\underline{a}}, 11^{\frac{a}{a}}$ aum, $7^{a}, 9^{a} \mathrm{M}$ e $\mathrm{m}$ ascendentes e/ou descendentes, que podem ser produzidos muito rapidamente ou com extrema lentidão, somados aos recursos dos ruídos da fala na tentativa de encontrar uma mediação entre o canto-falado e a fala-cantada, (Sprechgesang, Sprechstimme, Sprechmelodie) e ainda a experimentação de sons de uma escala não temperada.

Os graus conjuntos da escala cromática e mais a infinidade de combinações e permutações com as mistura das escalas diatônicas, cromática, tons inteiros, uma série dodecafônica e tudo o que essa horizontalidade pode gerar na construção vertical, soando simultaneamente, ou em uma, ou mais defasagem(s) canônica(s), são aquisições que definem um novo perfil musical. Viriam causar um "estranhamento", ou melhor, uma diferenciação sonora decisiva pelo uso da proposição de todas essas possibilidades.

Imaginem-se todas essas variáveis aliadas às questões da exploração de uso tímbrico eficiente dos formantes provocados pela produção e execução dos sons vocálicos em contraste com os sons consonantais.

Faz-se então necessária a promoção de uma técnica ainda mais refinada, que confira à nova curva melódica uma organicidade que venha respaldar flexibilidade e maleabilidade aos músculos do aparelho fono-respiratório que possam garantir a execução confortável desses requintes sonoros, desde 0 som mais claro ao mais escuro, do mais metálico ao mais aveludado, do mais denso ao mais cristalino; e ainda, considerá-los sob os efeitos da articulação, do legato, non legato, staccatto, com glissandi ou sem glissandi, para que se efetive toda a gama de nuances que esses permeiam.

No tocante a certos recursos, alguns intervalos até então tomados como dissonantes que eram evitados, ou utilizados com restrições tanto do ponto de vista harmônico quanto melódico, no despontar do século XX passam, então, a se instalarem como entidades de singular variedade na música escrita. Esse período trouxe acréscimos principalmente para a interválica, através, também, da adoção de ruídos produzidos pelo próprio fazer vocal ou instrumental que passam 
a participar da escrita musical como recursos que até então eram considerados antimusicais para a estética vocal anterior, logrando assim um novo status.

Costuma-se dizer que é muito mais confortável vocalizar emitindo o som de uma tríade perfeita maior do que emitindo uma tríade aumentada, diminuta, ou uma curva melódica mais tortuosa de saltos que utilizam intervalos compostos e/ou dissonantes. Para que esse conforto seja garantido é importante se familiarizar com mais esses elementos da composição.

Mas, há de se observar que os compositores da Segunda Escola de Viena e Steuermann, com muito esmero, foram todos bastante detalhistas na descrição dos parâmetros do som, naquilo que possivelmente a grafia poderia permitir, incluindo toda a expansão adquirida a partir daquele momento.

O lied, a cantata e o melodrama que são gêneros antigos que atravessaram por um longo período da História da Música, percorreram pelos vários estilos trazendo em sua carga inúmeros experimentos se acrescendo de riquezas sonoras até os dias de hoje, chegam consolidados à técnica dodecafônica como uma das formas grandemente utilizadas pelos compositores.

Surge uma nova sonoridade à instrumentação, e, à voz, uma nova vocalidade que pouco a pouco vêm se impondo até os nossos dias. Como se na transversalidade dessas duas categorias, uma invadisse o terreno da outra.

Esta nova gama de elasticidade impõe uma nova maneira na execução do cantar logrando também para a música uma nova vocalidade, o que exigirá um grau maior de habilitação técnica para o performer.

O performer deve ter a clara consciência que a execução desse repertório deve trazer à luz toda a historicidade técnica e musical, sem pular as etapas, ou seja, primar por uma execução portadora de todo contexto musical e histórico que transporta e transcende concomitantemente todo o aparato de conhecimento técnico. Assim como houve transcedência da forma, dos gêneros, que passou pela historicidade, o mesmo deve ocorrer com a técnica vocal.

Pode-se sugerir que o intérprete vocalize por todos os possíveis estilos dentro da estética dos movimentos e correntes musicais. É importante que o cantor experiencie em seu corpo uma prática que, em princípio retome a monodia, 
o cantochão, o canto gregoriano, a polifonia vocal, o organum, a frotola, o madrigal, que exercite a ópera, desde o seu surgimento no período barroco em direção período e clássico, e então insira o lied, o bel canto, a ópera romântica, as partes da cantata, os recitativos, o melodrama; analise com profundidade todos os possíveis gêneros vocais e os seus estilos que promovam um aprimoramento sobre os acréscimos que se desenvolveram de tempos em tempos. E então, só a partir daí, uma consciência e compreensão Ihe habilitarão uma interpretação satisfatória. Todo o embasamento técnico e musical faz-se, imprescindivelmente, necessário para que essa nova vocalidade seja absorvida pela memória cinestésica através de seu exercitar diário. As experiências devem ser um vívido cumprimento das várias etapas de procedimentos técnicos e históricos para que se tornem consciente de fato.

Não se pode excluir o aparato técnico conquistado através de todo desenvolvimento o qual passaram a voz e os instrumentos em seu percurso histórico. Essa historicidade conscencial é de um valor inegável.

É necessário compreender que um estudo de preparação consciente propõe etapas para amadurecer as propostas de exercíos técnicos e musicais, que seguem respeito à natureza do corpo humano. Não se devem pular etapas no estudo, como por exemplo, começar primeiro por este repertório, já que nele se admitira sons que para a estética anterior eram evitados. Importante lembrar que este repertório promove a expansividade dos vários parâmetros e aspectos do som e não uma redução de possibilidades, ou mera limitação técnica. Ele, acima de tudo, prima com mesmo esmero uma qualidade sempre em expansão, acrescida dos sons que foram incorporados pela nova vocalidade que surgia naquele momento.

Para compreender e dar acolhida a esta nova vocalidade é necessário uma reconfiguração de todo o pensar viciado aos seus pressupostos culturais e filosóficos. Deve haver a possibilidade de uma nova escuta em seu plano mais complexo, que está correlacionada com o sentido enquanto significado, em domínio conceitual vinculado às referências culturais estruturadas na liguagem. Entenda-se o termo cultura como foi estudado pelo antropólogo Clyde Kluckhohn: 
A cultura é um modo de pensar, sentir e acreditar. É o conhecimento do grupo armazenado (na memória dos homens; nos livros, nos objetos) para uso futuro.(...) Não é uma força dispersa; é criada e transmitida pelas pessoas ${ }^{28}$

\section{$(\ldots)$}

Se existe um princípio fundamental na cultura implícita, é ele muitas vezes chamado o ethos ou Zeitgeist ${ }^{282}$

Aproveitando o termo germânico, que significa e designa o estado geral, cultural, ou moral, ou ainda a tendência da cultura e o gosto característico de uma época, expressando, assim, o estado geral "do espírito do tempo" - ou Zeitgeist. Pode-se propor que a vocalidade é a própria linha do tempo contando cantando com as múltiplas faces da voz toda a história. História de homens que foram fazendo e refazendo; contando e recontando; cantando e recantando as coisas antigas que combinadas e inseridas na temporalidade dos fatos reinventaram outras. A vocalidade pode ser a própria história dos homens.

Onde existe um ser, este ser porta uma voz que canta e que conta a sua história, que por sua vez, vai burilando os aspectos de um novo fazer que somado a outros fazeres podem causar um novo refazer, até que uma boa quantidade de seres agarrados a uma mesma corrente aprimora uma ideia que semina em outra, que as alargam em uma nova e possível percepção.

Este trabalho não propõe diretamente um método efetivo de como realizar a execução técnica de tais peças. Proporciona uma reflexão e abertura a uma escuta que, através do reconhecimento dos elementos estruturais respaldado historicamente, venham dar suporte para um eficaz alargamento dos processos proprioceptivos que garanta consciência e qualidade do fazer musical durante a performance.

Os sons da música do século XX em todo seu escopo amparam toda uma sonoridade que reflete a mudança de parâmetros, de paradigmas do pensamento ocidental.

\footnotetext{
${ }^{281}$ KLUCKHOHN, Clyde. Antropologia, Um Espelho para o Homem. Belo Horizonte: Livraria Itatiaia Editora Ltda, 1972.p.33.

282 Idem. p.44.
} 
Ainda que muito já se tenha sido dito sobre estas preciosas obras, toda vez que nos deparamos com estas partituras, possivelmente encontraremos algo para relacionar e refletir sobre sua vocalidade. São obras primas que merecem constante exame criterioso para que se possa apreender a singularidade da beleza contida na proposta dos parâmetros sonoros. Deve haver uma busca e uma análise constantes que promovam um novo ouvir, enriquecido de uma abertura para apurar e experimentar em toda a sua profundidade esse novo som, como um sopro que vem inspirando novas gerações de artistas e ouvintes apreciadores com olhar de verdadeiros poetas, assim como poetas do som que foram estes compositores, souberam em tudo tornar poesia, porque sob o olhar de um poeta, em tudo pode haver beleza e poesia. 


\section{Referências bibliográficas}

ADORNO, Theodor W. Filosofia da Nova Música. São Paulo: Ed. Perspectiva, 1989.

ARANTES, Valéria Amorim. Afetividade e Cognição: Rompendo a dicotomia na Educação. Publicado originalmente em Oliveira, M. K.; Trento, D. ; Rego, T ( org ) . Psicologia, Educação e as Temáticas da vida contemporânea. São Paulo: Moderna, 2002.

ARGAN, Giulio Carlo. Arte Moderna. São Paulo: Companhia das Letras, 1999.

ARISTÓTELES. Obras. Política, livro VIII, cap 3. Tradução do grego por Francisco de P. Samarannch, Madri: Editora Aguilar, 1982, pp. 977-994

ARTAUD, Antonin. O Teatro e Seu Duplo. SP: Martins Fontes, 1999.

AZEVEDO, Sônia e GUINSBURG, J. A Poética do Corpo - Uma Reflexão Sobre a Circulação Estética do Ator. In J. Guinsburg - Diálogos Sobre Teatro, Armando Sergio da Silva, org. SPaulo: EdUSP, 2002.

BAILEY, Derek. L'improvisation. Ed. Outre Mesure, Paris : 1999.

BAILEY, Kathryn. "Webern" In; The New Grove Dictionnary of Music and Musicians. London : Macmillan Publishers Limited, 1980, pp. 179-195.

BANES, Sally. Greenwich Village 1963: avant-garde, performance e o corpo efervescente. RJ: Rocco, 1999.

BARBA, E. Além das Ilhas Flutuantes. Tradução - Luis Otávio Burnier. São Paulo - Campinas: Hucitec/Editora da UniCamp, 1991.

BARBIER, Patrick. História dos Castrati. Tradução Raquel Ramalhete. Rio de Janeiro: Nova Fronteira, 1993.

BARILIER, Etienne. Alban Berg. Ed. L'Age d'Homme, lausanne, 1978.

BECKER, Susie. A Voz Contemporânea. Dissertação de Mestrado - ECA-USP São Paulo, 2008

BENT, Ian. Analysis: "Analysis". In: SADIE, Stanley (ed.). The New Grove Dictionary of Music and Musicians. London: Mac Millan, 1980, v. 1, p. 340-388.

, lan. Analysis: The new Grove Handbooks in Books. London: MacMillan Press Ltd, 1987.

BEUTTENMÜLLER, Maria da Glória e LAPORT, Nelly. Expressão Vocal e Expressão Corporal. Rio de Janeiro: Forense - Universitária,1974. 
BOÉCIO. De Institutione musica, livro I. In Strunk Oliver, Source Readings in Music History. London/Boston, Faber and Faber Limited, 1981, vol I, Antiquity and Middle Ages, pp 25-33. Tradução: Carin Zwilling. São Paulo: 1998.

BOULEZ, Pierre. A Música Hoje. São Paulo: Editora Perspectiva S.A., 1995. Pierre. A Música Hoje 2. São Paulo: Editora Perspectiva S.A., 1992.

BOSCO, G. Gioanola, G., Vinay, G. "Prefazio" della ed. italiana de Armonia. Piston, Walter. Torino: Ed. Torino, 1989.

BOUSSER, D. et Bosseur, J-Y. Revoluções Musicais. Lisboa : Ed. Caminho, 1990. 1992. ,J-Y. Vocabulaire de la Musique Contemporaine. Paris : Ed. Minerve, CAMPBELL, Don. O Efeito Mozart. Rio de Janeiro: Rocco, 2001.

CANDÉ, Roland de. História Universal da Música - Volumes 1 e 2. (Tradução: Eduardo Brandão). São Paulo: Martins Fonte, 2001.

CAPRI, Antonio. Storia della Musica. Como: Casa Editrice Dr. Francesco Vallardi, 1969.

CARLSON, Marvin. Teorias do Teatro. São Paulo: Unesp, 1995.

CARMO JR, José Roberto do. Da Voz aos Instrumentos Musicais. São Paulo: Anablume; Fapesp, 2005.

CARNER, Mosco. Alban Berg - The Man and the Work. Great Britain: Duckworth, 1975.

CARPEAUX, Otto Maria. O Livro de Ouro da História da Música. Rio de Janeiro: EdiOuro, 2001.

CATANZARO, Tatiana Olivieri. Transformações na Linguagem Musical Contemporânea Instrumental e Vocal sob a Influência da Música Eletroacústica Entre as Décadas de 1950-70. Dissertação de Mestrado apresentada à ECA-USP, 2003.

CERQUEIRA, Fernando. Musicalidade e Poesia: anseio e recusa do sentido. Salvador: Quarteto, 2006.

CHAPMAN, Alan. Some Intervalic Aspect of Pitch-Class Set Pitch-Class Set Relations. Journal of Music Theory. 25/2:275-290. Ano de 1981.

CHASIN, Ibaney. O Canto dos Afetos: Um Dizer Humanista. SPaulo: Perspectiva, 
2004.

CHRISMAN, Richard. Indentification and Correlation of Pitch-Class Set Relations. Journal of Music Theory. 15:58-83. Ano de 1971.

COELHO, José Teixeira. Antonin Artaud. São Paulo: Editora Brasiliense s.a., s/d.

COHEN, Renato e GUINSBURG, J. Do Teatro à Performance - aspectos da significação da cena. In J. Guinsburg - Diálogos sobre Teatro. Armando Sérgio da Silva, org. SPaulo: EdUSP, 2002.

COOK, Nicholas. A Guide to Musical Analylsis. London: J.M.Dent \& Sons Ltd, 1987.

CORRÊA, Antenor Ferreira. Estruturações Harmônicas Pós-Tonais. São Paulo: EdUNESP, 2006.

COSTA, O. H. \& SILVA, M. A. Voz Cantada. São Paulo: LOVISE Ltda. 1998.

COSTA, Rogério Luiz Moraes. O Músico enquanto Meio e os Territórios da Livre Improvisação, Tese de Doutorado apresentada à PUC - SP, 2003.

COSTÈRE, Edmond. Lois et Styles dês Harmonies Musicales. Paris: Presses Universitaires de France, 1970.

, Edmond. Mort ou Transfigurations de l'Harmonie. Paris: Presses Universitaires de France, 1962.

DAHLHAUS, Carl. Analysis and Value Judgment. Tradução de Siegmund Levarie. Nova lorque: Pendragon Press, 1983.

DAHLHAUS, Carl. Estética Musical. Lisboa; Edições 70 s/d

DAHLHAUS, Carl. "Harmony" In; The New Grove Dictionnary of Music and Musicians. London: Macmillan Publishers Limited, 1980, pp.175-188.

, Schoenberg and the New Music. Tradução: Derrick Puffett and Alfred Clayton. Cambridge University press.Cambridge: (1964) 1987.

DALLIN, Leon. Techniques of Twentieth Century Composition. lowa: WM.C. Brown Company Publishers, 1975.

DUNSBY, Jonathan. Schoenberg: Pierrot Lunaire. Cambridge: University Press, 1992.

ECO, Umberto. A Definição de Arte. Tradução de José M. Ferreira. São Paulo: Martins Fontes, 1992. 
EIMERT, Herbert. Qué es la Musica Dodecafónica? Buenos Aires: Nueva Visión, 1973.

EKSTEIN, Modris. A Sagração da Primavera. Rio de Janeiro: Rocco, 1992.

ESSLIN, Martin. Artaud. SP: Cultrix: Editora da Universidade de São Paulo, 1978.

FERRAZ, Silvio. Música e Repetição - a diferença na composição contemporânea. São Paulo Educ, Fapesp, 1998.

FONTANELLA, Francisco. O corpo no limiar da subjetividade. Piracicaba: Unimep, 1995. Apud in Rosário, Nísia Martins do. Mundo Contemporâneo: Corpo em Metamorfose. Artigo disponível em www.comunica.unisinos.br/semiotica/nisia_semiotica/conteudos/corpo.htm

FORTUNA, Marlene. A Performance da Oralidade Teatral. São Paulo: Annablume, 2000.

FORTE, Allen. Schoenberg's Creative Evolution: The Path to Atonality, Musical Quarterly. 64/2:133-176. Ano de 1978.

1973.

, Allen. The Structure of Atonal Music. New Haven: Yale University Press,

FUBINI, Enrico. L'Estetica Musicale dal Settecento a Oggi. Torino: Piccola Biblioteca Einaudi, 2001.

FUHRMANN, Roderich. Perspektiven Neuer Musik. Mainz: B. Schotts's Söhne, 1974.

GAYOTTO, Lúcia Helena. Voz - Partitura da Ação. São Paulo: Plexus Editora, 1997.

GOLDSTEIN, Norma. Versos, Sons, Ritmos. São Paulo, Editora Ática, 1990.

GRIFFTHS, Paul. A Música Moderna. R. de Janeiro: Jorge Zahar Ed.1987.

GRIFFITHS, Paul. A Música Moderna: uma história concisa e ilustrada de Debussy a Boulez. RJ: Jorge Zahar Editora, 1998.

, Paul. Enciclopédia da Música do Século XX. Tradução de Marcos

Santarrita e Alda Porto. São Paulo: Martins Fontes, 1995.

GREINER, Christine. O Corpo - Pistas para estudos indisciplinares. São Paulo: Anablume, 2005.

GROUT, Donald J. e PALISCA, Claude V. História da Música Ocidental. Editora 
Gradiva, 2005.

HAOULI, Janete el. Demétrio Stratos: A Escuta da Voz-Música. Dissertação de Mestrado. ECA - USP, 1993.

HERLIHY, Bárbara e MAEBIUS, Nancy K. Anatomia e Fisiologia do Corpo Humano Saudável e Enfermo. São Paulo: Editora Manole Ltda, 2002.

HERR, Martha. In: Arte e Cultura II - Estudos Interdisciplinares. Maria de Lourdes Sekeff e Edson Zampronha (organizadores). São Paulo: Annablume: Fapesp, 2002.

HESÍODO. Teogonia, A Origem dos Deuses. Estudo e Tradução de Jaa Torrano. São Paulo: lluminuras, 1992.

HUSEBY, Gerardo V. A Música no Pensamento Grego in Trivium e Quadrivium: As Artes Liberais na Idade Média; coordenação: Mongelli, Lênia Márcia. Cotia, SP: Íbis, 1999.

IAZZETA, Fernando. Música - Processo e Dinâmica. São Paulo: Annablume, 1993.

JANUZELLI, Antônio. A Aprendizagem do Ator. São Paulo: Editora Ática, 2003.

JARMAN, Douglas. The Music of Alban Berg. London: Faber \& Faber, 1983.

JAMEAUX, D. L'École de Vienne. Paris, Ed. Fayard : 2002.

Bourgois Editeur, 1999. , - Introduction, Présentation et Notes » in Berg. Paris : Chirstian , Berg. Paris, Ed.Seuil, 1980.

, Musique Des Lumières. Etudes Atonales II, Note Sur la Société D'éxécutions Musicales Privées in Musique en Jeu n¹6. Paris : Ed. Seuil, 1974, pp.55-69.

JOURDAIN, Robert. Música, Cérebro e Êxtase - Como a música captura nossa imaginação. Rio de Janeiro: Objetiva, 1998.

JUSTI, Katia Regina Kato. O Oboé e a Representação da Confiança nas Árias das Cantatas Sacras de J.S.Bach. São Paulo: Dissertação de Mestrado - UNICAMP, 2007.

KERMAN, Joseph. Musicologia. São Paulo: Livraria Martins Fontes Editora Ltda., 1987.

KLUCKHOHN, Clyde. Antropologia, Um Espelho para o Homem. Belo Horizonte: 
Livraria Itatiaia Editora Ltda, 1972.

KRAMER, Lawrence. Music and Poetry. The Nineteenth Century and After. London: University of California Press, Ltd, 1984. p. 128

LEIBOWITZ, René. Introduction à La Musique de Douze Sons. Paris: L'Arche, Collection Références, 1949.

, René. Le Compositeur et Son Double. Ed. Gallimard, 1986.

, René. Schoenberg. São Paulo: Perspectiva Editora, 1981.

, René. Schoenberg and His School. New York: Da Cappo Press,

1970.

Seuil, 1969.

, René. Schoenberg. Collection Solfèges n³0. Paris: Editions du

LESSEM, Allan. Music and Text in the Works of Arnold Schoenberg: The Critical Years 1908 - 1922.

LESTER, Joel. Analytic Approaches to Twentieth-Century Music. New York: Norton, 1989.

LINDLEY, M. Temperaments - in Sadie, Stanley. The New Grove Dictionnary of Music and Musicians, vol.18. London: Macmillan Publishers Limited, 1980, pp.660674.

LIGETI, Gyorgy. Sciences, Musique et Langues. (trad do alemão por Lucie Kayas). In http: www.mac-texier.ircam.fr/textes. Extraído do discurso para o prêmio Balzan. Edição original in: Neue Zeitschrift für Musik, janeiro 1993.

LIMA, Marisa Ramires R. \& FIGUEIREDO, Sérgio Luiz F. de. Exercícios de Teoria Musical - Uma abordagem prática.São Paulo: Embraform, 2004.

LOBO, Roberto Jorge Haddock. A Filosofia e sua Evolução: Pequena história do pensamento humano. São Paulo: Ed. Populares, 1979.

MAEGAARD, Jan. Studien zur Entwicklung des Dodecaphonen Satzes bei Arnold Schoenberg. Copenhagen: Willelm Hansen, 1972.

MARCO, Tomás. Historia General de la Música - El siglo XX, vol.4. Madrid: Ediciones Istmo, s/d.

MARTINS, Maria Raquel Delgado. Ouvir Falar, Introdução á fonética do Português. Lisboa: Editorial Caminho, S.A., 1998. 
MASSIN, Jean \& Brigitte. História da Música Ocidental. Rio de Janeiro: Ed. Nova Fronteira, 1997.

MEDAGLIA, Júlio. Música Impopular. São Paulo: Global, 1988.

MENDES, Maria Isabel Brandão de Souza. Corpo, Natureza e Cultura: Contribuição para a Educação. Disponível no site www.anped.org.br/rbe27/anped$\underline{\text { n27-art08.pdf }}$

MENEZES Fo, Flo. A Acústica Musical em Palavras e Sons. Cotia, São Paulo: Ateliê. Editorial, 2003. Apoteose de Schoenberg. São Paulo: Nova Estela, 1987.

MENEZES, Philadelpho. Poesia Sonora: Poéticas Experimentais da Voz no Século XX. São Paulo: Educ, 1992.

MERLEAU-PONTY, M. A Natureza: notas: cursos no Collège de France. Martins Fonte, 2000 - in Apud Mendes.

MILLER, Richard. The Structure of Singing - System and Art in Vocal Technique Belmont - USA: Schirmer/Thomson Learning, 1996.

MINARELLI, ENZO. História da Poesia Sonora no século XX. In Poéticas Experimentais da Voz no Século XX. São Paulo: Educ, 1992.

MORIN, Edgard. O Paradigma perdido: A Natureza Humana. $5^{\text {a }}$ edição. Tradução de Hermano Neves. Lisboa: Publicações Europa-América, 1973. Apud Mendes, Maria Isabel Brandão de Souza.

MORIN, Edgar. Por uma Reforma do Pensamento. In: O pensar Complexo Edgar Morin e a crise da modernidade. Organizadores: Alfredo Pena-Veja e Elimar Pinheiro do Nascimento. Rio de Janeiro: Garamond, 1999.

NEWLIN, Dika. Schoenberg Remembered: Diaries and Dodecaphony, trans. R.Mann. London, Calder, 1977.

NIETZSCHE, F. W. A Origem da Tragédia. São Paulo: Editora Moraes, 1984.

OLIVEIRA JR, Antonio Wellington. Glossolalia: Voz e Poesia. São Paulo: Educ, Fapesp, Omni, 2004.

PAZ, Juan Carlos. Introdução a Música do Nosso Tempo. São Paulo: Duas Cidades, 1976. 
PAZ, Otávio. O Arco e a Lira. Rio de Janeiro: Editora Nova Fronteira S/A, 1956.

PENA-VEJA, Alfredo e STROH, Paula. Viver, Compreender, Amar. In O pensar Complexo - Edgar Morin e a crise da modernidade. Organizadores: Alfredo PenaVeja e Elimar Pinheiro do Nascimento. Rio de Janeiro: Garamond, 1999.

PERLE, George. La Evolutión de la Serie Tonal. Montevideu: Boletín LatinoAmericano de Música, vol.5, 1941.

PERRY, Marvin. Civilização Ocidental - Uma história concisa. São Paulo: Livraria Martins Fontes Editora Ltda, 1985.

PIANA, Giovanni. A Filosofia da Música. Bauru, São Paulo: Edusc, 2001.

PIROTTA, Nilthe Miriam. O Melos Dramático - Pequena Introdução ao Estudo das Relações Drama-Música no Teatro. Dissertação de mestrado apresentada à ECA - USP, 1992.

PISTON, Walter. Armonia. Torino. Ed. Torino, 1989.

PISTON, Walter. Harmony. New York: W. W. Norton \& Company, 1987.

POMBO, Fátima. Traços de Música. Aveiro: Universidade de Aveiro, 2001. p. 44

PLATÃO. A República, livro III, cap. 3. Tradução de Maria Helena da Rocha Pereira. Lisboa, Fundação Gulbenian, 1983.

PIVA, Luiz. Literatura e Música. Brasília: MusiMed, 1990.

POUSSEUR, Henri. Musique, Sémantique, Société. Belgique: Casterman/Poche, 1972.

RAHN, John. Basic Atonal Theory. New York: Longman, 1980.

REICHI, Willi. Les Dernières Oeuvres d'Alban Berg; in La Revue Musicale. Paris: 1989, pp. 109-116.

RENEGER, Eric. On Allen Forte's Theory of Chords - Perspective of New Music. 13/1:191-212. Ano de 1974.

- Panorama de la Musique Autrichienne du Côté de Chez Schoenberg: Anton Webern, Egon Wellesz; in La Revue Musicale. Paris: 1989, pp. 124-128.

RIEDEL, Elke Beatriz. O Gesto Vocal na Poesia Sonora em Performance. Dissertação de Mestrado apresentada à PUC-SP, 1998.

ROBERTSON, A. e STEVENS, D. - Historia General de la Música,- De las Formas 
Antiguas a la Polifonia, vol I. Dirigida por esses autores. Madrid: Ediciones Istmo, 1968.

ROEDER, John. A Geometric Representation of pitch-Class Series. Perspective of Music. 25:362-409. Ano de 1987.

, John. Harmonic Implications of Schoenberg's Observations of Atonal Voice Leading. Journal of Music Teory. Vol.33, no1, 1989. pp.27-62. Oxford University Press, 1981. URL: http://www.jstor.org/stable/843664

ROSEN, Charles. Schoenberg. Paris: Les Editions de Minuit, 1979.

Charles. A Geração Romântica, trad. de Eduardo Seincmann, São Paulo, EDUSP, 2000.

ROUBINE, Jean-Jacques. A Linguagem da Encenação Teatral. Rio de Janeiro: Jorge Zahar Editor, 1998.

RUSSOLO, Luigi. The Art of Noises. New York: Pendragon Press, 1986.

SADIE, Stanley. The Grove Concise Dictionary of Music. Jorge Zahar Editor, 1994. The New Grove Dictionnary of Music and Musicians (20 vol). London: Macmillan Publishers Limited, 1980.

Jorge Zahar Editor, 1994.

- Dicionário Grove de Música - Edição concisa - Rio de Janeiro:

SAMUEL, Claude. Panorama da Arte Musical Contemporânea. Lisboa: Editorial Estúdios Cor, Ltda, 1964.

SANTO AGOSTINHO. Confissões, livro X. Coleção Os Pensadores, Editora Abril. SANTOS, Fátima Carneiro dos Santos. Por Uma Escuta Nômade: a música dos sons da rua. SP: Educ, Fapesp, 2002.

SCHAEFFER, Pierre. Las Cuatro Escuchas in Tratado de los Objetos Musicales. Madrid: Alianza Editorial, 1988.

SCHAFER, Murray. O Ouvido Pensante. São Paulo: Editora Unesp, 1992.

SCHLOEZER, Boris e SCRIABINE, Marina. Problemas de la Música Moderna. Barcelona: Editorial Seix Barral, S.A., 1973.

SCHOENBERG, Arnold. Correspondance: 1910-1951. Stein, Erwin (org.), Collins, Dennis (trad.). Paris: Ed. Jean-Claude Lattès, 1983. 
Arnold. Funções Estruturais da Harmonia. Tradução Eduardo Seincman. São Paulo: Ed. Mônica Seincman, 2004.

- Arnold. Fundamentos da Composição Musical. Tradução Eduardo Seincman. São Paulo: Ed.USP, 1996.

UNESP, 1999.

Arnold. Harmonia. Tradução de Marden Maluf. São Paulo: Ed.

A. "La Composition à Douze Sons" - in La Revue Musicale. Paris : 1989 (b), pp. 81-108.

, A. "Les Soixante Ans de Shoenberg" - in La Revue Musicale. Paris, 1989 (a), pp. 79- 80.

, A. Stile e Idea. Milano: Rusconi e Paolazzi Ed., 1960.

Ed.L.Stein, trans. L. Black. London: Faber, 1975.

A. Style and Idea: Selected Writings of Arnold Scheonberg.

, A. Style and Idea. Edited by Leo Stein. Translation by Leo Black. Revised Paperback Edition. Berkeley and Los Angeles: University of California Press, 1984.

, A. Structural Function of Harmony. New York: Norton Company, 1969.

, A. Une analyse des Lieder avec Orchestre d'Arnold Schoenberg par le Compositeur Trad. Dennis Collins, in Musique en Jeu, $n^{\circ}$ 16. Paris: Ed. Seuil, 1974, pp. 43-54.

A. \& Stevens, Halsey. "Entretien sur la Peinture", in Musique en Jeu, n¹6. Paris: Ed. Seuil, 1974, pp. 70-71.

SCHULLER, Gunther \& STEUERMANN, Eduard - A Conversation with Steuermann - Perspectives of New Music, Vol. 3, No. 1 (Autumn - Winter, 1964), pp. 22-35. - URL: http://www.jstor.org/stable/832234.

SCHWARTZ, Elliot e GODFREY, Daniel. Music since 1945: Issues, Materials, and Literature. USA: Wadsworth/Thomson Learning, 1993.

SEVERINO, Antônio Joaquim. Filosofia. SP: Cortez Editora, 1992.

SEINCMAN, Eduardo. Do Tempo Musical. São Paulo: Via Lettera, 2001.

SOUZA, Luis Otavio C. G. de. A Música e os Efeitos Sonoros na Cena Teatral: Reflexões sobre uma Estética. Dissertação de doutorado apresentada à ECA USP, 1999. 
SPITTA, P. Johann Sebastian Bach, Vol II. Dover Publication, New York, 1952.

STADLEN, Peter. Schoenberg's Speech-Song-Music \& Letters, Vol. 62, no 1 pp. 1-11. Oxford University Press, 1981. URL: http://www.jstor.org/stable/734794.

STEFANI, Gino. Para entender a música. RJ: Globo, 1987.

STEFAN, Rudolf. 'Schoenberg's Entwurf über' Das komponieren mit selbständingen Stimmen. Archiv für Musikwiessenschaft, 29/4:239-256. Ano de 1972.

STOPPELMAN, Gabriela e HARDMEIER, Jorge. Artaud para principiantes. Buenos Aires: Era Naciente SRL, 1998.

STRAUS, Joseph N. Introduction to Post-Tonal Theory. Editora Prentice-Hall do Brasil, Rio de Janeiro, 1990.

STORÓLLI, Wânia M. Agostini. Movimento e Respiração: A Prática Vivenciada de Ilse Middendorf no Ensino de Canto. Dissertação de mestrado apresentada à ECA-USP, 2004.

STUCKENSCHMIDT, H. Arnold Schoenberg. London: Calder, 1959.

TERRA, Vera. Acaso e Aleatório na Música. São Paulo: Educ: Fapesp, 2000.

TOMATIS, Alfred. El Oido y el Lenguage. Traducción de la edición original francesa por Juan Godo. Ediciones Martinez Roca, S.A., Barcelona, 1969. , L'Oreille et la Voix. Éditions Robert Laffont, S.A., Paris, 1987.

O Ouvido à Escuta da Música. (Tomatis e Vilain, J). In: Música e Saúde, Even Ruud. org., São Paulo: Summus, 1991.

TORRANO. J. Hesíodo/Teogonia: Origem dos Deuses. São Paulo: Massao Ohno/Roswitha Kempf Editores, 1981.

VALENTE, Heloísa de Araújo Duarte. Os Cantos da Voz - entre o ruído e o silêncio. São Paulo: Annablume, 1999.

VASCONCELOS, Mário Sérgio. Afetividade na Escola: Alternativas Teóricas e Práticas. Educ. Soc, Campinas, vol. 25, n 87, maio/ago 2004. Disponível em www.cedes.unicamp.br.

VIGNAL, Marc (dir) Dictionnaire de la Musique. Paris : Larousse, 1994.

VIRMAUX, Alain. Artaud e o Teatro. SP: Editora Perspectiva S.A., 1978. 
WEBERN, Anton. O Caminho para a Música Nova. Tradução de Carlos Karter. São Paulo: Novas Metas, 1986.

WELLEZ, Egon. Arnold Schoenberg, in La Revue Musicale. Paris, 1926.

WHITE, John D. Comprehensive Musical Analysis. New Jersey: The Scarecrow Press, 1994.

WISNIK, José Miguel. O Som e o Sentido. São Paulo: Companhia das Letras, 1989.

ZANI, Amílcar. Edward Steuermann: Um Esboço de Figura. São Paulo: Tese de livre Docência - ECA-USP, 1991.

Amílcar. Steuermann: Versões Possíveis das Impossibilidades. In: Maria

L. Sekeff e E. Zampronha (org). Arte e Cultura IV Estudos Interdisciplinares. São Paulo: Anna Blume, 2006.

Amílcar. Vida e Arte na Coleção Clara e Edward Steurermann. www.projetosteuermann.usp.br.

ZANI, Heloisa. Correspondência - Clara e Edward Steuermann e René Leibowitz. São Paulo: Tese de Doutorado - ECA-USP, 2002.

ZUBEN, Paulo. Ouvir o Som. SP: Ateliê Editorial, 2005.

ZUMTHOR, Paul. A letra e a voz: A "Literatura" Medieval. Tradução de Amalio Pinheiro \& Jerusa Pires Ferreira. São Paulo: Companhia das Letras, 1993.

. Performance, Recepção, Leitura. Tradução Jerusa Pires Ferreira e Suely Fenerich. Cosacnaify - São Paulo, 2010.

Experimentais da Voz no Século XX. São Paulo: Educ, 1992

Poesia do espaço. In Poesia Sonora: Poéticas

SCHÖNBERG: Pierrot Lunaire.

Arnold Schönberg, conductor.

Erika Stiedry-Wagner, recitation.

Rudolf Kolisch, violin and viola.

Stefan Auber, 'cello.

Eduard Steuerrmann, piano.

Leonard Posella, flute and piccolo.

Kalman Bloch, clarinet and bass clarinet.

Columbia 78rpm set MM-461 (XH 23 - XH 30). Recorded in 1940. 
Digital transfer by F. Reeder

This audio is part of the collection: 78 RPMs \& Cylinder Recordings

http://archive.org/details/SchnbergPierrotLunaire

Anton Webern (1883-1945): Kantate II, per soprano, basso, coro e orchestra, su testo di Hildegard Jone op.31 (1943) - Halina Lukomska, soprano; Barry Mac Daniel, basso; Choeur et Orchestre de l'O.R.T.F. diretti da Pierre Boulez (Paris 8.II.1966) 
ANEXOS 


\section{ANEXO I}

(traduções)

As Sete Primeiras Canções - Alban Berg - p. 271

Três Canções - Edward Steuermann - p. 273

Pierrot Lunaire - Arnold Schoenberg - p. 276 


\section{Canções de Alban Berg - tradução dos textos do alemão para o português}

\section{Maria Cecília de Oliveira}

As Sete Canções da 1ª fase - Alban Berg (1885-1935)

1- Nacht - Carl Haputmann

Dämmern Wolken über Nacht und Tal, Nebel schweben, Wasser rauschen sacht. Nun entschlei ert sich's mit einemmal: O gib acht! Gib acht! Weites Wunderland ist aufgetan. Silbern ragen Berge traumhaft gross, stille Pfade silberlicht talan aus verborgnem Schoss, und die hehre Welt so traumhaft rein. Stummer Buchenbaum am Wege steht schattenschwarz, ein Hauch vom fernen Hain einsam leise weht. Und aus tiefen Grundes Düsterheit blinken Lichter auf in stummer Nacht. Trinke Seele! Trinke Einsamkeit! O gib acht! Gib acht!

\section{1-Noite}

As nuvens do crepúsculo avançam sobre a noite e o vale, A névoa paira no ar, as águas sussurram de mansinho. Agora revela-se de repente. Oh! Repare! Uma vasta terra maravilhosa descerrou-se -

Montanhas de prata erguem-se fantasticamente altas, veredas silenciosas prateadas resplandecem do regaço secreto, e um mundo majestoso tão fantasticamente puro. Uma árvore de faia projeta no caminho sua sombra negra, a brisa de um distante arvoredo sopra de forma solitária e silenciosa. E do profundo da escuridão cintilam luzes na noite calma. Alma sorva! Sorva a solidão! Oh! Repare.

2 - Schilflied - Nikolaus Lenau

Auf geheimem Waldespfade schleich“ ich gern im Abendschein an das öde Schilfgestade, Mädchen, und gedenke dein. Wenn sich dann der Busch verdüstert, rauscht das Rohr geheimnisvoll, und es klaget und es flüster, dass ich weinen, weinen soll. Und ich mein;, ich höre wehen leise deiner Stimme Klang, und im Weiher untergehen deinen lieblichen Gesang.

2- Canção do Junco

No entardecer eu gosto de andar furtivamente por uma vereda secreta da floresta, a beirada erma dos juncos, menina, e recorde-se.

Quando, então, o bosque escurece, o junco rumoreja misteriosamente clama, e sussurra que eu devo chorar, chorar.

E eu penso ouvir baixinho o som de sua voz soprar e no regato seu lindo canto chega ao fim.

\section{3 - Die Nachtigall - Theodor Storm}

Das macht, es hat die Nachtigall die ganze Nacht gesungen; da sind von ihrem süssen Schall, da sind in Hall und Widerhall die Rosen aufgesprungen. Sie war doch sonst ein wildes Blut; nun geht sie tief in Sinnen, trägt in der Hand den Sommerhut und duldet still der Sonne Glut, und weiss nicht, was beginnen. Das macht, es hat die Nachtigall die ganze Nacht gesungen; da sind von ihrem süssen Schall, da sind in Hall und Widerhall die Rosen aufgesprungen.

3-O Rouxinol

Eis que o rouxinol cantou a noite inteira, então por causa de seu som, seu eco e ressonância, as rosas saltaram bruscamente (estremeceram). 
Em geral seu temperamento era selvagem, mas, agora ele está quieto; carrega na mão o chapéu de verão e suporta calmamente o calor do sol e não sabe o que virá.

4 - Traumgekrönt - Rainer Maria Rilke

Das war der Tag der weißen Chrysanthemen,

Mir bangte fast vor seiner Pracht...

Und dann, dann kamst du mir die Seele nehmen

Tief in der Nacht.

Mir war so bang, und du kamst lieb und leise,

Ich hatte grad im Traum an dich gedacht.

Du kamst, und leis' wie eine Märchenweise

Erklang die Nacht.

\section{4- Coroado em Sonhos}

Era dia de crisântemos brancos, eu quase sentia medo diante de seu esplendor...

E então, então você veio mergulhar minha alma na noite.

Tive tanto receio, e você veio de um jeito amável e suave, que pensara estar sonhando com você. Você veio... e suave como a melodia de uma lenda antiga ecoou a noite.

5 - Im Zimmer - Johanne Schlaff

Herbstsonnenschein.

Der liebe Abend blickt so still herein.

Ein Feuerlein rot

Knistert im Ofenloch und loht.

So, mein Kopf auf deinen Knie'n,

So ist mir gut.

Wenn mein Auge so in deinem ruht,

Wie leise die Minuten zieh'n.

\section{5- No Quarto}

Brilho do sol outonal. A noite amável olha tão calma para dentro. Um pequeno fogo crepita vermelho no forno (lareira) e rutila.

Assim! Minha cabeça em seus joelhos, assim me sinto bem.

Quando meu olhar repousa assim no seu, como os minutos passam de forma suave.

6 - Liebesode - Otto Erich Hartleben

Im Arm der Liebe schliefen wir selig ein,

Am offnen Fenster lauschte der Sommerwind,

Und unsrer Atemzüge Frieden

Trug er hinaus in die helle Mondnacht. --

Und aus dem Garten tastete zagend sich

Ein Rosenduft an unserer Liebe Bett

Und gab uns wundervolle Träume,

Träume des Rausches -- so reich an Sehnsucht! 
6 - Ode ao Amor

Ditosos (bem-aventurados/felizes) adormeceremos nos braços do amor. Na janela aberta espreitava o vento de verão, e ele levava a paz de nossos suspiros para a noite clara de luar.

E do jardim tateava hesitante (lacilante) um aroma de rosas no nosso leito de amor e nos proporcionava sonhos maravilhosos, sonhos de êxtase, tão ricos em saudade.

7 - Sommertage - Paul Hohenberg

Nun ziehen Tage über die Welt, Gesandt aus blauer Ewigkeit, Im Sommerwind verweht die Zeit.

Nun windet nächtens der Herr

Sternenkränze mit seliger Hand

Über Wander- und Wunderland.

O Herz, was kann in diesen Tagen

Dein hellstes Wanderlied denn sagen

Von deiner tiefen, tiefen Lust:

Im Wiesensang verstummt die Brust,

Nun schweigt das Wort, wo Bild um Bild

Zu dir zieht und dich ganz erfüllt.

7 - Dias de verão

Agora os dias passam pelo mundo, enviado da eternidade azul, o tempo dissipa-se no vento de verão. Agora a noite o senhor tece com suas mãos ditosas coroas (guirlandas) de estrelas sobre os peregrinos e sobre o reino (país) das maravilhas.

Oh! Canção, o que podes dizer nestes dias a canção mais sonora de viandante (andarilho, peregrino) sobre sua vontade intensa: no canto da pradaria emudece o peito, agora a palavra silencia (se cala), onde cada quadro leva a você e te realiza.

\section{Canções de Edward Steuermann}

Drei Lieder (Três Canções)

I - Der Mensch

II - Wandrers Nachtlied

III - Gesang der Geister über den Wassern

\section{I - Der Mensch}

Empfanget und genähret vom Weibe, wunderbar

Kömmt er und sieht und höret

Und wird dês Trugs nicht wahr

Gelüstet und begehret,

Und bringt sein Tränlein dar

Verachtet und verehret

Hat Fruede und Gefahr.

Erbauet, und zerstöret

Und quält sich immerdar

Und alles dieses währet, 
wenn's hoch kommt, achtzig Jahr.

Dann legt er sich zu seinen Vätern nieder, Und Kommt nimmer wieder.

I - O Homem

Concebido e criado por mulher, um milagre

Ele vem e vê e ouve

E é desiludido eventualmente [a tempo]

Sua paixão e seu anseio

Seus prazeres e seus temores

Logo o trará às lágrimas

Seu ódio e sua reverência

Seus prazeres e seus temores

Criação e destruição

O assombrarão eternamente

E tudo isso continua

Por mais oitenta anos,

Então ele tomará seu lugar ao lado de seu pai

E não mais vagará

\section{II - Wandrers Nachtlied}

Der Du vom Himmel bist, alles Leid und Schmerzen stillest, Den, der doppelt elend ist

Doppelt mit Erquickung füllest.

Ach, ich bin des Treibens müde.

Was soll all der Schmerz und Lust?

Süsser Friede,

Komm, ach Komm in meine Brust.

II - A Canção Noturna do Andarilho

Tu que vens do céu,

Tu que aquietas dor e tormento

Tua divina compaixão

Pode reviver os desesperados, desgraçados

Ah, quão cansado estou de lutar

Por que existe tamanha dor, e desejo?

Doce paz,

Venha, ó venha já em meu peito.

\section{III - Gesang der Geister über den Wassern}

Des Menschen Seele gleicht dem Wasser:

Vom Himmel kommt es, zum Himmel steigt es

Und wieder nieder zur Erde muss es,

Ewig wechselnd

Strömt von der hohen steilen Felswand der reine Strahl, Dann stäubt er lieblich zu Wolkenwellen zum glatten Fels 
Und leicht empfangen

Wallt er verschleiernd leis

rauschend zur Tiefe nieder.

Ragen Klippen dem Sturz entgegen,

Schäumt er unmutig stufenweise zum Abgrund.

Im flachen Bette schleicht er das Wiesental hin

Und in dem glatten See

Weiden ihr Antlitz alle Gestirne.

Wind ist der Welle lieblicher Buhler;

Wind mischt von Grund aus schäumende Wogen.

Seele des Menschen, wie gleichst du dem Wasser;

Schicksal des Menschen, wie gleichst du dem Wind!

III - O Espírito do Vento sobre a Água

A alma do homem é como a água:

Ela vem do céu, ao céu retorna,

$\mathrm{E}$, novamente, à terra deve descer

Eterno movimento

De muito acima do cânion rochoso ela corre pura

Em nuvens de suave bruma, ela cai, ela flui, por sobre as pedras

Que jazem em espera

Afundando, invisivelmente, flutuando,

Em torrentes adentram a escuridão

De acidentados penhascos a cachoeira espuma

Ferozmente pela superfície rochosa rumo ao abismo.

Um rio tranquilo flui pelo vale verdejante

Indo para o mar cintilante,

Espelhando todas as estrelas nos céus

$O$ vento e as ondas são lindos amantes;

$O$ vento revolve a terra com ondas borbulhantes.

Alma da humanidade, tal qual a água

Destino da humanidade, tal qual o vento! 


\section{Pierrot Lunaire - de Arnold Schoenberg - tradução para o português de}

\section{Augusto de Campos in Música de Invenção - Editora Perspectiva}

\begin{tabular}{|c|c|}
\hline $\begin{array}{l}\text { 1. MONDESTRUNKEN } \\
\text { Den Wein, den man mit Augen trinkt, } \\
\text { Giesst Nachts der Mond in Wogen nieder, } \\
\text { Und eine Springflut überschwemmt } \\
\text { Den stillen Horizont. } \\
\text { Gelüste, schauerlich und süss, } \\
\text { Durschwimmen ohne Zahl die Fluten! } \\
\text { Den Wein, den man mit Augen trinkt, } \\
\text { Giesst Nachts der Mond in Wogen nieder. } \\
\text { Der Dichter, den die Andacht treibt, } \\
\text { Berauscht sich an dem heilgen Tranke, } \\
\text { Gen Himmel wendet er verzückt } \\
\text { Das Haupt und taumelnd saugt und schlürft er } \\
\text { Den Wein, den man mit Augen trinkt. }\end{array}$ & $\begin{array}{l}\text { 1. BÊBADO DE LUA } \\
\text { O vinho que meus olhos sorvem } \\
\text { A lua verte em longas ondas, } \\
\text { Que numa enorme enchente solvem } \\
\text { Os mudos horizontes. } \\
\text { Desejos pérfidos se escondem } \\
\text { No filtro do luar que chove. } \\
\text { O vinho que meus olhos sorvem } \\
\text { A Lua verte em longas ondas. } \\
\text { O Poeta, no silêncio absorto, } \\
\text { Absinto santamente absorve, } \\
\text { E o céu é seu até que cai, } \\
\text { Olhar em alvo, gesto tonto, } \\
\text { Do vinho que meus olhos sorvem. }\end{array}$ \\
\hline $\begin{array}{l}\text { 2. COLOMBINE } \\
\text { Des Mondlichts bleiche Blüten, } \\
\text { Die weissen Wunderrosen, } \\
\text { Blühn in den Julinächten - } \\
\text { O bräch ich eine nur! } \\
\text { Mein banges Leid zu lindern, } \\
\text { Such ich am dunklen Strome } \\
\text { Des Mondlichts bleiche Blüten } \\
\text { Die weissen Wunderrosen. } \\
\text { Gestillt wär all mein Sehnen, } \\
\text { Dürft ich so märchenheimlich } \\
\text { So selig leis - entblätern } \\
\text { Auf deine braunen Haare } \\
\text { Des Mondlichts bleiche Blüten! }\end{array}$ & $\begin{array}{l}\text { 2. COLOMBINA } \\
\text { As flores-luz da Lua, } \\
\text { Alvura luminosa, } \\
\text { Florem na noite nua - } \\
\text { Eu morro de brancura! } \\
\text { Meu alvo é só seu alvo. } \\
\text { Brusco num rio escuro } \\
\text { As flores-luz da Lua, } \\
\text { Alvura luminosa. } \\
\text { Eu só seria salvo } \\
\text { Se o céu me concedesse } \\
\text { O dom de ir desfolhando } \\
\text { À flor dos teus cabelos } \\
\text { As flores-luz da Lua! }\end{array}$ \\
\hline $\begin{array}{l}\text { 3. DER DANDY } \\
\text { Mit einem phantastischen Lichtstrahl } \\
\text { Erleuchtet der Mond die krystallnen Flacons } \\
\text { Auf dem schwarzen, hochheiligen Waschtissch } \\
\text { Des schweigenden Dandys von Bergamo. }\end{array}$ & $\begin{array}{l}\text { 3. O DÂNDI } \\
\text { Com seu mais fantástico raio } \\
\text { Espelha-se a Lua em cristais e gargalos } \\
\text { Sobre o negro lavabo sagrado } \\
\text { Do pálido dândi de Bérgamo. }\end{array}$ \\
\hline
\end{tabular}




\begin{tabular}{|c|c|}
\hline In tönender, bronzener Schale & Em amplas bacias de bronze \\
\hline Lacht hell die Fontaine, metallischen Klangs. & Gargalha uma fonte metálicos sons. \\
\hline Mit einem phantastischen Lichtstrahl & Com seu mais fantástico raio \\
\hline Erleuchtet der Mond die krystallnen Flacons & Espelha-se a Lua em cristais e gargalos. \\
\hline Pierrot mit dem wächsernen Antlitz & Pierrô com a cara de cera \\
\hline $\begin{array}{l}\text { Steht sinnend und denkt: } \\
\text { wie er heute sich schminkt? }\end{array}$ & $\begin{array}{l}\text { Se mira e remira: } \\
\text { qual será sua máscara? }\end{array}$ \\
\hline Fort schiebt er das Rot und des Orients Grün & Refuga o vermelho e o verde oriental \\
\hline Und bemalt sein Gesicht in erhabenem Stil & E maquila seu rosto no creme da Lua \\
\hline Mit einem phantastischen Lichstrahl. & Com seu mais fantástico raio. \\
\hline 4. EINE BLASSE WÄSCHERIN & 4. LAVADEIRA LÍVIDA \\
\hline Eine blasse Wäscherin & Lavadeira lívida \\
\hline Wäscht zur Nachtzeit bleiche Tücher; & Lava a noite em alvos lenços; \\
\hline Nackte, silberweisse Arme & Braços brancos, sonolentos, \\
\hline Streckt sie nieder in die Flut. & Pele nívea pelo rio. \\
\hline Durch die Lichtung schleichen Winde, & Pela névoa vêm os ventos \\
\hline Leis bewegen sie den Strom. & Levemente a vacilar \\
\hline Eine blasse Wäscherin & Lavadeira lívida \\
\hline Wäscht zur Nachtzeit bleiche Tücher. & Lava a noite em alvos lenços. \\
\hline Und die sanfte Magd des Himmels, & Suave serva em desalinho \\
\hline Von den Zweigen zart umschmeichelt, & Sob o amor dos ramos frio \\
\hline Breitet auf die dunklen Wiesen & Alva à treva nua lava \\
\hline Ihre lichtgewobnen Linnen - & Em seus luminosos linhos - \\
\hline Eine blasse Wäscherin. & Lavadeira lívida. \\
\hline 5. VALSE DE CHOPIN & 5. VALSE DE CHOPIN \\
\hline Wie ein blasser Tropfen Bluts & Como o sangue a gotejar \\
\hline Färbt die Lippen einer Kranken, & Tinge os lábios de um doente, \\
\hline Also ruht auf diesen Tönen & Também tomba destes timbres \\
\hline Ein vernichtungssüchtger Reiz. & Um mortífero torpor. \\
\hline Wilder Luft Accorde stören & Um a um, os sons ressoam \\
\hline Der Verzweiflung eisgen Traum - & No gelado pesadelo \\
\hline Wie ein blasser Tropfen Bluts & Como o sangue a gotejar \\
\hline Färbt die Lippen einer Kranken. & Tinge os lábios de um doente. \\
\hline Heis und jauchzend, süss und schmachtend, & Torturante, doce e doida, \\
\hline Melancholisch düstrer Walzer, & Melancólica é a valsa \\
\hline Kommst mir nimmer aus den Sinnen! & Que se infiltra nos sentidos \\
\hline Haftest mir an den Gedanken, & E retine na lembrança \\
\hline
\end{tabular}




\begin{tabular}{|c|c|}
\hline Wie ein Blasser Tropfen Bluts! & Como o sangue a gotejar. \\
\hline 6. MADONNA & 6. MADONNA \\
\hline Steig, o Mutter aller Schmerzen, & Paira, ó Mãe do Desespero, \\
\hline Auf den Altar meiner Verse! & Sobre o altar destes meus versos! \\
\hline Blut aus deinen magren Brusten & Sangue de teus magros peitos \\
\hline Hat das Schwertes Wut vergossen. & O furor da espada verte. \\
\hline Deine ewig frischen Wunden & Tuas chagas vejo abertas \\
\hline Gleichen Augen, rot und offen. & Como olhos ocos, cegos. \\
\hline Steig, o Mutter aller Schmerzen & Paira, ó Mãe do Desespero \\
\hline Auf den Altar meiner Verse! & Sobre o altar destes meus versos! \\
\hline In den abgezehrten Händen & Em teus fracos braços serves \\
\hline Hälst du deines Sohnes Leiche. & O cadáver, membros verdes, \\
\hline Ihn zu zeigen aller Menschheit - & Do teu filho ao universo - \\
\hline Doch der blick der Menschen meidet & Mas o mundo se diverte \\
\hline Dich, o Mutter aller Schmerzen! & Mais, ó Mãe do Desespero \\
\hline 7. DER KRANKE MOND & 7. A LUA DOENTE \\
\hline Du nächtig todeskranker Mond & Noturna, moritura Lua, \\
\hline Dort auf des Himmels schwarzen Pfühl, & Lá, no sem-fim do negro céu, \\
\hline Dein Blick, so siebern übergross, & Olhar de febre a vibrar \\
\hline Bannt mich wie fremde Melodie. & Em mim, qual rara melodia. \\
\hline And unstillbaren Liebesleid & Com infindável dor de amor \\
\hline Stirbst du, an Sehnsucht, tief erstickt, & Vais, num silente estertor, \\
\hline Du nächtig todeskranker Mond & Noturna, moritura Lua, \\
\hline Dort auf des Himmels schwarzen Pfühl. & Lá, no sem-fim do negro céu. \\
\hline Den Liebsten, der um Sinnenrausch & O amante que teu brilho faz \\
\hline Gedankenlos zur Liebsten schleicht, & Sonâmbulo perambular, \\
\hline Belustigt deiner Strahlen Spiel - & $\mathrm{Na}$ luz que flui vai beber \\
\hline Dein bleiches, qualgebornes Blut, & Teu alvo sangue que se esvai, \\
\hline Du nächtig todeskranker Mond. & Noturna, moritura Lua. \\
\hline 8. $\mathrm{NACHT}$ & 8. NOITE \\
\hline Finstre, schwarze Riesenfalter & Cinzas, negras borboletas \\
\hline Töteten der Sonne Glanz. & Matam o rubor do sol. \\
\hline Ein geschlossnes Zauber buch & Como um livro de magia \\
\hline Ruht der Horizont - verschwiegen. & O horizonte jaz - soturno. \\
\hline Aus dem Qualm verlorner Tiefen & Um perfume de incensório \\
\hline Steigt ein Duft, Erinnrung mordend! & Sobe de secretas urnas. \\
\hline Finstre, schwarze Riesenfalter & Cinzas, negra borboletas \\
\hline
\end{tabular}




\begin{tabular}{|c|c|}
\hline Töteten der Sonne Glanz. & Matam o rubor do sol. \\
\hline Und von Himmel erdenwärts & E do céu a revoar \\
\hline Senken sich mit schweren Schwingen & Revolvendo as asas lentas, \\
\hline Unsichtbar die Ungetüme & Vêm, morcegos da memória, \\
\hline Auf die Menschenherzen nieder... & Invisíveis visitantes... \\
\hline Finistre, schwarze Riesenfalter. & Cinzas, negras borboletas. \\
\hline 9. GEBET AN PIERROT & 9. PRECE AO PIERRÔ \\
\hline Pierrot! Mein Lachen & Pierrô! Meu riso \\
\hline Hab ich verlernt! & Se espedaçou! \\
\hline Das Bild des Glanzes & Seu brilho é um rastro: \\
\hline Zerfloss - Zerfloss! & Passou - Passou! \\
\hline Schwarz weht die Flagge & Negro estandarte \\
\hline Mir nun vom Mast. & Tem o meu mastro. \\
\hline Pierrot! Mein Lachen & Pierrô! Meu riso \\
\hline Hab ich verlernt! & Se espedaçou! \\
\hline O gieb mir wieder, & Ah! Traz de novo, \\
\hline Rossarzt der Seele, & Mago das almas, \\
\hline Schneemann der Lyrik, & Noivo da neve, \\
\hline Durchlaucht vom Monde & Milord da Lua, \\
\hline Pierrot - mein Lachen! & Pierrô - meu riso! \\
\hline 10. RAUB & 10. ROUBO \\
\hline Rote, fürstliche Rubine, & Rubros, rútilos rubis, \\
\hline Blutge Tropfen alten Ruhmes, & Sangue azul de velhas galas, \\
\hline Schlummern in den Totenschreinen, & Velam o sono dos mortos \\
\hline Drunten in den Grabgewölben. & Dentro de remotas tumbas. \\
\hline Nachts, mit seinen Zechkumpanen, & Só, de noite, sorrateiro, \\
\hline Stigt Pierrot hinab - zu rauben & Eis Pierrô que vem - roubar \\
\hline Rote, fürstliche Rubine, & Rubros rútilos rubis, \\
\hline Blutge Tropfen alten Ruhmes. & Sangue azul de velhas galas \\
\hline Doch da - straüben sich die Haare. & Mas estaca, seu cabelo \\
\hline Bleiche Furcht bannt sie am Platze: & Todo em pé, as mãos geladas: \\
\hline Durch die Finsterniss - wie Augen! - & Sob a escuridão mil olhos \\
\hline Stieren aus den Totenschreinen & Miram o sono dos mortos - \\
\hline Rote, fürstliche Rubine. & Rubros rútilos rubis. \\
\hline 11. ROTE MESSE & 11. MISSA VERMELHA \\
\hline Zu grausem Abendmahle & Cruel eucaristia: \\
\hline Beim Blendeglanz des Goldes, & Ao cintilar dos ouros, \\
\hline
\end{tabular}




\begin{tabular}{|l|l|}
\hline Beim Flackerschein der Kerzen, & Ao vacilar das velas, \\
Naht dem Altar - Pierrot! & Sobe ao altar - Pierrô. \\
Die Hand, die gottgewihte, & A mão, a Deus devota, \\
Zerreisst die Priesterkleider & Rasgou o santo manto. \\
Zu grausem Abendmahle, & Cruel eucaristia, \\
Beim Blendeglanz des Goldes. & Ao cintilar dos ouros. \\
Mit segnender Geberde & Com gestos piedosos \\
Ziegt er den bangen Seelen & Alça nos longos dedos \\
Die triefend rote Hostie: & A hóstia gotejante: \\
Sein Herz - blutgen Fingern - & Seu coração sangrando. \\
Zu grausem Abendmahle! & Cruel eucaristia. \\
\hline 12. GALGENLIED & 12. CANÇÃO DA FORCA \\
Die dürre Dirne & A virgem hirta \\
Mit langem Halse & De colo fino \\
Wird seine letzte & Idéia fixa \\
Geliebte sein. & Antes do fim. \\
In seinem Hirne & Dentro da mente \\
Steckt wie ein Nagel & Como um espinho \\
Die dürre Dirne & A virgem hirta \\
Mit langem Halse. & De colo fino. \\
Schlank wie die Pinie, & Como um caniço \\
Am Hals ein Zöpfchem- & De trança e fita, \\
Wollüstig wird sie & Carícia fina, \\
Dem Schelm umhalsen, & Lasciva o fita \\
Die dürre Dirne. & A virgem hirta. \\
\hline
\end{tabular}


13. ENTHAUPTUNG

Der Mond, ein blankes Türkenschwert

Auf einem schwarzen Seidenkissen,

Gespentisch gross - dräut er hinab

Durch schmerzensdunkle Nacht.

Pierrot irrt ohne Rast umher

Und starrt empor im Todesängsten

Zum Mond, dem blanken Türkenschwert

Auf einem schwartzen Seidenkissen.

Es schlottern unter inm die Knie,

Ohnmächtig bright er jäh zusammen.

Er wähnt: es sause strasend schon

Auf seinen Sünderhals hernieder

Der Mond, das blanke Türkenschwert.

14. DIE KREUZE

Heilge Kreuze sind die Verse,

Dran die Dichter stumm verbluten,

Blindgeschlagen von der Geier

Flatterndem Gespensterschwarme!

In der Liebern schwelgten Schwerter,

Prunkend in des Blutes Scharlach!

Heilge Kreuze sind die Verse,

Dran die Dichter stumm verbluten.

Tot das Haupt - erstarrt die Locken -

Fern verweht der Lärm des Pöbels.

Langsam sinkt die Sonne nieder.

Eine rote Königskrone -

Heilge Kreuze sind die Verse.
13. DECAPITAÇÃO

A Lua - um sabre oriental

Em seu divã sombrio de seda,

Horrendo e nu - ronda, fatal,

$\mathrm{Na}$ escura noite má.

Pierrô erra sem rumo, só,

E com terror vigia, mudo,

A Lua - um sabre oriental

Em seu divã sombrio de seda.

Tropeça, cheio de pavor,

Perde os sentidos, desfalece

E cai: julgando ver o fim,

Em seu pescoço sente o frio

Da Lua, um sabre oriental.

14. AS CRUZES

Cruzes santas são os versos

Onde sangram os poetas

Cegos, que os abutres bicam,

Fantasmas esvoaçantes.

Em seus corpos lentas lanças

Banham-se no rio de sangue!

Cruzes santas são os versos

Onde sangram os poetas.

Vem o fim - e findo o ato,

Vai morrendo o pranto fraco.

Longe põe o sol monarca

A coroa cor de lacre.

Cruzes santas são os versos.

\section{HEIMWEH}

Lieblich klagend - ein kristallnes Seufzen

Aus Italiens alter Pantomime,

Klingts herüber: wie Pierrot so hölzern,

So modern sentimental geworden.

Und es tönt durch seines Herzens Wüste,

Tönt gedämpft durch alle Sinne wieder, Lieblich klagend - ein kristallnes Seufzen
15. NOSTALGIA

Um suspiro de cristal partido

Traz da Itália velhas pantomimas

À memória: e Pierrô, tão seco,

Faz virar sentimental de novo.

No deserto de seu peito oco,

Surdamente sobre os seus sentidos,

Um suspiro de cristal partido 


\begin{tabular}{|c|c|}
\hline $\begin{array}{l}\text { Aus Italiens alter Pantomime. } \\
\text { Da vergisst Pierrot die Trauermienen! } \\
\text { Durch den bleichen Feuerschein des Mondes, } \\
\text { Durch des Lichtmeers Fluten - schweift die } \\
\text { Sehnsucht } \\
\text { Kühn hinauf, empor zum Heimathimmel, } \\
\text { Lieblich klagend - ein kristallnes Seufzen! }\end{array}$ & $\begin{array}{l}\text { Traz da Itália velhas pantomimas. } \\
\text { Já perdeu Pierrô seus ares tristes. } \\
\text { Pelo incêndio lívido da Lua, } \\
\text { Pelos mares mortos da memória, } \\
\text { Vai soar, além, num céu longínquo, } \\
\text { Um suspiro de cristal partido. }\end{array}$ \\
\hline $\begin{array}{l}\text { 16. GEMEINHEIT! } \\
\text { In den blanken Kopf Cassanders, } \\
\text { Dressen Schrein die Luft durchzetert, } \\
\text { Bohrt Pierrot mit Heuchlermienen, } \\
\text { Zärtlich - einen Schädelbohrer! } \\
\text { Darauf stopft er mit dem Daumen } \\
\text { Seinen echten türkschen Taback } \\
\text { in den blanken Kopf Cassanders, } \\
\text { Dessen Schrein die Luft durchzetert! } \\
\text { Dann dreht er ein Rohr von Weichsel } \\
\text { Hinten in die glatte Glatze } \\
\text { Und behäbig schmaucht und pafft er } \\
\text { Seinen echten türkschen Taback } \\
\text { Aus dem blanken Kopf Cassanders! }\end{array}$ & $\begin{array}{l}\text { 16. ATROCIDADE } \\
\text { Na cabeça de Cassandro, } \\
\text { Cujos gritos soam alto, } \\
\text { Faz Pierrô com ares sonsos, } \\
\text { Ágil - um buraco fundo! } \\
\text { Depois preme com o dedo } \\
\text { O seu fino fumo turco } \\
\text { Na cabeça de Cassandro, } \\
\text { Cujos gritos soam alto! } \\
\text { Um canudo de cachimbo } \\
\text { Mete nesse crânio calvo } \\
\text { E, sorrindo, sopra e puxa } \\
\text { O seu fino fumo turco } \\
\text { Na cabeça de Cassandro! }\end{array}$ \\
\hline $\begin{array}{l}\text { 17. PARODIE } \\
\text { Stricknadeln, blank und blikend, } \\
\text { Ih ihrem grauen Haar, } \\
\text { Sitzt die Duenna murmelnd, } \\
\text { Im roten Röckchen da. } \\
\text { Sie wartet in der Laube, } \\
\text { Sie liebt Pierrot mit Schmerzen, } \\
\text { Stricknadeln, blank und blikend, } \\
\text { In ihrem grauen Haar. } \\
\text { Da plötzlich - horch! - ein Wispern! } \\
\text { Ein Windhauch Kichert leise: } \\
\text { Der Mond, der böse Spötter, } \\
\text { Äft nach mit seinen Strahlen - } \\
\text { Stricknadeln, blink und blank. }\end{array}$ & $\begin{array}{l}\text { 17. PARÓDIA } \\
\text { agulhas pisca-pisca } \\
\text { no seu cabelo gris, } \\
\text { a dama murmureja, } \\
\text { vestida de cetim. } \\
\text { Espera na varanda } \\
\text { o seu Pierrô perverso. } \\
\text { Agulhas pisca-pisca } \\
\text { no seu cabelo gris } \\
\text { Mas ouve-se um sussuro } \\
\text { um riso risca a brisa: } \\
\text { a Lua, atriz burlesca, } \\
\text { imita com seus raios } \\
\text { agulhas pisca-pisca. }\end{array}$ \\
\hline $\begin{array}{l}\text { 18. DER MONDFLECK } \\
\text { Einen weißen Fleck des hellen Mondes }\end{array}$ & $\begin{array}{l}\text { 18. BORRÃO DE LUA } \\
\text { Um borrão de cal da clara lua }\end{array}$ \\
\hline
\end{tabular}




\begin{tabular}{|c|c|}
\hline $\begin{array}{l}\text { Auf dem Rücken seines schwarzen Rockes, } \\
\text { So spaziert Pierrot im lauen Abend, } \\
\text { Aufzusuchen Glück und Abenteuer. } \\
\text { Plötzlich stört inn was an seinem Anzug, } \\
\text { Er beschaut sich rings und findet richtig - } \\
\text { Einen weißen Fleck des hellen Mondes } \\
\text { Auf dem Rücken seines schwarzen Rockes. } \\
\text { Warte! denkt er: das ist so ein Gipsleck! } \\
\text { Wischt und wischt, doch - bringt inn nicht } \\
\text { herunter! } \\
\text { Und so geht er, giftgeschwollen, weiter, } \\
\text { Reibt und reibt bis an den frühen Morgen - } \\
\text { Einen weißen Fleck des hellen Mondes. }\end{array}$ & $\begin{array}{l}\text { sobre as costas do casaco preto, } \\
\text { vem aí Pierrô na noite morna, } \\
\text { procurando sorte e aventura. } \\
\text { Porém algo luz em suas costas: } \\
\text { ele espia, espia e acha logo } \\
\text { um borrão de cal da clara Lua } \\
\text { sobre as costas do casaco preto. } \\
\text { Ora! - pensa - é um borrão de gesso! } \\
\text { Sim ou não? Mas limpa e não consegue } \\
\text { E persegue, cheio de veneno, } \\
\text { (sim ou não?) até de madrugada } \\
\text { Um borrão de cal da clara Lua. }\end{array}$ \\
\hline $\begin{array}{l}\text { 19. SERENADE } \\
\text { Mit groteskem Riesenbogen } \\
\text { Kratzt Pierrot auf seiner Bratsche, } \\
\text { Wie der Storch auf einem Beine, } \\
\text { Knipst er trüb ein Pizzicato. } \\
\text { Plötzlich naht Cassander - wütend } \\
\text { Ob des nächtgen Virtuosen - } \\
\text { Mit groteskem Riesenbogen } \\
\text { Kratzt Pierrot auf seiner Bratsche. } \\
\text { Von sich wirft er jetzt die Bratsche: } \\
\text { Mit der delikaten Linken } \\
\text { Faßt den Kahlkopf er am Kragen - } \\
\text { Träumend spielt er auf der Glatze } \\
\text { Mit groteskem Riesenbogen. }\end{array}$ & $\begin{array}{l}\text { 19. SERENATA } \\
\text { Mil grotescas dissonâncias } \\
\text { faz Pierrô numa viola. } \\
\text { Sobre um pé, como cegonha, } \\
\text { ele arranha um pizzicato. } \\
\text { Logo vem Cassandro, tonto } \\
\text { com o estranho virtuose. } \\
\text { Mil grotescas dissonâncias } \\
\text { faz Pierrô numa viola. } \\
\text { Da viola já se cansa. } \\
\text { Com os delicados dedos } \\
\text { pega o velho pela gola } \\
\text { e viola o crânio calvo } \\
\text { com grotescas dissonâncias. }\end{array}$ \\
\hline $\begin{array}{l}\text { 20. HEIMFAHRT } \\
\text { Der Mondstrahl ist das Ruder, } \\
\text { Seerose dient als Boot; } \\
\text { Drauf fährt Pierrot gen Süden } \\
\text { Mit gutem Reisewind. } \\
\text { Der Strom summt tiefe Skalen } \\
\text { Und wiegt den leichten Kahn. } \\
\text { Der Mondstrahl ist das Ruder, } \\
\text { Seerose dient als Boot. } \\
\text { Nach Bergamo, zur Heimat, }\end{array}$ & $\begin{array}{l}\text { 20. REGRESSO } \\
\text { A Lua é o leme, } \\
\text { nenúfar o navio: } \\
\text { com vento em sua vela } \\
\text { Pierrô vai para o sul. }\end{array}$ \\
\hline
\end{tabular}




\begin{tabular}{|l|l|}
\hline Kehrt nun Pierrot zurück; & A Bérgamo, vogando, \\
Schwach dämmert schon im Osten & vai Pierrô volver. \\
Der grüne Horizont. & Já treme no oriente \\
- Der Mondstrahl ist das Ruder. & o verde horizonte. \\
& - A Lua é o leme. \\
\hline 21. O ALTER DUFT & 21. Ó VELHO OLOR \\
O alter Duft aus Märchenzeit, & o velho olor dos dias vãos, \\
Berauschest wieder meine Sinne; & penetra-me nos meus sentidos! \\
Ein närrisch Heer von Schelmerein & Idéias doidas a dançar \\
Durchschwirrt die leichte Luft. & Revém no leve ar. \\
Ein glückhaft Wünschen macht mich froh & Um sonho bom me faz sentir \\
Nach Freuden, die ich lang verachtet: & memórias que me abandonaram: \\
O alter Duft aus Märchenzeit, & ó velho olor dos dias vãos, \\
Berauschest wieder mich! & penetra-me outra vez! \\
All meinen Unmut gab ich preis; & Toda a tristeza se desfaz. \\
Aus meinem sonnumrahmten Fenster & Pela janela iluminada \\
Beschau ich frei die liebe Welt & eu vejo a vida que me vê \\
Und träum hinaus in selge Weiten ... & sonhar além a imensidade... \\
O alter Duft - aus Märchenzeit! & Ó velho olor dos dias vãos! \\
\hline
\end{tabular}

Poucas terão sido as apresentações do Pierrot Lunaire em nosso meio. Segundo me informou o crítico J.J.de Moraes, houve uma, integral, em São Paulo, em 12 de agosto de 1966, sob o patrocínio do Instituto Goethe, tendo como recitante Anneliese Kupper. Em julho de 1976, assisti a uma execução ao vivo de Pierrot, no MASP, pelo conjunto alemão Das Neue Werk. Nesse mesmo ano, a peça veio a ser interpretada em Belo Horizonte e em São Paulo, pela primeira vez por um conjunto local, sob regência de Ronaldo Bologna, tendo Edmar Ferreti como solista vocal e, como instrumenttistas, Amilcar Zanni Netto (pianista), Jean Noel Saghaard (flauta e flautim), Leonardo Righi (clarineta), Nicola Gregório (clarinete baixo), Maria Vischnia (violino), Perez Dwoewcki (viola) e Zygmunt Kubala (violoncelo). O espetáculo foi reprisado no Teatro Municipal [São Paulo], em 29 de março de $1977 .{ }^{283}$

${ }^{283}$ CAMPOS, Augusto de. Música de Invenção, p.39. 


\section{KANTATE no 2 - opus 31 - Anton Webern - Tradução dos textos I, IV, V}

\section{Movimento I}

Embora esteja calmo

o mundo possui todas as suas cores

quando cai o beijo da luz do sol;

O rouxinol, à noite,

quando as sombras

são mais severas e obscuras,

chora alegremente.

Ouça, pois, aquelas notas

quando ninguém mais foge

de tal confinamento,

então o brilho enche o ouvido.

Mas se esmaecer

aquela fugaz visão colorida,

então o movimento vem em som,

em notas se aproxima.

\section{Movimento IV}

Levando das árvores o mais leve dos fardos, aspirjo pelos espaços sua fragrância.

Trazendo-te de longe a limeira

na brandura de um alento.

\section{Movimento V}

Caridade é das palavras [do Verbo],

que nos atrai para si clamando por nosso amor, não temas, sou eu,

vem uma voz nos consolar, através da escuridão constante, quando nos amansamos.

Que outro poder poderia haver entre nós, senão a palavra [o Verbo]?

Por ter morrido na cruz, continuaremos;

em toda a angústia das lágrimas a si seguem nosso suspiro.

Apesar disso, quando novamente soou ao amanhecer, nós todos a si nos voltamos alegremente, e sabemos que fomos chamados.

Caridade é do Verbo.

e quando perceberes que sabe de ti todas as coisas, então saberás: te ferirá mais profundamente que a morte, quando uma nuvem negra se aproxima, cólera amarga, a mãe de todas as lamúrias, assim te ensombrando e fazendo de ti frio como a morte. 
SCHULLER, Gunther \& STEUERMANN, Edward - A Conversation with Steuermann Perspectives of New Music, Vol. 3, No. 1 (Autumn - Winter, 1964), pp. 22-35. -

URL: http://www.jstor.org/stable/832234

\title{
Gunther Schuller (GS) e Edward Steuermann (ES) p.23 - traduzido por Rafael Paiola
}

\begin{abstract}
Primeiros encontros
GS: Sob que circunstâncias você conheceu Schoenberg? ES: Devia ser o final de 1911 ou o começo de 1912, depois de um concerto de Busoni, no restaurante do Hotel Link em Potsdamer Platz, onde todos costumávamos ir. De repente, Busoni levantou-se, pegou-me pelo braço e disse "eu gostaria de apresentá-lo ao Sr. Schoenberg". Schoenberg estava lá sentado com sua esposa e Direktor Hertzka da Universal Edition, e Busoni disse "Deixe-me apresentar o Sr. Steuermann, um aluno muito talentoso que eu gostaria que estudasse com o senhor". Schoenberg imediatamente sacou sua agenda e disse "Quando você gostaria de começar?". E eu fiquei um pouco surpreso - embora Busoni tenha falado de Schoenberg para mim antes - mas marcamos um encontro, e dois dias depois eu fui a Zehlendorf onde Schoenberg morava.
\end{abstract}

GS: Você havia ouvido falar sobre Schoenberg na época?

ES: Eu mal conhecia sua música. Eu havia lido algumas críticas no Neue Freie Presse sobre a performance de seu Segundo Quarteto e algumas outras peças. As críticas eram todas negativas, mas, a despeito disso, de alguma maneira me ocorreu que essa música deveria ser original e interessante.

As aulas começaram. Schoenberg acabou sendo a primeira pessoa que não apenas elogiou minha música. Mas ele me ensinava de uma maneira nem um pouco ortodoxa. Ele parecia então desinteressado em ensinar contraponto e achou que eu não precisava mais de nenhuma lição de harmonia. Eu simplesmente comecei a compor; ele corrigia o que eu trazia e me dava conselhos algumas vezes de uma maneira extremamente engenhosa e precisa, outras de uma maneira muito mais nobre e formal ${ }^{284}$. Você vê, ele nunca me ensinou como ele havia ensinado Webern e Berg, e depois Eisler e outros. Uma vez, por exemplo, eu o trouxe o começo de um quarteto de cordas e a introdução estava um pouco longa demais. Ele foi a sua estante de livros, pegou o Parerga und Paralipmena de Schopenhauer, mostrou-me a primeira sentença que descreve o conteudo do trabalho e disse "Isso é uma introdução!"

Mais tarde em 1912, ele quis que eu fizesse reduções para piano de suas óperas, começando com Ewartung. Gastamos muito tempo e energia nessa partitura, retrabalhando-a várias vezes para torná-la executável sem perder as características da instrumentação. Depois eu tentei Die Glückliche Hand. Mas depois de muitas tentativas eu decidi que isso não poderia ser reduzido para um piano, então foi arranjada para dois pianos com as vozes principais na parte do primeiro piano.

GS: Você conheceu Berg e Webern na época?

ES: Eu os conheci em Berlim. Webern estava vivendo em Zehlendorf, não muito longe de Schoenberg - Webern nunca esteve longe de Schoenberg! - e Berg veio uma ou duas vezes com sua jovem esposa. Nesse período (1912) a primeira apresentação de Gurrelieder aconteceu.

GS: Quantos ensaios foram necessários para essa peça?

ES: Na verdade, eu não sei, posto que só ouvimos os últimos dois ou três. Ela não soava muito satisfatoriamente no Musikvereinsaal vazio, e havia muitos erros nas linhas. Schercker conduziu, e embora ele fosse certamente um bom músico, seu trato foi um pouco teatralisch, que era contra o espírito da escola de Schoenberg. A performance foi um grande sucesso e tornou Schoenberg oficialmente famoso. Eu lembro-me de estar sentado numa caixa quando, ao último $\mathrm{C}$ maior fortissimo com os seis trompetes e dez trompas, Schoenberg virou pra mim e perguntou "Hoeren Sie das Pizzicato in den Celli?", ele estava tão orgulhoso desse pizzicato, mas, é claro, não podiase ouví-lo em absoluto.

\footnotetext{
${ }^{284}$ N. do T. Em inglês, the grand manner, 'de maneira nobre, grandiosa'.
} 


\section{Pierrot e Sprechstimme}

ES: Então veio Pierrot Lunaire com a Sra. Zehme. Duas ou três vezes por semana, com a primeira correspondência, eu recebia uma nova peça de Pierrot e ia ensaiar a Sra. Zehme em sua casa, Olivaerplatz, 40. Ela era uma atriz aposentada que ainda tinha ambições artísticas e algumas ideias estranhas, incluindo a identificação que ela tinha com o personagem Pierrot. Foi ideia dela de escrever a partir de um livro de poemas de Otto Erick Hartleben, que traduziu o texto de Albert Giraud da língua francesa. Primeiro ela pediu a um compositor chamado Friesländer escrever alguns acompanhamentos para piano, os quais ela usou ao recitar os poemas de Pierrot. Mas de algum jeito ela não estava satisfeita com essa música, e uma vez que alguém a disse que havia um compositor chamado Schoenberg que dizia-se ser um grande gênio, ela o pediu para escrever a música para os poemas de Pierrot, e ele aceitou fazê-lo.

GS: Qual foi a reação dele ao texto?

ES: Ele achou alguns trechos um pouco indecentes. Lembro de uma vez estar presente quando ele disse à Sra. Zhme, "Da schauen Sie, das ist doch nicht wirklich Ernst zu nehmen! Das machen wir doch nicht mit!", mas no final das contas, tais coisas pareciam de alguma forma inspirá-lo, e Pierrot é, é claro, a melhor prova disso.

A princípio, Srta Zehme queria que Schoenberg usasse apenas um piano; seu contrato com ela também estipulava que haveria uma turnê em catorze ou quinze cidades, portanto o tamanho do conjunto era uma consideração muito importante. Mas como Schoenberg era Schoenberg, a primeira coisa que ele fez foi ligar para Sra Zehme e avisá-la que ele já havia escrito a primeira peça para piano e clarineta (essa era "Gebet na Pierrot"). Logo em seguida ele a telefonou noamente para perguntar se ele poderia também usar uma flauta. Ental veio a terceira peça, que agora é a primeira - "Den Wein, den man mit Augen trinkt" - e muito em breve ele já tinha clarineta, flauta, violino e violoncelo. Então, já que ele queria mais variedade instrumental, teve a ideia de que cada peça deveria ter um conjunto de instrumentos diferentes, alternando flauta com Piccolo, clarineta com clarineta baixo, e violino com viola (que era na época muito incomum nosso violinista Maliniak com certeza não estava acostumado a isso).

GS: Foi o próprio Schoenberg quem conduziu todas as apresentações durante a excursão?

ES: Schoenberg não queria muito viachar, então ele regeu apenas as apresentações principais, três em Berlim, uma em Hamburgo (onde ele conheceu Klemperer), Praga (seu cunhado, Zemlinsky, estava lá) e Viena. As outras foram regidas por Schechen, a quem Schoenberg acabara de conhecer.

Scherchen, assim como Malinak, era um membro da Blüthner Orchestra. Ele era um dos jovens em quem Sra. Zehme estava interessada. Ele vinha aos ensaios, onde Schoenberg trazia-lhe muito, e ocasionalmente o pedia para conduzir a fim de ouvir como iria soar de certa distância. O violoncelista do grupo, Kindler, mais tarde, é claro, tornou-se o renomado regente; o clarinetista era Essberger, e o flautista era De Vriess, a quem encontrei novamente anos mais tarde com a Goldman Band.

GS: Como os ensaios de Schoenberg?

ES: A princípio era largamente uma questão de experimentação. Tudo tinha de ser experimentado, e a paciência e o zelo de Schoenberg em explorar todas as possibilidades era incrível. Mais tarde, na época da gravação de Columbia em 1940, a situação era diferente, é claro, porque os problemas do conjunto não eram mais tão grandes.

GS: Schoenberg fez alguma mudança baseada na experimentação dos ensaios para a estreia?

ES: Dificilmente o fazia; algumas poucas mudanças dinâmicas, um ritardando em um lugar. A concepção da peça estava muito clara.

GS: Há muito vários músicos tem estado profundamente curiosos quanto à origem da ideia de Schoenberg para o Sprechstimme; como ele chegou a isso?

ES: Originou-se na mente de Schoenberg. Foi - se desejar - uma inspiração.

GS: Mas Humperdinck já havia usado Sprechstimme, talvez logo em 1895; e Max Von Schilling utilizou a ambos, o discurso normal e o Sprechstimme em seu Mona Lisa. Schoenberg não conhecia essas peças?

ES: Não acredito que ele conhecesse. Posto que Schoenberg vivia, por assim dizer, num mundo completamente diferente, é muito improvável que ele tenha ouvido qualquer peça de Humperdinck, 
exceto, talvez, Hänsel und Gretel. E eu, como discípulo fiel de Schoenberg, também não havia ouvido a tais obras. A ideia do "melodrama", como ele a chamou, era certamente amplamente conhecida - Hexenlied de Max Von Schilling era uma espécie de "Best seller". Mas a maneira como Schoenberg a usou era sem dúvida completamente nova. A diferença é que a palavra não é "adptada" à musica, nem a música usada para "dramatizar" a palavra, mas o discurso é uma parte integrante da música, "musizieren mit Worten". A explicação que Schoenberg apresentou em seu prefácio de Pierrot infelizmente soluciona apenas parte do problema.

GS: Sim, isso parece resultar num grande número de ligaduras e glissandos, os quais eu não acredito que fossem a intenção de Schoenberg.

ES: Eu trabalhei com muitas pessoas nisso também. A mim me parece que se deve encontrar a expressão de cada sentença que cobrirá uma linha inteira. E a ênfase não deve ser posta em cantar. Parece-me que muitas pessoas cantam o Sprechstimme em demasia.

GS: Você conhece a interpretação meio cantada, meio falada de Lotte Lenya em peças como Dreigroschenoper e Mahagonny? Ela também é mais uma atriz do que uma cantora; e parece-me que o que ela faz é interessante e aplica-se como Sprechstimme.

ES: Talvez, mas não se esqueça que as expressões extraordinárias em Pierrot são muito mais complexas que Brecht e Weill. Assim como Rex Harrison em My Fair Lady: também é um tipo de Sprechstimme, mas muito mais natural que Pierrot provavelmente jamais pudesse ou devesse ser.

\section{Apresentações no círculo de Schoenberg: Gesellschaft für Privatauffürungen}

GS: Schoenberg regia bem o bastante para fazer-se claramente entendido por seus gestos? Ele alguma vez já conduziu alguma música que não fosse sua?

ES: Sua habilidade - talvez fosse mais correto dizer seu poder - como regente era algumas vezes incrível, outras, menos convincente. Eu ouvi uma interpretação de seu Pelleas em Barcelona com a orquestra de Casals. Casals o permitiu ter quantos ensaios ele desejasse, mas Schoenberg usou apenas de seis ou sete ensaios e fez uma apresentação perfeita. Da mesma forma, nunca ouvi apresentações mais impressionantes de Verklärte Nacht e o Quarteto em F\# menor que aquelas num arranjo para orquestra de câmara, interpretadas por um grupo de amadores em Viena sob sua direção. Um detalhe sobre os ensaios: o começo de Verklärte Nacht a princípio soava pouco claro. Schoenberg começou a ensaiar apenas os Ds graves dos violoncelos e dos contrabaixos. Quando o ritmo desses estava resolvido, tudo se encaixou como se por mágica. Em contrapartida, lembrome do ensaio para a primeira apresentação da Suite para Clarineta Opus 29 em Paris. A peça era então muito difícil para os intérpretes; ninguém estava muito preparado, e Schoenberg não era muito claro. Acabamos tocando em um andamento mais lento. Schoenberg costumava dizer em tais circunstâncias: "Isso não é música para primeiras apresentações!"

A respeito de outras músicas, eu me lembro particularmente de um concerto que a Sra. Mahler arranjou em Viena em 1914 quando a guerra já havia estourado. Ela acreditava que Schoenberg fosse um grande regente. Ele regeu a Abertura Egmont e a Nona com a segunda orquestra em Viena, Tonkünstler-Verein, cuja qual os músicos com certeza não eram simpáticos ao grande "inovador". Para nós era lindo, embora a interpretação fora muito adversamente criticada. Você pode perguntar, o que era tão bonito? Você sabe quão difícil é descrever qualquer impressão musical; na "Musizieren" de Schoenberg era primariamente o caráter de seus tempos, especialmente sua habilidade de fazer a música mover-se e ficar estática ao mesmo tempo, que eu nunca me esquecerei. Nunca foi um "tempo" em especial - o contrário de "motor" [motoric].

GS: Quando foi a primeira vez que você tocou o Opus 11?

ES: Em 1911 ou 1912, mas toquei o Opus 19 em público ainda antes. Eu mal havia começado a estudar com Schoenberg quando ele me falou sobre um concerto com suas composições no Choralionsaal e pediu-me para tocar o então recentemente composto Opus 19. Também era pra eu acompanhar a Sra. Winternitz-Dorda, uma soprano muito bonita de Hamburgo, no GeorgeLieder. Eu devia ir a Hamburgo, mal conhecendo a música, para ensaiar com ela. Mas ela tinha uma afinação perfeita, então não foi muito difícil. Também tocamos a primeira, a segunda e a quarta das Cinco Peças para Oquestra em uma versão para dois pianos, a oito mãos, arranjada por Webern e Schoenberg. Meu parceiro era Louiss Closson, um pupilo Belga de Busoni; a outra dupla era muito interessante: Webern e Louis Gruenberg. Havia forte oposição a essas "heresias", mas também entusiasmo. Mais tarde, lembro-me que toquei o Opus $11 \mathrm{em}$ Regensburg num 
Turnhalle horrivelmente frio e tosco, e lembro-me dos rostos de todos aqueles Bierphilister. Tocar o Opus 11, No. 2 tão devagar quanto Schoenberg queria para tal audiência realmente foi um acontecido naqueles dias! Isso foi em 1913; então a guerra irrompeu e fomos todos para o Exército.

Mas imediatamente após a guerra, Schoenberg começou a Sociedade para Performances Privadas. O primeiro concerto parece em retrospecto um evento histórico, uma vez que a Sociedade foi provavelmente a primeira a ser devotada à música do séc. XX. Na inauguração eu toquei a quarta e a sétima Sonatas de Scriabin, e o arranjo a quatro mãos da Sétima Sinfonia de Mahler com o pianista, Bachrich, ensaiado por Schoenberg. Tínhamos uma hierarquia de supervisão para performances em nosso "Verein": havia três chamados "Vortragsmeister" a quem cabia praticar com os intérpretes - Webern, Berg e eu mesmo, e mais tarde Erwin Stein. A autoridade mais elevada dentre todos nós, é claro, era Schoenberg.

GS: Você havia tocado muitas outras músicas além da de Schoenberg antes disso?

ES: Na verdade, eu tocava Schoenberg apenas em concertos especiais. Mas fiz muitos outros recitais, especialmente quando eu era um estudante em Berlim, onde toquei no Bechsteinsaal.

GS: Que outras músicas você tocou para a Sociedade? Você tocou alguma peça de Debussy, Bartók, Stravinsky, por exemplo?

ES: É claro, toquei Elegies e a Sonatina de Busoni; Gaspard de la nuit de Ravel; Sonata de Berg, etc. Não me lembro de ter feito nenhum Bartók, mas interpretei Piano Rag Music de Stravinsky, assim como as Easy Pieces a quatro mãos. Uma vez eu até toquei Petrouchka com Serkin em um arranjo a quatro mãos, mas isso foi mais tarde, depois de Schoenberg ter deixado Viena. E eu fui provavelmente um dos primeiros a tocar o Livro I dos Estudos de Debussy, primeiramente para a Sociedade, depois em turnê. Havia também um grande número de música contemporânea que eu tocava sem memorizar, em leituras, ou apresentações especiais, ou para publicadores. Por exemplo, eu fui o primeiro a tocar a Sonata de Ludwig Zenk, que era um discípulo e, eu acho, também um primo de Webern. Zenk me foi muito grato por eu ter tocado sua Sonata para Universal Edition, e eles aceitaram-na para publicação. Eu descobri mais tarde que ele era ao mesmo tempo um nazista convertido. Isso era apenas uma marca do "duplo contraponto" de Viena. Antes de as Variações de Webern terem sido publicadas, Webern as enviou para mim com uma dedicatória muito cordial num manuscrito lindamente copiado por Zenk.

GS: A despeito da dedicação, de qualquer forma, eu entendo que você nunca tocou as Variações em público.

ES: Eu as ensinei a alunos. A despeito de algumas razões pessoais, eu ainda não encontrei tempo para estudá-las à perfeição que eles desejavam. Hoje eu sinto que eu gostaria de tocar a peça, especialmente quando ouvi algumas das péssimas interpretações de alguns pianistas mais jovens.

GS: O discípulo de Webern, Peter Stadlen, parece concordar com você. Ele escreveu bastante negativamente sobre as interpretações de Webern nos dias de hoje por pianistas "conscientesseriais" [conscious-serial].

ES: É certamente verdade que eles são muito rígidos. O próprio Webern foi o mais livre intérprete de sua própria música que se possa imaginar.

GE: Você já tocou em algum das peças de Webern para conjunto, e ele trabalhou contigo preparando as partes de piano?

ES: Eu toquei nas primeiras apresentações do Concerto para Nove Instrumentos e do Quarteto de Saxofone. De fato, eu estava quase presente quando Webern compôs o Concerto. Um dia ele veio e me disse "Você sabe, eu encontrei uma linha (lei) que é única - três sons, suas inversões, movimento retrógrado e inversão retrógrada!" Ele imaginou que isso tinha algo a ver com o antigo palíndromo - "Amor, Roma," etc. (ele era bem ingênuo a esse respeito). Depois de ter terminado o primeiro movimento, ele tocou um pouco dele pra mim em sua casa em Maria-Enzersdorf. Ele tocou tão livremente que eu dificilmente pude acompanhar a música, mas era extraordinário. Quando ele regia, entretanto, ele não era tão livre; eu acredito que não se possa ser, ou, ao menos, ele não podia. Mas até onde se dizia respeito ao piano, ele dizia muito pouco, mesmo quando eu acompanhei suas canções pela primeira vez.

Eu também toquei muitas outras músicas com Webern regendo: o Concerto Emperor em Barcelona e Viena, o concerto em Mi bemol de Mozart em Viena e Berlim, e um Concerto de Bach - a meu ver, ele regia Bach melhor que tudo. Ele combinava uma projeção da estrutura motívica, que fazia a música vibrante com vida interior, com uma sensação de uma grande linha, sempre 
suportada por dinâmicas simples e claras. Devo dizer que ele influenciou fortemente minha concepção de Bach.

GS: Sob que tipo de circunstâncias econômicas e sociais todas essas interpretações tiveram lugar? Por exemplo, você deve ter tido que engajar intérpretes de fora para a Sociedade; como foi possível você realizar isso?

ES: Contratar intérpretes foi a parte mais difícil de administrar a Sociedade. Schoenberg sempre insistia em algum pagamento aos músicos, mas não tínhamos praticamente dinheiro algum graças à inflação. Não havia concertos avulsos vendidos; os concertos eram apenas para assinantes. Por conta da fama de os vienenses serem penetras, todo mundo devia ter um cartão de membro com uma foto e assinatura. Nosso amigo, Dr. Polnauer, ficava à porta conferindo a todos. Os programas também nunca eram anunciados previamente, porque Schoenberg não queria que as pessoas fossem aptas a "pegar as velas dos bolos". Aplausos eram proibidos; a audiência não deveria determinar ou não o sucesso, mas simplesmente aceitar o que era oferecido.

Uma vez, quando as finanças da Sociedade estavam indo muito mal, Schoenberg teve a ideia de levantar fundos com uma "Tarde Johann Strauss". Nossa "orquestra" consistia do Quarteto Kolisch, piano (eu), e - já que não tínhamos dinheiro pra contratar músicos para as madeiras - um harmonium tocado pela irmã de Hans Gal. Na Áustria nós tínhamos aqueles Kunstharmoniums não como os pequenos harmoniums aqui - e as instrumentações de Schoenberg para Rosen aus dem Suden e Eine Nacht in Venedig, especialmente pela forma com que ele usava o harmonium, eram obras-primas absolutas.

GS: $\quad$ Essas alsas existem?

ES: Gostaria de saber - os manuscritos foram vendidos num leilão, mas ninguém parece saber onde foram parar durante o período nazista. Webern fez Zigeunerbaron Waltz e Berg fez Wein, Weib, und Gesang. A instrumentação de Webern era boa, mas era muito brilhante e clara. Eu me lembro de que o piano sempre tocava as fanfarras de metais.

GS: Você se lembra de outros instrumentistas que tocaram para a Sociedade?

ES: Nós raramente conseguíamos ter instrumentistas para as madeiras, mas havia, por exemplo, um Quarteto Faisst em Viena que tocava o Quarteto em Ré menor de Zemlinsky. Webern os ensaiou interminavelmente para isso. Cantores, é claro, sempre eram difícil de se encontrar; mas nessa época Felicie Michacek, que se tornou bem famosa na Europa, cantava as canções de Webern e Proses lyriques de Debussy para nós

$\mathrm{Na}$ verdade tentávamos conseguir qualquer um que fosse bom o bastante para tocar nossa música. Não era muito difícil: os músicos menos conhecidos sempre, especificamente no difícil período pós-guerra, ficavam felizes em ter a oportunidade de serem ouvidos em público. Alguns eram apenas semi-profissionais; por exemplo, um de nossos violinistas, Dr. Oskar Adler, um amigo de infância de Schoenberg, era um físico e também um famoso astrólogo. Ele tocava Reger especialmente bem, um pouco altmodish, provavelmente à tradição de Joachim. A Sonata de Debussy ficava menos autêntica mas, talvez apenas por sua "falta de jeito", tocante.

GS: Você conheceu Stiegler, primeira trompa da Opera e da Filarmônica? Schoenberg uma vez me disse que ele era o maior trompista que ele havia conhecido.

ES: Não conheci Stiegler pessoalmente, mas o filho de Schoenberg estudou trompa com ele. Em geral, os músicos mais velhos não estavam disponíveis para nós. Não podíamos ter pedido a Stiegler que tocasse para a Sociedade.

GS: Você chegou a ouvir Schoenberg tocar violoncelo?

ES: É claro; e também a viola. Durante o período da Sociedade, ele era bastante aficionado por tocar música de câmara. Isso foi durante os anos em que eles estava desenvolvendo a técnica dodecafônica e não estava publicando novas peças para que tivesse mais tempo para outras atividades.

GS: Se ele tocava viola, deve ter estudado todos os instrumentos de cordas em algum momento. Ele tocava outros instrumentos?

ES: Um pouco de piano, mas eu acho que só.

GS: Eu pergunto isso porque Schoenberg foi um dos grandes orquestradores. Sua inspiração para os instrumentos - especialmente as cordas - é memorável. E George Szell uma vez me disse que todo mundo que estudava em Viena tinha que aprender a tocar todos os instrumentos em alguma parte de seus anos de estudo. 
ES: Mas Schoenberg não estudou composição em Viena; ele foi completamente autodidata, e ele nunca foi de fato um estudante de música. Uma vez, em Hollywood, tivemos uma discussão sobre um ponto questionável na Nona Sinfonia de Beethoven - o ponto no último movimento em que a clarineta toca Dó sustenido contra um Dó no coro. Quando perguntei a Schoenberg sobre isso, ele olhou em sua partitura - ele já havia marcado aquela passagem em especial - e disse que era um erro. Eu quis, é claro, defender Beethoven, mas ele disse que todos poderiam cometer um erro. "Por exemplo, você sabe que eu nunca escrevi uma única nota para um instrumento de cordas sem antes experimentá-la." Eu sabia o quanto isso era verdade - basta considerar o uso de harmônicos na Fantasia, por exemplo. Então ele trouxe uma partitura de Gurrelieder e, na última parte, apontou para um Dó bemol grave nas violas. Eu o indaguei sobre o que havia acontecido nos ensaios; ele disse "Ninguém parece ter percebido".

GS: Mas todas as apresentações da Sociedade eram de peças para câmara. As peças de palco de Schoenberg alguma vez foram executadas? Por exemplo, o Erwartung era conhecido mesmo entre os membros desse círculo?

ES: Erwartung foi composta antes de eu ter conhecido Schoenberg. Cópias manuscritas foram feitas; Webern e Berg certamente a conheciam, provavelmente outros amigos em Viena também. Em Berlim, onde eu ficava, dificilmente alguém conhecia essa peça. Mas na primavera de 1914 fomos com Schoenberg a Dresden, que tinha a casa de ópera mais progressiva da Alemanha. $O$ regente era Ernst Von Schuch, que conduziu todas as primeiras apresentações de Strauss. Ele era um velho Hof-Mann muito charmoso. O Intendant era Graf Von Seebach. Eles estavam muito interessados em ouvir algo de Schoenberg para saber se deveriam executar. Eu toquei o Erwartung inteiro para eles ao piano, com Schuch seguindo a partitura. Eles ficaram ainda mais interessados em Die Glückliche Hand, e Schuch pediu a Schoenberg para contar-Ihe sobre a trama. Schoenberg começou a falar, mas Seebach, o velho monarquista, interrompeu e falou ele mesmo extremamente bem. Eu fiquei bem impressionado. Os diretores da Dresden Opera estavam obviamente planejando interpretar uma peça de Schoenberg, mas então a guerra começou e isso nunca passou daí. Eles eram artistas muito refinados e mostraram uma grande dose de coragem e independência na época quando as pessoas, especialmente em Berlim, ignoravam Schoenberg, com as notáveis exceções de Busoni, Schnabel e, até um certo nível, anteriormente, Richard Strauss.

\section{Encontros com compositores e regentes}

GS: Quando você esteve em Viena na década de vinte, você conheceu algum dos compositores importantes da época - Stravinsky, Milhaud, Hindemith, etc?

ES: Milhaud uma vez veio a Viena. Ele havia executado Pierrot em Pariz, e a Sra. Mahler deu uma recepção para ele e Poulenc na qual eu toquei meu arranjo para a Kammersymphonie e Schoenberg conduziu Pierrot. Então Milhaud foi responsável por também conduzir partes de Pierrot para mostrar como ele havia feito isso. Minha lembrança mais inesquecível, entretanto, é que Milhaud e Poulenc convidaram-me ao Hotel Bristol para um almoço maravilhoso. Era 1920, dirante a inflação, e praticamente não havia comida em Viena; essa foi minha primeira refeição de verdade em anos!

Eu também conheci Ravel naquele período, inclusive toquei com ele a quatro mãos. Conhecemonos na casa de Sra. Mahler e tocamos Ma Mere l'Oye e a Rhapsodie Espagnole para o regente, Oskar Fried, que estava planejando um concerto de Ravel e sempre queria ouvir novas peças tocadas primeiro ao piano. A propósito, Webern uma vez tocou as canções Mallarmé; ele as adorava, especialmente a última, que é muito similar a Schoenberg.

GS: Você alguma vez encontrou-se com Hindemith?

ES: Sim, uma vez aparecemos juntos num programa da BBC em Londres. Eu me lembro, eu toquei a Toccata em Mi menor de Bach, ele tocou como um membro do Quarteto Amar. Tivemos uma conversa interessante posteriormente, entre outras coisas sobre o amplamente discutido sistema de quartos de tom de Haba. Hindemith, que estava tão convencido quanto eu a respeito desse tipo de desenvolvimento, disse numa maneira direta e radical "Por que não pegar o touro pelos chifres e dizer o número exato de vibrações para cada som? Com instrumentos elétricos isso será possível".

GS: E quanto a Stravinsky? 
ES: Eu não havia conhecido Stravinsky então. Há alguma confusão a respeito disso. Ano passado uma secretária de Stravinsky me ligou para perguntar se eu me lembrava de que Stravinsky estava presente na apresentação de Pierrot em Berlim. Eu não me lembro em absoluto de ter encontrado Stravinsky lá.

GS: Mas os livros recentes dão a impressão de que Stravinsky sempre foi um grande admirador de Schoenberg.

ES: Schoenberg era bem interessado em Stravinsky; ele achava sua instrumentação muito inteligente. Nós executamos Pribaoutki, e Schoenberg disse "Ele sempre escreve mezzo-forte, e quão bem isso soa" (Schoenberg sempre aconselhava seus alunos a nunca escreverem mezzoforte, mas forte ou piano). Então apareceu uma entrevista de Stravinsky dizendo que a música de Schoenberg era um beco sem saída. É claro, Schoenberg, com seu temperamento usual, ficou enfurecido, e virou-se contra Stravinsky.

GS: Foi esse episódio que gerou as Drei Satiren?

ES: Schoenberg escreveu as Satiren mais tarde, e uma delas é sobre "Modernsky". Como sabemos, essa peça coral, uma das conquista mais "virtuoso" no campo do contraponto, está escrita em quatro claves e é lida da mesma maneira quando a página é virada de cabeça para baixo.

Mas Stravinsky é muito imparcial e realmente pratica a independência artística que ele prega. Por exemplo, depois de Gerhard Eisler ter sido deportado, houve uma reação aqui nos Estados Unidos, e as pessoas certamente queriam que Hanns Eisler, seu irmão, também deixasse o país, o que ele fez. Quando um concerto com as peças de Eisler era organizado para protestar contra essa ação e uma petição circulou, a primeira pessoa a assinar foi Stravinsky.

GS: Krenek estava envolvido no círculo de Schoenberg nos anos vinte?

ES: Não, porque ele vivia principalmente em Berlim; mas Schoenberg o considerava muito talentoso e costumava dizer "Aquele é um homem cujo a língua mãe é a música". Ele era então intenso nas ideias do atonalismo - em sua Chaconne para piano, por exemplo - antes de Jonny spielt auf.

GS: Você conheceu Varèse em Berlim em 1912?

ES: Sim, e ainda ouvi uma peça dele chamada, acredito, Bourgogne.

GS: Essa foi uma das obras destruídas num incêndio antes de Varèse vir à América, então você ouviu uma composição que não existe mais.

ES: Eu mal me recordo como ela era, exceto que havia uma passagem em particular das cordas em que havia um divise extraordinário - não sei de quantas partes individuais - que formou uma tremenda floresta de som de cordas. A apresentação ficou a cargo da Blüthner Orchestra.

GS: As orquestras de Berlim tocavam muita música contemporânea?

ES: Um bocado, me lembro de Strauss conduzindo a Terceira de Mahler na Königliche Kapelle, e uma apresentação de Rosenkavalier com Muck que foi completamente sem Viennese Schmalz ou sentimentalidade, e muito clara. Mais tarde eu a ouvi tocada por Klemens Krauss e outros, mas a interpretação de Muck ainda está em minha memória.

GS: Podemos conversar sobre os problemas pianísticos na música de Schoenberg? Vindo da tradição de Busoni e Liszt, como você veio, houve algum problema que você teve de resolver pessoalmente? Schoenberg te ajudou de algum jeito específico?

ES: Dificilmente. Quando ele me ouviu tocar o Opus 11 pela primeira vez, ele fez algumas pequenas mudanças na primeira edição. Ele adicionou algumas indicações de marcato, indicações "sem pedal", etc. Lembro-me que ele queria a segunda peça muito vagarosa, o que era espantoso para mim à vista da indicação, "Massige Achtel". Quando tive de tocar essas peças pela primeira vez em Regensburg, ele me deu esse conselho memorável: "Não tema que a audiência possa ficar nervosa por causa do andamento lento. Se você acredita em seu tempo de todo o coração, a peça não vai parecer longa; se você está incerto quanto a isso, vai se tornar chata." Mas na segunda edição a marcação do metrônomo indicava um tempo mais rápido. Por outro lado, até onde o estilo pode ser considerado, a tradição de Brahms (da qual eu também vim) é a principal influência nas primeiras obras para piano de Schoenberg. Mais tarde, no Opus 23, Opus 25 e Opus 33 a e b, o sistema dodecafônico trouxe um trato muito diferente ao estilo do piano, especialmente em termos de identidade ou harmonia e melodia. Até que ponto minhas interpretações foram a realização completa das ideias de Schoenberg eu não sei. Um compositor como Schoenberg tem uma visão imaginária de sua música que alcança muito mais longe que qualquer outra. $O$ intérprete pode 
apenas tentar alcançar a esfera dessa imaginação, para trazer à vida os símbolos mortos sobre o papel. Mas isso é para qualquer música, exceto talvez música eletrônica, e isso é algo que eu tenho contra a música eletrônica: que ela nega a possibilidade de rejuvenescimento perpétuo por meio da interpretação de um significado em uma variedade de maneiras.

GS: $\mathrm{E}$ a respeito dos pedais [do piano] na música de Schoenberg? Eu sei que você tem ideias muito específicas sobre esse assunto.

ES: Schoenberg sempre insistiu para que sua música fosse tocada quase sem pedal o que, francamente, eu obedeci apenas com "metade de meu coração". Você não pode tocar o piano moderno sem pedal. Você deve usá-lo, é claro, de maneira que os sons não fiquem embolados, e com a certeza de que a sonoridade "sóbria" sem a vibração proveniente do uso do pedal, que é tão característica, venha à tona.

GS: Você se importaria de dizer algo sobre a música de hoje em dia?

ES: Falar sobre música contemporânea de vanguarda é difícil já que ela muda quase todo ano. Primeiro, havia um tipo de super-serialismo, a música "totalmente predeterminada"; e então, como Dr. Steinecke me disse, como uma reação a tudo isso, a música aleatória; e provavelmente mais alguma coisa por agora. Em Darmstadt eu ouvi a música de Nono, a quem considero muito talentoso; Stockhausen é com certeza um homem muito memorável; Boulez é um excelente artesão. Mas eu nunca entendi por que, depois do estabelecimento do sistema dodecafônico, deve-se seguir serializando todos os parâmetros da música. A meu ver, serializar de alguma maneira as alturas fixadas do repertório dodecafônico é como usar um fio de Ariadne para guiar-se para fora do labirinto da chamada "atonalidade livre" que, sem um princípio guia, pode tornar-se confusa, repetitiva, não característica. Se essa serialização é indispensável na construção de formas maiores não se pode dizer. Um compositor inspirado pode, a qualquer hora, provar que não é. De qualquer forma, serializar uma dada quantidade de alturas fixadas é algo inteiramente diferente de tentar fazer o mesmo com uma infinidade de durações (ritmo), dinâmicas, timbres. Sempre me pareceu uma aplicação mecânica para o princípio.

A meu ver, a composição dodecafônica possui dois aspectos: um é harmônico, o outro contrapontístico. O aspecto harmônico consiste na urgência de o complexo cromático alcançar a inteireza, para fechar o ciclo de 12 sons. (Essa urgência, a propósito, nem sempre deve ser satisfeita - assim como a dominante com sétima nem sempre tem de se resolver à tríade do primeiro grau). O aspecto contrapontístico eu comparei anos atrás ao conceito de Freud de eterna repetição das primeiras experiências pré-natais. Este aspecto contrapontístico é, a propósito, tão antigo quanto a própria música. Basta pensar nas técnicas de ampliação e diminuição dos tempos mais remotos. A ideia de série rítmica é usada, até certo ponto, no Concerto Duplo de Berg, no "Rondo Ritmico". Ela é obviamente antecipada pelas estruturas iso-rítmicas que, incidentalmente, sempre me pareceram exemplos de pensamento esquemático. Schoenberg geralmente usou o serialismo com mais liberdade que Webern, mas Webern não escreveu trabalhos tão longos e envolvidos.

Quanto a musica aleatória, eu não entendo por que alguém faz isso. Niezsche diz que para o perseguidor da verdade a regra é mais importante que a exceção. Para mim, nenhuma busca da razão é tão frustrante quanto experimentos de "sorte". Mas tem muita gente interessada nisso: mesmo meu amigo Adorno escreve que ele ficou impressionado com o Concerto para Piano de Cage. Provavelmente isso tem a ver com nosso tempo e sua filosofia - nossa Idade das Trevas nuclear. Talvez uma nova religião vá emergir disso, mas no presente momento é mais "Credo quia absurdum".

GS: Em geral, então, o que você pensa da significância da música de Schoenberg no contexto da nossa atual situação musical?

ES: Antes de qualquer coisa, dificilmente há um músico vivo que não tenha sido influenciado por Schoenberg, de um jeito ou de outro; mesmo escritores de comercias para rádio e televisão se apropriaram de seu idioma atonal. Mas o serialismo, ao qual mesmo seus adversários mais amargos estão agora convertidos, parece estar mais claramente sustentado a partir dele. Talvez devesse ser mais importante distinguir o que não é devido à influência de Schoenberg.

Tem havido desde a morte de Schoenberg uma tendência a salientar as diferenças entre ele e Webern, a enfatizar a independência de Webern. O grito de batalha foi pós-Webernismo. Na minha opinião antiquada, seria importante examinar essas tendências e validá-las como questões artísticas, como por exemplo, mais como questões de personalidade que de "estilo". Mas perseguir 
esse ponto colocaria em prova a paciência até mesmo de um entrevistador simpático como você tem sido.

20 de maio de 1964. 


\section{ANEXO II}

(partituras analisadas) 
Duas das sete canções do Ciclo Sieben Frühe Lieder (1905-1908) - Alban Berg

1- Nacht - de Alban Berg - p. 299

2- Die Nachtigall - p. 306

3- Melodrama no 8 - Nacht - Pierrot Lunaire (1912) - Arnold Schoenberg - p. 310

Cantata ํo 2 (1943) - Anton Webern

4- Movimento I- da - p. 313

5- Movimento IV - p. 316

6- Movimento V - p. 318

Drei Lieder (1931) - de Edward Steuermann

7- I - Der Mensch - p. 324

8- II - Wandrers Nachtlied - p. 329

9- III - Gesang der Geister über den Water - p. 332

10- As outras canções do Ciclo Sieben Frühe Lieder - p. 341

11-Sonata opus1 - de Alban Berg - p. 355 


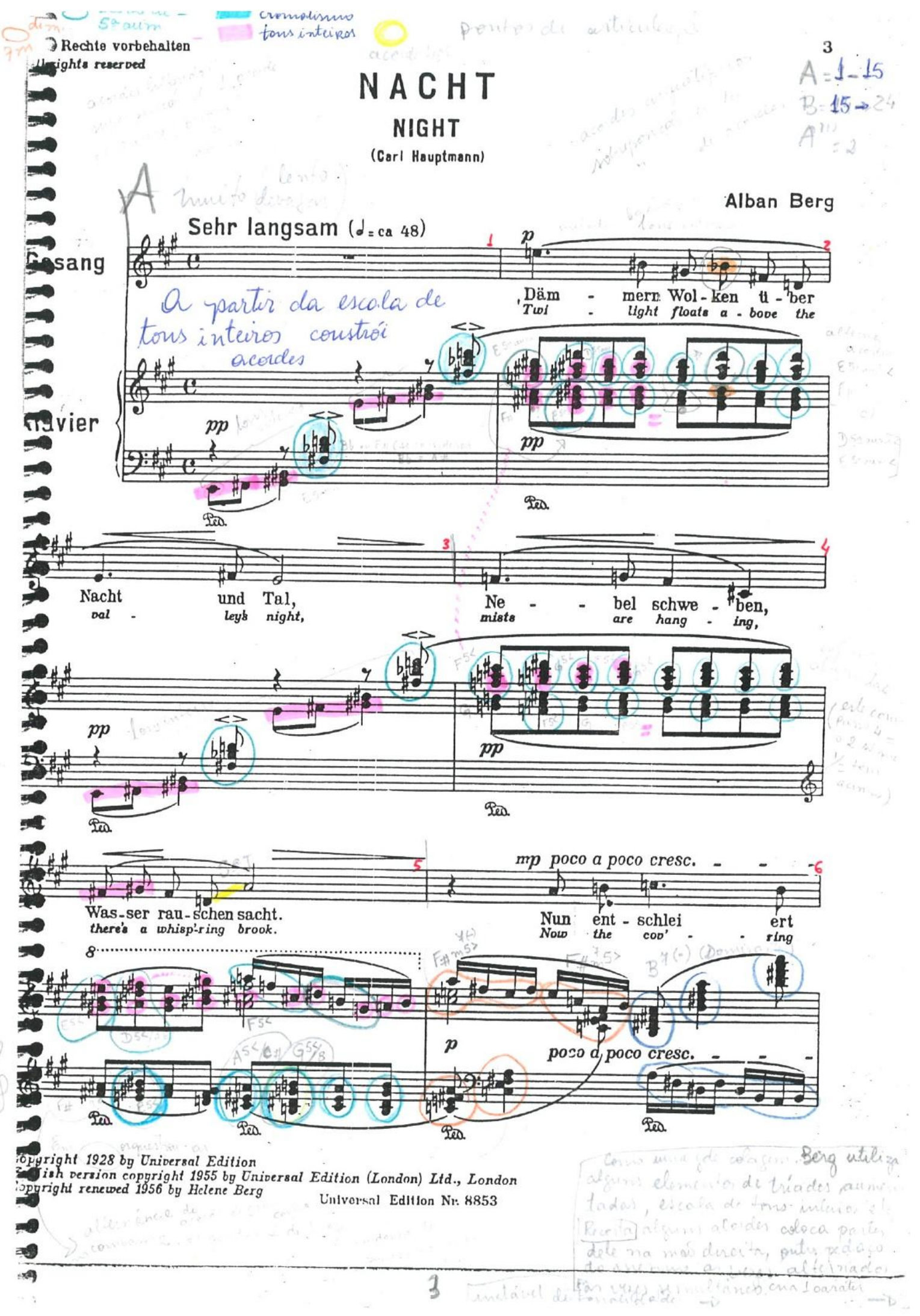




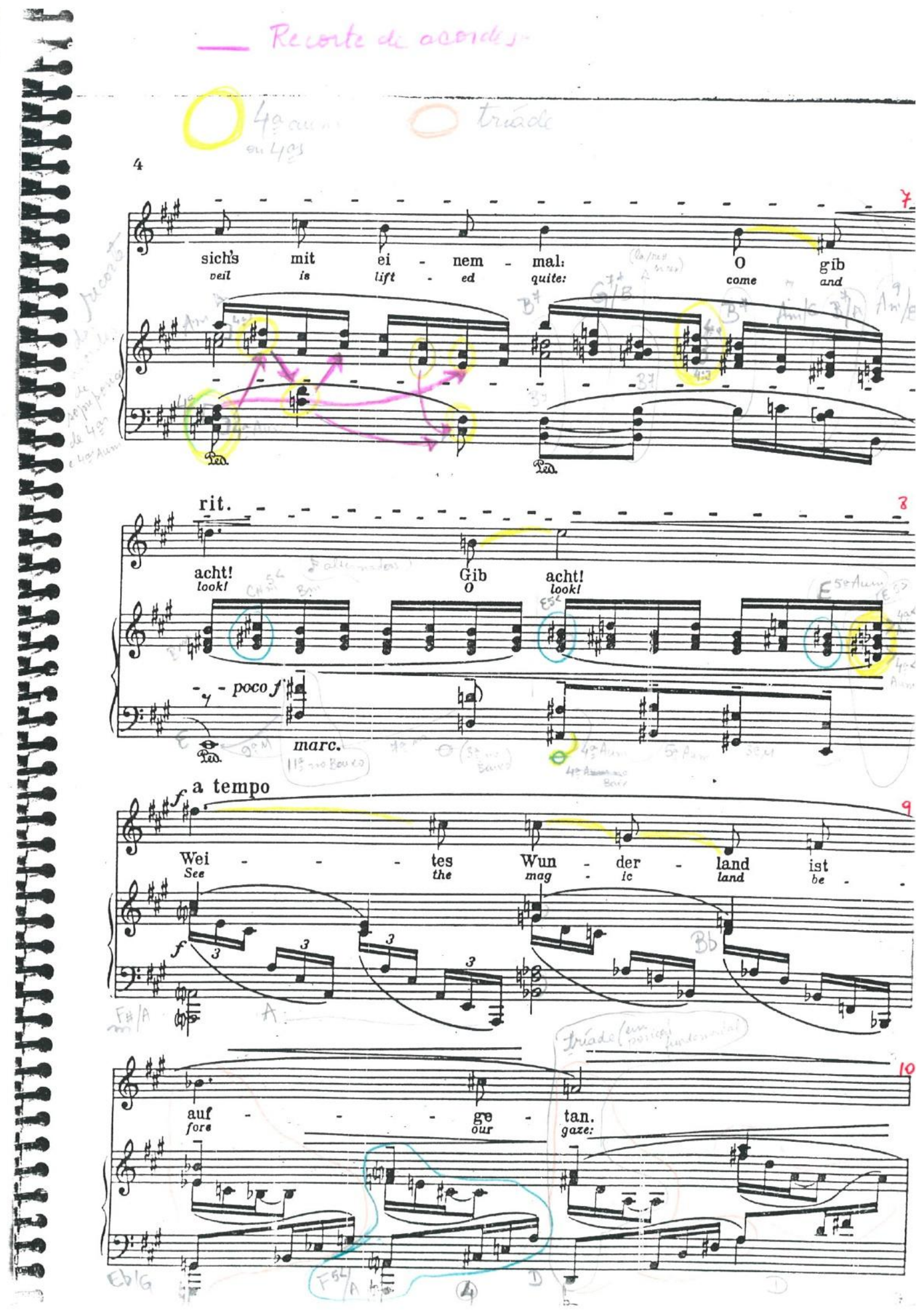




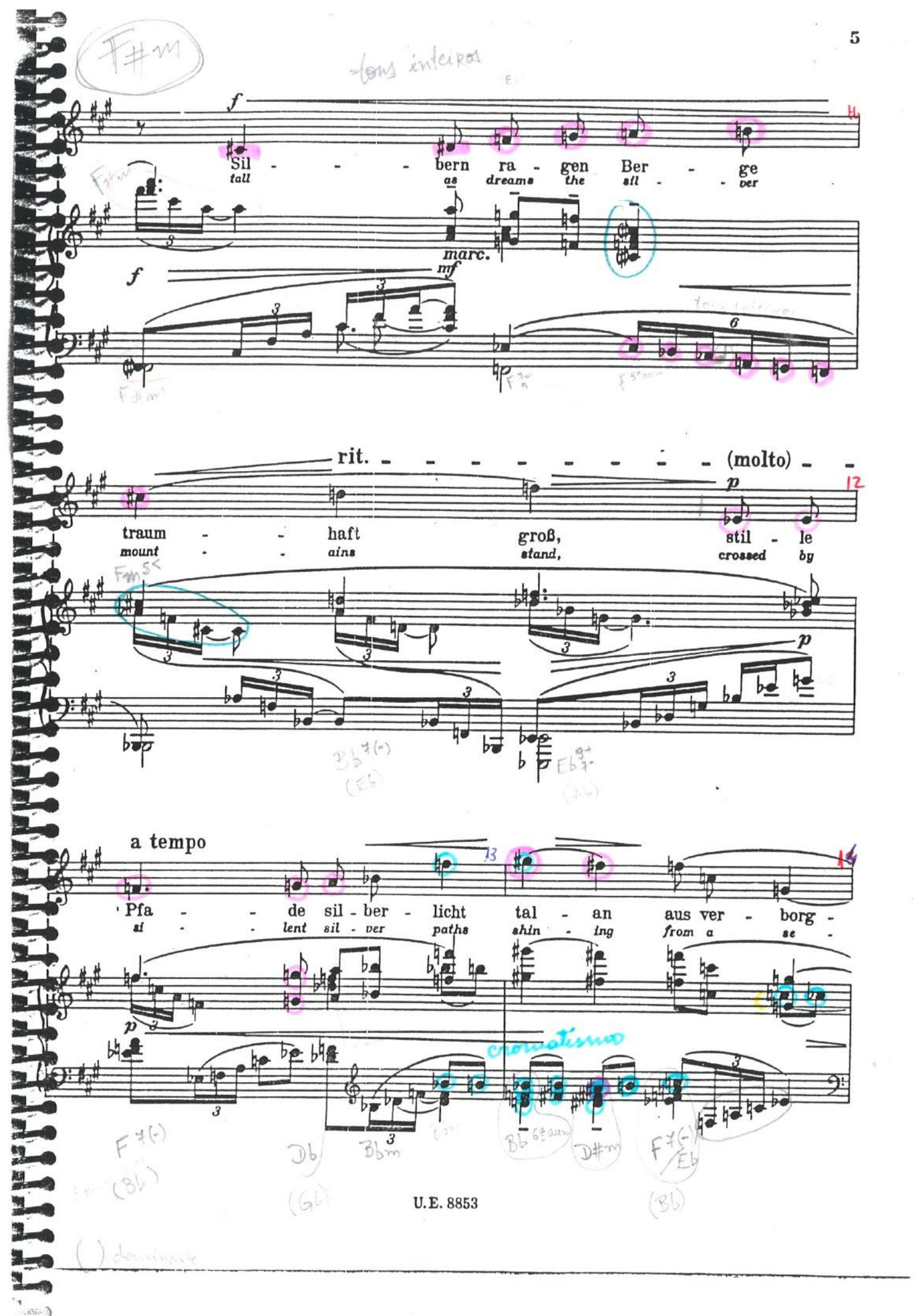




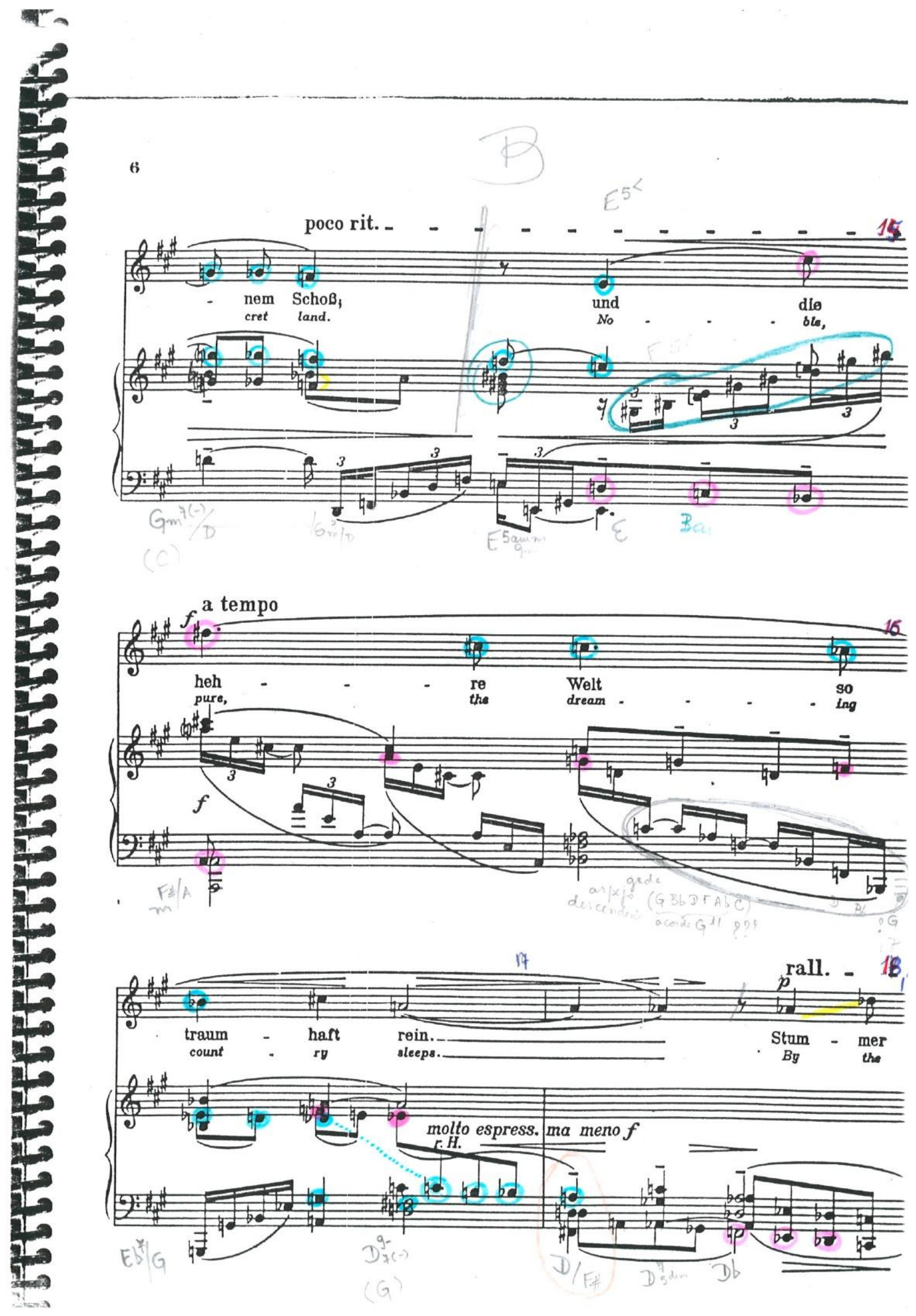




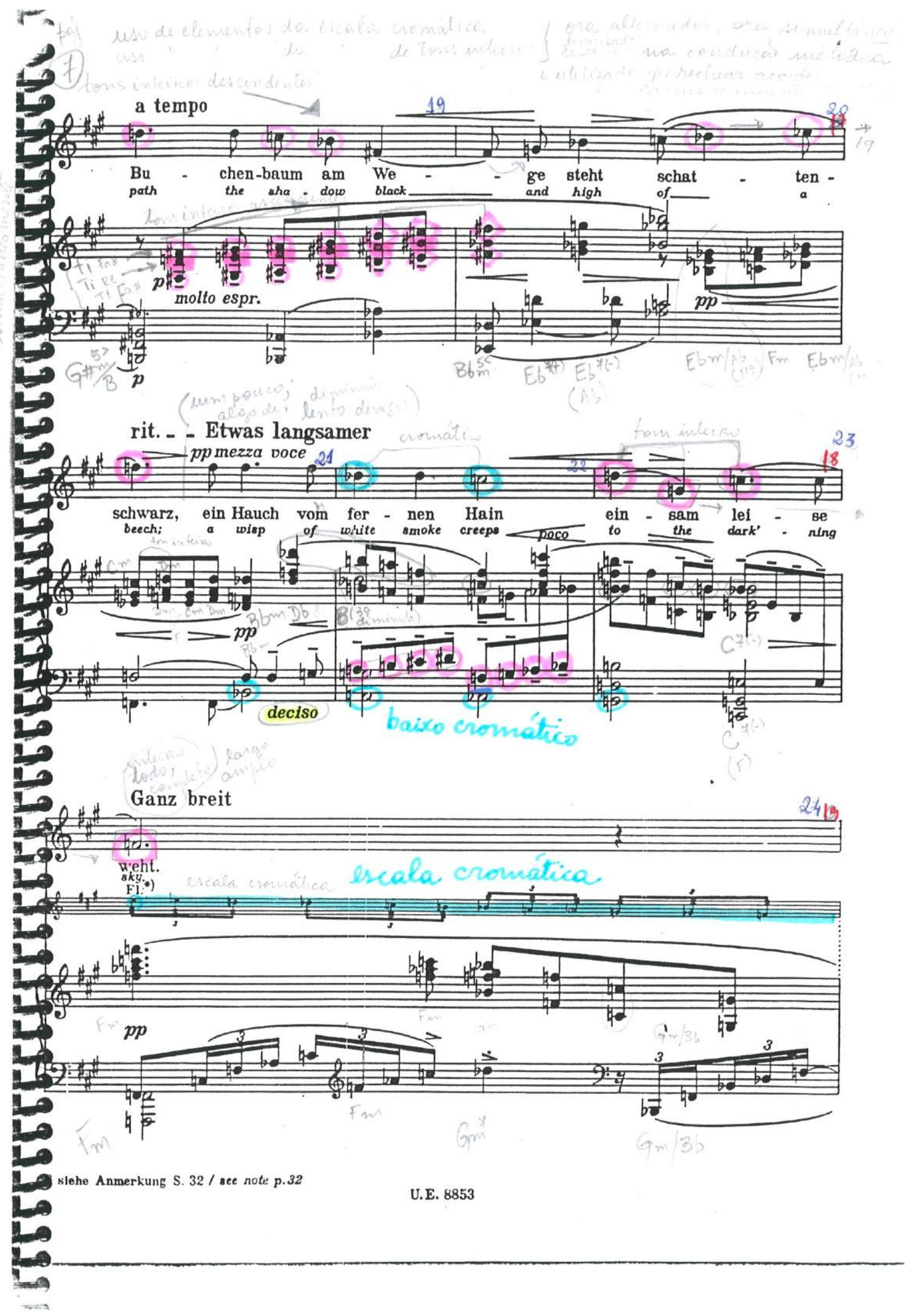




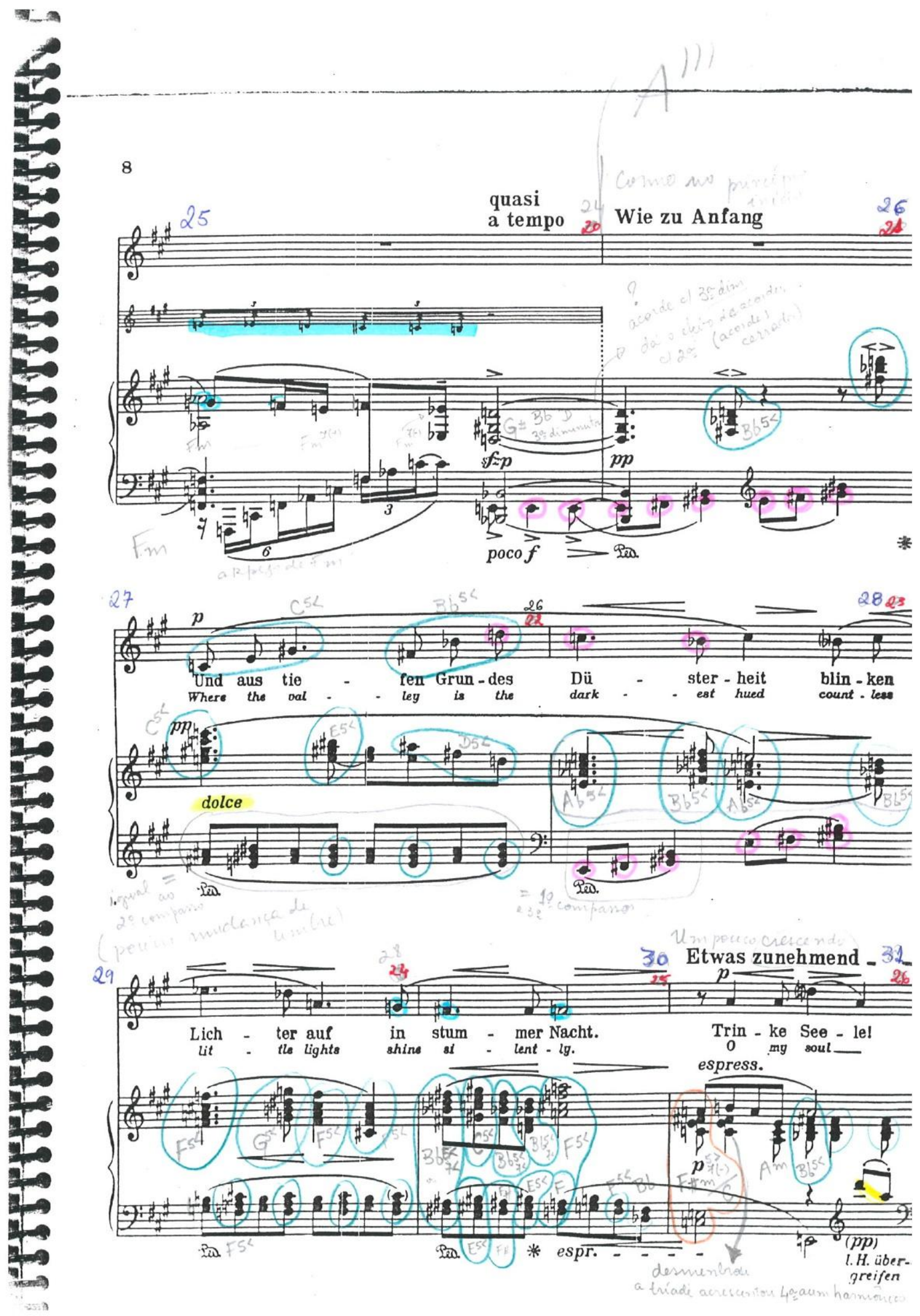




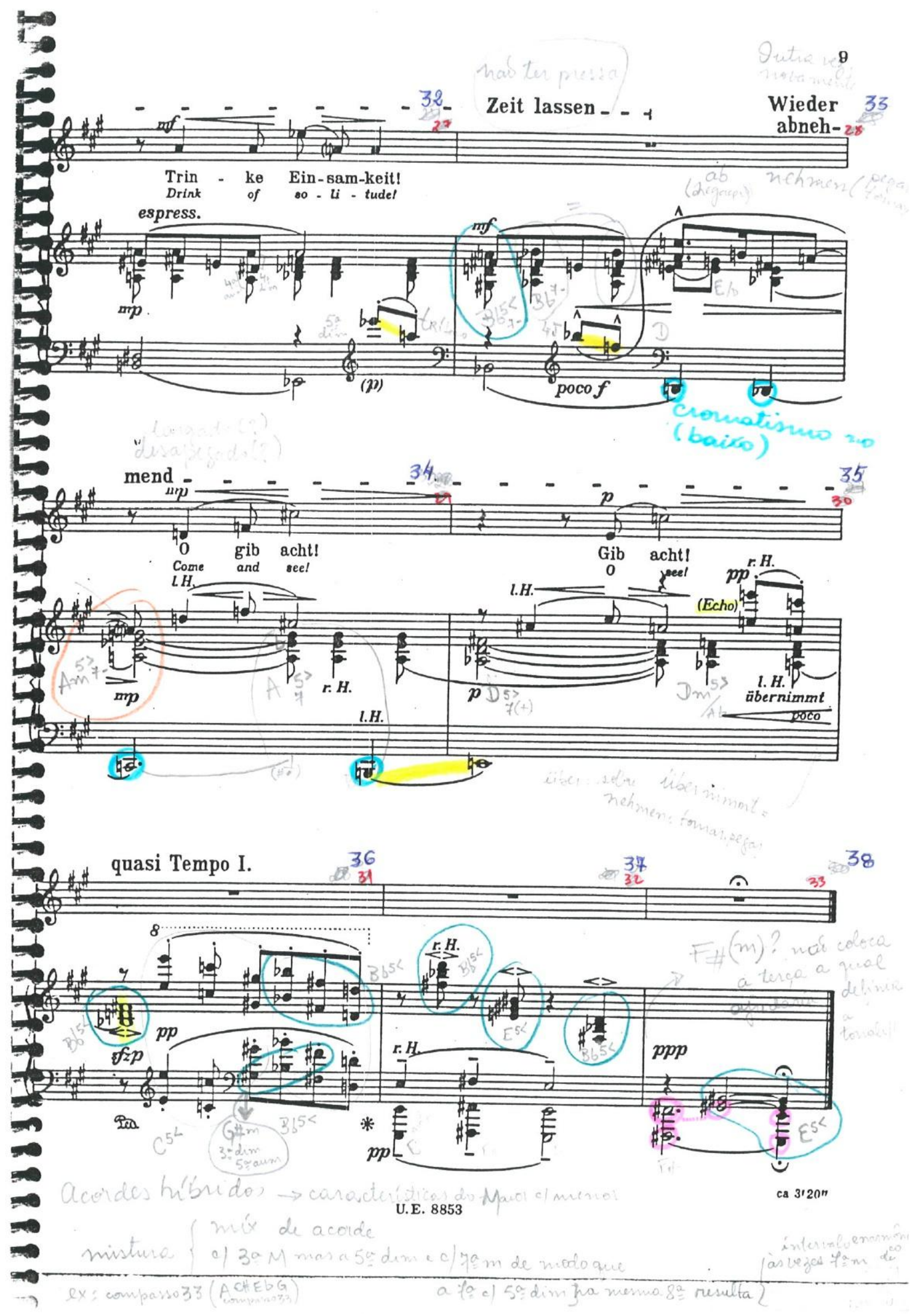




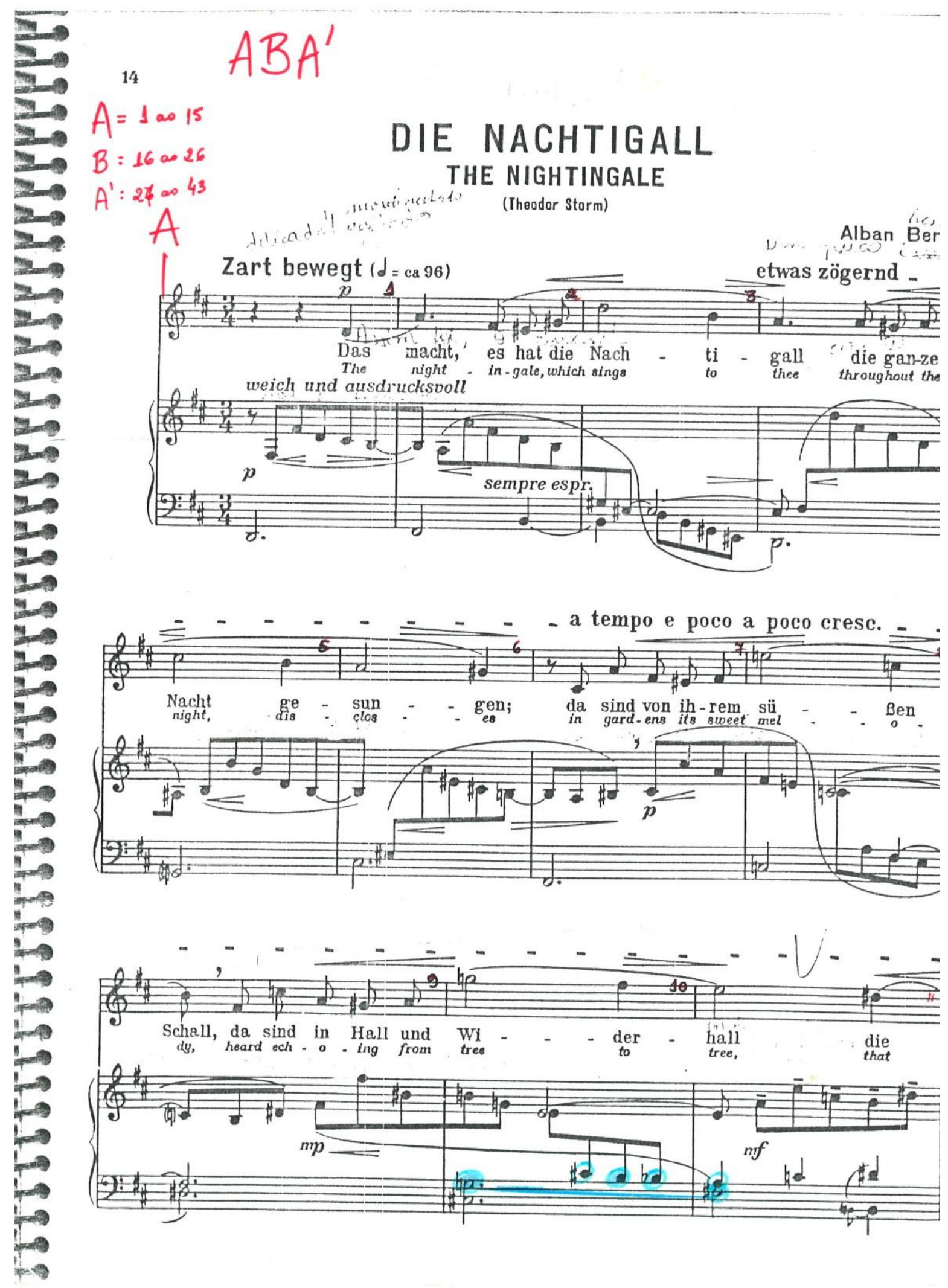




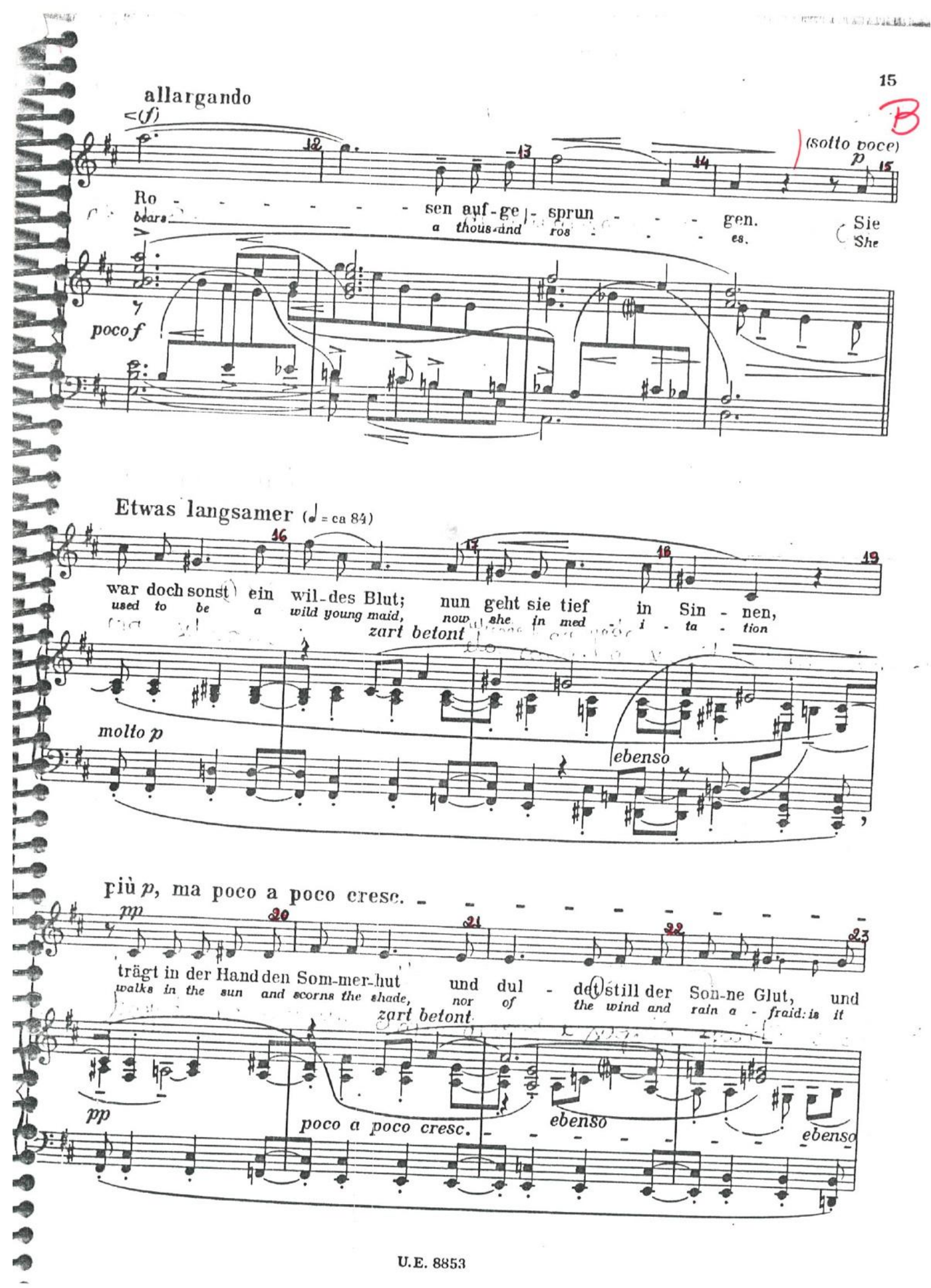




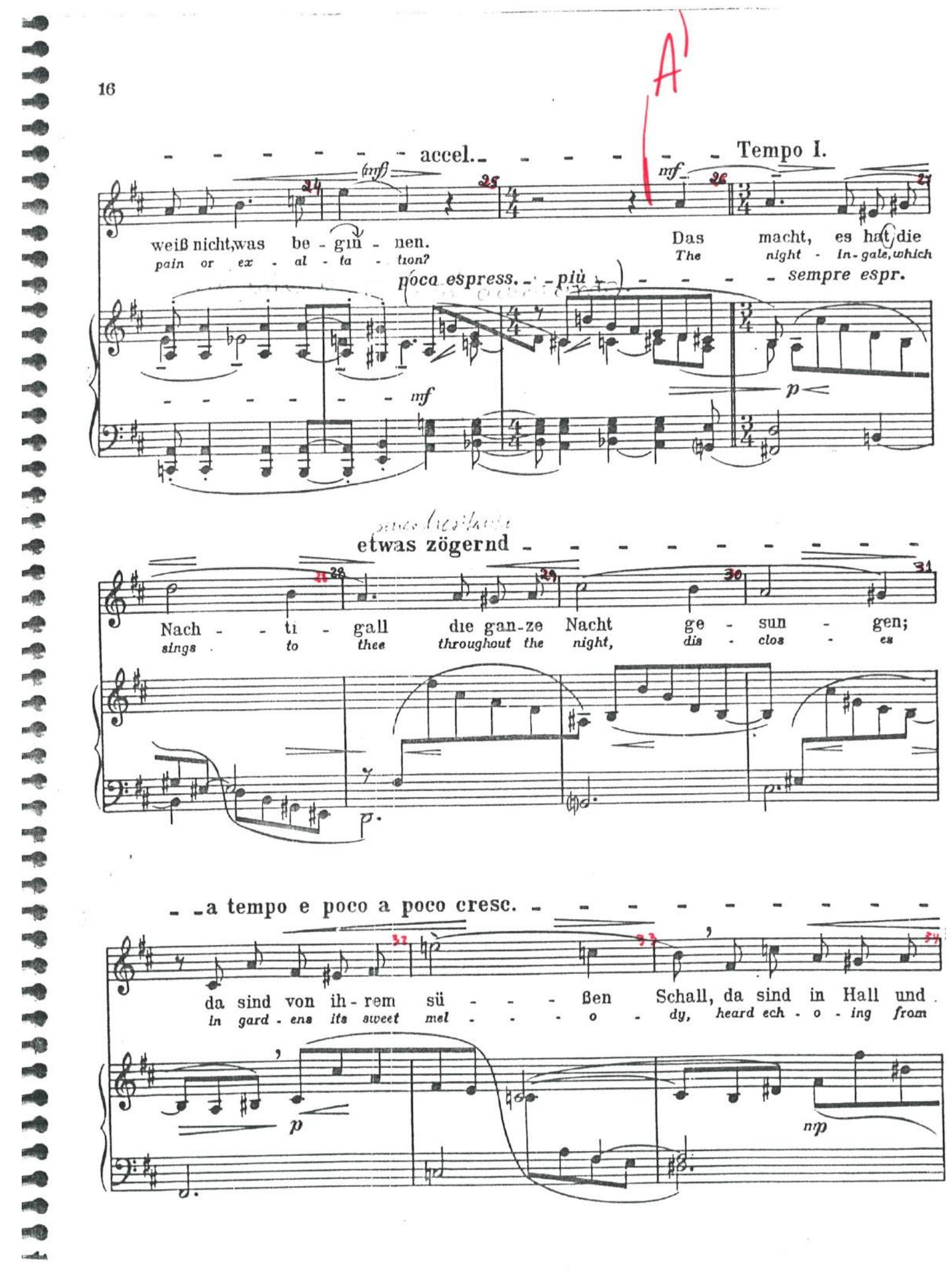




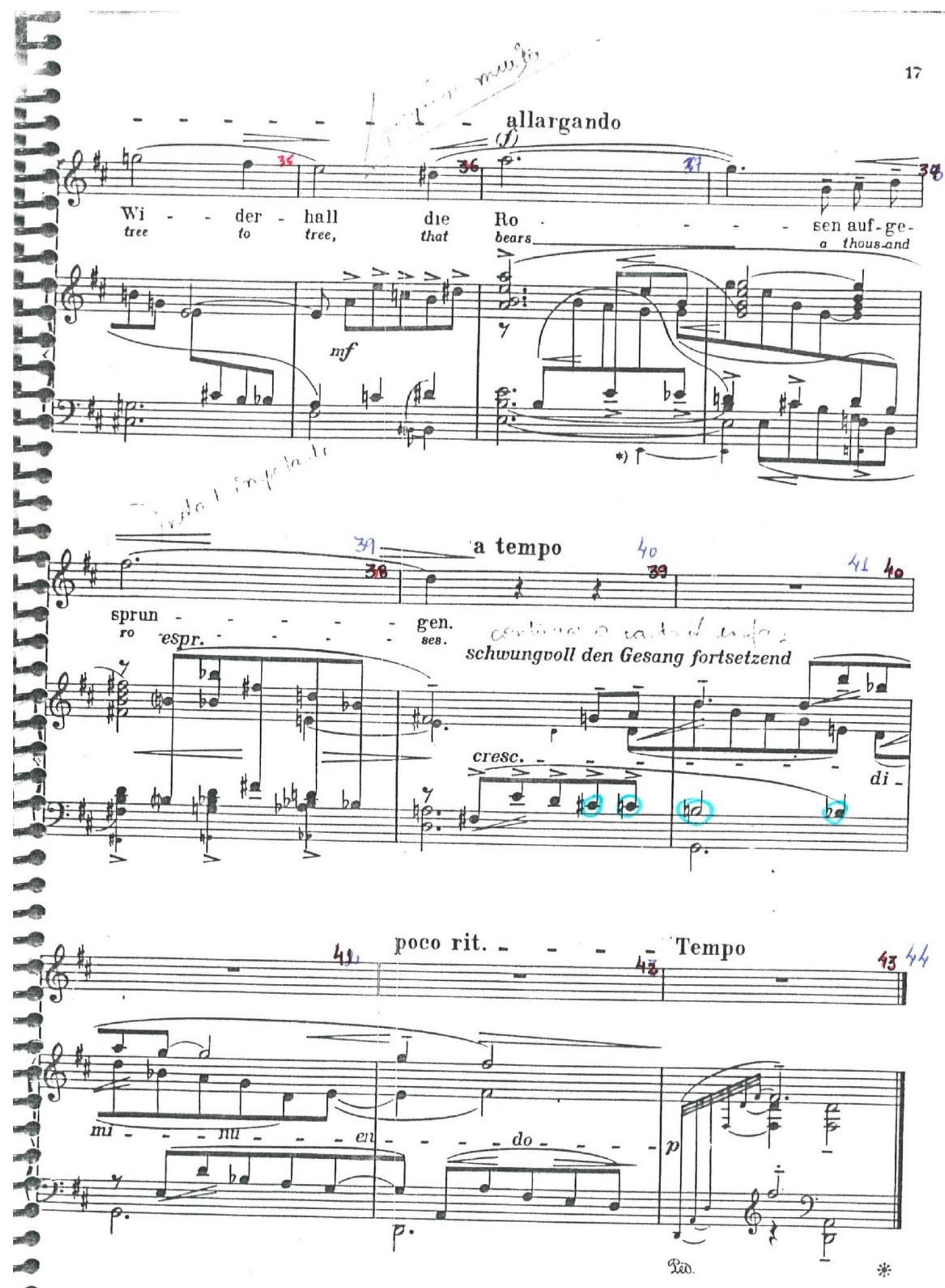

(2.) siche Anmerkung Seitc 32/see note p. 32

U.E. 8853

ca 1' 40 " 


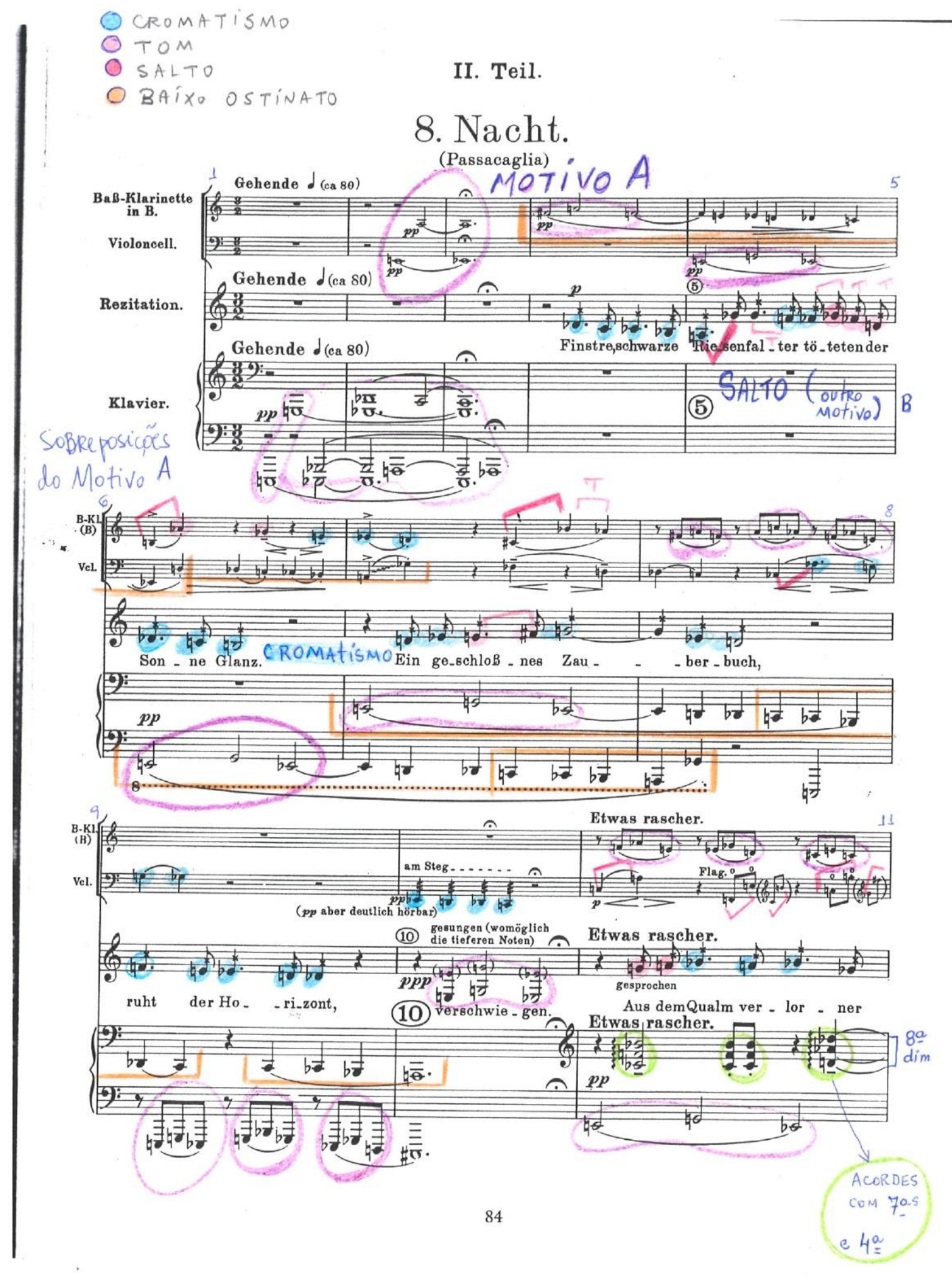




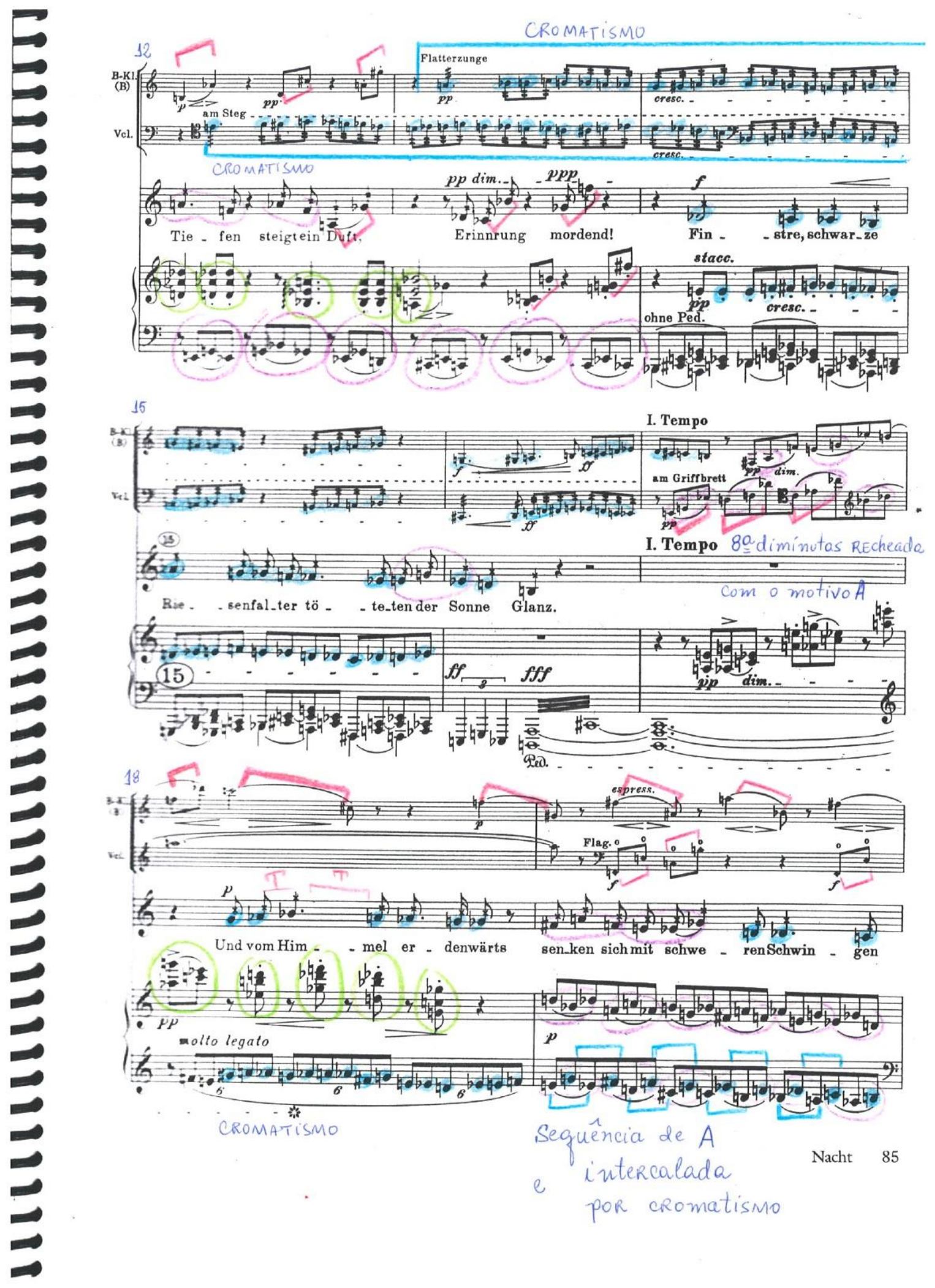



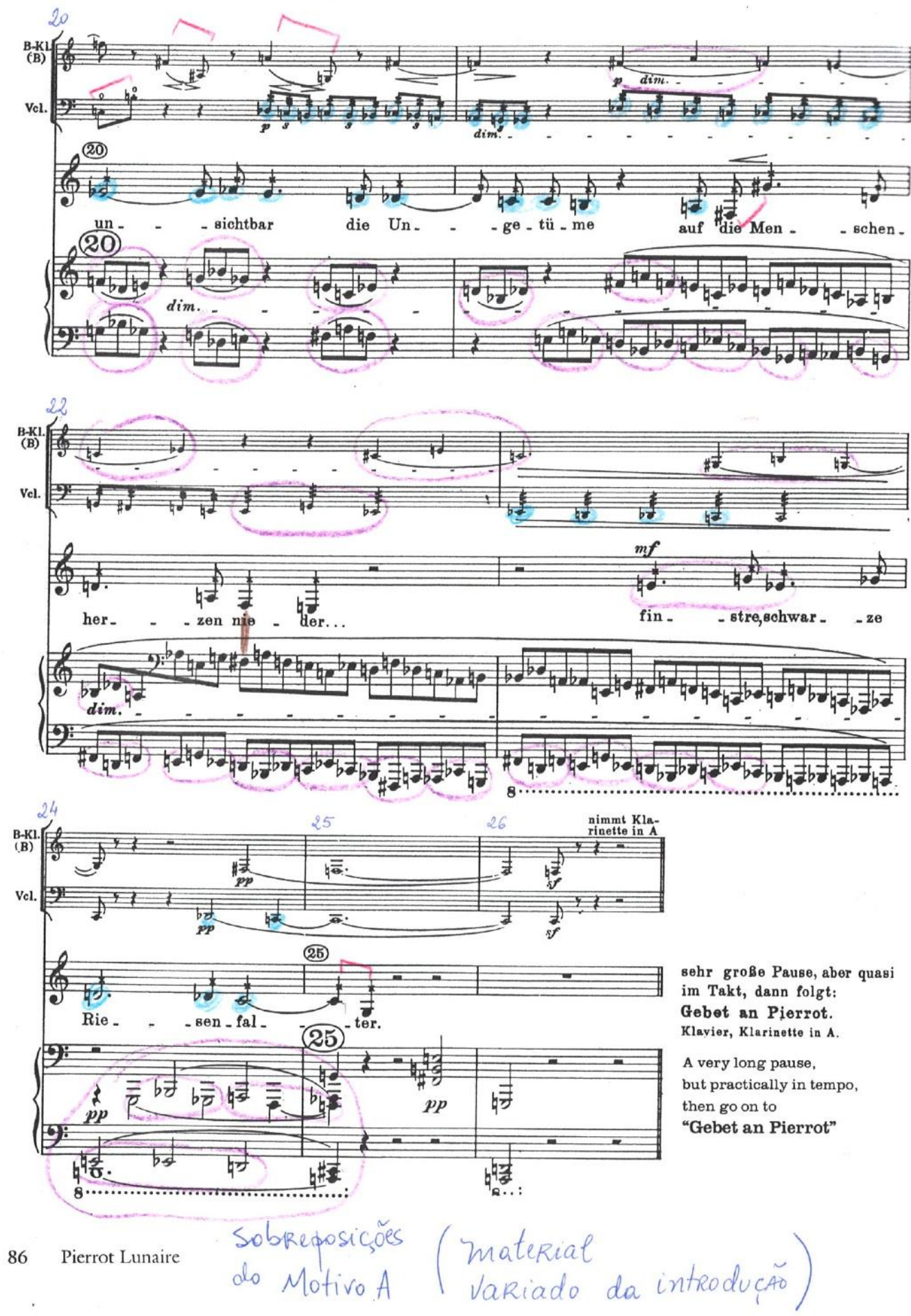


\section{KANTATE}

für Sopran- und Baß-Solo, gemischten Chor und Orchester

Wurte von Hildegard Jone I

English version by Eric'Smith

Anton Webern, op. 31

rit. tempo
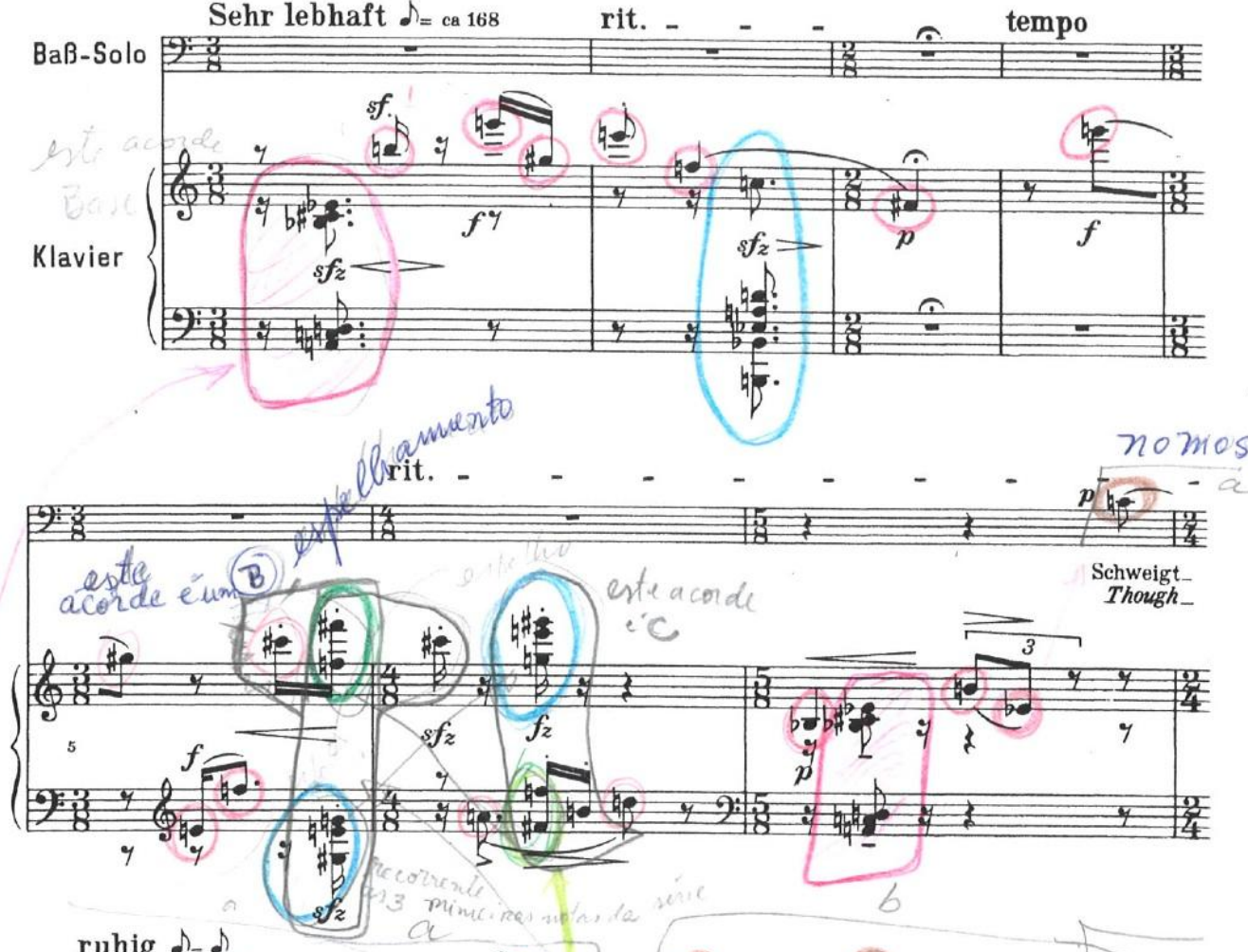

ruhig $\Lambda=\varnothing$

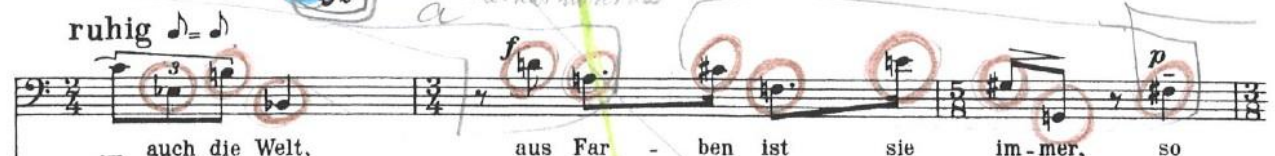

- auch die Welt

aus Far - ben ist

has all

sie im-mer

co-lour when

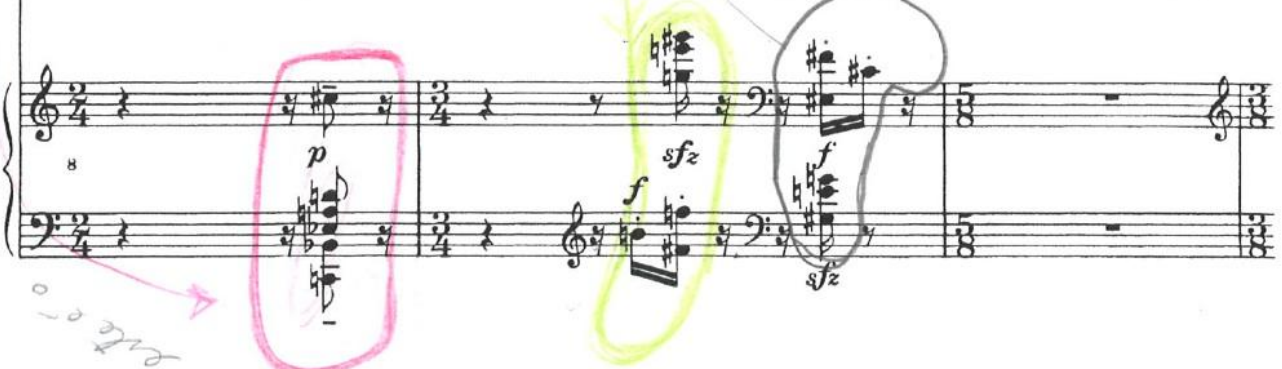

() Copyright 1951 by Universal Edition, Wien

English version copyright 1955 by Universal Edition A.G. Wien

Universal Edition UE 11885 


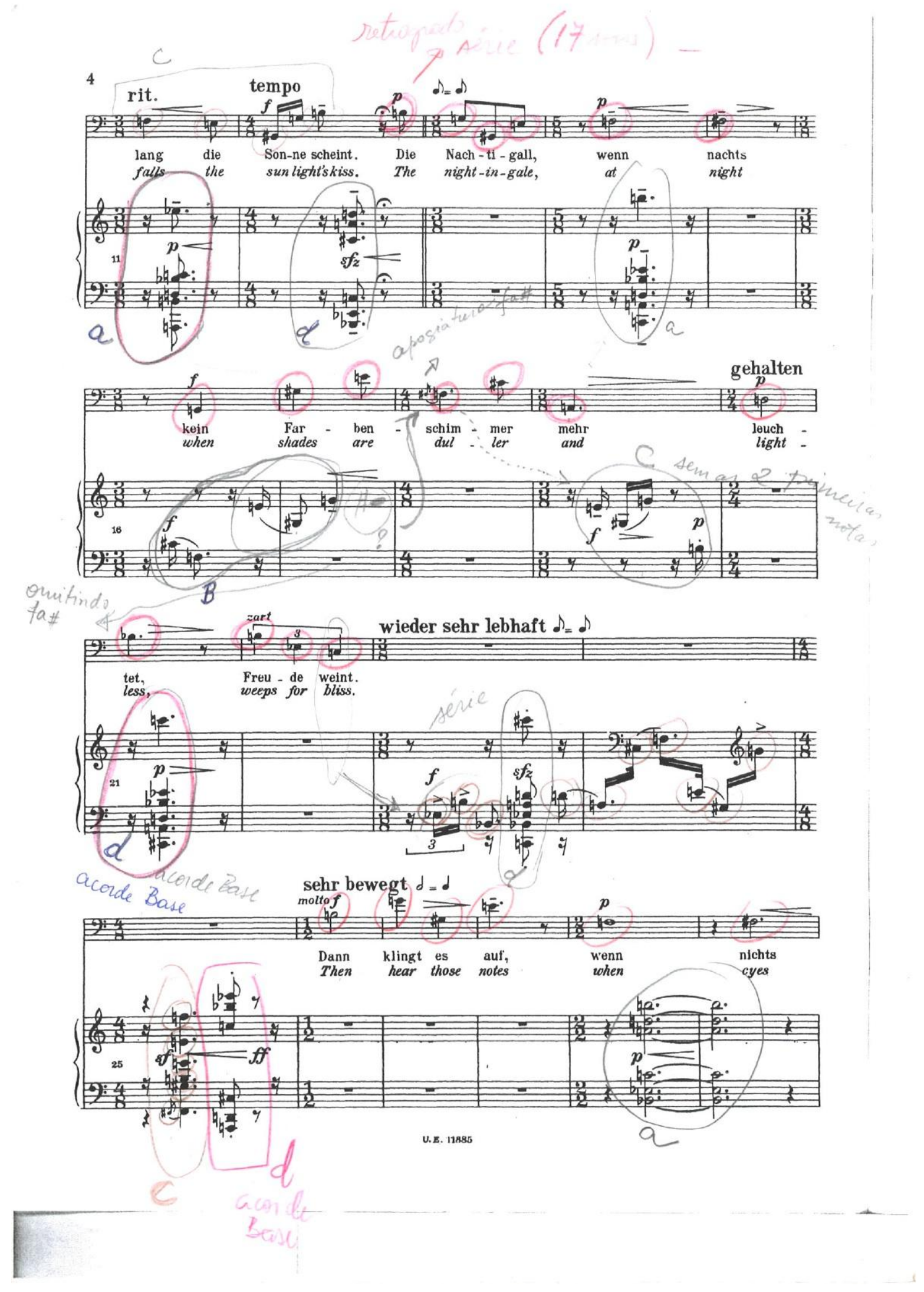



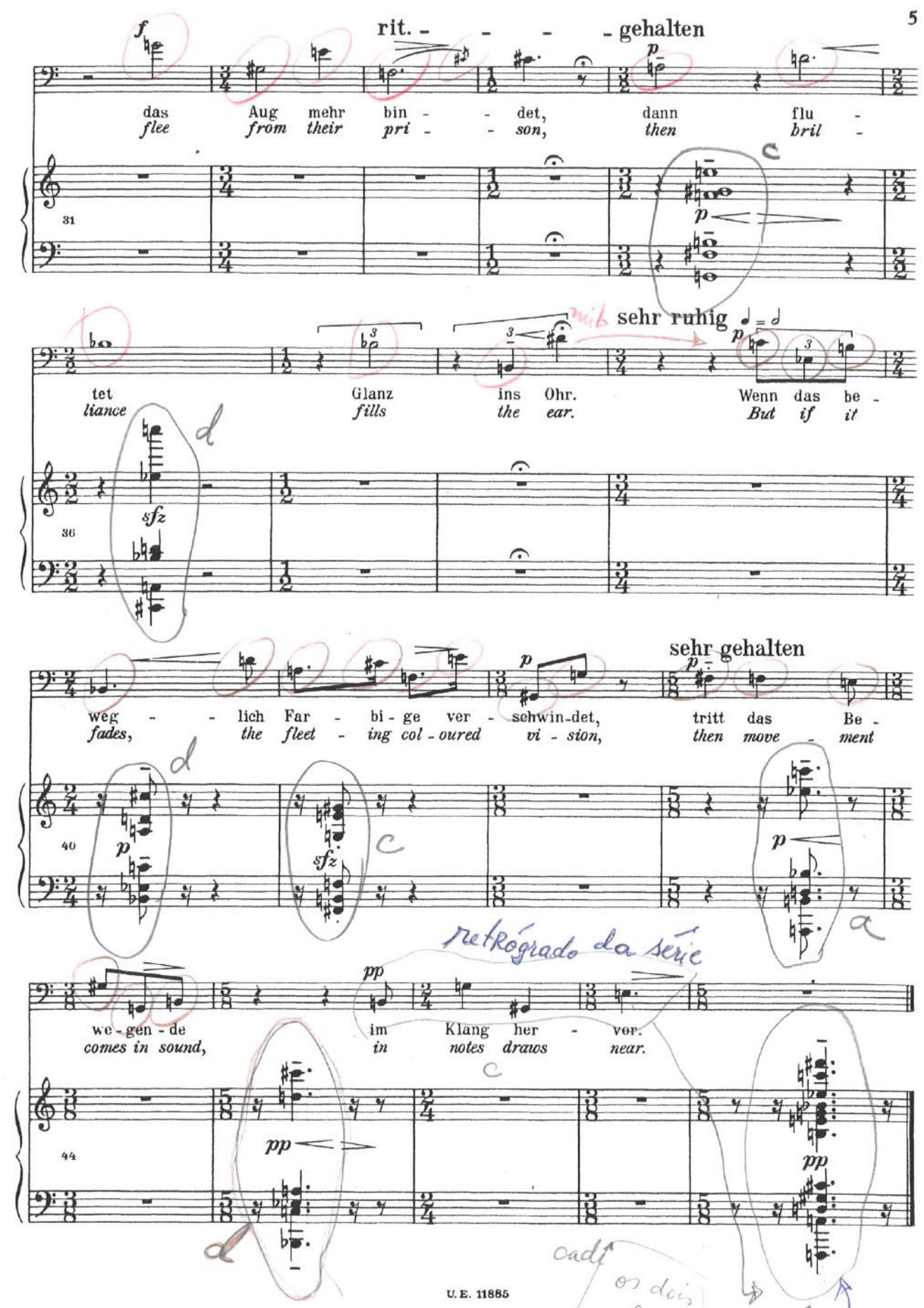
cadê es 2 fás? 

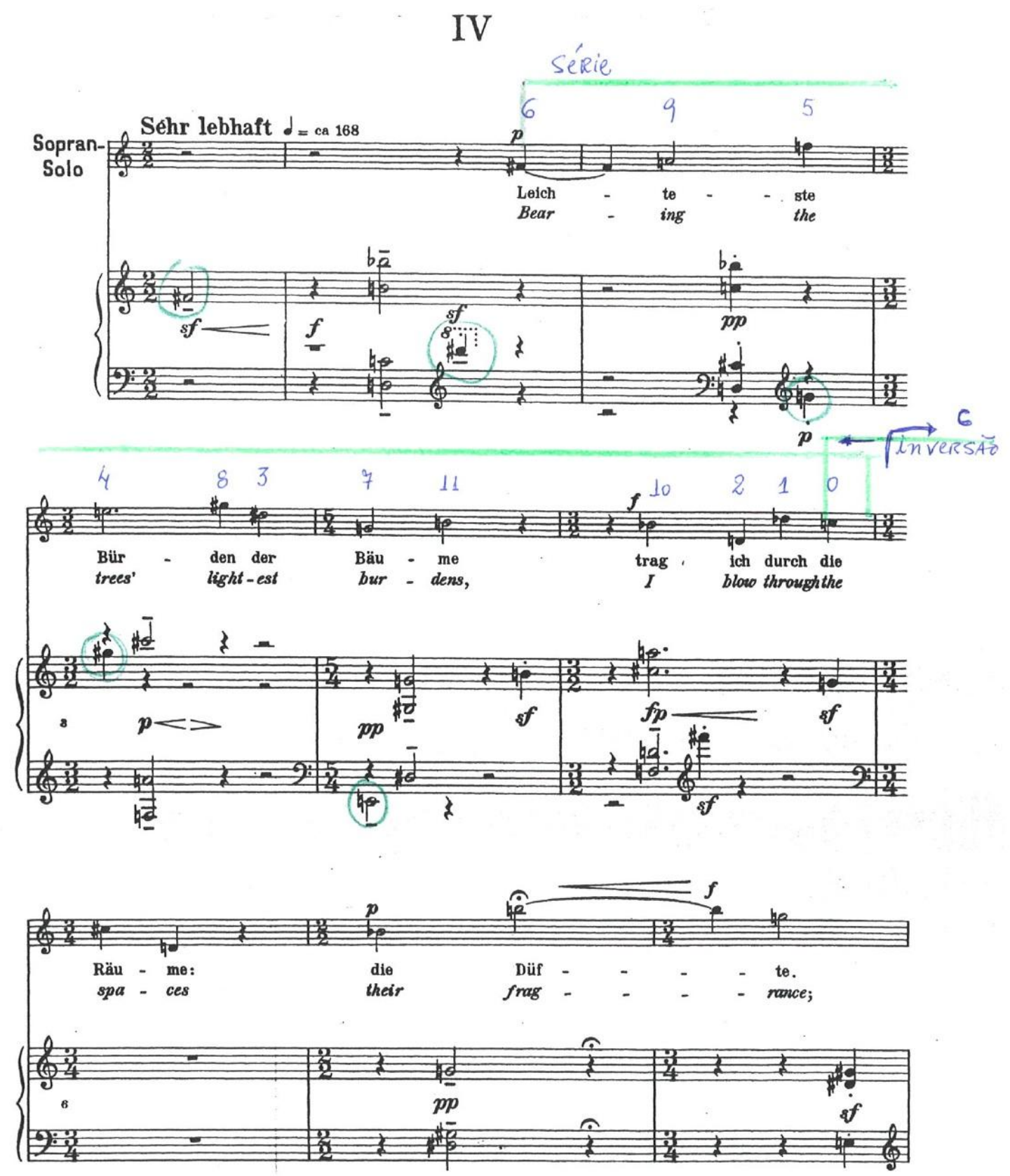

U. E. 11885 

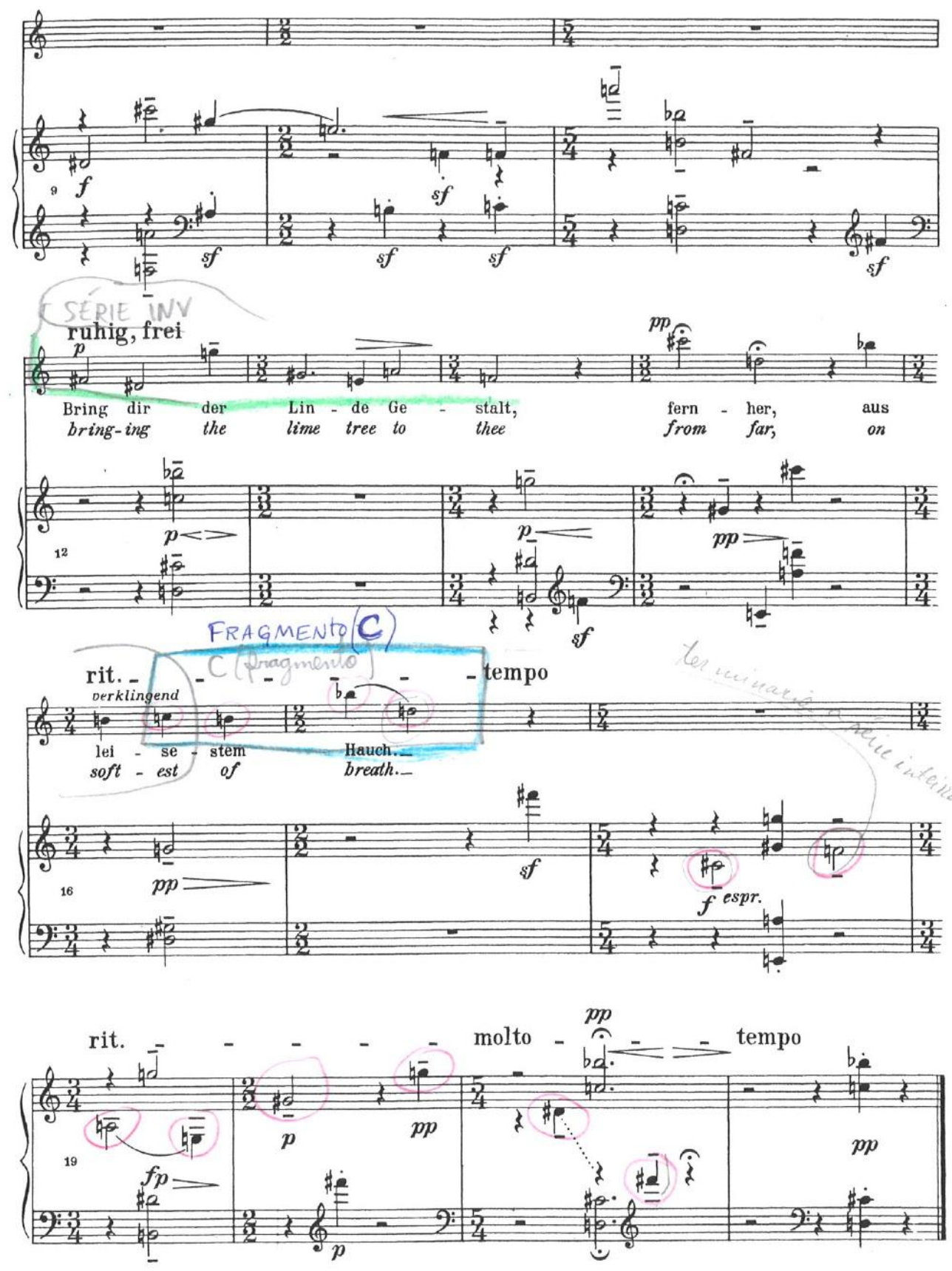

U.E. 11885 


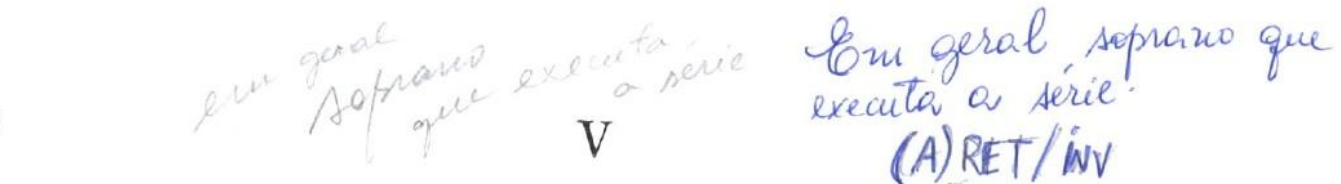
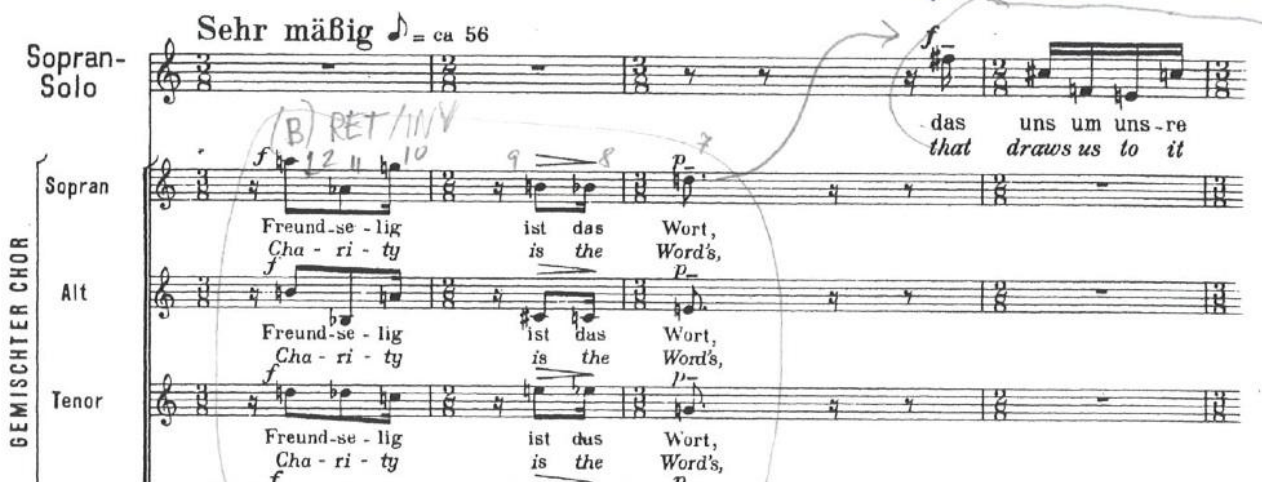

Baß

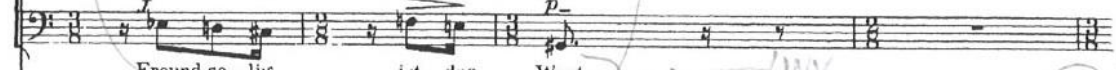

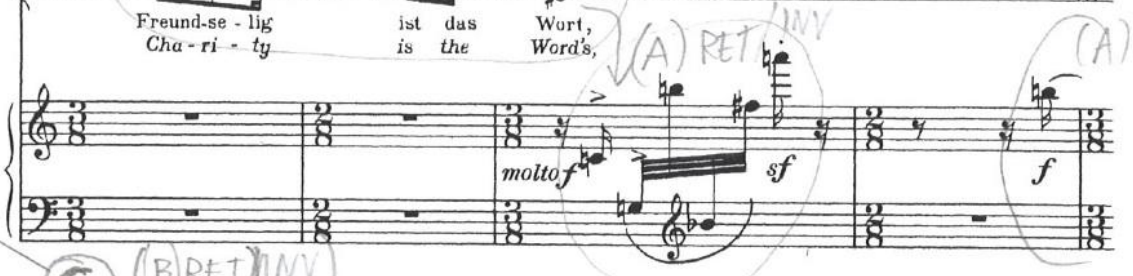

C $(B \mid R E T) \mid 1$
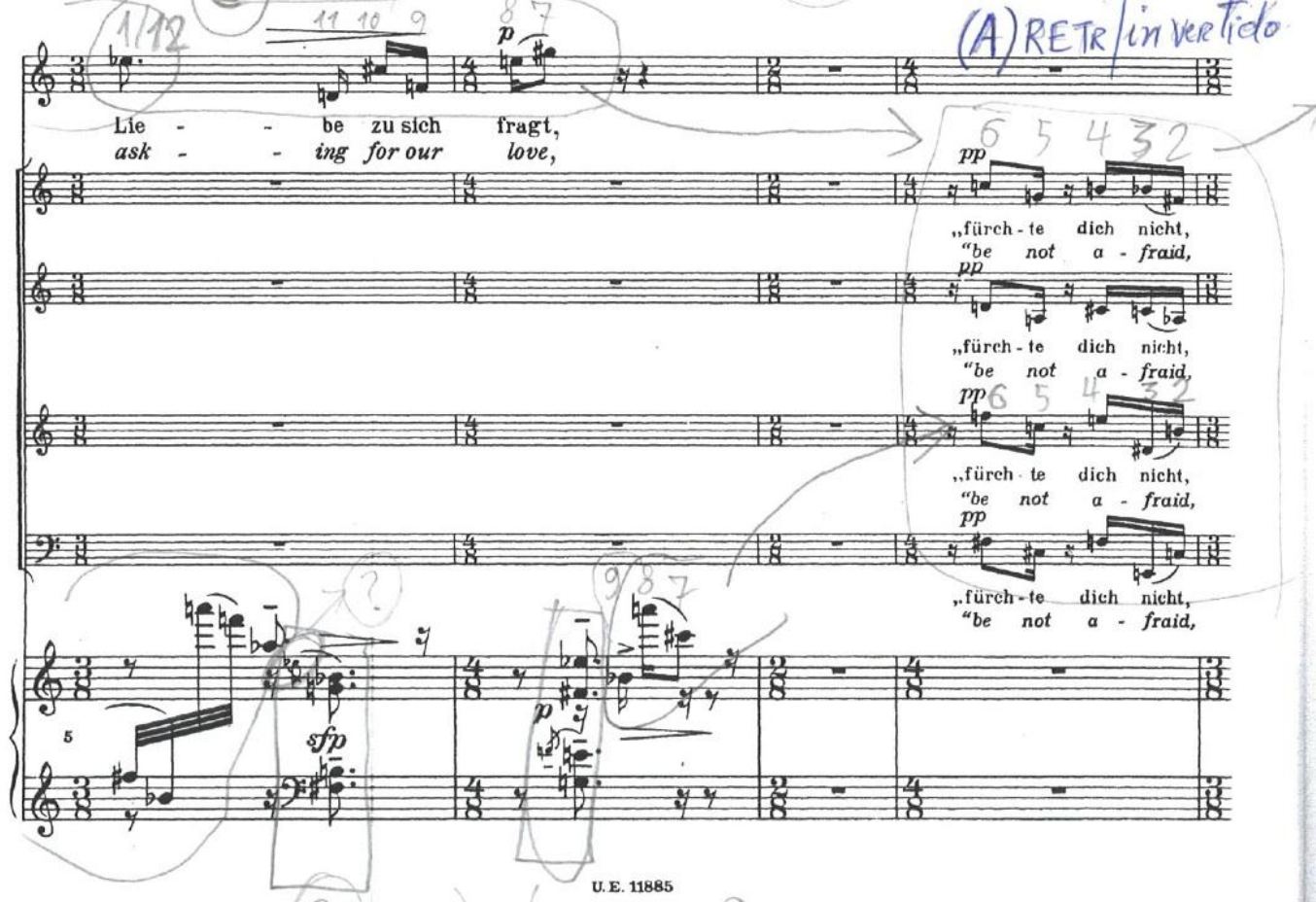

$(7)(2,245) \quad \rightarrow(8910 \% 12 \%)$

(7) aposiotura 


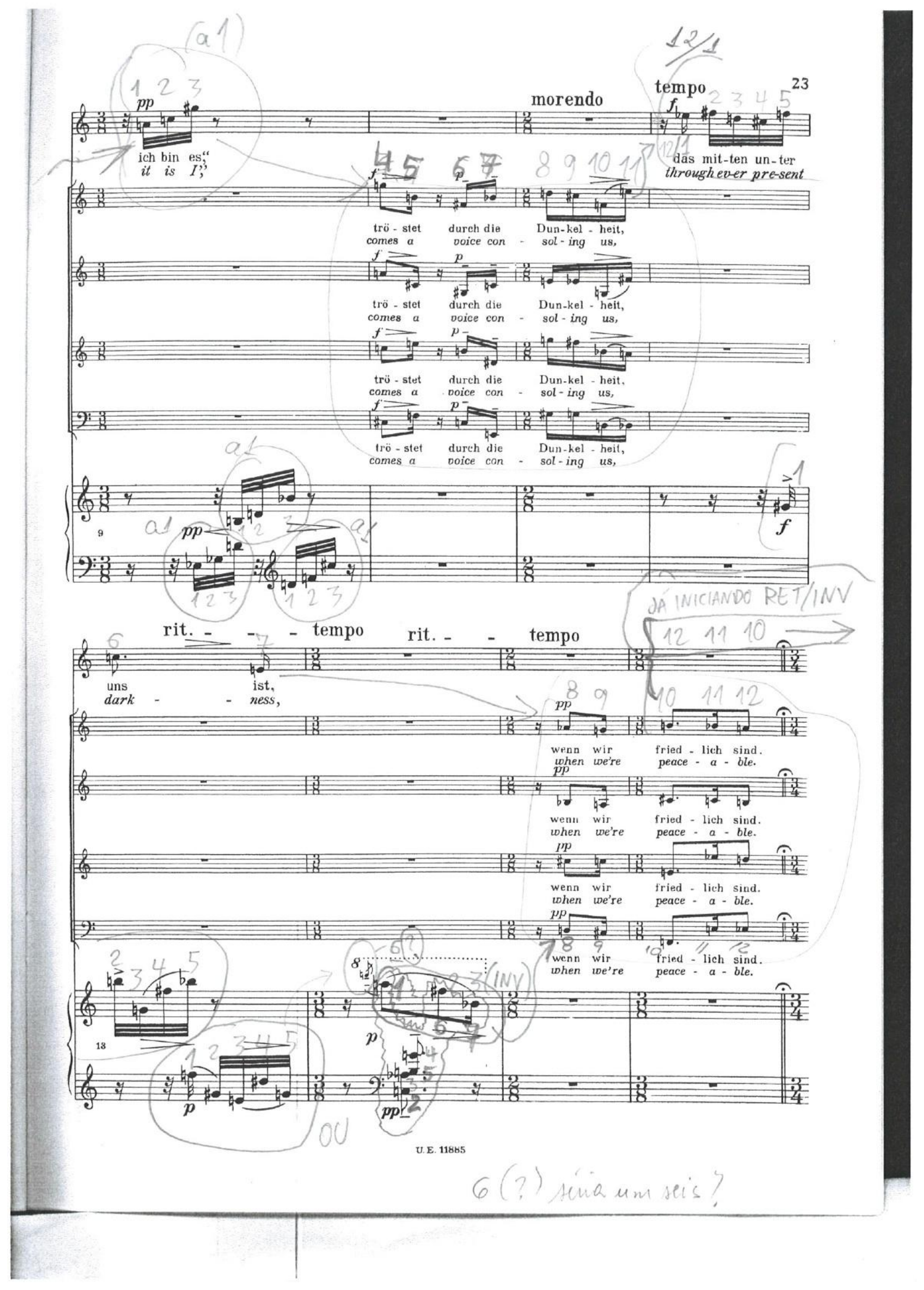




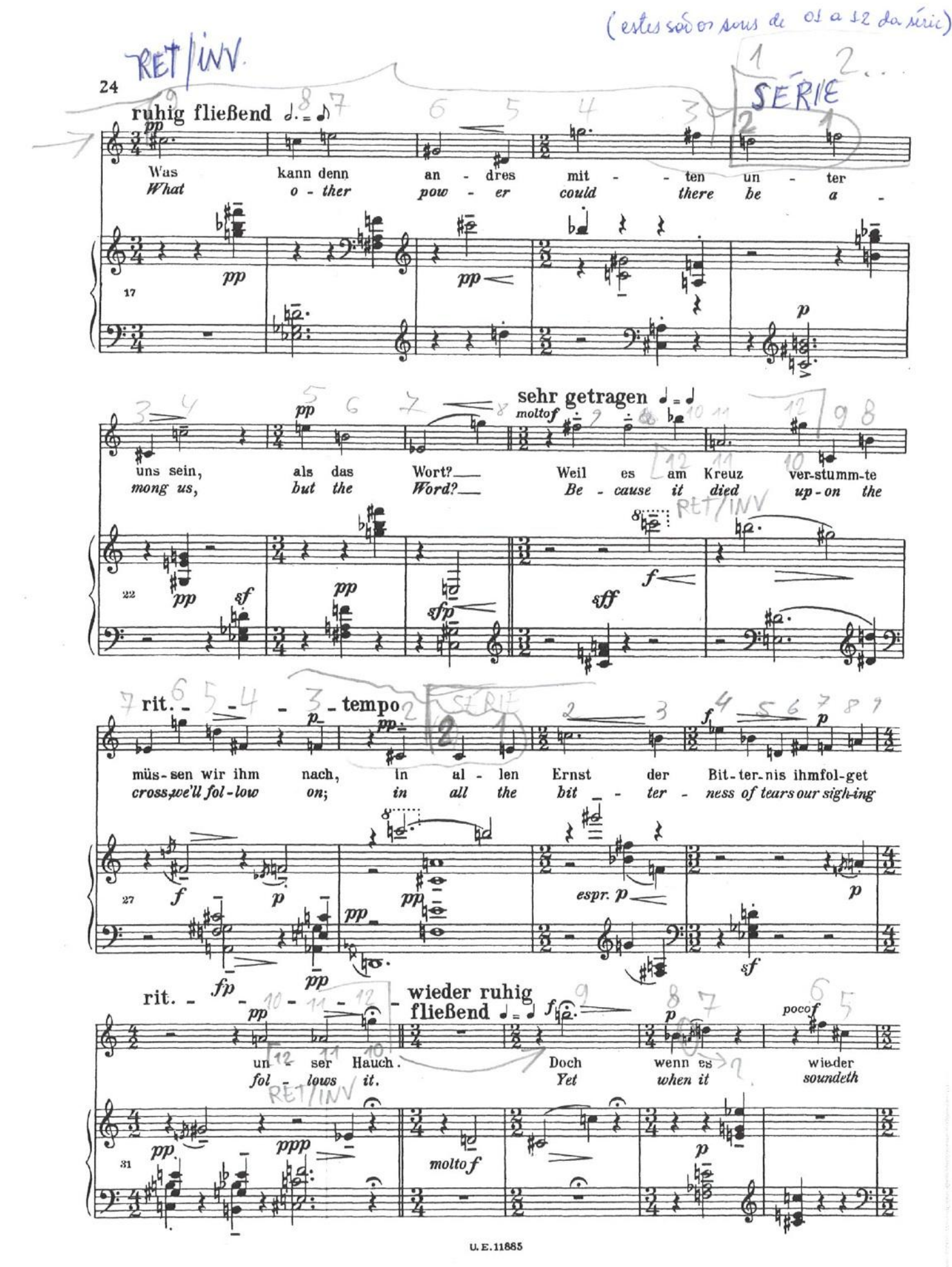




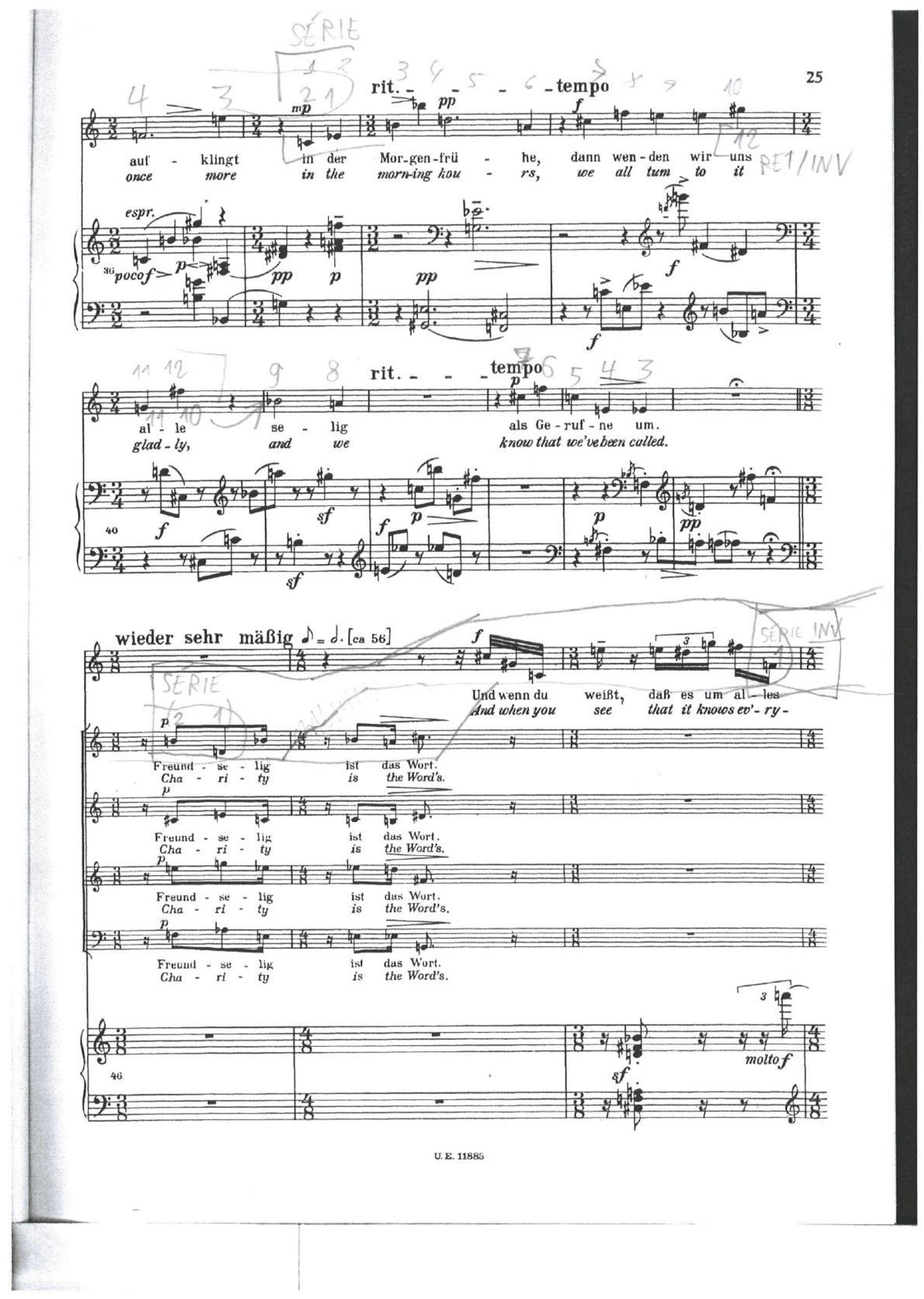




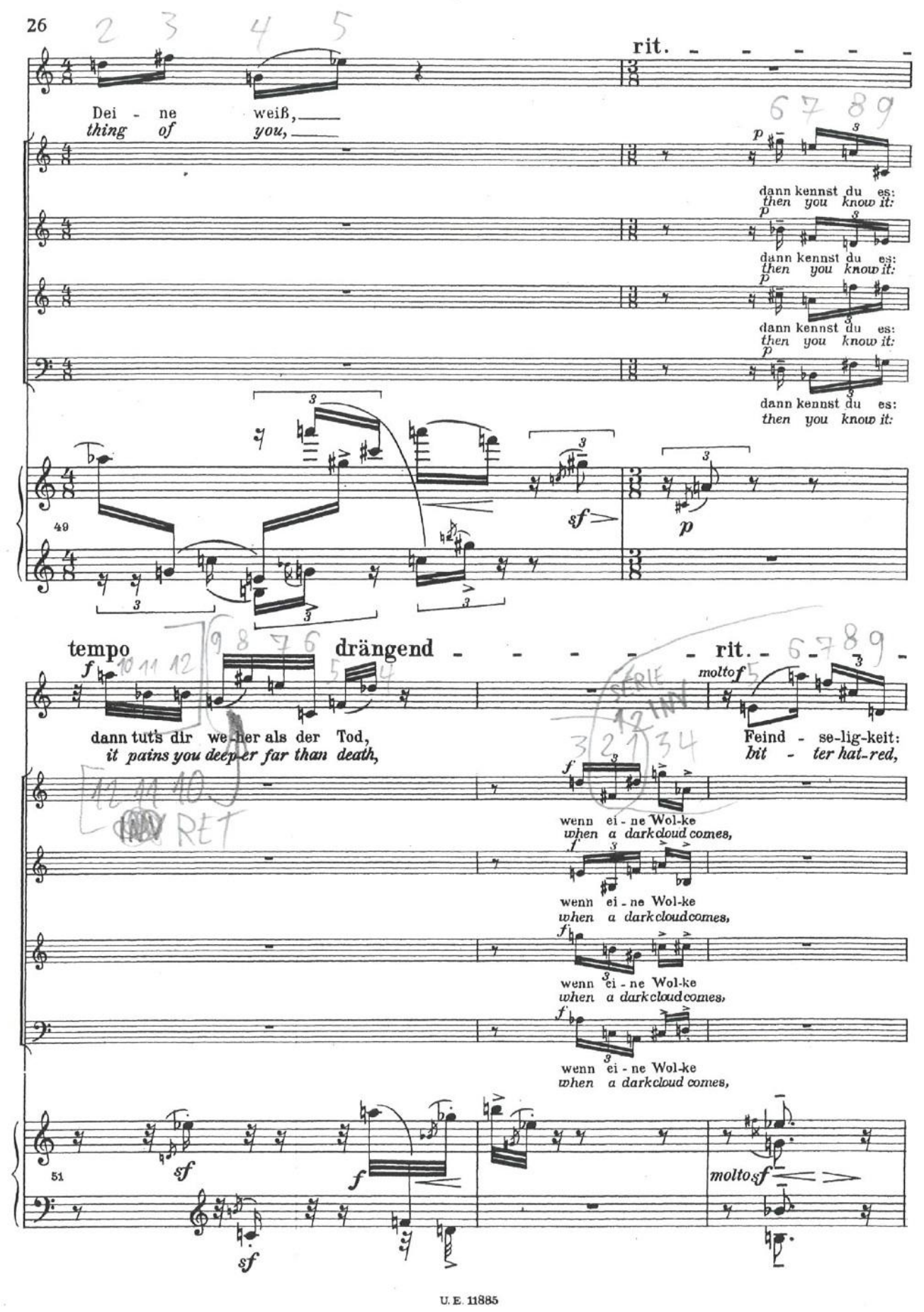




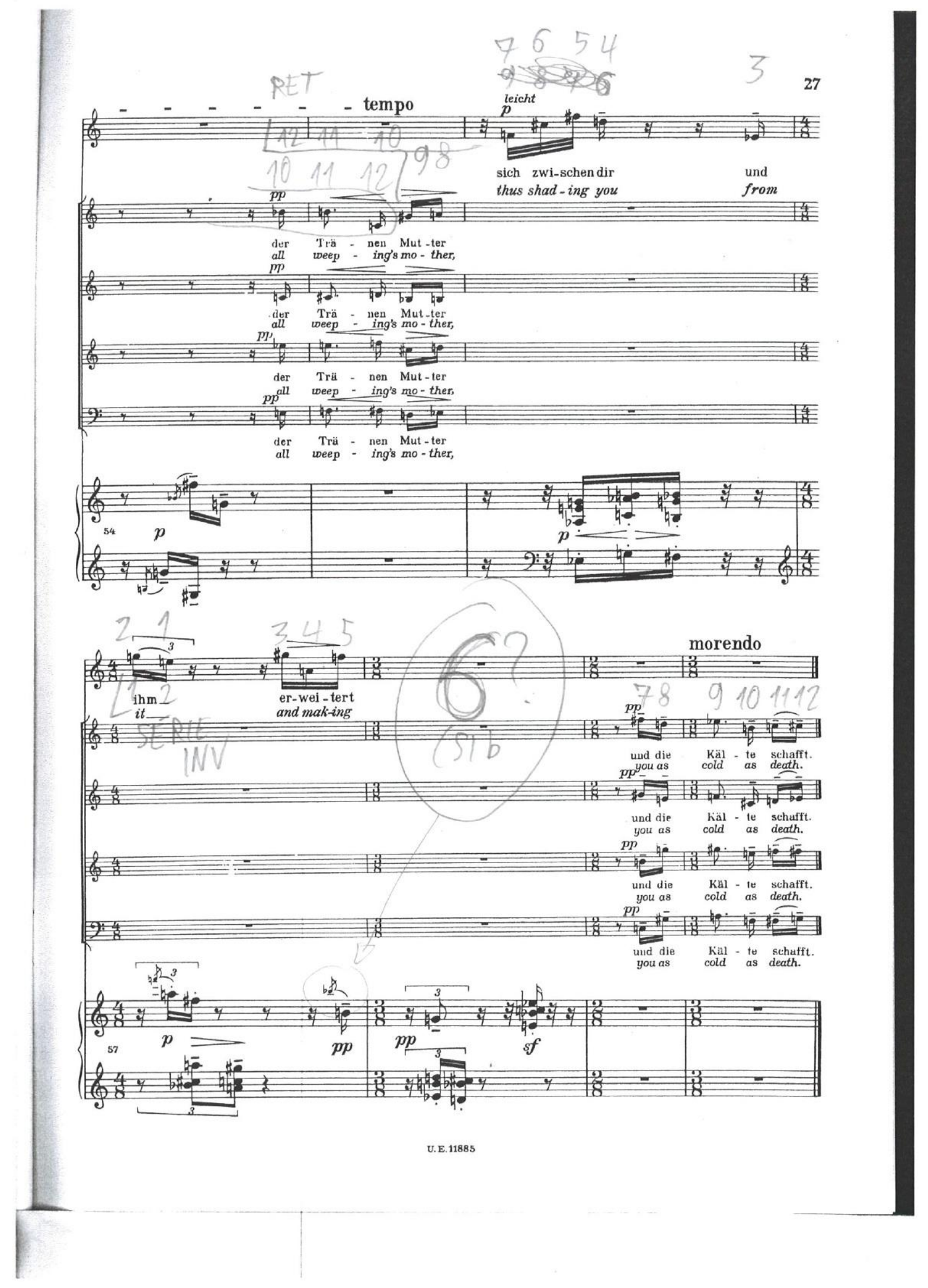


for Alban Berg

\section{DREI LIEDER}

\section{THREE SONGS}

for Bass Voice

English Version by

Maurice Wright

(1931)

Edited by Jacques-Louis Monod

Eduard Steuermann (1892-1964)

\section{Der Mensch}

The Man

(Claudius)

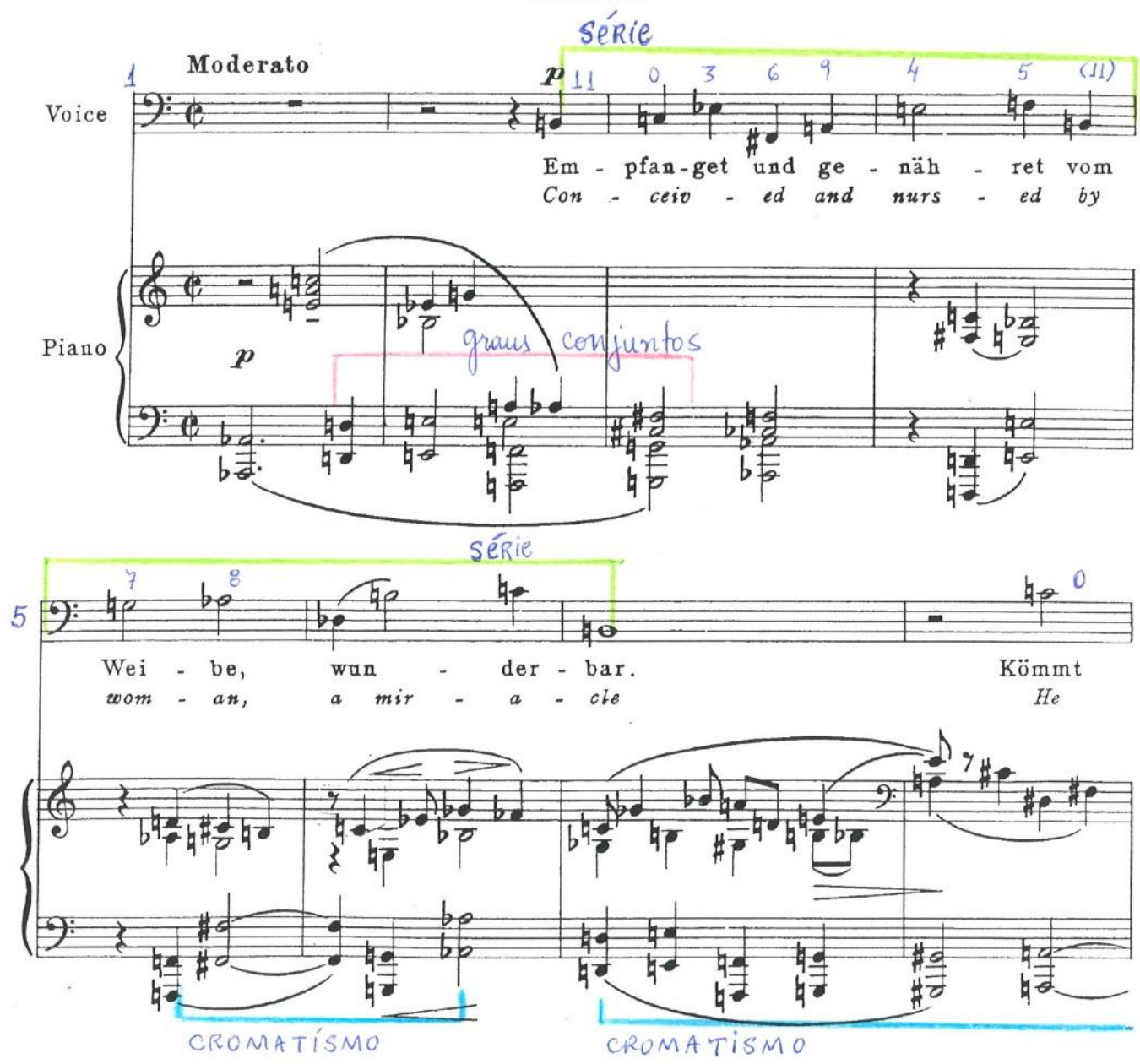

(c) Copyright 1985 by Mobart Music Publications, Inc Hillsdale, New York 12529

M 348

A11 Rights Reserved

Printed in U.S.A.
C.A (Classes de altura)

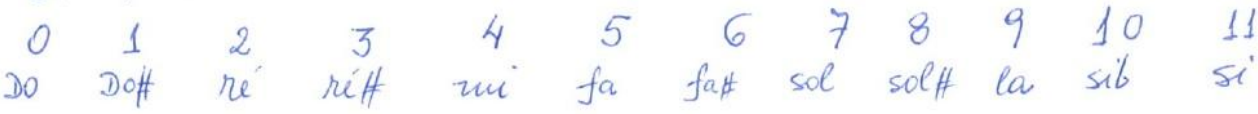



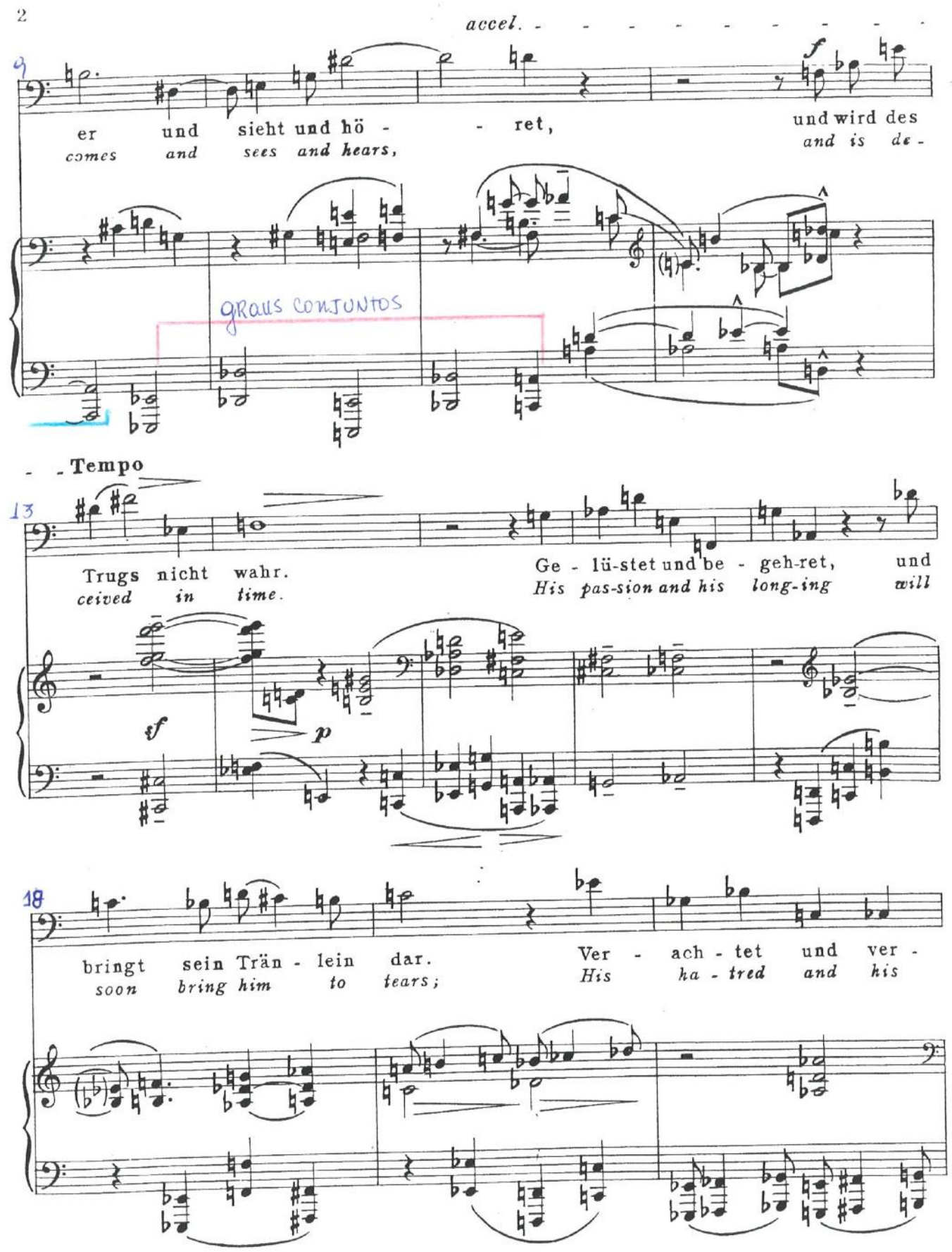

M 348 

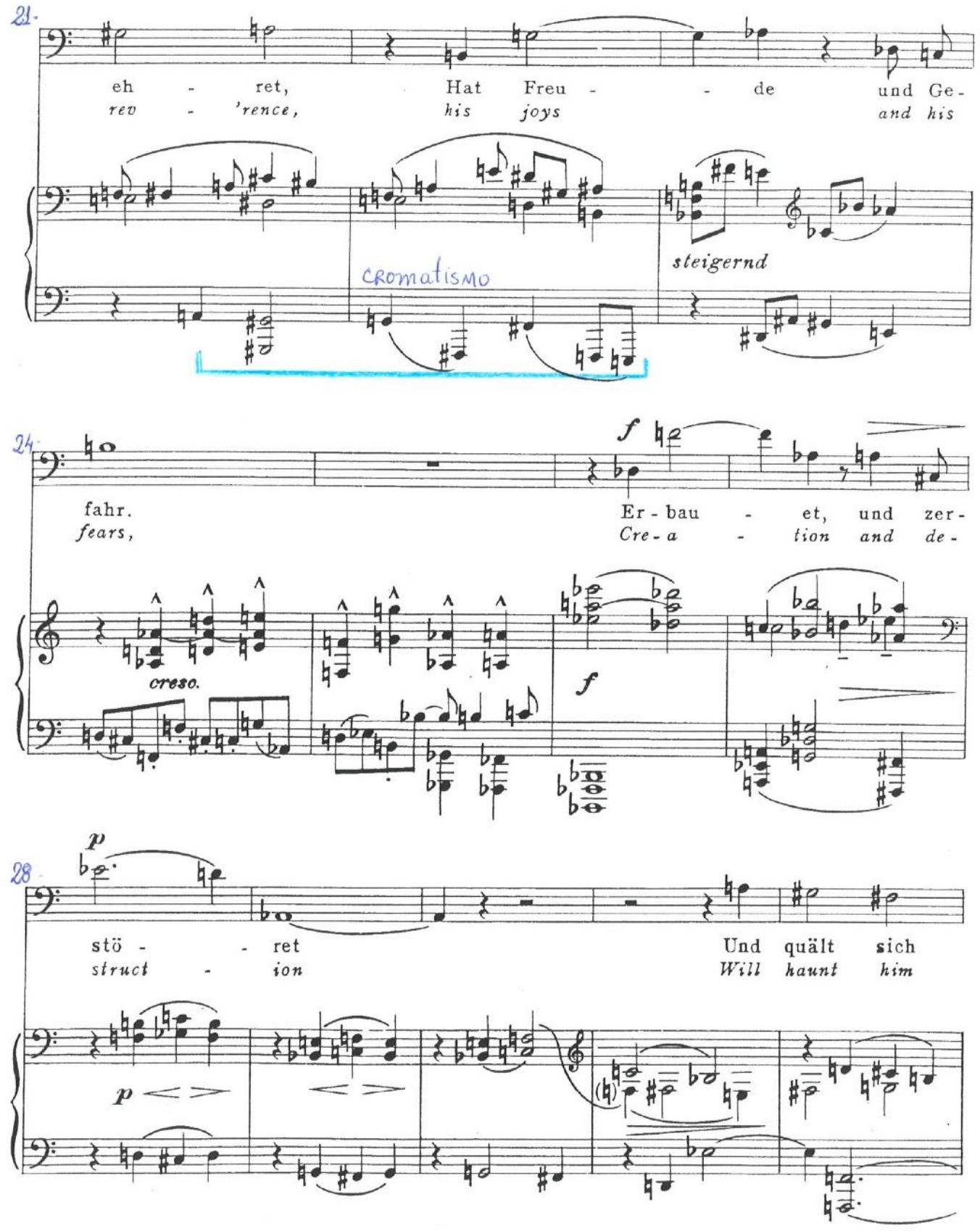

M 348 
4
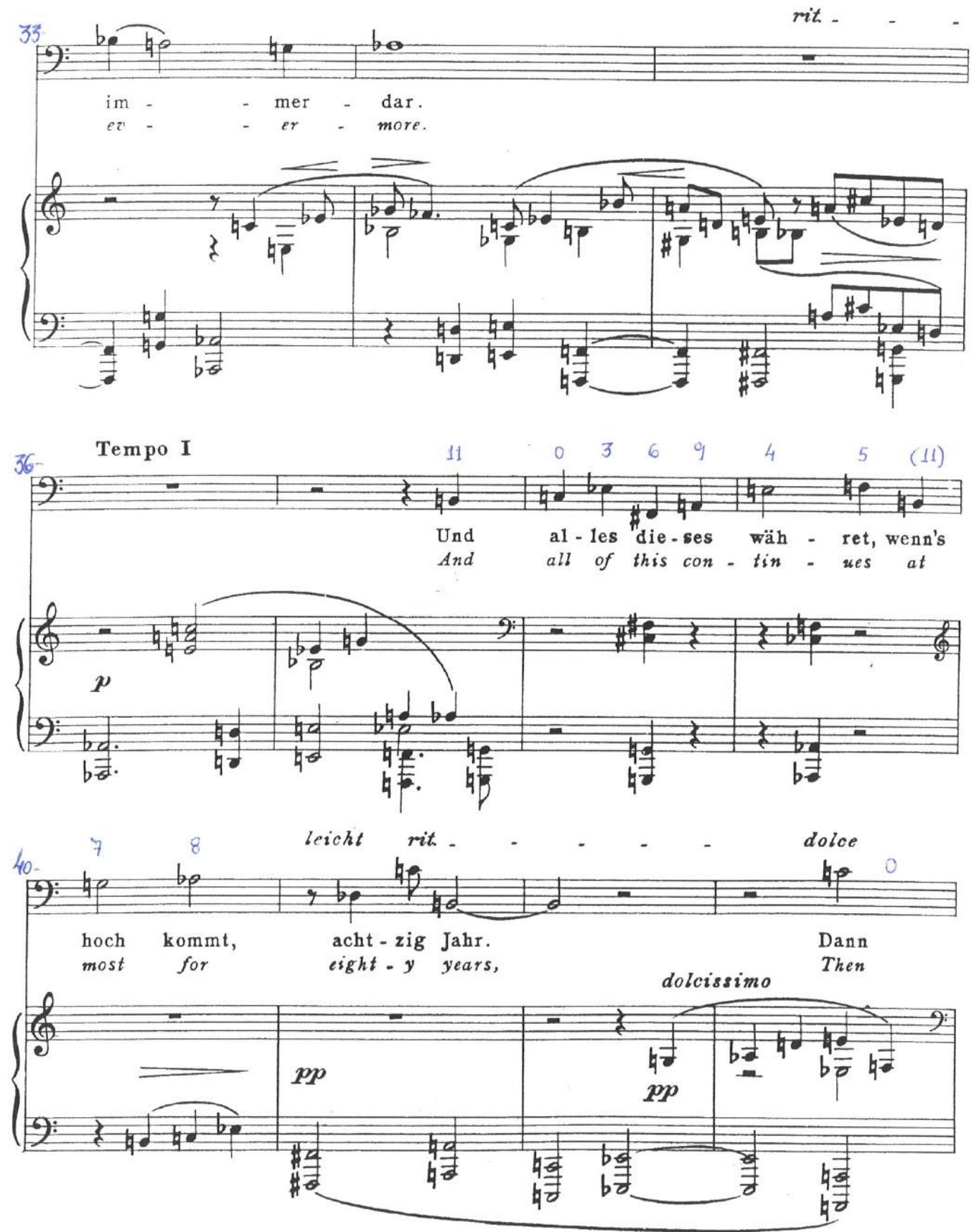

M 318 

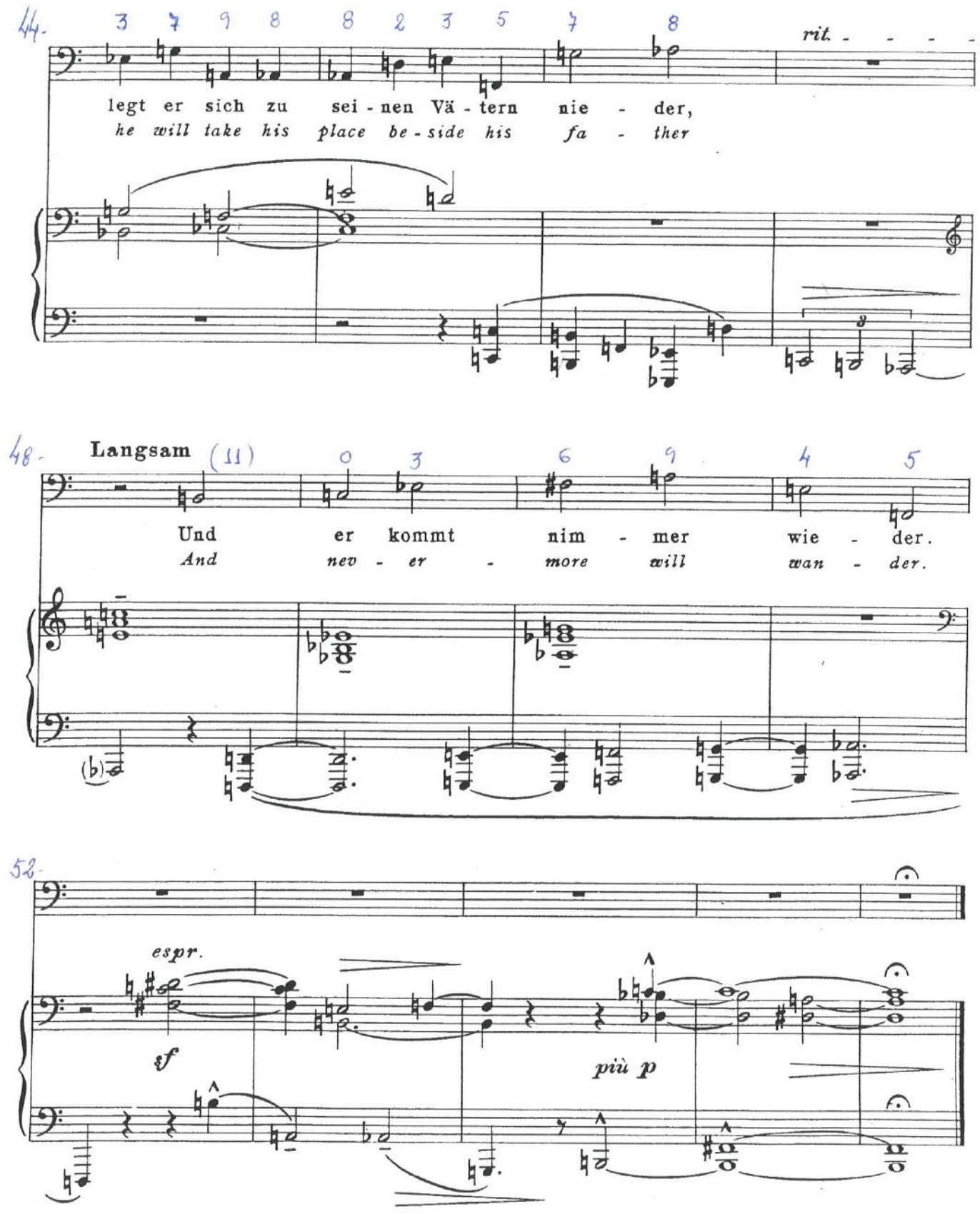

M 348 
6

II. Wandrers Nachtlied

The Wanderer's Night Song

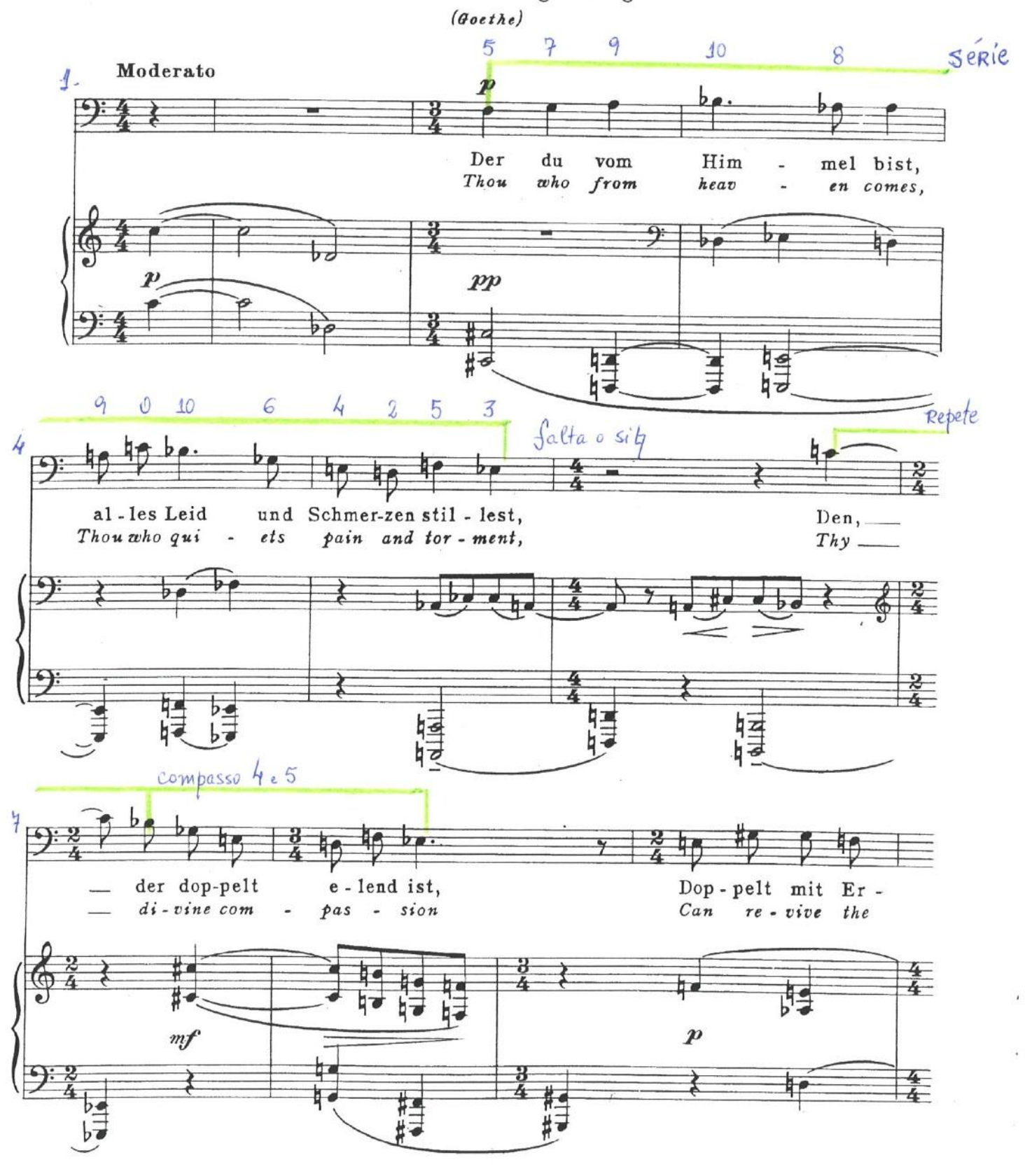

M 348 

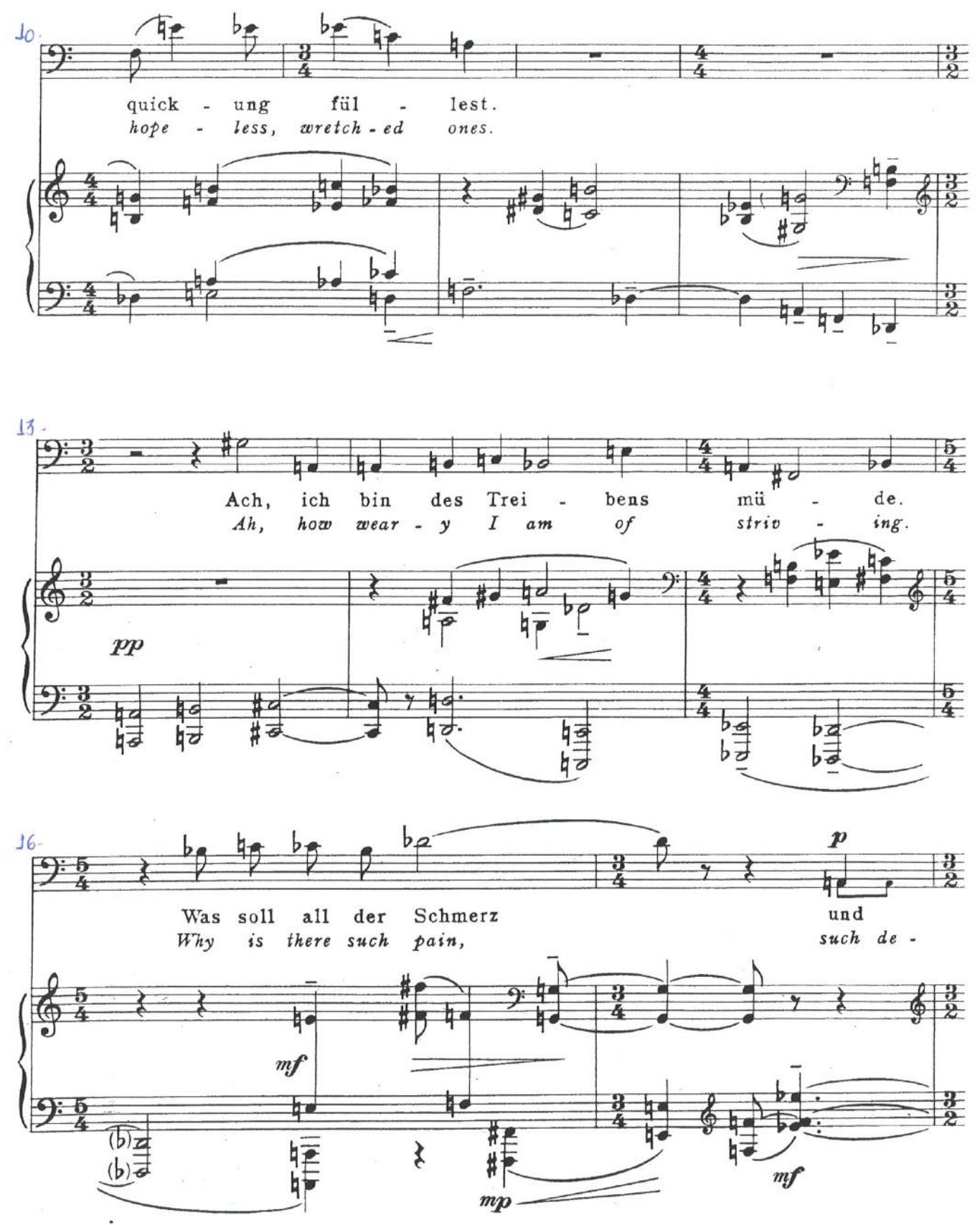

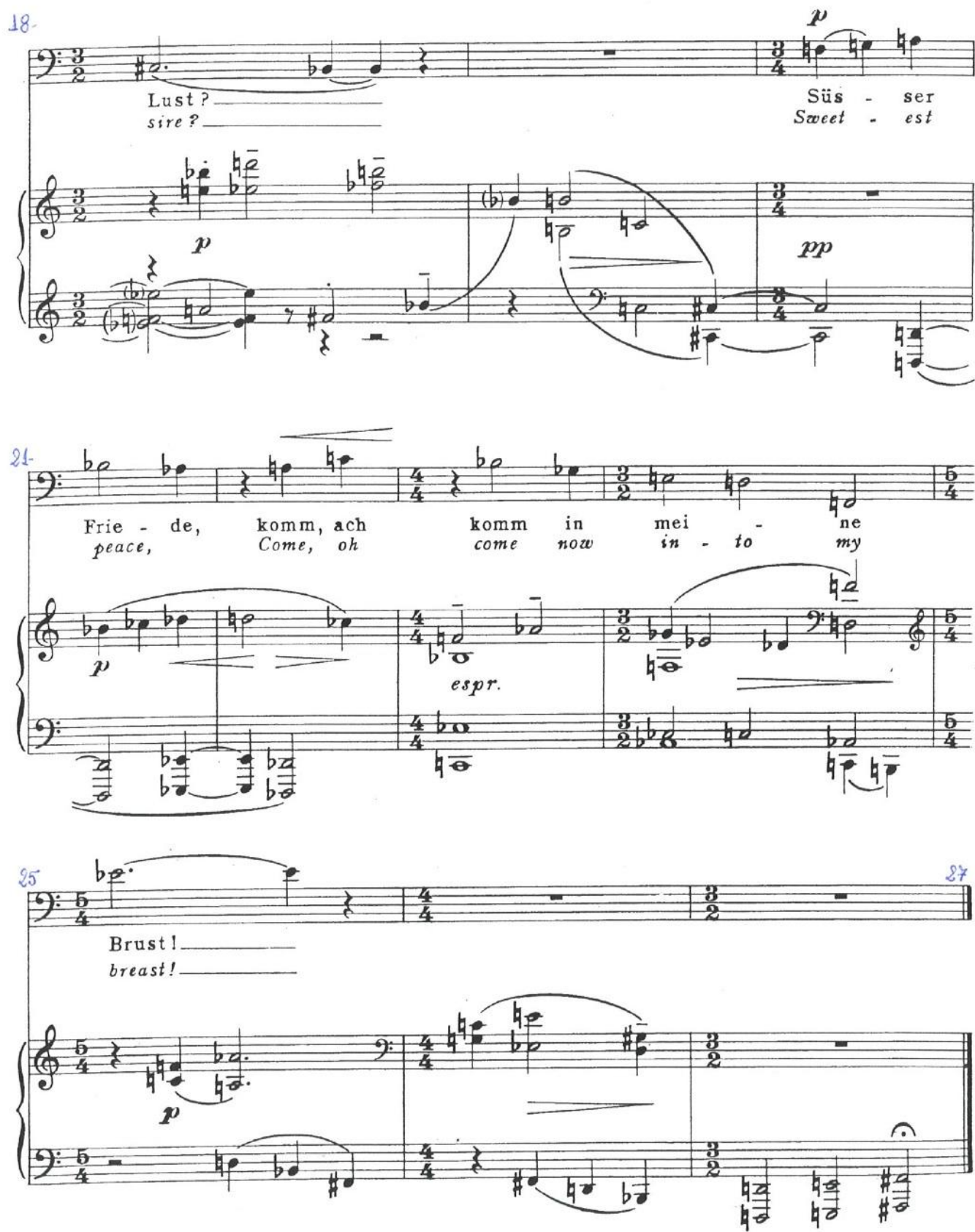

M 348 
III. Gesang der Geister über den Wassern

The Spirit of Wind Above the Water

(Goethe)
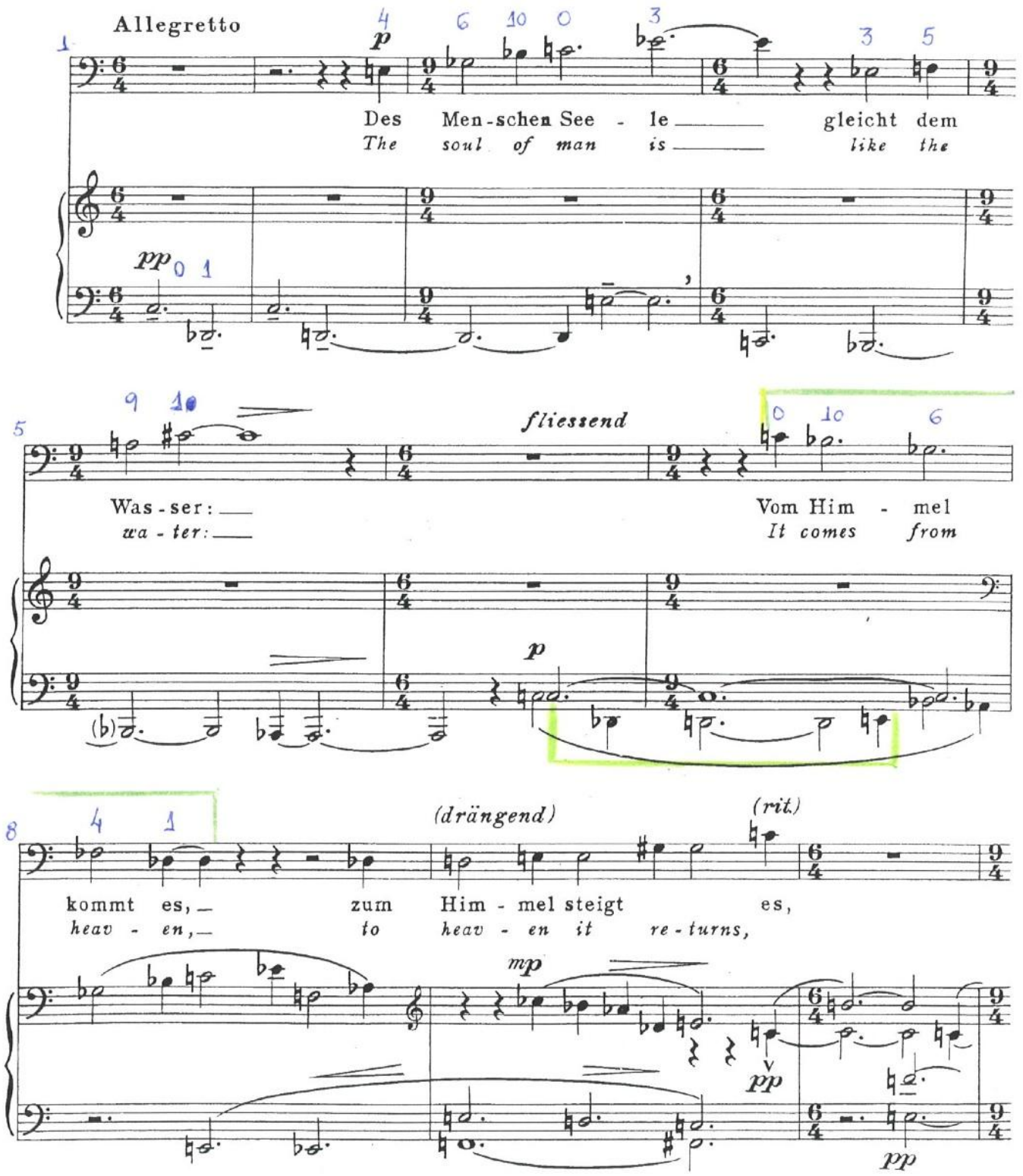

M 348 
10
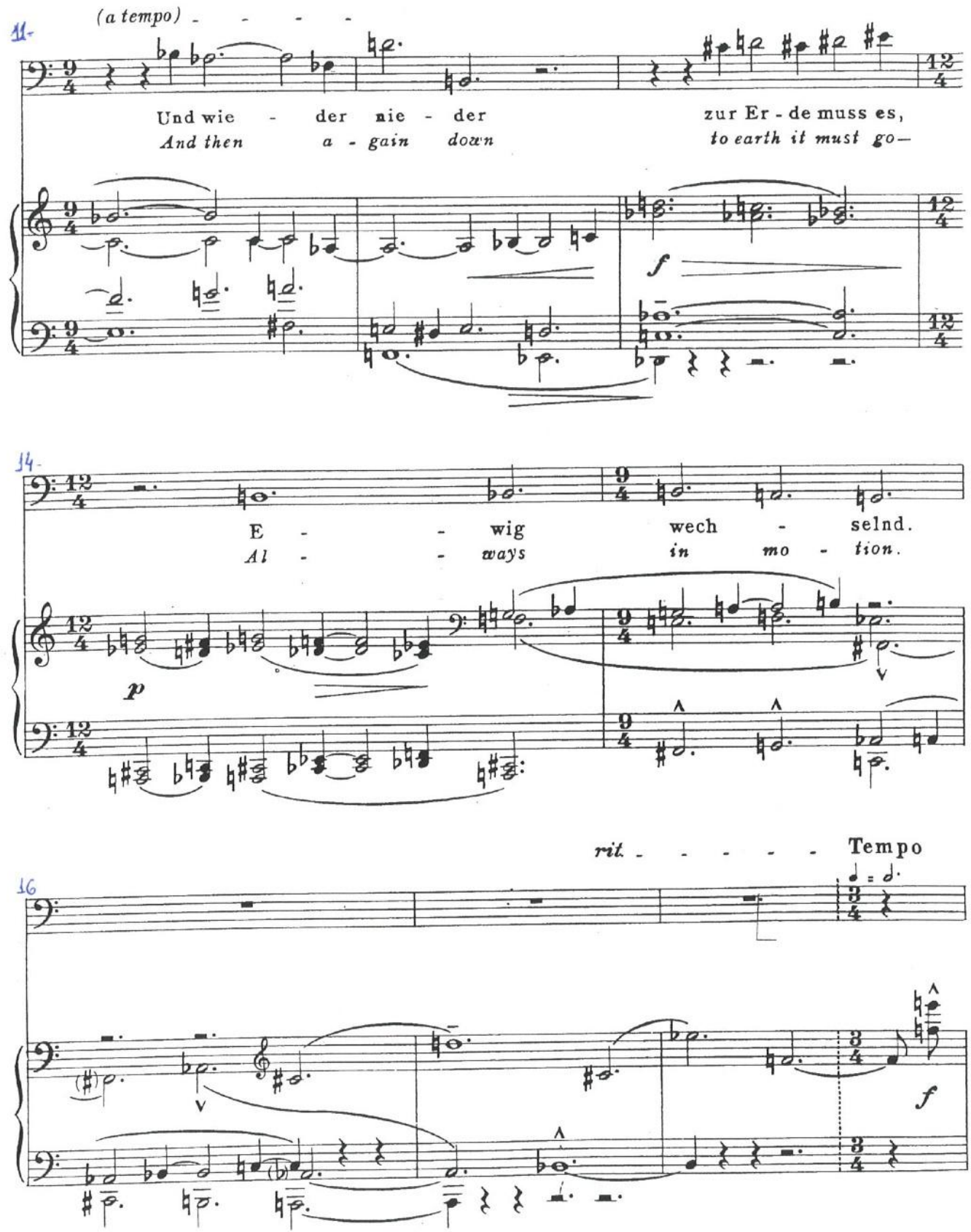

M 348 

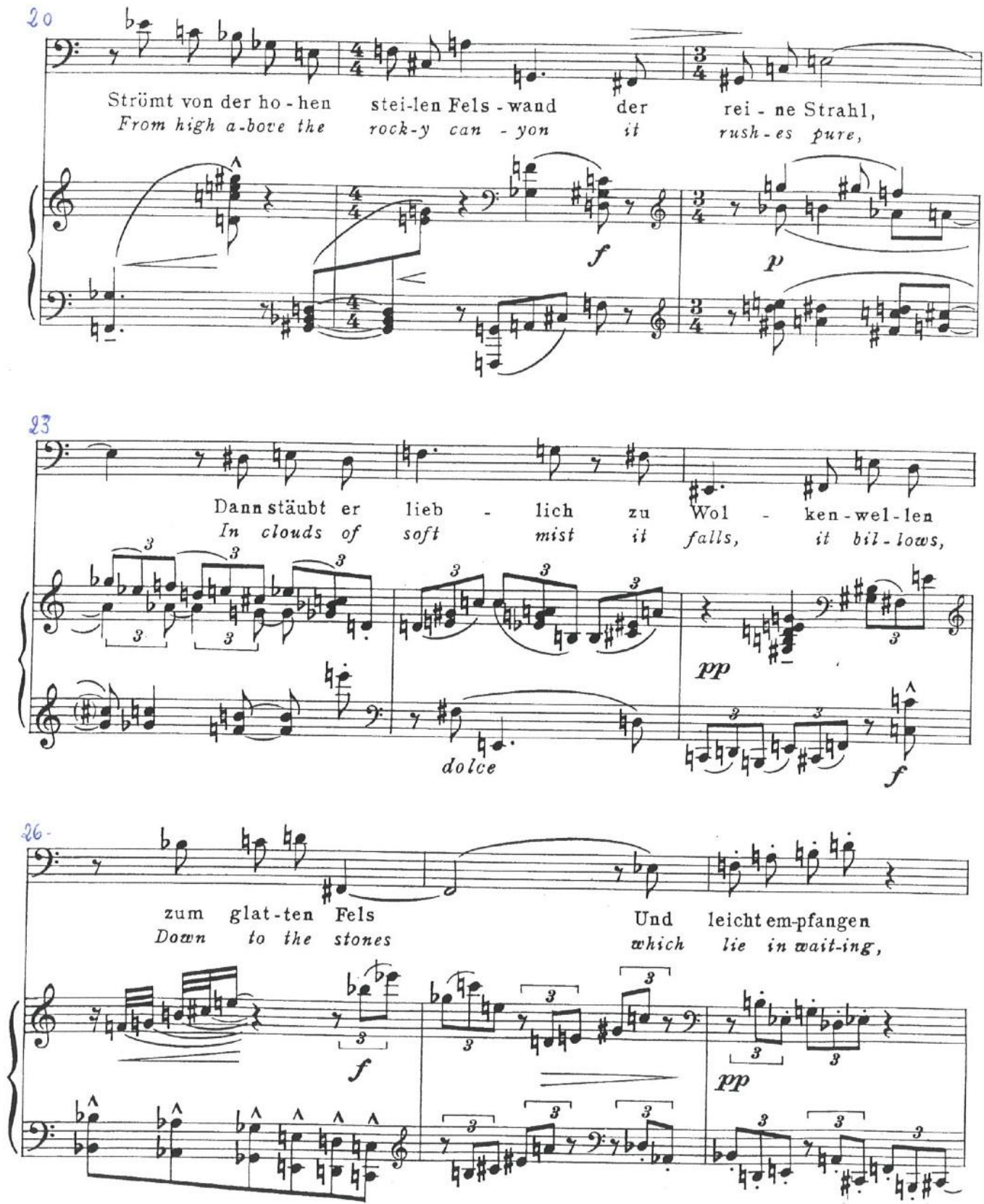

M 348 

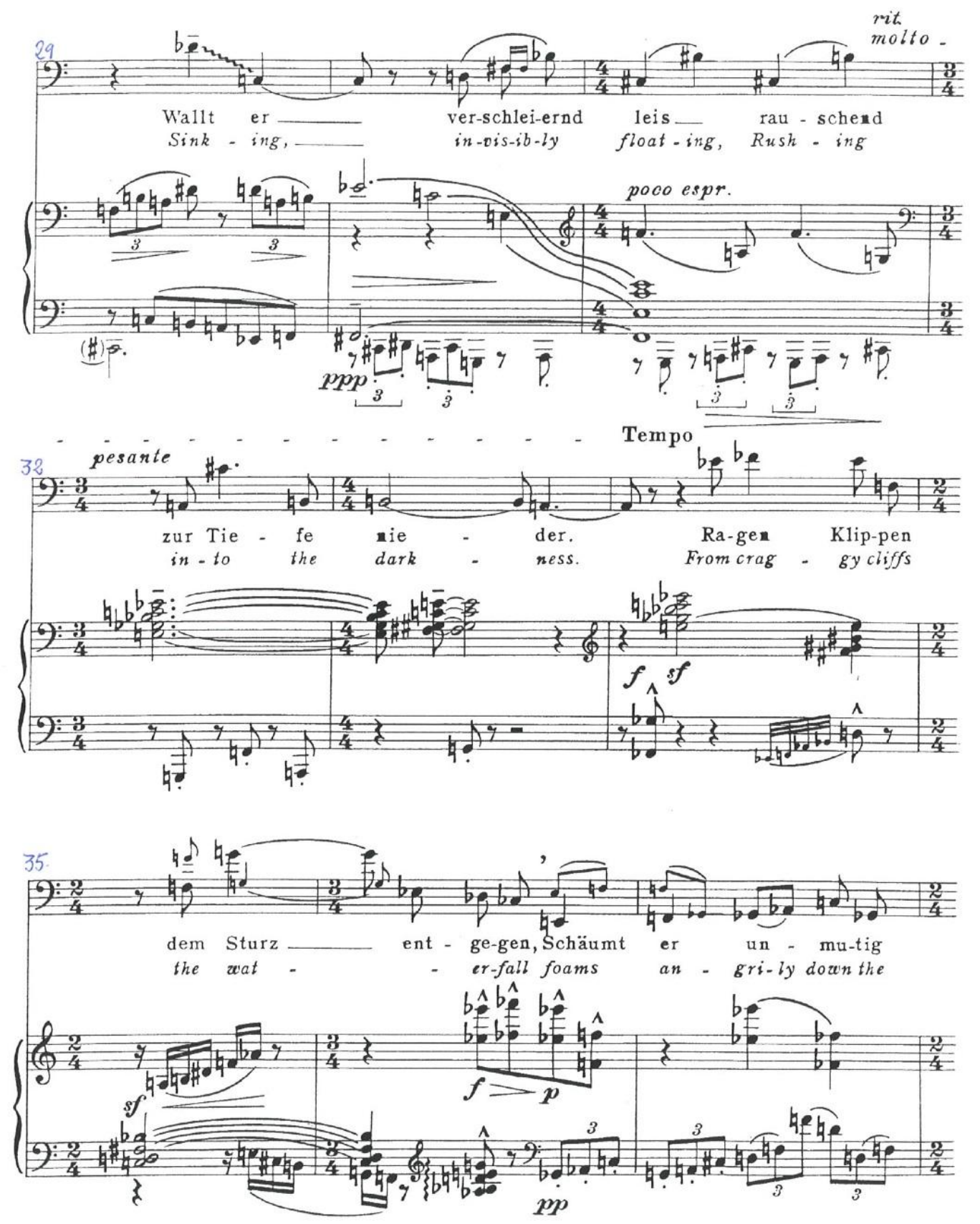

M 348 

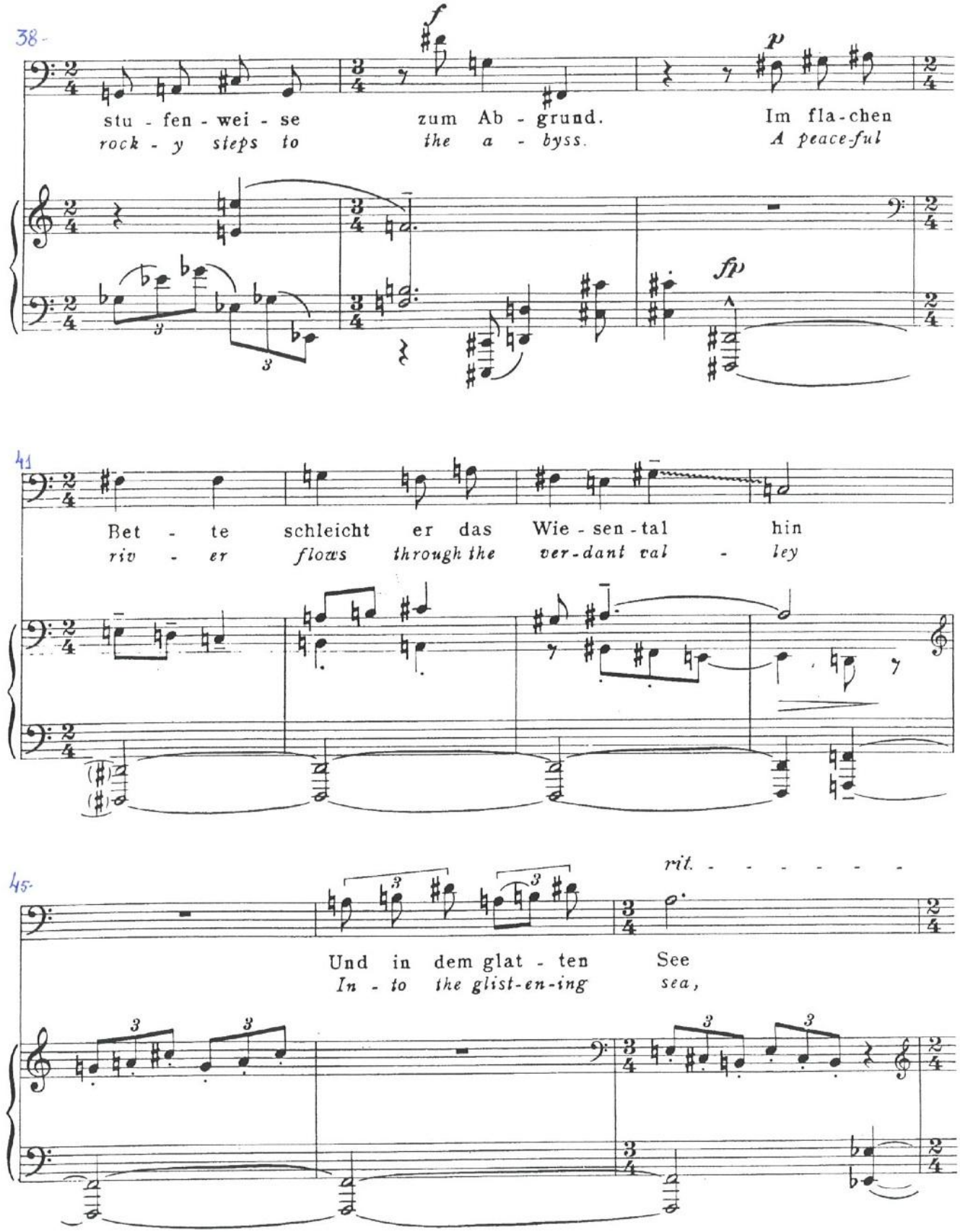

M 348 

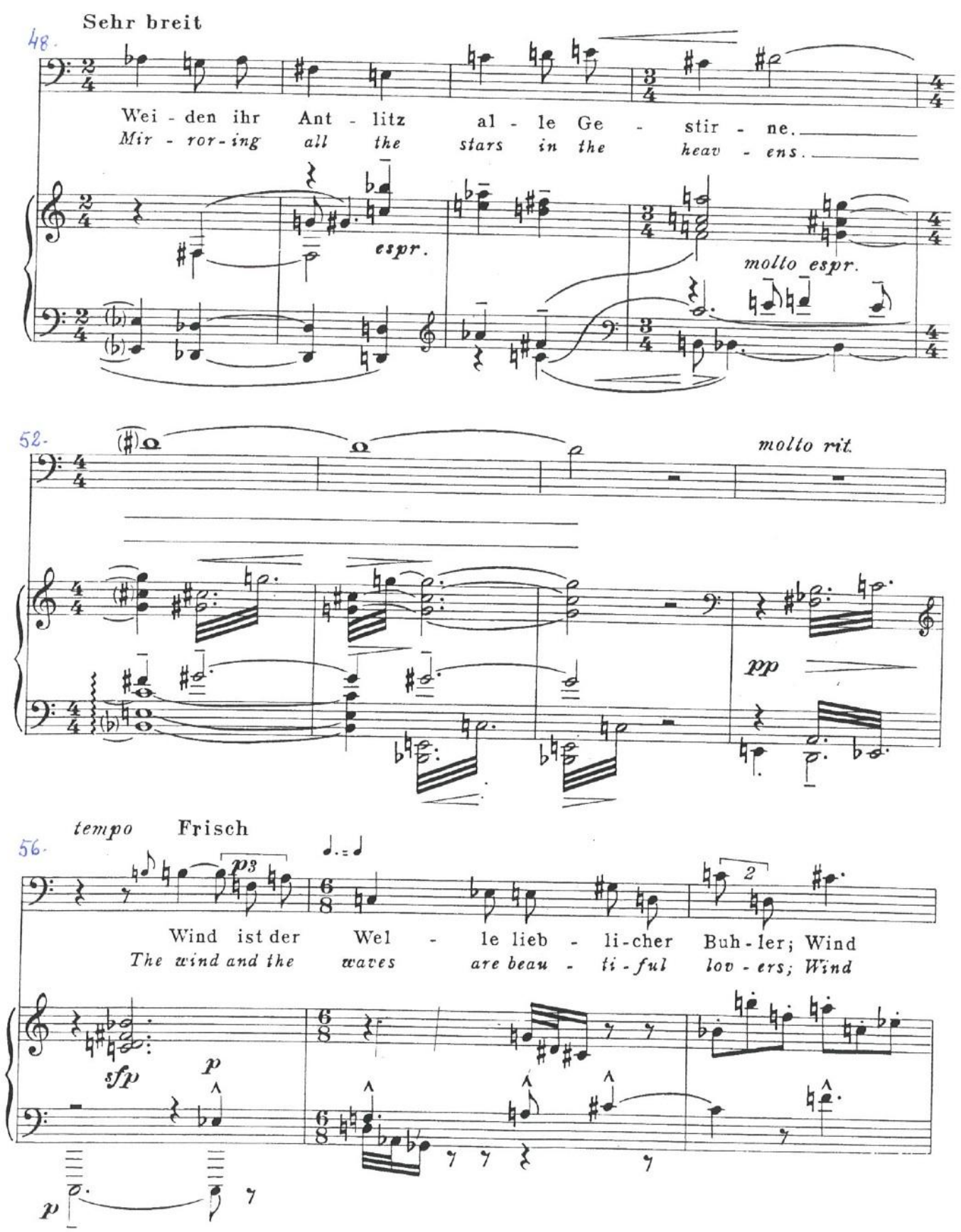

M 348 

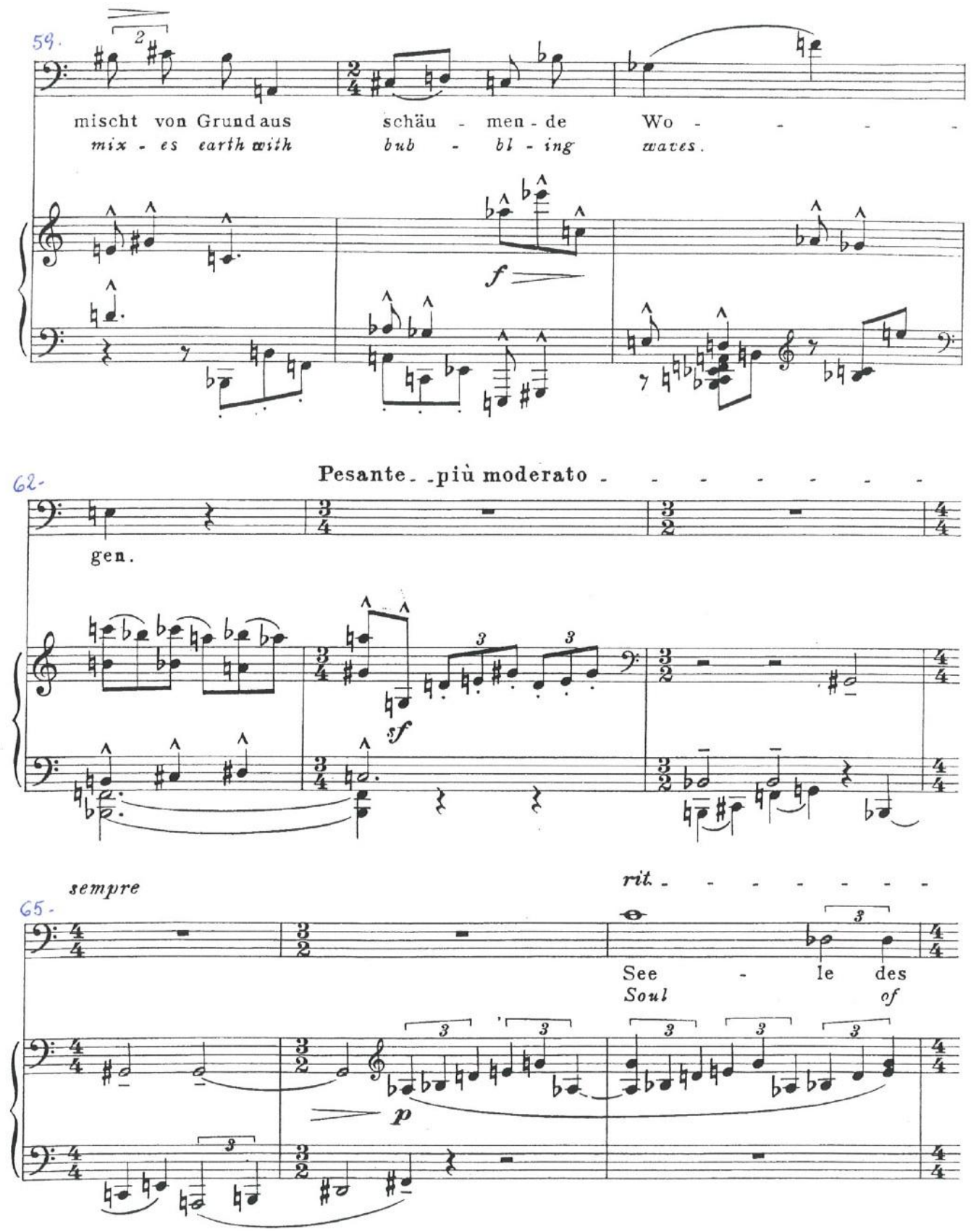
11.
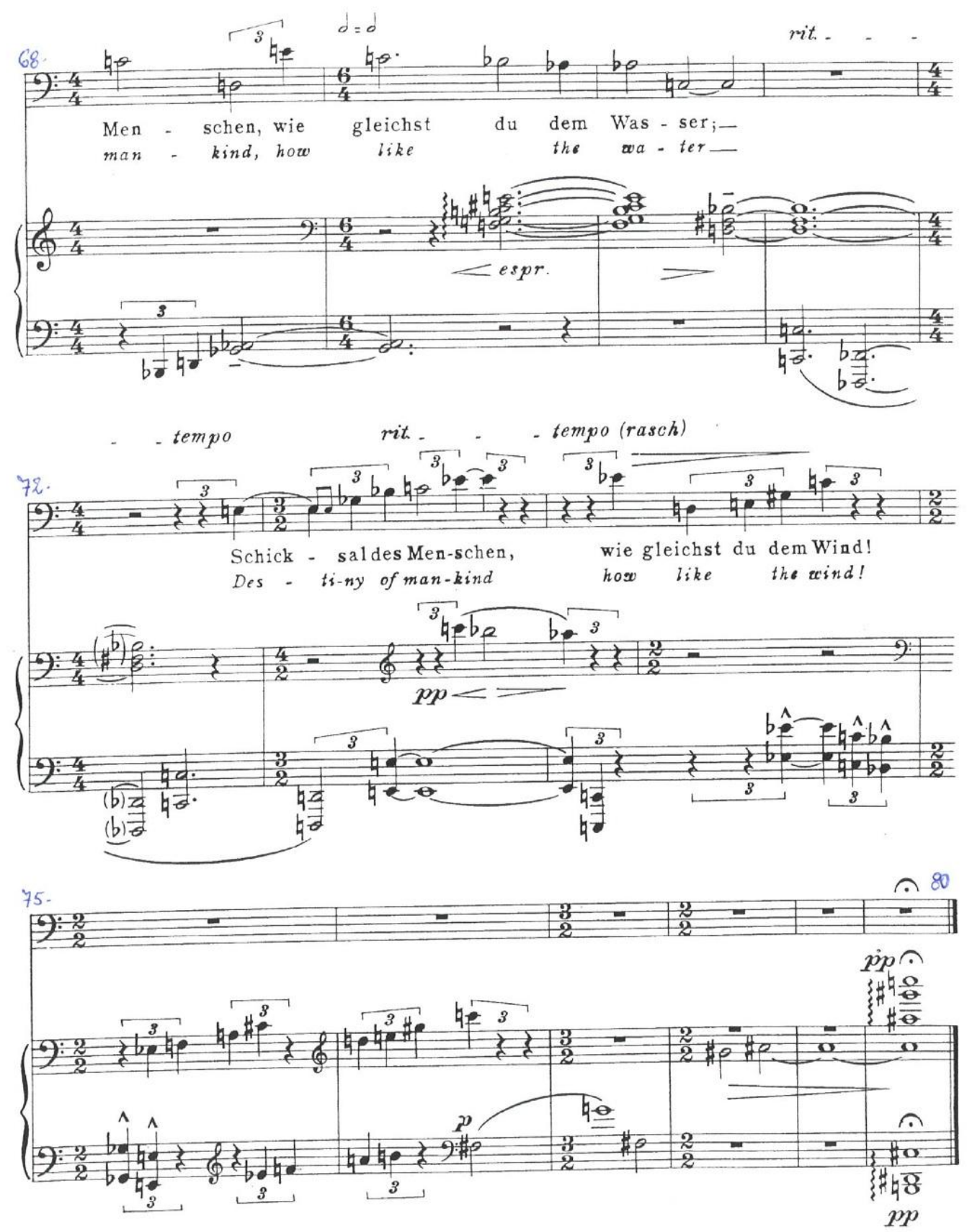


\section{CICLO \\ SIEBEN FRÜHE LIEDER}

(1905-1907)

ALBAN BERG 


\section{SOMMERTAGE} SUMMER DAYS

(Poul Hohenberg)

Schwungroll $(d=$ ca 60$)$

Alban Berg

2

?

tr

1

$\rightarrow \int \frac{2}{2}$

10

1

ing

㸵
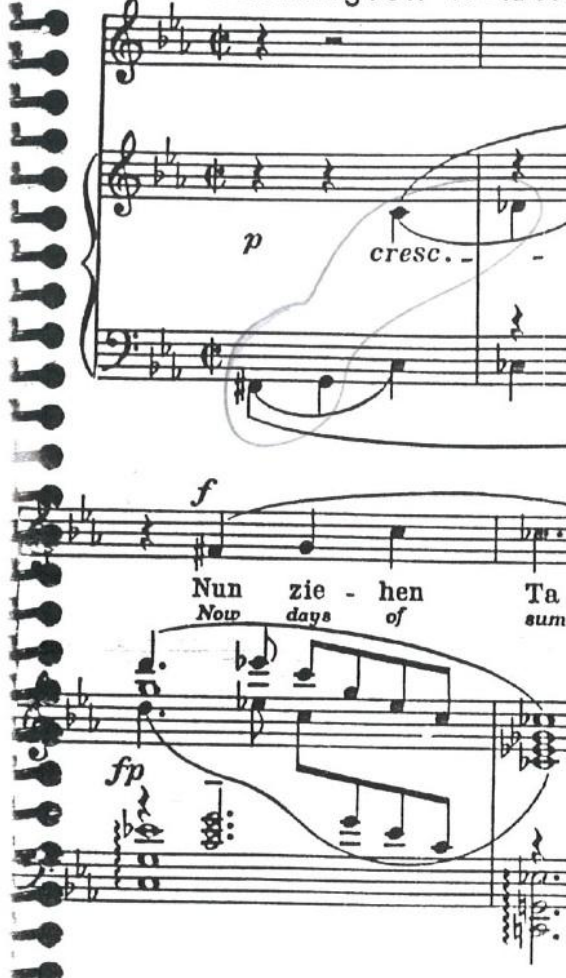

(a)

둔
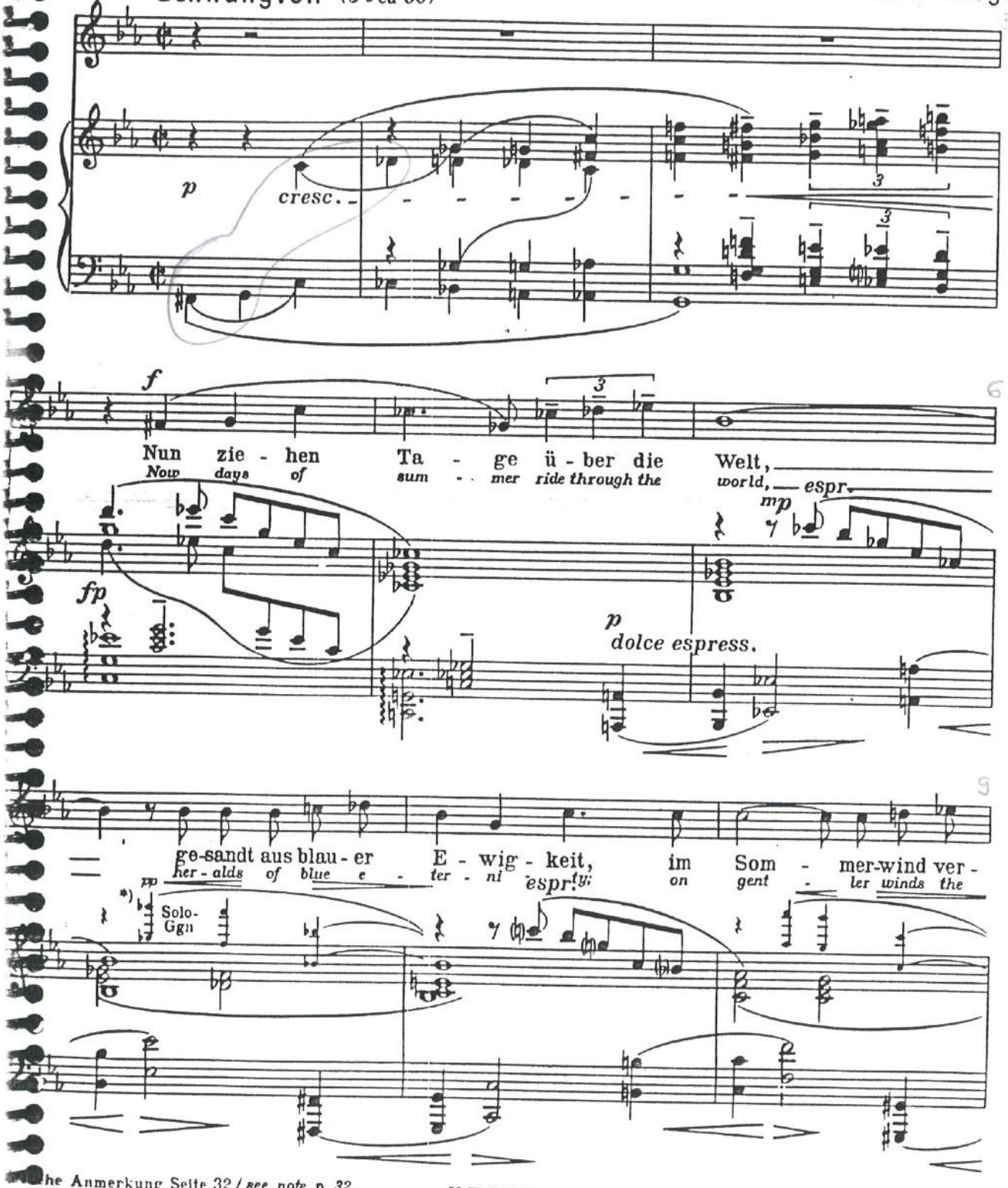

Whe Anmerking Selte $32 /$ see note p. 32

U.E. 8853 


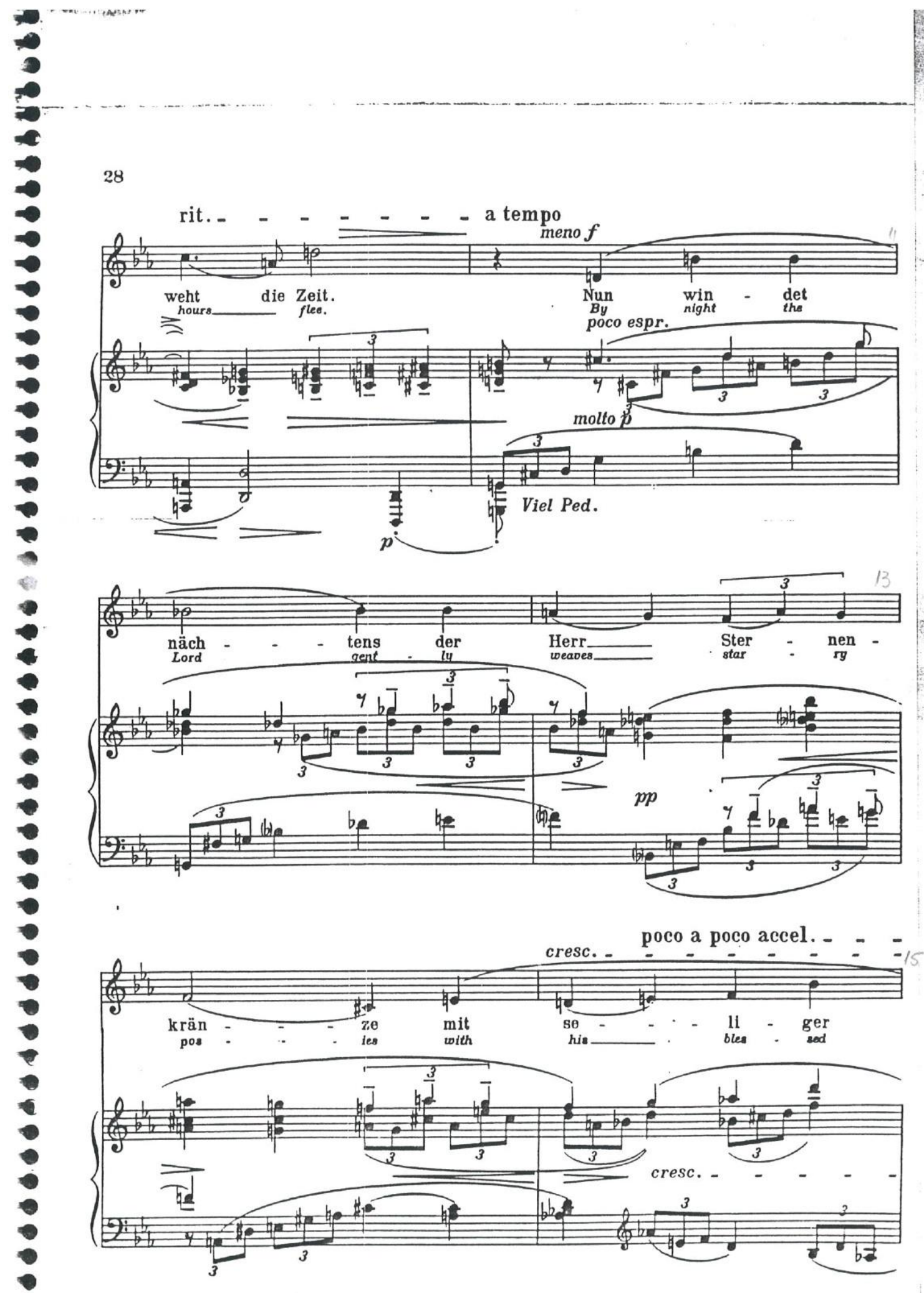




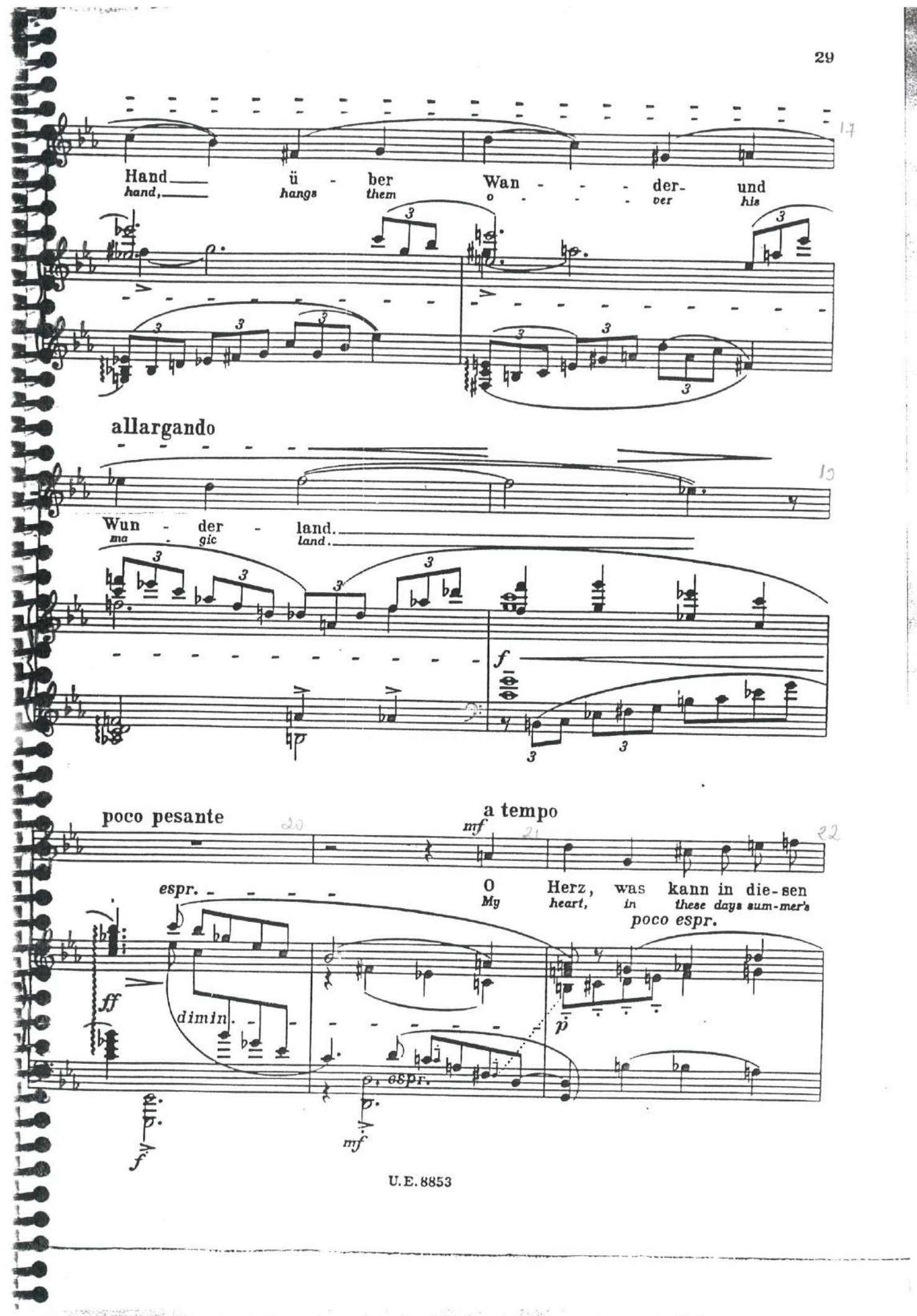



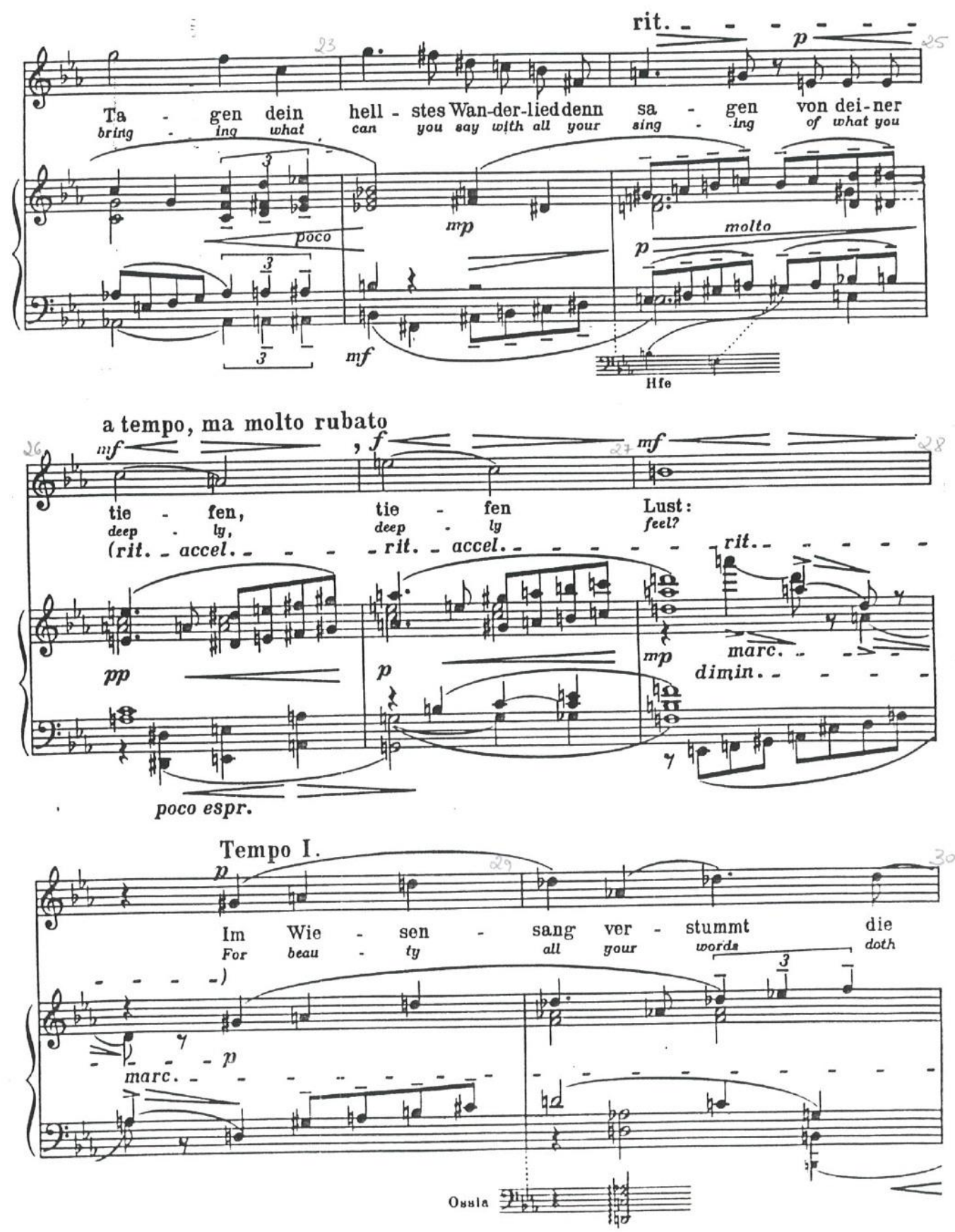

U. E. 8853 


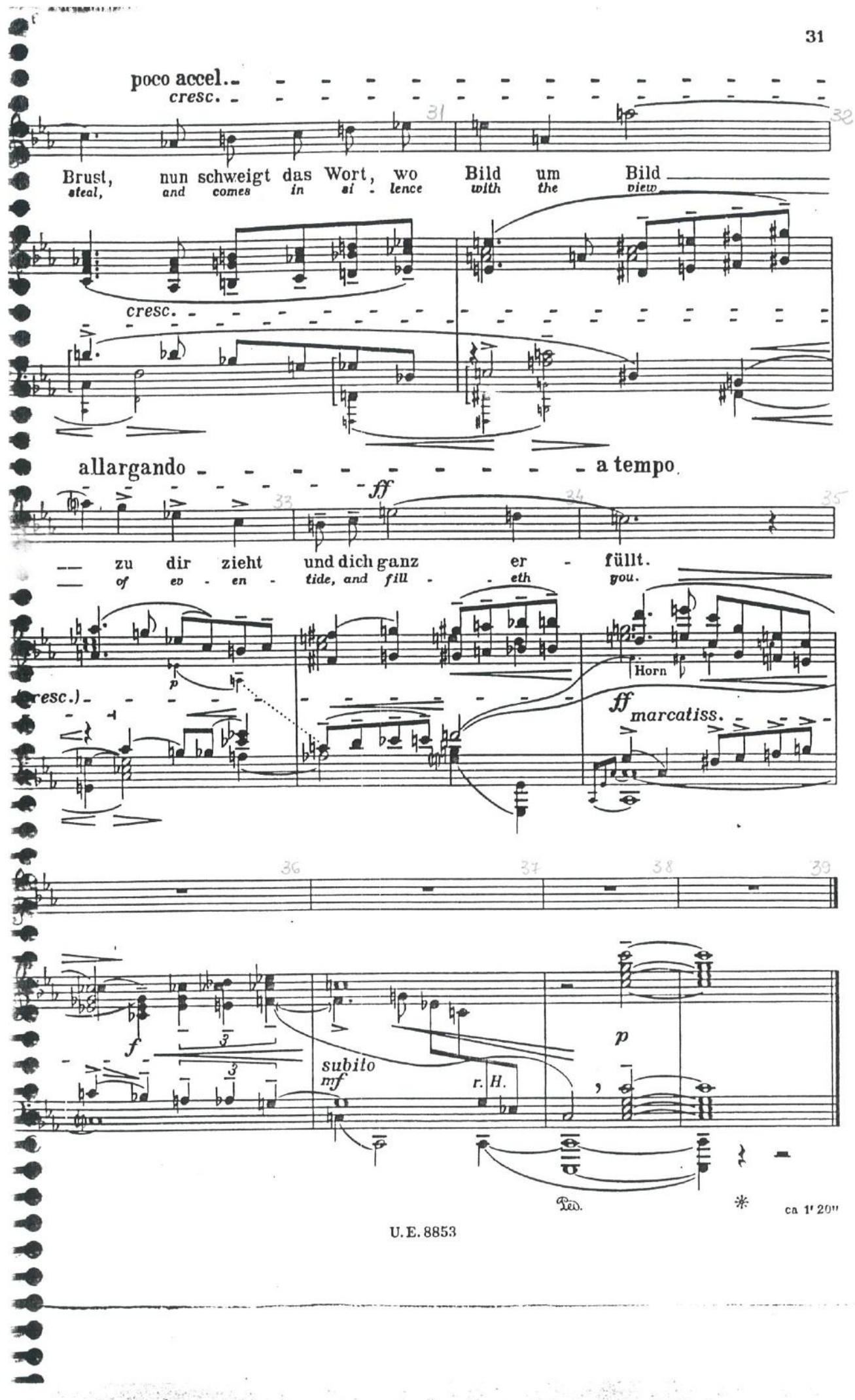




\section{TRAUMGEKRÖNT A CROWN OF DREAMS}

(Rainer Maria Rilke)

Alban Berg

Langsam $(d=$ ea 46 )
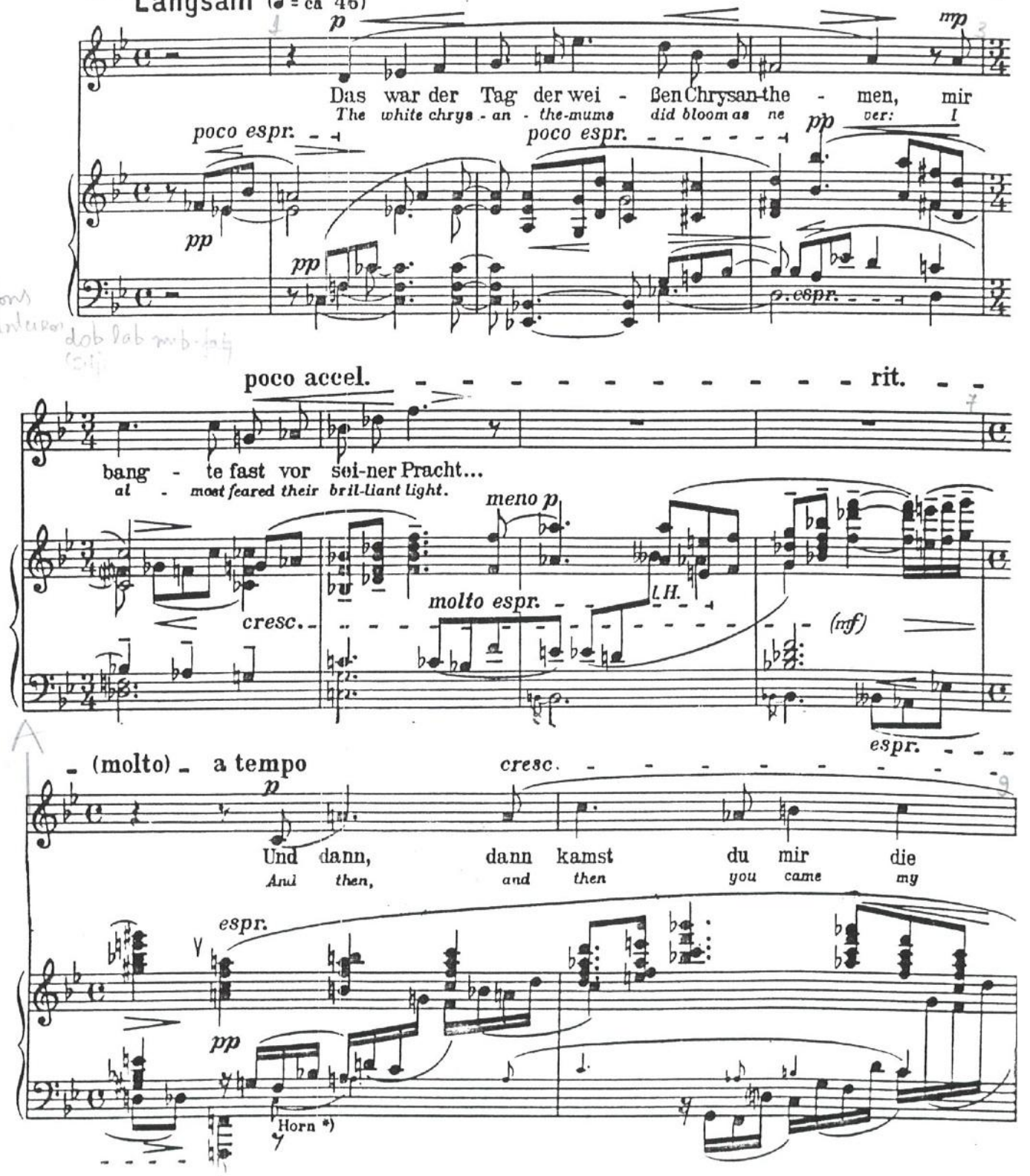


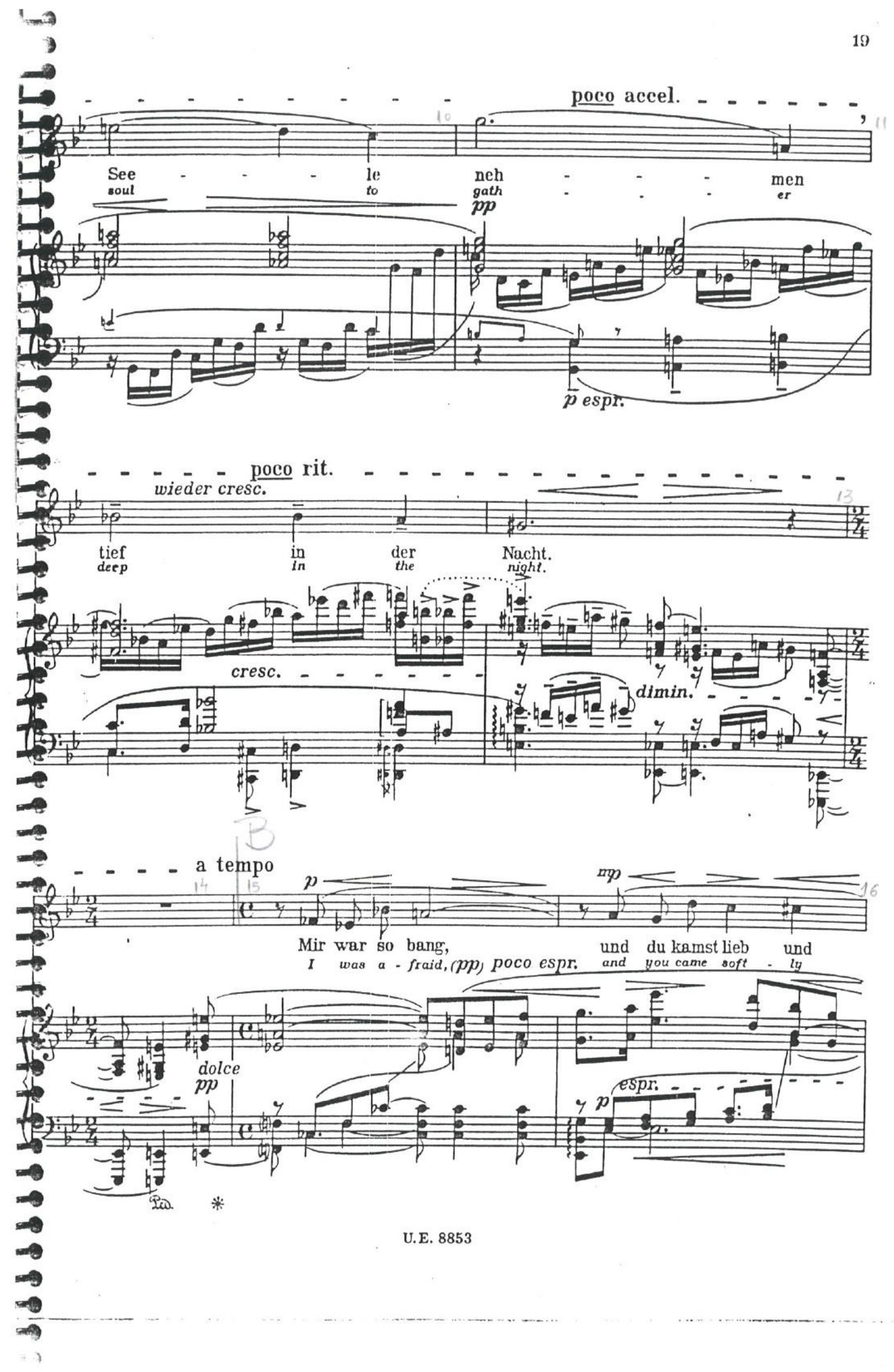




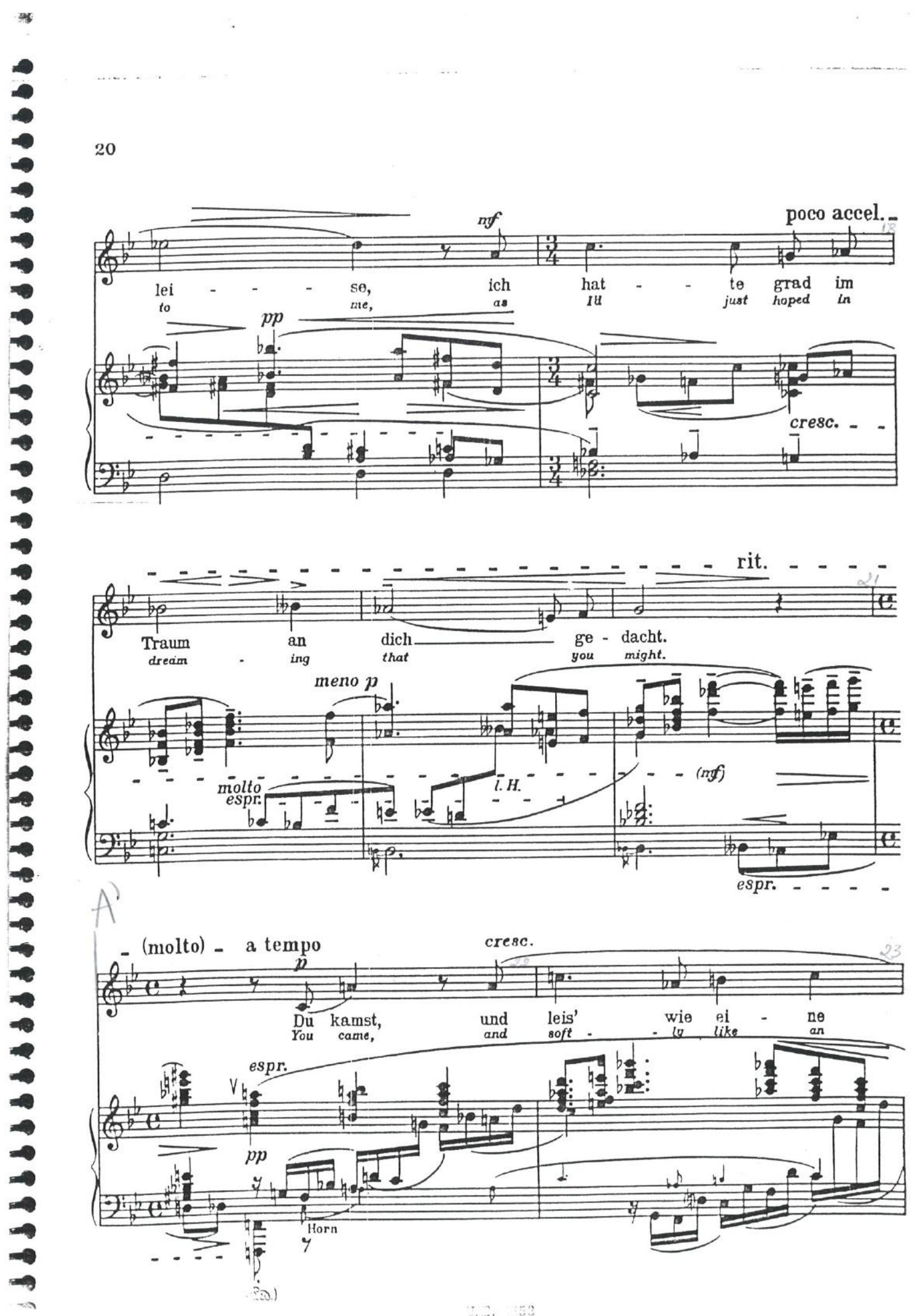




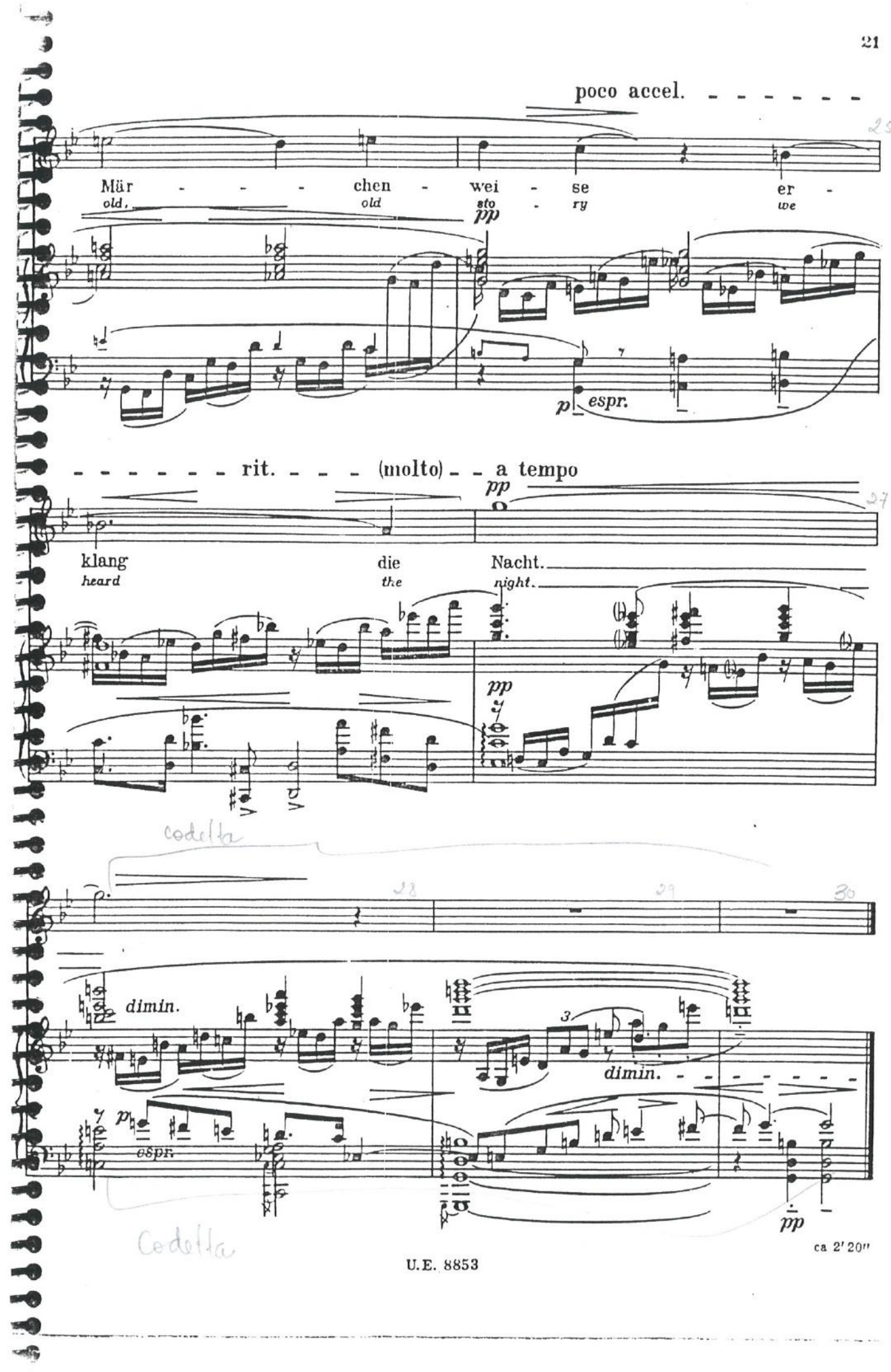




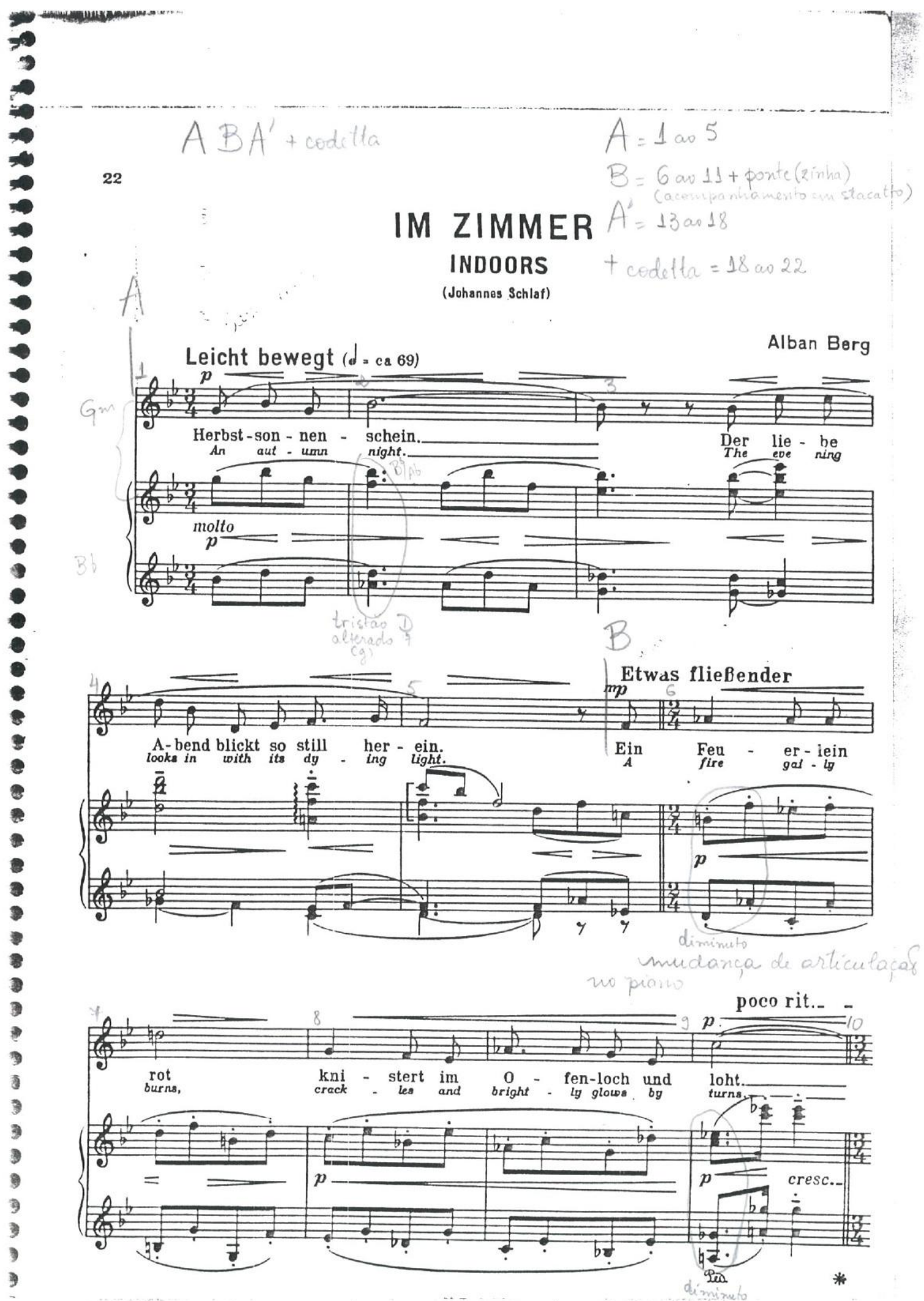




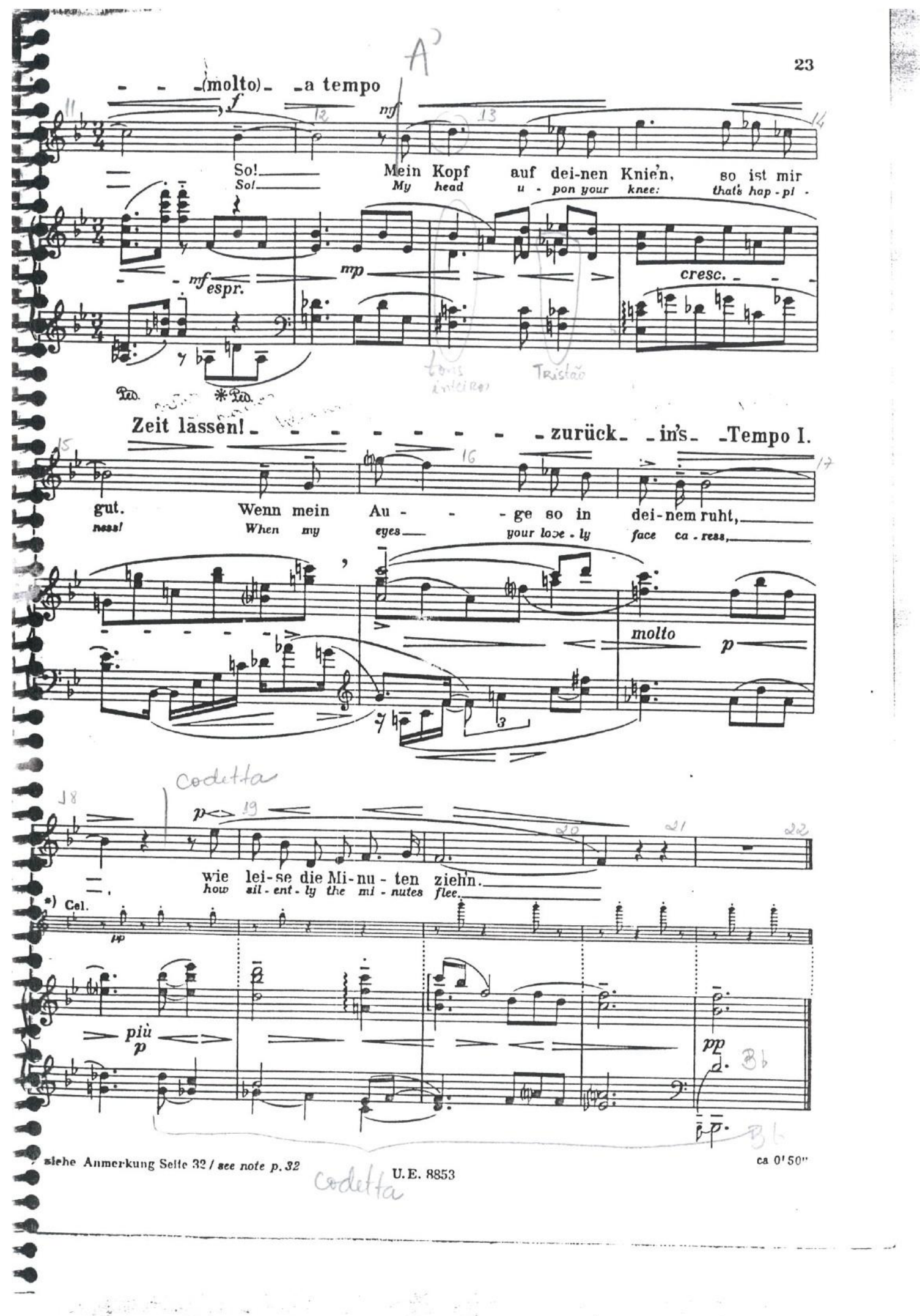



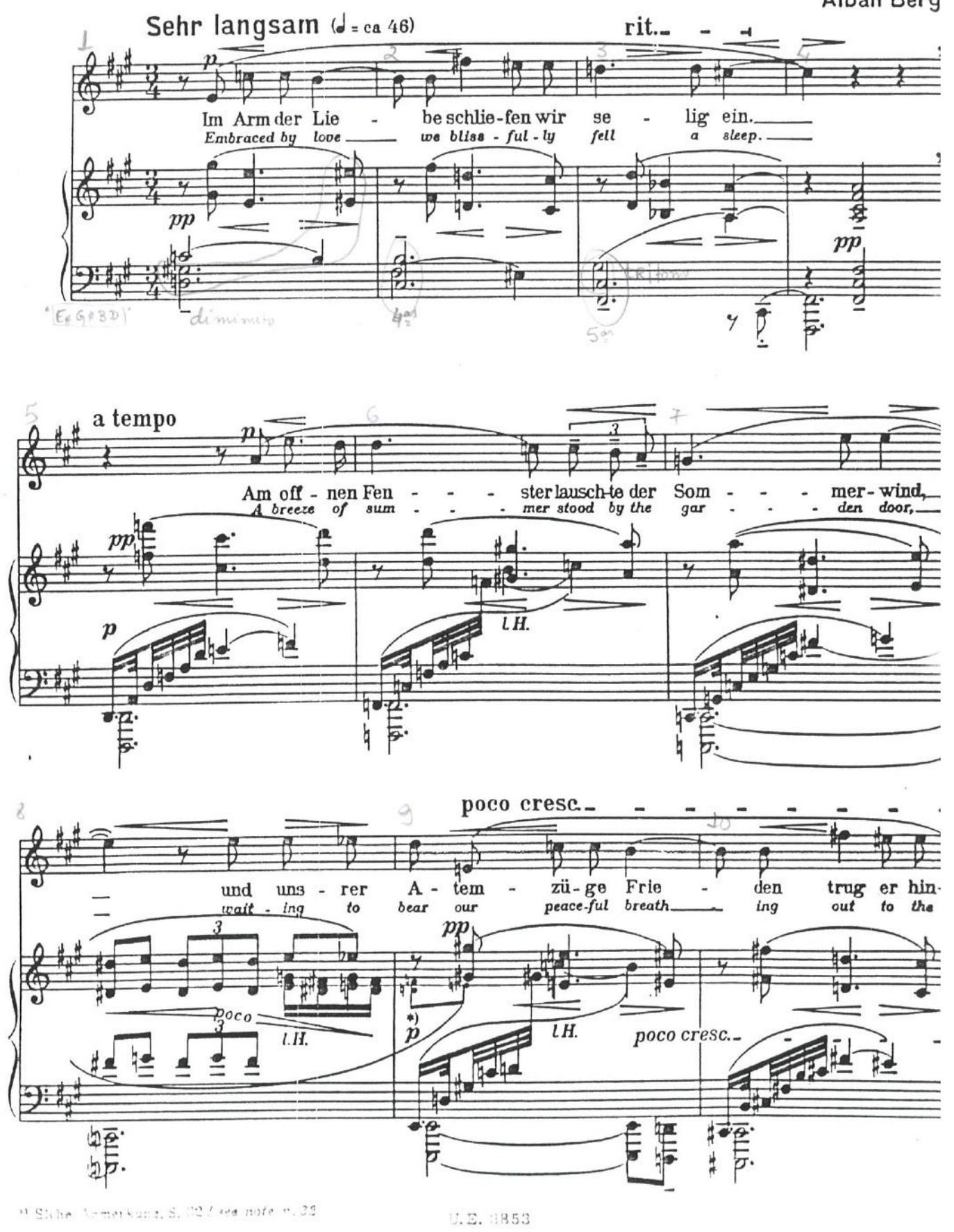


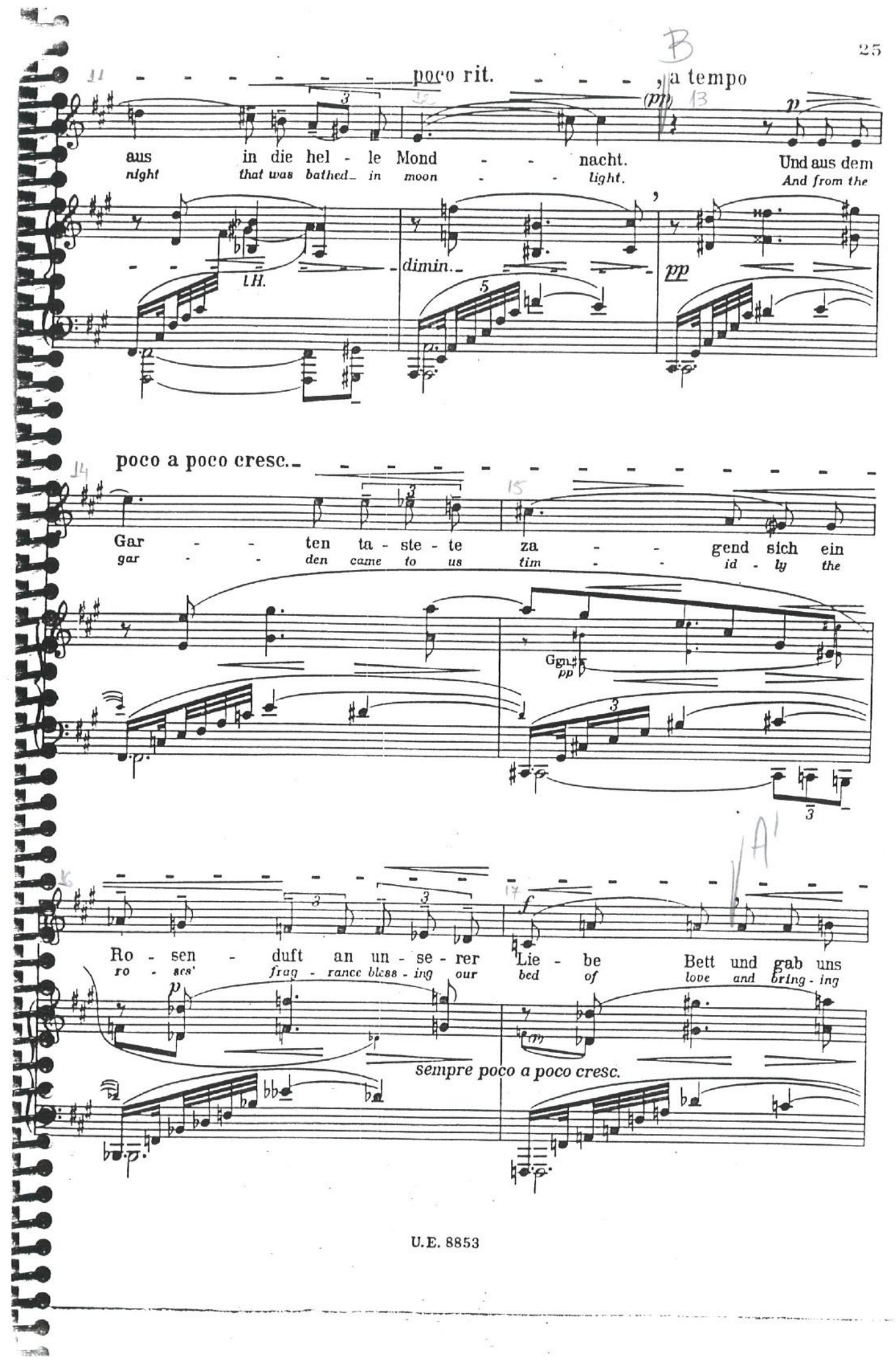



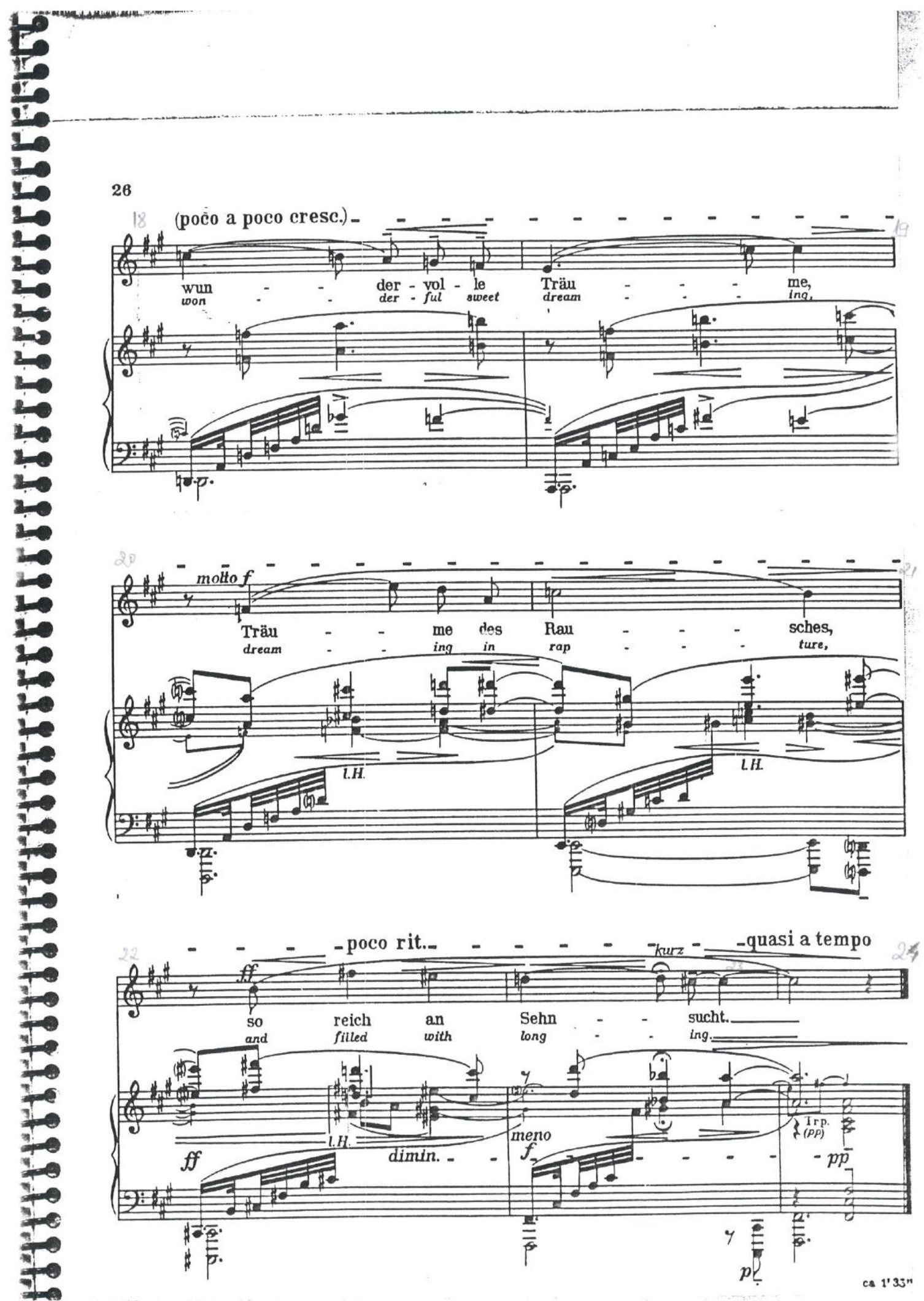


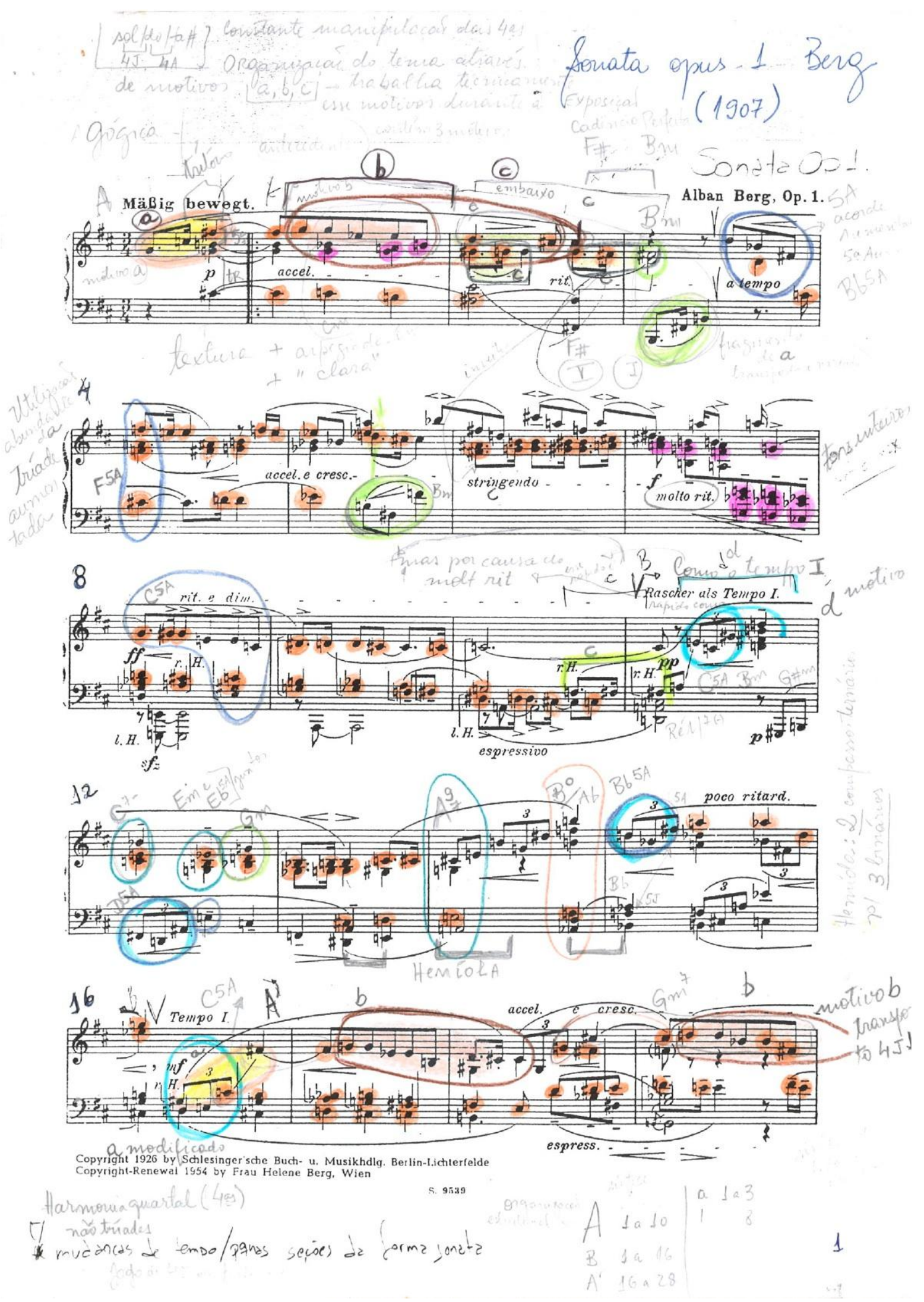




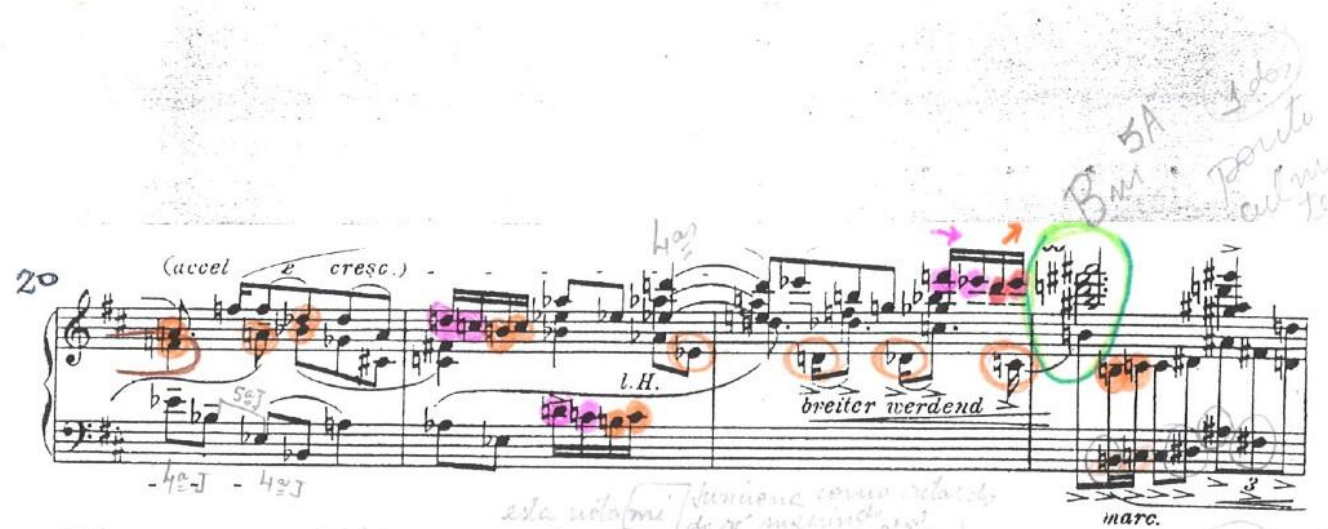

(24)
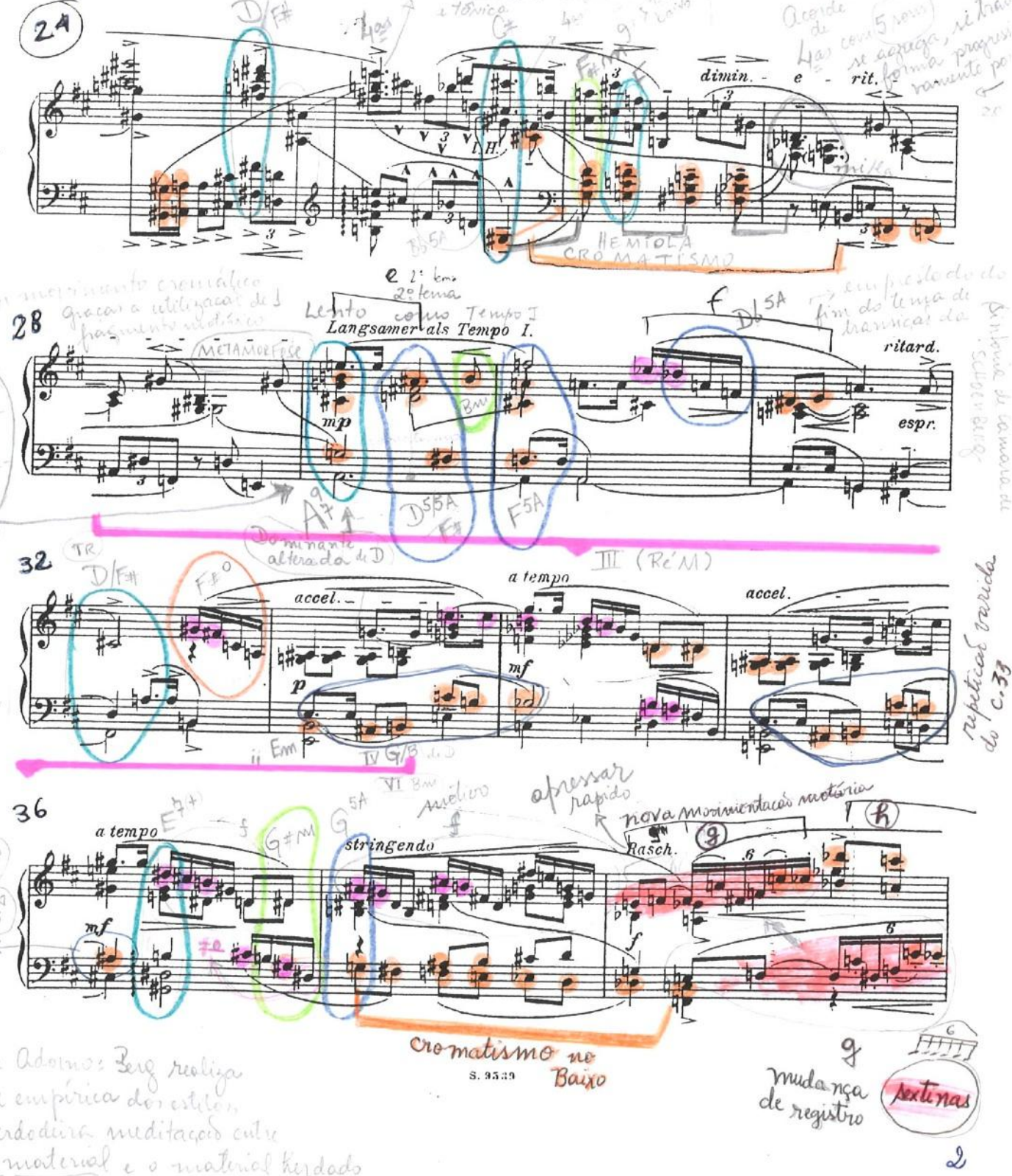

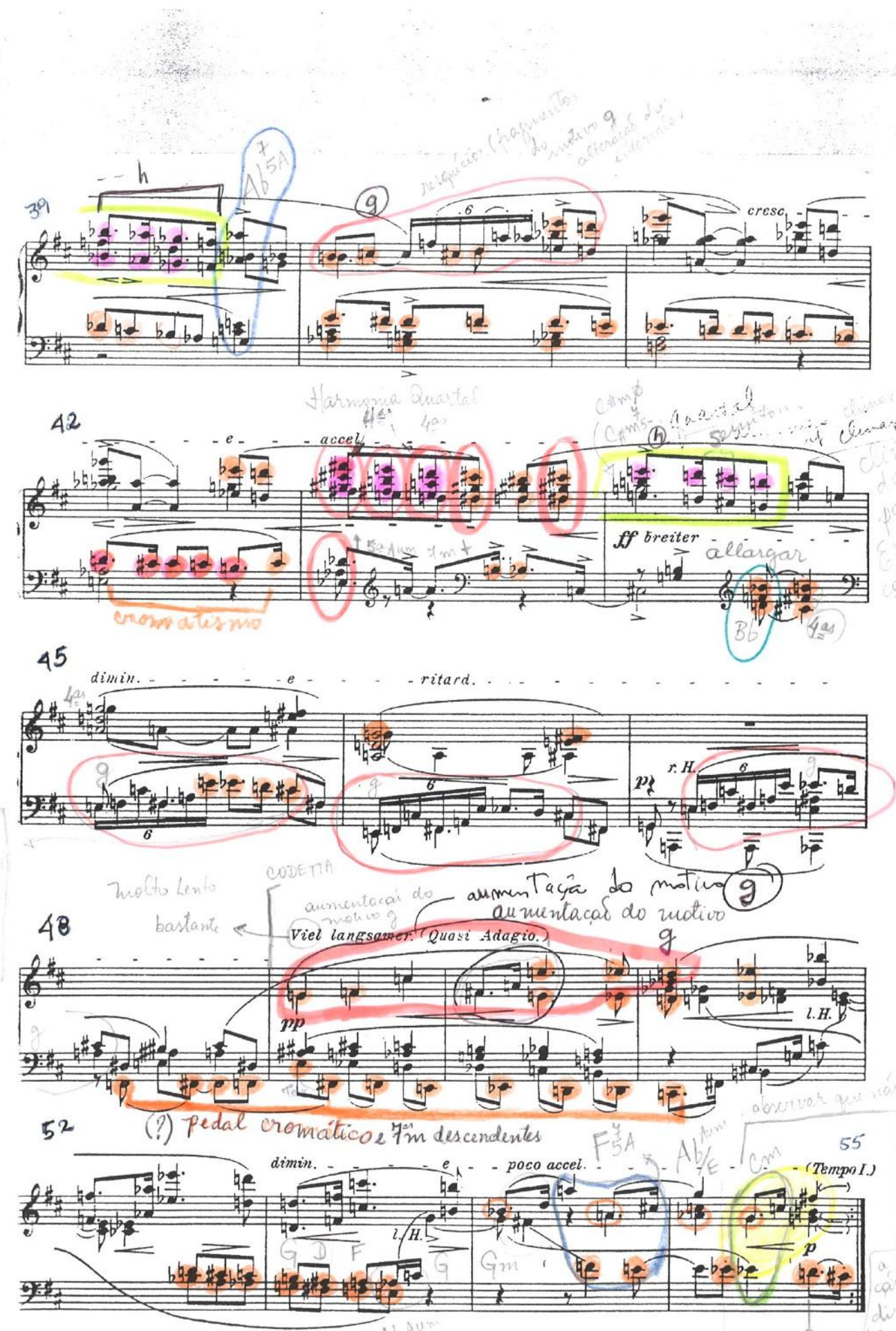

fragumer 


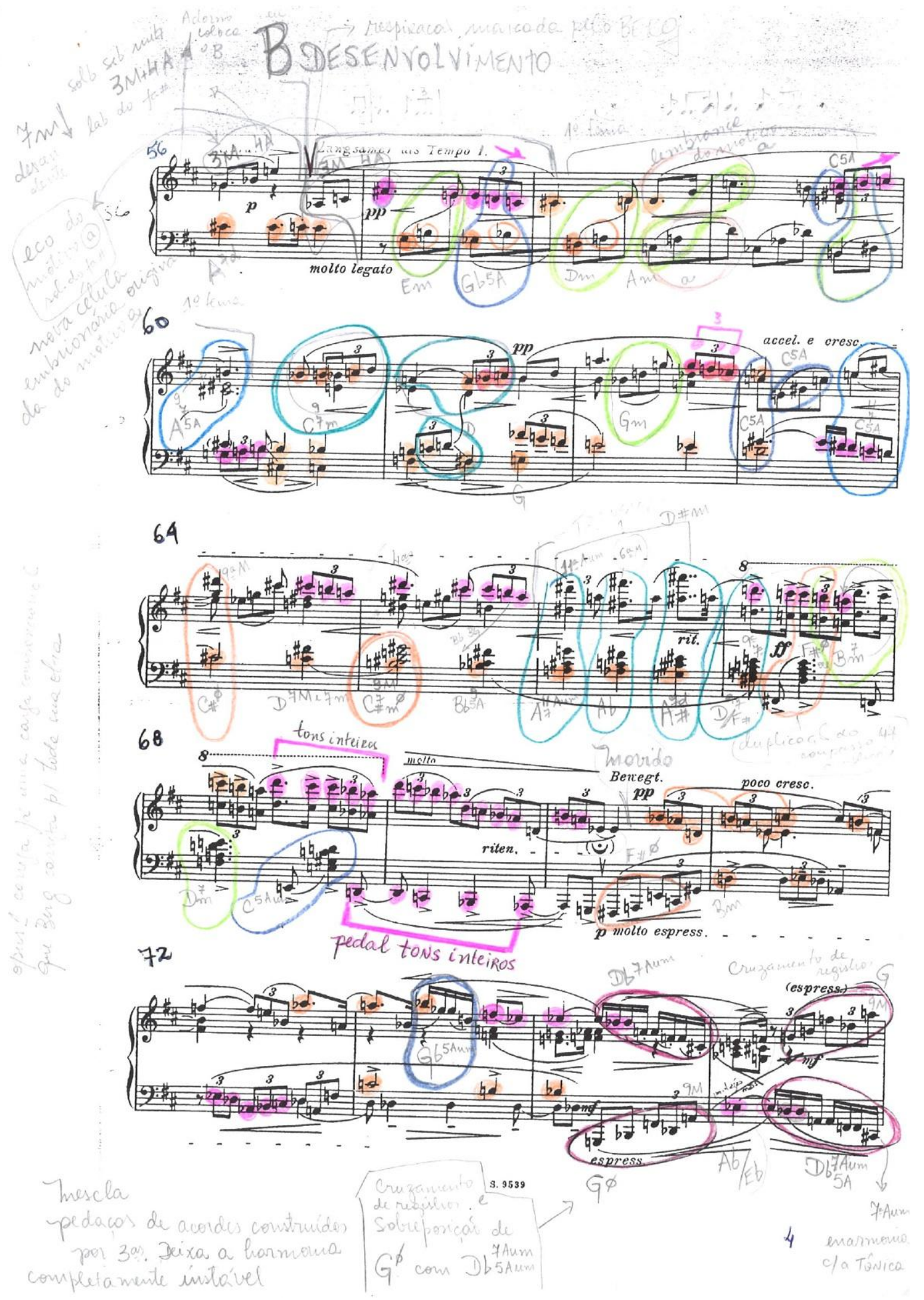



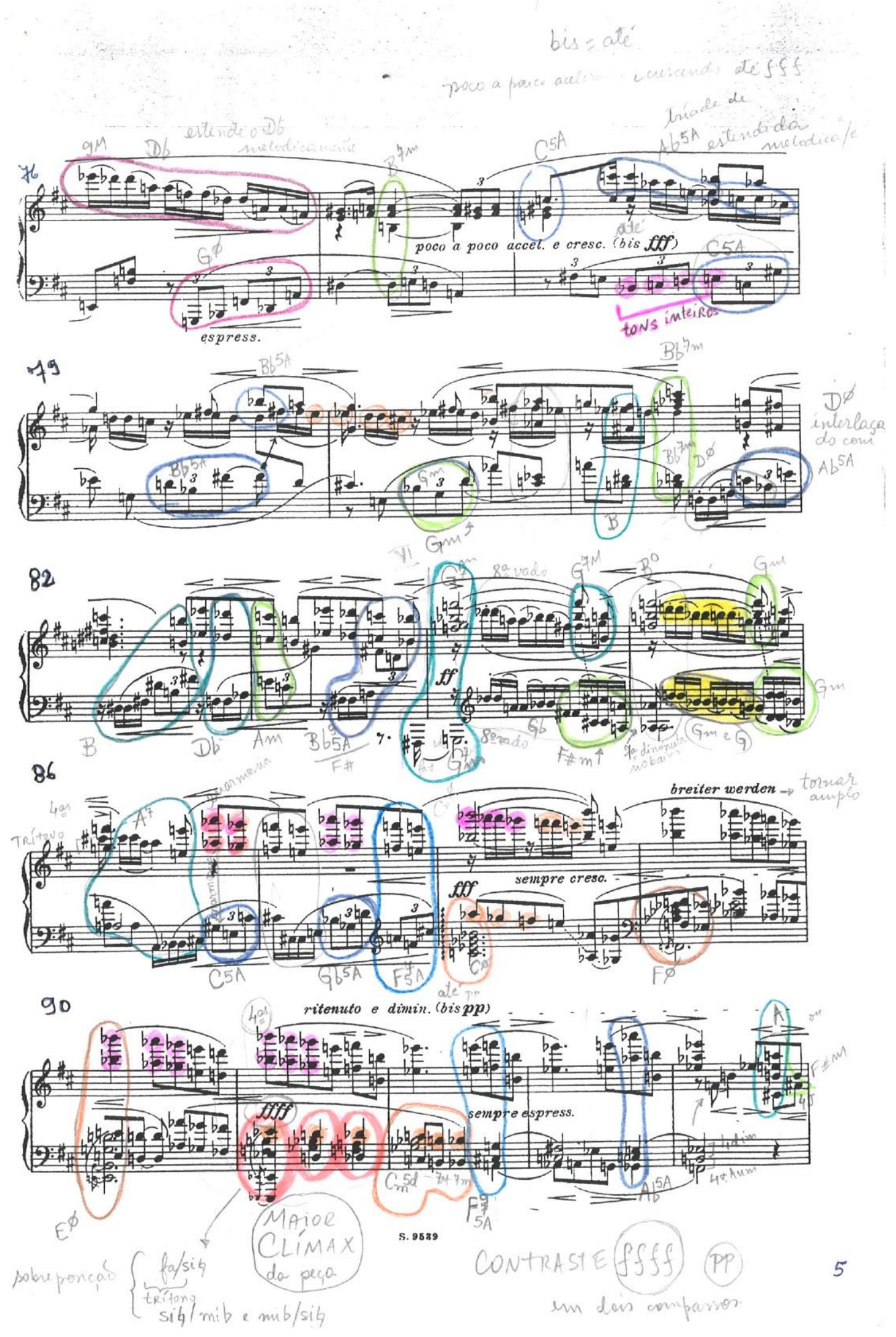

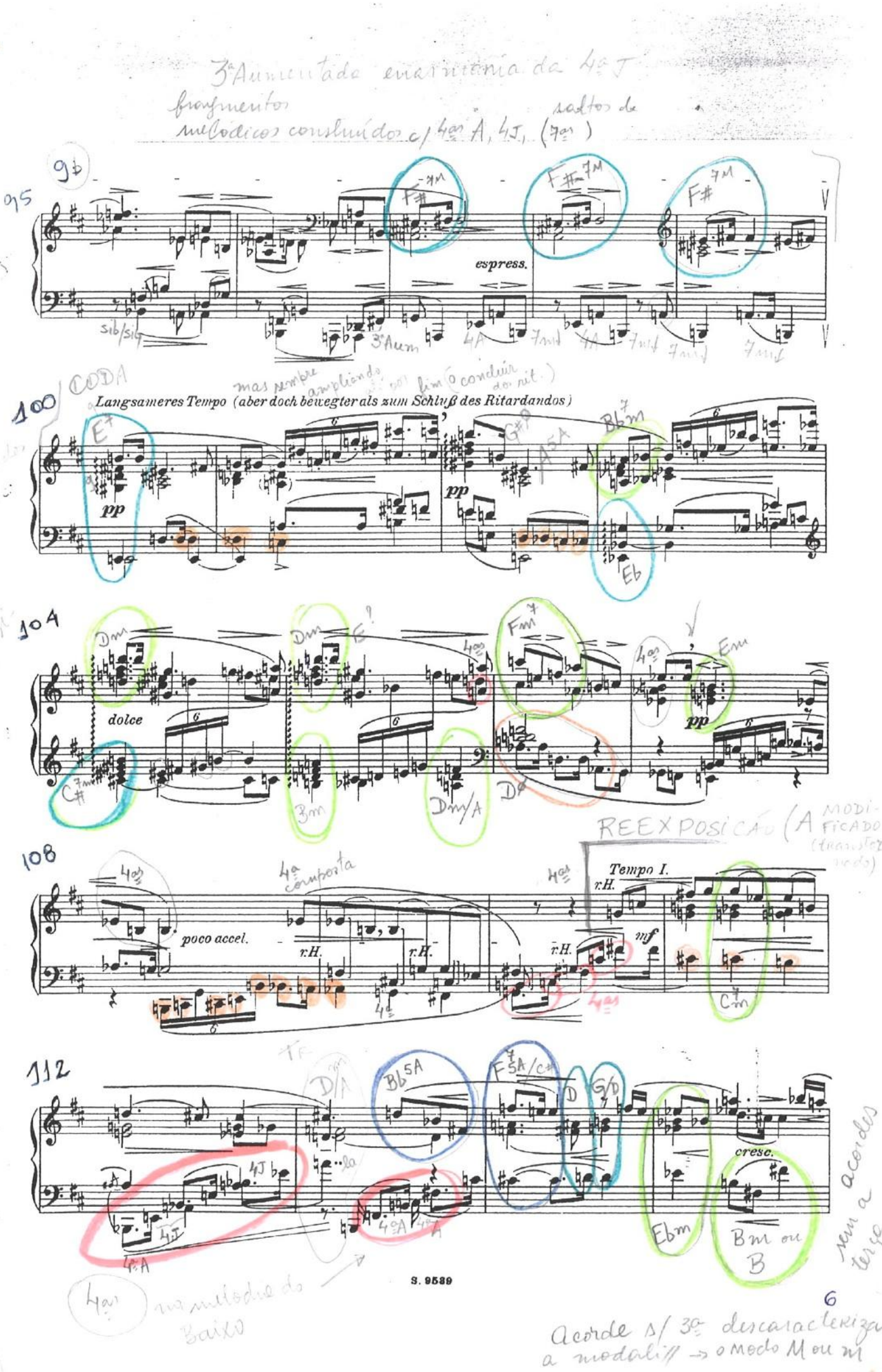


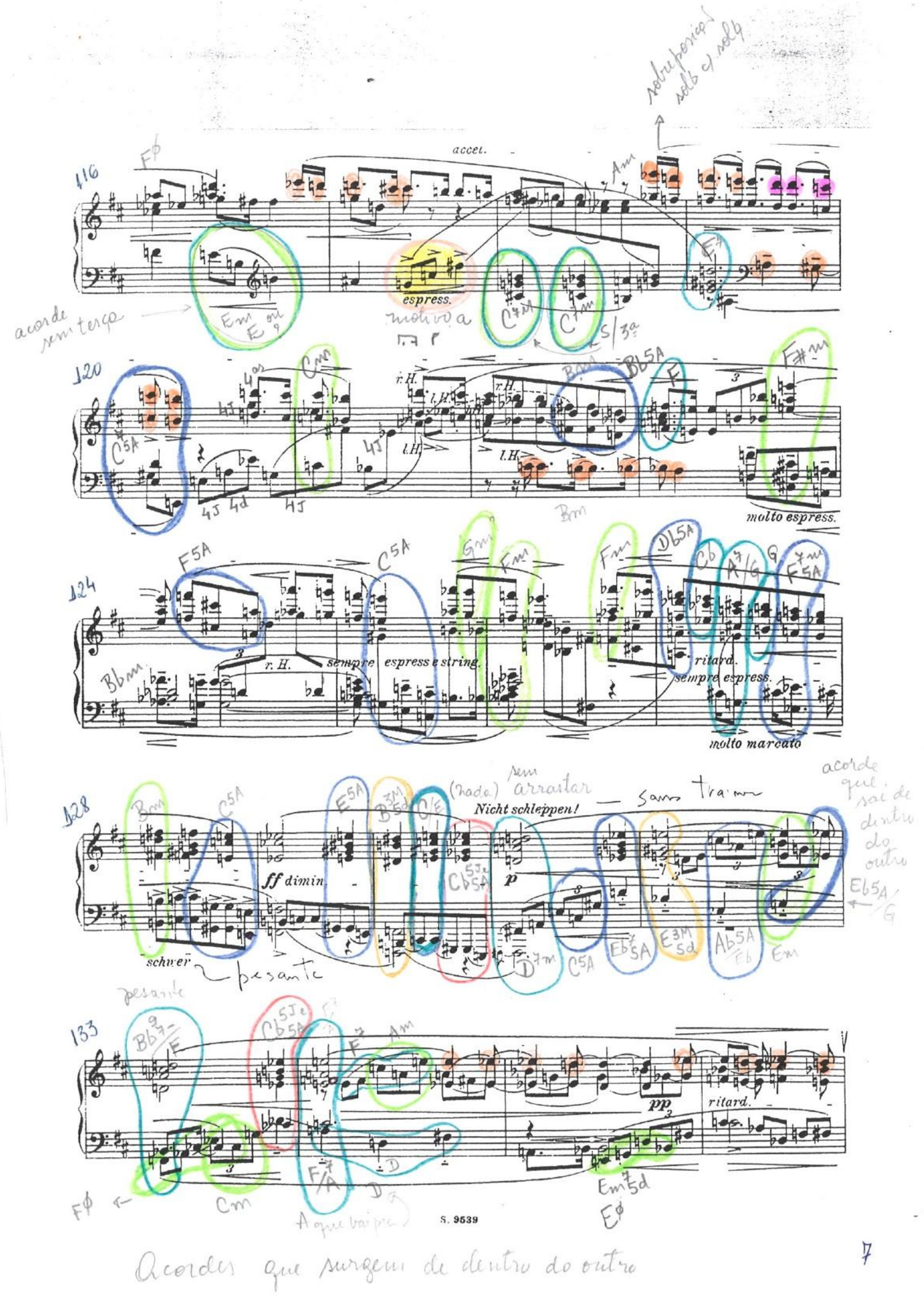



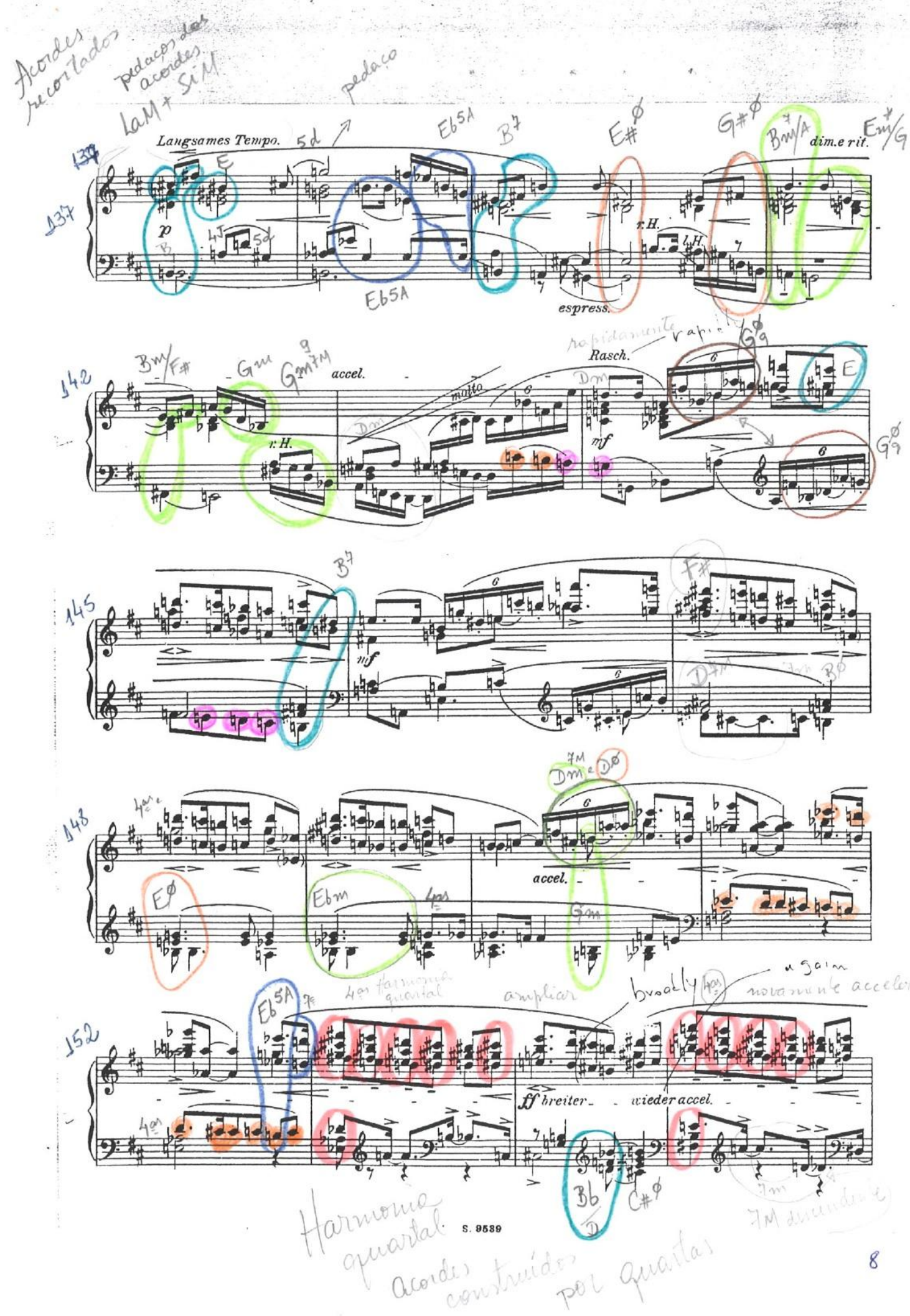

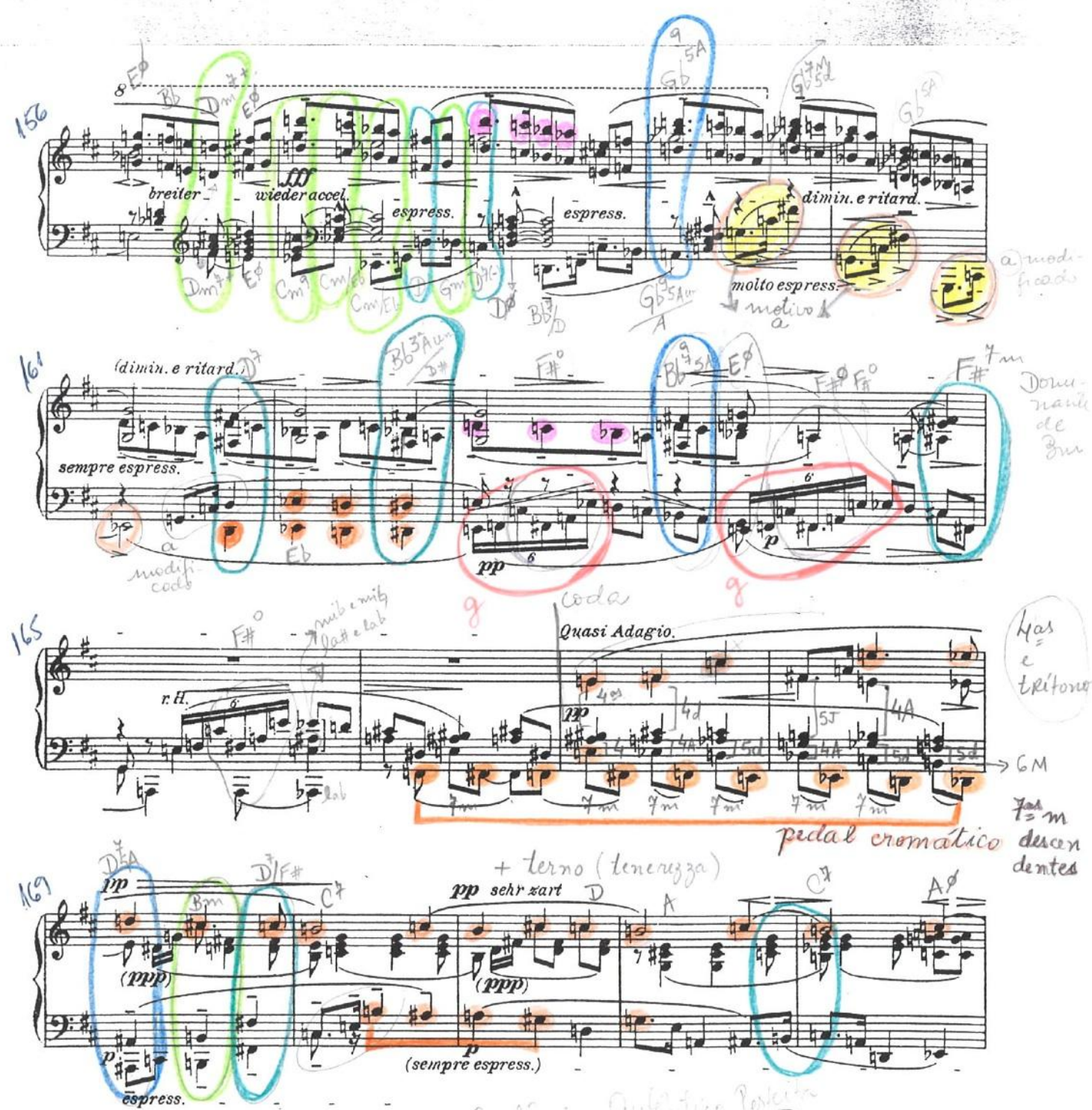

dentes
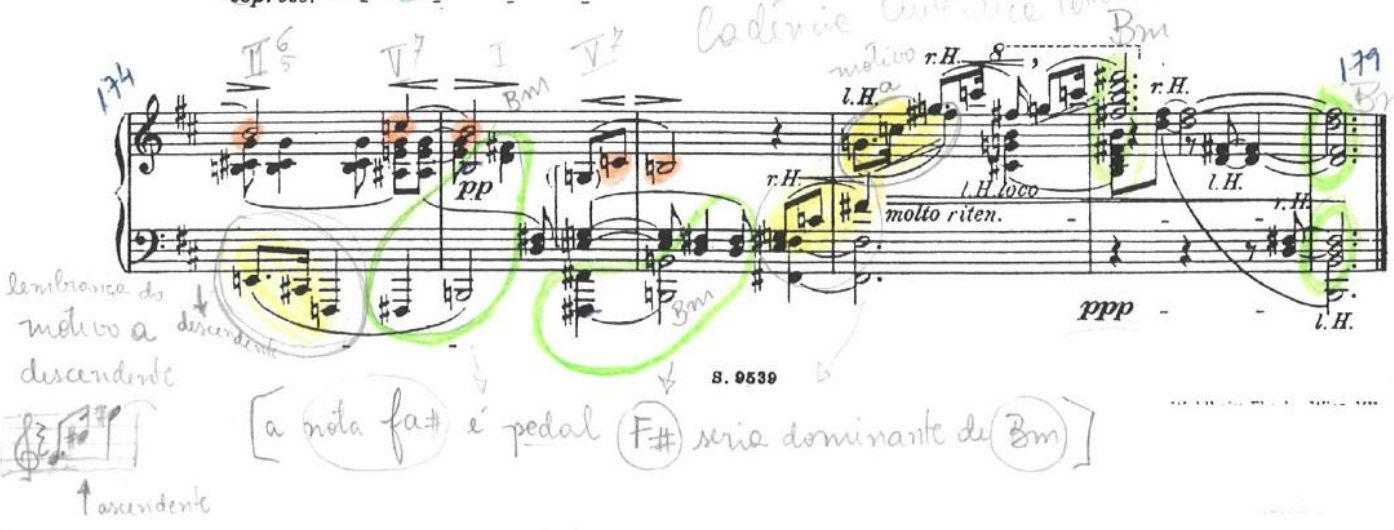